\title{
The history of the Nederlandsche Cocaïne Fabriek and its successors
}

Citation for published version (APA):

Bosman, H. H. (2012). The history of the Nederlandsche Cocaïne Fabriek and its successors: as manufactorers of narcotic drugs, analyzed from an international perpective . [Doctoral Thesis, Maastricht University]. Hans Bosman. https://doi.org/10.26481/dis.20121108hb

Document status and date:

Published: 01/01/2012

DOI:

10.26481/dis.20121108hb

Document Version:

Publisher's PDF, also known as Version of record

\section{Please check the document version of this publication:}

- A submitted manuscript is the version of the article upon submission and before peer-review. There can be important differences between the submitted version and the official published version of record.

People interested in the research are advised to contact the author for the final version of the publication, or visit the DOI to the publisher's website.

- The final author version and the galley proof are versions of the publication after peer review.

- The final published version features the final layout of the paper including the volume, issue and page numbers.

Link to publication

\footnotetext{
General rights rights.

- You may freely distribute the URL identifying the publication in the public portal. please follow below link for the End User Agreement:

www.umlib.nl/taverne-license

Take down policy

If you believe that this document breaches copyright please contact us at:

repository@maastrichtuniversity.nl

providing details and we will investigate your claim.
}

Copyright and moral rights for the publications made accessible in the public portal are retained by the authors and/or other copyright owners and it is a condition of accessing publications that users recognise and abide by the legal requirements associated with these

- Users may download and print one copy of any publication from the public portal for the purpose of private study or research.

- You may not further distribute the material or use it for any profit-making activity or commercial gain

If the publication is distributed under the terms of Article $25 \mathrm{fa}$ of the Dutch Copyright Act, indicated by the "Taverne" license above, 


\section{The History of the Nederlandsche Cocaïne Fabriek and its Successors}


Printed by

Foot \& Playsted Pty. Ltd.

Launceston, Tasmania.

ISBN Volume 1 978-0-9872751-2-7

Volume 2978-0-9872751-3-4

(C) 2012 by Hans Bosman

All rights reserved. No part of this publication may be reproduced, stored in retrieval systems, or transmitted, in any form or by any means, electronic, mechanical, photocopying, recording, or otherwise, without written permission from the author. 


\title{
The History of the Nederlandsche Cocaïne Fabriek and its Successors as Manufacturers of Narcotic Drugs, analysed from an International Perspective
}

\author{
PROEFSCHRIFT \\ ter verkrijging van de graad van doctor aan de Universiteit Maastricht, \\ op gezag van de Rector Magnificus, Prof. dr. L.L.G. Soete \\ volgens het besluit van het College van Decanen \\ in het openbaar te verdedigen \\ op donderdag 8 november 2012 om 14.00 uur
}

door

Hans Harold Bosman 
Promotor:

Prof. dr. E. Homburg

Beoordelingscommissie:

Prof. dr. A. Knotter (voorzitter)

Dr. A.I. Bierman (Universiteit Leiden)

Prof. dr. F.G. Huisman (tevens Universiteit Utrecht)

Prof. dr. K.E. Sluijterman (Universiteit Utrecht) 
"e numeris scientia"

\section{WRITING IS CREATING ORDER}

FROM DISORDER

WHAT IS IMPORTANT IS

INTERNAL ORDER

ORDER OF THE MIND

It a lo Calvino (1923-1985) 


\section{ACKNOWLEDGEMENTS}

I wish firstly to sincerely thank my supervisor, Professor Dr Ernst Homburg, for his guidance, constructive criticism and encouragement throughout this project. The large distance that separated us has made that most of the communication was maintained by e-mail and the extensive files thereof are proof of the large amount of assistance provided by him, for which I am most grateful. I thank Dr Leen Maat for establishing the contact with professor Homburg and for his continued interest in my endeavours.

Appreciation is also extended to Fred and Hans Nieukerke for handing over to me the original manuscript of the Minutes (Notulenboek) of the Board Meetings of the NCF 1934-1950, containing detailed information on the company not available from any other source.

I express my thanks to Corinne Staal of the Stadsarchief Amsterdam for showing me the way in the archives on building permits (hinderwetvergunningen) having reference to the NCF and for providing me with copies of many important documents. My thanks go also to the late Tineke Bosman (Royal Tropical Institute, Amsterdam) and her colleagues at libraries and archives all over the world, including those at the United Nations Library, Geneva, and the International Narcotics Control Board, Vienna, for assistance with my searches.

I wish to thank Ekkehard Buchholz (Midas Pharmachemie) for assisting me in contacting the archives of Merck Darmstadt, Boehringer Ingelheim and Histochem (Hoechst), and for other help. The support of Brian Hartnett (Tasmanian Alkaloids), David Mercer (Macfarlan), Gérard Dumont (Francopia), Lloyd Nystrom (Mallickrodt), Andrew Grant (Noramco, Penick), Dr Werner Wessling (Lohmann Therapie Systeme), Dr Konstantin Ikonomovski (Alkaloid Skopje, Penick) and Eric Slot (journalist, Amsterdam) is gratefully mentioned. I thank Alison Flood for typing the draft in the earlier stages of the project.

Last, but by no means least, I extend my sincere appreciation to my partner, Sue, for her constant encouragement and for the many hours spent on proof-reading the drafts. 


\title{
I N D E X
}

\author{
Volume 1
}

\section{PART I THE HISTORY OF THE NCF AND ITS SUCCESSORS}

CHAPTER 1 INTRODUCTION

17

Chapter 2 The Emergence of Alkaloids as Medicinal Products Manufacture of AlKaloids DuRING THE $19^{\text {TH }}$ CENTURY

2.1 Plant Origin of Medicines 25

2.2 Alkaloids as Medicinal Products 26

2.3 The Commercial Production of Alkaloids until $1860 \quad 30$

2.4 Alkaloids at the Inception of the Modern Bulk Pharmaceutical Industry 34

$\begin{array}{lll}2.5 & \text { Summary and Conclusions } & 37\end{array}$

CHAPTER 3 THE DISCOVERY OF COCAINE AND THE EMERGENCE OF THE COCAINE INDUSTRY

3.1 The Coca Plant and Its Origin

3.2 Coca in Europe and the USA and the Discovery of

Cocaine as a Local Anesthetic

3.3 The Emergence of the Cocaine Industry

3.4 Science and Technology and the Manufacture of Cocaine 55

$\begin{array}{lll}3.5 & \text { Summary and Conclusions } & 60\end{array}$

Chapter 4 JAVA CoCA AND ThE Establishment OF THE NCF

4.1 Java Coca

4.2 Roots of the NCF

4.3 Establishment of the NCF

4.4 The Cocaine Manufacturing Process 70

$\begin{array}{lll}4.5 & \text { Summary and Conclusions } & 71\end{array}$

CHAPTER 5 DEVELOPMENTS IN THE COCAINE MARKET DURING THE PERIOD 1900-1913

$\begin{array}{lll}5.1 & \text { Manufacture of Cocaine Worldwide } & 73\end{array}$

$\begin{array}{lll}5.2 & \text { Manufacturers } & 76\end{array}$

$\begin{array}{lll}5.3 & \text { Marketing and Prices } & 79\end{array}$

5.4 Manufacturing Cost and Margin on Sales of Cocaine $\mathrm{HCl}$

5.5 Raw Materials - The Trade in Java Coca 88

5.6 Interlude to International Narcotics Control 92

$\begin{array}{lll}5.7 & \text { Summary and Conclusions } & 94\end{array}$ 
ChaPter 6 NCF, The EARLy YeARS - THE PerIOd 1900-1914

6.1 Overview, Organization and Marketing 95

6.2 Supply of Java Coca to NCF - The Soekamadjoe Plantation 99

6.3 Building the Factory and Manufacturing at Amsterdam 1900-1909 103

6.4 Building and Operating the New Factory at Ouder Amstel 1910-1914 117

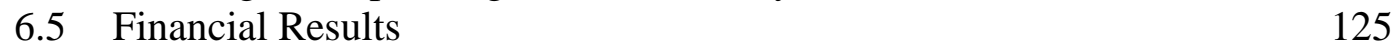

$\begin{array}{lll}\text { 6.6 Summary and Conclusions } & 128\end{array}$

CHAPTER 7 DeVElopments In THE WORLd MARKet FOR COCAINE DURING THE PERIOD 1914-1930

$\begin{array}{llr}7.1 & \text { Overview } & 129\end{array}$

$\begin{array}{ll}\text { 7.2 Manufacture of Cocaine Worldwide } & 130\end{array}$

$\begin{array}{lll}7.3 & \text { Raw Materials - The Trade in Java Coca } & 134\end{array}$

$\begin{array}{lll}7.4 & \text { International Narcotics Control } & 144\end{array}$

$\begin{array}{lll}7.5 & \text { The Cocaine Market Worldwide } & 146\end{array}$

$\begin{array}{lll}7.6 & \text { Summary and Conclusions } & 158\end{array}$

Chapter 8 Culmination of Cocaine Production AT THE NCF - THE PERIOD 1914-1930

8.1 NCF Overview, Organization and Marketing 159

8.2 Coca Supplies to the NCF - Soekamadjoe 165

8.3 Expanding and Operating the NCF Factory 168

$\begin{array}{lll}\text { 8.4 NCF - Financial Results } & 175\end{array}$

$\begin{array}{lll}\text { 8.5 Summary and Conclusions } & 177\end{array}$

ChAPTER 9 The OPIUM PoPpy AND OPIATE MANUfacture UnTIL 1930

$\begin{array}{lll}9.1 & \text { The Opium Poppy and Opium } & 179\end{array}$

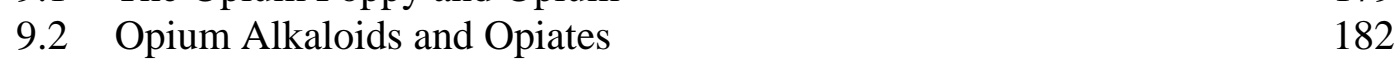

$\begin{array}{lll}\text { 9.3 The Manufacture of Morphine and Codeine until } 1930 & 185\end{array}$

9.4 Development of the World Market for Morphine and Cocaine 189

9.5 Profitability of the Opiate Business in the 1920s 193

$\begin{array}{lll}9.6 & \text { Summary and Conclusions } & 195\end{array}$

CHAPTER 10 ENTERING THE OPIATE BUSINESS

THE NCF DURING THE PERIOD 1931-1939

10.1 Statistical Information on Narcotic Drugs 197

10.2 The Opiate and Cocaine Business during the 1930s 199

$\begin{array}{lll}10.3 \text { Bonnema } & 208\end{array}$

$\begin{array}{ll}10.4 \text { Organisation and Marketing } & 211\end{array}$

$\begin{array}{ll}10.5 \text { Manufacturing } & 218\end{array}$

10.6 Opiate Factories and Work Conditions in the 1930s 221

$\begin{array}{ll}10.7 \text { Financial } & 223\end{array}$

$\begin{array}{ll}10.8 \text { Summary and Conclusions } & 225\end{array}$ 
CHAPTER 11 THE SECOND WORLD WAR AND REVIVAL NCF AND BONNEMAVPF FROM 1940 TO THE EARLY 1960S

$\begin{array}{lll}11.1 & \text { Overview } & 227\end{array}$

11.2 Opiate Manufacture during World War II 228

11.3 The World Market for Opiates 1946-1960 233

11.4 Opiate Manufacture in the Netherlands and Trade 1946-1960 240

11.5 The NCF during the Period 1946-1962 246

11.6 Bonnema/VPF during 1946-1964 260

$\begin{array}{lll}11.7 \text { Summary and Conclusions } & 266\end{array}$

CHAPTER 12 ACQUiSITIONS AND MERGERS

NCF AND VPF UNDER KZO DURING THE 1960S

$\begin{array}{ll}12.1 & \text { Introduction and Overview }\end{array}$

12.2 The World Market for Opiates 1961-1970 269

12.3 Opiate Manufacture in the Netherlands and Trade 1961-1970 277

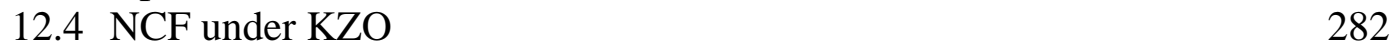

12.5 Impact of the Acquisition on VPF 283

12.6 VPF under KZO - The Years 1964-1970 285

12.7 Summary and Outlook for the next Period 288

CHAPTER 13 A MARKET IN TURMOIL AND REORGANISATIONS: VPF AND DIOSYNTH DURING THE 1970s

$\begin{array}{lll}13.1 & \text { Overview } & 289\end{array}$

13.2 Turkey Abandoning Poppy Cultivation and its Consequences 290

13.3 International Narcotics Control 292

13.4 The World Market for Opiates 1971-1980 295

$\begin{array}{ll}13.5 \text { Organizational Changes at Akzo } & 300\end{array}$

13.6 Alternatives to Turkish Poppy Straw at VPF 301

13.7 Construction of the Opiate Manufacturing Facility at 306

Bolvadin (Turkey) - Involvement of Akzo 306

13.8 Morphine and Codeine Manufacture at VPF/Diosynth 307

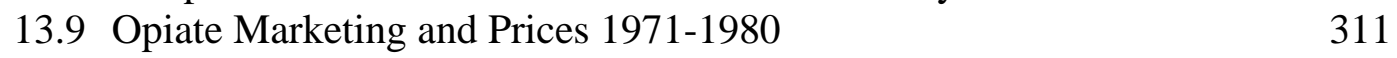

13.10 Summary and Outlook for the next Period 312

CHAPTER 14 THE END OF AN ERA

DECLINE OF DIOSYNTH’s OPIATE BUSINESS 1981-2005

$\begin{array}{lll}14.1 & \text { Overview } & 313\end{array}$

$\begin{array}{ll}14.2 & \text { International Narcotics Control } \\ 14.3\end{array}$

14.3 The Opiate Market Worldwide during the 1980s 316

14.4 Raw Material Supplies and Morphine Manufacture

14.5 Codeine Manufacture at Diosynth during the Period 1981-1994 323

$\begin{array}{ll}14.6 \text { Nal-Compounds } & 324\end{array}$

14.7 Survey of the Production of Opiates at Diosynth 1981-2005 326

$\begin{array}{lll}14.8 & \text { Summary and Conclusions } & 328\end{array}$ 


\section{Volume 2}

\section{PART II ESTIMATES AND MODELS}

CHAPTER 15 Estimates OF THE MANUfacturing Cost OF CoCAINE HYDROCHLORIDE FROM VARIOUS RAW MATERIALS AND THE MARGIN ON SALES DURING THE PERIOD 1902-1912.

15.1 Introduction

15.3 Margin on the Sales of Cocaine $\mathrm{HCl}$

15.4 Summary and Conclusions

CHAPTER 16 ESTIMATES OF COCAINE MANUfACTURED WORLDWIDE (1892-1930) PART I: EXPORTS AND IMPORTS OF PERUVIAN COCA LEAF

16.1 Introduction

16.2 Discussion of the Statistics on the Trade in Coca Leaf 348

16.3 Bringing it All Together 354

16.4 Evaluation of the Results of Table 16.4 - The period 1897-1903 356

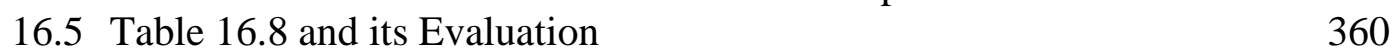

$\begin{array}{ll}\text { 16.6 The Remaining Scenario } & 364\end{array}$

$\begin{array}{lll}16.7 \text { Summary and Conclusions } & 369\end{array}$

Chapter 17 Estimates of Cocaine Manufactured WorldWide (1892-1930) PART II:TRADE IN CRUDE COCAINE - COCA LEAF FOR BEVERAGES THE ESTIMATES

17.1 Discussion of the Statistics on the Trade in Crude Cocaine from Peru 371

$\begin{array}{ll}17.2 \text { Coca Leaf used for Beverages } & 379\end{array}$

17.3 Estimate of Cocaine Manufactured Worldwide 385

$\begin{array}{ll}17.4 & \text { Estimate of the Accuracy of the Estimates } 398\end{array}$

$\begin{array}{lll}17.5 & \text { Summary and Conclusions } & 400\end{array}$

Chapter 18 Estimate of QuANTITIES OF COCAINE HydRochloride SOLD BY NCF DURING THE PERIOD 1902-1930 AND THE PRICES THEREOF

18.1 Introduction 403

$\begin{array}{ll}18.2 \text { Net Profit } & 405\end{array}$

$\begin{array}{ll}18.3 \text { Fixed Cost } & 408\end{array}$

18.4 Variable Cost - Coca Leaf Supplies 412

18.5 Other Factors - Ethocaine 416

18.6 Solving the Equation for V and P respectively 420

18.7 The Accuracy of the Estimates 423

18.8 Summary and Conclusions 428 
CHAPTER 19 SUMmary AND CONCLUSIONS OF PARTS I AND II

Part I The History

433

Part II Estimates and Models

435

\section{PART III APPENDICES, ARCHIVES AND BIBLIOGRAPHY, SUMMARY IN DUTCH, CURRICULUM VITAE}

Appendix 1 Relationships between the families van Hengst and Huygen de Raat in the former Durch East Indies (Java) 441

Appendix 2 Some adverse publicity on the NCF

Appendix 3 The Development and Applications of the

Goods-in-Transit Method

Archives and Bibliography

Summary in Dutch (Samenvatting in het Nederlands) 477

$\begin{array}{ll}\text { Curriculum Vitae } & 491\end{array}$

General List of Acronyms and Abbreviations 493

\section{PART IV SOURCE DATA}

$\begin{array}{ll}\text { Index } & 496\end{array}$

$\begin{array}{ll}\text { Peru Coca Leaf (PCL) } & 498\end{array}$

$\begin{array}{ll}\text { Peru Crude Cocaine (PCC) } & 508\end{array}$

Java Coca Leaf (JCL) 513

$\begin{array}{ll}\text { Cocaine (COC) } & 521\end{array}$

$\begin{array}{ll}\text { Opiates (OPI) } & 527\end{array}$

$\begin{array}{ll}\text { Financials (FIN) } & 538\end{array}$ 
VOLUME 1

PART I

HISTORY OF THE NCF AND ITS SUCCESSORS 


\section{Chapter 1 \\ INTRODUCTION}

\section{Brief overview of the history}

Immediately after the discovery by Koller, in 1884, that cocaine was an effective anaesthetic for the eye, the demand for the product exceeded supply possibilities many times over. This resulted in the shipping of substantial quantities of the raw material, coca leaf from South America, to cocaine manufacturers in Germany and the USA, and substantial price increases for the raw material and the end product.

At the time the coca plant was also cultivated on a small scale in the Botanical Gardens at Buitenzorg, Java. The increased commercial interest in coca leaf led to an expansion of the cultivation on Java and to attempts to sell commercial quantities of the leaf in London and Amsterdam in the early 1890s. Initially, Java coca was not well received by cocaine manufacturers because it was of a variety different from that of South America, and the cocaine yields were low. That changed when German chemists discovered and patented new methods whereby cocaine could be made from Java coca with a good yield and thereafter modest quantities of the leaf were sold to a German manufacturer during the 1890s.

This development was noticed by two Germans, Mr Boldemann and Dr Eberhard, who realised that manufacturing cocaine from Java coca in a factory located in the Netherlands would be a profitable venture because the low priced Java coca could be processed in the Netherlands without a patent infringement arising. An arrangement was made with the Koloniale Bank, an organisation involved in agricultural enterprises in the Dutch East Indies, and Mr van Hengst, one of the early growers of coca on Java. The ultimate result was the establishment of the Nederlandsche Cocaine Fabriek (NCF) in 1900 and the building of a cocaine factory in Amsterdam.

Although not recognised at the time, this was the beginning of the narcotics industry in the Netherlands. Cocaine was not a controlled substance and could be manufactured and traded without restrictions. That would change after World War I when international controls of cocaine and other drugs such as opium and heroin were agreed upon by the Geneva Convention of 1925. Cocaine remained NCF's only product for quite a long time, but after the Convention was ratified NCF redefined its position in the market as being part of the narcotic drugs industry, the industry that manufactured controlled substances. Opiates, such as morphine and codeine, became major products of NCF during the 1930s.

In the 1920s another Dutch company, "Bonnema" located at Apeldoorn, became involved in the manufacture of narcotic drugs on a small scale. Until after World War II NCF remained the larger supplier, supplying two-thirds of the Dutch home market for opiates and cocaine. From 1946, both NCF and Bonnema, renamed Verenigde Pharmaceutische Fabrieken (VPF) in 1948, concentrated on the manufacture of opiates from poppy straw, the ripe capsules of the plant Papaver somniferum, as an economic alternative to making opiates from opium. That was successful, and the companies operated effectively in the open world market for codeine and, additionally, sold a substantial part of their output as Concentrate of Poppy Straw (CPS) to other codeine manufacturers in Europe.

In the early 1960s both NCF and VPF became part of the multinational company Koninklijke Zwanenberg Organon (KZO) and their operations were merged, continuing the marketing activities under the VPF name. Reorganisations within the parent company KZO, later Akzo, resulted in the production of opiates and other controlled substances becoming the 
responsibility of Diosynth, the leading manufacturer of Active Pharmaceutical Intermediates (APIs) within the Akzo Pharma division, in the mid-1970s.

From 1960 Turkey had become the main source of poppy straw, the raw material for VPF's opiate business. Turkey, under pressure of the USA, abandoned poppy cultivation in 1972 causing a shortfall in supply, but the resumption of the cultivation in 1975 led, during the period 1977-1981, to substantially increased production levels of opiates and excellent profits for Diosynth. However, thereafter Turkey ceased to supply poppy straw again and procurement of sufficient quantities of low cost poppy straw from other sources turned out to be an unsurmountable problem for Diosynth. Poppy straw extraction was discontinued in 1988 and codeine manufacture stopped in 1993.

The interesting aspect of the history of the narcotics industry in the Netherlands is to see how the companies coped with the challenges resulting from operating in a highly competitive international market subject to exceptionally strict controls. The challenges were manifold; they included first of all regulatory matters and raw material procurement, as well as customer relations and the technology to remain low cost producers.

\section{Objective and scope of the study}

The objective of this dissertation is to explain how and why the Dutch narcotics drugs industry came into existence, experienced periods of variable profitability over a time span of more than 90 years, and ultimately did not survive. It will be argued that ongoing access to a reliable source of a low cost raw material and being located in a sufficiently large protected home market are essential for survival in the industry.

It is written from the point of view of the management of the companies involved and analyses the situation from an international perspective. The production of and trade in raw materials such as coca leaf, crude cocaine, opium and poppy straw are discussed as far as required for a good understanding of the narcotic drugs business. The scope does not include abuse of the products nor the illicit trade in narcotic drugs and their raw materials beyond the extent as such activities have affected the legal industry which supplied the products for medical and scientific needs.

The study deals with the products manufactured by an industry subject to special restrictions, operating in a controlled international market affected by the uncertainties of political decisions made by countries and multinational bodies. It will contribute to an understanding of forces which were essential in shaping the narcotic drugs industry world-wide and the conditions that have to be fulfilled by a manufacturing company to be successful therein.

It is intended to be a contribution to the understanding of the functioning of a small but important and interesting Netherlands industry against the background of the fabric of the narcotics industry worldwide.

The broad structure of the dissertation is that Volume 1 contains Part I in which the history is told chronologically. Chapter 1 is the introduction, chapters $2-8$, covering the period until 1930, deal mainly with cocaine, and chapters 9-14, describing the years thereafter, deal principally with opiates. Volume 2 covers Parts II, III and IV. Of Part II, chapters 15-18 deal with making estimates of quantities of cocaine manufactured and costs thereof. Chapter 19 comprises the summary and conclusions of Parts I and II. Part III contains three appendices, a list of archives and the bibliography, a summary in Dutch, the curriculum vitae and a list of abbreviations. In Part IV source data are compiled. It covers a large volume of statistical data 
on the manufacture and trade in cocaine and opiates, their raw materials, and financial information. Volume 2 is bound separately for easy access to the statistical data.

\section{Existing studies on the narcotics industry in the Netherlands}

So far the history of the Dutch narcotics industry has not been investigated and told comprehensively. Research on the narcotics industry in the Netherlands has concentrated almost exclusively on the NCF, Java coca and cocaine during the years until ca 1930. The history of Bonnema/VPF and Diosynth as manufacturers of opiates has not been the subject of published studies.

Studies which include facts and opinions of the history of the NCF are those by Emma Reens (1919) ${ }^{1}$, Anne W.K. de Jong (1948) ${ }^{2}$, Dirk Korf and Marcel de Kort (1990) ${ }^{3}$, Eric Slot $(1994)^{4}$, Marcel de Kort $(1995)^{5}$ and $(1999)^{6}$, Steven B. Karch $(1999)^{7}$ and $(2006)^{8}$, Annemarie Bos $(2006)^{9}$, Paul Gootenberg (1999) ${ }^{10}$ and (2008) ${ }^{11}$ and Jyri Soininen (2008) ${ }^{12}$.

Reens describes the coca cultivation on Java, mentioning coca leaf exports and the establishment of the NCF. De Jong reviews the history of the coca cultivation in the former Dutch East Indies and the founding of the NCF. He is the first to mention the existence of a patent by Farbwerke Hoechst on the manufacture of cocaine.

Kolf and de Kort provide a brief description of the coca industry on Java and an account of the establishment and the early history of the NCF. De Kort searched the records of the Koloniale Bank and documents on the involvement of the Dutch government in the League of Nations conferences on narcotic drugs in the 1920s and 1930s at the Nationaal Archief, The Hague, thereby finding valuable information on the NCF which he included in his dissertation of 1995.

Slot bases his article on the NCF mainly on the publication Kolf and de Kort, supplemented by information obtained from the Stadsarchief Amsterdam and the autobiography by Ger Harmsen. ${ }^{13}$ Karch depicts, rather inaccurately, the early history of the NCF.

Bos' study reviews the literature on the NCF and describes the history of the company as a cocaine producer until 1931 in conjunction with the cultivation of coca on Java from an

\footnotetext{
${ }^{1}$ E. Reens, La Coca de Java. Monographie historique, botanique et pharmacologique. Dissertation University of Paris (Lons-le-Saunier 1919).

${ }^{2}$ A.W.K. de Jong, Chapter 'Coca' in: C.J.J. van Hall and C. van de Koppel, editors, De Landbouw in de Indische Archipel Vol II A (The Hague 1948) 866-888.

${ }^{3}$ D.J. Korf and M. de Kort, Drugshandel en Drugsbestrijding (Amsterdam 1990).

${ }^{4}$ E. Slot, 'Legaal Snuiven, Slikken en Spuiten. De Nederlandsche Cocaine Fabriek (1900-1962)' "Ons Amsterdam" 46 [3] (1994) March, 70-74.

${ }^{5} \mathrm{M}$. de Kort, Tussen patiënt en delinquent, geschiedenis van het Nederlandse drugsbeleid. (Between patient and delinquent, the history of drug policy in the Netherlands); Dissertation Erasmus University , Rotterdam (Hilversum 1995).

${ }^{6}$ M. de Kort, 'Doctors, diplomats and businessmen. Conflicting interests in the Netherlands and Dutch East Indies', Chapter 6 in: P. Gootenberg, editor, Cocaine: Global Histories, (London 1999).

${ }^{7}$ S.B. Karch, 'Japan and the cocaine industry of Southeast Asia, 1864-1944' Chapter 7 in: P. Gootenberg, editor, Cocaine: Global Histories (London 1999) 146-161.

${ }^{8}$ S.B. Karch, A Brief History of Cocaine $2^{\text {nd }}$ Ed (Boca Raton 2006).

${ }^{9}$ A. Bos , Legale Nederlanse Cocaine, Master Thesis History, University of Amsterdam (2006) and A. Bos, The history of licit cocaine in the Netherlands, De Economist 154 (2006) 581-586.

${ }^{10}$ P. Gootenberg, 'Reluctance or resistance? Constructing cocaine (prohibitions) in Peru, 1910-50' Chapter 3 in:

P. Gootenberg, editor, Cocaine: Global Histories (London 1999) 46-79.

${ }^{11}$ P. Gootenberg, Andean Cocaine, the making of a global drug (North Carolina 2008).

${ }^{12}$ J. Soininen, Industrial Geographies of Cocaine, Master Thesis Geography, University of Helsinki (2008).

${ }^{13}$ G. Harmsen, Herfsttijloos (Colchicum autumnale), een levensverhaal. (Nijmegen 1993).
} 
economic point of view, using documents from the Nationaal Archief. Research on the cost of Java coca grown on government plantations during the period 1914-1919 is included in her study.

Gootenberg draws somewhat tendentious conclusions on the history of the NCF, mainly from what has been written on the subject by others. Soininen is the most critical of the authors, identifying several errors in previous publications.

It is noticeable that information and conclusions mentioned in earlier publications were sometimes uncritically repeated by other authors in later books and papers. An example is the statement by Kolf and de Kort who mention (incorrectly) in 1990 that the NCF "in 1910 could claim to be the largest cocaine manufacturer in the world". This statement, with minor variations, has been repeated several times in later publications by de $\mathrm{Kort}^{14}$, and by others, for example by Gootenberg, Karch and Soininen.

Making of estimates of quantities of cocaine manufactured on the basis of trade statistics on the raw materials and on the basis of financial data is the main subject of part II of this dissertation. Publications dealing with making such estimates are those by David Musto $(1998)^{15}$, Joseph Spillane (1994) ${ }^{16}$ and (2000) $)^{17}$, Gootenberg (2008 1.c.) and Soininen (2008 1.c.). Musto compiled extensive data on the export of raw materials for cocaine and made estimates of the quantities of alkaloids contained therein. Spillane provides estimates of cocaine and coca leaf imported into New York. Gootenberg's book includes data on exports of crude cocaine and coca leaf from Peru and an appendix on the problems on dealing with historical statistics on cocaine, while Soininen adds critical notes to some cocaine statistics appearing in the literature.

\section{Methodology}

The history of the NCF and its successors is written from the point of view of management, and profit and growth of the business are considered essential parameters to judge performance of the companies. It was the aim of the literature research to find, describe and analyse all organisational, financial, scientific, technological, commercial and control aspects of the industry which determined the profitability of NCF and its successors. Major repositories of important documents were the Nationaal Archief, the Hague, the Stadsarchief, Amsterdam, the International Institute of Social History, Amsterdam, the Archives of the League of Nations at Geneva, and the Library of the International Narcotics Control Board, Vienna.

The author's exclusive access to the Minutes of Board Meetings of the NCF 19341950 has been most advantageous. ${ }^{18}$ The knowledge acquired by the author from 1960 onwards in managerial positions at the NCF, VPF and Diosynth, and from 1977 at Tasmanian

\footnotetext{
${ }^{14}$ De Kort adds in his publication of 1999 a note stating that Friman has shown that “...in aggregate German factories produced more cocaine than the Dutch...".

${ }^{15}$ D.F. Musto, 'International Traffic in Coca through the early $20^{\text {th }}$ Century' Drug and Alcohol Dependence 49

[2] (1998) 145-156.

${ }^{16}$ J. F. Spillane, Modern Drug, Modern Menace: the legal use and distribution of cocaine in the United States, 1880-1920. Dissertation Carnegie Mellon University (1994).

${ }^{17}$ J. F. Spillane, Cocaine (Baltimore 2000).

${ }^{18}$ Nederlandsche Cocaine Fabriek Notulenboek, Commissaris vergaderingen 23 Februari 1934 -

15 May 1950. (Minutes of Board Meetings 23 February 1934 - 15 May 1950).

Original Manuscript, in the possession of Hans Bosman. It is gratefully acknowledged that this manuscript was made available to the author by Messrs F. and J. Nieukerke, sons of the late Ir. J.P.H. Nieukerke, former Managing Director of the NCF.
} 
Alkaloids, Australia, has assisted in his gaining insight into connexions which exist between the various factors that govern the course of events.

The extensive statistics on narcotic drugs, available for the years from 1929 onwards, from the international control organisations have been used as the basis for describing the world market for cocaine and opiates and the place of the Netherlands manufacturers therein beyond 1929. Combining all available elements chronologically results in the story of the vicissitudes of the business during the existence of the narcotics industry in the Netherlands, which story is presented in Part I.

The main source of information on the history of the NCF during the early period was the archives of the Koloniale Bank / Cultuurbank (1881-1973) at the Nationaal Archief, The Hague. The Minutes of Board Meetings of the Koloniale Bank contain sections on the NCF and the archives also include Annual Reports and Minutes of Board Meetings of 'Soekamadjoe', the supplier of coca leaf to the NCF, and a report on the NCF covering the period 1900-1945. A further important source of information on the building and operation of the NCF factories in Amsterdam (from 1900) and in Ouder-Amstel (from 1909) was the files on Hinderwetvergunningen (Permits to build and operate factories) from the Stadsarchief Amsterdam.

For the years 1934-1950 the author, as mentioned, had exclusive access to the Minutes of Board Meetings of the NCF which provided many details on the history of the company. Financial information on NCF (1950-1960) and VPF (1948-1963) was collected from annual reports available for these periods.

For the period after the acquisition of NCF (1962) and VPF (1964) by KZO written information on the companies is virtually non-existent and the history is mainly recorded on the basis of United Nations (PBOB/INCB) statistics on the production of and trade in opiates, and recollection by the author supported by incidental publications on the subject. Repeated requests by the author to Akzo management for access to NCF/VPF archives were declined. The lack of detailed written information after 1964 has caused that the style of the description of the history of NCF and its successors from that date has changed markedly.

The overview of sources presented above, illustrates the handicap to construct one uniform basis of sources for the entire period of the history of the NCF and its successors. As a result, some chapters will shed more light on the decision making of the company management than others.

In Part II estimates are made of the quantities of cocaine produced from raw materials exported during the period 1892-1930, for which period no extensive statistics are available. During the calculations it came to light that not all statistics on the raw materials were compatible. Mathematical methods were developed to make estimates of the disputed numbers and of missing data. For the calculation of the quantities of cocaine produced estimated yield factors were applied. A method to make estimates of quantities of cocaine sold by NCF by period on the basis of financial figures was devised.

The estimates are the quantitative basis for the portrayal of the cocaine industry worldwide during the years before 1930 and the place of the NCF therein, are appearing in Part I.

Three appendices appearing in Part III deal with subjects that fit less well in the other sections. Appendix 2 has as subject adverse publicity on the NCF, including hype resulting from a recently published novel by Conny Braam on alleged immoral activities by the NCF during World War I. ${ }^{19}$ Her accusations are totally unfounded. Using the estimates of Part II it

${ }^{19}$ C. Braam, De handelsreiziger van de Nederlandsche Cocaine Fabriek (Amsterdam 2009) 203. 
is substantiated that the quantity of cocaine manufactured by NCF at the time was in the order of 20 times smaller than claimed.

Part IV, "Source Data" is intended for reference. Data pertaining to the manufacture and trade in cocaine and opiates and their raw materials are brought together and presented as a collection of tables. Also included are tables of prices of the various products and tables containing financial information on the companies. Some tables contain the results of calculations by the author of values derived from published data such as averages and totals or expressed in different units (e.g. weight, currency etc.).

\section{Characteristics of the Narcotics Industry}

The Nederlandsche Cocaine Fabriek in Amsterdam was established in 1900; this was well before the time that cocaine and other habit forming drugs such as opium and opiates were controlled as 'narcotic drugs'. These were considered to be valuable medicinal products and, although the abuse potential was recognised, the manufacture and trade was not regulated. Cocaine and opiates were sold by the manufacturers in relatively small quantities to pharmacies and wholesalers and were expensive products.

In the beginning of the $20^{\text {th }}$ century international movements to control drugs gained momentum and the ultimate outcome was that major countries signed Conventions by which the production and trade in habit forming substances and their raw materials became regulated. The Geneva Convention of 1931 was convened after the Convention of 1925 to provide a practical system for an effective control of legally manufactured 'narcotic drugs', as these substances were collectively called from then onwards. In the early 1930s the major manufacturers who supplied the market with cocaine and opiates became licensed manufacturers of narcotic drugs, while the traditional suppliers of the plant raw materials were authorised to continue their business. In all producing countries, manufacturers of narcotic drugs were licensed by their governments to produce limited quantities which were supplied within the country to permit holders, such as pharmacies and wholesalers. For international trade, a system of import and corresponding export permits to regulate all international movements of the drugs was put into place; only the quantities specified in the permit issued by the importing country could be exported.

After the Convention of 1931 came into force the demand by recreational users did not change and a chain of illicit producers and suppliers came into existence to serve their needs. Attempts to control the illicit production and supply had very limited success. Currently, the illicit production of cocaine and heroin are very large. There is no relation whatsoever between the licit and illicit industry. Amounts of narcotics drugs diverted from the licit into the illicit trade are extremely small. Seized illicit product is routinely destroyed.

Governments of countries which were signatories to the Convention had from 1929 the obligation to report statistical information on all production, consumption, conversions and imports and exports of the controlled substances to the Permanent Central Opium Board (PCOB) of the League of Nations, and from 1968 to the International Narcotics Control Board (INCB) of the United Nations. These administrative control organisations published and still publish annually Statistics on Narcotic Drugs containing very detailed quantitative information, by country, on the manufacture of all controlled substances and trade therein. As a result, the legal narcotics industry is one of the most, if not the most transparent of all industries in terms of production and movements of goods. Data from the Statistics on Narcotic Drugs are extensively used in this dissertation to describe the position of the 
Netherlands narcotics manufacturers in comparison to competitors in the world market.

One of the characteristics of the industry is that the demand for the products is very inelastic with respect to price. Being essential medical products, the quantities necessary for treatment of ailments are bought even if the price is very high; on the other hand a low price will not result in selling more than the required amount.

The manufacturer sells its products in bulk to wholesalers and makers of the pharmaceutical product in dosage form. The bulk products are commodities which mean that they have to comply with certain fixed quality specifications, usually as per a pharmacopoeia, and as a consequence the buying decision is mainly made on price. The price inelasticity of demand means that one manufacturer selling more implies that another manufacturer sells less because the total demand for the product is independent of price. This characteristic, combined with the relatively small number of manufacturers, results in unstable markets, in which overproduction leads to serious price deterioration, and shortages to very high prices. Shortages do occur from time to time as the result of crop failures of the plant raw material. In the early 1900s cartels were formed by manufacturers in an attempt to try to control prices through a quota system.

The international control system of import and export permits made it possible for governments of countries with local manufacture to create a de facto protected market for the industry by not issuing import permits. In such cases, domestic prices became higher than open world market prices and manufacturers located in countries with a large domestic consumption could absorb a large part of the fixed cost on sales in the home market, e.g. in France and the UK, allowing them to quote aggressively in the open world market to obtain additional sales. This resulted in a disadvantaged position for manufacturers located in countries with a small domestic consumption. The above is an example of how individual governments could unilaterally use the narcotics control system to further their own objectives.

Other examples of such unilateral actions are those by the US government, in the early 1970s when it used cash incentives to convince the Turkish government to cease poppy cultivation, and in 1980 when its new regulations on imports of narcotic raw materials seriously disadvantaged certain supply countries. 


\section{CHAPTER 2 \\ The Emergence of AlKaloids as Medicinal Products MANufaCture OF Alkaloids DURING THE $19^{\text {TH }}$ CENTURY}

\subsection{Medicines from Plants}

Plants were among the first medicines available to mankind. And still today many medicinal products are derived either directly or indirectly from compounds produced by plants.

From time immemorial, mankind has acquired knowledge about plants. We must assume that humans in a very early stage of their existence knew from experience which plants might be used as foods, which were poisonous and which had some medicinal value. Plants provided early humans with virtually the only possibility to attempt a cure or to find relief if illness or injury befell them.

In the 16th and the 17th century many new plant species were brought into Europe from the newly discovered distant parts of the world. Some of these e.g. cinchona bark (as a cure for malaria fever) and ipecacuanha root (as an emeticum) were soon incorporated into the European arsenal of medicinal plants. ${ }^{1}$ The rapidly growing demand for medicinal products derived there from resulted in a corresponding expansion in the output of pharmacies. Furthermore, new chemical compounds such as calomel, antimonials and ferrous sulfate were introduced in medicine. ${ }^{2}$ This led to increased manufacturing activities by the "chymists".

During the second half of the $18^{\text {th }}$ century chemistry developed rapidly as a science and its influence on pharmacy increased. The need that pharmacists felt to be better educated in chemistry is illustrated by the success of the chemistry courses given by chemically welleducated pharmacists such as Wiegleb, Hermbstaedt and Trommsdorff in Germany. Wiegleb taught at his boarding school both chemistry and pharmacy, and provided practical training in making chemical and pharmaceutical preparations on a large scale in his laboratory. ${ }^{3}$ Also the development of analytical chemistry was important for pharmacists. It allowed them to test the purity of their chemical preparations themselves. ${ }^{4}$ As a matter of course it was the pharmacists who applied the new techniques to medicinal plants. A result was renewed attempts to isolate the active principles from such plants.

In most German states the position of the pharmacists was protected from competition by druggists; they were the only certificated suppliers of medicinal preparations. Up to the end of the $18^{\text {th }}$ century they were required to manufacture the medicines completely in their own pharmacies or to buy these from other qualified pharmacists. It was only during the first half of the $19^{\text {th }}$ century that German pharmacists became authorized to buy some ingredients manufactured in chemical factories. ${ }^{5}$

\footnotetext{
${ }^{1}$ H. A. Bosman-Jelgersma, Poeders, pillen en patiënten (Amsterdam 1983) 53; J. Liebenau, G.J. Higby, and E.C. Stroud, Pill Peddlers - Essays on the History of the Pharmaceutical Industry (Madison Wisconsin 1990) 78.

${ }^{2}$ Liebenau et al., Pill Peddlers, 7-8.

${ }^{3}$ E. Homburg, Van beroep 'Chemiker.’ Dissertation University of Nijmegen (Delft 1993) 103.

${ }^{4}$ H. A. M. Snelders, De geschiedenis van de scheikunde in Nederland [1] (Delft 1993) 78.

${ }^{5}$ G. Huhle-Kreutzer, Die Entwicklung arzneilicher Produktionsstätten aus Apothekenlaboratorien (Stuttgart 1989) 44-66.
} 


\subsection{Alkaloids as Medicinal Products}

In the early $19^{\text {th }}$ century, two pharmacists attempted almost simultaneously to isolate the active principle from opium, the coagulated latex from the plant Papaver somniferum. ${ }^{6}$ One was Charles Derosne, a pharmacist from Paris, who, in 1803, published an article in which he described the isolation of a substance from opium that he named "Sel de Derosne", which later was shown to be a mixture of narcotine and morphine.

The other was Friedrich Sertürner, a young pharmacist from Paderborn, Germany, who was the first to isolate the active principle from a plant in a reasonably pure form and to describe its properties. He experimented with opium and published his results in a series of papers. The first paper was published in 1805 in Trommsdorff's Journal der Pharmacie; it deals with the isolation of "Opiumsäure" (meconic acid) a compound that, however, when tested turned out not to be the active principle of opium. ${ }^{8}$

In 1806 Sertürner published a paper in which he reported on the successful isolation of a compound that he characterized as the "principium somniferum", the sleep-inducing principle of opium. ${ }^{9}$ He mentions that it had alkaline-like properties (in German: "den Kalien fast ähnliche Eigenschaft") and that, to dissolve it [in water], it was sufficient to add meconic or another acid. In his publication of 1811, Sertürner is more explicit on the alkali-like properties and he writes that the sleep-inducing compound was able to form salts [with acids] (in German: "das dieser Stoff [.... ] sich als salzfähige Basis bezeigt"). ${ }^{10}$ In 1817 Sertürner is completely clear on the alkaline character of morphine. ${ }^{11}$ He mentions "the discovery of a new alkaline principle (morphine), able to form salts, similar to ammonia" (in German: "der Entdeckung einer neuen alkalischen salzfaehigen Grundlage [....] dem Morphium [....] welche sich mit der Ammoniak anzuschliessen scheint").

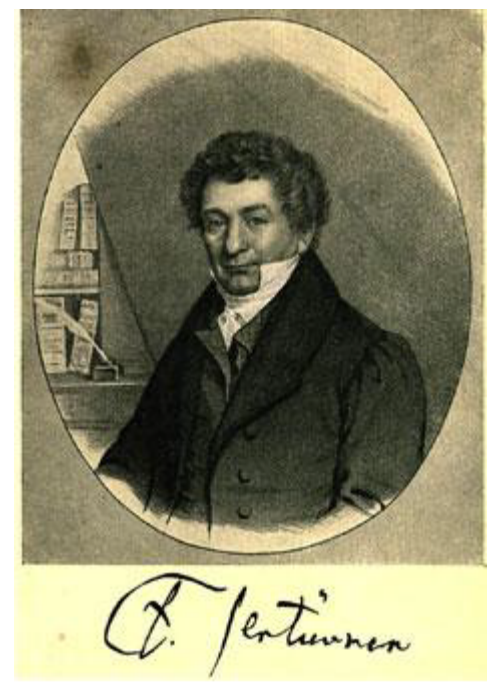

Figure 2.2

Friedrich Sertürner

(en.wikipedia.org)

\footnotetext{
${ }^{6}$ M. Goerig and J. Schulte am Esch, 'Friedrich Wilhelm Adam Sertürner - dem Entdecker des Morphins zum 150. Todestag' Anasthesiol. Intensivmed. Notfallmed. Schmerzther. 26 (1991) 492-498.

${ }^{7}$ C. L. Derosne, Annales de chimie 45 (1803) 257.

${ }^{8}$ F. W. A. Sertürner, 'Säure im Opium' Trommsdorff's Journal der Pharmacie 13 (1805) 234-235.

${ }^{9}$ F. W. A. Sertürner, 'Darstellung der reinen Mohnsäure (Opiumsäure) nebst einer chemischen Untersuchung des Opiums mit vorzüglicher Hinsicht auf einen darin neu entdeckten Stoff und die dahin gehörigen Bemerkungen' Trommsdorff's Journal der Pharmacie 25 (1806) 47-93.

${ }^{10}$ F. W. A. Sertürner, 'Ueber das Opium und dessen krystallisirbare Substanz' Journal der Pharmacie 20 (1811) Reprint Berlin 1983, 56-89.

${ }^{11}$ F. W. A. Sertürner, 'Über das Morphium, eine neue salzfähige Grundlage und die Mekonsäure, als Hauptbestandtheil des Opiums' Gilbert's Annalen der Physik 25 (1817) 62.
} 
This was something entirely new, as the influential French chemist J.-L. Gay-Lussac emphasized in 1817. Until that time scientists believed that plants contained (organic) acids, salts and ballast substances, not, however, organic alkaline compounds. ${ }^{12}$ Sertürner mentions in his publication the possibility that in the future medical doctors might use the new substance instead of opium to have more control over the action on the human body. He foreshadowed the possible isolation of other active principles from "Giftpflanzen" (toxic plants) with similar methods as used by himself. ${ }^{13}$

Sertürner's publications did not draw much attention at the time. He continued his work on the sleep-inducing compound, including further tests of its effects on animals and humans including himself. In 1817 he published the results in the widely read Gilbert's Annalen der Physik in which he named the new compound "Morphium" after the Greek God of sleep, Morpheus. ${ }^{14}$ A translation of the article into French appeared in the important journal Annales de chimie et de physique and thereupon followed international recognition of Sertürner's work.

The influential French chemist Gay-Lussac reviewed and praised Sertürner's work, mentioning in particular the importance of the discovery of the alkaline character of the active principle isolated from the opium. ${ }^{15}$ This view resulted in the search for the active principles of other medicinal plants.

Sertürner's recognition for his isolation of morphine encouraged other scientists, initially mainly pharmacists, to attempt to isolate the active principles from other medicinal and toxic plants. The hypothesis that active principles from plants had an alkali-like character proved to be correct in many cases and was a useful line of action for the practical isolation of these active principles from the plant raw material and their subsequent purification. The new compounds could usually be extracted with aqueous acid from plant raw material and subsequently precipitated as the base. Crystallization of the salts they formed with, for example hydrochloric or sulfuric acid, was often a good method of purification.

The idea of isolating the active principles from other plants was soon taken up, especially in France. In 1817, the Parisian pharmacist Pierre-Joseph Pelletier jointly with the physiologist François Magendie isolated emetine from ipecac root. ${ }^{16}$ Magendie was a physician from Paris, with strong ideas on the biological sciences, an aversion to the existing theories and a great experimenter. ${ }^{17}$

The discovery of emetine was followed in 1818 by the isolation of strychnine from Strychnos nux-vomica by Pelletier and Joseph-Bienaimé Caventou. ${ }^{18}$ Investigation of the alkaloids from the cinchona bark, an extract of which was a well-known cure for malaria fever, began with the isolation of a crude mixture by Gomez, a Portuguese physician, in

\footnotetext{
${ }^{12}$ Goerig and Schulte am Esch, 'Sertürner', 492-498; M. Hesse, Alkaloide. Fluch oder Segen der Natur? (Weinheim 2000) 319.

${ }^{13}$ Goerig and Schulte am Esch, 'Sertürner', 492-498.

${ }^{14}$ Sertürner, 'Über das Morphium', 56-89.

${ }^{15}$ Goerig and Schulte am Esch, 'Sertürner', 492-498.

${ }^{16}$ P. J. Pelletier and F. Magendie, 'Mémoire sur l'émetine et sur trois espèces d'ipecacuanha' Journal générale de médecine, de chirurgie et de pharmacie 59 (1817) 223-231.

17 'François Magendie, French Physiologist' www.whonamedit.com/doctor.cfm/2104html [accessed 09.03.2007].

${ }^{18}$ P. J. Pelletier and J. B. Caventou, Annales de chimie et de physique (Paris) [2] 15 (1820) 291 \& 337 cf. R. B. Turner and R. B. Woodward, 'The Chemistry of Cinchona Alkaloids' in: R. H. F. Manske and H. L. Holmes ed., The Alkaloids. Chemistry and Physiology 3 (New York 1950) 2.
} 
1810. From such a crude mixture, quinine and cinchonine were isolated by Pelletier and Caventou in $1820 .^{19}$

It was Wilhelm Meissner who is 1819 proposed the name "alkaloids", meaning alkalilike, for the new organic compounds. Thereby he was expressing the experience that the compounds, although capable of forming salts with acids, had other properties different from common inorganic bases. ${ }^{20}$

After 1820 German and French scientists continued to search for new alkaloids and the study thereof. Magendie tested morphine and the other recently isolated alkaloids on their physiological action. ${ }^{21}$ His book on this subject, Formulaire pour la préparation et l'emploí de plusieurs nouveaux medicaments, had a great influence on the emergence of the commercial production of alkaloids in France, Germany and other countries. It was published in 1822, and translated in German and Dutch shortly thereafter. ${ }^{22}$

Data on alkaloids isolated for the first time during the period 1805-1860 are summarized in the following table:

\footnotetext{
${ }^{19}$ P. J. Pelletier and J. B. Caventou, Annales de chimie et de physique (Paris) [2] 15 (1820) 289 cf. P. J. Pelletier and J. B. Caventou cf. M. A. W. Algera, Dr Johan Eliza de Vrij, apotheker en kinoloog (1994) 54.

${ }^{20}$ Hesse, Alkaloide, 1-2.

${ }^{21}$ Huhle-Kreutzer, arzneilicher Produktionsstätten, 130.

${ }^{22} \mathrm{~F}$. Magendie, Formulaire pour la préparation et l'emploí de plusieurs nouveaux medicaments (Paris 1822).
} 
Table 2.1 Overview of Alkaloids discovered during the period 1805-1860

\begin{tabular}{|c|c|c|c|c|}
\hline Year & Alkaloid & Raw material & Discoverer & Application \\
\hline 1806 & Morphine & Opium & Sertürner & Strong analgesic \\
\hline 1817 & Emetine & Ipecac Root & $\begin{array}{l}\text { Pelletier \& } \\
\text { Magendie }\end{array}$ & Anti-amoebic, emetic \\
\hline 1818 & Strychnine & $\begin{array}{l}\text { Strychnos nux } \\
\text { vomica }\end{array}$ & $\begin{array}{l}\text { Pelletier \& } \\
\text { Caventou }\end{array}$ & Rat poison \\
\hline 1819 & Atropine & $\begin{array}{l}\text { Atropa } \\
\text { belladonna }\end{array}$ & Runge & Mydriatic \\
\hline 1820 & $\begin{array}{l}\text { Quinine \& } \\
\text { Cinchonine }\end{array}$ & Cinchona bark & $\begin{array}{l}\text { Pelletier \& } \\
\text { Caventou }\end{array}$ & Treatment of malaria \\
\hline 1827 & Coniine & $\begin{array}{l}\text { Conium } \\
\text { maculatum }\end{array}$ & Giseke & Neurotoxin \\
\hline 1828 & Nicotine & $\begin{array}{l}\text { Nicotiniana } \\
\text { tabacum }\end{array}$ & $\begin{array}{l}\text { Posselt \& } \\
\text { Reimann }\end{array}$ & Insecticide \\
\hline 1832 & Codeine & Opium & Robiquet & Analgesic, anti-tussive \\
\hline 1833 & Colchicine & $\begin{array}{l}\text { Colchicum } \\
\text { autumnale }\end{array}$ & $\begin{array}{l}\text { Geiger \& } \\
\text { Hesse }\end{array}$ & Treatment of gout \\
\hline 1835 & Thebaine & Opium & $\begin{array}{l}\text { Thiboumery \& } \\
\text { Pelletier }\end{array}$ & $\begin{array}{l}\text { Raw material for strong } \\
\text { analgesics }\end{array}$ \\
\hline 1848 & Papaverine & Opium & G Merck & $\begin{array}{l}\text { Muscle relaxant, } \\
\text { vasodilator }\end{array}$ \\
\hline 1860 & Cocaine & $\begin{array}{l}\text { Erythroxylon } \\
\text { coca }\end{array}$ & Niemann & Local anaesthetic \\
\hline
\end{tabular}

Source: Based on Hesse, Alkaloide (2000), 322.

Note to the Table: Some of the alkaloids were used as medicines shortly after they were isolated for the first time; examples are morphine from opium and quinine from cinchona bark. Other applications were discovered only many years after the discovery of the alkaloids; examples: cocaine as a local anesthetic and papaverine as a vasodilator.

The alkaloids, when isolated and described for the first time, were often not pure or well characterized. Common impurities present in the isolated product were other alkaloids originating from the same plant. These secondary alkaloids had often a chemical structure similar to that of the main alkaloid and therefore had similar properties which made separation very difficult. During the first half of the $19^{\text {th }}$ century, analytical chemistry of organic compounds was still in its infancy and methods for testing the alkaloids for purity had still to be developed. As an example, it took until 1823 before Pelletier and Dumas found 
that emetine was a base, and the alkaloid character of atropine was not recognized before $1833 .^{23}$

However, the knowledge of the chemistry of alkaloids improved steadily during the $19^{\text {th }}$ century. Both academic organic chemists and pharmacists involved in the commercial production of alkaloids contributed to this.

In 1831 Justus Liebig was the first to determine the empirical formula of morphine. ${ }^{24}$

He recognized the nitrogen in the morphine molecule as the seat of its basic character. ${ }^{25}$ Progress with acquiring knowledge on the structure of alkaloid molecules was slow, however. This was because it was an extraordinarily difficult task at the time. Some of the basics of organic chemistry and analytical techniques had to be discovered virtually simultaneously, as part of the alkaloid research. ${ }^{26}$

It took even much longer before the structural formula of most alkaloids was established. Because of the complex structure of the alkaloids, elucidation of these structural formulas could only be achieved once organic chemistry had developed much further. An extreme example is strychnine, discovered in 1819, of which the correct structural formula was established only in $1947 .^{27}$

Total synthesis of the alkaloids can only be achieved once the structural formula is known. The first total synthesis of an alkaloid was that of coniine, which has a relatively simple structure. It was achieved by Ladenburg in 1886.

\subsection{The Commercial Production of Alkaloids until 1860}

Immediately after their discovery, alkaloids such as morphine and quinine were identified as potential medicinal products. The action of the alkaloids on the human body was shown to be essentially the same as that of the plant, although much stronger. A major advantage of using the active principle as a medicine rather than the plant itself is that the variations in the content of the active principle in the plant are eliminated and therefore the action on the patient is much more predictable. Medicinal alkaloids were prescribed by the medical profession shortly after they became available in commercial quantities.

That pharmacists were pioneers in the field can be understood as their having the commercial objective to produce alkaloids as a driving force behind their research efforts.In France, the commercial production of alkaloids on a small scale commenced in 1803 when the pharmacist Derosne from Paris offered for sale his "Sel de Derosne", a mixture of narcotine and morphine that he had isolated from opium. Pelletier started the commercial production of quinine shortly after its discovery in 1820 . Quinine was rapidly accepted by the medical profession as a treatment for malaria and fever in general. From the start its production was quite a large operation and already in 1826 Pelletier reached a dominating position in the market when he produced $1,840 \mathrm{~kg} .^{28}$

Production of alkaloids on an industrial scale commenced earlier in France than in other countries. Although pharmacists were prime movers in France, a contributing factor was the development of chemistry during the $18^{\text {th }}$ century that had promoted the establishment of a chemical industry in that country. ${ }^{29}$ The processes for the isolation and

\footnotetext{
${ }^{23}$ Hesse, Alkaloide, 323.

${ }^{24}$ L.F. Small, Chemistry of the Opium Alkaloids (Washington 1932) 138.

${ }^{25}$ Huhle-Kreutzer, arzneilicher Produktionsstätten, 78, note 3.

${ }^{26}$ Hesse shows for coniine, that the empirical formula first determined in 1831 as $\mathrm{C}_{12} \mathrm{H}_{14} \mathrm{NO}$, over time was "adjusted" to $\mathrm{C}_{13} \mathrm{H}_{22} \mathrm{NO}$, to $\mathrm{C}_{8} \mathrm{H}_{16} \mathrm{~N}$ and to $\mathrm{C}_{16} \mathrm{H}_{15} \mathrm{~N}$ until, in $1881, \mathrm{C}_{8} \mathrm{H}_{12} \mathrm{~N}$ was accepted as the correct one. Hesse, Alkaloide, 119.

${ }^{27}$ Hesse, Alkaloide, 321.

${ }^{28}$ Huhle-Kreutzer, arzneilicher Produktionsstätten, 80-82.

${ }^{29}$ Huhle-Kreutzer, arzneilicher Produktionsstätten, 16.
} 
purification of the alkaloids are in essence chemical ones and the production of alkaloids on a commercial scale was a rapid development in France. Progress of science and industrial application thereof went hand in hand. Pelletier, besides continuing the quinine production, took up the manufacture of morphine. The process he used for the extraction of opium was developed by his factory manager Thiboumery; it was published in $1835 .^{30}$

However, France gradually lost its leading position in the chemical and pharmaceutical industry. From the middle of the $19^{\text {th }}$ century, that role was taken over by Germany and the United Kingdom. It has been argued that this was caused by the "cumul" practice in France, which gave well-established chemists a multitude of part-time positions, which made it difficult for young chemists to become successful in their profession, and the competitiveness of the French chemical industry diminished. ${ }^{31}$ Another factor that contributed to the stagnation of the French pharmaceutical industry in the $19^{\text {th }}$ century was that legislation of 1803 resulted in a virtual monopoly for pharmacists with respect to the manufacture of drugs. ${ }^{32}$

In the UK alkaloid production commenced shortly after Sertürner's publication of 1817 . It is claimed that Thomas Morson of London produced morphine and quinine sulfates already in 1821 and that he built up a substantial business. ${ }^{33}$

In 1831, William Gregory a physician of Edinburgh with a strong interest in chemistry developed a new process for the isolation and purification of morphine. ${ }^{34}$ That method was soon taken up by Surgeon-Apothecary J. F. Macfarlan, also of Edinburgh, and commercial production of morphine began in Scotland in $1834 .{ }^{35}$ Also in Edinburgh, the brothers Thomas and Henry Smith, both qualified in medicine, owned pharmacies. Thomas had a keen interest in the isolation and action of drugs. ${ }^{36}$ In 1836 the brothers entered a formal partnership under the name T \& H Smith, whereby Henry took charge of commercial affairs and Thomas of production and research. T \& $\mathrm{H}$ Smith commenced manufacturing of morphine, using the Gregory process in $1837 .^{37}$

During the $19^{\text {th }}$ century both Scottish companies concentrated on opium alkaloids; quinine and cocaine were never made commercially. They faced fierce competition from England but the Edinburgh firms had the advantage of a substantially lower duty on alcohol, a solvent that was used in considerable quantities in the processing of opium. ${ }^{38}$ That financial advantage resulted in a gradual ousting of the competition. Morson commented in 1860 that there was "precious little profit in Morphia" [for him]. ${ }^{39}$

The production of morphine by T \& H Smith in 1858 is estimated at about $70 \mathrm{~kg}$ and that of Macfarlan "probably matched Smith's - may have been greater". 40 The invention of the hypodermic syringe by Dr Alexander Wood in 1853 "revolutionised the treatment of

\footnotetext{
${ }^{30}$ A. Barbier, 'The Extraction of Opium Alkaloids' Bulletin on Narcotics 2 (1950) 22-29.

${ }^{31}$ Huhle-Kreutzer, arzneilicher Produktionsstätten, 19.

${ }^{32}$ M. Robson, 'The French Pharmaceutical Industry' in Liebenau et al, Pill Peddlers 108.

${ }^{33}$ D. L. Howard, 'Presidential Address to the British Pharmaceutical Conference Aug 1926' Yearbook Pharm (1926) 347.

${ }^{34}$ W. M. Gregory, 'On a Process for Preparing Economically the Muriate of Morphia' Edinburgh Medical \& Surgical Journal 35 (1831) 331.

${ }^{35}$ K. C. Reid, The Macfarlan Smith Company. A Brief Review of its Origins. Unpublished manuscript. (1988, modified version 1990) E2.

${ }^{36}$ D. Bolton, 'The Development of Alkaloid Manufacture in Edinburgh 1832-1939' Chemistry and Industry (4 September 1976) 701-702.

${ }^{37}$ Ibidem.

${ }^{38}$ Reid, The Macfarlan Smith Company, E2.

${ }^{39}$ Ibidem.

${ }^{40}$ Ibidem.
} 
wounded soldiers in the Crimean War". ${ }^{41}$ Wood, a physician from Edinburgh published in 1855 his findings in a short paper titled "A New Method of Treating Neuralgia by the Direct Application of Opiates to the Painful Points". ${ }^{42}$ This invention certainly contributed to an increased demand for morphine.

Liebenau reports on the production of alkaloids in the USA that during the aftermath the war of 1812 it became economically attractive to produce basic remedies locally rather than importing them from England. ${ }^{43}$ Laboratories of many pharmacies were converted into manufacturing plants. An early example (1818) is the Marshall Drug Store in Philadelphia that began large-scale production of pharmaceutical products that included opiate (opium?) preparations from an unknown date thereafter. The firm Rosengarten and Sons which had its origin in the partnership of the immigrants Seitler and Zeitler offered in the 1830's morphine salts, quinine sulfate and strychnine. Rosengarten and Sons, and Powers and Weightman were the only firms that produced quinine sulfate on a large scale before the civil war of $1862 . .^{44}$

Gabriele Huhle-Kreutzer notes that while in France Pelletier and Caventou soon reached a dominant position in the quinine market, in Germany the early alkaloid chemists, Sertürner, Geiger and Runge did not capitalize on their discoveries. ${ }^{45}$

It was the translation of Magendie's book that drew the attention of several German pharmacists to the production of alkaloids. One of them was Emanuel Merck. ${ }^{46}$ In 1816 Merck had assumed control of his fathers "Engel Apotheke" (Angel Pharmacy) at Darmstadt which had been in possession of the Merck family since 1668. He proved to be both a good scientist and an astute businessman, and already in 1823 Merck commenced production of morphine. From 1827 his production exceeded the requirements of his own pharmacy and he offered morphine salts to other pharmacists. ${ }^{47}$ Emanuel Merck was not the first to produce alkaloids on a larger scale, as the pharmacist Friedrich Koch had started the commercial production of quinine in Oppenheim in $1824 .^{48}$

From the start Emanuel Merck saw each and every alkaloid (he calls them "the most excellent vegetable alkalines") as his field of activity. From the very beginning Merck put emphasis on manufacturing of alkaloids of high purity. He experimented on improving methods of isolation and purification and published his results in Geiger's Magazin für Pharmacie. His first publication, from 1826, was titled "On the Preparation of Morphium".49

In 1827 Merck presented to the medical and scientific community a collection of sixteen alkaloids and alkaloid-salts as his Pharmaceutisch-chemisches Novitäten-Cabinet, containing morphine, narcotine, quinine, cinchonine, piperine, emetine, strychnine and brucine. ${ }^{50}$ Merck's intention was to bring his new class of medicinal products to the attention

\footnotetext{
${ }^{41}$ A. Walker, 'The Pain and Pleasure Principle' Chemistry in Britain (2002) 24-27.

${ }^{42}$ Edinburgh Medical and Surgical Journal, 1855. Ref: Hypodermic Needle - Syringe Needle www.inventors.about.com [accessed on 24.06.2007].

${ }^{43}$ J. Liebenau, Medical Science and Medical Industry - The Formation of the American Pharmaceutical Industry (Baltimore 1987) 11-18.

${ }^{44}$ Ibidem, 18.

${ }^{45}$ Huhle-Kreutzer, arzneilicher Produktionsstätten, 80-82.

${ }^{46}$ Huhle-Kreutzer, arzneilicher Produktionsstätten, 130-132.

${ }^{47}$ S. Bernschneider, W. T. Huber, I. Possehl, "Was der Mensch thun kann . . . ." History of the Pharmaceutical and Chemical Company Merck $3^{\text {rd }}$ ed., (Darmstadt 2002) 28.

${ }^{48}$ Huhle-Kreutzer, arzneilicher Produktionsstätten, 81, 336.

${ }^{49}$ Bernschneider et al., "Was der Mensch thun kann . . . ." 30.

${ }^{50} \mathrm{H}$. Dumitriu, Die wissenschaftlische Entwicklung der Alkaloidchemie am Beispiel der Firma Merck in den Jahren 1886-1920 Inaugural Dissertation (Heidelberg 1993) 24.
} 
of physicians and pharmacists and to enable them to do experimental work. ${ }^{51}$ Lists of dates of the commencement of the production of various alkaloids at Merck have been published; however no information is provided on the quantities produced. ${ }^{52}$ It should be assumed that for the majority of the alkaloids only small quantities were produced in or before 1827 . In Merck's production statistics 1832-1855 only morphine and salts, strychnine and veratrine appear; no other alkaloids.

Table 2.2 Statistics Alkaloid Production ( $k g$ )

E. Merck 1832-1855

\begin{tabular}{|c|c|c|c|}
\hline Year & $\begin{array}{c}\text { Morphine and } \\
\text { Salts }\end{array}$ & Strychnine & Veratrine \\
\hline 1838 & - & - & 2.8 \\
\hline 1841 & - & 19 & 5.6 \\
\hline 1842 & 78.5 & - & - \\
\hline 1847 & 285 & 58 & 22 \\
\hline
\end{tabular}

Source: Bernschneider 53

The purity of the alkaloids produced by Merck was high in comparison to the quality of alkaloids produced by others at the time. During the $19^{\text {th }}$ century the Merck products became the recognized standard of purity worldwide. Merck alkaloids were recognized as superior to those offered by other producers, including those from France, at the "General German Industrial Exhibition", in Mainz in $1842 .{ }^{54}$

Testing of purity in a modern sense was, however, not possible at the time because the necessary analytical techniques were not available. The quality of pharmaceutical bulk products were largely judged on appearance: well-formed white crystals or colorless clear liquids and on some other characteristics such as melting point. The accurate composition of the products was not always known. As an example: emetine was produced by Merck before 1832. But it took until 1894 before Paul and Cownley showed that emetine of the trade is the mixture of two alkaloids; emetine and cephaline. ${ }^{55}$

In Germany there was a certain amount of specialization in the alkaloid production. Merck was the most diversified company; after 1831 it produced most of the known alkaloids with the exception of quinine. The factories of Trommsdorff and Riedel manufactured a range of alkaloids but not as extensive as Merck's range. ${ }^{56}$ With respect to quinine, the situation was different. Quinine was a commercially important alkaloid which was manufactured by some as a single product. After Koch, who started production in 1824, Riedel, Merck and Jobst and some smaller producers commenced quinine manufacture around 1828. Because of the strong competition, quinine prices were unstable and for that

\footnotetext{
${ }^{51}$ Huhle-Kreutzer, arzneilicher Produktionsstätten, 131.

${ }^{52}$ Dumitriu, Entwicklung der Alkaloidchemie, 199.

${ }^{53}$ Bernschneider et al., “Was der Mensch thun kann ...", 31; Huhle-Kreutzer, arzneilicher Produktionsstätten, 135-137.

${ }^{54}$ Bernschneider et al., "Was der Mensch thun kann ...", 33.

${ }^{55}$ Dumitriu, Entwicklung der Alkaloidchemie, 61.

${ }^{56}$ Huhle-Kreutzer, arzneilicher Produktionsstätten, 81-82.
} 
reason Merck and Riedel discontinued quinine production from ca 1831. They kept quinine on their respective pricelist however; they resold the product bought from the actual producers. ${ }^{57}$

Hermann Trommsdorff started alkaloid production in 1837-1838 in the pharmacy of his father. ${ }^{58} \mathrm{He}$ specialized in the manufacture of atropine, coniine and veratrine which he supplied to Merck and Riedel. In return he received morphine, codeine and strychnine from Merck and quinine from Zimmer. ${ }^{59}$ We see that a collaboration and allocation of tasks existed within the group of German alkaloid manufacturers. The collaboration extended also to training of young pharmacists, often sons of the owners of other pharmacists (e.g. Hermann Trommsdorff was trained by E. Merck, who had been taught by Hermann's father Johann B. Trommsdorff twenty years earlier). ${ }^{60}$ In 1837 Conrad Zimmer, a former employee of Merck, started his own quinine factory. During the period 1855-1859 two more new quinine producers were established: Chininfabrik Braunschweig, Buchler \& Co and C. F. Boehringer, Mannheim. ${ }^{61}$ At that stage these companies did not produce other alkaloids.

\subsection{Alkaloids at the Inception of the Modern Bulk Pharmaceutical Industry}

The discovery of alkaloids and their pharmaceutical application added a new opportunity, that of producing them, to the activities of the pharmacist. Pioneers in the field, such as Sertürner and Pelletier, were pharmacists and they produced the alkaloids in their own pharmacies. In the beginning of the $19^{\text {th }}$ century advanced pharmacies in Germany contained a special section (room) where large quantities of certain preparations were made and that room also served as the place of training and for experimental work. ${ }^{62}$ It was obvious from the beginning that production of alkaloids was very much an operation that was much more suited to be accomplished in a specialized manufacturing facility than by individual pharmacists in their own pharmacy. That is how the alkaloid industry commenced. Pharmacists Pelletier and Caventou in France and Merck and Koch in Germany took on alkaloid manufacture on a scale beyond the requirements of their own pharmacies and supplied the products to other pharmacists. Manufacture on a large scale had clear advantages: it was a better guarantee for quality of the alkaloids manufactured because specialists were controlling the complex operations; mother liquors could be processed, and solvents regenerated. Last but not least; the plant raw material could be purchased in large quantities, and be of tested quality. It should be noted that initially the manufacturing facilities were very small by today's standards. As an example: the building in which the production of alkaloids took place at Merck in Darmstadt was until 1850 called the "laboratory". It was only after further expansions that Emanuel Merck himself talked about "factory buildings". 63

\footnotetext{
${ }^{57}$ Ibidem, 175-176.

${ }^{58}$ Ibidem, 151-154.

${ }^{59}$ Ibidem.

${ }^{60}$ Bernschneider et al. "Was der Mensch thun kann ...", 22.

${ }^{61}$ E. P. Fischer, Wissenschaft für den Markt (München 1991) 54-56.

${ }^{62}$ Huhle-Kreutzer, arzneilicher Produktionsstätten, 84.

${ }^{63}$ Bernschneider et al. "Was der Mensch thun kann ...", 37.
} 
Alkaloids are complex organic compounds. They were the first representatives of a new class of products, that of bulk pharmaceuticals. Bryant concludes that:

"The production of alkaloids in factories in the first half of the $19^{\text {th }}$ century can be considered as the founding of the modern bulk pharmaceutical industry". ${ }^{6}$

Bulk pharmaceuticals, or as they are called today Active Pharmaceutical Ingredients (API's), are the substances responsible for the pharmacological effect of the medicines made there from. Bulk pharmaceuticals are well defined organic compounds with strong physiological action, made by using the methods of chemical technology; they are delicate fine chemicals, of high purity, commonly with a small production and sales volume, and they are (usually) expensive.

Soon after the isolation of alkaloids, active principles were isolated from plants that were not alkaline substances. These compounds did not contain nitrogen and hence they were not alkaloids. Examples are salicin (salicyl alcohol glucoside), an analgesic isolated from the bark of poplar and willow by the French pharmacist Leroux in 1829 and santonin (a naphthalene derivative), an anthelmintic isolated from wormseed by Kahler and independently by Alms in 1830. Both salicin and santonin are bulk pharmaceuticals; they were manufactured by Merck around 1840.

The bulk pharmaceutical industry continued to expand rapidly during the second half of the $19^{\text {th }}$ century. Merck remained the leading alkaloid manufacturer in Germany, with Gehe \& Co., Knoll (codeine) and Zimmer and Boehringer-Mannheim (quinine) entering the alkaloid market. In the UK, Macfarlan and T. \& H. Smith expanded their opiate production considerably towards the end of the century. In the USA, Parke-Davis and Squibb were the main cocaine suppliers, while Mallinckrodt commenced opiate production in the 1890s.

From 1850 onwards the use of synthetic organic compounds in medicine became gradually more important. Examples of such compounds introduced in medicine were: phenol (a disinfectant), choral hydrate (a hypnotic), salicylic acid and aspirin (a fever and pain reducing agent). Fine chemical divisions of large German chemical companies such as Bayer and Farbwerke Hoechst became major manufacturers of bulk pharmaceutical products made by chemical synthesis. ${ }^{65}$

Still later, around 1900, the bulk manufacturers started to promote and sell the formulated products (e.g. as tablets) under their own name. Early examples are "Pyramidon" (an antipyretic) by Farbwerke Hoechst in 1897 and "Aspirin" by Bayer in 1899. This move was the beginning of the modern pharmaceutical industry as we know it today.

Customers of the alkaloid manufacturers were mainly wholesalers, pharmacists and other pharmaceutical companies. Manufacturers published pricelists to bring their products to the attention on the customers. Merck was a pioneer with respect to pharmaceutical marketing. From the beginning Merck presented itself in the market as a science based company and made the knowledge that it had acquired on the products available to physicians and pharmacists in the form of regular publications. ${ }^{66}$ That approach installed trust in the company and promoted important feed-back on the experiences with the Merck products from medical practitioners. At Merck, strong emphasis was placed on quality, the purity of its

\footnotetext{
${ }^{64}$ R. J. Bryant, 'The Manufacture of Medicinal Alkaloids from the Opium Poppy' Chemistry and Industry (March 1988) 146-153.

${ }^{65}$ T. J. Rinsema, De natuur voorbij. Het begin van de productie van synthetische geneesmiddelen Dissertation University of Leiden (Meppel 2000).

${ }^{66}$ Bernschneider et al., “Was der Mensch thun kann ...”, 28-29, 60.
} 
products. The purity of the Merck product became the standard against which the quality of the same product manufactured by others was measured. ${ }^{67}$

From about 1850 pharmacopoeias, officially published books containing lists of drugs, their preparation, properties and quality requirements, appeared in most European countries. Sections on the major alkaloids were included. Alkaloids used in pharmaceutical preparations had to comply with the initially scant, but in later editions of the pharmacopoeias more extensive, quality standards. Through this development alkaloids became commodities i.e. products that are considered identical irrespective of their provenance provided that they comply with certain established quality specifications. The result was that although the reputation of the manufacturer remained important, price became a factor for the customer with respect to his decision from which supplier to buy.

A characteristic of the market for pharmaceutical alkaloids is that the demand for the products is very inelastic. Because alkaloids are essential medicinal products, any shortage in supply will cause a sharp price increase while oversupply will result in price decline. As health is at stake, the price of such indispensable medicine is only a minor consideration. On the other hand, lower prices for such products do not result in increased consumption.

The raw materials for alkaloids are natural products of plant origin and their availability depends on the result of the harvest which is affected by the climatic conditions in a particular year. This dependence on the weather causes the alkaloid markets to be inherently unstable and result often in considerable price movements.

As discussed in section 2.2 the German alkaloid manufacturers collaborated from the inception of the industry. That was a natural development. Pharmacies were family businesses that were passed on to the next generation, the sons succeeding the fathers as the pharmacist. Leading pharmacists knew each other well and often maintained friendly relationships, the sons serving apprenticeships at the pharmacy of a befriended colleague.

This arrangement led as a matter of course to a transfer of technology between the German pharmacists/alkaloid manufacturers. As we have seen, Merck is a prime example; Emanuel Merck was trained by Johann B. Trommsdorff and Trommsdorff's son Hermann was apprentice at the Merck factory 20 years later. Also Gustav Riedel and Conrad Zimmer were trained by Merck. ${ }^{68}$ Zimmer was subsequently employed by Friedrich Jobst for setting up a quinine factory in Stuttgart.

The close relationships between the German alkaloid manufacturers led also to specialization whereby not all manufacturers produced the whole range of alkaloids, but supplied each other with the ones in which they had specialized (see Section 2.2 for examples). A result was that for most of the $19^{\text {th }}$ century we do not see strong competition and strong price fluctuations in the German alkaloid market, with the exception of the market for quinine.

The collaborations discussed in the previous section appear to have been quite informal. Towards the end of the $19^{\text {th }}$ century the collaborations between manufacturers were put on a more formal basis. This often took the form of a written agreement, a cartel, whereby prices and production quota were agreed upon. The name "Convention" (German: Interessengemeinschaft) was often used for such arrangements. ${ }^{69}$

The quinine market had all the characteristics of an open inelastic commodity market with sharp price fluctuations from the start. ${ }^{70}$ As a result Merck ceased quinine production

\footnotetext{
${ }^{67}$ Rinsema, De natuur voorbij, 259.

${ }^{68}$ Huhle-Kreutzer, arzneilicher Produktionsstätten, 176; Fischer, Wissenschaft für den Markt, 54-56.

${ }^{69}$ K. Burkert, Die deutsche "Pharmazeutische Interessengemeinschaft" (1906-1918) (Stuttgart 1990) 31-34.

${ }^{70}$ Huhle-Kreutzer, arzneilicher Produktionsstätten, 80-82.
} 
already in $1831 .^{71}$ To bring the situation somewhat under control and to restore profitability, new entrants to the market, Zimmer and Boehringer-Mannheim, established a quinine convention in $1859 .^{72}$ In 1883 members of the quinine convention were Boehringer, Zimmer, Jobst, Société Traitement des Quinquinas (Paris), Chininfabrik Braunschweig and the Amsterdamsche Chininefabriek (ACF). ${ }^{73}$ The ACF was founded in 1881 and became a member of the convention shortly thereafter. This is an example of the convention accepting the newcomer as a member rather than fighting him on price. In 1902 Merck was a member of a large number of conventions in which many other German manufacturers were also involved. ${ }^{74}$

Cartels and conventions were not illegal in those days. ${ }^{75}$ In practice such arrangements were not easy to operate successfully. Strong rivalry between the participating companies often existed and vexation and friction were not uncommon. ${ }^{76}$ Hexner writes: "It would be a mistake to assume that co-operation among chemical companies extinguished international industrial rivalry". ${ }^{77}$ Dethloff's opinion of alkaloid cartels was that "in both the opiate convention and the cocaine convention an unhealthy climate prevailed". ${ }^{78}$

\subsection{Summary and Conclusions}

The German pharmacist Sertürner was the first to isolate an "active principle" from a medicinal plant. His experiments were performed during the period 1806 to 1817 . He isolated morphine, the sleep inducing principle from opium and found that morphine exerted the same action on humans and animals as opium but much stronger. Sertürner also discovered the alkaline character of morphine. Morphine was to become the first representative of a new class of organic compounds named alkaloids: alkaline compounds, isolated from plants, exhibiting a significant physiological activity. Many more alkaloids followed; a few early examples are atropine, quinine and nicotine. It was shown that the alkaloids had the same action on the human body as the plant part from which they were isolated, but more powerful. That led to the use of alkaloids as medicinal products with the advantage over the plant that the dosage could be controlled much more precisely.

Commercial production of alkaloids began soon after their discovery. France led the way. Quinine was produced on quite a large scale during the 1820 s by the pharmacist Pelletier in Paris. However, France gradually lost its leading position; that role was taken over by Germany and Scotland. Pharmacists E. Merck, Darmstadt, and Macfarlan and T. \& H. Smith in Edinburgh were the prime movers here. Production of alkaloids initially took place in the "laboratories" of their pharmacies. Later these were expanded to become real factories. This development can be considered as the founding of the modern bulk pharmaceutical industry.

The alkaloid industry continued to expand during the second half of the $19^{\text {th }}$ century. Processes for the production of alkaloids gradually improved with experience; this facilitated the manufacture of new alkaloids such as cocaine. New manufacturers entered the market but there was specialisation, and for each alkaloid there were only a small number of manufacturers; the alkaloid market was a collection of oligopolies.

\footnotetext{
${ }^{71}$ Ibidem, 135-137.

${ }^{72}$ Fischer, Wissenschaft für den Markt 54-56.

${ }^{73}$ E. Homburg, Review of: Ziegler, V., 'Die Familie Jobst und das Chinin' Ambix 54 (2007) 102-103.

${ }_{74}$ Merck, Conventionen und Vertretungen, Bericht über das Geschäftsjahr (1901-1902) Merck-Archiv F03/6a.

${ }^{75}$ E. Hexner, International Cartels (London 1946) 296-339.

${ }^{76}$ Bernschneider et al. "Was der Mensch thun kann ...", 77.

${ }^{77}$ Hexner, International Cartels, 296-339.

${ }^{78}$ W. Dethloff, Gründung der Firma und Weiterentwickling der Abteilung Pharmazeutische Chemikalien.

(Section on cocaine). Manuscript ca 1957 Ingelheim, Firmen- und Familienarchiv von C. H. Boehringer Sohn.
} 
The market for pharmaceutical alkaloids is very inelastic. Any shortage causes a sharp price increase while oversupply results in price decline, sales volume remaining virtually unchanged. In attempts to control excessive price fluctuations manufacturers formed "conventions" (cartels) to agree on production quota and prices. Access to a reliable source of the plant raw material at a low cost is essential for the long term success of the alkaloid manufacturer.

Towards the end of the $19^{\text {th }}$ century the alkaloids morphine, codeine, quinine, cocaine, pilocarpine and atropine were important pharmaceutical products. Manufacturers were mainly located in Germany, the UK, the USA and in France. Interest from the Netherlands in commercial alkaloid enterprises dates from 1872, after the first auction of Cinchona ledgeriana bark with a high alkaloid content. Quinine was produced from the bark by the Amsterdamsche Chinine Fabriek from 1882.

The coca plant, the raw material for cocaine, was cultivated on a commercial scale on Java from the late 1880s onwards. This led ultimately to the founding of the Nederlandsche Cocaine Fabriek in 1900. The discovery of cocaine and the emergence of the cocaine industry is the subject of the next chapter. 


\section{Chapter 3 \\ THE Discovery OF COCAINE AND THE EMERGENCE OF THE COCAINE INDUSTRY}

This chapter provides an outline of the history of the coca plant and cocaine until the end of the $19^{\text {th }}$ century. 1900 was the year that the Nederlandsche Cocaine Fabriek (NCF) was established and entered the market for cocaine; the situation of the cocaine industry at the time is described. It was the situation the NCF had to face upon entering the market and which had been evaluated by the founders of the company for their decision whether or not to proceed with the project.

The description primarily deals with the developments from 1860, the year of the isolation of cocaine, and concentrates on the years from 1884, when the local anaesthetic properties of cocaine were discovered and a rapidly growing market for the product emerged.

\subsection{The Coca Plant and its Origin}

The coca plant is an evergreen shrub, the leaves of which contain cocaine. It is indigenous in Peru and Bolivia where it occurs naturally on the eastern slopes of the Andes. The Indians of the Andes had been aware of the effects of ingestion of coca leaves for a very long time. Excavated ceramic figurines of Coqueros (coca-chewers) and lime pots indicate that the custom of chewing coca leaves could be more than a thousand years old. It is certain that coca leaves were chewed during the Inca empire. ${ }^{1}$ It is plausible that the habit was taken up by the Indians of Peru and Bolivia to endure fatigue and hunger while working under harsh conditions at high altitudes. The cocaine from the leaves produces local anesthesia of the stomach, so that hunger and thirst are not felt; the cortex of the brain is stimulated and the sensation of fatigue disappears. ${ }^{2}$

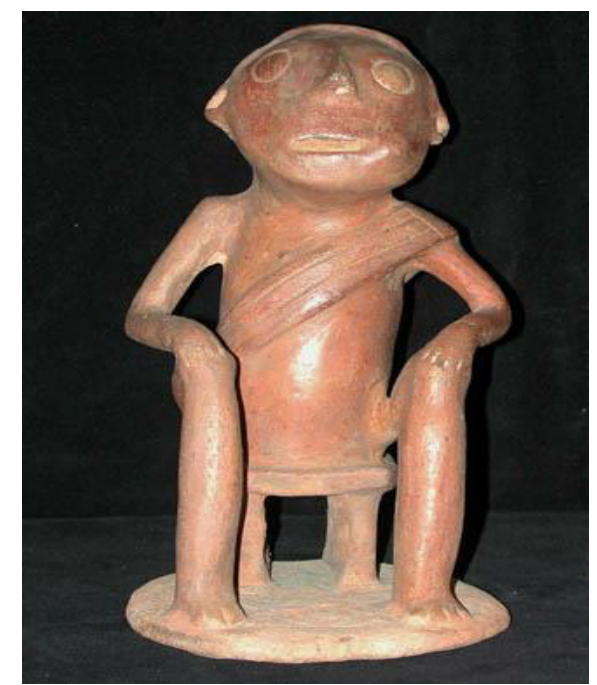

Figure 3.1

Coquero (a coca-chewer) Figurine

Highland Narino region, Colombia

$850 A D-1500 A D$

(The Morley Collection, University of Kansas)

\footnotetext{
${ }^{1}$ V. W. Von Hagen, 'The Commission of Enquiry on the Coca Leaf', Bulletin on Narcotics 1 (1949) 20-41.

2 'Cocaine' Encyclopedia Britannica Vol 5 (Chicago 1963) 994.
} 
Coca cultivation was well established in South America before the arrival of the Spaniards in the early 1500 s. $^{3}$ The habit of chewing coca leaves by the South American Indians continues today.

The first botanist to collect a sample of the coca plant was Joseph de Jussieu, who came to South America in the $18^{\text {th }}$ century with the expedition of the French mathematician la Condamine. In 1750, Joseph sent the sample of the coca plant together with other botanical specimens to his brother Antoine in Paris, who passed them on to the Museum of Natural History. ${ }^{4}$ Later this coca specimen was examined by Lamarck, who described it in his Encyclopédie Méthodique of $1786 .^{5}$ The coca plant was placed in the genus Erythroxylon (the name meaning red-wood) and the species received the name Erythroxylon coca Lamarck.

Around 1850 more samples of coca were sent to Europe and some of these were morphologically considerably different from the plant described by Lamarck. ${ }^{6}$ These samples originated from different regions. Coca leaves were traded under the name of the region of origin e.g. coca from Huánuco, Cuzco and Truxillo. In the 1870s the coca plant was not only cultivated in Peru but also in Ceylon and in Java. These plants were different from those cultivated in Peru.

Burck, chief-botanist at the Government Botanical Gardens at Buitenzorg (Java), who reviewed the situation in a publication of 1890 , concluded that all samples from Peru and Bolivia, including the sample collected by de Jussieu, were from cultivated plants. ${ }^{7} \mathrm{He}$ distinguished four different types of Erythroxylon coca: ${ }^{8}$
Botanical name
Trade name
E. coca Lamarck
Not much cultivated
E. coca var. novogranatense Morris
Peruvian or Trujillo coca
E. coca var. spruceanum Burck
Java coca
E. bolivianum Burck
Bolivian or Huánuco coca

Peruvian or Trujillo coca was the type preferred by native users. It was rich in aromatic compounds and contained crystallisable alkaloid (cocaine) and uncrystallisable alkaloids in about equal proportions. ${ }^{9}$ It was extensively used in the manufacture of

coca-beverages and coca-wines. ${ }^{10}$ The alkaloids of Bolivian or Huánuco coca consisted mainly of crystallisable alkaloid (cocaine). This coca was initially the preferred type for producing cocaine. The coca collected by de Jussieu came from Bolivia. ${ }^{11}$ Java coca stood out in terms of its high total alkaloid content, uncrystallisable alkaloids prevailing. After 1910 it became the major raw material for the manufacture of cocaine $\mathrm{HCl}$.

\footnotetext{
${ }^{3}$ A. G. Gibson, 'Freud's magical drug (Erythroxylon coca)' From: Course on economic botany at the UCLA (1984 - .....). www.botgard.ucla.edu/. Accessed 2004.

${ }^{4}$ W.G. Mortimer, History of Coca: "The Divine Plant" of the Incas (New York 1901 reprinted 1974) 165.

${ }^{5}$ W. Burck, 'Opmerkingen over de onder de naam Erythroxylon coca in Nederlandsch-Indië gecultiveerde gewassen', Teysmannia, 1 (1890) 385-398 and 449-467, p 452.

${ }^{6}$ Ibidem, 450.

${ }^{7}$ Ibidem, 449.

${ }^{8}$ Ibidem, 452-456.

${ }^{9}$ Mortimer, History of coca, 342-344.

${ }^{10}$ T. Plowman, 'The identification of Coca (Erythroxylum species): 1860-1910', Botanical Journal of the Linnean Society 84 (1982) 350.

${ }^{11}$ Mortimer, History of coca, 252.
} 
The trade names of coca were quite confusing and sometimes contradictory. The name 'Bolivian or Huánuco coca' referred to Bolivia as a country and Huánuco as a town in the centre of Peru respectively, which were quite a distance apart. The quality of the leaves from both regions was apparently similar but, for what in trade publications was referred to as Huánuco coca, the country of origin of coca could well have been Bolivia. Another example of the confusion: during the period 1880-1890 Gehe's Handelsbericht distinguished between three varieties of coca: coca from Bolivia, coca from Peru and coca from Truxillo; after 1890 Gehe also mentioned Huánuco and Cuzco coca. ${ }^{12}$ Peruvian and Truxillo were considered to be different by Gehe while Burck grouped the two together. Furthermore Gehe (1897) reported on exports from all ports of Peru. Because coca from Bolivia was mainly exported via the port of Mollendo in South Peru, the reported amounts will have included coca from Bolivia.

Other botanists disagreed with Burck's classification of the Erthroxylon species and varieties. Henry Rusby and O. E Shultz proposed other classifications and corresponding name changes. ${ }^{13}$ Although botanically correct, these further name changes contributed to the confusion with respect to the names used for the coca. The taxonomic problem goes ultimately back to the great variability of the Erythoxylon species which made classification and identification difficult.

More recently, in 1982, Plowman, after an extensive review of all botanical evidence concluded that four (cultivated) varieties of the coca plant exist: ${ }^{14}$

Botanical name

Erythoxylum coca var. coca

Erythoxylum coca var. ipadu

Erythoxylum novogranatense var. novogranatense

Erythoxylum novogranatense var. truxillense
Trade name

Bolivian or Huánuco coca

Amazonian coca

(not traded)

Columbian or Java coca

Peruvian or Truxillo coca

In 2005 Johnson et al. published an article on their research regarding the genetic diversity within and among the four Erythoxylum taxa, using DNA fingerprinting (AFLP) and other methods, to assess the pattern and level of genetic variation. ${ }^{15}$ Their conclusion was that there is a clear distinction between $E$. coca and E. novogranatense but that the differentiation between E. novogranatense var. novogranatense and E. novogranatense var. truxillense (the genetic distance) was negligible. The plants cultivated in various regions should be considered as cultivars.

NB: the name of the genus has been changed, from Erthroxylon to Erythoxylum.

\footnotetext{
${ }^{12}$ Gehe's Handelsberichte were published from 1876 to 1914 by the company Gehe \& Co., Dresden. Gehe \& Co was a well respected firm founded in 1835, that originally manufactured and traded in dried medicinal herbs and later also in galenic preparations and pharmaceutical substances such as alkaloids. The Handelsberichte contained reliable information on the trade in pharmaceutical raw materials and were a valued source of information for the industry as a whole.

${ }^{13}$ H. H. Bushby, 'The botanical origin of coca leaves' in: S. B. Karch A History of Cocaine. The Mystery of Java Coca and the Kew Plant (London 2003) 205-218; O. E. Schultz, 'Erythoxylaceae' in A. Engler (Ed.) Das Planzenreich 4134 (1907) 1-64, ref. A. W. K. De Jong, 'De Cocaplanten', Teysmannia 19 (1908) 419.

${ }^{14}$ Plowman, 'The identification of Coca, 329-353.

${ }^{15}$ E. L Johnson, D. Zhang and S. D Emchie, 'Inter- and Intra-specific Variation among Five Erthyroxylum Taxa Assessed by AFLP', Annals of Botany 95[4] (2005) 601-608.
} 


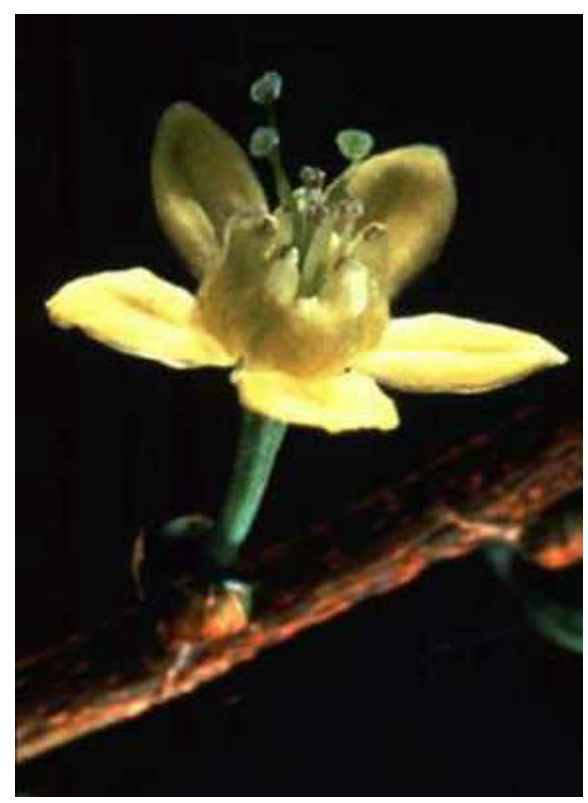

Figure 3.2

Erythoxylum coca, Flower (Google Images/cocaine.org)

Figure 3.3

Erythroxylum novogranatense leaves and fruit (Google Images/en.wikipedia.org)

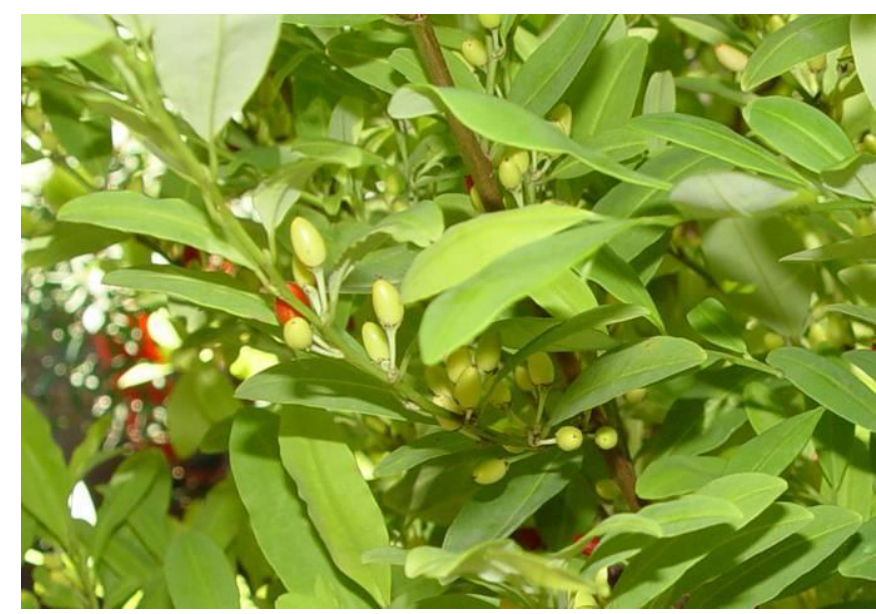

\subsection{Coca in Europe and the USA and the Discovery of Cocaine as a Local Anesthetic}

The existence of coca and its properties became known in Europe through early Spanish visitors to the New World. The first person who reported on the stimulating effects of coca was the Jesuit Bernabé Cobo, in 1653. He also noted that toothache disappears when coca leaves are chewed. ${ }^{16}$ However, the plant did not arouse great interest in Europe. It was only much later, in 1836, that the German scientist Eduard Pöppig, after travelling the Amazon region, described the sustaining power of coca, including a warning of the dangers of coca abuse. ${ }^{17}$ Another traveller, the French botanist Weddel who participated in a scientific expedition sent out by King Louis Philippe in 1845 confirmed the stimulant action of coca. ${ }^{18}$ These publications drew attention and the Austrian naturalist Carl von Scherzer became interested in the plant. During his stay in Peru in 1857-1858 he collected a fair sized sample of the leaves of Erythoxylum coca, which he sent to professor Friedrich Wöhler in Göttingen for analysis. Wöhler entrusted the research on the contents of the coca leaves to his assistant, Albert Niemann. ${ }^{19}$ The leaves collected by Von Scherzer and used by Niemann were of the

\footnotetext{
${ }^{16}$ J. Calatayud and A. González, 'History of the development and evolution of local anesthesia since the coca leaf', Anesthesiology 98[6 (2003) 1503-1508.

${ }^{17}$ Mortimer, History of Coca, 171.

${ }^{18}$ Ibidem, 172-173.

${ }^{19}$ S.B. Karch, A Brief History of Cocaine $2^{\text {nd }}$ Ed (Boca Raton 2006) 24-25; Mortimer, History of Coca, 296.
} 
same variety as those collected by de Jussieu. Burck classified these leaves as from $E$. Bolivianum (now: E.coca var. coca). ${ }^{20}$

Niemann was able to isolate an alkaloid in a pure form from the sample. He named it cocaine and established its chemical and physical characteristics; he found that the isolated product caused numbness when it was placed on the tongue. He noted that benzoic acid was formed by heating of cocaine aurichloride. These results were published in $1860 .^{21}$ Unfortunately Niemann died in 1861 at the age of 27; his work on cocaine was continued by his colleague, Wilhelm Lossen, who established the molecular formula of cocaine in $1865 .^{22}$ Wöhler and Lossen found that cocaine, upon hydrolysis with dilute acid, yielded benzoic acid and a nitrogen containing compound of unknown structure that they named ecgonine (the name meaning "offspring"). ${ }^{23}$

Based on Niemann's work, the company E. Merck, Darmstadt, started production of pure cocaine hydrochloride on a very small scale already in $1862 .{ }^{24}$

Reports on the travels of Weddel and Von Scherzer and the subsequent discovery of cocaine brought about an increased interest in coca in Europe. Shortly after 1860 'Vin Mariani', an extract of coca leaves made with wine was developed by the French pharmacist Angelo Mariani, and it was a most successful product. It was introduced in 1863 and promoted as a tonic-stimulant that "strengthens, refreshes and restores the vital forces". Mariani was an accomplished marketing man and succeeded in building a strong branded product. By 1870 Vin Mariani was sold all over France and branch offices were established in other countries. ${ }^{25}$ The praises of Vin Mariani were sung by numerous notable people, including popes, writers, and heads of state. ${ }^{26}$ The introduction of Vin Mariani was the start of the creation of an export market for coca leaves from Peru and Bolivia.

By 1877 the use of aqueous coca extracts (teas) as a general stimulant had become quite extensive in Germany. ${ }^{27}$ By this time they were commonly used as remedies for stomach ailments, asthma and even morphine addiction. ${ }^{28}$

An even more successful product was Coca Cola, invented in the USA in 1886 by the pharmacist John S. Pemberton. It was made originally from extracts of coca leaves and cola nuts, phosphoric acid, caramel and sugar. However, the formulation was changed in 1903, after which Coca Cola was made with a de-cocainized coca extract and did not contain cocaine thereafter. ${ }^{29}$

Following the isolation of cocaine its action on animals was studied experimentally; firstly, in 1868, by the Peruvian surgeon Thomas Moreno y Maiz, who found that injecting cocaine caused insensitivity in rats, guinea pigs and frogs. ${ }^{30}$ A similar study was set up in 1880 by the Russian physician Basil von Anrep who experimented with cocaine on various animals, and

\footnotetext{
${ }^{20}$ Burck, Erythroxylon coca, 459.

${ }^{21}$ A. Niemann, 'Ueber eine neue organische Base in den Cocablättern', Achiv der Pharmacie 153 (1860) 129-55 and 291-308.

${ }^{22}$ W. Lossen, 'Ueber das Cocain', Annalen der Chemie und Pharmacie 133 (1865) 351-371.

${ }^{23}$ F. Wöhler, 'Fortsetsung der Untersuchungen über das Coca und das Cocain', Annalen der Chemie und Pharmacie 121 (1862) 372-375.

${ }^{24}$ H. Dumitriu, Die wissenschaftlische Entwicklung der Alkaloidchemie am Beispiel der Firma Merck in den Jahren 1886-1920. Inaugural Dissertation (Heidelberg 1993) 38.

${ }^{25}$ Karch, A Brief History of Cocaine, 31-36.

${ }^{26}$ Mortimer, History of Coca, 177-180.

${ }^{27}$ Gehe \& Co. Dresden, Handelsbericht, (April 1877) section Folia Cocae.

${ }^{28}$ Ibidem, (April 1883).

${ }^{29}$ D. F. Musto, 'Opium, Cocaine and Marijuana in American History', Scientific American 265[1] (1991) 20-27.

${ }^{30}$ Calatayud and González, 'Evolution of local anaesthesia'.
} 
on himself. Von Anrep concluded from his experiments that he could recommend cocaine as a local anaesthetic for surgical procedures. ${ }^{31}$ Cocaine aroused a good deal of interest by the medical profession at the time and in 1883 the German army physician Theodor Aschenbrandt published an article on his studies titled "Die physiologische Wirkung und Bedeutung des Cocain.muriat. auf den menschlichen Organismus" in which he reported on the positive effects of cocaine on Bavarian Soldiers regarding their ability to endure fatigue during manoeuvers. ${ }^{32}$

The break-through for the clinical use of cocaine came in 1884 after Karl Koller, a physician at the General Hospital in Vienna, disclosed his finding that a $2 \%$ aqueous solution of cocaine hydrochloride applied to the eye causes complete insensitivity. This cleared the way for performing eye surgery that previously had been extraordinarily difficult because of the involuntary reflex movements of the eye at the slightest touch. ${ }^{33}$

Koller had earlier done experimental work, however unsuccessfully, to achieve anaesthetic of the eyes of laboratory animals by using morphine, chloral hydrate and other compounds. It was Sigmund Freud, also working at the General Hospital in Vienna at the time, who introduced Koller to cocaine. Freud had studied the effect of the use of cocaine as a stimulant and had published the results earlier in 1884 in an article titled "Über Coca". Freud had noted the anaesthetic effect of cocaine solutions on mucous membranes. That gave Koller the idea that cocaine could also be effective as an anaesthetic for the eye. ${ }^{34}$

Koller disclosed the results of his work in September 1884 through a friend, the ophthalmologist Dr Josef Brettauer, who read Koller's short paper at a meeting of the Ophthalmologic Society at Heidelberg. A month later, Koller himself presented his epochmaking results to a meeting of the Medical Society in Vienna. At that meeting he also reported that a number of successful eye operations had been performed under cocaine anesthesia by Professor Von Reuss. The presentation was a great success for Koller. His work was published in October $1884 .{ }^{35}$ A summary of that publication appeared in the New York Medical Record of October and the authoritative British medical journal The Lancet carried an English translation in its December issue of the same year. Koller's findings were immediately accepted by the medical profession worldwide.

Despite this triumph, Koller was unable to obtain the desired position of assistant to the professor at one of the Viennese ophthalmological clinics. This was the reason why Koller left Vienna late in 1885 after being nominated as the assistant to the eminent Professor Donders at the eye clinic in Utrecht, the Netherlands. A few years later Koller migrated to the United States where he stayed, practicing ophthalmology. ${ }^{36}$

In December 1884, the prominent US surgeon Dr William Halsted and his co-worker Richard Hall reported on their finding that cocaine injected near a nerve produces total anesthesia in the area served by that nerve. ${ }^{37}$ Very soon this led to extensive use of cocaine as a local anesthetic in dentistry.

\footnotetext{
${ }^{31}$ Ibidem.

${ }^{32}$ T. Aschenbrandt, 'Die physiologische Wirkung und Bedeutung des Cocain.muriat. auf den menschlichen Organismus’ Deutsche Medizinische Wochenschrift 50 (1883) 730-732.

${ }^{33}$ H. Honegger and H. Hessler, 'Die Entdeckung der Lokalanästhesie durch Karl Koller', Pharmazeutische Zeitung 117 (1972) 1153-1159.

${ }^{34}$ Ibidem.

${ }^{35}$ K. Koller, 'Ueber die Verwendung des Cocaïns zur Anästhesirung am Auge',

Wien. Med. Wochenschrift 34 (1884) 1276-1278 and 1309-1311.

${ }^{36}$ Honegger and Hessler, 'Lokalanästhesie'.

${ }^{37}$ Calatayud and González, 'Evolution of local anaesthesia'.
} 


\subsection{The Emergence of the Cocaine Industry}

\section{Cocaine Supply during the First Three Years after Koller's discovery (1884-1887)}

At the time of Koller's discovery, E. Merck, Darmstadt, was virtually the only manufacturer of pure cocaine. The cocaine was produced in small quantities from coca leaves originating from Peru; in the year 1882-83 Merck produced 294 grams cocaine hydrochloride and in 1883-84 1,413 grams. ${ }^{38}$ Koller's discovery caused a sudden unprecedented worldwide demand for the product that could not be satisfied immediately. A first result was that stocks that would otherwise have been sufficient for years were exhausted in a few days and the price sky-rocketed. ${ }^{39}$

In Germany, Merck's price for cocaine hydrochloride, that had been Marks 6 per gram before the publication of Koller's discovery, went to Marks 15 shortly thereafter. The price reached a record Marks 23 early in 1885, to fall back rapidly to the original level later that year as a result of increased availability. ${ }^{40}$ Merck's cocaine was also traded in the USA where the price of the product increased in a similar fashion, from USD 2.50 (equivalent to ca Marks 10) per gram mid-1884 to USD 13 (ca Marks 50) in January 1885. Cocaine manufacture in the USA was started by E. R. Squibb, New York in 1884. Mid 1885 the price for cocaine from Squibb came down from USD 4.60 (ca Marks 19) to USD 1.53 (ca Marks 6) per gram. ${ }^{41}$

The sharply increased demand for cocaine resulted in an immediate shortage of its raw material, coca leaves from South America. The price for the coca moved up very rapidly to 4-5 times the original price and much of the coca offered for sale was of doubtful quality. Originally most coca leaves that were traded contained ca $0.3 \%$ crystallisable cocaine but after the onset of the shortage the average cocaine content of available coca was substantially less. ${ }^{42}$ The stocks of coca in Europe and in the USA were virtually nil early 1885 but the situation changed rapidly and from 1885 onwards substantial quantities of coca leaves were shipped from Peru/Bolivia to the United States (to New York, 130 tonnes in 1885) and to Germany (to Hamburg, 86 tonnes in 1886). ${ }^{43}$ This influx satisfied the demand and prices for the leaves came back to the original level. ${ }^{44}$ The shortage of the coca leaves available for export was actually caused by a lack of drying and packing facilities in the countries of origin rather than a shortage of the leaves. The annual production of coca leaves at the time has been estimated at ca 7,000 tonnes for Peru and ca 3,500 tonnes for Bolivia. ${ }^{45}$ That large quantity was mainly produced for consumption by the local coca-chewers. The demand for coca as a raw material for cocaine production and for beverages was only a small fraction thereof. As an example: 500 tonnes of coca at a conservative yield of $0.3 \%$ would be sufficient to produce $1,500 \mathrm{~kg}$ of cocaine.

For coca intended for export it was essential that coca leaves were harvested during dry weather; rain would immediately spoil the product by initiating fermentation, resulting in a black discoloration and a reduction of the alkaloid content. For the same reason the leaves had to be carefully dried as soon as possible after harvest. ${ }^{46}$ Finally the coca needed to be

\footnotetext{
${ }^{38}$ A. Hirschmüller, 'E. Merck und das Kokain’ Gesnerus 52 (1995) 116-132.

${ }^{39}$ Gehe, Handelsbericht, (April 1885) 59.

${ }^{40}$ H. R. Friman, 'Germany and the transformations of cocaine, 1860-1920' Chapter 4 in: Gootenberg P, editor. Cocaine: Global Histories (London 1999) 85; Gehe, Handelsbericht, (September 1885) 33.

${ }^{41}$ Hirschmüller, 'E. Merck und das Kokain', 130.

${ }^{42}$ Gehe, Handelsbericht, (April 1885) 59.

${ }^{43}$ Gehe, Handelsbericht, (April 1886) 18 and (April 1887) 19.

${ }^{44}$ Gehe, Handelsbericht, (September 1885) 15.

${ }^{45}$ Ibidem.

${ }^{46}$ Mortimer, History of Coca, 280-281 and 240-241.
} 
packed in such a way that it remained dry during storage and sea-transport. ${ }^{47}$ The very high prices paid for coca for export early in 1885 spurred on a number of entrepreneurs to organize the collection, drying and packing of the leaves. Because this was not a coordinated effort, the market was soon oversupplied and as a consequence the price of coca dropped to a low level.

From the susceptibility of the leaves to deterioration during storage and transportation, and the cost of sea transport, it followed that extraction of the leaves in the country of origin was considered. Arnaldo Kitz (or Kilz), a local entrepreneur, was one of the first to explore that possibility by setting up an extraction facility producing crude cocaine from coca at Pozuso in the interior of Peru. ${ }^{48}$ Kitz used a relatively simple process invented by Alfredo Bignon, a pharmacist of Lima. It appears that the process worked well under the primitive conditions. ${ }^{49}$ Other entrepreneurs followed and within a few years four factories were producing crude cocaine in Peru. ${ }^{50}$

These enterprises competed and the crude cocaine was offered to manufacturers of cocaine hydrochloride at such a low price that outside the USA most of them changed to using this new raw material instead of coca leaves, simply because it was the more economical option. ${ }^{51}$ In summary: strong competition resulted in low prices, not only for coca leaves and crude cocaine but also for the final product, cocaine hydrochloride. The price of the latter came down very fast; from DEM 6 per gram (DEM 6,000 per kg) mid 1885 to DEM 4 per gram (DEM 4,000 per kg) in October 1885 and to DEM 850 per kg in $1887 .{ }^{52}$

For Merck cocaine had become an important product; its production of cocaine hydrochloride, which had been $1.4 \mathrm{~kg}$ in $1883-84$, amounted to $30 \mathrm{~kg}$ during the year 1884-85 and $70 \mathrm{~kg}$ during $1885-86 .^{53}$ The company did not want to remain dependent on unreliable imports of coca from Peru and its fluctuating prices. Merck turned to Kitz \& Co and commenced buying crude cocaine as the raw material for its cocaine manufacture in Germany. ${ }^{54}$ Things were moving amazingly fast; already in 1886-87 Merck imported $389 \mathrm{~kg}$ of crude cocaine from Peru that yielded $243 \mathrm{~kg}$ pure cocaine hydrochloride. ${ }^{55}$ Exact quantities of cocaine produced by other manufacturers during the early years are not known but Merck retained its dominant position in the market.

Other pharmaceutical companies, from both Germany and the USA, also wanted to have a share of the profitable cocaine business and all turned to South America, and mainly Peru, to obtain coca or crude cocaine as the raw material very shortly after Koller's discovery. Boehringer Mannheim sent the chemist Louis Schäfer to Peru to explore the possibility of local production of crude cocaine. That venture has been reported as successful

\footnotetext{
${ }^{47}$ E. Reens, 'Java Coca', dissertation University of Paris (Lons-le-Saunier 1919), Chapter 5 in S.B. Karch $A$ History of Cocaine. The Mystery of Java Coca and the Kew Plant (London 2003) 53-100.

${ }^{48}$ Mortimer, History of Coca, 234.

${ }^{49}$ Reens, 'Java Coca', 75.

${ }^{50}$ J. F. Spillane, Cocaine (Baltimore 2000) 52.

${ }^{51}$ Gehe, Handelsbericht, (April 1887) 50.

${ }^{52}$ Hirschmüller, 'E. Merck und das Kokain', 125.

${ }^{53}$ Ibidem, 119.

${ }^{54}$ Ibidem.

${ }^{55}$ Ibidem, 120.
} 
and Boehringer supplied cocaine in Europe already in $1885 .{ }^{56}$ Other German alkaloid manufacturers producing cocaine in 1885 were Zimmer and Gehe \& Co. ${ }^{57}$

Early 1885, Parke Davis \& Co of the United States engaged the botanist Henry H. Rusby to travel to Bolivia to locate sources of coca. After a most adventurous trip Rusby managed to organise supply of the coca to Parke Davis but unfortunately the first shipment of ten tonnes of leaves was lost. ${ }^{58}$ Despite this setback, Parke Davis became the leading manufacturer of cocaine in the USA shortly thereafter. E. R. Squibb \& Company was active as a cocaine producer for a few years from 1884 but later withdrew from the market. ${ }^{59}$ Most US cocaine manufacturers continued to rely on imported coca rather than switching to crude cocaine. Transportation time for the leaves to the USA was less than to Europe and therefore deterioration resulting in a lower cocaine content was less severe. ${ }^{60}$

Competition between cocaine manufacturers was strong from the very beginning. Manufacturers were seeking publicity to stress the quality of their product and to justify its price. In 1885 Parke Davis engaged Sigmund Freud to give an opinion on the quality of its cocaine in comparison to that of Merck. That opinion, which was published in the Wiener Medizinische Presse, favoured the Parke Davis product, and also stated that Merck could not supply and was too expensive. E. Merck replied in a letter to the Wiener Medizinische Presse that supply was not a problem and that its cocaine was of such good quality that a slightly higher price was fully justified. ${ }^{61}$

\section{Cocaine Production during the period 1888-1899}

From 1888 until the turn of the century Peru was the major source by far of the raw materials for cocaine: crude cocaine and coca leaves. Crude cocaine became the main raw material in Europe but most US manufacturers continued to use coca leaf from Peru. From the late 1880s cultivation of the coca plant was attemped in a number of countries outside South America, notably on Java and Ceylon. Java coca had a high total alkaloid content but was intially rejected by cocaine manufacturers as a raw material because it contained mainly secondary coca-alkaloids and the direct yield of cocaine from the leaves was low. The appreciation for Java coca changed from 1890, after German chemists had discovered a process to convert the secondary alkaloids into cocaine with a good yield. Initially the process was used only to increase the cocaine yield from Peruvian coca, but during the 1890s it opened the way for the use of Java coca as a raw material which was exported in comparatively small quantities at the time (see Section 3.4).

Merck, Darmstadt, remained the largest manufacturer but had to face keen competition from not only Boehringer Mannhein, Gehe, Trommsdorff and Zimmer but also from Knoll, who entered the cocaine business after $1890 .^{62}$ Merck acquired the alkaloid business from Trommsdorff in the early 1890s and absorbed it in its own activities, in so doing eliminating a competitor. ${ }^{63}$

\footnotetext{
${ }^{56}$ E. P. Fischer, Wissenschaft für den Markt (München 1991) 81; Spillane, Cocaine, 51; Letters to the Editor of the Pharmaceutisch Weekblad. E. Merck, 22 (December 1885) 167; C. F. Boehringer, 22 (December 1885 ) 174.

${ }^{57}$ B. Hoppe, Aus der Frühzeit der chemischen Konstitutionsforschung: die Tropanalkaloide Atropin und Cocain in Wissenschaft und Wirtschaft (München 1979) 53; Gehe, Handelsbericht (April 1885) 60.

${ }_{58}^{5}$ Karch, A Brief History of Cocaine, 93-95; Karch, A History of Cocaine, 206.

${ }^{59}$ Spillane, Cocaine, 55

${ }^{60}$ Ibidem, 53

${ }^{61}$ Hirschmüller, 'E. Merck und das Kokain', 131.

${ }^{62}$ H. R. Friman, 'Germany and the transformations of cocaine', 85.

${ }^{63}$ Hirschmüller, 'E. Merck und das Kokain', 127; S. Bernschneider, W. T. Huber, I. Possehl, “Was der Mensch thun kann ..." History of the pharmaceutical and chemical company Merck (Darmstadt 2002) 62.
} 
In the USA we see a similar picture, that of a few manufacturers and strong competition. The major local manufacturer was Parke Davis \& Co. Other early US cocaine producers were E. R. Squibb and McKesson \& Robbins, which latter company merged later with the "New York Quinine and Chemical Works". From 1885 Merck and other German manufacturers sold cocaine produced in Germany in the USA through agents. In 1887 Merck, Darmstadt, established an affiliate in the USA that sold cocaine under its own label ${ }^{64}$ Shortly after the turn of the century Merck built manufacturing facilities in the US, where along with other products, morphine and other alkaloids were produced; it is, however, unlikely that cocaine was included at this stage. ${ }^{65}$

Cocaine manufacture outside Germany and the USA is hardly mentioned in the literature. It has been reported that in 1885 Bignon obtained a 10 year privilege to supply crude cocaine to France; Houdé and Midy are mentioned as modest cocaine manufacturers in France at the time. ${ }^{66}$ During the $19^{\text {th }}$ century cocaine was manufactured in the UK by Howard \& Sons and May \& Baker; apparently on a small scale and no further information is available. ${ }^{67}$ The international cocaine market was largely supplied by German companies, in particular Merck, who exported its products all over the world. ${ }^{68}$ By 1890 imports of German cocaine exceeded USA local production from coca leaves. ${ }^{69}$

Cocaine was not only sold for strict medical applications i.e. as a local anaesthetic, but also for home remedies and for recreational use. Musto states: "Within a year of cocaine's introduction, the Parke Davis Company provided coca and cocaine in 15 forms, including cocaine cigarettes, cocaine for injection and cocaine for sniffing". ${ }^{70}$ In the USA cocaine was furthermore offered as a tobacco habit cure, in lozenges for relief of sore throats, as catarrh and asthma cures and much more. ${ }^{71}$

In Europe, the cocaine manufactures were less directly involved in the marketing of such products. They supplied mainly pure cocaine hydrochloride to wholesalers and pharmacies. Vin Mariani remained popular during the period and many imitations thereof were introduced to the market. In the USA the sales of Coca Cola rose forty fold from 1890 to 1900 .

\section{Cocaine Production by Merck, Darmstadt, until 1900}

E. Merck, Darmstadt, was the foremost cocaine manufacturer in the 1890s. Detailed cocaine production statistics have been published for this company for the period 1880-1918. Such information is not available for any other manufacturer. The annual production volumes of cocaine achieved during the period 1880-1918 were recorded by Carl Scriba, production manager of Merck's alkaloid division. Hirschmüller has summarised Scriba's manuscripts of 1908, 1919 and 1926 and published the results in $1995 .^{72}$ The following statistics on cocaine production for the period 1884-1899 are taken from Hirschmüller's publication:

\footnotetext{
${ }^{64}$ Spillane, Cocaine, 56.

${ }^{65}$ Bernschneider e.a., History of Merck, 63.

${ }^{66}$ Paul Gootenberg, "A Forgotten Case of "Scientific Excellence on the Periphery": The Nationalist Cocaine Science of Alfredo Bignon, 1884-1887', Comparative Studies in Science and History 491 (2007) 202-232.

${ }^{67}$ L. Richmond, J. Stevenson, Alison Turton, The Pharmaceutical Industry: A guide to Historical Records (Hampshire 2003) 8, 205

${ }^{68}$ Bernschneider e.a., History of Merck, 63

${ }^{69}$ Spillane, Cocaine, 56

${ }^{70}$ Musto, 'Opium, Cocaine and Marijuana in American History', Scientific American 265[1] (1991) 24.

${ }^{71}$ Spillane, Cocaine, 81-89.

${ }^{72}$ Hirschmüller, 'E. Merck und das Kokain', 116-143.
} 
Table 3.1 and Figure 3.4 Cocaine Production at Merck 1884-1899

\begin{tabular}{|c|r|}
\hline Year & $\begin{array}{c}\text { Cocaine } \mathrm{HCl} \\
\mathrm{kg}\end{array}$ \\
\hline $1883 / 84$ & 1 \\
$1884 / 85$ & 30 \\
$1885 / 86$ & 70 \\
$1886 / 87$ & 257 \\
$1887 / 88$ & 300 \\
$1888 / 89$ & 303 \\
$1889 / 90$ & 511 \\
$1890 / 91$ & 557 \\
$1891 / 92$ & 437 \\
$1892 / 93$ & 505 \\
$1893 / 94$ & 626 \\
$1894 / 95$ & 645 \\
$1895 / 96$ & 791 \\
$1896 / 97$ & 831 \\
$1897 / 98$ & 1,509 \\
$1898 / 99$ & 1,553 \\
& \\
\hline
\end{tabular}

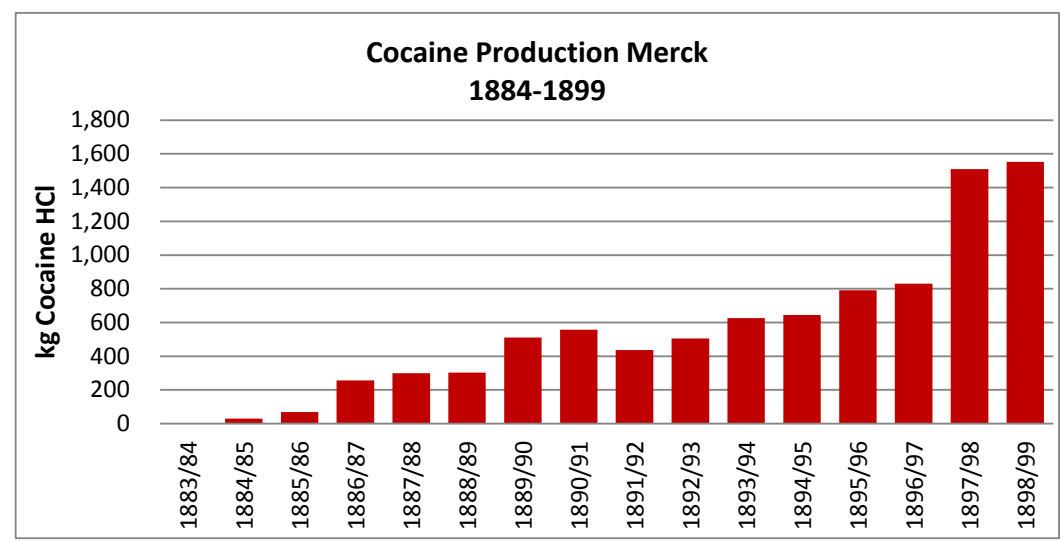

Source: A. Hirschmüller, 'E. Merck und das Kokain', 116-143.

During the period 1879-1887 Merck, Darmstadt, extracted 31,580 kg Peruvian coca which yielded $115 \mathrm{~kg}$ pure cocaine hydrochloride. That equates to a yield of $0.364 \%{ }^{73}$.

From 1886/1887 onwards Merck exclusively used crude cocaine from Peru as the raw material. During the period 1886-1899, 10,226 kg crude cocaine was processed yielding $8,812 \mathrm{~kg}$ pure cocaine hydrochloride. That represents a yield of $86 \%{ }^{74}$

The graph above shows the strong growth of Merck's cocaine output over the latter part of the period. While world production remained rather static at an estimated $6,200 \mathrm{~kg}$ p.a. during the period 1892-1899, Merck's production grew from 437 to $1,553 \mathrm{~kg}$, representing a share of the world market that grew from ca $7 \%$ to ca $25 \%$. The reasons for Merck's rising to such a dominant position in such a short span of time were both technical and commercial. Merck's scientific and technical prowess meant it made a product of excellent quality at a high yield, resulting in low production cost. Merck's purchasing power, resulting in their obtaining the raw material (crude cocaine) at the best possible price, will have contributed to the low production cost. Merck's commercial skills made it possible to translate the low manufacturing cost of the product into increased market share. Which event(s) caused the large jump in production between 1897 and 1898 is not known. The large production in 1898 could have been a fluke resulting from the production of cocaine in excess of immediate requirements because of factory scheduling and incidental large raw material stocks. As a result of very strong competition, the price for cocaine had declined strongly during the period 1892 to 1897 . Attempts to stem the price decline by a Convention (cartel) of manufacturers failed (see below). Profit margins came under very severe pressure for all manufacturers and the weaker ones ceased producion. Merck was one of the winners and its marketshare increased very considerably.

\footnotetext{
${ }^{73}$ Ibidem, 119; Hirschmüller reports $0.292 \%$ but that appears to be an arithmetical error.

${ }^{74}$ Ibidem, 120.
} 
Estimate of the World Production of Cocaine for the Period 1890-1899

The developments of the cocaine market during the 1890s are illustrated with the following table and graph of the quantities of cocaine hydrochloride manufactured worldwide calculated from the amounts of raw materials exported. ${ }^{75}$

Table 3.2 Estimate of Cocaine HCl manufactured worldwide from Raw Materials exported during the Period 1890-1899

\begin{tabular}{|c|c|c|c|c|}
\hline \multirow{2}{*}{$\begin{array}{c}\text { Year } \\
\text { of } \\
\text { Export }\end{array}$} & \multicolumn{2}{|c|}{ Cocaine Manufuctured } & \multirow{2}{*}{ Total } \\
\cline { 2 - 3 } & $\begin{array}{c}\text { from Peru } \\
\text { Coca }\end{array}$ & $\begin{array}{c}\text { from Peru } \\
\text { Crude }\end{array}$ & $\begin{array}{c}\text { from Java } \\
\text { Coca }\end{array}$ & \\
\hline 1890 & 500 & 1,500 & 0 & 2,000 \\
1891 & 700 & 2,700 & 200 & 3,600 \\
1892 & 2,000 & 3,800 & 600 & 6,400 \\
1893 & 2,000 & 2,000 & 600 & 4,600 \\
1894 & 1,900 & 4,000 & 500 & 6,400 \\
1895 & 2,100 & 3,800 & 900 & 6,800 \\
1896 & 2,300 & 3,700 & 800 & 6,800 \\
1897 & 2,100 & 3,500 & 900 & 6,600 \\
1898 & 1,700 & 3,700 & 800 & 6,300 \\
1899 & 1,300 & 3,800 & 500 & 5,700 \\
Average & & & & \\
1892-1899 & $\mathbf{1 , 9 0 0}$ & 3,600 & 700 & $\mathbf{6 , 2 0 0}$ \\
Percent & 31 & 58 & 11 & 100 \\
\hline
\end{tabular}

Source: For the years 1892-1899 the amounts are taken from Table 17.11 and for the years 1890-1891 the amounts are calculated from the quantities of raw materials exported as per Tables PCL 1, PCC 1 and JCL 2 multiplied by the yield factors appearing in Table 17.11.

All figures are rounded to the nearest hundred $\mathrm{kg}$.

Figures in blue are estimates by the author.

${ }^{75}$ The calculations are set-out in detail in Chapter 17. 
Figure 3.5 Estimate of Cocaine $\mathrm{HCl}$ manufactured worldwide from Raw Materials exported during the Period 1890-1899

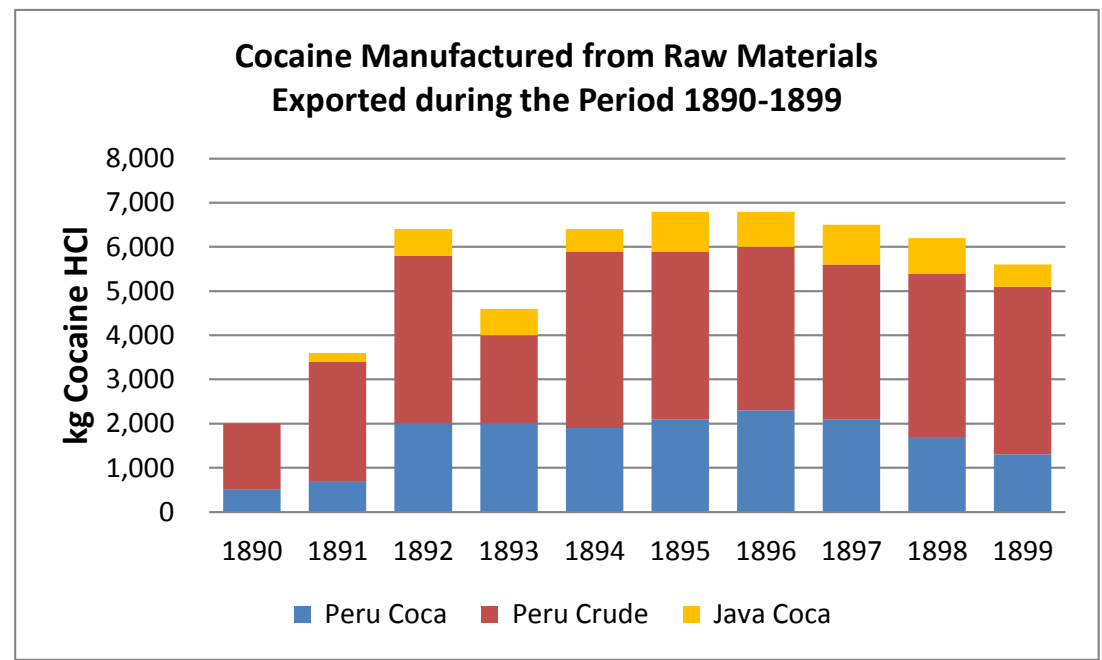

In table 3.2 the amounts of cocaine hydrochloride manufactured appear on the same line, i.e. in the same year, as the raw materials were exported. This does not imply, however, that all the exported raw materials were processed in the very same year. For coca leaves, there will have been a considerable difference between the date of export and the time the end product manufactured from these leaves was available for supply to the customer. It is estimated that this period was in the order of 6 to 12 months. For crude cocaine this time lag will have been less. Variations in raw material stocks held in the importing countries contributed also to the time lag. The overall result is that in a particular year the actual production could have been markedly different from the calculated production as appearing in the table. Anomalies appearing for a particular year, e.g. the low figure for 1893, should not be considered as significant. For a series of consecutive years the differences between actual and calculated production average out, however. In our case, the calculated average annual production for the eight year period 1892-1899 can be considered as a fair estimate of the average, although more realistically representing a somewhat later period, say, 1893-1900.

The graph shows that after a sharp increase between 1890 and 1892, cocaine production stabilized at a level around $6,200 \mathrm{~kg}$ p.a., where it stayed until 1899. The phenomenal speed by which this production level was reached in 1892 starting from a few kilograms in 1885 represents the introduction of cocaine as a local anaesthetic in medicine and dentistry; and also its use in popular patent medicines and its lure as a recreational drug will have contributed. ${ }^{76}$ The stabilization of production after 1892 suggests a (temporary) saturation of the market. Over the period 1892-1899 ca 58\% of all cocaine was produced from Peru crude and $31 \%$ from Peru coca, while ca $11 \%$ came from Java coca. Estimates of the production of cocaine in Germany, the USA and 'Other Countries' over the period 18921899 are made in Table 17.9; they appear as rounded figures in the following table and graph.

\footnotetext{
${ }^{76}$ Spillane, Cocaine, 81-93.
} 
Table 3.3 Estimate of average quantities Cocaine HCl manufactured from Raw Materials Exported during the Period 1892-1899 by Country of Destination

\begin{tabular}{|c|rrr|r|}
\hline $\begin{array}{c}\text { Raw } \\
\text { Material }\end{array}$ & Germany & USA & Other Europe & Total \\
\hline Peru Coca & 400 & 1,000 & 500 & 1,900 \\
$\begin{array}{c}\text { Peru Crude } \\
\text { Java Coca }\end{array}$ & 3,100 & 100 & 400 & 3,600 \\
& 700 & 0 & 0 & 700 \\
Total & & & & \\
$\%$ & $\mathbf{4 , 2 0 0}$ & $\mathbf{1 , 1 0 0}$ & 900 & $\mathbf{6 , 2 0 0}$ \\
& 67 & 18 & 15 & 100 \\
\hline
\end{tabular}

Source: The quantities by country in this Table pertain to the period 1892-1899.

They are calculated from the figures contained in Table 17.9 for the periods 1892-1896 and $1897-1903$ pro rata in proportion to the number of years.

The quantities are rounded to the nearest hundred $\mathrm{kg}$.

Figures in blue are estimates by the author.

Figure 3.6 Estimate of average quantities Cocaine $\mathrm{HCl}$ manufactured from Raw Materials Exported during the Period 1892-1899 by Country of Destination

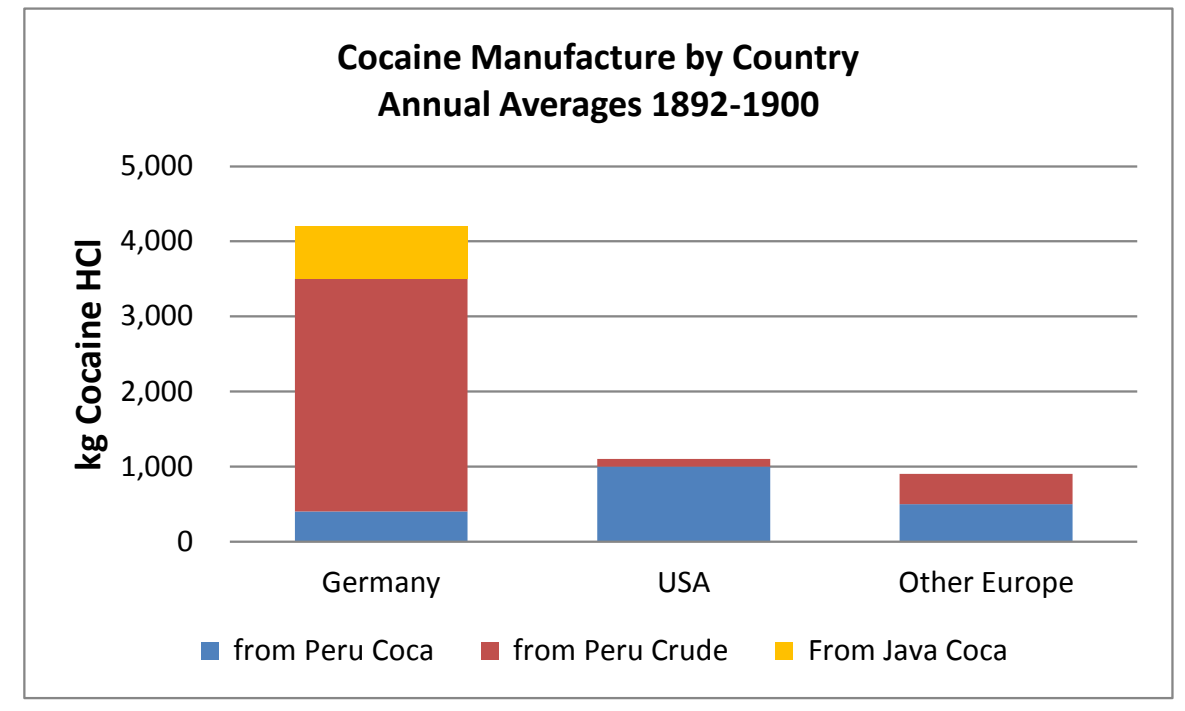

As the table and the graph show, Germany was the largest cocaine producer over the period with $67 \%$ of the world total. The main raw material used by German manufacturers during the 1890s was crude cocaine from Peru as that had become the more convenient and more economical option. Shipping of the coca leaf was risky because the possibility of losing part of its alkaloid content during the long sea voyage, and processing of crude cocaine required a lower investment. As mentioned earlier, in the 1890s coca leaf from Java was reportedly only used in modest quantities by a single German manufacturer. 
The low use of Peru crude in the USA resulted from an ad valorem import duty of $25 \%$ imposed on (crude) cocaine. ${ }^{77}$ Only one US manufacturer, Powers-WeightmanRosengarten, used crude cocaine, the others stayed with coca leaf from Peru.

Cocaine manufacture in "Other Countries" (mainly the UK and France) represented ca $15 \%$ of the world total; both Peru coca and crude cocaine were used as raw material.

\section{Price Movements in the Cocaine Market over the Period 1887 to 1899}

Over the years 1887 to 1892 the cocaine market grew fast from less than $1,000 \mathrm{~kg}$ to more than $6,000 \mathrm{~kg}$. Despite this rapid growth in volume the competition between manufacturers was strong, creating downward pressure on prices. Early in 1889 the lower prices resulted in a decision of the Peruvian manufacturers to close the production facilities temporarily. Later that year they announced a price increase for crude cocaine but Gehe's expectation was that such an increase would not be sustainable. ${ }^{78}$

For 1889 a price of cocaine $\mathrm{HCl}$ of USD 0.15 per gram (equivalent to Marks 630 per $\mathrm{kg}$ ) was reported. ${ }^{79}$ For the period 1892-1916 average bi-annual cocaine prices in the USA have been calculated by J. Spillane on the basis of weekly wholesale prices as appearing in a trade publication the Oil, Paint and Drug Reporter. ${ }^{80}$ Spillane presents the results of his calculations in the form of a graph. The information from that graph has been digitalized and for the sake of comparison the US prices in USD/oz and German prices in DEM/kg have been converted into Dutch Guilders (NLG) per kg, using the exchange rates contained in the following table.

Table 3.4 Exchange Rates, Values of USD, DEM and NLG 1876-1915. ${ }^{81}$

\begin{tabular}{|c|c|c|c|c|}
\hline \multirow{2}{*}{ Currency } & \multirow{2}{*}{ Gram Gold } & \multicolumn{3}{|c|}{ V a I u e } \\
\cline { 3 - 5 } & & USD & NLG & DEM \\
\hline USD & 1.5048 & 1.000 & 2.488 & 4.199 \\
NLG & 0.6048 & 0.402 & 1.000 & 1.688 \\
DEM & 0.3584 & 0.238 & 0.593 & 1.000 \\
\hline
\end{tabular}

The cocaine prices are included in Table COC 4 (Part IV). US cocaine prices for the period 1892-1899 together with the only available German prices (1898-1899) are shown in the table and graph below:

\footnotetext{
77 The duty was imposed from 1896 (Gootenberg, Cocaine, 50) and amounts of duty paid appear in the FN\&C statistics from 1900/01 (Table PCC 2 Part III).

Spillane (Cocaine $, 53,177$ ) argues in his note 42 that the import duty was applicable to crude cocaine and that it originally also applied to "finished product" but was later replaced by a duty of $50 \notin / 1 b$ to cocaine hydrochloride in "medical preparations". This is a confusing statement; from the FN\&C statistics it is clear from the quantities involved that the duty was levied on both crude cocaine and (bulk) cocaine hydrochloride.

${ }^{78}$ Gehe (April 1889) 47; (September 1889) 41.

${ }^{79}$ Hirschmüller, 'E. Merck und das Kokain', 130.

${ }^{80}$ Spillane, Cocaine, 54.

${ }^{81}$ During the period 1876-1915 a number of countries including the USA, Germany and the Netherlands had linked the values of their currencies to a defined weight of pure gold (the Gold Standard). From 1834 to 1933 the price of 1 Troy Ounce (31.103481 gram) of gold was fixed at USD 20.67.
} 
Table 3.5 and Figure 3.7 US and German Prices Cocaine HCl 1892-1899

\begin{tabular}{|c|cc|c|}
\hline Year & $\begin{array}{c}\text { U S A } \\
\text { Price } \\
\text { USD / oz }\end{array}$ & $\begin{array}{c}\text { U S A } \\
\text { Price } \\
\text { NLG / kg }\end{array}$ & $\begin{array}{c}\text { Germany } \\
\text { Price } \\
\text { NLG / kg }\end{array}$ \\
\hline 1892 & 6.20 & 544 & \\
1893 & 5.40 & 474 & \\
1894 & 5.65 & 496 & \\
1895 & 4.80 & 421 & \\
1896 & 3.80 & 333 & \\
1897 & 3.15 & 276 & \\
1898 & 3.10 & 272 & 213 \\
1899 & 4.85 & 426 & 415 \\
\hline
\end{tabular}

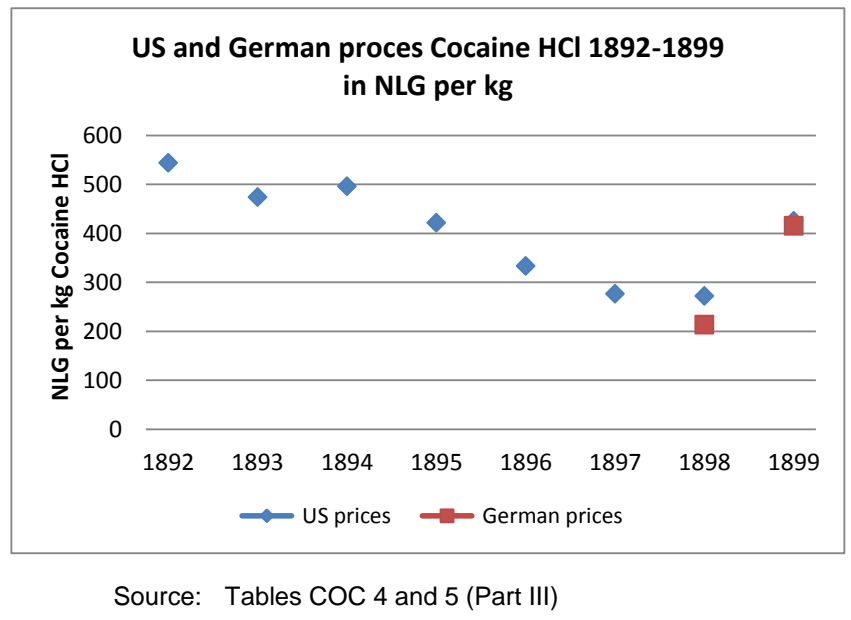

For the period 1892 to 1898 we see the US price for cocaine hydrochloride steadily going down from ca NLG 540 to ca NLG 270 per kg. For 1898 the US cocaine price was about $120 \%$ of the German price; this reflects the $25 \%$ US import duty. It is likely that the US prices for cocaine $\mathrm{HCl}$ for the years before 1896 were roughly equal to the German prices.

In an attempt to stabilize prices at a reasonable level (German) cocaine manufacturers established a 'convention'. The first time that a cocaine convention was mentioned is in a publication 1895 where it is stated that the convention broke-up as a result of the appearance of an (unidentified) competitor. ${ }^{82}$ In April 1898 Gehe reported that the Convention was (again) dissolved: apparently the convention had been reinstated in the meantime. The steady price decline over the period 1892-1897 was caused by persistent overproduction and strong competition. The convention had been abandoned for the second time because of ongoing competition between the members; the urgently needed price increase could not be achieved. In early 1898 Gehe stressed that a price increase of cocaine hydrochloride had become essential because its price was much too low in relation to the price of the raw materials. ${ }^{83} \mathrm{By}$ the end of 1898 a change occurred when the news of a bad harvest in Peru resulted in a price increase of cocaine hydrochloride from Marks 320 (NLG 190) to Marks 400 (NLG 237) per kg. ${ }^{84}$ Over 1899 the cocaine price continued to increase sharply to reach Marks 700 (NLG 415 ) in November. This was the result of a combination of the very small harvest and transportation problems in Peru, caused by political problems. ${ }^{85}$ In 1900 the cocaine convention was re-instated. ${ }^{86}$ Early in 1900 the price eased to Marks 600 (NLG 356) when more raw material came to the market. The price movements over the 1890 s are a good example of the inelasticity of the market for pharmaceutical alkaloids, as discussed in Section 2.4. The demand did not increase despite the price halving.

\footnotetext{
${ }^{82}$ Gehe, Handelsbericht (September 1895) 43.

${ }^{83}$ Gehe, Handelsbericht (April 1898) 64.

${ }^{84}$ Gehe, Handelsbericht (April 1899) 65.

${ }^{85}$ Gehe, Handelsbericht (April 1900) 61.

${ }^{86}$ Merck, Conventionen und Vertretungen, Bericht über das Geschäftsjahr (1901-1902) Merck-Archiv F03/6a, 6. Cf Klaus Burkert, 'Die Deutsche "Pharmazeutische Interessengemeinschaft” (1906-1918)' (Stuttgart 1990), 24-36.
} 


\subsection{Science and Technology and the Manufacture of Cocaine}

During the $19^{\text {th }}$ century most cocaine was produced from coca leaves cultivated in South America. The variety preferred for the production of cocaine was Erythoxylon coca var coca (Bolivian or Huánuco coca) containing 0.5-1.0\% total alkaloids, 70-90\% of which is cocaine. ${ }^{87}$ Mortimer provided the results of 24 assays of the total alkaloid content, ranging from $0.40-0.85 \%$ with an average of $0.627 \%$; he considered the leaves as being of good average quality. ${ }^{88}$ Tromp de Haas mentioned a content of $0.5-0.6 \%$ of "crystallisable cocaine" in export quality coca leaves of South American origin. ${ }^{89}$

The other common coca species of South America, E. novogranatense (Peruvian or Truxillo coca) contained ca $1-2 \%$ total alkaloids but only $20-50 \%$ thereof was cocaine which is difficult to isolate. It contained more flavouring substances and was mainly used for the production of aromatic coca wines.

The term 'total alkaloids' of coca in most publications is tacitly understood to mean the alkaloids which are extracted from coca leaves under factory conditions. ${ }^{90}$ Under these conditions cocaine, cinnamoylcocaine and other ecgonine alkaloids plus some tropacocaine are extracted while the so called 'volatile alkaloids', cuscohygrine and hygrine, remain largely in the aqueous phase. At the time, the assay of coca leaves for "total alkaloids" followed the same procedure as used for the manufacture of cocaine and was the basis that determined the price of the leaves.

Outlines for processes of the production of crude cocaine from Peru coca leaf as practiced in the late $19^{\text {th }}$ and early $20^{\text {th }}$ century have been described by Reens. ${ }^{91}$ The oldest process for the extraction of coca on a commercial scale was that of Bignon, a French pharmacist living in Lima, who developed and patented it in 1885. De Jong's annotated description of the Bignon process (restated by the author) is the following. ${ }^{92}$

The powdered coca leaves are macerated with a solution of sodium carbonate and subsequently agitated with kerosene (boiling point 200-250 degrees C) at a slightly elevated temperature to extract the alkaloids. The mass is pressed and the alkaloids are re-extracted with dilute hydrochloric acid from the petroleum phase and the crude base is precipitated from the acidic extract by adding sodium carbonate.

This crude base contained about 70\% "crystallisable" cocaine which could be isolated with relative ease from the crude cocaine. ${ }^{93}$ The crude base contained furthermore $10-20 \%$ other ecgonine alkaloids ("amorphous bases"). ${ }^{94}$

\footnotetext{
${ }^{87}$ The Merck Index (Rahway 1989), Item 2448, 'Coca'.

${ }^{88}$ Mortimer, History of Coca, 311.

${ }^{89}$ W. R. Tromp de Haas, 'De Coca-Cultuur' Teysmannia 14 (1903) 302-303.

${ }^{90}$ E. Bierling, K. Pape, A. Viehöver, 'Wertbestimmung der Cocablätter' Archiv der Pharmacie 248 (1910) 303336.

${ }^{91}$ E. Reens, 'Java Coca' Chapter 5 in Karch S.B. A History of Cocaine. The Mystery of Java Coca and the Kew Plant (London 2003) 75-80.

${ }^{92}$ A. W. K. de Jong, 'Extractie van Cocablad', Teysmannia 17 (1906) 176-187.

${ }^{93}$ Tromp de Haas, 'De Coca-Cultuur', 302-303.

${ }^{94}$ Gootenberg mentions that Peru exported crude cocaine in the form of sulfates (of 85-94\% purity) rather than as the crude base mentioned elsewhere. Gootenberg, 'Reluctance or resistance?' 47-48.
} 
The Bignon process was relatively simple and designed for use under primitive conditions as prevailing in the interior of Peru at the time. It was most successful; using this process large quantities of crude cocaine were produced in Peru from as early as 1886/1887, when $389 \mathrm{~kg}$ was processed by Merck, and culminating in 1901 when 10,668 kg was exported. $^{95}$

Yields of crude cocaine from the leaves as obtained in Peru were reported to be in the order of $0.5 \% .^{96}$ According to Mortimer Peruvian crude cocaine yielded $50-75 \%$ "pure crystallisable alkaloid". ${ }^{97}$ Merck, however, reported an average yield of $86.3 \%$ for the production of cocaine hydrochloride from Peru crude. ${ }^{98}$

Liebermann and Giesel described in a patent of 1889 an extraction process very similar to that of Bignon. ${ }^{99}$ The main difference is that they used ethyl ether as the extraction solvent instead of kerosine. Ether is a more selective solvent and its use results in cleaner extracts. Both the cocaine and the secondary alkaloids ("amorphous bases") are extracted into the ether, both are re-extracted with dilute hydrochloric acid and precipitated as crude cocaine. Liebermann and Giesel isolated the cocaine from the crude cocaine by dissolving the latter in a small amount of hot ethanol and subsequently cooling whereupon most of the cocaine crystallized. The amorphous (non-crystallising) secondary alkaloids stayed in the mother liquors.

\section{The Conversion of the Secondary Alkaloids into Cocaine}

For a good understanding of the differences between South American and Java coca as a raw material for the manufacture of cocaine some insight in the chemistry of the coca alkaloids is required. It is particularly useful for the appreciation of the various patents on the conversion of secondary alkaloids into cocaine that were granted towards the end of the $19^{\text {th }}$ century.

Wöhler and Lossen found that cocaine upon hydrolysis with dilute acid yields benzoic acid, methanol and a nitrogen compound of unknown structure that they called ecgonine. ${ }^{100}$ From this reaction it was concluded that ecgonine contains a carboxylgroup $(-\mathrm{COOH})$ and an alcohol function $(-\mathrm{OH})$ and that cocaine is the methylester $(-\mathrm{COOMe})$ of O-benzoylecgonine.

\footnotetext{
${ }^{95}$ Hirschmüller, E. Merck und das Kokain, 120.

${ }^{96}$ Reens, 'Java Coca' 77; [S.S. Abrahamson et al], 'Het Cocavraagstuk' Tijdschrift voor Nijverheid en Landbouw in Nederlandsch-Indië 85 (1912) 146.

${ }^{97}$ Mortimer, History of Coca, 318.

${ }^{98}$ Hirschmüller, E. Merck und das Kokain, 120.

${ }^{99}$ C. Liebermann and F. Giesel, Verfahren zur Ueberführung der amorphen Basen der Cocablätter in Ecgonin und Benzoylecgonin. German Patent No. 47,602, 1889, June 1.

${ }^{100}$ Wöhler, 'Ueber das Coca und das Cocain' Annalen 121 (1862) 372-375.
} 
The reaction is depicted as follows ${ }^{101}$ :

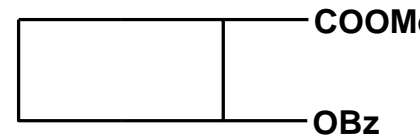

Cocaine

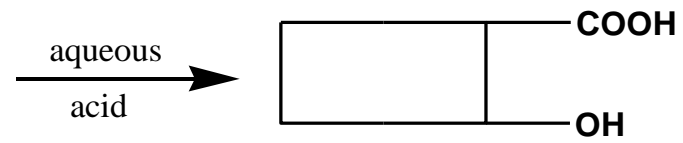

Ecgonine

$$
B z=\text { benzoyl and } M e=\text { methyl }
$$

Willy Merck was the first to try to re-synthesise cocaine from ecgonine. He succeeded but his method was not suitable for application on a factory scale. ${ }^{102}$

The success of cocaine as a local anesthetic resulted in a renewed interest in the chemistry of the coca alkaloids and a need for improved manufacturing methods. In Germany, shortly after Koller's discovery, two teams of organic chemists commenced research on coca. These teams were Carl Liebermann and Fritz Giesel on one side, and Alfred Einhorn and Otto Klein on the other. At the time Liebermann was professor of chemistry at the Technical University, Berlin-Charlottenburg, and his former student Giesel was employed by the Chininfabrik Braunschweig. Of the other team, Einhorn was lecturer at the Technical University, Aachen, and Klein held a position at C.F. Boehringer, Mannheim. The objective was to find an economical method for the conversion of the secondary alkaloids occurring in the coca into cocaine.

Both teams were successful and published and patented their respective methods in 1888 . The patent granted to Liebermann and Giesel (DRP 47,602), valid from August 14, 1888, was the commercially stronger one because it covered the manufacture of the essential intermediate ecgonine; it also covered the conversion of ecgonine into benzoylecgonine. The patent based on the invention by Einhorn and Klein (DRP 47,713) claimed the synthesis of cocaine from ecgonine methylester. It was valid from November 3, 1888 and was assigned to C.F. Boehringer \& Söhne at Waldhof-Mannheim.

\footnotetext{
${ }^{101}$ The simplyfied structural formula's (e.g. $\square{ }^{\text {сон }}$ for ecgonine) reflect that the molecular structure of the coca-alkaloids was not known in detail at the end of the $19^{\text {th }}$ century. Einhorn ${ }^{101}$ uses the formula $\mathrm{C}_{5} \mathrm{H}_{4} \mathrm{~N}\left(\mathrm{CH}_{3}\right) \cdot \mathrm{H}_{3} \cdot \mathrm{CHOH}-\mathrm{CH}_{2} \cdot \mathrm{COOH}$ for ecgonine. See A Einhorn and O Klein, 'Ueber die Einwirkung von Säurechloriden auf den salzsauren Ecgoninmethylester' Berichte der Deutschen Chemischen Gesellschaft; 21 (1888) 3335-3338.

${ }^{102}$ W.Merck, Berichte der Deutschen Chemischen Gesellschaft; 18 (1885) 2264-2266 and 2952-2955, cf Hoppe, Cocain in Wissenschaft und Wirtschaft (1979) 57.
} 
The secondary alkaloids of the coca have a molecular structure very similar to that of cocaine. The only difference is that they contain other acyl-groups than benzoyl. The principal secondary alkaloid is cinnamoylcocaine (O-cinnamoyl ecgonine methylester). The secondary alkaloids can be converted with good yield into ecgonine and a process for that has been described and claimed in the patent by Liebermann and Giesel. ${ }^{103}$

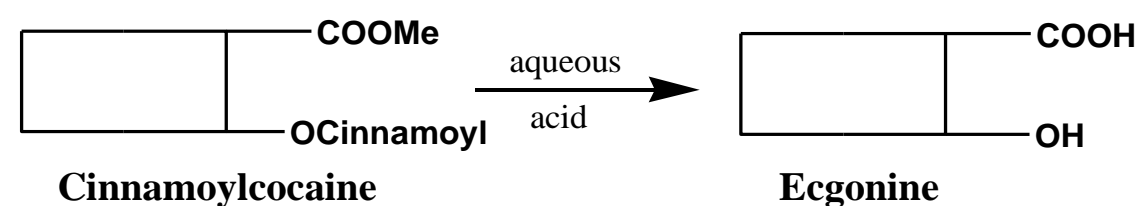

For the synthesis of cocaine from ecgonine two routes are possible, one via the intermediate benzoylecgonine as published and patented by Liebermann and Giesel, the other via ecgonine methylester invented by Einhorn and Klein and assigned to Boehringer Mannheim. ${ }^{104}$ These routes are depicted in the following diagram:

Figure 3.8

\section{Conversion of Ecgonine into Cocaine}

Route Liebermann and Giesel

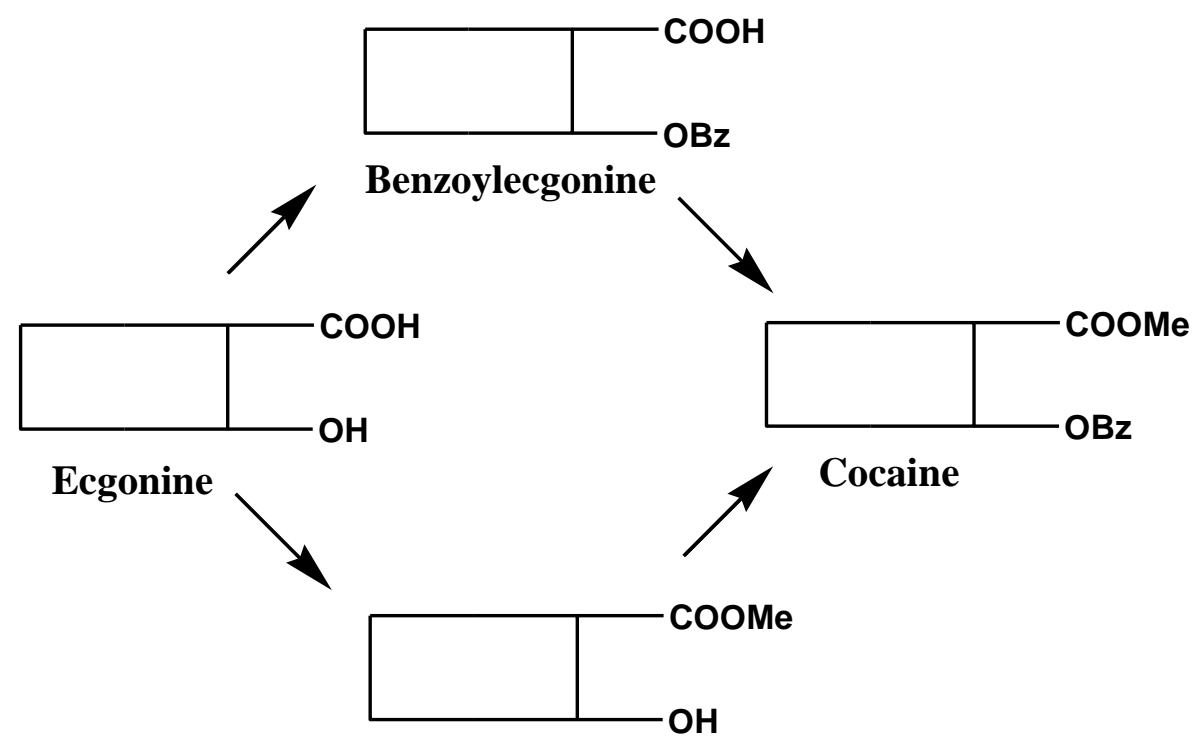

Ecgonine methylester

Route Einhorn and Klein

$B z=$ benzoyl and $M e=$ methyl

\footnotetext{
${ }^{103}$ C. Liebermann and F. Giesel, 'Über eine neue technische Darstellungsart und theilweise Synthese des Cocains' Berichte der Deutschen Chemischen Gesellschaft 21 (1888) 3196-3202; Liebermann and Giesel, German Patent No. 47,602.

${ }^{104}$ C. F. Boehringer \& Söhne, Verfahren zur Darstellung von Alkaloiden aus den Estern des Ecgonins durch Einführung von Säureradicalen in die letzteren. German Patent No. 47,713, 1889, July 9
} 
In their patent, Liebermann and Giesel claimed the first step, the process for making benzoylecgonine from ecgonine. The second step from benzoylecgonine to cocaine had been described earlier by Willy Merck. The route by Einhorn and Klein was the better one for manufacturing purposes. In their publication in Berichte of 1888 they mention that their method gave excellent yields and that it had been used in the factory of Boehringer Mannheim for quite some time. ${ }^{105}$ The Boehringer patent depended however on Liebermann's method for making the essential raw material ecgonine.

Liebermann mentions in 1894 that their method had been used to produce substantial amounts of ecgonine. ${ }^{106}$ It seems very likely that Liebermann and Giesel entered a commercial arrangement with one or more of the larger cocaine manufacturers, probably Boehringer-Mannheim, regarding licensing of their patent.

The Boehringer Mannheim patent (DPR 47,713) was relinquished already in 1891, just over two years after it was issued. Hoppe argues that the reason was that Boehringer could not get around the Liebermann patent for access to ecgonine. ${ }^{107}$

Until 1890 the value of the patents was that they provided a practical method for the conversion of the secondary alkaloids of Peru coca into cocaine, thereby increasing the overall yield of cocaine from the leaves by ca 15 percent, which was of considerable value to the manufacturers.

However, after Liebermann and Giesel had identified cinnamoyl-cocaine as a major alkaloid in Java coca, it became obvious that, because its high total alkaloid content (up to 2 percent), Java coca would be an excellent raw material for cocaine manufacture when the total alkaloid could be converted into cocaine with a good yield. ${ }^{108}$ This increased the value of the Liebermann and Giesel patent substantially because the essential process step of hydrolysing cinnamoylcocaine to ecgonine was covered by that patent.

In 1894, the German company "Farbwerke vormals Meister Lucius und Brüning" (Hoechst) obtained a patent on making ecgoninemethylester from the non-crystallising alkaloids. ${ }^{109}$ These non-crystallising alkaloids were directly converted into ecgonine methylester by reacting them with a mixture of methanol and a mineral (e.g. sulfuric) acid. On an industrial scale this is a superior method for making cocaine from Java coca. The Farbwerke patent referred to the Liebermann and Giesel patent, apparently for the isolation of the secondary alkaloids. $^{110}$

This "Farbwerke" patent was the result of research by Einhorn and Willstätter that was published in 1894. ${ }^{111}$ Liebermann was most upset by the publication by Einhorn. He considered Einhorn's method as nothing new and no improvement of his own method. ${ }^{112}$

\footnotetext{
${ }^{105}$ A. Einhorn and O. Klein, 'Ueber die Einwirkung von Säurechloriden’ Berichte der Deutschen Chemischen Gesellschaft 21 (1888) 3335-3338.

${ }^{106}$ C. Liebermann, 'Zur Abhandlung von Einhorn und Willstätter über die technische Darstellung von Cocaïn aus seinen Nebenalkalö̈den', Berichte der Deutschen Chemischen Gesellschaft 27 (1894) 2051-2053.

${ }^{107}$ Hoppe, Cocain in Wissenschaft und Wirtschaft (1979), 59.

${ }^{108}$ C. Liebermann, 'Ueber die isomeren Truxillsäuren', Berichte der Deutschen Chemischen Gesellschaft 22 (1889) 2240-2256, footnote on page 2251.

${ }^{109}$ Farbwerke vormals Meister Lucius \& Brüning. Verfahren zur Darstellung von Ecgoninalkylester. German Patent No. 76,433; 1894, July 16.

${ }^{110}$ Liebermann and Giesel, German Patent No. 47,602.

${ }^{111}$ A. Einhorn and R. Willstätter, 'Ueber die technische Darstellung des Cocaïns aus seinen Nebenalkaloïden', Berichte der Deutschen Chemischen Gesellschaft 27 (1894) 1523-1524.

${ }^{112}$ Liebermann, Berichte 27 (1894) 2051-2053.
} 
Hoppe has reviewed this controvesy extensively. ${ }^{113}$ Her conclusion is that Liebermann had reacted much too strongly. From a scientific point of view Einhorn's method was a transesterification and as such different from the hydrolysis patented by Liebermann. From a commercial technical point of view, it reduced the number of reaction steps for making ecgonine methylester from two to one and thereby providing cost advantage. Despite these advantages the Farbwerke patent was waived ("infolge Verzichts") for unknown reasons on 9 May 1900. ${ }^{114}$ Later in the $20^{\text {th }}$ century the process described in the Farbwerke patent was used by Merck, Darmstadt, on a large scale. ${ }^{115}$ The role that the Farbwerke patent played in the cocaine industry around 1900 has been overstated since 1948 when A.W.K. de Jong mentioned in a publication that during the 1890s Java coca could only be sold to Farbwerke. ${ }^{116}$ In 2008, Soininen reviewed the various patents covering the conversion of the secondary alkaloids into cocaine. ${ }^{117}$

\subsection{Summary and Conclusions}

A first specimen of the coca plant from Peru was sent to Europe in 1750. It was classified as Erythroxylon coca and a wider interest in the plant arose after reports by scientific expeditions on the invigorating properties of its leaves reached Europe during the first half of the $19^{\text {th }}$ century. Cocaine, the active principle of the coca leaves, was isolated by Niemann in Germany in 1860. Shortly after, coca wines such as Vin Mariani were promoted as a tonic and became popular in Europe and the USA. The anaesthetic properties of cocaine were discovered by Koller in Vienna in 1884 . This discovery led to a very rapid acceptance by the medical profession of the use of cocaine in surgery and dentistry.

\footnotetext{
${ }^{113}$ Hoppe, Cocain in Wissenschaft und Wirtschaft, 62-70.

${ }^{114}$ E-mail dated 23 April 2008 from Evelyn Benke, Deutsches Patent- und Markenamt, Berlin, to HHB. Ref. ' $\$ 20$ (1) Nr. 1 PatG: Das Patent erlischt, wenn der Patentinhaber darauf durch schriftliche Erklärung an das Patentamt verzichtet'. (ipwiki.de: 'Verzicht af das Patent', accessed 7 November 2010).

${ }^{115}$ British Intelligence Objectives Sub-Committee (BIOS).Report No. 766, 'Cocaine, E. Merck, Darmstadt', 1947, 209.

${ }^{116}$ A. W. K. de Jong, 'Cocacultuur in Indonesië’ In: Van Hall C.J.J., Van de Koppel C, editors. De Landbouw in de Indische Archipel. Vol II A. (The Hague 1948) 873. De Jong reasoned that Farbwerke had a monopoly position in Germany because of the patent it held for the processing of secondary (non-crystallisable) alkaloids of coca which are prevailing in Java coca. According to de Jong this monopoly position resulted in seriously depressed prices for Java coca. De Jong assumed that the Nederlandsche Cocaine Fabriek (NCF) used the Farbwerke process from 1900. The key position of the Farbwerke patent as surmised by de Jong has been repeated by other authors in a number of publications. M. de Kort, Tussen patiënt en delinquent, geschiedenis van het Nederlandse drugsbeleid. (Between patient and delinquent, the history of drug policy in the Netherlands); (Hilversum 1995) 57; M de Kort, 'Doctors, diplomats and businessmen. Conflicting interests in the Netherlands and Dutch East Indies', Chapter 6 in: Gootenberg P, editor. Cocaine: Global Histories, (London 1999) 129 and S.B. Karch, A Brief History of Cocaine, 96.

De Jong does not mention the Liebermann \& Giesel patent of 1888 which was more important than the Farbwerke patent of 1894. The Liebermann patent remained in force until 1903 while the Farbwerke patent remained in force until 1900 (Hoppe, Cocain in Wissenschaft und Wirtschaft, 60). Farbwerke is not mentioned as a cocaine manufacturer in any other publications. A search by HistoChem $\mathrm{GmbH}$ of the Hoechst archieves from 1883 did not yield any positive information on cocaine production by Farbwerke (Personal communication HHB from HistoChemGmbH of 4 September, 2006). NCF did not use the Farbwerke process; in 1901 NCF converted the alkaloids via ecgonine into cocaine (Report on the NCF by Dr H.G. Ringeling dated 1 May 1901, file 2082PW1901, Municipal Archives Amsterdam). In other words: it used the Liebermann process.

${ }^{117}$ J. Soininen, Industrial Geographies of Cocaine, Masters Thesis Geography, University of Helsinki (2008) 42-44 and 110-111. Soininen seems not to recognize that the Liebermann and Giesel patent covered the manufacture of ecgonine, which made the Boehringer patent dependent on it. He appears not to be aware that the Farbwerke patent lapsed already in 1900.
} 
Initially cocaine was in short supply and its price was very high. Merck, in Germany, was the first manufacturer of cocaine from imported leaves from Peru, followed soon by many others. The price of cocaine came down quite quickly after transportation of the raw material and production of the alkaloid became organised. However, shipment of the coca leaves caused deterioration of the quality and already in 1886 extraction facilities were set up in Peru. The product of these facilities, crude cocaine, was shipped to manufacturers of the end product, cocaine hydrochloride, mainly in Europe. Manufacturers in the USA stayed largely with coca leaf as the raw material because of a $25 \%$ import duty imposed on crude cocaine.

From 1887 to 1892 the cocaine market grew from less than $1,000 \mathrm{~kg}$ to ca $6,000 \mathrm{~kg}$ and during the second half of the 1890s the world demand for cocaine stabilised at a level of ca $6,200 \mathrm{~kg}$ p.a. Competition between maufacturers was fierce and from 1892 prices started to decline; from ca DEM 900 in that year to DEM 450 in 1898. A manufacturers' "convention" (cartel) was established but strict price control could not be achieved. Merck enforced its position as the leading cocaine manufacturer as a result of its technological and marketing prowess. During 1898-1899 a raw material shortage caused a very strong but short lived price recovery of cocaine

From the late 1880s cultivation of the coca plant was attemped in a number of countries outside South America, notably on Java. Java coca had a high total alkaloid content but was intially rejected by cocaine manufacturers as a raw material because it contained mainly secondary coca-alkaloids and the direct yield of cocaine from the leaves was low. That changed from 1890 after German chemists had discovered a process to convert the secondary alkaloids into cocaine with a good yield. Initially the process was used only to increase the cocaine yield from Peruvian coca, but during the 1890s it opened the way for the use of Java coca as a raw material on a small scale. 


\section{CHAPTER 4 JAVA COCA AND THE ESTABLISHMENT OF THE NCF}

From 1885 the coca plant was cultivated on Java in increasing quantities in an attempt to take advantage of the demand for coca leaf that developed after Koller's discovery. Initially the coca leaf produced on Java was not well received by the trade because of its high content of secondary alkaloids but in the late 1880's German chemists found ways to convert these secondary alkaloids into cocaine and thereby Java coca became of interest as an economical raw material for cocaine manufacture. During the 1890s modest quantities of Java coca were sold to an unidentified cocaine manufacurer for that purpose; the price that could be obtained was however low. The processes for the conversion of the secondary alkaloids were patented in Germany. The low cost of Java coca and the idea that the patents could be circumvented by manufacturing the cocaine from Java coca in the Netherlands lead ultimately to the establishment of the Nederlandsche Cocaine Fabriek (NCF).

\subsection{Java Coca}

In December 1854, J.K. Hasskarl (the Civil Servant in charge of cinchona cultivation on Java), returning to Batavia from a fact-finding mission to Peru, submitted a report to A.J. Duijmaer van Twist, Governor-General of the Dutch East Indies, on the knowledge he had acquired on the coca plant. Hasskarl described the extensive use of coca leaves in Peru to promote health in general and to increase the ability of man to work under strenuous conditions, especially in mountainous areas. He recommended commencement of a trial to cultivate the coca from seeds brought with him from Peru in the Botanical Gardens ('s Lands Plantentuin) at Buitenzorg and to find out what the effect of the leaves would be when used by certain categories of inhabitants of the Dutch East Indies.

Duijmaer van Twist obtained advice from P.F.H. Fromberg, the official agriculturalchemist, and from G. Wassink, head of the Department of Health. Both recommended not to embark on the proposed experimental cultivation of coca in the Dutch East Indies. Reasons given for the negative advice were the risk of abuse of coca by the Javanese population and the limited potential of the coca for medicinal applications and profit. As result of the negative recommendations Hasskarl's proposal for a trial was not taken up. ${ }^{1}$

In the 1860s the economic potential of the coca plants was increasingly recognized in Europe. From 1869 coca plants grown from seeds sourced from Huanuco were cultivated at the Royal Botanical Gardens at Kew, in England. Thiselton Dyer, director of that botanical garden, indentified the plants grown at Kew as E.coca var. novogranatense. Young coca plants from Kew were sent to many places around the world, including Ceylon and other British colonies. $^{2}$

The first time that a specimen of the coca plant arrived on Java was in 1875 or 1876 when the Botanical Gardens at Buitenzorg (Java) received two coca plants from the company Herman

\footnotetext{
${ }^{1}$ [P.H. van der Kemp and A.H. Berkhout], 'Dr Hasskarl's mislukte poging tot invoering der coca-cultuur op Java: officiële stukken, wedergegeven door de redactie', Tijdschrift voor Nijverheid en Landbouw in Nederlandsch Indië, 32 (1886) 413-459.

${ }^{2}$ W. Burck, 'Opmerkingen over de onder de naam Erythroxylon coca in Nederlandsch-Indië gecultiveerde gewassen', Teysmannia, 1 (1890) 397 and 453-454.
} 
Linden at Ghent (Belgium). ${ }^{3}$ During the period 1883-1886 seeds from the two motherplants were the starting material for a seed multiplication programme by the Botanical Gardens. After Koller's discovery of the local anaesthetic properties of cocaine, the demand for coca leaf rose sharply and thereby the price and the interest of growers. ${ }^{4}$ Seed and seedlings were made available to interested planters on Java and other parts of the archipelago. ${ }^{5}$ In 1889 , 300,000 coca plants (seedlings) were under cultivation at the Government experimental station at Tjikeumeuh. ${ }^{6}$

W. Burck, assistant director of the Botanical Gardens, found in 1890 that the plants grown on Java from the seeds originating from Herman Linden differed very considerably from plants grown at Kew. Burck proposed to name the plants E. coca var. Spruceanum (now $E$ novogranatense var. novogranatense) and E. Bolivianum (now E. coca var. coca) respectively. Apart from morphological differences Burck emphasized the big difference in alkaloid content between the two species. He reported a range of 0.40 to $0.80 \%$ for the cocaine content of 14 samples of coca from various British colonies and around $2 \%$ for the total alkaloid content of young coca leaves from Java. ${ }^{7}$

In the early 1890 s there was confusion on the value of Java coca as a raw material. As an example: During the period 1888-1890 the German cocaine manufacturer Zimmer received several samples of coca from Java. The first sample resembled the Bolivia variety but it did not contain any cocaine. Thereafter Zimmer received another coca sample from Java; this time with all the properties of the Truxillo variety but containing ca $0.3 \%$ alkaloid only. Later samples contained a satisfactory content of $0.6-0.7 \%$ alkaloid and in 1890 Zimmer \& Co advised Treub of their assays of samples of Java coca received from 's Lands Plantentuin: young leaves contained ca $2.0 \%$ total alkaloid and older leaves ca $1.0 \%$, which was considered a big improvement. ${ }^{8}$

Merck also showed an early interest in Java coca. Willy Merck visited the Buitenzorg gardens in 1888 and obtained samples from which Merck was able to isolate $0.34 \%$ pure cocaine. ${ }^{9}$

Burck mentions that the Buitenzorg gardens distributed only the Spruceanum variety to growers but that growers themselves had imported coca seed from Ceylon or London. ${ }^{10}$ This could explain the above mentioned large variation in cocaine content of the samples which Zimmer had experienced.

First attempts to sell commercial quantities of Java coca were not a success. The first lots of ca 20 tonnes each, offered for sale in London (1890) and in Amsterdam (1891), were not well received by the trade. ${ }^{11}$ The quality was judged as being inferior. ${ }^{12}$ That judgement

\footnotetext{
${ }^{3}$ Burck mentions on page 397 of his publication that importation of the first coca plants took place in 1875 and on page 454 of the same publication (part 2) that the plants had been received in 1876. Melchior Treub, the director of the Botanical Gardens, replied in 1885 in writing on the specific question of when the plants had been received, that he could not give an exact answer but that two coca plants had been in the gardens for at least 8 years. That implies that the plants were cultivated from 1877 or earlier. Burck, 'Erthroxylon coca' and [van der Kemp and Berkhout], 'Dr. Hasskarl's mislukte poging', 441.

${ }^{4}$ A.H. Berkhout, 'De coca, cuca, Erythroxylon coca, Een nieuw landbouwproduct voor Nederlandsch-Indië,' Tijdschrift voor Nijverheid en Landbouw in Nederlandsch Indië, 31 (1885) 251-265.

${ }^{5}$ E. Reens, 'Java Coca', dissertation University of Paris (Lons-le-Saunier 1919), Chapter 5 in S.B. Karch A History of Cocaine. The Mystery of Java Coca and the Kew Plant (London 2003) 62.

${ }^{6}$ G. van der Sleen, 'Over Java-Coca', De Indische Mercuur, 25 February [8] (1908) 127.

${ }^{7}$ Burck, 'Erthroxylon coca', 449-467.

${ }^{8}$ Zimmer \& Co Jahresbericht, 1888-1889, Teysmannia, 1 (1890) 174-175 and 189-190.

${ }^{9}$ W. R. Tromp de Haas, 'De Coca-Cultuur', Teysmannia 14 (1903) 296-297.

${ }^{10}$ Burck, 'Erythroxylon coca', 458.

${ }^{11}$ Gehe, Handelsbericht, (April 1890) 19.

${ }^{12}$ Reens, 'Java Coca', 70.
} 
was probably based on the low content of "crystallisable" cocaine. It is not unlikely that the high total alkaloid content was disregarded because the possibility of conversion of the secondary alkaloids into cocaine was not generally recognised at the time. After 1891 Java coca was not any longer sold via auctions but it was sold on consignment by the Kolonale Bank in quantities of 40-80 t p.a. ${ }^{13}$

Java coca (E. novogranatense var. novogranatense) turned out to grow well locally. It was often cultivated as a secondary crop in conjunction with rubber or tea. De Jong mentions that "between 1890 and 1900 only a few plantations of coca existed on Java encompassing ca 200 ha" and that "Mr. Massing at Tjibadak owned the largest; he was the first to try to commercialise Java coca". ${ }^{14}$ Several coca samples analysed in 1888 by Greshoff came from the plantation "Soekamadjoe" located at Tjibadak. ${ }^{15}$ Hence "Soekamadjoe" almost certainly was the name of the plantation at Tjibadak owned by Mr. Massing.

\subsection{Roots of the NCF}

The high price of Peru coca and crude cocaine during the 1890s drew attention to Java coca as an alternative raw material. Java coca had a high total alkaloid content and processes had been invented in Germany for the conversion of these total alkaloids into cocaine with a good yield.

Using the German processes, the yield of cocaine from Java coca was approximately twice as much as from Peru coca and hence, at equal raw material cost, the raw material part of the unit manufacturing cost of cocaine hydrochloride from Java coca was about half of that compared to using Peru coca. In fact, the price of Java coca was even substantially lower than that of Peru coca. During the 1890s coca growers from Java were at the mercy of a single buyer, a (German) cocaine manufacturer, to whom modest quantities were sold at a low price. $^{16}$

These factors led to the establishment of the Nederlandsche Cocaine Fabriek (NCF). Two Germans, Georg Boldemann and Dr Otto Eberhard, were at the inception of the Company in the mid-1890s. Boldemann, a businessman operating from Sweden, became aware of the situation in the cocaine industry. He realised that in view of the low cost and the high alkaloid content of Java-coca considerable profits could be made if a way could be found to circumvent the German patents. The solution occurring to him was to establish a cocaine factory in the Netherlands which would allow the use of the German patents without an infringement arising because in the Netherlands no patent legislation existed at the time.

Boldemann and Eberhard met with the Koloniale Bank and J. van Hengst, a major coca grower from Java, to evaluate the project. From cost estimates the group will have concluded that the cost advantage of using Java coca was so substantial that the NCF was a low risk

\footnotetext{
${ }^{13}$ The quantities sold in consignment are reported in: Koloniale Bank, Jaarverslagen (Annual Reports) 18891935. Nationaal Archief, The Hague, Access No. 2.20.04, Items 4-7; Van der Sleen in 'Over Java-Coca', 127.writes in 1908 that outside the years 1890-1892 and 1906-1907 no coca was offered for sale at Amsterdam. ${ }^{14}$ A.W.K. de Jong, Chapter 'Coca' in: C.J.J. van Hall and C. van de Koppel, editors, De Landbouw in de Indische Archipel Vol II A (The Hague 1948) 873. That amount of ca 60 tonnes coca p.a. traded on consignment by the Koloniale Bank is in broad agreement with a crop that could be expected from the 200 ha reported as the area under cultivation. Because areas under cultivation with coca were mostly shared with other crops, acreage actually planted with coca could have been substantially smaller than 200 ha, say $60 \%$ or 120 ha. At a modest yield of $350 \mathrm{~kg}$ dry coca per "bouw" (500 kg per hectare), 120 ha would have resulted in ca 60 tonnes coca. ${ }^{15}$ Burck, 'Erythroxylon coca', 459-460.

${ }^{16}$ [Anonymous], 'De Nederlandsche Cocainefabriek NV' Pharmaceutisch Weekblad (1939) 798; Koloniale Bank, Jaarverslagen (Annual Reports) 1889-1935.
} 
project. Even if the cocaine prices would return to the Marks 320 (NLG 190) level of early 1898 , a reasonable profit would be still be achieved if an annual quantity of $300-400 \mathrm{~kg}$ cocaine hydrochloride could be sold.

Boldemann's strategic views which resulted in the establishment of the NCF earned him the name of "mastermind behind the NCF" (in Dutch: "geestelijk vader der NCF"); the NCF was his brain-child. ${ }^{17}$ His partner, Dr Eberhard, a chemist from Ludwigslust (Mecklenburg), will have contributed by obtaining the necessary processes for making the cocaine from Java coca.

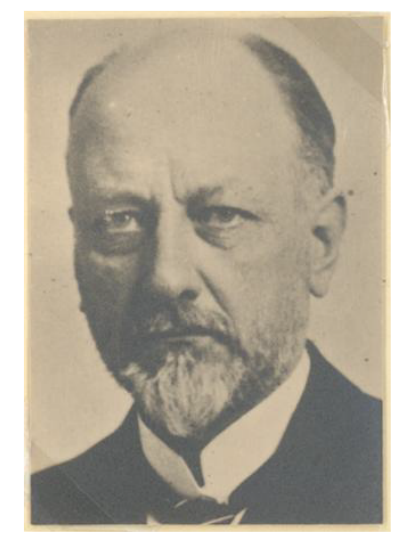

Figure 4.2 Mr Georg Boldemann (NCF 1900-1950, IISH Amsterdam)

As mentioned above, other parties involved in the establishment of the NCF were J. van Hengst, a principal coca grower from Java and the Koloniale Bank. Van Hengst owned or co-owned with Massink the plantation "Soekamadjoe" at Tjibadak in the Preanger (Java) where coca was cultivated since ca $1890 .{ }^{18}$ The Koloniale Bank was involved in the trade of Java coca from 1890; the product was sold on consignment. As mentioned above, until 1900 there was only one buyer, an unidentified cocaine manufacturer, most likely from Germany. ${ }^{19}$ That single buyer was later named as "Farbwerke" (Hoechst), but no reference was provided. ${ }^{20}$ It seems unlikely that this is correct because nothing was found on commercial cocaine activities of this company, neither in trade publications nor in the Farbwerke archives. ${ }^{21}$ The Farbwerke patent of 1893 was abandoned already in 1900, eight years before its expiry date, but it is uncertain what conclusions can be drawn from that fact. $^{22}$

\footnotetext{
${ }^{17}$ Jubileumboek "N.C.F." NV Nederlandsche Cocaine Fabriek 12 Maart 1900-1950. A collection of photos with index 1950. Library of the International Institute of Social History, Amsterdam.

${ }_{18}^{18}$ de Jong, 'Coca', 873.

It is interesting to note that the name A. Massink appears in the Minutes of the Board Meeting of 12 August 1910 as a director of N.V. Landbouwmaatschappij Soekamadjoe. ${ }^{18}$ Also mentioned in the Minutes is Mrs H.F. Massink née van Hengst, as a shareholder. It seems likely that Massing and Massink were one and the same person and that Mrs Massink was the sister of J.van Hengst, the future major shareholder of the NCF. For further details on the relationshps between the families van Hengst, Huygen de Raat and Massink see Appendix 1 to this dissertation.

${ }^{19}$ [Anonymus], “De Nederlandsche Cocainefabriek NV.', 798; Reens, 'Java Coca', 70.

${ }^{20}$ de Jong, 'Coca', 873.

${ }^{21}$ Histocom $\mathrm{GmbH}$, Industriepark Höchst, preliminary search on "Farbwerke", e-mails to HHB dated 31 August 2006 and 5 September 2006.

${ }^{22}$ B. Hoppe, Aus der Frühzeit der chemischen Konstitutionsforschung: die Tropanalkaloide Atropin und Cocain in Wissenschaft und Wirtschaft (München 1979) 60; Deutsches Patent- und Markenambt, Berlin, e-mail to HHB dated 23 April 2008.
} 
In the Netherlands, industrialization commenced late in comparison with Great-Britain and Germany. Only towards the end of the $19^{\text {th }}$ century did Dutch industrialization get momentum. One of the factors contributing to this change was the opening up of the Dutch East Indies (Nederlandsch Oost Indië, now Indonesia) for private enterprise in 1870. Before that time all major commercial activities in the Dutch East Indies had been controlled by the Government. $^{23}$

One of the early companies established in 1881 with the objective to take advantage of the new situation in the Dutch East Indies was the Koloniale Bank. It was the result of an initiative by J. Hudig, who was to become the first managing director. Activities of the Koloniale Bank were initially to provide working capital for agricultural enterprises in the Dutch East Indies and to act as bank in general. Furthermore, the bank was trading in coffee, tea, rubber and coca leaves on Java and in Amsterdam. The seat of the Koloniale Bank was at Amsterdam and its main office (Hoofdagentschap) in the Dutch East Indies was initially located at Batavia (now Jakarta). Share capital of the Koloniale Bank amounted to NLG 5 million. ${ }^{24}$

Companies established in the motherland with the specific objective to do business abroad are called "free-standing companies" and were quite common in the Netherlands at the time as a vehicle to organise business activies in the Dutch East Indies. ${ }^{25}$ The Koloniale Bank was an example of such a free-standing company. The collective of the free-standing companies in the Dutch East Indies formed an informal network that played an important role in the economic functioning of the colony. ${ }^{26}$

Shortly after commencing its operations the Koloniale Bank had to face serious problems as a result of an agricultural recession that resulted in very low sugar prices. In 1884 the Bank had to apply for a letter of licence. The immediate problems were solved by the issue of a debenture loan of NLG 5 million. To limit its losses, the Bank decided to change its original strategy from being a capital provider for other companies to investing itself in agricultural companies by buying the assets of a number of sugar companies under execution. The resultt was that the Koloniale Bank began diversifying into managing sugar plantations and sugar factories. The company was reorganised and its main office was moved to Soerabaja. In the following years the Bank also acquired agricultural companies involved in coffee and rubber. In 1894 sugar prices nose-dived again and as a part of the reorganisation J.W. Benjamin was appointed as the managing director (hoofdagent) of the operations in the Dutch East Indies. ${ }^{27}$

The new strategy proved successful and from the late 1890s the financial results improved considerably. At this time the Koloniale Bank became involved in the cocaine venture, which was small in comparison with its existing activities on Java.

\subsection{Establishment of the NCF}

The Nederlandsche Cocaine Fabriek (NCF) was established in the year 1900 with the object of making pharmaceutical grade cocaine from coca leaves cultivated on Java and to trade in

\footnotetext{
${ }^{23}$ K.E. Sluyterman, Kerende Kansen Het Nederlandse bedrijfsleven in de twintigste eeuw (Amsterdam 2003) 52.

${ }^{24}$ Cultuurbank N.V. (Koloniale Bank), Kort Historisch Overzicht. (Brief history of the Cultuurbank, written on the occasion of its 75th Anniversary) 1956 Nationaal Archief, The Hague, Access No. 2.20.05 Item 108.

${ }^{25} \mathrm{M}$. Wilkins, 'The free-standing company revisted', in: The free-standing company in the world economy, 1830-1996. M. Wilkins and H. Schröter, eds. (Oxford 1998) 3-64.

${ }^{26}$ B.P.A Gales. and K.E. Sluyterman 'Dutch free-standing companies, 1870-1940', in: The free-standing company in the world economy, 1830-1996. W. Wilkins and H. Schröter, eds. (Oxford 1998) 293-322.

${ }^{27}$ Cultuurbank N.V Kort Historisch Overzicht.
} 
the product and its by-products. Cocaine was not a controlled substance at the time and no restrictions applied to its manufacture and sale. Process know-how was obtained from an unknown source in Germany and a small factory was built in Amsterdam. The product was to be traded both in the Netherlands and internationally.

The NCF was an early example of a pharmaceutical-chemical (bulk pharmaceutical) industry located in the Netherlands; it was one of the very first companies in the Netherlands to use synthetic organic chemical processes in the manufacture of its product. Another company at the time manufacturing bulk pharmaceuticals from plant raw material from the Dutch East Indies was the Amsterdamsche Chinine Fabriek (ACF), established in 1881, which produced quinine and other alkaloids by the extraction of cinchona bark. ${ }^{28}$

The NCF also had its roots in the Dutch East Indies. J. Van Hengst, the principal coca grower from Java, and the Koloniale Bank became its major shareholders immediately after incorporation when the two founders transferred their shares to them (see below). Van Hengst's being a shareholder implied a virtually guaranteed source of supply of the essential raw material, coca leaves from Java. ${ }^{29}$ From the beginning the Koloniale Bank was the managing partner ("directie") of the NCF. This involvement of the Koloniale Bank in NCF's business meant mainly financial control but also general supervision by the Bank as a member of the Board The Koloniale Bank provided a further link to the important colonial network in the Dutch East Indies.

The limited liability company (Naamlooze Vernnootschap) 'Nederlandsche Cocainefabriek' was established by a Memorandum of Association (Akte van Oprichting) dated 14 March 1900. The Certificate of Incorporation (Koninklijke Bewilliging) was obtained on 5 April 1900. ${ }^{30}$ As founders are mentioned: Georg Boldemann, merchant from Stockholm and Dr Otto Eberhard Jr, chemist from Ludwigslust in Mecklenburg. ${ }^{31}$

The main clauses of the Memorandum of Association were:

Object of the company: the production of cocaine complying with the Pharmacopae Germanica III and trade in the product and by-products;

Norminal capital: NLG 12,000, divided over 12 shares of NLG 1,000 each, Boldemann and Eberhard jointly owning the total of 12 shares;

Boldemann and Eberhard bringing into the company a process to manufacture pure cocaine, complying with the Pharmacopae Germanica III, from coca leaves. As compensation, Boldemann and Eberhard received jointly four shares in the Company, free of charge;

\footnotetext{
${ }^{28}$ M.A.W. Algera-van der Schaaf, Dr Johan Eliza de Vrij Apotheker en Kinoloog 1813-1898 Dissertation University of Leiden (Alphen a/d Rijn 1994). 82-87.

${ }^{29}$ The NCF and van Hengst are mentioned for the first time in the Minutes of Board Meetings of the Koloniale Bank of 12 December 1899. It is stated there that the share of Van Hengst in the future profit of the cocaine factory would be used to relinquish his debt with the Koloniale Bank. A contract for the supply of coca leaves to NCF by van Hengst is referred to in the Minutes of the Board of the Koloniale Bank of 19 February 1901. See: Koloniale Bank, Notulen Commissarissen Vergaderingen (Minutes of Board Meetings), meeting of 19 December 1899 and Koloniale Bank, Minutes of Board Meetings, Meeting of 19 February 1901.

${ }^{30}$ Emma Reens in her dissertation: La Coca de Java, mentions 1895 as the year that the first cocaine factory was established in Amsterdam. Several later authors (Korf and de Kort, and Slot) have repeated that apparently incorrect date. See: Reens, Java Coca, 70, D.J. Korf and M. de Kort, Drugshandel en Drugsbestrijding. (Amsterdam 1990) 8 and E. Slot, Legaal Snuiven, Slikken en Spuiten. De Nederlandsche Cocaine Fabriek (1900-1962) "Ons Amsterdam": 46 [3] March (1994) 70-74.

${ }^{31}$ Nederlandsche Staatscourant Naamloze Vennootschap: Nederlandsche Cocaine-fabriek, te Amsterdam (No. 222), June 1 (1900) 365-366.
} 
The issue of two profit-sharing notes, each entitling the holder to $12.5 \%$ of the profit of the Company during the first 10 years of operation. After this period of 10 years the profitsharing notes would be converted into common shares.

In the Memorandum of Association (Clause 7) a "separate agreement" is mentioned by which it would be determined who would own the profit-sharing notes; it was to be signed immediately after the execution of the Memorandum. Eberhard and Boldemann together are mentioned as one party to the "separate agreement". The other party is not specified in the Memorandum of Association but it must have been Van Hengst together with the Koloniale Bank. Clause 5 of the Memorandum states that depositing the required amount (NLG 8,000) for the eight remaining shares shall take place within 14 days from the date of the Certificate of Incorporation (obtained on 5 April 1900).

No further information is available on the exact wording of the "separate agreement" (above) but we know that 4 shares were allocated to the Koloniale Bank at no cost, for their exertions, and conclude from the shareholdings in 1910 that the remaining eight shares were acquired by Van Hengst against the deposit of NLG 8,000. ${ }^{32}$ Eberhard and Boldemann each received one of the profit-sharing notes, entitling them jointly to $25 \%$ of the profit of the NCF during the first 10 years of operation of the company. An amount of NLG 4,000 must have been included in NCF's opening balance sheet for the value of the process. It was written off in total at the end of $1901 .{ }^{33}$ It is very likely that the "separate agreement" included a clause on a guarantee that the process supplied by Eberhard and Boldemann would give the promised results when applied at factory scale (cf. Section 4.4)

In the volume covering the year 1900 of Van Nierop \& Baak's "Naamloze Vennootschappen" the Nederlandsche Cocainefabriek appears for the first time. ${ }^{34}$ Mentioned are, as Managing Partner ("Directeur"): the Koloniale Bank, and as Board Members (Commissarissen): A. Roelvink, W.F.L. Gericke, J.H. de Groot, G. Boldemann and O. Eberhard. A. Roelvink was the chairman of the Board of the Koloniale Bank at the time.

\subsection{The Cocaine Manufacturing Process}

The process of manufacturing cocaine from Java coca comprised of two stages. The first stage was that of the extraction of the leaves, yielding the total alkaloids. The second stage was that of the conversion of the secondary alkaloids into cocaine. The process for the extraction of the leaves was straightforward. The process used by the NCF will have been a modification of the relatively simple Bignon process using an extraction solvent suitable for the venue. For the conversion of the total alkaloids into cocaine the process will have been based on the German patents of 1888, most likely on that from Liebermann and Giesel for making the ecgonine and on that from Einhorn and Klein for the subsequent synthesis of cocaine. It is unlikely that the NCF used the Farbwerke process for converting the total alkaloids into ecgoninemethylester. ${ }^{35}$

\footnotetext{
${ }^{32}$ Koloniale Bank Report inzake N.V. Nederlandsche Cocaine Fabriek dated 26 November 1945, Nationaal Archief, The Hague, Access No. 2.20.04 Item 928. It is mentioned here that after the recapitalisation of the NCF in 1910 J. van Hengst (Soekamadjoe) held 20 shares and the Koloniale Bank 10.

${ }^{33}$ Koloniale Bank, Notulen Commissarissen Vergaderingen (Minutes of Board Meetings), 21 January 1902

${ }^{34}$ Van Nierop \& Baak, Naamloze Vennootschappen, 19 (1900) 1569

${ }^{35}$ It has been reported by Schwyzer that in the Netherlands the total alkaloids (including the cocaine present in the coca) were converted into ecgonine. See: J. Schwyzer, Die Fabrikation de Alkaloide, (Berlin 1927) 82. In 1960 at the NCF the secondary alkaloids of coca were converted (still) using the Einhorn and Klein process (HHB personal experience).
} 
The description in the German patents of the processes for the conversion of the secondary alkaloids into cocaine is scant. More process information was available from the publications of the original research by Liebermann and Giesel and from Einhorn and Klein (for details see Chapter 3.4). Boldemann and Eberhard had the task to convince the other partners that the process information in their possession was beyond a mere literature study and that they had access to practical, detailed process know-how that worked on a factory scale. The exact provenance of such practical know-how is not known but the name of Dr Franz Loth, a German organic chemist, holder of a doctorate from the University of Rostock ${ }^{36}$ appears here. Dr Otto Eberhard, was also an organic chemist and he had obtained his doctorate at the same university and in the same year as Loth (1894), and they must have known each other well. ${ }^{37}$

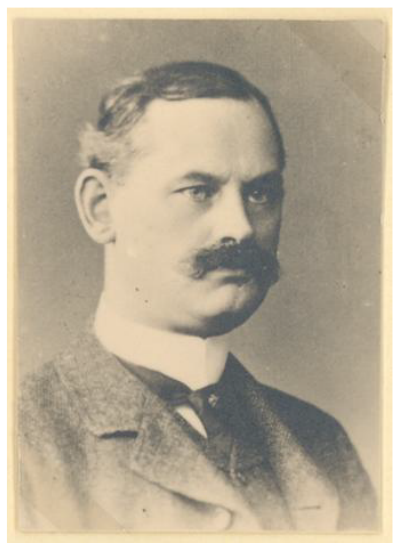

Figure 4.3 Dr Franz Loth

Technical Director NCF 1900-1907

(NCF 1900-1950, IISH Amsterdam)

Oral history circulating at the NCF in 1960 recalled that the Koloniale Bank before committing to participating in the cocaine factory wanted to have proof that the process would work. ${ }^{38}$ This problem was reportedly solved by inviting the chemist responsible for the process to come to Amsterdam where he was "locked up" in a laboratory with coca leaves and chemicals, from which laboratory he was to be released only after having produced the right quantity of cocaine of the right quality.

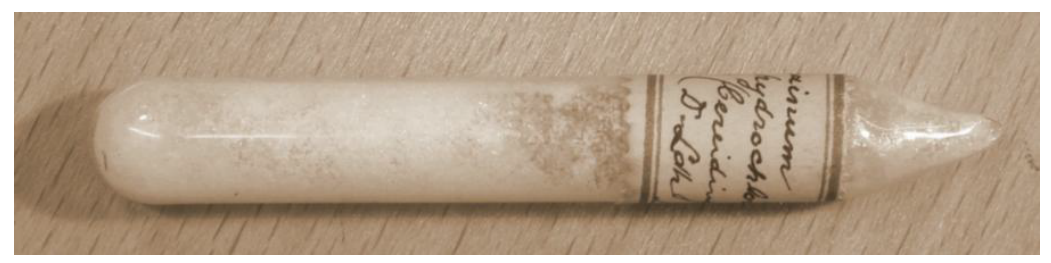

Figure 4.4 The glass ampoule with the cocaine produced by Dr Loth (Photo collection HHB)

That procedure worked. The chemist produced cocaine of the right quality and the deal was on. The Merck product was used as the standard. A sealed glass ampoule labeled:

\footnotetext{
${ }^{36}$ F. Loth, Einwirkung von Thionylchlorid auf Phenol - und Naphtoläther sowie auf Ketone und Aldehyde, Dissertation University of Rostock (Mecklenburg, Germany) 1894.

${ }^{37}$ O. Eberhard, Zur kenntnis der Reactionen des Sulfurylchlorids mit aromatischen Kohlenwasserstoffen, Thiophen und einige Derivaten der Fettreihe, Dissertation University of Rostock (Mecklenburg, Germany) 1894.

${ }^{38}$ HHB recollection.
} 
"C. Cocainum hydrochloric (bereiding [preparation] Dr. Loth)", pictured above, was kept at the NCF together with a virtually identical ampoule labelled "B. Cocainum hydrochlor. Merck". Dr Franz Loth became the first technical director of the NCF.

The first factory of the NCF was the size of a pilot-plant. ${ }^{39}$ It was located in a dwelling in a residential area (at the corner of the Schinkelkade and the $1^{\text {st }}$ Schinkelstraat) in Amsterdam. The factory consisted of an extraction room (with 15 extraction vessels and a stirred reactor), an engine room (with a steam generator and a compressor) and a storage facility. The office and the laboratory were located in the living room of an adjacent dwelling. ${ }^{40}$

It is not unlikely that the final proof that the process worked satisfactorily was provided by Loth in the new facilities during the year 1900. In the Minutes of the Board Meeting of the Koloniale Bank of 19 February 1901 it is mentioned that the technical director (Loth) had produced "good" cocaine but in quantities insufficient to judge the factory results. $^{41}$

\subsection{Summary and Conclusions}

The first coca plants that arrived on Java were sent to the Botanical Gardens, Buitenzorg, around 1875. After Koller's discovery of 1884 of the local aneasthetic properties of cocaine, interest in the commercialisation of Java coca arose and a seed multiplcation programme was started. The plants grew well but in 1890 it was found by Burck that they were not of the Peruvian variety commonly used for the production of cocaine. The total alkaloid content of Java coca was high but only a minor part of the alkaloids was cocaine. This led to the initial rejection of Java coca as a raw material for cocaine but that changed when German manufacturers started to use one of the recently invented processes for the conversion of the total alkaloids into cocaine. A (German) cocaine manufacturer became the sole buyer of Java coca during the 1890s. The Java coca was sold on consignment by the Koloniale Bank, a merchant bank from Amsterdam operating in the Dutch East Indies.

As a result of an initiative by Georg Boldemann, a businessman operating from Sweden, he and his partner, the German chemist Dr Otto Eberhard, joined with the Koloniale Bank and Mr. J van Hengst, the major coca producer from Java, to evaluate the feasibility of establishing a cocaine factory in the Netherlands. The factory would be able to use the recently patented German processes without paying a royalty because the Netherlands did not entertain a patent law at the time.

The initiative led eventually to the establishment of the Nederlandsche Cocaine Fabriek (NCF) in the year 1900 and the building of a small factory in Amsterdam. Van Hengst obtained two-thirds of the shares and the Koloniale bank one-third.

The NCF was founded on sound business principles. Through its major shareholder, van Hengst, it had virtually guaranteed access to a low cost, high yielding plant raw material. The other shareholder, and managing partner, was the Koloniale Bank, a company with a good track record in managing agricultural operations on Java and in the export trade of agricultural produce from the Dutch East Indies via Amsterdam. A validated production

\footnotetext{
${ }^{39}$ [Anonymous]. "De Nederlandsche Cocaine Fabriek NV".

${ }^{40}$ Slot, Legaal Snuiven, Slikken en Spuiten. 70-74.

${ }^{41}$ Koloniale Bank, Notulen Commissarissen Vergaderingen (Minutes of Board Meetings), Meeting of 19 February 1901.
} 
process was obtained that should result in low unit cost for the end product cocaine hydrochloride. The unit cost of the cocaine manufactured would be substantially lower than cocaine made from Peru coca. That implied that the new company should be able to withstand serious price competition if required. 


\section{CHAPTER 5 \\ Developments in the Cocaine Market during the Period 1900-1913}

In Chapter 5 the developments in the world market for cocaine during the period 1900-1913 are reviewed to provide the background against which the position of the NCF is evaluated in Chapter 6. Key elements are the size and structure of the markets, the manufacturers, and prices for cocaine hydrochloride and its raw materials. During the period the foundations were laid for international narcotics control at meetings in Shanghai and The Hague, the scope of which is reviewed.

\subsection{Manufacture of Cocaine Worldwide.}

Estimate of the World Manufacture of Cocaine during the Period 1900-1913

The developments of the cocaine market during the early 1900s are illustrated with the following table and graph of the quantities of cocaine hydrochloride manufactured worldwide estimated from the amounts of raw materials exported. These calculations are set-out in detail in Chapter 16 and 17, culminating in Table 17.11; the end results are presented here rounded to the nearest hundred $\mathrm{kg}$ to reflect the confidence interval.

Table 5.1 Estimate of Cocaine $\mathrm{HCl}$ manufactured worldwide from

Raw Materials exported during the Period 1900-1913 (kg)

\begin{tabular}{|c|c|c|c|c|}
\hline \multirow{2}{*}{$\begin{array}{c}\text { Year } \\
\text { of } \\
\text { Export }\end{array}$} & \multicolumn{2}{|c|}{ Cocaine Manufuctured } & \\
\cline { 2 - 3 } & $\begin{array}{c}\text { from Peru } \\
\text { Coca }\end{array}$ & $\begin{array}{c}\text { Trom Peru } \\
\text { Crude }\end{array}$ & $\begin{array}{c}\text { Trom Java } \\
\text { Coca }\end{array}$ & \\
\hline & & & 300 & \\
1900 & 2,400 & 6,500 & 9,200 \\
1901 & 2,600 & 9,000 & 800 & 12,400 \\
1902 & 4,000 & 7,000 & 800 & 11,800 \\
1903 & 4,400 & 6,600 & 800 & 11,800 \\
1904 & 4,000 & 6,400 & 800 & 11,200 \\
1905 & 6,600 & 5,700 & 700 & 13,000 \\
1906 & 5,300 & 5,000 & 1,300 & 11,600 \\
1907 & 2,900 & 5,100 & 2,200 & 10,200 \\
1908 & 1,800 & 4,400 & 4,500 & 10,700 \\
1909 & 2,200 & 4,400 & 4,100 & 10,700 \\
1910 & 2,200 & 4,700 & 4,700 & 11,600 \\
1911 & 2,400 & 4,600 & 8,100 & 15,100 \\
1912 & 2,500 & 2,500 & 11,700 & 16,700 \\
1913 & 1,300 & 2,800 & 14,500 & 18,600 \\
& & & & \\
\hline
\end{tabular}

Source: Table 17.11 The amounts are rounded to the nearest hundred $\mathrm{kg}$ Figures in blue are estimates by the author 
Figure 5.1 Graph of Cocaine HCl manufactured worldwide from

Raw Materials exported during the Period 1900-1913

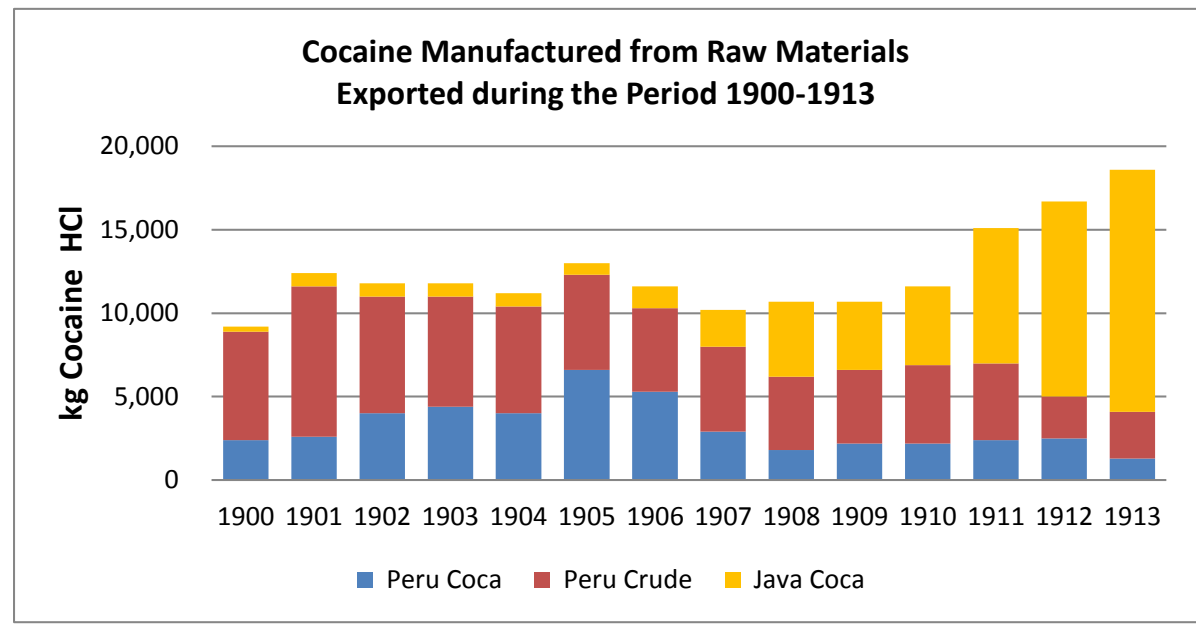

Source: Table 5.1

The picture emerging from the above table and graph is that cocaine manufacture worldwide, which had been at a relatively stable level of ca. $6,200 \mathrm{~kg}$ p.a. during the $1890 \mathrm{~s}$, increased sharply in 1900 to reach a level of ca 11,000 kg p.a. where it stayed for the next ten years. In 1911 there was another jump in the production to a level of ca 17,000 kg p.a. This pattern in cocaine consumption was already noted by Musto. He mentions a first rise about 1890, a second one about 1900 and third one about 1910-1912. The "great reduction" in consumption occurring about 1905-1910, signalled by Musto, is, however, not apparent in the above graph. ${ }^{1}$

From 1906 a fundamental shift occurred in the raw materials used. Peru coca and crude cocaine which had been the main raw materials until that time were rapidly and to a large extent replaced by Java coca. By 1913 Java coca was the raw material for $78 \%$ of the cocaine manufactured.

Average cocaine production by period split over Germany, the USA and Other Countries, mainly the UK and France, are presented with the following Table 5.2. The amounts are calculated by the author on the basis of the estimates as developed in Chapters 16 and 17 . Key data and parameters for the calculations are those brought together in Table 17.9 and 17.10. The periods used for Table 5.2 are somewhat different from those in Table 16.9. The reason is that the periods 1892-1896 and 1897-1903 in Table 16.9 are the consequence of using the GIT-method (Appendix 3) in the calculations. The new periods 1892-1899 and 1900-1903 used in this chapter break at the year 1900, which is a pivotal year. It represents a sharp increase in the worldwide production of cocaine and the year of the establishment of the NCF.

The data for the period 1892-1899, already included in Table 3.3, are also presented in Table 5.2 for the sake of comparison with the data of the later periods.

\footnotetext{
${ }^{1}$ D.F. Musto, 'International Traffic in Coca through the early $20^{\text {th }}$ Century' Drug and Alcohol Dependence 49 [2] (1998) 151.
} 
Table 5.2 Estimates by Period of Annual averages of Cocaine $\mathrm{HCl}$ manufactured from Raw Materials exported during the years 1897-1903 split over

Countries and Raw Materials ( $\mathrm{kg}$ Cocaine $\mathrm{HCl}$ per annum)

\begin{tabular}{|c|c|c|c|c|c|c|}
\hline Period & $\begin{array}{c}\text { Raw } \\
\text { Material }\end{array}$ & Germany & USA & $\begin{array}{l}\text { Other } \\
\text { Europe }\end{array}$ & NCF & Total \\
\hline \multirow[t]{5}{*}{ 1892-1899 } & Peru Coca & 400 & 1,000 & 500 & 0 & 1,900 \\
\hline & Peru Crude & 3,100 & 100 & 400 & 0 & 3,600 \\
\hline & Java Coca & 700 & 0 & 0 & 0 & 700 \\
\hline & Total & 4,200 & 1,100 & 900 & 0 & 6,200 \\
\hline & $\%$ & 68 & 18 & 15 & 0 & 100 \\
\hline \multirow[t]{5}{*}{$1900-1903$} & Peru Coca & 600 & 2,500 & 200 & 0 & 3,300 \\
\hline & Peru Crude & 6,300 & 100 & 800 & 0 & 7,200 \\
\hline & Java Coca & 300 & 0 & 0 & 200 & 500 \\
\hline & Total & 7,200 & 2,600 & 1,000 & 200 & 11,000 \\
\hline & $\%$ & 65 & 24 & 9 & 2 & 100 \\
\hline \multirow[t]{5}{*}{ 1904-1910 } & Peru Coca & 200 & 3,200 & 200 & 0 & 3,600 \\
\hline & Peru Crude & 4,400 & 100 & 600 & 0 & 5,100 \\
\hline & Java Coca & 1,800 & 500 & 0 & 300 & 2,600 \\
\hline & Total & 6,400 & 3,800 & 800 & 300 & 11,300 \\
\hline & $\%$ & 57 & 34 & 7 & 3 & 100 \\
\hline \multirow[t]{5}{*}{$1911-1913$} & Peru Coca & 100 & 1,900 & 100 & 0 & 2,100 \\
\hline & Peru Crude & 2,900 & 100 & 200 & 0 & 3,200 \\
\hline & Java Coca & 8,700 & 1,800 & 400 & 500 & 11,400 \\
\hline & Total & 11,700 & 3,800 & 700 & 500 & 16,700 \\
\hline & $\%$ & 70 & 23 & 4 & 3 & 100 \\
\hline
\end{tabular}

Source: The amounts are calculated from the information contained in Table 17.9.

The split of the amounts by country for the period 1987-1903 over the years 1897-1899 and 1900-1903 is made using the ratio of the total amounts for the periods.

Note: The amounts are rounded to the nearest hundred $\mathrm{kg}$

Figures in blue are estimates by the author.

Analysing the trends we note that from the period 1892-1899 to the period 1900-1903 the world production of cocaine virtually doubled. The largest increase as a percentage occurred in the USA but was also considerable in Germany and in Other Countries. Spillane attributes the increase of consumption in the USA almost entirely to non-medical use i.e. as a stimulant. $^{2}$ This rising non-medical ("recreational") use will undoubtedly also have contributed to the increase in consumption in Germany and Other Countries. The high prices

\footnotetext{
${ }^{2}$ Initially the main users of cocaine as a stimulant were young professionals. However, cocaine use soon became widespread among waterfront workers and agricultural labourers in the Southern States to sustain hard labour and "fast living". Some employers supplied cocaine to the labour force instead of the customary whisky rations. Its use spread later to the Northern States e.g. to labourers in the textile mills, and to the 'low criminal classes'. Spillane, Cocaine (Baltimore 2000) 90-99.
} 
and relative low cost of crude cocaine from Peru during 1900-1904 will have attracted new, small manufacturers.

Comparing the periods 1900-1903 and 1904-1910 we see a decrease in German production of ca $1,000 \mathrm{~kg}$ p.a. and an increase in USA production by about the same amount. The increased cocaine production in the USA reflects the commencement of manufacture by Mallinckrodt (St. Louis) and possibly Merck (Rahway). ${ }^{3}$

The jump in production after 1910 mainly took place in Germany, where the production increased by about $80 \%$. In Other Countries the production increased by a similar percentage. The USA production stayed constant, probably the result of enforcement of the Pure Food and Drugs Act of $1906 .{ }^{4}$ Recreational use flourished in Europe but it is unclear how and where the large European cocaine production was consumed. ${ }^{5}$ Hirschmüller comments on the 67,000 kg cocaine $\mathrm{HCl}$ produced by Merck over the period 1879-1918:

"Man weiss nicht, welcher Teil davon wirklich in den Praxen der Augenärzte und Chirurgen verwandt wurde - Kokain wurde nach der Jahrhundertwende mehr und mehr von den Lokalanästhetika Novocain und Procain abgelöst - und welcher Teil in die Hände derjenigen gelangte, die Kokain als Rauschdroge konsumierten."

Musto remarks in this context: "This series of quick rises may reflect the early enthusiasm for cocaine as it entered new markets".

\subsection{Manufacturers}

\section{German Manufacturers}

In the early 1900s the most prominent of the German manufacturers was Merck, Darmstadt; other major producers were Boehringer-Mannheim, Knoll, Gehe and Riedel. ${ }^{8}$ BoehringerIngelheim commenced cocaine manufacture in 1906 or $1909 .{ }^{9}$

The following tables and graph on the cocaine production by Merck ${ }^{10}$ illustrate the dominant position of Merck and provide perspective for the position of the NCF in the market.

\footnotetext{
${ }^{3}$ See Section 5.2.

${ }^{4}$ D. Gieringer, 'Centennial of an Unnatural Disaster', Liberty 20[6] (2006),

www.libertybound.com/archive/2006_06/gieringer-centennial.html.

${ }^{5}$ See e.g. M. Kohn, 'Cocaine girls' Chapter 5 in: P. Gootenberg, editor, Cocaine: Global Histories (London 1999) $105-122$.

${ }^{6}$ Hirschmüller, ‘E. Merck und das Kokain’ Gesnerus 52 (1995) 122.

${ }^{7}$ D.F. Musto, 'International Traffic ' 151.

${ }^{8}$ H.R. Friman, 'Germany and the transformations of cocaine, 1860-1920' Chapter 4 in: P. Gootenberg, editor. Cocaine: Global Histories (London 1999) 89. Friman mentions that Bayer, Hoechst and Schering had little stake in the cocaine trade.

${ }^{9}$ W. Dethloff, Gründung der Firm und Weiterentwickling der Abteilung Pharmazeutische Chemikalien. (Section on cocaine) Manuscript ca 1957 Ingelheim, Firmen- und Familienarchiv von C.H. Boehringer Sohn. Cocaine was the first pharmaceutical product manufactured at Ingelheim. In 1892 Boehringer-Ingelheim employed the chemist Arthur Eichengrün giving him the assignment to develop a process for making cocaine. Eichengrün was not successful and left Boehringer the following year. E. Vaupel, Angewandte Chemie 117 (2005) 3408-3419 and a personal communication to Prof. E. Homburg dated 1 May 2007.

${ }^{10}$ Hirschmüller, 'E. Merck und das Kokain', 116-132.
} 
Table 5.3 and Figure 5.2 Cocaine Production at Merck 1900-1918 (kg Cocaine HCl)

\begin{tabular}{|c|rr|r|}
\hline Year & $\begin{array}{c}\text { From } \\
\text { Crude } \\
\text { Cocaine } \\
\text { [1] }\end{array}$ & $\begin{array}{c}\text { From } \\
\text { Java } \\
\text { Coca } \\
\text { [2] }\end{array}$ & $\begin{array}{c}\text { Total } \\
\text { Production } \\
\text { [3] }\end{array}$ \\
\hline $1900 / 01$ & 1,418 & 0 & 1,418 \\
$1901 / 02$ & 1,886 & 0 & 1,886 \\
$1902 / 03$ & 2,453 & 0 & 2,453 \\
$1903 / 04$ & 2,157 & 0 & 2,157 \\
$1904 / 05$ & 2,426 & 0 & 2,426 \\
$1905 / 06$ & 2,146 & 323 & 2,469 \\
1907 & 821 & 1,060 & 1,881 \\
1908 & 1,339 & 2,304 & 3,643 \\
1909 & 1,172 & 3,011 & 4,183 \\
1910 & 2,810 & 2,431 & 5,241 \\
1911 & 1,783 & 2,898 & 4,681 \\
1912 & 1,093 & 4,956 & 6,049 \\
1913 & 1,423 & 7,260 & 8,683 \\
1914 & 534 & 5,678 & 6,212 \\
1915 & 30 & 235 & 264 \\
1916 & 115 & 332 & 447 \\
1917 & 0 & 1,246 & 1,246 \\
1918 & 0 & 1,739 & 1,739 \\
& & & \\
\hline
\end{tabular}

Source: Hirschmüller, 'Merck und das Kokain' (1955) 119-120

Note: 1905/06 Hirschmüller: 0,323 kg. HHB $323 \mathrm{~kg}$.

Figure 5.2

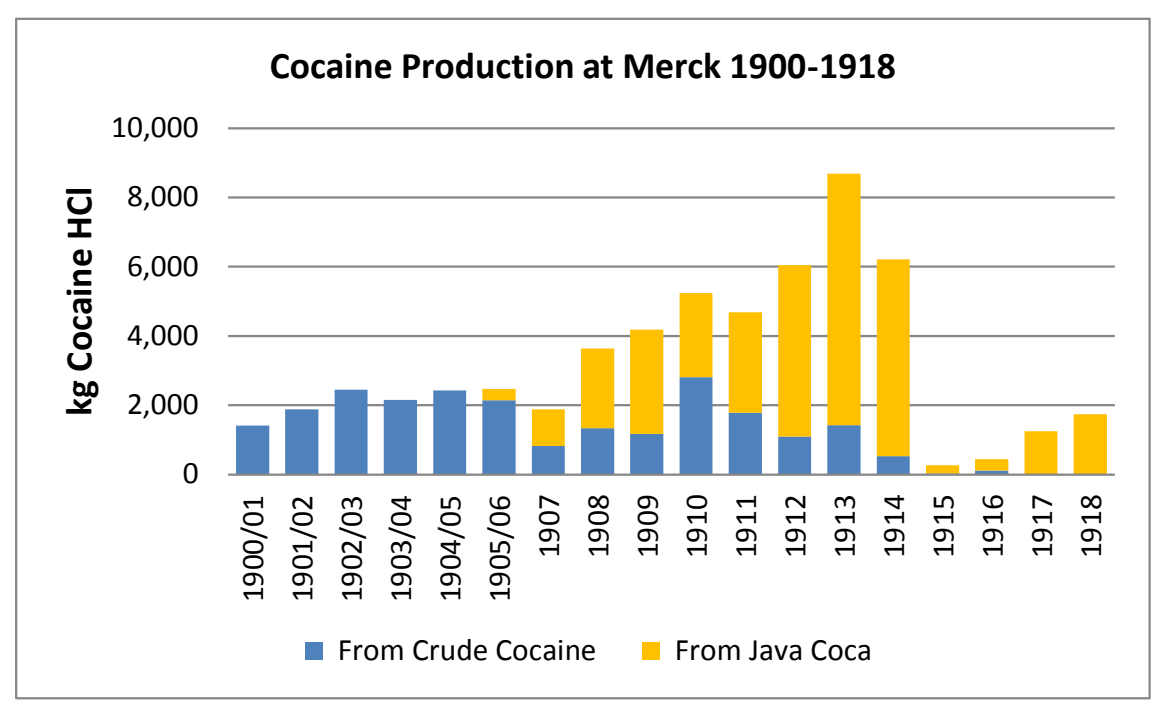

Source: Table 5.3 
From 1907 Merck increased its cocaine production substantially to an all time high of 8,683 $\mathrm{kg}$ in 1913. During that period Merck moved from Crude Cocaine ex Peru as the raw material to Java coca. In 1903 Merck participated in the establishment of a company on Java with the objective to cultivate coca and to manufacture crude cocaine. ${ }^{11}$ From 1900 to the beginning of World War I Merck's market share continued to increase as is shown in the following table

Table 5.4 Cocaine Production at Merck as a Percentage of the

Production in Germany and the Total World

Averages by Period (kg Cocaine $\mathrm{HCl}$ per annum)

\begin{tabular}{|c|c|cc|cc|}
\hline Period & $\begin{array}{c}\text { Production } \\
\text { Merck }\end{array}$ & $\begin{array}{c}\text { Estimated } \\
\text { Production } \\
\text { Germany }\end{array}$ & $\begin{array}{c}\text { Merck \% } \\
\text { of Germany }\end{array}$ & $\begin{array}{c}\text { Estimated } \\
\text { Production } \\
\text { the World }\end{array}$ & $\begin{array}{c}\text { Merck \% } \\
\text { of the World }\end{array}$ \\
\hline $1900-1903$ & 1,900 & 7,200 & 26 & 11,000 & 17 \\
$1904-1910$ & 3,100 & 6,400 & 48 & 11,300 & 27 \\
$1911-1913$ & 6,500 & 11,700 & 56 & 16,700 & 39 \\
\hline
\end{tabular}

Source: Tables 5.2 and 5.3

Figures in blue are estimates by the author.

As mentioned in Chapter 3, C.F. Boehringer und Söhne, Mannheim, was another important German manufacturer already in the 1890s. After Merck, Boehringer and Knoll entered a broad collaboration agreement ("Interessengemeinschaft") in 1906, Merck adopted the Boehringer process for making cocaine from Java coca because of higher yields. ${ }^{12}$ Boehringer-Mannheim produced ca $1,500 \mathrm{~kg}$ during $1912 .{ }^{13}$ At that time Merck and Boehringer-Mannheim together produced ca $70 \%$ of Germany's output and almost $50 \%$ of the world production. ${ }^{14}$

\section{USA Manufacturers}

Little is known with certainty about cocaine manufacturers outside Germany over the period 1900-1913. The USA manufacturers appear to be the same as during the 1890s with Mallinckrodt commencing cocaine manufacture in the early $1900 \mathrm{~s}^{15}$ The position of Merck's US affiliate in Rahway NJ as a manufacturer of cocaine in the US during the period 19001913 is unclear. In a publication by Merck Darmstadt it is stated that Merck \& Co (USA) commenced the production of morphine and other alkaloids in $1899 .{ }^{16}$ In quite a few articles on cocaine this has been interpreted as including the manufacture of cocaine but no

\footnotetext{
${ }^{11}$ Koloniale Bank, Minutes of Board Meetings, Meeting of 14 August 1903; A. Hirschmüller, 'E. Merck und das Kokain', 116-132.

${ }^{12}$ H. Dumitriu, Die wissenschaftlische Entwicklung der Alkaloidchemie am Beispiel der Firma Merck in den Jahren 1886-1920, Inaugural Dissertation. (Heidelberg 1993) 117.

${ }^{13}$ E.P. Fischer, Wissenschaft für den Markt (München 1991) 122.

${ }^{14}$ Ref. Table 5.4 for the period 1911-1913: $(6,500+1,500) / 11,700=68 \%,(6,500+1,500) / 16,700=48 \%$.

${ }^{15}$ Mallinckrodt Chemical Works started alkaloid manufacture with morphine and codeine in 1898

(Mallinckrodt/Tyco company brochure - undated) and showed large glass bowls filled with cocaine $\mathrm{HCl}$ at the St Louis Fair of 1904. Some data from Mallinckrodt's manufacturing records for the period 1905-1909 are mentioned by Spillane, Cocaine (2000) 62.

${ }^{16}$ S. Bernschneider, W.T. Huber, I. Possehl, "Was der Mensch thun kann . . . ." History of the pharmaceutical and chemical company Merck $3^{\text {rd }}$ ed., (Darmstadt 2002) 63.
} 
confirmation from a primary source has been found. ${ }^{17}$ The US import data for cocaine remained large for the years until 1905 (Table PCC 2, column [9]) and it seems unlikely that Merck produced cocaine in the USA before 1904. During 1905/06 Merck in Germany began the change-over from crude cocaine to Java coca as the raw material of choice. Using Java coca in the USA would have been a profitable option for Merck, especially after the duty increase of 1909.

\section{Manufacturers in Other Countries}

Manufacturers in countries other than Germany and the USA in the early 1900s were the ones located in the UK and France mentioned in Chapter 3, plus Burroughs Wellcome of London. ${ }^{18}$ Hoffmann La Roche, Basle, Switzerland commenced cocaine manufacture around 1901 and the NCF, Amsterdam, entered the business in $1900 .{ }^{19}$

\subsection{Marketing and Prices}

\section{Marketing in Europe}

Virtually the only information available on the structure of the market is from Gehe's Handelsbericht which describes the situation annually. ${ }^{20}$ From these reports we get the impression that a single German (European) market existed for cocaine hydrochloride, located in Hamburg, where most of product was traded and where the price was established. The manufacturers apparently sold to pharmaceutical wholesalers. How the contact between buyers and sellers was established and maintained is not clear.

In Germany, in a reaction on the depression of the 1880 s, industrial companies started to form associations in an attempt to limit excessive, profitability destroying competition. These associations ("Interessengemeinschaften") took the form of rather loose collaboration arrangements at one end of the scale, to strict agreements on prices, production quota and markets (cartels) at the other. In the 1890s court decisions in Germany sanctioned such cartels by declaring the articles of association as legally binding. ${ }^{21}$ Within the German pharmaceutical industry a multitude of cartels which were called Conventions ("Konventionen") were formed. The conventions were often unstable because of rivalry among the members and competition from "outsiders" that forced frequent price adjustments. $^{22}$ Many conventions were short-lived but were re-established as the situation changed. During the 1890s at least two cocaine conventions had come and gone and in 1900 another was established. ${ }^{23}$ The conventions were also influenced by market developments outside Europe. Germany exported quite large quantities to the USA and it has been recorded that the cocaine price in New York influenced the price setting by the German Convention. ${ }^{24}$ It was not uncommon to protect the convention from price cutting by "outsiders" by inviting

\footnotetext{
${ }^{17}$ For example see H.R. Friman, 'Germany and the transformations of cocaine', 85 and P. Gootenberg, Andean Cocaine, The Making of a Global Drug, (Chapel Hill 2008) 58, who writes: "by 1899 [the US affiliate of Merck] was making its quality Merck cocaine in Rahway, New Jersey". No sources are mentioned.

${ }^{18}$ A.P. Bhargava, Cocaine and its demoralizing effects (1916), quoted by J. Soininen, Industrial Geographies of Cocaine, Master's Thesis University of Helsinki (2008). Spillane, Cocaine (2000) 62.

${ }^{19}$ Merck, Conventionen und Vertretungen, Bericht über das Geschäftsjahr (1901-1902) Merck-Archiv F03/6a;

${ }^{20}$ Gehe \& Co., Dresden, Handelsbericht (1887 - 1914).

${ }^{21}$ K. Burkert, 'Die Deutsche "Pharmazeutische Interessengemeinschaft" (1906-1918)' (Stuttgart 1990) 10-11.

${ }^{22}$ E. Hexner, International Cartels (London 1946) 297; H.R. Friman, 'Germany and the transformations of cocaine', 89; Burkert, Pharmazeutische Interessengemeinschaft, 35-37.

${ }^{23}$ Gehe \& Co., Handelsbericht, September (1895) 43; April (1898) 64; Burkert, "Pharmazeutische Interessengemeinschaft" 34.

${ }^{24}$ Merck, Conventionen und Vertretungen, Bericht (1901/1902) 7.
} 
the outsiders to become members, offering them a reasonable production or sales quota. Such outsiders could include manufacturers from other countries. The Cocaine Convention of 1900 acted in this way when, in February 1901, it offered NCF a deal by which NCF would obtain a quota of $300 \mathrm{~kg}$ p.a. NCF accepted and the contract took the form of NCF supplying the cocaine to the well-respected company Gehe \& Co., Dresden. At about the same time the Cocaine Convention offered affiliation to Hoffmann la Roche, Basle, and to the firm Joh. Dietr. Biler. ${ }^{25}$

\section{Cocaine Prices}

Prices for cocaine hydrochloride from Germany and crude cocaine from Peru for the period 1898-1913 have been compiled by the author. They were mainly sourced from Gehe's Handelsbericht and are summarised in tables COC 4-5 and PCC 5 (Part IV). Cocaine prices from the USA were compiled by J. Spillane from data published weekly in the Oil, Paint and Drug Reporter for the period 1892-1916. Spillane presents average bi-annual wholesale prices in the form of a graph. ${ }^{26}$ The graph has been digitized by the author and annual averages calculated; they are contained in Table COC 3 (Part IV). US cocaine prices had been reported in USD per oz (avdp), the German cocaine prices in DEM per kg. For further calculations all prices are expressed in DEM and NLG per $\mathrm{kg}$. Those in NLG are used in preference over those in other currencies to facilitate later comparisons with NCF data.

For the period 1900-1913 cocaine prices in the USA are compared with those in Germany in the following table and graph:

\footnotetext{
${ }^{25}$ Merck, Conventionen und Vertretungen, Bericht (1901/1902; Burkert, Pharmazeutische Interessengemeinschaft, 35-36.

${ }^{26}$ Spillane, Cocaine (Baltimore 2000) 54.
} 
Table 5.5 and Figure 5.3 Cocaine Prices in the USA Compared with German prices 1900-1913 (NLG per kg)

\begin{tabular}{|c|c|c|c|c|c|}
\hline & Year & $\begin{array}{c}\text { Price } \\
\text { USA } \\
\text { [1] }\end{array}$ & $\begin{array}{c}\text { Price } \\
\text { Germany } \\
\text { [2] }\end{array}$ & $\begin{array}{c}\text { Price Difference } \\
\text { USA - Germany } \\
\text { Per cent [3] }\end{array}$ & $\begin{array}{c}\text { Price Difference } \\
\text { USA - Germany } \\
\text { NLG/kg [4] }\end{array}$ \\
\hline Average & $\begin{array}{c}1900 \\
1901 \\
1902 \\
1903 \\
1904 \\
1905 \\
1906 \\
1907 \\
1908 \\
1900-1908 \\
1909 \\
1910 \\
1911 \\
1912 \\
1913 \\
1909-1913\end{array}$ & $\begin{array}{l}494 \\
489 \\
363 \\
354 \\
306 \\
310 \\
258 \\
219 \\
188 \\
\\
\\
267 \\
297 \\
328 \\
284 \\
258\end{array}$ & $\begin{array}{l}378 \\
382 \\
336 \\
295 \\
256 \\
249 \\
230 \\
183 \\
146\end{array}$ & $\begin{array}{r}31 \% \\
28 \% \\
8 \% \\
20 \% \\
20 \% \\
25 \% \\
12 \% \\
19 \% \\
29 \% \\
21 \%\end{array}$ & $\begin{array}{l}105 \\
135 \\
151 \\
136 \\
136 \\
\\
\mathbf{1 3 2}\end{array}$ \\
\hline
\end{tabular}

Source: $\quad$ Tables COC $3, \quad 4$ and 5 (Part IV)

Differences: $\quad 1900-1908:[3]=([1] /[2]-1) * 100 \%$ 1909-1913: [4] = [1] - [2]

Import Duty: 1900-1908: 25\% ad valorem on German export price, which was equal to about $72 \%$ of the European price 1909-1913: USD 1.50 per oz. $=$ NLG 132 per kg

Figure 5.3

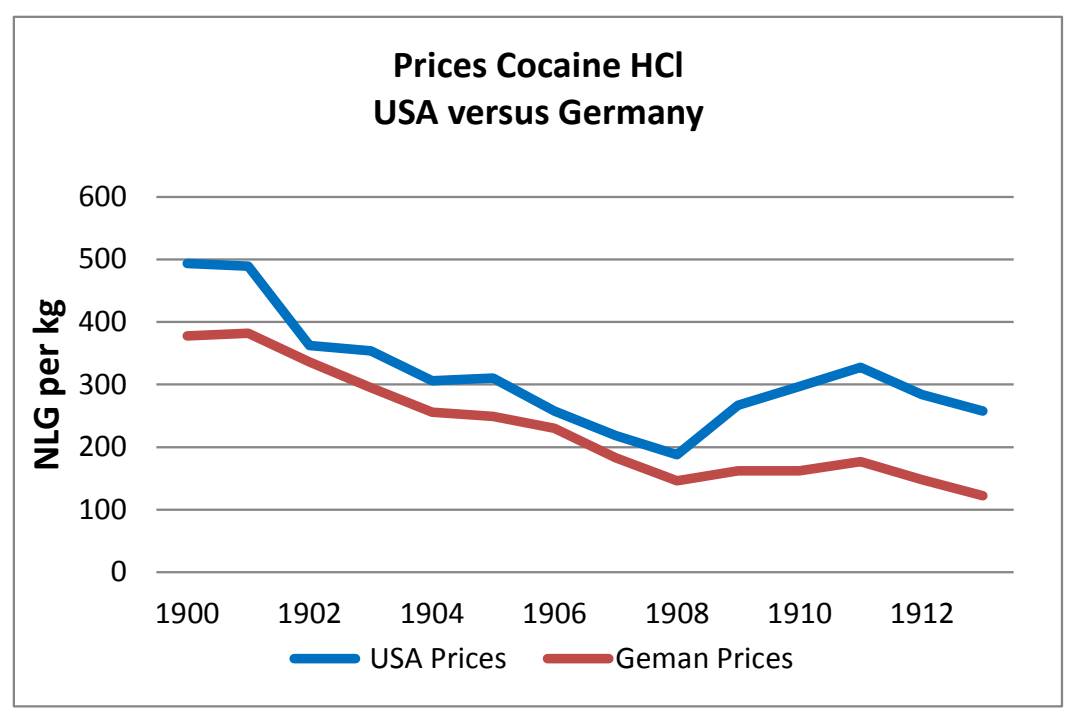


When comparing the cocaine prices in the USA and Germany we see that during the period 1900-1908 the USA prices were on average 20\% higher than the German prices which was the result of the $25 \%$ ad valorem duty applied to cocaine imports into the USA from $1896 .{ }^{27}$ In 1909 the import duty of $25 \%$ ad valorem was replaced by a duty of USD 1.50 per ounce (equivalent to NLG 132 per $\mathrm{kg}$ ) resulting in a substantial increase in the price difference from 1909 onwards. ${ }^{28}$ The consequences of the duty on the profit margin on cocaine sales in the USA are extensively discussed in Section 5.4.

Striking is the continuous price decline in the world-market from 1901 to 1908 , of which relentless competition was the main cause. The cocaine price, as set by the Convention in 1901, was much higher than the production cost of cocaine from Peruvian crude. That resulted in outsiders entering the market and slow but ongoing price erosion that could not be halted by the Convention. ${ }^{29}$ Around 1906 German manufacturers became interested in Java coca because it was the more economical raw material. This trend can be seen clearly in the graphs 5.1 and 5.2. Coca cultivation on Java expanded and from 1907 substantial quantities went to Germany. In that year Merck began to change over to Java coca as its main raw material. $^{30}$

In 1907 it was noted in the Chemiker Zeitung that the "[cocaine] prices were ruinous for growers (of coca) and for manufacturers" and "the business was paralyzed". ${ }^{31}$ During 1908 the cocaine price came down so much that the margin for cocaine manufactured from crude cocaine and also from Java coca had all but disappeared. The Convention was dissolved in early 1908 and the price slumped to a low of DEM 200 per $\mathrm{kg}^{32}$ Prices recovered a little during 1909-1911 but the profit margin for cocaine remained at a very low level. The cocaine price came down again in 1912 and in December 1913 the price reached an all-time low of DEM 165 (NLG 97) per kg. ${ }^{33}$ Gehe comments in its report for 1913 that the prices had become weapons ("Kampfpreisen") and that profitability had become a second order objective. $^{34}$

As a result of the outbreak of World War I the situation changed completely in 1914 when Germany imposed an export embargo on cocaine. ${ }^{35}$

\section{Marketing in the USA}

How cocaine hydrochloride was marketed in the USA is not known in any detail. US manufacturers and German exporters shared the market. Major German exporters were Merck and Boehringer Mannheim. As mentioned above, from 1900 the US prices were close to European prices plus 20\%. This suggests a cartel-like arrangement between US manufacturers and German exporters. The arrangement would have been to keep the price at the maximum i.e. the US price at the European price plus duty, and not to compete too strongly for market share. Assuming that before 1896 the US price was about equal to the European price, the arrangement would give the US manufacturers an additional margin of $20 \%$ of the European price and the margin for the German exporters would remain the same

\footnotetext{
${ }^{27}$ P. Gootenberg, 'Reluctance or resistance? Constructing cocaine (prohibitions) in Peru, 1910-50, Chapter 3 in: P. Gootenberg, editor, Cocaine: Global Histories (London 1999) 50.

${ }^{28}$ United States Department of Commerce, Foreign Commerce and Navigation of the United States, an annual publication (1892/93). See Table PCC 2 (Part III) of this dissertation.

${ }^{29}$ Gehe \& Co., Dresden, Handelsbericht, Section Cocainum (1903-1908).

${ }^{30}$ Hirschmüller, 'E. Merck und das Kokain', 116-132.

${ }^{31}$ Chemiker Zeitung, 94 (1907) 1178.

${ }^{32}$ Gehe, Handelsbericht (1909) 122.

${ }^{33}$ Gehe, Handelsbericht (1914) 139.

${ }^{34}$ Ibidem.

${ }^{35}$ Koloniale Bank, Report of Management to the Board, (1914) 6. Nationaal Archief, The Hague, Access No. 2.20.04 Item 58 .
} 
or become slightly better, assuming the $25 \%$ duty was levied on the export price amounting to a maximum of $80 \%$ of the European price. ${ }^{36}$

During the fiscal year 1909/10 the US Government changed the import duty from $25 \%$ ad valorem to a fixed amount of USD 1.50 per oz. which meant a hefty increase of the duty to an equivalent of ca $80 \%$ ad valorem. ${ }^{37}$ It appears that the arrangement continued unchanged i.e. the US price became equal to the European price plus USD 1.50/oz. For the US manufacturers this was a favourable development while the imports slumped to ca $100 \mathrm{~kg}$ p.a. during the following years. The effects of the changes on the profit margins are discussed in more detail in section 5.4

\section{Cocaine Consumption USA}

Spillane has made estimates of the quantities of cocaine consumed in the USA. To arrive at his figures he added the quantities of cocaine imported (the sum of pure cocaine $\mathrm{HCl}$ and crude cocaine) into the USA to estimates of the quantities of cocaine produced from imported coca leaf. ${ }^{38}$ In principle this method is a good approximation. The inclusion of crude cocaine in imported cocaine causes minor errors only.

The accuracy of Spillane's estimates of cocaine imported is variable. As indicated by Spillane himself, for the years 1892 to 1900 the value of the estimates is 'problematic' because information available on incoming shipments is sparse. Spillane's estimates for 1901 to 1907 are based on the USD value of the imports and are considered reasonably accurate. ${ }^{39}$ For the years from 1907/08 onwards he has used the quantities as appearing in the official import statistics. ${ }^{40}$

Spillane's estimates of quantities of cocaine manufactured from imported coca leaf are discussed in Chapter 16. In that Chapter it is concluded that Spillane' factor 2 for the ratio of imports into the USA/NY is too high for the period 1897-1903, which resulted in his overestimating the quantities of coca leaf imported into the USA. Moreover, Spillane does not take into account that part of the imported Peru coca was used for beverages. In the following Table 5.6 Spillane's estimates of cocaine consumption in the USA are compared with those calculated by the author, which are based on the findings presented in Chapters 16 and 17.

\footnotetext{
${ }^{36}$ The German exporters would achieve an additional margin of $20 \%$ over the European price offset by a duty payable of $25 \%$ over the export price (equal to or less than $80 \%$ of the European price).

The calculation: $20 \%-25 \%$ of $80 \%=0 \%$.

${ }^{37}$ See Table PCC 2 (Part III).

${ }^{38}$ Spillane, Cocaine, 57-66.

${ }^{39}$ Spillane's estimates result in an average value of the ratio value at US customs / US wholesale price of ca 0.6 for the period 1900-1908. (Calculations HHB).

${ }^{40}$ For the year 1909/10 Spillane has used a value for cocaine import which is ca $118,000 \mathrm{oz}(3,300 \mathrm{~kg})$ too high (Ref. Chapter 14, Section Table PCC 2: Import of Cocaine into the USA-1). This resulted in a serious distortion of the calculated average imports during the period 1904-1910.
} 
Table 5.6 Estimates of Cocaine Consumption USA 1892-1913

Averages by Period ( $\mathrm{kg}$ Cocaine $\mathrm{HCl}$ per annum)

Spillane's figures compared with those by the author (HHB)

\begin{tabular}{|c|l|c|rrrr|}
\hline $\begin{array}{c}\text { Estimate } \\
\text { by }\end{array}$ & \multicolumn{1}{|c|}{ Cocaine } & Note & $\mathbf{1 8 9 2 - 9 9}$ & $\mathbf{1 9 0 0 - 0 3}$ & $\mathbf{1 9 0 4 - 1 0}$ & $\mathbf{1 9 1 1 - 1 3}$ \\
\hline \multirow{2}{*}{ Spillane } & US Production ex Leaf & {$[1]$} & 1,500 & 4,300 & 4,000 & 3,400 \\
& Cocaine Import & {$[2]$} & 1,100 & 1,600 & 1,100 & 100 \\
& US Consumption & {$[3]$} & $\mathbf{2 , 6 0 0}$ & $\mathbf{5 , 9 0 0}$ & $\mathbf{5 , 1 0 0}$ & $\mathbf{3 , 5 0 0}$ \\
HHB & US Production ex Leaf & {$[4]$} & 1,000 & 2,500 & 3,700 & 3,700 \\
& Cocaine Import & {$[5]$} & 1,100 & 1,600 & 700 & 100 \\
& US Consumption & {$[6]$} & $\mathbf{2 , 1 0 0}$ & $\mathbf{4 , 1 0 0}$ & $\mathbf{4 , 4 0 0}$ & $\mathbf{3 , 8 0 0}$ \\
Spillane & Difference [3] - [6] = & {$[\mathbf{7}]$} & $\mathbf{5 0 0}$ & $\mathbf{1 , 8 0 0}$ & $\mathbf{7 0 0}$ & -300 \\
-- HHB & World Production & {$[8]$} & 6,200 & 11,000 & 11,300 & 16,700 \\
& US Consumption (HHB) & & & & & \\
& \% of World Production & {$[9]$} & 34 & 37 & 39 & 23 \\
\hline
\end{tabular}

Notes: The calculated amounts are rounded to the nearest hundred $\mathrm{kg}$.

Figures in blue are estimates by the author.

[1] Imports Coca Leaf (Table PCL 3 column [6]) * 6.25

[2] Imports Cocaine (Table PCC 2, column [9])

The figure for 1892-1899 is somewhat uncertain.

$[3]=[1]+[2]$

[4] Calculated using the amounts appearing in Table 17.9 for the USA (imports Peru Coca less quantities used for beverages) $* 6.0$ plus imports Java Coca * 10.9 (Table 5.2)

[5] Imports Cocaine Table PCC 2, column [9] for 1892-1907 (Spillane's figures) and PCC 2, column [2] for 1908-1913 (FN\&C figures).

The figure for 1892-1899 is somewhat uncertain.

Notes Table 5.6 continued

$$
\begin{aligned}
& {[6]=[4]+[5]} \\
& {[7]=[3]-[6]} \\
& {[8] \text { Table } 5.2} \\
& {[9]=[6] /[8] * 100 \%}
\end{aligned}
$$

The figures in the above table show the effect of the calculations. The differences in amounts of cocaine produced from extraction of coca leaf result mainly from the use of the factor 2.00 versus 1.38 for the ratio imports USA/NY, from not taking into account the quantities of Peru coca used for beverages, and from the use of Java coca during the later periods. The overall effect is that Spillane's estimates are considerably higher for the years until 1911. For the period 1911-1913 the estimates by the author are larger than Spillane's as a result of substantial quantities of high yielding Java coca rather than Peruvian coca being imported during that period. The difference in the figures for cocaine imports for the period 1904-1910 is entirely caused by the erroneous import figure for the year 1909/10 used by Spillane. 
The consumption of cocaine in the USA represented 34-39\% of the total cocaine production worldwide during the years 1892-1910; for the period 1911-1913 this figure was 23\%.

\subsection{Manufacturing Cost and Margin on Sales of Cocaine $\mathrm{HCl}$}

The survival of a manufacturer in the alkaloid business depends on its having a low manufacturing cost in comparison to its competitors. The margin between the selling price and the manufacturing cost can be small and even temporarily negative in times of overproduction. Because the raw material cost is an important part of the total manufacturing cost, access to a reliable source of cheap raw material and good yields are essential.

These general principles were certainly valid for the cocaine business in the early 1900s. How profit margins fluctuated for the various raw materials at that time provides a good insight as to the state of the industry. In Chapter 15 (Tables 15.5-15.7) estimates are made of the cost of manufacturing cocaine hydrochloride from the three different raw materials: Java coca, Huanuco (Peru) coca and crude cocaine, in a factory of similar design and operating cost to the $\mathrm{NCF}$, at a fixed production level of $500 \mathrm{~kg}$ cocaine $\mathrm{HCl}$ p.a. during the period 1902-1913. These cost estimates together with the selling prices of cocaine $\mathrm{HCl}$ for the period yield the profit margins on an annual basis. The results of the calculations show clearly the merits of each raw material and the effect of the duty on cocaine and its raw materials on the margins in the USA. These results are presented in this chapter as Tables 5.7-5.9 and as graphs in Figures 5.4-5.6.

The results relate to cocaine manufacturers of average size, buying the raw materials on the open market. Large producers such as Merck, Darmstadt, will have had a somewhat lower manufacturing cost and the position of the NCF was also somewhat better than average because of the low cost raw material sourced from Soekamadjoe, but the trends in the calculated margins are valid for all manufacturers. 
Tables 5.7-5.9 and Figures 5.4-5.6

Margin on Sales of Cocaine HCl made from Various Raw Materials

Europe versus the USA (NLG per kg)

Table 5.7

\begin{tabular}{|r|rr|}
\hline & \multicolumn{2}{|c|}{ CRUDE COCAINE } \\
& Europe & USA \\
& & \\
\hline & & \\
1902 & 117 & 94 \\
1903 & 70 & 81 \\
1904 & 37 & 40 \\
1905 & 51 & 70 \\
1906 & 17 & -1 \\
1907 & 32 & 37 \\
1908 & 1 & 13 \\
1909 & -3 & 67 \\
1910 & -23 & -18 \\
1911 & -13 & 7 \\
1912 & -15 & -10 \\
& & \\
\hline
\end{tabular}

Table 5.8

\begin{tabular}{|r|rr|}
\hline & \multicolumn{2}{|c|}{ HUANUCO COCA } \\
& Europe & USA \\
& & \\
\hline & & \\
1902 & 129 & 155 \\
1903 & 98 & 159 \\
1904 & 52 & 103 \\
1905 & 28 & 91 \\
1906 & 18 & 47 \\
1907 & -4 & 33 \\
1908 & -29 & 13 \\
1909 & -8 & 98 \\
1910 & -40 & 51 \\
1911 & -54 & 52 \\
1912 & -55 & 36 \\
\hline
\end{tabular}

Table 5.9

\begin{tabular}{|r|rr|}
\hline & \multicolumn{2}{|c|}{ JAVA COCA } \\
& Europe & USA \\
& & \\
\hline & & \\
1902 & 222 & 248 \\
1903 & 179 & 240 \\
1904 & 140 & 191 \\
1905 & 99 & 162 \\
1906 & 87 & 116 \\
1907 & 48 & 85 \\
1908 & 24 & 67 \\
1909 & 15 & 121 \\
1910 & -19 & 82 \\
1911 & -3 & 113 \\
1912 & 18 & 119 \\
\hline
\end{tabular}

Figure 5.4

CRUDE COCAINE

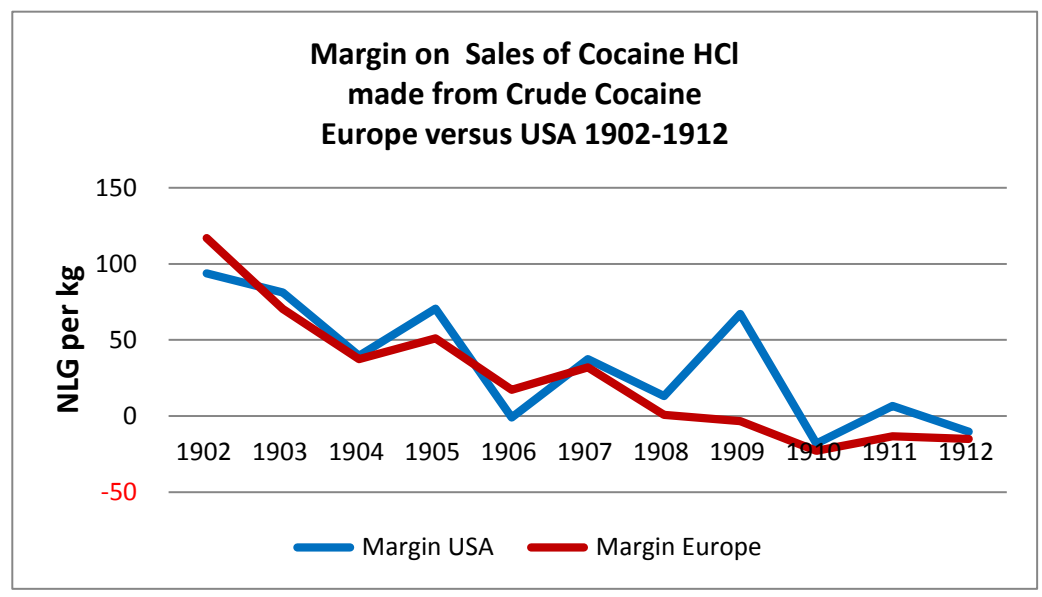

Figure 5.5

HUANUCO COCA

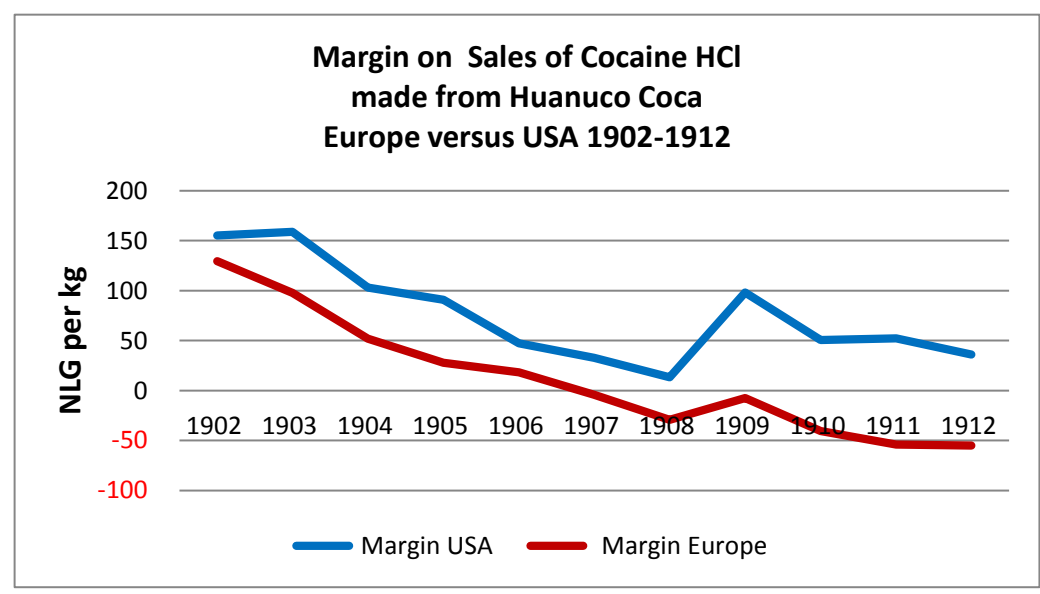

Figure 5.6

JAVA COCA

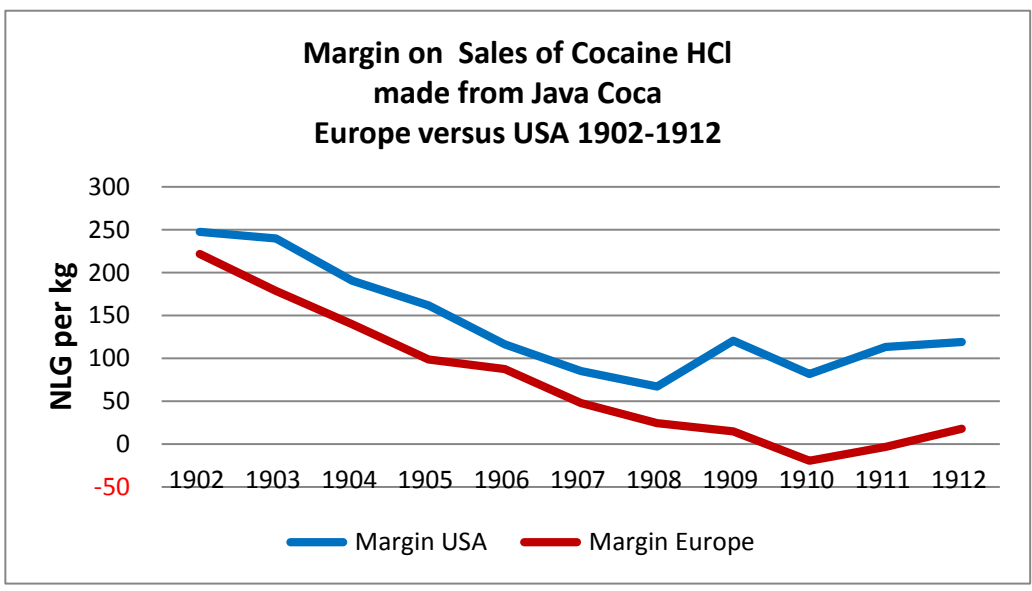


The trends in margin apparent from the graphs are the result of the market prices of cocaine $\mathrm{HCl}$, raw material prices and import duties in the USA. For the European trade the trend (the blue lines in the graphs) for all three raw materials is a steep decline in margin from 1902 onwards, the margin becoming zero and even negative for the years after, say, 1908. The reason for this trend was relentless competition for sales of the cocaine $\mathrm{HCl}$ in combination with raw material prices which came down, but insufficiently to allow cocaine manufacturers a make a profit. This applied in particular to crude cocaine and Huanuco coca from Peru, the use of which would have resulted in unacceptably large negative margins, reason for the change over by most cocaine manufacturers to Java coca, on which the margin was slightly better. As a result Peru lost its position of dominant supplier of cocaine raw materials after 1910.

As a result of the import duty on cocaine, for US manufacturers using coca leaf as the raw material the situation was better. The single US manufacturer using crude cocaine as the raw material was in the same position as the European manufacturers. As mentioned earlier in this chapter an import duty on cocaine applied from 1896 onwards amounting to $25 \%$ ad valorem which equated to ca USD 1.00 per oz around 1903. The effect was that the US cocaine price became on average ca $20 \%$ higher than the European price which difference carried over into the margin.

During the fiscal year 1909/10 the US Government changed the duty on cocaine from $25 \%$ ad valorem to USD 1.50 per oz and introduced $5 \phi$ per lb import duty on coca leaf. ${ }^{41}$ These changes resulted in a price increase of cocaine $\mathrm{HCl}$ by ca USD 0.80 per oz and an increase in margin in cocaine made from Huanuco coca of ca USD 0.30 per oz. On cocaine made from Java coca the margin increase was ca USD 0.50 per oz. These changes are incorporated in Table 15.4 and show up in the above graphs.

The figures from Tables 5.7-5.9 above are re-arranged in the following tables and graphs to compare the margins on the various raw materials within USA and within Europe:

\footnotetext{
${ }^{41}$ In import duty of $5 \notin$ per $\mathrm{lb}$ on coca leaf is equivalent to an increase in cocaine cost of USD $50 /\left(6^{*} 16\right)=$ about USD 0.50 per oz for Huanuco coca. For Java coca the increase is about USD 0.29 per oz.
} 
Tables 5.10-5.11 and Figures 5.7-5.8

Margin on Sales of Cocaine HCl made from Various Raw Materials

Margins within Europe and within the USA (NLG per kg)

Table 5.10

\begin{tabular}{|r|rrr|}
\hline & \multicolumn{3}{|c|}{ U S A } \\
& Crude & Java & Huanuco \\
& & & \\
\hline 1902 & 94 & 248 & 155 \\
1903 & 81 & 240 & 159 \\
1904 & 40 & 191 & 103 \\
1905 & 70 & 162 & 91 \\
1906 & -1 & 116 & 47 \\
1907 & 37 & 85 & 33 \\
1908 & 13 & 67 & 13 \\
1909 & 67 & 121 & 98 \\
1910 & -18 & 82 & 51 \\
1911 & 7 & 113 & 52 \\
1912 & -10 & 119 & 36 \\
& & & \\
\hline
\end{tabular}

Table 5.11

\begin{tabular}{|r|rrr|}
\hline & \multicolumn{3}{|c|}{ E U R O P E } \\
& Crude & Java & Huanuco \\
& & & \\
\hline & 117 & 222 & 129 \\
1902 & 70 & 179 & 98 \\
1903 & 37 & 140 & 52 \\
1904 & 51 & 99 & 28 \\
1906 & 17 & 87 & 18 \\
1907 & 32 & 48 & -4 \\
1908 & 1 & 24 & -29 \\
1909 & -3 & 15 & -8 \\
1910 & -23 & -19 & -40 \\
1911 & -13 & -3 & -54 \\
1912 & -15 & 18 & -55 \\
& & & \\
\hline
\end{tabular}

Figure 5.7

U S A

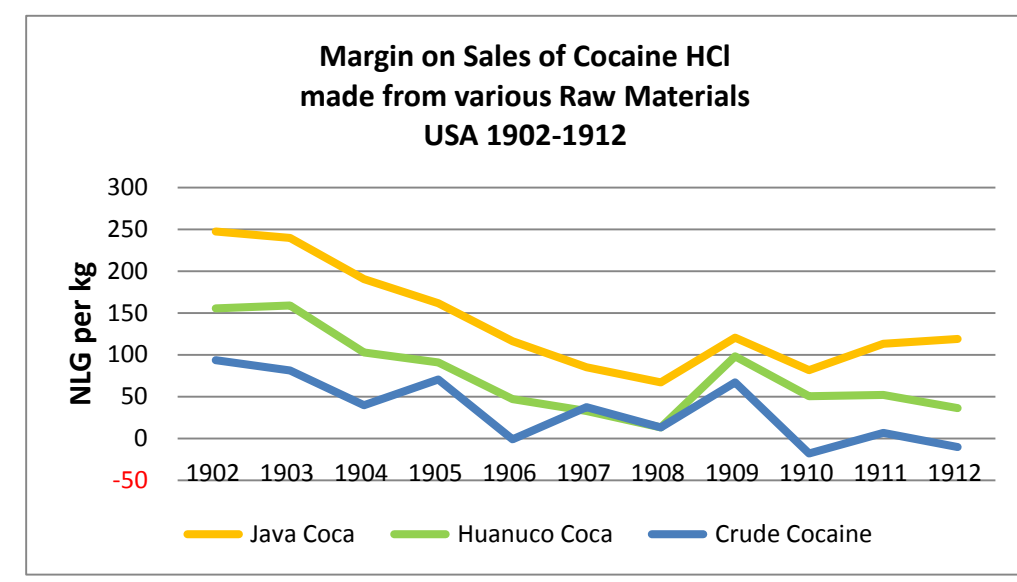

Figure 5.8

E UROPE

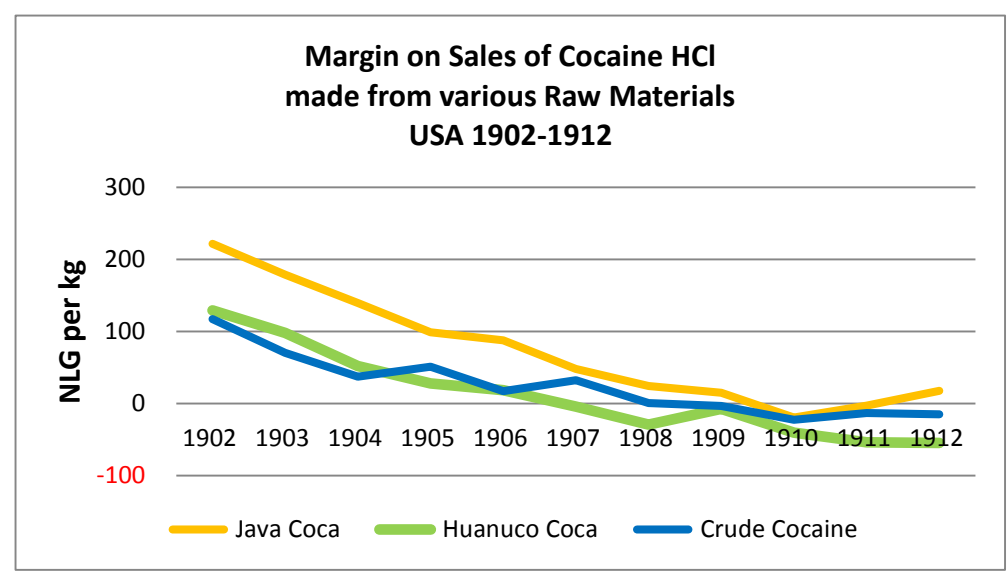

Source: Tables 5.7 -5.9.

For both the USA and Europe Java coca was the more economical raw material but for reasons of lack of awareness, process technology and availability of the Java coca, the change-over to this raw material did not take place on a large scale until 1907. One unknown German manufacturer and the NCF were the front runners. Crude cocaine as the raw material performed equally badly in the USA as in Europe; Huanuco coca retained some of its position in the USA because of the duty.

\subsection{Raw Materials - The Trade in Java Coca}

Java coca was sold in consignment by the Koloniale Bank from 1892. Until 1900 an average quantity of ca 64 tonnes of leaf was sold annually to the single (German) customer at an unknown price. Presumably there were no other exporters of Java coca at the time. From 1900 to 1908 about 30 tonnes p.a. was supplied by Soekamadjoe to NCF and the Koloniale Bank continued to sell modest quantities to other buyers. From 1904, after the Liebermann patent had expired, German manufacturers could switch to Java coca without paying a 
royalty and Merck and others did so, because it was a more economical raw material than crude cocaine from Peru. ${ }^{42}$ Coca cultivation on Java expanded very rapidly and from 1907 substantial quantities went to Germany. ${ }^{43}$ Other European manufacturers followed and as the table below shows there was a very steep increase in export of Java coca from 1907 to the beginning of World War I. By that time coca leaf had become an important export product for Java, its value exceeding 1 million guilders in $1912 .^{44}$

Table 5.12 Export of coca leaf from Java 1892-1914 (tonnes per annum) Statistiek van den Handel en de In-en Uitvoerrechten (Statistics Dutch East Indies), Deel IIa (Java en Madoera) Weltevreden 1874-1923

\begin{tabular}{|c|c|c|c|c|c|c|c|}
\hline \multirow{2}{*}{$\begin{array}{c}\text { Year } \\
\text { of } \\
\text { Export }\end{array}$} & \multirow{2}{*}{$\begin{array}{c}\text { Total } \\
\text { Exports } \\
\text { from Java } \\
{[1]}\end{array}$} & \multirow{2}{*}{$\begin{array}{c}\text { Total } \\
\text { Value } \\
\text { NLG } 000 \\
\text { [2] }\end{array}$} & \multirow{2}{*}{$\begin{array}{c}\text { Calculated } \\
\text { Value } \\
\text { NLG per kg } \\
{[3]}\end{array}$} & \multicolumn{4}{|c|}{ [4] Export to } \\
\hline & & & & $\begin{array}{l}\text { the Nether- } \\
\text { lands }\end{array}$ & the UK & Germany & $\begin{array}{c}\text { Other } \\
\text { Countries }\end{array}$ \\
\hline $\begin{array}{c}1892-1899 \\
1900-1904 \\
1905 \\
1906 \\
1907 \\
1908 \\
1909 \\
1910 \\
1911 \\
1912 \\
1913 \\
1914\end{array}$ & $\begin{array}{r}64 \\
66 \\
67 \\
122 \\
200 \\
417 \\
373 \\
430 \\
741 \\
1,075 \\
1,332 \\
1,353\end{array}$ & $\begin{array}{r}167 \\
149 \\
646 \\
815 \\
1,182 \\
799 \\
568\end{array}$ & $\begin{array}{l}0.40 \\
0.40 \\
1.50 \\
1.10 \\
1.10 \\
0.60 \\
0.42\end{array}$ & $\begin{array}{r}311 \\
353 \\
401 \\
645 \\
1,043 \\
1,231 \\
1,250\end{array}$ & $\begin{array}{r}3 \\
0 \\
15 \\
84 \\
26 \\
92 \\
103\end{array}$ & $\begin{array}{r}102 \\
21 \\
9 \\
12 \\
5 \\
9 \\
0\end{array}$ & $\begin{array}{l}0 \\
0 \\
5 \\
0 \\
0 \\
0 \\
0\end{array}$ \\
\hline
\end{tabular}

Sources and Notes

[1] Table JCL 2, 1892-1899 and 1900-1904 are annual averages

[2] and [4] Statistiek van den Handel en de In-en Uitvoerrechten (Statistics Dutch East Indies), Deel IIa (Java en Madoera) Weltevreden 1874-1923

$[3] \quad[3]=[2] /[1]$

The use of Java coca in the Netherlands for cocaine production was only small and the imported quantities were largely re-exported. The coca went mainly to Germany but during 1908-1914 quantities of Java coca in the order of 100-200 t per annum were imported into the USA, most probably from the Netherlands. ${ }^{45}$

\footnotetext{
${ }^{42}$ Tables 5.10-5.11.

${ }^{43}$ Table 7.5 and Hirschmüller, 'E. Merck und das Kokain', 121, Tabelle 3.

${ }^{44}$ Statistiek van den Handel en de In-en Uitvoerrechten (Statistics Dutch East Indies), Deel IIa (Java en Madoera) Weltevreden 1874-1923.

45 Table 7.5.
} 
Figure 5.9 Export of Coca Leaffrom Java 1892-1914 (tonnes)

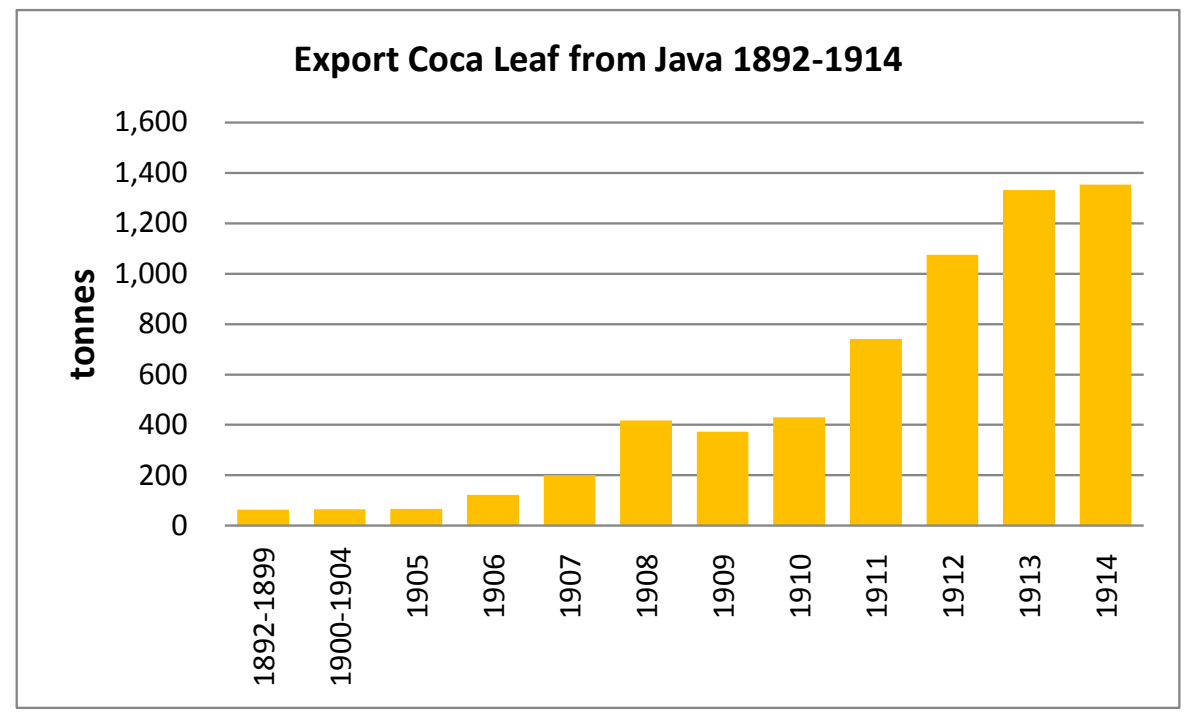

Source: Table 5.12

Table 5.12 shows that most of the Java coca was exported to the Netherlands; comparatively small quantities went directly to Germany and to the UK. The coca exported to the Netherlands was to a large extent sold at auctions in Amsterdam or sold in consignment by the Koloniale Bank and was mostly re-exported. ${ }^{46}$

Direct exports from Java to Germany were only small and from the amounts appearing in the above table it is concluded that from 1909 onwards Merck has obtained its raw material largely from the Netherlands.

The fast substantial expansion of the coca cultivation on Java was a result of the increased demand for coca in combination with a high price. However, coca prices declined from 1906-1908 caused by the combination of sufficient supply and sharply declining cocaine prices.

\footnotetext{
${ }^{46}$ P. Brusse, Jaarverslag voor kinabast en coca (Annual Report for Cinchona bark and Coca) (1930); T.C.J. Pex and J.C. Davids, Java-coca. Samenstelling en afloop gedurende de te Amsterdam gehouden veilingen (Amsterdam 1909-1915). Library Royal Tropical Institute (KIT) Amsterdam; Koloniale Bank, Jaarverslagen (Annual Reports) 1908-1914. Nationaal Archief, Access No. 2.20.04, Items 4-7.
} 
Price movements at the Amsterdam auctions are summarized in the following table and graph:

Table 5.13 and Figure 5.10 Prices Java Coca at Auctions Amsterdam 1905-1914

\begin{tabular}{|c|c|}
\hline Year & $\begin{array}{c}\text { Price } \\
\text { NL cents } \\
\text { per unit }\end{array}$ \\
\hline 1905 & 28.6 \\
1906 & 25.9 \\
1907 & 23.2 \\
1908 & 18.6 \\
1909 & 27.6 \\
1910 & 39.6 \\
1911 & 39.1 \\
1912 & 21.6 \\
1913 & 19.5 \\
1914 & 15.1 \\
\hline
\end{tabular}

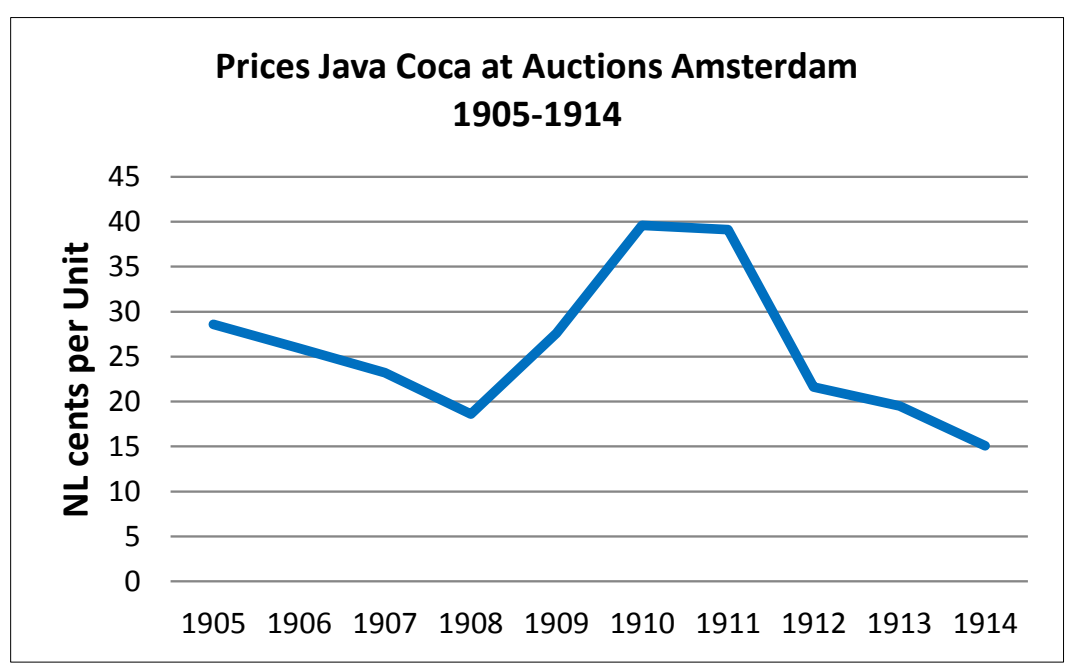

Source: P. Brusse, Jaarverslag over Kinabast en Coca (Annual Report) (1930)

Note: A Unit is $1 / 2 \mathrm{~kg}$ coca blad at $1 \%$ total alkaloid content

From 1909 to 1910 the price of Java coca doubled, which will have been caused by demand outstripping supply. By 1910 Java coca had largely replaced Peruvian as the raw material and prices paid for Java coca at the Amsterdam auctions were high. This provided an excellent profit to the Java growers but did not allow for a reasonable margin for the cocaine manufacturers. The reason behind this somewhat paradoxical situation must have been very strong competition between cocaine manufacturers, wanting to keep market share at any price, in combination with a strongly growing demand for the product. The situation came to a crunch early in 1912 when the prices for Java coca at the auctions in Amsterdam suddenly collapsed, dropping to less than half of the prices paid a few months earlier. ${ }^{47}$ The main reason for this collapse was that coca supply had outstripped demand, which was negatively affected by the fear of future restrictions in cocaine sales that could result from the recommendations of the recent International Opium Convention in The Hague that opiates and cocaine should be manufactured for medical and scientific purposes only. ${ }^{48}$ Coca prices recovered somewhat during 1913 but fell back again in early 1914.

In 1912, coca growers and others on Java became quite concerned about the future of their business. A meeting of interested parties was held in Bandoeng where the situation was discussed. A group led by Mr van Delden, president of the Kedirish Society for Agriculture ("Kedirische Landbouwvereniging"), Mr van Wely and Dr A.W.K. de Jong, a government employed chemist and keen promoter of local production, proposed that growers should unite and collectively establish an extraction facility on Java where the coca could be processed into crude cocaine (Java quality) which product would be sold to cocaine manufacturers

\footnotetext{
${ }^{47}$ Abrahamson, 'Het Cocavraagstuk', Tijdschrift voor nijverheid en landbouw in Nederlandsch- Indië (1912) ,101-110, 132-153 and 234-241.

${ }^{48}$ Ibidem.
} 
worldwide instead of the coca leaf. ${ }^{49}$ This initiative led to the establishment of a committee for the founding of the Cocasyndicate ("Commissie tot oprichting van het Cocasyndicaat") which published a report to disseminate its ideas and to get support. ${ }^{50}$ Another group of people interested in the cultivation of coca, of which Mr S.S. Abrahamson, editor of the "Tijdschrift voor Nijverheid en Landbouw in Nederlandsch Indië" was the spokesman, held views diametrically opposite to those of the Committee. They did not believe that the plans of the Committee were viable. A lively dispute developed between Abrahamson, de Jong and others which was published in detail in various printed media on Java. ${ }^{51}$ It took on the character of a polemic and lasted for quite some time. The Committee remained convinced on the good chances of success, while Abrahamson's group was of the opinion that the Committee was naïve in the extreme in its optimism.

The Committee was ultimately not successful in forming the Coca-syndicate because of a lack of sufficient interest by growers. However, an extraction facility was established at Soekaboemi in 1914 by Mr. Ligtvoet, former president of the Kedirish Society for Agriculture, with technical assistance by de Jong and financial assistance by the firm Geo Wehry. However, as a result of World War I the commissioning of the plant was a problem and the company was later liquidated. ${ }^{52}$ The outbreak of World War I was the beginning of an entirely new period for the cocaine industry as a whole.

\subsection{Interlude to International Narcotics Control}

International controls of narcotic drugs, drugs of dependence, is an extensive and complex subject about which much has been published. Only a brief historical overview is provided here, concentrating on the impact of the controls on the manufacturing industry. It is primarily based on publications of Musto, Bruun, Arnold and McAllister. ${ }^{53}$

Opium had been used for its pain relieving and euphoric properties since antiquity. Until late in the 19th century abuse of opium was not common in Europe and the USA. If abuse was occurring it was considered to be a vice, the result of lack of willpower of the individual involved. It was not considered to be a problem for society. In 1900 the trade in products such as opium, morphine, heroin and cocaine was in essence uncontrolled and the products were easily obtainable.

The situation was different in China. The habit of opium smoking by mixing opium with tobacco originated in Southeast Asia in the 17th century; it was soon taken up by many Chinese. First attempts to control the abuse of opium were made in China already towards the end of the 18th century by making the opium trade illegal. However, most of the opium used by the Chinese came from British India and opium trade was an important source of income for the colony. The British did not accept losing an important market and the result was two

\footnotetext{
${ }^{49}$ A.W.K. de Jong, Chapter 'Coca' in: C.J.J. van Hall and C. van de Koppel, editors, De Landbouw in de Indische Archipel Vol II A (The Hague 1948) 874.

${ }^{50}$ Verslag der Commissie for Oprichting van het Cocasyndicaat, Batavia (1912). This report could not be located.

${ }^{51}$ Abrahamson, 'Het Cocavraagstuk', Tijdschrift voor nijverheid en landbouw in Nederlandsch- Indië (1912) ,101-110, 132-153 and 234-241; A.W.K. de Jong, 'Het Cocavraagstuk', Teysmannia (1912) 669-681.

${ }_{52}$ A.W.K. de Jong, 'Coca' (1948) 874; J.J. Paerels, 'Cocacultuur op Java', Cultura 34 (1922) 328-330.

${ }^{53}$ D.F. Musto, The history of legislative control over opium, cocaine and their derivatives DRCNet Library, Schaffer Library of Drug Policy. www.druglibrary.org. [2003].

K. Bruun, L. Pan and I. Rexed, The Gentlemen's Club - International control of drugs and alcohol (Chicago 1975).

A.H. Taylor, American diplomacy and the narcotics traffic, 1900-1939 (Durham 1969).

William B. McAllister, Drug Diplomacy in the Twentieth Century (London 2000).
} 
consecutive opium wars, the last one ending in 1858. China lost both wars, resulting in unrestricted imports of opium into China.

Towards the end of the 19th century the impact of the opium problem in China had become so severe that the world became aware that China would not be able to solve the problem on its own. In the early 1900s, for a variety of reasons, the USA assumed a leading role in attempts to establish international control of the use of opium for non-medical purposes. These reasons included the wish for an economically stronger China, a developing domestic opium problem in the Philippines (a country under US control at the time), and a moral element. In the opinion of the Americans the ultimate solution had to be the prohibition of the use of opium for non-medical purposes, and this would only be possible if countries that were major opium producers/users would collaborate.

In 1909, to mobilize such collaboration, a conference of thirteen world powers was held in Shanghai, chaired by the American Protestant Bishop Charles Brent. Britain participated for complex reasons including growing political anti-opium forces and the wish to retain opium revenues from India. British diplomatic skills led to the USA proposal being watered down. ${ }^{54}$ The result of this Shanghai Opium Commission was a series of vaguely worded resolutions recommending joint measures to control the production and trade of opium and opiates (morphine). The resolutions were not binding for the participants of the Shanghai meeting but led to three more conferences held in The Hague during the period 1911-1914.

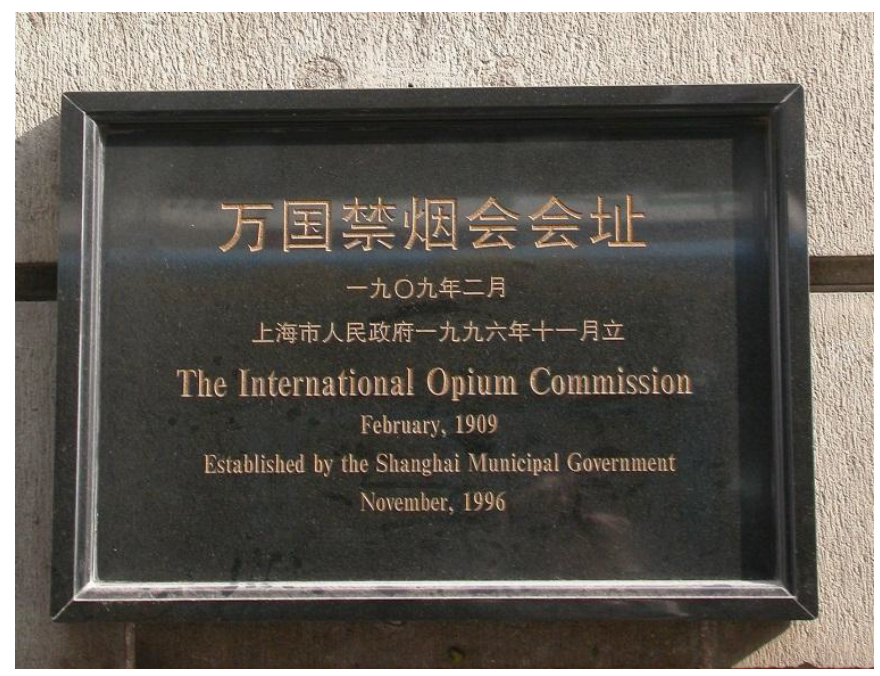

Figure 5.11 Plaque on the wall of the Peace Hotel in Shanghai, in remembrance of the Conference of 1909 (Photo collection HHB)

During preliminary negotiations for the Hague Conference of 1911 it became clear that the various participants had different objectives. As a major manufacturing country the German delegation resisted stringent controls of opiates and cocaine while the English and the Dutch, for economic reasons, were not overly keen on a complete ban of the production of opium for non-medical purposes. The US was again outmanœuvred by the British delegation who proposed to include morphine, heroin and cocaine in the controls and to collect and share data on domestic production and trade. This proposal shifted the attention from opium to the other

\footnotetext{
${ }^{54}$ Friman, 'Germany and the transformation of cocaine', 91; McAllister, Drug Diplomacy, 32.
} 
products and put pressure on Germany to disclose quantitative information. ${ }^{55}$ The German industry, which was consulted by the Interior Ministry, resisted the proposal that had the potential "to hurt legitimate trade and commerce". 56 The German Ministry, after a delay of almost a year, replied to the British proposal by suggesting that restricting wholesaler-ship to the major manufacturers would solve the problems. Several other countries supported the British proposal because the medical profession had gradually become aware of the problems resulting from non-medical use of opiates and cocaine.

In 1912 parties met again in the Hague and ultimately signed a Convention by which they agreed to take measures to limit manufacture, trade and use of opium, and 'use their best efforts to control' and to limit the manufacture of certain opiates (morphine and heroin) and cocaine to quantities required for medical and scientific purposes. ${ }^{57}$

As a consequence of the First World War ratification and implementation of the Convention was delayed. Germany became a signatory in the framework of the Treaty of Versailles in 1919. The League of Nations became responsible for implementation and administrative control of the Convention from 1920.

In the United States, the Hague Convention led to the Harrison Narcotics Act of 1914 which not only controlled the trade but also made possession of controlled substances a criminal offence. In the Netherlands, narcotics control became embodied in the "Opiumwet" (Opium Act) of 1919 by which the trade in opium, opiates and cocaine became restricted. In the UK, the "Dangerous Drugs Act" came into force in 1920.

\subsection{Summary and Conclusions}

During the period 1900-1913 the market for cocaine doubled in size, from 9 to 18 tonnes.

The foundations for future international narcotics control were laid during meetings of leading manufacturing countries at conferences at Shanghai and The Hague in 1909 and 1912 respectively. However, cocaine and opiates were manufactured and traded internationally without restrictions during the period.

The largest single manufacturer was Merck in Germany. Germany in total produced over $60 \%$ of the world requirements, with the USA, producing ca $25 \%$, occupying second place. The world market was characterized as one of relentless competition resulting in very low prices from 1908. Prices in the USA were substantially higher as a result of an import duty. Until 1910 most of the cocaine was manufactured from raw materials from Peru but for the reason of being more economical Java coca gradually replaced these and became the raw material of choice thereafter.

The outbreak of World War I in 1914 created fundamentally different circumstances, also for the cocaine industry, thereby making 1913 truly the end of a period.

\footnotetext{
${ }^{55}$ H.R. Friman, 'Germany and the transformation of cocaine' 92.

${ }^{56}$ Ibidem, 93.

${ }^{57}$ Ibidem, 95.
} 


\section{CHAPTER 6 \\ NCF, The Early Years - The Period 1900-1914}

\subsection{Overview, Organization and Marketing}

From the beginning the Koloniale Bank was responsible for management ("Directie") of the NCF. Furthermore, the Bank provided working capital and supervised the financial administration. The Minutes of the Board Meetings of the Koloniale Bank, although brief on NCF, show the keen interest the Board had in the cocaine business in the early 1900s. ${ }^{1} \mathrm{~A}$. Roelvink, chairman of the Board of the Bank was also chairman of the NCF Board. The degree of interest has to be seen in the perspective of the NCF representing only a very small part of the value of the companies in which the Koloniale Bank was involved. ${ }^{2}$ The NCF, although formally a small separate company, was for practical purposes operating as part of a larger group.

The first major action required after the establishment of the company was to find a suitable location for the factory and to apply for a permit to build and operate it (the "Hinderwetvergunning"). That location was found at the far western side of Amsterdam along the river Schinkel. The application for the permit was signed and submitted to the municipality of Amsterdam by architect H.H. Baanders in May 1900 (see 6.3). Remarkably, neither the Koloniale Bank nor the NCF is mentioned in the application. In the application for a permit for an extension of the factory in April 1901, the Koloniale Bank formally authorized Mr Baanders to act on their behalf. ${ }^{3}$ However, we have to assume that Dr Loth, who became technical director of the NCF in 1900, played a major role in the design of the factory, the procurement of the equipment, training of the employees and the start-up of the production. ${ }^{4}$ The earliest located document signed by Dr F. Loth as Technical Director of the NCF, is a statement dated 8 November $1902 .^{5}$

The other major task for the Koloniale Bank and the NCF Board was to establish a sales outlet for the cocaine produced. It is likely that Georg Boldemann, the businessman who took the initiative to found the NCF played a major role here.

A most important circumstance for the NCF was that the German Cocaine-Convention, headed by Merck, Darmstadt, was offering supply contracts to emerging cocaine producers in an attempt

\footnotetext{
${ }^{1}$ Koloniale Bank Notulen Commissarissen Vergaderingen (Minutes of Board Meetings) 1892-1930, National Archief, The Hague, Access No. 2.20.04, Items 13-19.

${ }^{2}$ On the balance sheet of the Koloniale Bank as at 31/12/1900, an amount of NLG 3,464,747 appears as the total value of Participations (“Aandelen Cultuurmaatschappijen”).Koloniale Bank, Jaarverslagen (Annual Reports), Report for 1900, Nationaal Archief, The Hague, Access No. 2.20.04 Item 5. According to a hand written note on the copy of the Annual Report at the "Nationaal Archief", only NLG 4.00 of that total amount of almost 3.5 million Dutch Guilders represents the NCF. This NLG 4 is the written down value of the NCF shares with a nominal value of NLG 4,000. On the balance sheet as at 31/12/1906 the NCF appears (again as a handwritten note) for the full nominal value of NLG 4,000.

${ }^{3}$ Statement dated 23 April 1901signed by two directors of the Koloniale Bank. File 2923 PW 1901.

${ }^{4}$ Jubileumboek "N.C.F." NV Nederlandsche Cocaine Fabriek 12 Maart 1900-1950, Library of the International Institute for Social History, Amsterdam.

${ }^{5}$ Statement authorizing the firm Groeneveld, Ruempel \& Co. to act on behalf of the NCF. Municipal Archive Amsterdam, File 9427 PW 1902. Dr Loth is mentioned as Technical Director of the NCF in the annual: Van Nierop \& Baak, Naamlooze Vennootschappen (1902) 914.
} 
to control the market price. ${ }^{6} \mathrm{NCF}$ and the Convention commenced negotiations and the result was that in February 1901 the company entered a contract under which it obtained a firm annual sales quota of $300 \mathrm{~kg} .{ }^{7}$ Under the contract, NCF would supply the cocaine to the respected pharmaceutical company Gehe \& Co., Dresden. At the then current convention price of DEM 620 (NLG 372) per $\mathrm{kg}$ cocaine hydrochloride and an approximate manufacturing cost of NLG 100 per kg this contract represented for NCF a potential annual gross profit (before depreciation and interest charges) of ca NLG 80,000 p.a. ${ }^{8}$ This contract more or less guaranteed a successful future of the NCF; the amount was so large that it provided justification for virtually any investment required to achieve the desired production level. Even if the cocaine prices were to come down substantially, profit would be still very attractive. Because of the agreement with the Convention NCF did not have to build its own sales organization. Who maintained the contact with Gehe is not entirely clear, but it appears that Dr Eberhard was involved. ${ }^{9}$

The coca leaves used by the NCF as raw material were primarily supplied by "Soekamadjoe", the plantation owned by Van Hengst, NCF's major shareholder. As a result, a vertical integration of the NCF and the producer of the coca leaves was established, guaranteeing continuity of supply of the basic raw material at low cost. The Koloniale Bank maintained the communications with Van Hengst on the supply of the coca leaves. ${ }^{10}$

When NCF entered the cocaine business in 1900, prices were high and the demand increasing. However, as a result of very severe competition in the world market, from 1901 to 1908 prices declined steadily and profits eroded (section 5.3). But because of there being continued access to low cost Java coca, sufficient income was still generated at NCF to make the owners feel confident enough to make positive decisions regarding continuation of the business.

\footnotetext{
${ }^{6}$ Such "conventions" (price and quota agreements) were not illegal and quite common on those days. (ref. Section 2.4).

${ }^{7}$ Merck, Conventionen und Vertretungen, Bericht über das Geschäftsjahr (1901-1902) Merck-Archiv F03/6a p 6-7.

${ }^{8}$ The cost figure of ca NLG 100 / kg is mentioned in Koloniale Bank, Notulen Commissarissen Vergaderingen (Minutes of Board Meetings), Meeting of 21 January 1902.

${ }^{9}$ Dr Eberhard gave (unspecified) "further information on the Convention" at a Board meeting. Koloniale Bank, Minutes of Board Meetings, Meeting of 17 December 1907.

${ }^{10}$ Koloniale Bank, Minutes of Board Meetings, Meetings of 19 February 1901 and 14 August 1903.
} 


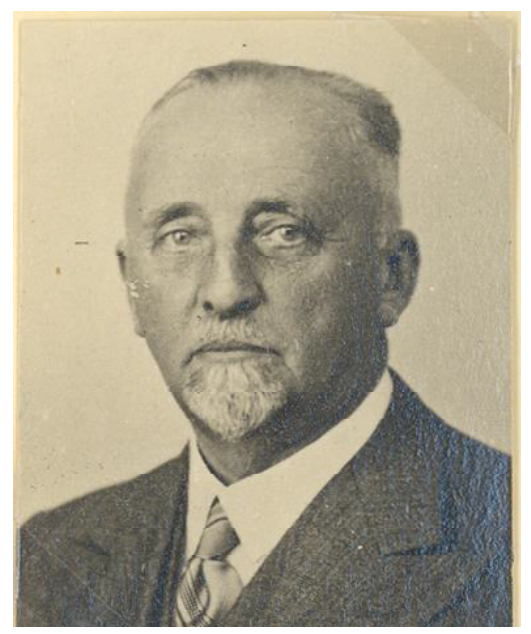

Figure 6.1 Dr G.H. Kramers

Technical Director NCF 1907-1946

(NCF 1900-1950, IISH Amsterdam)

With respect to the factory, a noteworthy organizational change for the period was that Mr. Waterman, assistant to Dr Loth, resigned end 1905 and Dr G. H. Kramers was appointed as his successor in January $1906 .{ }^{11}$ Dr Kramers was a chemical engineer and alkaloid specialist who had obtained his doctorate on his thesis Sur quelques alkaloides de l'opium (1901), at the University of Geneva (Professor Amé Pictet). Dr Kramers was appointed despite his demanding a salary twice as high as his predecessor. The justification for the approval of the remuneration by the Board was that Kramers had much more experience in the field. ${ }^{12}$ Another important appointment of 1906 was that of Hans Brunner as the chief-engineer. ${ }^{13} \mathrm{Dr}$ Kramers succeeded Dr Loth as technical director of the NCF in 1907 at the age of 29 and he remained the Technical Director for almost forty years. The reason for the departure of $\mathrm{Dr}$ Loth is not known. ${ }^{14}$

A critical event occurred in 1907 , when a request to the municipality to approve an increase of the quantities of inflammable solvents allowed to be held in the factory was declined because it was considered to be an unacceptable fire risk. As a result the final purification step of the cocaine [hydrochloride] could not be completed and NCF decided to make cocaine [base] exclusively after March 1, 1908, which was allowed under the existing permit. It was noted by the Board that making cocaine hydrochloride from the base could be done quickly [at a later stage]. ${ }^{15}$ The Directors considered having the final product made at Naarden [the location of its competitor 'Cheiron'] but decided against this option for reasons of cost and lack of control. ${ }^{16}$ The only long term solution for the problem was to build a new factory outside the city.

Another crucial development of 1907 was Gehe's advising NCF that the Cocaine Convention would be dissolved as of 1 March 1908. The price deterioration of cocaine in the world market could not be halted by the Convention and a situation of sauve qui peut had arisen (ref. 5.3). Gehe offered an alternative contract but the conditions were unacceptable and NCF felt sufficiently confident to cancel supplies to Gehe starting immediately and to sell the

\footnotetext{
${ }^{11}$ Koloniale Bank, Minutes of Board Meetings, Meetings of 12 December 1905 and 16 January 1906.

${ }^{12}$ Koloniale Bank, Minutes of Board Meetings, Meeting of 12 December 1905.

${ }^{13}$ Hans Brunner was a Swiss national brought in by Kramers. Oral history relayed to the author in the early 1960s and Jubileumboek "N.C.F 1900-1950".

${ }^{14}$ Jubileumboek "N.C.F. 1900-1950". Neither the departure of Dr Loth nor his replacement by Dr Kramers is mentioned in the Minutes of the Board Meeting of the Koloniale Bank.

${ }^{15}$ Minutes of the Board Meeting of the Koloniale Bank of 18 February 1908. Halting the production of cocaine sulphate is mentioned here. This must be by mistake; the production of cocaine hydrochloride was halted.

${ }^{16}$ Koloniale Bank, Report No 385 from the Directors to the Board dated 15 August 1908.
} 
product themselves. ${ }^{17}$ Nothing is known about how these sales activities were organized and who the customers were.

In August 1908 a fundamental decision was made on the future of the company. Despite the then prevailing very low cocaine prices, the Koloniale Bank accepted the plan by the recently appointed Technical Director Dr Kramers for a new factory, on the rationale that the downside risk of the investment was judged as not excessive. The Board of the Koloniale Bank approved a proposal by the Directors to invest NLG 30,000 in the new factory and agreed to finance the project by making the necessary funds available as a first mortgage. ${ }^{18}$

The new factory was built during 1909 and was operational from the end of that year. No dividend was paid over 1909 and production and sales would have been small, if any. In 1910 cocaine production commenced but prices declined further and dividend payments, though resumed in 1910, did not reach the level of the years before 1906. The situation changed the second half of 1914 when prices increased substantially as a result of World War I. The quantity of cocaine manufactured and sold during the period 1910-1914 is estimated at ca 500 kg p.a. (ref. chapter 18)

In the Minutes of the Board Meetings of the Koloniale Bank there are virtually no records of any direct involvement of Van Hengst in decisions regarding the NCF. It is assumed that Van Hengst's input as NCF's major shareholder in the decision process was channeled via NCF Board member J.H. de Groot. ${ }^{19}$ In the Minutes of the Board Meeting of 16 November 1909 it is however reported that agreement had been reached with Van Hengst on the increase of the statutory capital of the NCF on 12 March 1910.

At the same meeting the Board of the Koloniale Bank approved the acquisition of $84 \%$ of the shares of the Soekamadjoe plantation on Java, where the coca for the NCF was cultivated, from Van Hengst. The major reason for this acquisition was, however, Soekamadjoe's tea plantations, not the coca cultivation. ${ }^{20}$ For NCF the acquisition meant an even tighter integration with the Koloniale Bank. Van Hengst died in 1910 or 1911; the majority of his estate, including the $20 \mathrm{NCF}$ shares (ref. 6.6), went apparently to his widow Mrs J. Van Hengst née Huygen de Raat.

At the start of the $20^{\text {th }}$ century the manufacture of and trade in cocaine was still unrestricted. Conferences leading to proposals for international control of narcotic drugs were held in Shanghai in 1909 and in The Hague in the period 1911-1914 but because of the First World War the proposals were not generally acted upon until 1918.

The financial results of the NCF were very good over the period especially during the years until 1906. Shareholders and holders of the profit sharing notes (Boldemann and Eberhard) received excellent returns on their input.

\footnotetext{
${ }^{17}$ Minutes of the Board Meeting of the Koloniale Bank of 17 December 1907.

${ }^{18}$ Koloniale Bank, Minutes of Board Meetings, Meeting of 14 August 1908.

${ }^{19}$ J.H. de Groot is mentioned as a member of the NCF Board in Van Nierop \& Baak's Naamlooze Vennootschappen for the year 1908 but not for1910. J.H. de Groot was probably a cousin of Van Hengst's wife Jenny (ref. Appendix 1)..

${ }^{20}$ Koloniale Bank, Minutes of Board Meetings, Meeting of 16 November 1909.
} 


\subsection{Supply of Java Coca to NCF - The Soekamadjoe Plantation.}

From 1900 the primary source of NCF's raw material, Java coca, was the plantation "Soekamadjoe", owned by J. van Hengst, NCF's major shareholder. The low cost of this raw material was a key competitive advantage for NCF, allowing it to stay in the market when the cocaine price was low. In 1909 Soekamadjoe was acquired by the Koloniale Bank. The histories of Soekamadjoe and the van Hengst / Huygen de Raat families are interwoven with that of the NCF and provide a background for the business of the latter. The relationships between the families van Hengst and Huygen de Raat have been researched and are described in Appendix 1.

The plantation (estate) "Soekamadjoe" is mentioned as the source of the samples of coca assayed by Greshoff in $1888 .^{21}$ Between 1890 and 1900 only a few coca plantations existed on Java, covering in total an area of about 200 ha. Soekamadjoe at Tjibadak, was the largest. $^{22}$ It appears that van Hengst's brother-in-law Antoine Massink, who was acting manager of the experimental section of the Botanical Gardens at Buitenzorg, introduced van Hengst to the cultivation of coca. ${ }^{23}$ The result was that Soekamadjoe became the first plantation where the crop was grown commercially. ${ }^{24}$

Little is known in detail on the supply of coca leaf to NCF by Soekamadjoe during the early 1900s. In 1901 the Koloniale Bank discussed the continuation of a contract with van Hengst and in 1903 van Hengst was contacted for additional supplies. ${ }^{25}$ From the minutes of a Board Meeting of the Koloniale Bank we know that the price was considered low. ${ }^{26}$ For 1902 a price of 50 Dutch (NL) cents per $\mathrm{kg}$ was reported for coca containing $2 \%$ total alkaloids, which is equivalent to $40 \mathrm{NL}$ cents per $\mathrm{kg}$ for average coca of 1.5\%-1.6\% alkaloid. ${ }^{27} 40 \mathrm{NL}$ cents per $\mathrm{kg}$ was the average price at which Java coca was exported during 1908-1909; it was also the contract price at which Soekamadjoe supplied NCF during the period 1910-1920. ${ }^{28}$ From this information we conclude that the contract price for the period 1900-1910 was almost certainly also 40 NL cents per $\mathrm{kg}$ (irrespective of the alkaloid content). No exact information is available on the quantities of coca shipped by Soekamadjoe to the NCF during the period 1900-1908. It is estimated that ca 25 tonnes were supplied annually (ref. chapter 15).

Soekamadjoe was incorporated on 29 May 1903 under the name of N.V, Landbouwmaatschappij "Soekamadjoe" at Soerabaja, but no details are available. In 1909 the acquisition of Soekamadjoe by the Koloniale Bank was discussed in a Board Meeting of the Bank. $^{29}$ At that meeting it was stated that the primary reason for the acquisition was the interest of the Koloniale Bank in the cultivation of tea, in which the Soekamadjoe estate was already involved and for which it was considered very suitable. At the meeting, the Board

\footnotetext{
${ }^{21}$ W. Burck, 'Opmerkingen over de onder de naam Erythroxylon coca in Nederlandsch-Indië gecultiveerde gewassen', Teysmannia 1 (1890) 459; W.R. Tromp de Haas, 'De Coca-Cultuur', Teysmannia 14 (1903) 295.

22 A.W.K. de Jong, Chapter 'Coca' in: C.J.J. van Hall and C. van de Koppel, editors, De Landbouw in de Indische Archipel Vol II A (The Hague 1948) 873.

${ }^{23}$ J. van Hengst, Laatste woord van J. van Hengst contra Perelaar c.s. (1890) 12. For details see Appendix 1 to this dissertation: "Relationships between the families van Hengst en Huygen de Raat".

${ }^{24}$ De Jong in Chapter 'Coca', 873, writes that in the 1890s Massing at Tjibadak was the owner of the largest coca plantation on Java. It appears that de Jong mistakenly assumed that Massink (not Massing) was the sole owner of Soekamadjoe.

${ }^{25}$ Koloniale Bank, Minutes of Board Meetings, Meetings of 15 February 1901 and 14 August 1903.

${ }^{26}$ Koloniale Bank, Minutes of Board Meetings, Meeting of 16 November 1909.

${ }^{27}$ Van der Sleen (1908).

${ }^{28}$ Statistiek van den Handel en de In-en Uitvoerrechten (Statistics Dutch East Indies), Deel IIa (Java en Madoera) Weltevreden 1874-1923, Library Royal Tropical Institute (KIT) Amsterdam.

${ }^{29}$ Koloniale Bank, Minutes of Board Meetings, Meeting of 16 November 1909.
} 
decided unanimously to purchase 420 out of the total of 500 Soekamadjoe shares. The other 80 shares remained with van Hengst, Massink and family members.

The total area of the estate amounted to ca 1280 bouws (ca 900 ha) out of which ca 450 bouws (ca $300 \mathrm{ha}$ ) was under cultivation for tea. The price paid for the 420 shares represented ca NLG 100 per bouw (ca NLG 108,000 in total) which was considered not expensive. At the Board meeting it was explicitly stated that the Board recognized the importance of the contracted low coca price for the NCF, which the Board would like to continue. The Board had considered making the acquisition of the NCF shares from van Hengst a condition for the Soekamadjoe deal, but did not continue with the idea when it appeared that other parties had also shown an interest in buying Soekamadjoe. ${ }^{30}$

Figure 6.2 Location of the Soekamadjoe estate ca $24 \mathrm{~km}$ West of Soekaboemi (situation $1894)^{31}$

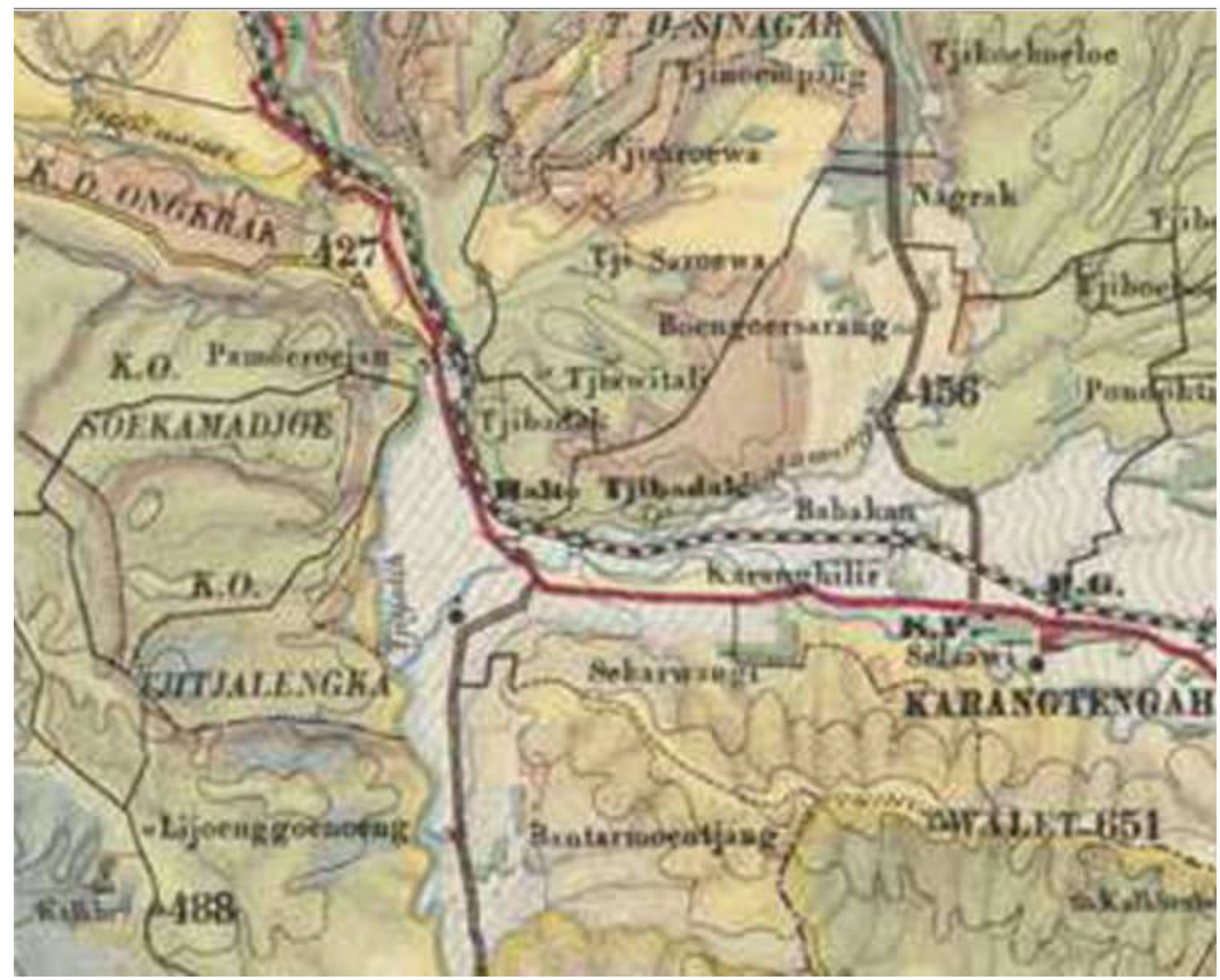

Scale: $10 \mathrm{~cm}=$ ca $7.5 \mathrm{~km}$

\footnotetext{
${ }^{30}$ Ibidem.

${ }^{31}$ Topographical map of the Preanger region (updated 1894), Beeldbank Vrije Universiteit Amsterdam.
} 
Figure 6.3 Tea harvest at the Soekamadjoe estate near Tjibadak (ca 1920) $)^{32}$

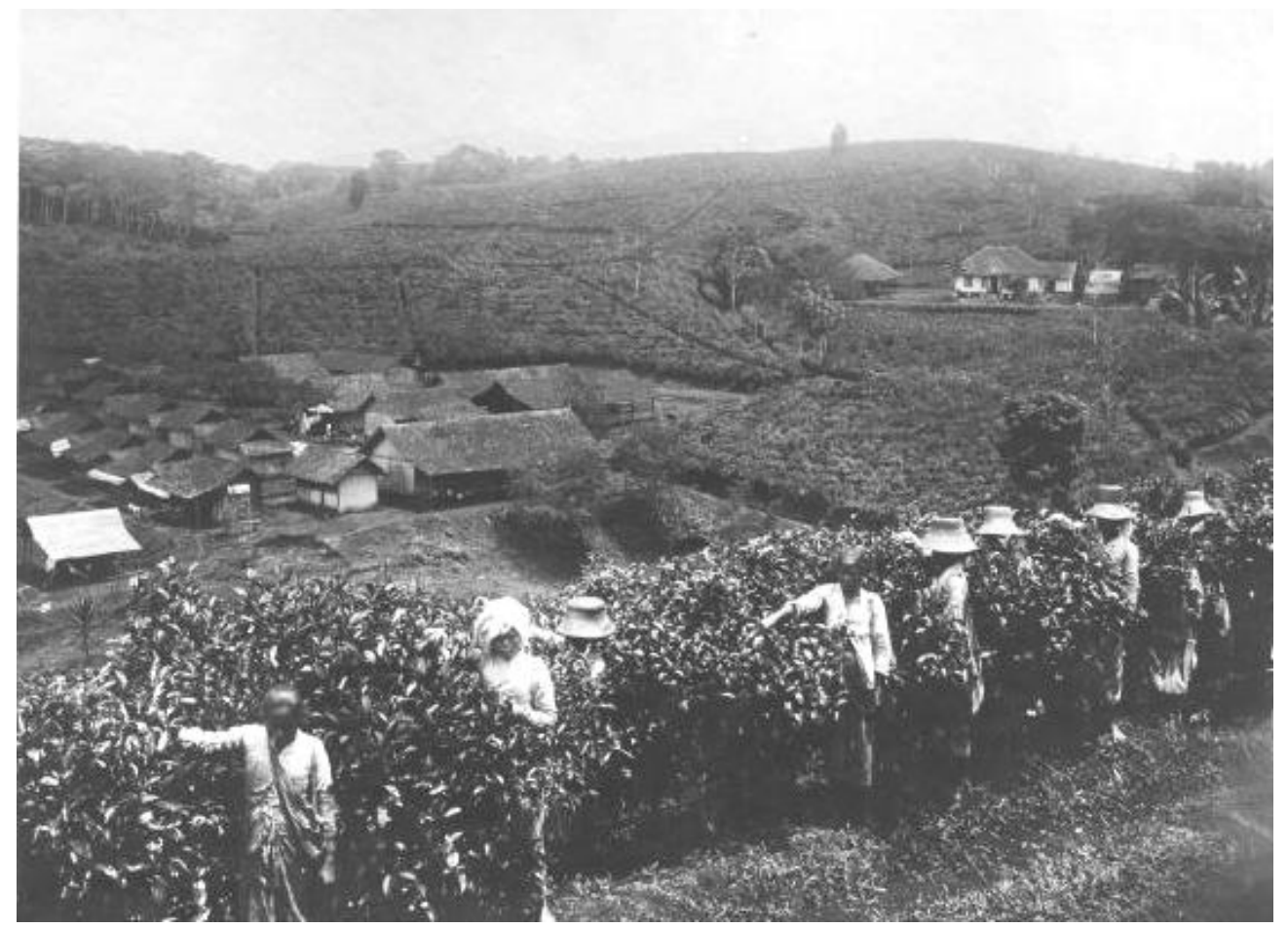

From the Minutes of the Annual General Meeting of Soekamadjoe we know the distribution of ownership of the shares in 1910:

$\begin{array}{lc}\text { Koloniale Bank } & 420 \text { shares } \\ \text { Mrs J. van Hengst - Huygen de Raat } & 55 \text { shares } \\ \text { A. Massink } & 10 \text { shares } \\ \text { Mrs H.F. Massink - van Hengst } & 10 \text { shares } \\ \text { Mrs M.J. Van Weelderen-van Hengst } & 5 \text { shares } \\ ------------- \\ \text { Total }\end{array}$

Board members were: W.C. Bonebakker (Koloniale Bank), A. Massink, M.E.G. Bartels and H. Adams.

In the minutes of 1911 Miss L. Maarschalk is mentioned as the proxy of "Mrs J. Van Hengst - Huygen de Raat, widow of the late J. van Hengst", ${ }^{33}$ implying that J. van Hengst had died in 1910 or 1911. Miss Maarschalk became a director ("commissaris") of Soekamadjoe in 1912. ${ }^{34}$ At a later stage, Miss Maarschalk became the majority shareholder of the NCF. Upon the Koloniale Bank's taking over management of Soekamadjoe it appointed F.G.H. van Houtem as the manager ("administrateur") of the estate. Early in 1910 van Houtem reported on the state of affairs. His verdict was that, although the condition of crops currently under cultivation was bad and that maintenance at the factory had been neglected, the enterprise had

\footnotetext{
32 'Theepluksters op een perceel van de Landbouw Maatschappij Soekamadjoe', Digital Image Library KITLV, Leiden.

${ }^{33}$ Soekamadjoe, Notulen Bestuursvergaderingen (Minutes of Board Meetings), Annual General Meeting of 12 June 1911, National Archief, The Hague, Access No 2.20.04 Item 1481.

${ }^{34}$ Soekamadjoe, Jaarverslagen (Annual reports), Annual report for 1912, 8, Nationaal Archief, The Hague, Access No. 2.20.04 Items 1477 and 1478.
} 
very good prospects. ${ }^{35}$ The soil was rich and, provided sufficient money was spent, excellent profits should be expected within a few years. ${ }^{36}$ With respect to the coca cultivation, van Houtem remarked in his report that the condition of the plants was not good in comparison to that of coca at other plantations. No harvest had taken place recently and the production had been mainly based on purchased leaf. For 1910 a harvest of ca $20 \mathrm{t}$ of coca leaf was expected. In general, the coca cultivation had not been given much attention and the soil allocated to the crop was poor. He announced that radical pruning of existing plants was necessary. A nursery would be set up and, in 1910, a new coca plantation 50 bouws (35 ha) would be established from which a future harvest of 20-25 t leaf was expected. ${ }^{37}$

Progress reports on coca cultivation are contained in subsequent Annual Reports of Soekamadjoe. From those reports a summary table of coca production has been made and is included Part IV, Source Data. Table JCL 7. During the period until 1915 the area under coca cultivation was expanded to ca 93 bouws (65 ha) and the development of both the old and the new plants was satisfactory. However, the capacity of Soekamadjoe's drying facilities, which had to serve both tea and coca, was insufficient and that had had a quite severe negative impact on the amount of coca leaf harvested. ${ }^{38}$

The total coca harvest of 1910 (ca 20 t) will have been shipped to NCF, as was all coca leaf produced over the period 1911-1914.

Table 6.1 Java Coca shipped from Soekamadjoe to NCF 1900-1914

\begin{tabular}{|c|rcc|}
\hline Year & $\begin{array}{c}\text { Java Coca } \\
\text { shipped } \\
\text { kg }\end{array}$ & $\begin{array}{c}\text { Alkaloid } \\
\text { Assay } \\
\%\end{array}$ & $\begin{array}{c}\text { Cocaine HCl } \\
\text { equivalent } \\
\text { kg }\end{array}$ \\
\hline & & & \\
1900 & 20,000 & 1.50 & 200 \\
1911 & 7,850 & 1.52 & 80 \\
1912 & 23,230 & 1.52 & 235 \\
1913 & 31,410 & 1.59 & 333 \\
1914 & 32,850 & 1.75 & 383 \\
\hline
\end{tabular}

Sources: 1911-1914 Table JCL 7 (Part IV); 1900 Estimate (Chapter 18)

Coca supplies to NCF during the period 1910-1920 were governed by a new supply contract. The contract price was $20 \mathrm{NL}$ cents per $1 / 2 \mathrm{~kg}$ (irrespective of the alkaloid content) c.i.f. Amsterdam. ${ }^{39}$ Soekamadjoe board members were not happy with this supply contract. The price was considered low and the contract was exclusive (all the coca produced had to be supplied to NCF). ${ }^{40}$ Furthermore, the contract required an extension of the area under coca cultivation to 100 bouws ( $70 \mathrm{ha}$ ) which was considered as disadvantageous for the company because the proceeds from coca cultivation were less than from other crops. ${ }^{41}$

\footnotetext{
${ }^{35}$ The "factory" was the facility where the agricultural products of the plantation (tea, coca) were dried and packed for shipping.

${ }^{36}$ Soekamadjoe, Annual report for 1909, 7-10.

${ }^{37}$ Ibidem.

${ }^{38}$ Soekamadjoe, Annual reports for 1910-1914.

${ }^{39}$ Soekamadjoe, Minutes of Board Meeting, Meeting of 12 June 1912.

Note: It was customary in the trade to quote prices of Java coca in Dutch cents per half $\mathrm{kg}$.

${ }^{40}$ Soekamadjoe, Minutes of Board Meeting, Meeting of 16 April 1910.

${ }^{41}$ Ibidem.
} 
The quantity of cocaine $\mathrm{HCl}$ produced by NCF during the period 1910-1914 has been estimated at ca. $500 \mathrm{~kg}$ p.a. (chapter 18). For the manufacture of $500 \mathrm{~kg}$ of cocaine $\mathrm{HCl}$ ca 50 $\mathrm{t}$ of coca leaf is required. The average quantity of coca shipped by Soekamadjoe over the period 1910-1914 was ca $23 \mathrm{t}$ p.a., sufficient for production of ca $250 \mathrm{~kg}$ cocaine $\mathrm{HCl}$. The additional raw material requirements of $\mathrm{NCF}$ for the period were ca $25 \mathrm{t}$ coca p.a.

\subsection{Building the Factory and Manufacturing at Amsterdam 1900-1909}

\section{Building the Factory in 1900}

After the decision was taken to establish the NCF the task at hand was to build an efficient factory. It was probably in 1899 that the Koloniale Bank commissioned the architect H.H. Baanders to draw up plans for a cocaine factory in Amsterdam. ${ }^{42}$ Technical input for the layout would have been provided by Dr. Loth and probably Dr. Eberhard. These plans, were submitted by Baanders to the municipal authorities of Amsterdam on 8 May 1900; neither the NCF nor the Koloniale Bank is mentioned in the documents.

Approval was requested to build and operate a cocaine factory on a vacant lot on the corner of the Schinkelkade and the $1^{\text {st }}$ Schinkelstraat. The location chosen for the factory was at the extreme west of Amsterdam along the canalized river Schinkel which formed part of the border between the municipalities of Amsterdam and Sloten at the time (Figure 6.4). The considerations that led to the choice are not known. The plot selected had already been approved by the municipality for building purposes in 1898 but the previous owner had not exercised the option. ${ }^{43}$

Figure 6.4 Plan showing the location of the NCF factory 1900-1909. ${ }^{44}$

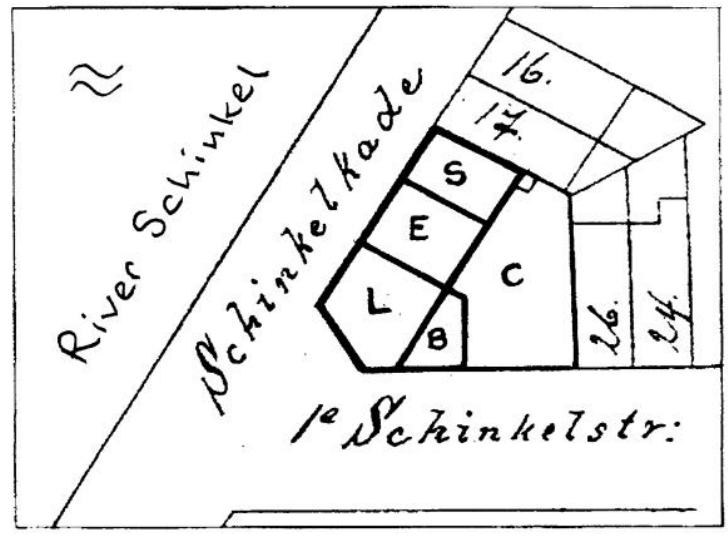

$$
\begin{aligned}
& \text { Legend: } \\
& \mathrm{S}=\text { Store room } \\
& \mathrm{E}=\text { Extraction facility } \\
& \mathrm{L}=\text { Laboratory (production space } \\
& \quad \text { for making the cocaine) } \\
& \mathrm{B}=\text { Boiler house } \\
& \mathrm{C}=\text { Walled court yard }
\end{aligned}
$$

\footnotetext{
${ }^{42}$ Hermanus Hendrikus Baanders (1849-1905) was a well known independent architect in Amsterdam, who designed dwellings and commercial buildings in the neo-renaissance style, which he combined with art nouveau elements. V. van Rossum, Binnenstad 226, February 2008 and the article on Baanders in Wikipedia (accessed 19.06.2010).

${ }^{43}$ Letter from the Building Inspector dated 21 May 1900. Stadsarchief Amsterdam. File 3584 PW 1900.

${ }^{44}$ Based on a plan by Bouw- en Woningtoezicht dated 11 February 1902. Stadsarchief Amsterdam.
} 
Figure 6.5 Plan for the NCF factory as submitted with 3582 PW 1900

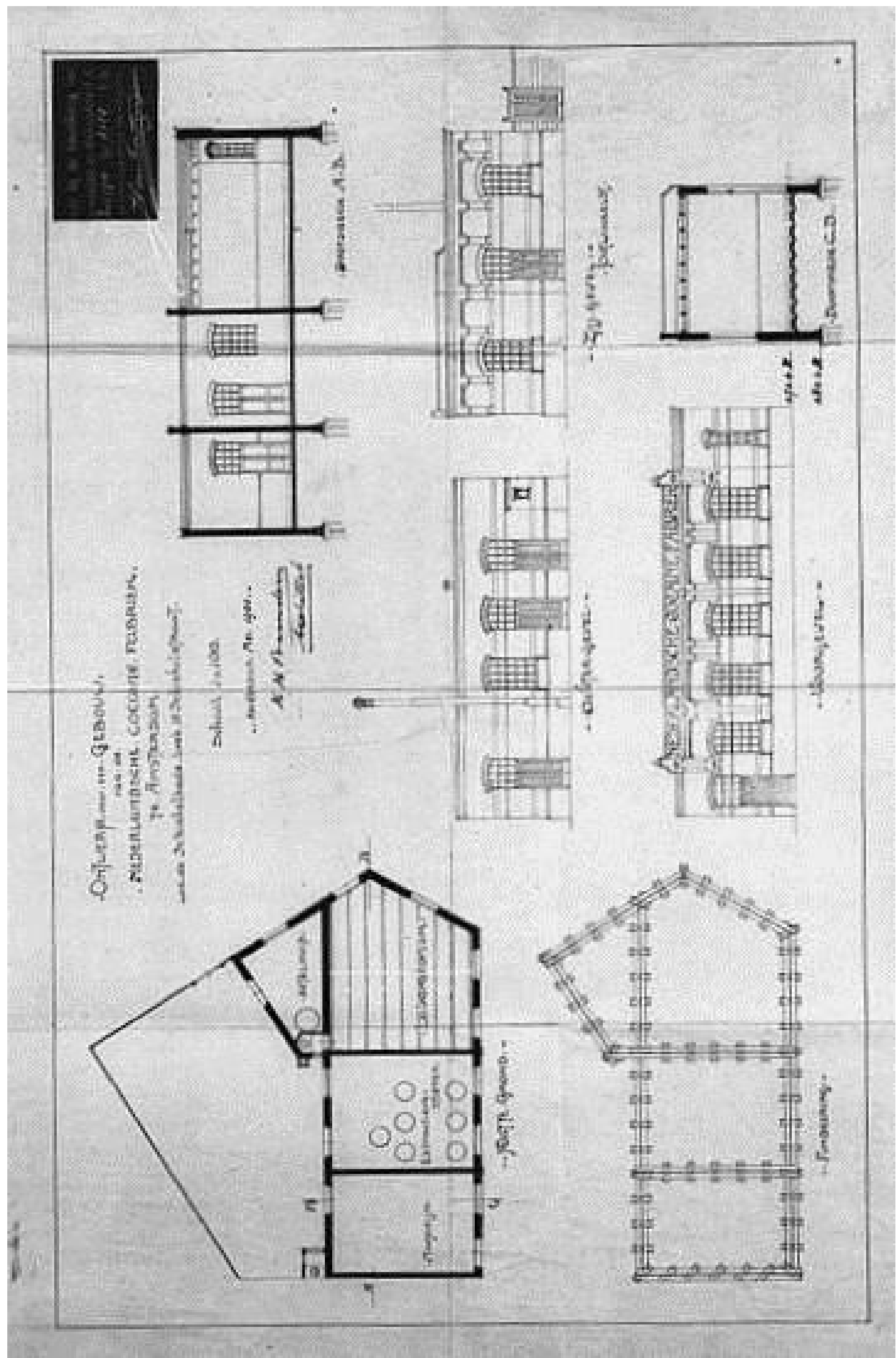


The NCF application was processed and advice was obtained by the municipal Department of Public Works (PW) from the municipal Building Department, the Labour Department and the Fire-brigade regarding acceptability of the proposal. The building permit was issued on June 9. ${ }^{45}$

A public hearing at which objections against establishment of the factory could be raised was held on the $7^{\text {th }}$ of June, but no opposition was recorded and the permit to operate the factory (the "Hinderwetvergunning") was granted on 28 June $1900 .{ }^{46}$ The permit specified a few constructional details to be complied with, and the conditions imposed by the Fire-brigade. The maximum quantities of ethanol and ether allowed to be held in storage were 50 and 25 litres respectively. The ethanol and ether had to be stored in metal bottles of not more than five litres capacity each, placed in a separate space built in brick and accessible during daylight hours only.

Figure 6.3 shows the plan submitted with the application. The total area of the plot was ca $270 \mathrm{~m}^{2}$ of which $160 \mathrm{~m}^{2}$ was occupied by the building; the court yard represented 110 $\mathrm{m}^{2}$. The accompanying description of the factory mentions the laboratory ("Laboratorium") in which "some equipment and tools" and ca 40 litres of ethanol and ca 20 litres ether would be present. $^{47}$ Next to the laboratory was the location of the extraction department ("Extractieve Stoffen") which was equipped with seven closed cylindrical iron vessels with shale oil ("Schieferöl") in which the process took place at room temperature. Not indicated are the quantities of extraction solvent (shale oil) which would be present in the vessels. The factory description also mentioned a boiler-house ("Ketelhuis") with a boiler of $7.5 \mathrm{~m} 2$ heated surface and a store room ("Magazijn") in which spare equipment and fuel were stored. All motive power was manual.

\section{Figure 6.6 Façade of the NCF factory in Dutch neo-renaissance style ${ }^{48}$}

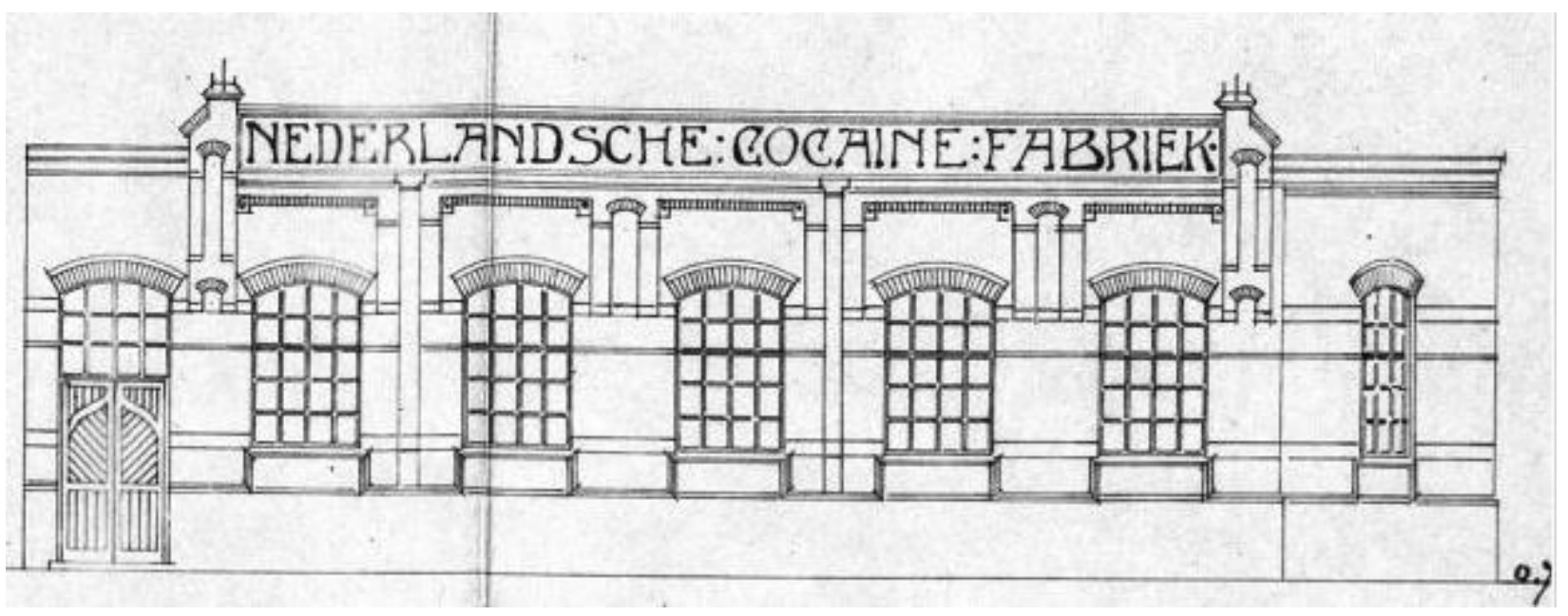

Architect: H.H. Baanders.

\footnotetext{
45 Application 3582 PW 1900.

${ }^{46}$ Hinderwetvergunningen (Permits to operate potentially dangerous establishments as required by the eponymous Act of 1875), Municipal Archives of Amsterdam ("Stadsarchief"), PW file 5180, No 5053 (dossier 5203) and No 5050 (dossier 3413).

${ }^{47}$ These quantities of ethanol and ether were allowed to be present in the laboratory over and above the quantities held in storage.

${ }^{48}$ Stadsarchief Amsterdam, Afbeeldingsbestand 5221 BT 906179.
} 
Figure 6.7

\section{COCA LEAF COUNTER CURRENT EXTRACTION}

Schematic representation

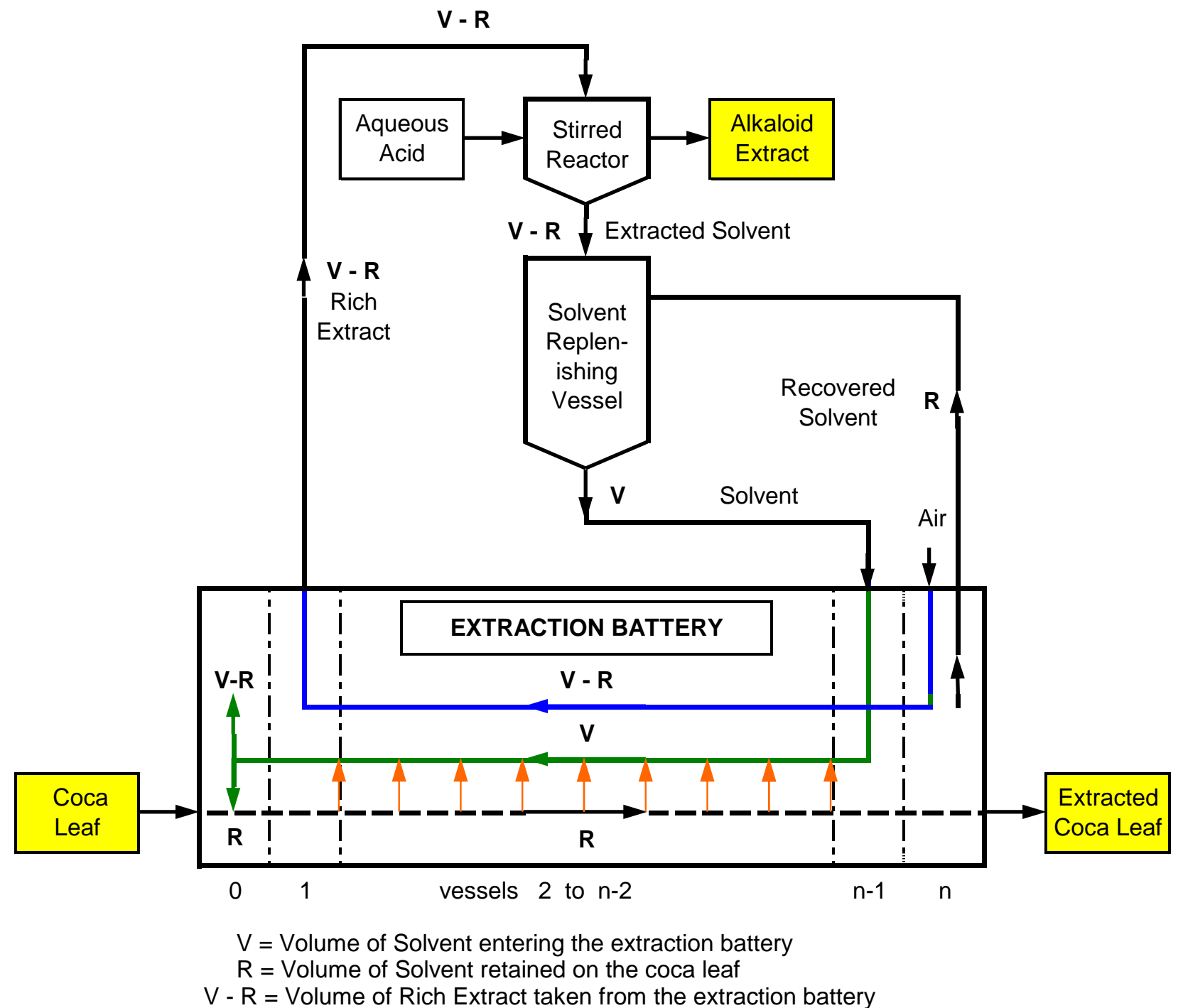

$\mathrm{V}-\mathrm{R}=$ Volume of Rich Extract taken from the extraction battery

Alkaloid transfer from $\mathrm{R}$ to $\mathrm{V}$

Flow of Rich Extract through vessels

Flow of Solvent through vessels

Movement of coca leaf through extractor 
The process description as submitted was very brief and incomplete. Based on later submissions and general knowledge of the cocaine manufacturing process the following explanations are provided to facilitate the understanding of the operations at the original NCF factory: ${ }^{49}$

The raw material, Java coca, was pre-treated with alkali before being subjected to the extraction process. The extraction process took place in six of the seven vessels, presumably using the counter-current method (Figure 6.7). ${ }^{50}$ The remaining vessel (the replenishing vessel) was used to store the shale oil after transfer of the alkaloids from the rich extract into an acid aqueous phase. The vessel containing the extracted coca leaf was most likely subjected to a steam distillation process to recover the retained solvent before the extracted leaf was discarded. The acid aqueous solution of the total alkaloids produced was processed in the "laboratory" via ecgonine in several steps into pure cocaine hydrochloride as described in section 3.4. The "laboratory" was a production facility, rather than a laboratory in the sense of a room for experiments. That all operations were performed using manual power only would have been cumbersome.

The building of the factory took place during the second half of 1900. On November 2 the municipal Building Inspector issued a statement declaring that the building had taken place in conformity with the permit.

According to an insider article in the Pharmaceutisch Weekblad, the factory in its set-up of 1900 was not more than a pilot-plant. ${ }^{51}$ In the minutes of the Board Meeting of the Koloniale Bank of 19 February 1901 it is mentioned that the technical director (Dr Loth) had produced "good" cocaine but in quantities insufficient to judge factory performance. ${ }^{52}$

\footnotetext{
${ }^{49}$ Ref. F.E. Hamerslag, Chapter V: The Alkaloids of Coca in: 'The technology and chemistry of alkaloids' (New York 1950) 57-65.

${ }^{50}$ Solid-liquid countercurrent extraction is a process in which, over several stages, a solid and a liquid (the solvent) are in contact with each other and flow in opposite directions (Figure 4, opposite). During that process the desired product (here alkaloids) moves from the solid phase into the liquid phase. The equipment comprises a series of vertical cylindrical vessels connected with pipes to direct the flow of the solvent. The solvent (shale oil, kerosene) is immiscible with water. For the following process description we presume that all but one of the vessels are filled and that the factory has been in operation for a sufficient long time to bring the system into equilibrium. The first step of the process is to put air pressure on the last vessel (vessel \# n containing the fully extracted coca) to move all not adhering solvent to the next vessel (\# n-1) thereby causing that an equal volume of the solvent flows through the battery of interconnected vessels to vessel \#1 from where it passes into a stirred reactor where the alkaloids are extracted into aqueous acid. The now alkaloid-free solvent flows into a solvent storage tank, the replenishing vessel. During the first step the so far empty vessel \#0 is filled with coca leaf pretreated with alkali to liberate the alkaloids. The second step of the process is the recovery of solvent retained on the extracted coca in vessel \#n by means of steam distillation. Simultaneously a quantity of solvent from the replenishing tank is transferred to vessel \# n-1, resulting in an equal volume of the solvent flowing through the battery of interconnected vessels onto the fresh coca leaf in vessel \#0.Thereafter the system is left for sufficient time to reach equilibrium again. This completes the extraction cycle.

${ }^{51}$ [Anonymous]. "De Nederlandsche Cocaine Fabriek NV", Pharmaceutisch. Weekblad (1939) 798.

${ }^{52}$ Koloniale Bank, Notulen Commissarissen Vergaderingen (Minutes of Board Meetings),

Meeting of 19 February 1901. Nationaal Archief, The Hague, Access No. 2.20.04, Items 13-19.
} 
Figure 6.8 Floor plan NCF factory and equipment 1900-1901 53

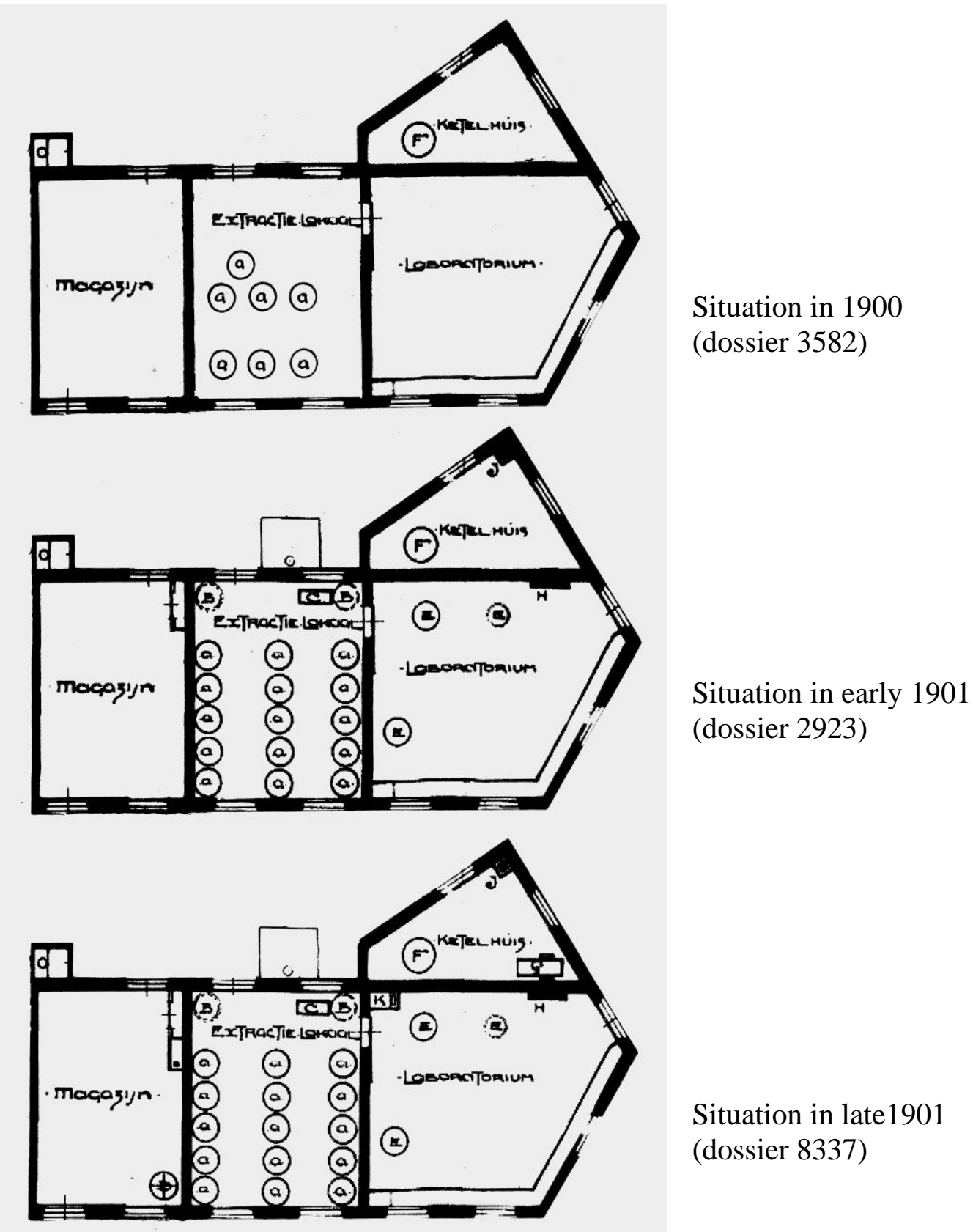

Legend:

$\begin{array}{llll}\text { a } & \text { Extraction vessel } & \text { F } & \text { Boiler } \\ \text { B } & \text { Replenishing vessel } & \text { G } & \text { Compressor } \\ \text { C } & \text { Stirred reactor } & \text { H } & \text { Central heating } \\ \text { D } & \text { Condenser } & \text { J } & \text { Reactor } \\ \text { E } & \text { Still } & \text { K } & \text { Steam-pump }\end{array}$

${ }^{53}$ Stadsarchief Amsterdam, the drawings are submitted with 'Hinderwetaanvragen' (Applications) Nos 3582 PW 1900, 1923 PW 1901 and 8337 PW 1901. 


\section{Expansions of the factory in 1901}

After entering into the contract with the Cocaine-Convention it was clear that the production capacity of the new plant was too small. On 13 March 1901 architect Baanders submitted another "Hinderwetaanvraag" to obtain permission to expand the facility with 9 extraction vessels resulting in a system comprising 15 extraction vessels and 2 replenishing vessels ("bijvulketels") (Figure 6.8). ${ }^{54}$ The accompanying process description is considerably more extensive and specific than the one submitted in 1900. The information provided confirms and expands our earlier understanding of the operations.

The 1901 disclosed process details included that:

- The vessels were cylindrical and were interconnected. They had a capacity of 3,000 litres each and contained $500 \mathrm{~kg}$ coca leaf and the same quantity [500 kg $=625 \mathrm{~L}]$ of solvent;

- The extraction solvents were shale oil, kerosene, toluene or similar;

- The alkaloids ("de uit de bladeren opgenomen stoffen") were extracted from the solvent by acid in a stirred reactor; ${ }^{55}$

- The coca leaf was stored in the general store room.

As in 1900, the process was run entirely by hand (i.e. no mechanical power was used).

From the drawings submitted with the application it appears that all extraction vessels, the 6 existing ones and the 9 new ones, were of equal size (3,000 litres). This is a large volume considering that each vessel contained $500 \mathrm{~kg}$ coca leaf and an equal quantity $(500 \mathrm{~kg}=625$ litres) solvent according to the process description. To extract the coca alkaloids from the leaf with a reasonable yield a much larger quantity of solvent than 625 litres in each vessel is required to achieve an acceptable extraction yield. ${ }^{56}$ It is estimated that a minimum of ca 1,500 litres solvent must have been present in each vessel during the extraction. ${ }^{57}$ The conclusion is that NCF had seriously understated the quantity of extraction solvent present in the vessels.

The Amsterdam Department for Public Works ("Publieke Werken", "PW"), responsible for the processing of applications under the Act ("Hinderwet"), obtained advise from the municipal Fire-brigade, the Building Inspection Department and the Department of Labour, and a public hearing was organized. The permit was granted on 25 June 1901. It was stipulated that the conditions of the permit of 28 June 1900 remained in force, and the extra condition that neither open fire nor artificial light should ever be present in the extraction department was added.

In mid 1901 plans were developed for further expansion of the facilities. In August Mr Baanders prepared preliminary drawings for an annex to be built in the courtyard. ${ }^{58}$ This

\footnotetext{
54 Application 1923 PW 1901. In a statement dated 34 April 1901 the Koloniale Bank empowered H.H. Baanders to act as its represenative with respect to the application of the permits and subsequent discussions. In the submission it is mentioned that the existing are $6+2=8$ vessels, which is one more than the 7 vessels included in the process description of 1900.

${ }^{55}$ In the process description the word "zuurstof" (oxygen) is used, this should be "zuur" (acid).

${ }^{56}$ For calculations on solid-liquid extraction, see e.g. W.L. Badger and J.T. Banchero, Introduction to Chemical Engineering, New York (1955) 340-353.

${ }^{57}$ According to the process description the quantity of solvent present in an extraction vessel equates to 1.25 liters per kg coca leaf. This should be considered as very small, even for the adhering quantity. When milled coca leaf, pretreated with an aqueous solution of sodium carbonate, is percolated with kerosene a large amount of solvent is retained after drainage. Experiments by de Jong showed that when $1 \mathrm{~kg}$ coca leaf pretreated with $500 \mathrm{ml}$ of an aqueous solution of sodium carbonate is percolated with 4 liters of kerosene, it retains ca 1.6 liters thereof. A.W.K. de Jong, 'Extractie van Cocablad', Teysmannia 17 (1906) 183.

${ }^{58}$ Gemeentearchief Amsterdam, Initial Drawings 291 BTA 922936 - 938 (1901).
} 
idea was abandoned and replaced by plans for realizing the expansion by constructing a second floor on top of the existing building. ${ }^{59}$ These plans were implemented in 1902.

On 7 October 1901 another Hinderwet application was submitted for approval to place a steam-pump (2HP) in the laboratory, a compressor (2HP) in the boiler-house, and a sink and a condenser in the store room (Figure 6.6). The application was signed by the Koloniale Bank as the director ("de directeur") of the NCF. After advice was obtained from the Fire-brigade and from other municipal departments the permit was granted on 13 December of that year. ${ }^{60}$

Installation of the steam-pumps to reduce the amount of manual labour as moving power and for the creation of the low pressure required for the distillation operations appears timely. The placement of a condenser seems long overdue as solvent recovery from extracted coca leaf can only be achieved satisfactorily by steam distillation, an operation that requires condensation of the generated vapour phase. It is unclear how solvent recovery was achieved before the installation of the condenser.

\footnotetext{
${ }^{59}$ Ibidem, Initial Drawings 291 BTA 922940 - 941.

${ }^{60}$ Application 8337 PW 1901.
} 
Figure 6.9 Plan for the NCF factory as submitted with 340 PW1902

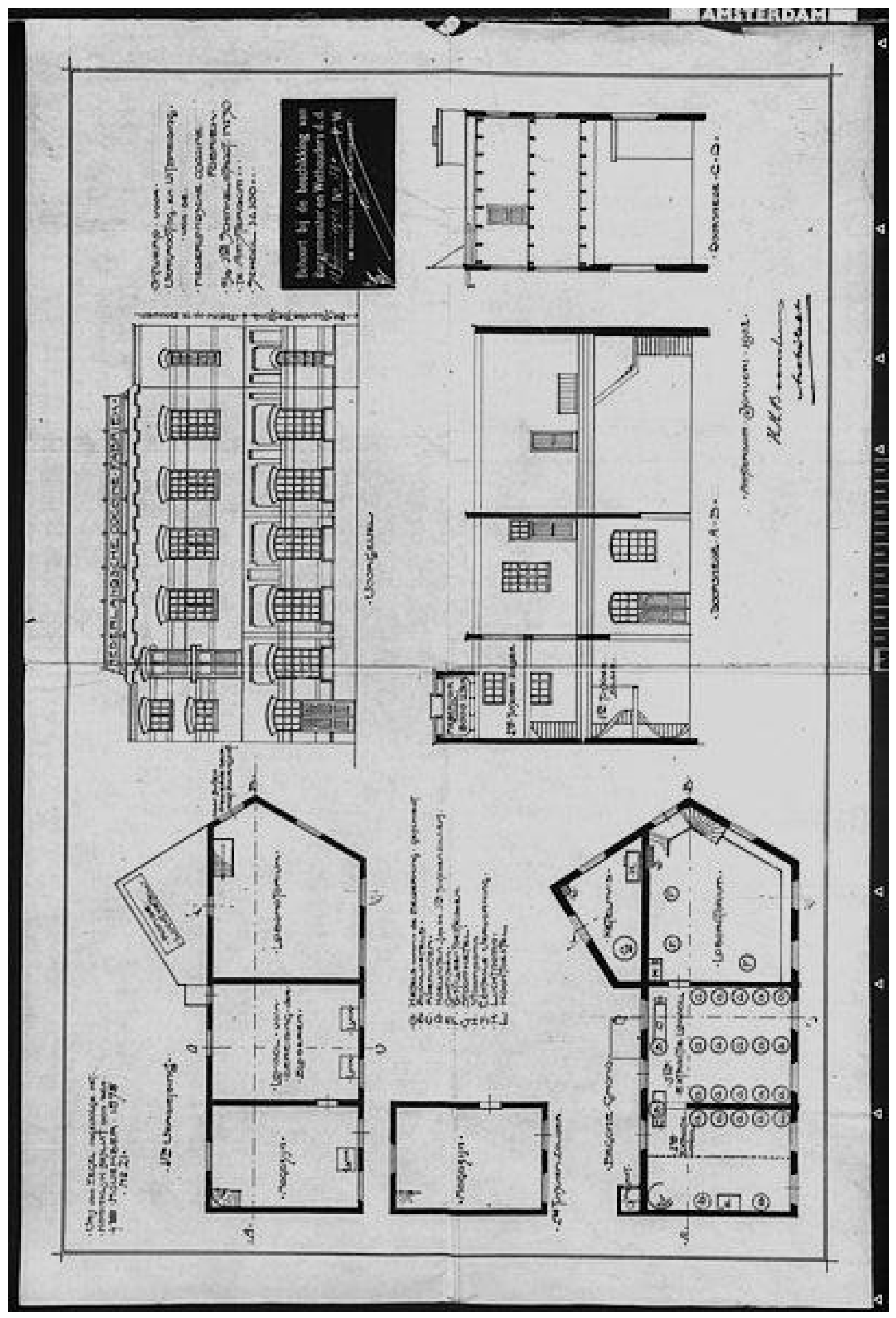




\section{Expansions of the factory of 1902 and 1903}

During the year 1901 the factory was expanded to such an extent that the production of the annual quota of $300 \mathrm{~kg}$ cocaine hydrochloride became possible. However, for the smooth functioning of the factory more space was required and a plan, which included the building of a second floor and an interrelated upgrade of the factory as a whole, was developed. That plan was submitted for approval on January 22, $1902 .{ }^{61}$ The Fire-brigade and the Building Department provided advice which mainly dealt with the fire hazards. It was re-stipulated in the permit issued on March 20 that open fire and artificial light would never be allowed in the extraction department or in the laboratory.

Expansion of the equipment by adding five extraction vessels, a replenishing vessel, a stirred reactor and a condenser was included in the plan. From the floor plan submitted (Figure 6.8) we learn that the new extraction vessels and two condensers (one new) were to be placed in the former store room on the ground floor. The expanded extraction facility consisted of two batteries comprising ten extraction vessels, a replenishing vessel, a stirred reactor and a condenser each. On the second floor the space above the extraction department became the location where the coca leaf was milled and mixed with alkali in preparation for its extraction. There were three covered openings (hatches) in the floor above the extraction department; these were presumably used for feeding the pretreated coca leaf into the extraction vessels. The remainder of the second floor was used for a store room and an expansion of the laboratory. On the plan (Figure 6.8) we note a compressor and a cylindrical tank for compressed air placed in the boiler-house and the space above, and a reservoir of 5,000 litres (presumably for cooling water) in a covered space on the roof of the building.

The number of extraction vessels (20) installed in 1902 appears excessive for a production of $300 \mathrm{~kg}$ cocaine hydrochloride p.a. One vessel contained $500 \mathrm{~kg}$ coca leaf yielding ca $5 \mathrm{~kg}$ cocaine hydrochloride. Hence, an annual production of $300 \mathrm{~kg}$ cocaine hydrochloride required completion of 60 extraction cycles, equating to completion of one cycle every 5 working days. ${ }^{62}$ That should easily have been achievable with one battery of 10 extraction vessels. This ties in with the comment by Dr Kramers in 1907 that several vessels in the factory were empty. ${ }^{63}$

In October 1902 the company Groeneveld Ruempol \& Co, acting on behalf of the NCF, submitted an application for the placement of a gas-engine (13 HP) to power a dynamo (110 $\mathrm{V}, 7.5 \mathrm{KW}$ ) to provide electricity for two electric motors, one of 3.5 PK in the laboratory for powering the existing pulley and belt system and one of $2 \mathrm{PK}$ for operating the mixer for pretreatment of the leaves. ${ }^{64}$ The electrical system was also to be used for lighting (50 bulbs) in the factory. Advice by the Building Inspection Department and the Fire-brigade contained no comment other than that the electrical installation should comply with the safety regulations of the "Koninklijk Instituut van Ingenieurs" dated 7 April 1900. The permit was granted on December 20.

With the expansions of 1902 the factory had reached the stage that production would be sufficient to satisfy the needs under the sales contract with the Cocaine Convention.

No applications under the Hinderwet appear in the municipal archives for the period 19041906. To cope with the need for additional space NCF made arrangements to occupy the

\footnotetext{
${ }^{61}$ Application 340 PW 1902.

${ }^{62}$ In the new NCF factory in Ouder-Amstel (operational in 1910) initially only one extraction battery of 10 vessels was installed which had a capacity of $750 \mathrm{~kg}$ cocaine hydrochloride p.a.; this capacity is equivalent to an extraction cycle of 2 days The vessels installed in the Ouder-Amstel factory were most likely the original vessels from the Amsterdam factory (they were of the same size). The second battery of 10 vessels was installed in the Ouder-Amstel factory in 1915 thereby increasing the capacity to $1,500 \mathrm{~kg}$ p.a.

${ }^{63}$ Report ("Proces-verbaal") on the hearing regarding application 1810 PW 1907 of 2 August 1907).

${ }^{64}$ Application 9427 PW 1902.
} 
ground-floor of the adjacent dwelling $1^{\text {st }}$ Schinkelstraat house-number 26 . The front-room became the office and the [analytical] laboratory was located in the back-room and the kitchen. Access from the factory was through an opening in the wall of the court yard. ${ }^{65}$

\section{Production of cocaine during the period 1901-1909}

Information on the quantities of cocaine manufactured at the factory in Amsterdam is sparse and mainly indirect. From the minutes of an early 1902 Board Meeting we know that profit for 1901 amounted to ca NLG 21,500 before depreciation and that the manufacturing cost of the cocaine $\mathrm{HCl}$ had been ca NLG 100 per kg. ${ }^{66}$ Combining these figures with the average selling price of cocaine $\mathrm{HCl}$ of NLG 382 per kg during 1901, we calculate that during 1901 ca $78 \mathrm{~kg}$ cocaine $\mathrm{HCl}$ was produced and sold. ${ }^{67}$

In the minutes of the Board Meeting of the Koloniale Bank of 21 January 1902 it is mentioned that the debt of the NCF of ca NLG 50,000 would be repaid by the end of the year if the supplies to Gehe would continue at a price of DEM 600 (NLG 360) per $\mathrm{kg}$. This equates to a sales estimate for 1902 of ca $200 \mathrm{~kg}$ cocaine hydrochloride. ${ }^{68}$ For 1903 it was recorded that the factory functioned satisfactorily and that supplies to Gehe continued at a level of $30-35 \mathrm{~kg}$ per month. ${ }^{69}$

No quantitative information is available on the production during 1904-1909 but on the basis of financial data it is estimated that for the total period 1902-1908 the average output of NCF amounted to $320 \mathrm{~kg}$ cocaine hydrochloride p.a. (chapter 18). A new factory was built during 1909 and was operational from the end of that year. No dividend was paid over 1909 and production and sales must have been small, if any.

\section{Safety concerns that ultimately led to the relocation of the factory}

An apparently minor incident, occurring in February 1901, was a complaint lodged at the municipal offices against the presence of the cocaine factory at its location. ${ }^{70}$ It was the first sign that the location chosen in 1900 was not the right one, a fact which would ultimately lead to the compulsory move of the factory to a location at considerable distance from residential areas.

The complaint was submitted by Mr. P Bosma, occupant of the dwelling Schinkelkade 17, adjacent to the factory. The complaint was based on concerns by Mr Bosma and other occupants of dwellings in the neighbourhood, relating to the risks posed by the presence of the factory in a densely populated residential area. Specifically the concerns related to the presence of large amounts ( 24 drums) of kerosene ("petroleum") and five large demijohns stored in the court yard. Mentioned was that sparks originating from a close-by building site had been blown into the court yard. This had caused great concern to the complainant and others in the neighbourhood for their safety. ${ }^{71}$

The complaint was discussed in a meeting of the Municipal Council on 13 March 1901 and it was decided to hold an inquiry. The matter was investigated by the head of the Fire-brigade (Mr. Klein) and the head of the Department of Health (Dr. H.G. Ringeling). In the report by the head of the Fire-brigade it was mentioned that the solvent used was shale oil, and not kerosene. The director of the factory stated that replenishing of the solvent was required only once every 2-3 months and that stocks of solvent were not retained; supplies

\footnotetext{
${ }^{65} \mathrm{NCF}$ is listed as an occupant of the dwelling in the notice of the hearing of 2 August 1907 and the opening in the wall is shown on the plan (Documents Hinderwet application 1810 PW 1907).

Use of the spaces: "De Nederlandsche Cocaine Fabriek NV", Pharm. Weekblad (1939) 798.

${ }^{66}$ Koloniale Bank, Minutes of Board Meetings, Meeting of 21 January 1902.

${ }^{67}$ For cocaine prices see Part III, Source Data, Table COC 5. The calculation: 21,500 / $(382-100)=78$.

${ }^{68}$ Calculation: 50,000 / (360-100) $=192$.

${ }^{69}$ Koloniale Bank, Minutes of Board Meetings, Meeting of 14 August 1903.

${ }^{70}$ Gemeentearchief Amsterdam, File 1484 PW 1901.

${ }^{71}$ Ibidem.
} 
were immediately pumped into the [extraction] vessels upon arrival. It is from the report by the head of the Department of Health that we learn that the coca leaves were crushed prior to extraction and that the extraction solvent was a mixture of shale oil and kerosene. ${ }^{72}$

It was disclosed that the alkaloids were extracted from the solvent with sulfuric acid and converted into ecgonine during which process step acidic-aromatic vapours of benzoic acid were generated. Reportedly, the only waste product of the factory was extracted coca leaf mixed with chopped straw ("no unpleasant smell was detectable") which was collected in the court yard from where it was removed by a municipal service.

From the reports, Mayor and Aldermen of Amsterdam concluded that the NCF did not constitute an undue safety risk; the parties involved were advised accordingly on May 9, $1901 .^{73}$

However, over time the municipal authorities, and specifically the fire-brigade, became more concerned and foreshadowed in 1906 that, because of the large amounts of inflammable solvents present in the factory, longer term relocation of the factory to a place outside of the build-up area would be required. ${ }^{74}$ As a result Dr Eberhard explored the possibility of replacing benzene as the extraction solvent with a nonflammable solvent but without success. ${ }^{75}$ This is the first time that benzene is mentioned as the extraction solvent at NCF. The use of benzene was allowed because benzene fell under the description of extraction solvents: "kerosene, shale oil, toluene and similar" appearing in the NCF application of April 1901. Benzene is a much better extraction solvent for coca alkaloids than kerosene; it was also used by Merck for that purpose.

The quantities of ethanol and ether allowed to be held in the factory under the permit of 28 June 1900 turned out to be insufficient for production at the 1907 level and in January 1907 NCF requested the municipality to approve an increase of these quantities from 45 to 115 litres for ether and for 90 to 110 litres of ethanol. ${ }^{76}$ This request was declined and NCF submitted on March 25 a second application, providing more details and an up-to-date floorplan. ${ }^{77}$ The chief of the Fire-brigade (Mr. Klein) stated in his advice of May 10, 1907, that from 1900 to 1907 the number of extraction vessels (when in use containing 500 litres solvent each) had increased from 7 to 21 , whereby the total amount of extraction solvent present in the factory had very considerably increased. The possible use of benzene as the solvent under the existing permit was mentioned in his advice. His greatest objection, however, was against the fourfold increase of the quantities of ethanol and ether that would be allowed to be present in the factory if the request was granted. He concluded that the safety considerations demanded that the request of the NCF be declined.

The advice of the Building Inspection Department to the Department of Public Works largely followed the advice of the Fire-brigade but it was recommended to continue the procedure with a hearing. The reason was that a formal rejection of the request after the hearing would bring the matter to its final conclusion. The NCF had in the discussions with Mr. Klein agreed that relocation of the factory was the only solution and the company would not appeal the decision.

\footnotetext{
${ }^{72}$ Ibidem.

${ }^{73}$ Ibidem.

${ }^{74}$ Koloniale Bank, Minutes of Board Meetings, Meeting of 18 September 1906.

${ }^{75}$ Ibidem, Meetings of 20 November and 18 December 1906.

${ }^{76}$ Application 129 PW 1907.

77 Application 1810 PW 1907. From the factory plan submitted with the second "Hinderwet" application of 1907 we learn that quite a few new pieces of equipment were installed since the 1902 application. We note a steam engine, a second tank for compressed air, several additional (stirred) reactors, vacuum distillation equipment and stills.
} 
The hearing was organized for August 2, 1907; present were Dr Kramers for the NCF and the Alderman ("Wethouder") for Public Works for the Municipality. ${ }^{78}$ Dr. Kramers argued that NCF was in a difficult position because the company had a contractual obligation to process all output from a coca leaf producer until 1910, and that the continually declining cocaine prices meant that work on a large scale was the only way to make a profit. Therefore he urged that a permit for the larger quantities of ethanol and ether be granted valid at least until 1910 . The Alderman replied that prior to entering the contract NCF should have made certain that they would be able to fulfill their obligations. In support of his case Dr Kramers mentioned that several vessels in the factory were empty and that the increase in the quantities of ethanol and ether was 1\%-2\% only. He explained that ether and ethanol were used for the crystallization in the cocaine [hydrochloride], the product being precipitated by ether. It was also difficult for him to predict exactly where the distillation [of the mother liquors containing the ethanol and ether] would take place. The Alderman replied that if the process could be specified more rigidly, an alternative solution might be considered.

On 14 November Mr. Klein issued a further advice to the Building Inspection Department in which he disclosed details of his earlier discussions with the NCF. He had suggested that the company start immediately with building of a new factory to try to avoid disruption of the production. The NCF had initially agreed but a director of the Koloniale Bank, residing in the Dutch East Indies, had put the plans on hold because he believed that approval [for holding increased amounts of solvents] would ultimately be given. However another director of the Koloniale Bank, residing in the Netherlands declared that it was fully appreciated that upon refusal of the application relocation was unavoidable. The decision would be taken within the next six months. ${ }^{79}$

The final decision by Mayor and Aldermen of Amsterdam dated 16 December 1907 was not to approve the requested increase of the quantities ethanol and ether allowed to be present in the factory.

\footnotetext{
${ }^{78}$ Dr Kramers appeared at the meeting as the Technical Director of the NCF.

${ }^{79}$ Letter Mr Klein to the Municipal Building Inspector No. 2819 Br, dated 14 November 1907.
} 
Figure 6.10 Location of the new NCF factory at the "Groot Duivendrechter Polder" in the municipality of Ouder-Amstel

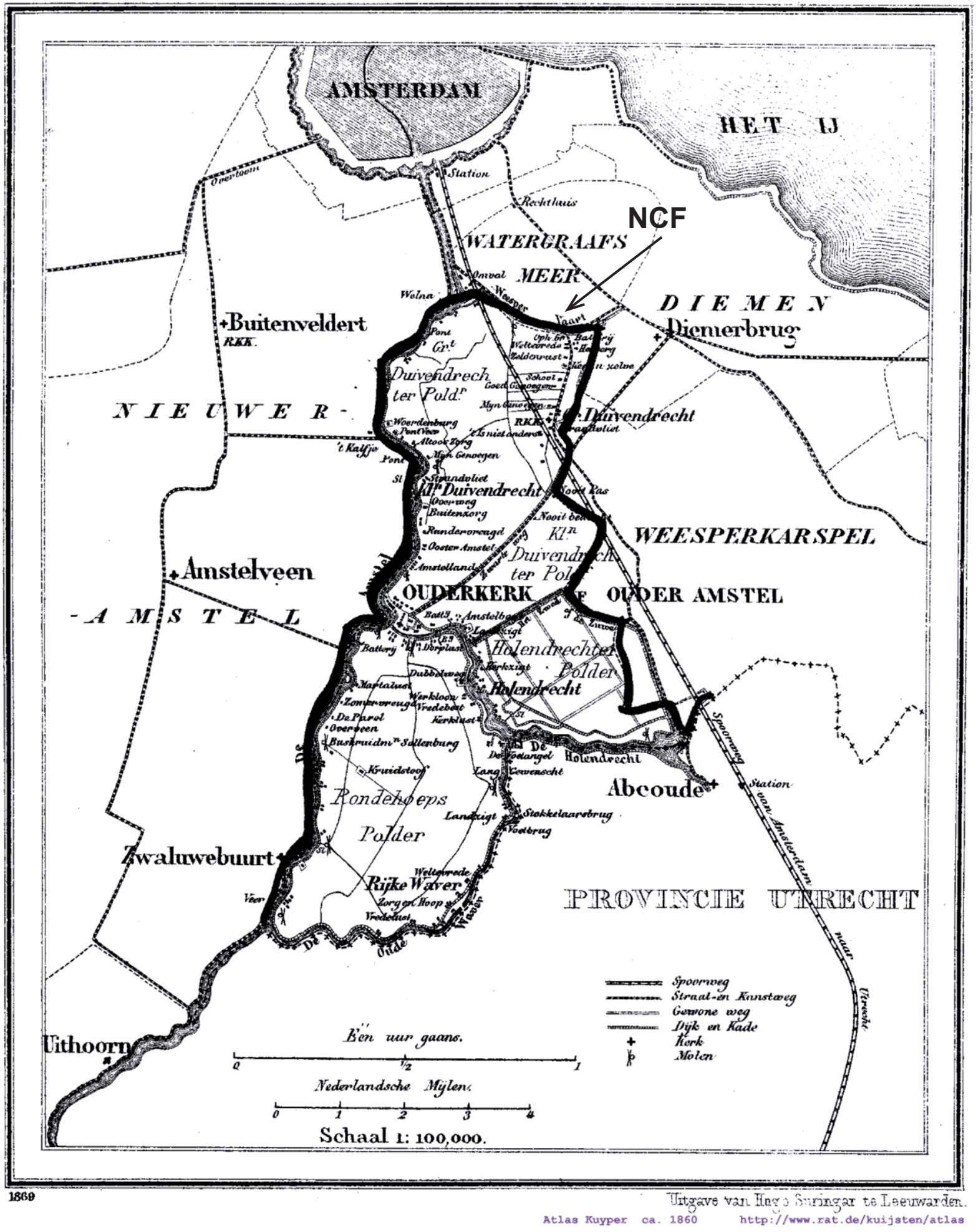

Source: J. Kuyper, Gemeente Atlas van Nederland (1865-1870) 


\title{
6.4 Building and Operating the New Factory at Ouder Amstel 1910-1914
}

\author{
Application for a 'Building Permit and Operating License' \\ (Hinderwetvergunning) for the new factory
}

During 1907-1908 plans for the construction of a new factory outside the municipality of Amsterdam were drawn up. A suitable site was found in the polder "Groot Duivendrecht", a farming area in the municipality of Ouder-Amstel ca $5 \mathrm{~km}$ South-East of Amsterdam. It was a plot abut on the Weespervaart, a major canal bordering the North side of the polder (Figure 6.8). The plot was remote from residential areas, and only a few small dwellings existed on adjacent lots. There was easy access to water for cooling and fire-fighting purposes and the plot was sufficiently large $\left(\mathrm{ca} 4,000 \mathrm{~m}^{2}\right.$ ) allowing for future expansion (Figure 6.9). NCF directors made enquiries with the Mayor of Ouder-Amstel and learned that the municipality would be willing to issue a 'Building Permit and Operating License' ("Hinderwetvergunning") for a factory at the selected location. Also the head of the firebrigade of Amsterdam had no objection; this was important because it was known that plans existed to annex the area involved to the municipality of Amsterdam in the not too distant future. $^{80}$

Dr Kramers was the driving force behind the plans; he was assisted with the engineering aspects by the chief engineer of the NCF, Hans Brunner, and for the design of the buildings by the architect J.P. van Rossum. ${ }^{81}$

On 4 September 1908 an application was submitted to the authorities of the municipality of Ouder-Amstel requesting a permit for building the facilities and operating the factory. ${ }^{82}$ The plans were based on the eventual installation of two extraction batteries with a design capacity of $750 \mathrm{~kg}$ cocaine hydrochloride p.a. each; the first phase of the realization was to install one extraction battery; the second battery was to be built later depending on sales prospects. $^{83}$

\footnotetext{
${ }^{80}$ Ibidem.

${ }^{81}$ Hans Brunner and Kramers worked closely together until Kramers' retirement in 1946 (oral history as told to HHB in 1960). In the early 1960s Brunner was still living in the dwelling close to the factory entrance.

${ }^{82}$ All documents related to the application and the approval process are contained in the Files Municipality Ouder-Amstel, Hinderwetvergunningen ('Building Permits and Operating Licenses'), Stadsarchief Amsterdam, Access No.5500, Item 690, file 619.

${ }^{83}$ In the description ('beschrijving') of the manufacturing process as submitted by the NCF it is not stated explicitly that it was the intention to realize the project in two stages. The production (design) capacity of 750 $\mathrm{kg}$ cocaine hydrochloride p.a. for one extraction battery is not specifically mentioned. The $750 \mathrm{~kg}$ follows from the capacity of $1,500 \mathrm{~kg}$ cocaine $\mathrm{HCl}$ (for two extraction batteries) mentioned for the NCF in a report by Van Walree c.s. to the Ministers for Foreign Affairs and for Labour, Trade and Industry of the Netherlands of 9 December 1930 (Nationaal Archief, The Hague, Access Number 2.05.21, Item 1468). A capacity of $750 \mathrm{~kg}$ cocaine $\mathrm{HCl}$ p.a. corresponds with a capacity of loading $250 \mathrm{~kg}$ Java coca leaf (one extraction vessel) per day, a yield of $1 \%$ i.e. $2.5 \mathrm{~kg}$ cocaine $\mathrm{HCl}$ per day, and 300 extraction days (50 weeks of 6 days) per annum [HHB].
} 


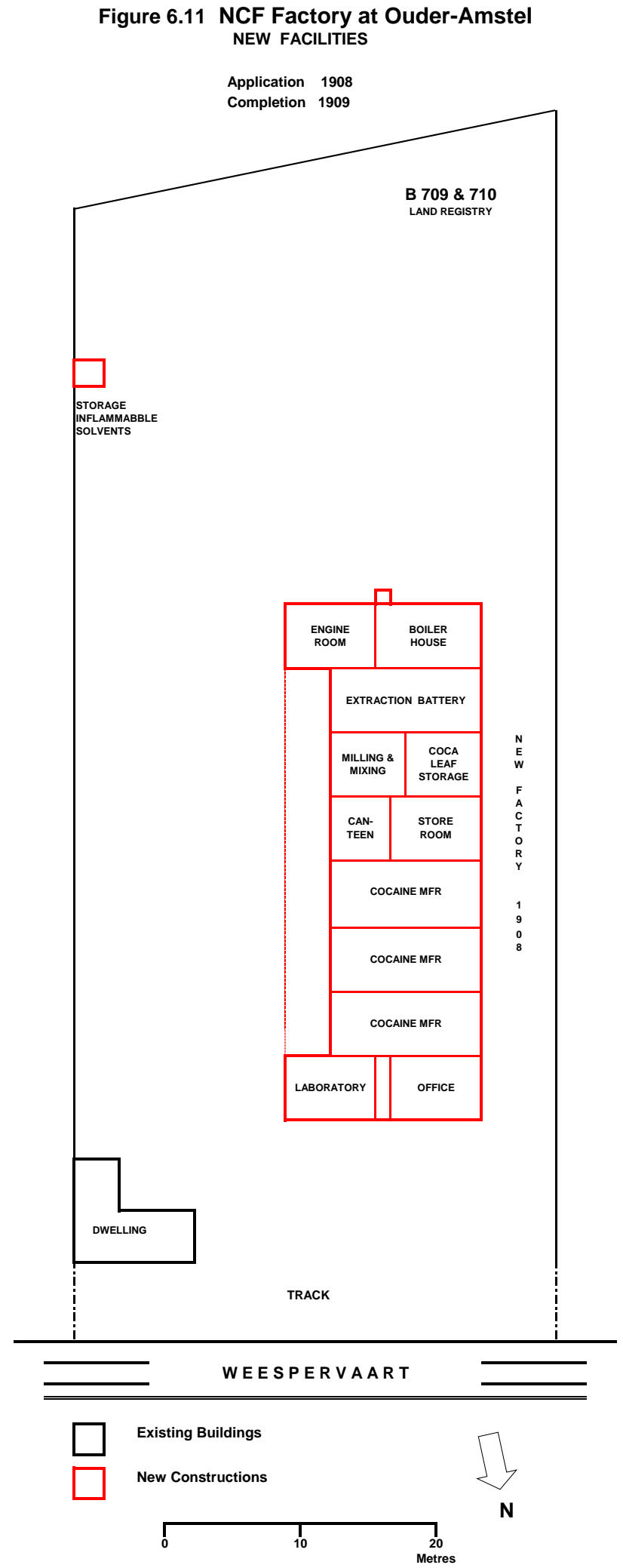

Drawing HHB. Based on plans submitted by NCF on 4 September 1908 to obtain a 'Building Permit and Operating License' ("Hinderwetvergunning”). Files Municipality of Ouder-Amstel, Stadsarchief Amsterdam, Access No 5500, Item 680, file 619 (1908). 
The process description as submitted mentioned the two extraction batteries, each consisting of ten vertical cylindrical vessels (capacity: $500 \mathrm{~kg}$ solvent each) connected with pipes. The blue-prints for the buildings as submitted showed, however, space for one extraction battery only; this was stage one of the plan. The process description submitted with the application mentioned $10,000 \mathrm{~kg}$ extraction solvent (kerosene, benzene or toluene), $500 \mathrm{~kg}$ ethanol and $250 \mathrm{~kg}$ ether as the maximum quantities that would be present in the factory at any time. An additional maximum quantity of 1,000 kg extraction solvent, $250 \mathrm{~kg}$ ethanol and $250 \mathrm{~kg}$ ether could be present in a specially constructed storage shed. These quantities would be sufficient to operate two extraction batteries simultaneously and reflected the situation after completion of stage two of the plan. ${ }^{84}$

It was also mentioned in the description that with exception of the boiler-house no open fire would be used anywhere in the factory. Heating of all process equipment would be achieved exclusively by means of steam and all lighting would be electrical. A steam-engine would provide mechanical power which was to be transmitted to the various laboratories via a system of shafts and pulleys attached to the outside of the buildings.

The municipal authorities obtained written advice from the Departments of Labour and of Health, and organized a public hearing for 18 October 1908 at which interested parties could ask questions and oppose the granting of a permit. Dr Kramers and Mr. van Rossum represented the Koloniale Bank (Director of the NCF) at the hearing. Appearing at the hearing were Mr. E van Zadelhoff, president of the polder-board, who emphasized that according to polder regulations no buildings should be constructed within 200 meters from the (drainage)mill and that no factory effluent should be discharged into the secondary canals ('sloten') of the polder. Messrs F.C. and H. H. Mus, owners and occupants of dwellings on adjacent plots, commented that the danger of explosion presented by the factory was lifethreatening and that effluent from the factory that would be discharged in the main canal (the Weespervaart) posed a problem because cattle depended on that water for drinking in winter. They had made enquiries in Amsterdam and had heard that NCF was discharging very dirty water in the Schinkel (canal). They objected on the grounds that local market-gardeners were rinsing vegetables in the canal and that contamination of the canal water would pose a health risk.

\footnotetext{
${ }^{84}$ Files Municipality Ouder-Amstel, Hinderwetvergunningen ('Building Permits and Operating Licenses'), Stadsarchief Amsterdam, Access No.5500, Item 690, file 619.
} 
Figure 6.12 NCF - Floor plan and elevation of the factory building (1908)

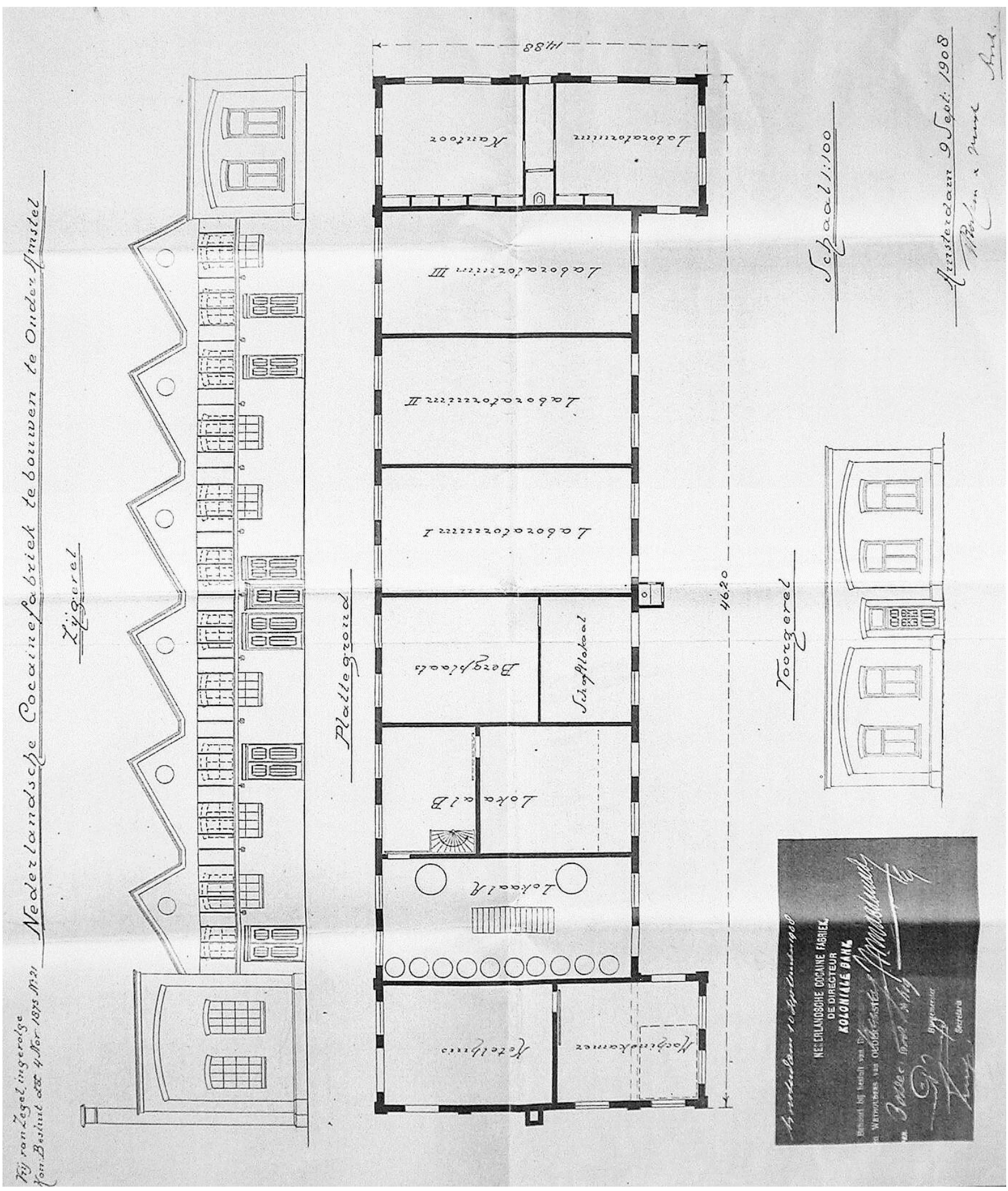

Source: Application dated 4 September 1908 to obtain a 'Building Permit and Operating License' ("Hinderwetvergunning"). Files Municipality of Ouder-Amstel, Stadsarchief Amsterdam, Access No 5500, Item 680 , file $691(1908)$ 
Mr. Vrolijk, cattle breeder and owner of adjacent pastures, was afraid of unspecified perils which could be the result if such dangerous a factory were built. Dr Kramers and Mr. van Rossum replied to the various questions. Dr Kramers stressed that the solvents to be used in the factory were inflammable and posed a fire-hazard but that they did not explode. ${ }^{85}$

During the month of November 1908 written declarations of no objection against the establishment of the factory were obtained from the occupants of two nearby dwellings and from Dr G. Hondius Bolding, owner of an adjoining plot. Mayor and Aldermen of OuderAmstel signed the permit for establishing the factory on 30 December 1908. The permit was granted subject to adherence to a set of twelve conditions, ten of which pertained to safety and public health issues. The quantities of ethanol and ether in storage were subject to limitations and the fire-fighting equipment that had to be present on site was specified. Discharge of effluent was restricted to the Weespervaart and was allowed only after dilution with cooling-water, and not near places where vegetables are rinsed. The facilities had to be built and commissioned before 1 September $1909 .{ }^{86}$

\section{Lay-out of the factory}

The floor-plan of the factory (Figure 6.12) showed six serried production spaces of ca $12 \times 6$ metres each with saw-tooth roofs, flanked by an office and laboratory at the canal-end and by a boiler-house with chimney and an engine-room at the other. The buildings were ca 7.50 meteres high, the glass in the saw-teeth facing directly north thereby excluding direct sunlight. The first of the production spaces ("Lokaal A") contained the extraction battery and the stirred tanks for extracting the alkaloids into aqueous acid. The next space ("Lokaal B") was for processing the coca leaf prior to extraction; these first two spaces contained mezzanine floors made of wooden slats allowing for working at two levels. ${ }^{87}$

In extraction space A, a mezzanine floor was required for the operators to walk on when opening or closing the valves to control the flow of the extraction solvent through the battery. In space B equipment was installed for milling the coca leaves and mixing the ground product with (weak) aqueous alkali as a pretreatment for the extraction. The third space, the space next to B, contained a solid mezzanine floor and was used for coca leaf storage; it included a canteen ("Schaftlokaal"). The following three spaces were indicated on the construction drawings as laboratories ("Laboratoriums") and were intended for processing the acid alkaloid extract via a series of chemical reactions and purification steps into pure cocaine hydrochloride.

The laboratory in the building at the front was presumably for quality control and for research work. It was located next to the office ("Kantoor"). The photographs reproduced as Figures 6.14 and 6.15 show the façade of the factory as seen from the canal and a view of extraction space A and its mezzanine floor.

\footnotetext{
${ }^{85}$ Ibidem.

${ }^{86}$ Ibidem.

${ }^{87}$ The mezzanine floors do not appear in Figure 6.10, they are included in another drawing.
} 
Figure 6.13 NCF Factory at Ouder-Amstel FIRST EXPANSION

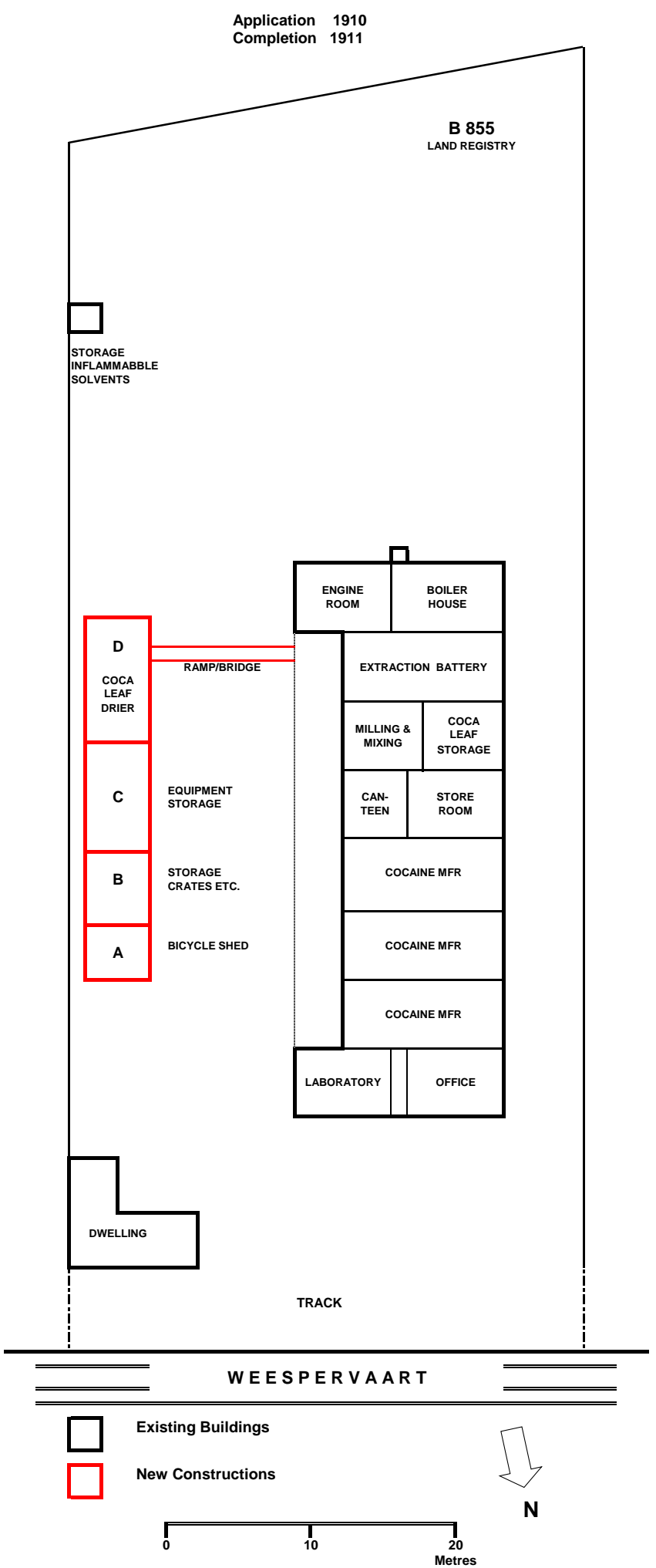

Drawing HHB. Based on plans submitted by NCF on 29 Decmber 1910 to obtain a 'Building Permit and Operating License' ("Hinderwetvergunning”). Files Municipality of Ouder-Amstel, Stadsarchief Amsterdam, Access No 5500, Item 82 (1911). 
The process as described in the application.

The process used by NCF for making cocaine hydrochloride from Java coca was described in the application for the license as follows: The coca leaf was treated in the extraction vessels with the solvent (kerosene, benzene or toluene) and in due time the liquid was transferred into a tank where it is stirred with dilute aqueous acid whereby the crude alkaloid passed into the aqueous phase. This crude aqueous alkaloid extract was treated further in the various laboratories [processing spaces] by means of boiling, extracting, neutralizing, filtering and concentrating solutions by evaporating under reduced pressure. The obtained product [crude cocaine base] had to be purified. That was done by extracting it with ethanol in filter-pots made of porcelain. The residual cocaine is dissolved in ether and the solution was thereafter filtered and subjected to a distillation process whereby the purified cocaine was isolated. To manufacture cocaine hydrochloride the purified base was neutralized with hydrochloric acid and the resulting product wss re-crystallized from ether in porcelain pots provided with lids. Ethanol and ether were recovered as much as possible from the mother-liquors by means of distillation. $^{88}$

The process description as submitted by NCF did not provide many details. Essential process steps not described are: the alkalinization of the coca leaf prior to extraction and the conversion of the secondary alkaloids (cinnamoylcocaine etc.) into cocaine. By not disclosing its process in more detail than required by the authorities NCF protected the secrecy of is processes and retained some flexibility with respect to possible future process changes.

\section{Expansion of the factory in 1910}

Already at the end of $1910 \mathrm{NCF}$ submitted were granted approval for an expansion of the production facilities to the municipality of Ouder-Amstel. This expansion comprised a series of connected workspaces, covering in total $30.00 \mathrm{~m} \times 4.50 \mathrm{~m}$ floor space, situated opposite the factory built in 1909 (Figure 6.13). The largest of the new workspaces was 5.50 meters high and accommodated a steam-heated rotary drier for coca leaf on the lower floor (D). The coca leaf to be dried was transported via a bridge-like ramp to the floor above the drier and from there it was fed to the drier through a funnel.

The reason for investing in the drier will have been that the alkaloids in not well dried coca leaf decompose over time resulting in lower cocaine yields. ${ }^{89}$ Drying the coca leaf shortly after arrival at the factory and storing them under proper conditions must have been an economic consideration.

The other three new workspaces were 3.00 meters high and were intended for use as a bicycle-shed (A), a store for crates etc. (B) and storage accommodation for equipment not in use and for coca leaf (The permit was granted on 10 February 1911 without additional conditions but with the stipulation the installation had to be completed by 1 July $1911 .{ }^{90}$

\footnotetext{
${ }^{88}$ Ibidem.

${ }^{89}$ A.W.K. de Jong, Chapter 'Coca' in: H.C. Prinsen Geerligs, editor, K.W. Van Gorkom's Oost-Indische Cultures $2^{\text {nd }}$ Ed [3] (Amsterdam 1919) 292.

90 Files Municipality of Ouder-Amstel, Stadsarchief Amsterdam, Access No 5500, Item 82 (1911).
} 
Figure 6.14 The New Factory of the NCF at the Weespervaart, Ouder-Amstel, in 1909.

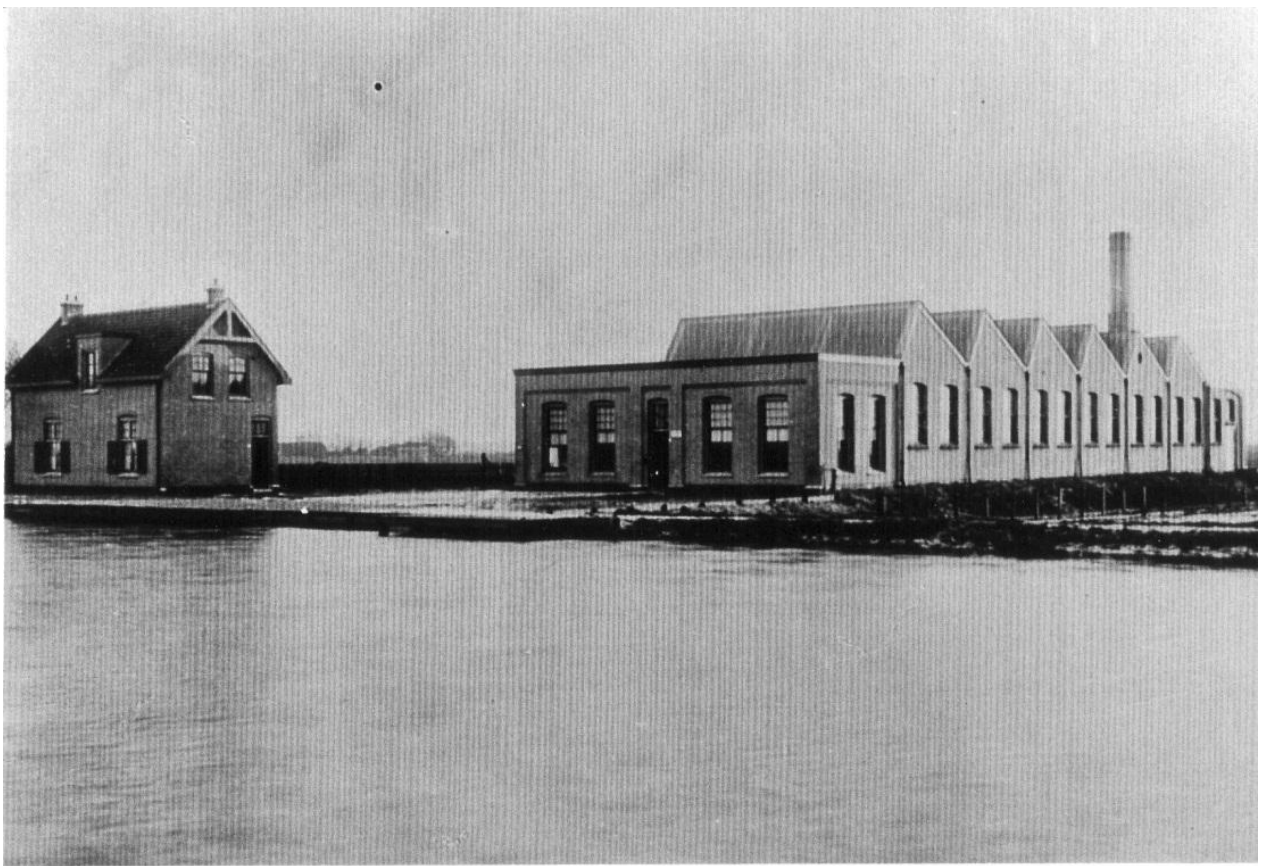

Figure 6.15 Extraction Battery for processing coca leaf at the NCF (undated).

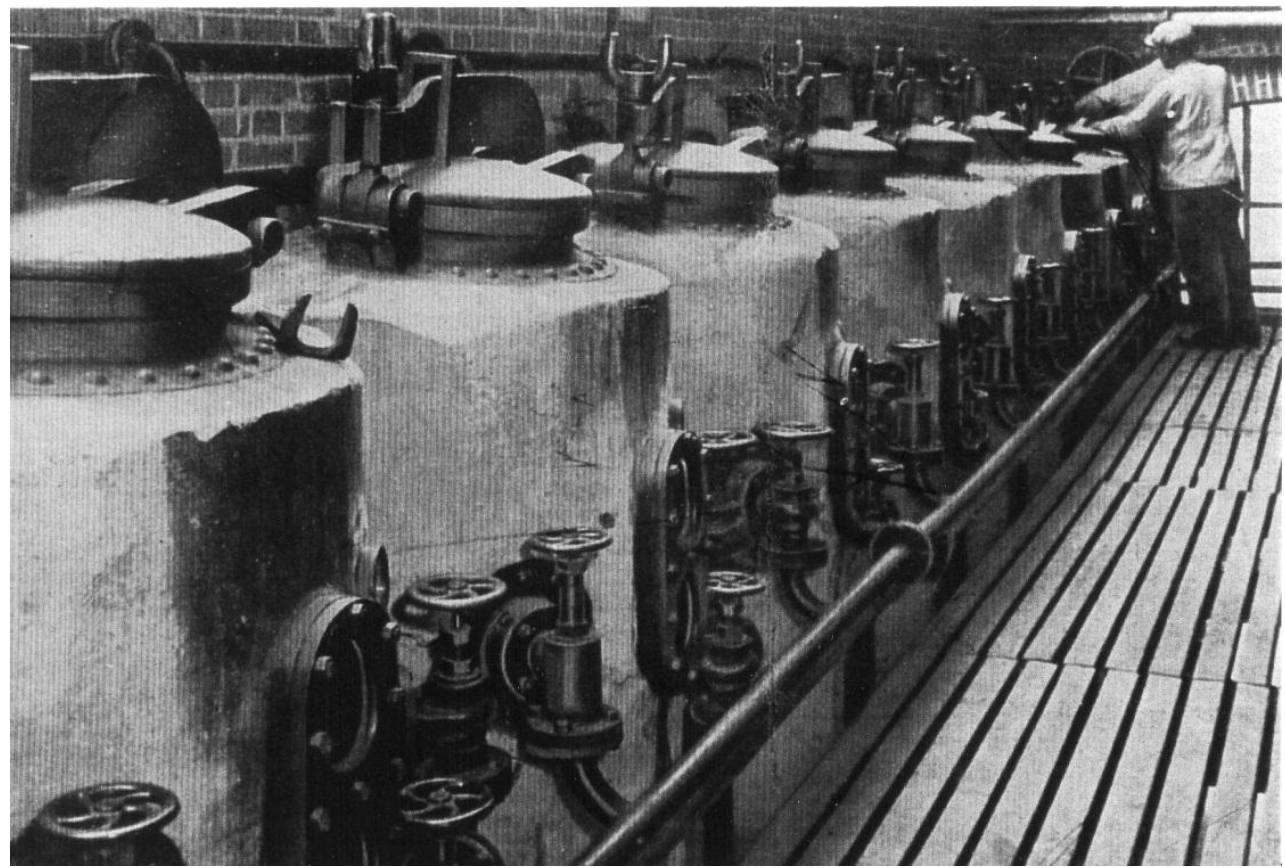

Photo's Archive Akzo Pharma, Oss (the Netherlands) 
Production of cocaine during the period 1910-1914.

Direct information on the quantities of cocaine manufactured at the new factory at Ouder Amstel is virtually non existent for the period 1910-1914. In the minutes of the Board Meetings of the Koloniale Bank over the period the NCF is hardly mentioned. The new factory had a design capacity of $750 \mathrm{~kg}$ cocaine $\mathrm{HCl}$ per annum and the estimates in chapter 18 of the actual sales and production during the period result in an estimate of an average output of approximately $500 \mathrm{~kg}$ p.a.

As a result of an incorrect interpretation (1989) of a publication of 1925 on the importance of the position of the NCF in the world market in 1910, the erroneous statement that "around $1910[\mathrm{NCF}]$ was in a position to call itself the largest cocaine factory in the world" has been repeated many times. ${ }^{91}$

\subsection{Financial Results}

The NCF was successful from the beginning. In the year 1900 the first batches of cocaine hydrochloride of good quality were made but the amount produced was insufficient to evaluate the economic performance of the factory. ${ }^{92} 1901$ was the first year of production on a commercial scale and the preliminary profit \& loss account showed a profit of NLG 16,000 after a write-off of ca NLG 5,500, representing the price paid for the process and start-up costs. ${ }^{93}$ However, total profit was apparently retained and no dividend was paid over the year.

Dividend payments commenced with the year 1902. A table of dividends paid to shareholders as a percentage of the nominal share capital over the period 1902-1944 is contained in a report by the Koloniale Bank on the NCF ${ }^{94}$ From that input the amounts paid as dividends have been calculated by the author (Part III, Source Data, Table FIN 1).

The Articles of Association of the NCF specified that $75 \%$ of the net profit should be paid as dividend to shareholders and $25 \%$ to the holders of the profit-sharing notes (Boldemann and Eberhard). ${ }^{95}$ An amendment of 1905 of the Articles of Association provided for the establishment of a Special Reserve for possible future losses by putting aside $15 \%$ of

\footnotetext{
${ }^{91}$ It is stated in a newspaper article of 1989 that "around $1910[\mathrm{NCF}]$ was in a position to call itself the largest cocaine factory in the world" (translation HHB); D. Korf and M. de Kort, "NV De Witte Waan. De geschiedenis van de Nederlandsche Cocaïnefabriek' NRC Handelsblad (Newspaper) (1989) May 13. Around 1910 NCF produced in the order of $500 \mathrm{~kg}$ annually (Chapter 18) and because Merck produced 5,241 $\mathrm{kg}$ in that year it is obvious that the statement cannot be correct. The statement reappeared in de Kort's dissertation of 1995; M. de Kort, Tussen patiënt en delinquent, geschiedenis van het Nederlandse drugsbeleid. (Between patient and delinquent, the history of drug policy in the Netherlands); Dissertation University of Erasmus, Rotterdam (Hilversum 1995) 60-61 referring to Pharmaceutisch Weekblad 62 (1925) 269 as the source.

However, the year 1910 is not mentioned at all in that article in the Pharmaceutisch Weekblad of 1925. In the article it is stated that: "Despite great foreign competition, it [the NCF] has succeeded in gaining a premier position in the world market with its products." Translation: M. de Kort, 'Doctors, diplomats and businessmen. Conflicting interests in the Netherlands and Dutch East Indies', Chapter 6 in: P. Gootenberg, editor, Cocaine: Global Histories, (London 1999) 133.

Similar statements on NCF's dominant position in the world market around 1910 have appeared in various other publications e.g. P. Gootenberg, 'Introduction. Cocaine: the hidden histories'. Chapter 1 in: P. Gootenberg, editor, Cocaine: Global Histories (London 1999) 11; D.J. Korf and M. de Kort, Drugshandel en

Drugsbestrijding (Amsterdam 1990); S.B. Karch, 'Japan and the cocaine industry of Southeast Asia, 18641944' Chapter 7 in: P. Gootenberg, editor, Cocaine: Global Histories (London 1999) 146-161; Corrie Verkerk, 'Toen cocaine nog een gewoon geneesmiddel was' Het Parool (Newspaper) (1994) March 12 (Interview with M. de Kort).

${ }^{92}$ Koloniale Bank, Minutes of Board Meetings, Meeting of 19 February 1901.

${ }^{93}$ Koloniale Bank, Minutes of Board Meetings, Meeting of 21 January 1902.

${ }^{94}$ Koloniale Bank, Rapport inzake N.V. Nederlandsche Cocainefabriek (Report on the NCF) (1945), Nationaal Archief, The Hague, Access No. 2.20.04 Item 928.

95 'Naamlooze Vennootschap; Nederlandsche Cocaine-fabriek' (No 222)

Nederlandsche Staatscourant (1900) June 1.
} 
the profit before the remainder was distributed in the 3:1 ratio to shareholders and holders of the profit-sharing notes respectively. ${ }^{96}$ On that basis 'Net Profit for Distribution' was calculated by the author from dividend paid to shareholders. The results are presented with the following table:

Table 6.2 NCF Net Profit and its Distribution 1900-1909 (NLG)

\begin{tabular}{|c|rrrrr|}
\hline Year & $\begin{array}{c}\text { Net Profit } \\
\text { for } \\
\text { Distribution }\end{array}$ & $\begin{array}{c}\text { Dividend } \\
\text { to } \\
\text { Shareholders }\end{array}$ & $\begin{array}{c}\text { to Holders } \\
\text { of Profit- } \\
\text { Sharing Notes }\end{array}$ & $\begin{array}{c}\text { to } \\
\text { Special } \\
\text { Reserve }\end{array}$ & $\begin{array}{c}\text { Special } \\
\text { Reserve } \\
\text { (accumulated) }\end{array}$ \\
\hline & & & & & \\
1900 & 0 & 0 & 0 & & \\
1901 & 0 & 0 & 0 & & \\
1902 & 32,000 & 24,000 & 8,000 & & \\
1903 & 48,000 & 36,000 & 12,000 & & \\
1904 & 57,600 & 43,200 & 14,400 & & \\
1905 & 42,353 & 27,000 & 9,000 & 6,353 & 10,353 \\
1906 & 15,059 & 9,600 & 3,200 & 2,259 & 14,118 \\
1907 & 10,353 & 6,600 & 2,200 & 1,553 & 14,118 \\
1908 & 26,353 & 16,800 & 5,600 & 3,953 & \\
1909 & 0 & 0 & 0 & 0 & \\
& & & & & \\
\hline
\end{tabular}

Source: Dividend to Shareholders, Table FIN 1(Part III)

Other amounts - calculated as described in the text above

Over 1909 no dividend was paid to shareholders. In 1910 the nominal share capital of the NCF was increased from NLG 12,000 to NLG 32,400 (36 shares of NLG 900 each) by transfer of funds from the Special Reserve. ${ }^{97}$ Van Hengst became the holder of 20 of the new shares and the Koloniale bank of $10 .{ }^{98}$ Pursuant to the Articles of Association, the profitsharing notes were converted into common shares and Boldemann and Eberhard received 3 new shares each. ${ }^{99}$

Simultaneously the distribution of net profit was changed once more. From 1910, net profit permitting, shareholders would receive annually an amount NLG 1,944, representing $6 \%$ of the nominal capital of NLG 32,400. Of the remainder, $15 \%$ was put into the Special Reserve and the rest was paid as dividend to shareholders and as bonuses to Directors and Board members in the ratio 9:1. ${ }^{100}$ The profit distribution for the period 1910 to 1914 as appearing in the following table has been calculated by the author on that basis.

\footnotetext{
${ }^{96}$ NCF, Bijvoegsel No 338, Nederlandsche Staatscourant (1906) June 19.

${ }^{97}$ NCF, Bijvoegsel No 110, Nederlandsche Staatscourant (1911) January 21.

${ }^{98}$ Koloniale Bank, Report on the NCF (1945).

${ }^{99}$ Boldemann and Eberhard were to receive each a number of shares equal to one tenth of the share capital against payment of NGL 5,000 (the maximum). NCF, Nederlandsche Staatscourant 222 (1900) June 1. Three new shares at NLG 900 were less in value than the 3.6 shares (10\%) representing their entitlement and presumably they paid proportionally less (NLG 4,167 each) for the 3 shares received. It is likely that these payments were used by the Company to bring the Special Reserve up to of NLG 20,400, the required level for the recapitalization.

${ }^{100}$ NCF, Bijvoegsel No 110, Nederlandsche Staatscourant (1911) January 21.
} 
Table 6.3 NCF Net Profit and its Distribution 1910-1914 (NLG)

\begin{tabular}{|c|rrrrr|}
\hline Year & $\begin{array}{c}\text { Net Profit } \\
\text { for } \\
\text { Distribution }\end{array}$ & $\begin{array}{c}\text { Dividend } \\
\text { to } \\
\text { Shareholders }\end{array}$ & $\begin{array}{c}\text { Bonuses } \\
\text { to } \\
\text { Directors }\end{array}$ & $\begin{array}{c}\text { to } \\
\text { Special } \\
\text { Reserve }\end{array}$ & $\begin{array}{c}\text { Special } \\
\text { Reserve } \\
\text { (accumulated) }\end{array}$ \\
\hline & & & & & \\
1910 & 20,922 & 16,200 & 1,584 & 3,138 & 3,138 \\
1911 & 31,511 & 24,300 & 2,484 & 4,727 & 7,865 \\
1912 & 14,993 & 11,664 & 1,080 & 2,249 & 10,114 \\
1913 & 0 & 0 & 0 & 0 & 10,114 \\
1914 & 8,216 & 6,480 & 504 & 1,232 & 11,346 \\
& & & & & \\
\hline
\end{tabular}

Source: Dividend to Shareholders, Table FIN 1(Part III)

Other amounts - calculated as described in the text above

Figure 6.16 NCF Net Profit and its Distribution 1902-1914

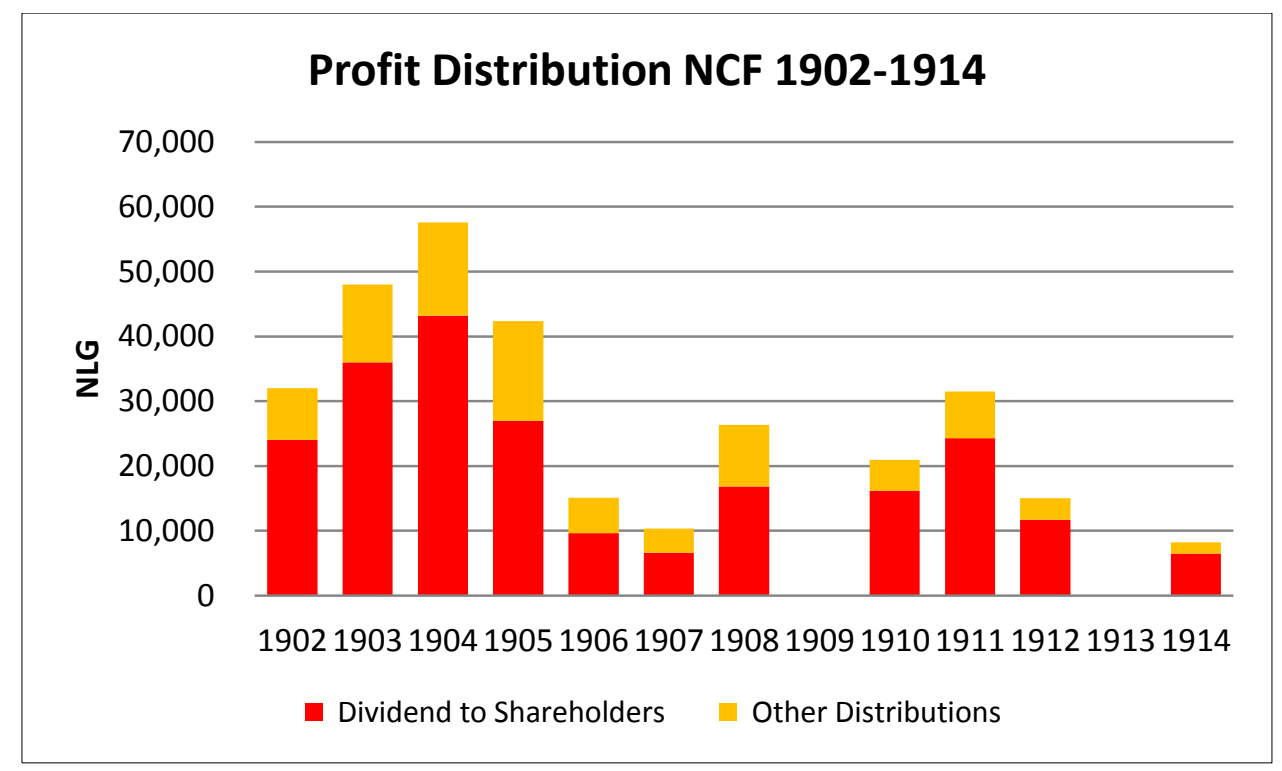

Source: Dividend to Shareholders, Table FIN 1(Part III),

Other amounts - calculated as described in the text above.

"Other Distributions" is the total of "to Holders of Profit -Sharing Notes",

"Bonuses to Directors" and contributions "to Special Reserve".

Though small in an absolute sense, the profit achieved by NCF was excellent as a percentage of NLG 12,000 shareholders capital. Over the first five years of the existence of the Company profit can even be qualified as outstanding. The reason for the large profit during this period was the result of the, for NCF very favourable, combination of a low cost product, a high cocaine price and a substantial sales volume. However, prices declined continually from 1900 to 1908 , thereafter hovering at a low level until the outbreak of World War I, resulting in a much lower profit. 
In chapter 18 estimates are made of average product cost and profit margins at NCF by period, on the basis of the amounts of dividends paid and estimates of the various costs incurred. The estimates result in approximate values of variable and fixed costs. These values are summarised in the following table:

Table 6.4 Estimated Manufacturing Cost Cocaine $\mathrm{HCl}$ and Profit Margin at NCF 1902-1914

\begin{tabular}{|l|rr|}
\hline Cocaine Hydrochloride NCF & 1902-1908 & 1910-1914 \\
\hline & 61 & 68 \\
Variable Cost (NLG per kg) & 82 & 54 \\
Fixed Costs (NLG per kg) & 143 & 122 \\
Total Cost (NLG per kg) & 99 & 30 \\
Profit Margin (NLG per kg) & $\mathbf{4 1}$ & $\mathbf{2 0}$ \\
Profit Margin \% of Selling price & & \\
\hline
\end{tabular}

Source: Table 18.16

The figures in Table 6.4 are approximations but provide a fair estimate of the various costs and the profit margin. The profit margin as a percentage of the selling price is primarily an internal performance index over time for the company. For comparison with the performance of other companies the index can only be used when the other companies are of the same type. Very broadly, a profit margin of $20 \%$ on sales is considered satisfactory for a bulk pharmaceutical manufacturer. The figures show that the NCF performed excellently during 1902-1908 and satisfactorily thereafter.

\subsection{Summary and Conclusions}

The first 15 years of NCF's existence was eventful. The start of the company went well. There were no production problems and already in 1901 NCF entered a deal with the German cocaine Convention by which it obtained a quota of $300 \mathrm{~kg}$, and the factory built in 1900 was substantially expanded in 1901 and 1902. The cocaine price was high at the start but declined steadily in the years thereafter leading to the dissolution of the Convention in 1908 and NCF taking on the marketing itself. Profit and dividend payments declined markedly after 1905.

NCF's first factory was located in a residential area of Amsterdam and in 1906 the fire-brigade began to make objections against the storage of large volumes of flammable solvents. The ultimate result was that in 1909 the NCF moved to a new factory in a rural area in the municipality of Ouder Amstel.

From 1908 until 1914 world market prices for cocaine stayed at a low level. As a consequence NCF's profit was reduced but due to the low cost coca supplies by the Soekamandjoe plantation the company was in a somewhat better position than most of its competitors. In the second half of 1914 the outbreak of World War I resulted for NCF in access to new markets and increased profit margins. 


\section{CHAPTER 7 \\ DEVELOPMENTS IN THE WORLD MARKET FOR COCAINE DURING THE PERIOD 1914-1930}

\subsection{Overview}

This chapter provides an outline of the world market for cocaine, describing the major forces that determined the market as the perspective for interpreting NCF's position. Emphasis is placed on the size of the market, the manufacturers, raw materials and international narcotics control.

The period 1914-1930 was a tumultuous one for the world in general and also for the cocaine industry. The outbreak of World War 1 resulted in an export embargo for cocaine in Germany and thereby the virtual disappearance of the German cocaine manufacturers from the world market. This opened up the market for others and especially the NCF was well placed to fill the gap. Shipping of the raw materials became increasingly difficult during the War but NCF was able to obtain sufficient Java coca and the years 1915-1920 were particularly profitable for the company.

From 1920 onwards German manufacturers returned to the market and new cocaine producers emerged in Japan and Switzerland. This resulted in strong competition and price erosion, and consequently profitability of the cocaine business diminished greatly during the period 1921-1924.

At the end of the war implementation of the narcotic control measures as agreed by countries at The Hague Conventions of 1912-1914 received renewed attention. The essence of the measures was to regulate the production of opium and to restrict the manufacture of cocaine and other narcotic drugs to supply for medicinal purposes only. In 1920 the supervision of the implementation of the Hague Conventions was entrusted to the League of Nations. A special 'Advisory Committee' was created that laid the ground work for a new conference to be held in Geneva. That conference resulted in the Geneva Convention of 1925 whereby parties agreed to accept a system of import and export permits for all international trade in the controlled substances and their raw materials

Well before the Geneva conference was held cocaine manufacturers realised that such a system would have a considerable negative impact on their sales. In 1924 the major European cocaine manufacturers, among them NCF, formed a new Cocaine Convention in an attempt to control the market and to restore the price to a reasonable level. In the early 1920s suppliers of Java coca also began to cooperate. Coca producers on Java, together with importers in the Netherlands, set minimum prices below which the coca would not be sold.

From 1925 the control system adopted in Geneva was gradually implemented and as a result cocaine sales by the legal manufacturers diminished substantially. For them, by 1930 cocaine had become a product of only limited commercial interest. 


\subsection{Manufacture of Cocaine Worldwide}

\section{Estimate of the World Manufacture of Cocaine 1914-1930}

A good indicator for the course of events in the cocaine industry is a record of the annual amounts of cocaine hydrochloride produced worldwide. It shows trends and changes, pointing to major events that took place. It provides a perspective for the position of the NCF in the market. Estimates of the quantities of cocaine $\mathrm{HCl}$ that were produced worldwide from raw materials exported during the period 1892-1930 are set-out in detail in Chapters 16 and 17. In this chapter the results are presented for the period 1914-1930. Table 7.1 shows the annual quantities rounded to the nearest hundred $\mathrm{kg}$ to reflect the accuracy. In Figure 7.1 the same data are displayed in graphical form.

Table 7.1 Estimate of Cocaine HCl manufactured worldwide from Raw Materials exported during the Period 1914-1930 ( $\mathrm{kg}$ cocaine $\mathrm{HCl}$ )

\begin{tabular}{|c|c|c|r|r|r|}
\hline \multirow{2}{*}{$\begin{array}{c}\text { Year } \\
\text { of } \\
\text { Export }\end{array}$} & \multicolumn{4}{|c|}{ Cocaine Manufuctured } & \\
\cline { 2 - 5 } & $\begin{array}{c}\text { from } \\
\text { Peru } \\
\text { Coca }\end{array}$ & $\begin{array}{c}\text { from } \\
\text { Peru } \\
\text { Crude }\end{array}$ & $\begin{array}{c}\text { from } \\
\text { Java } \\
\text { Coca }\end{array}$ & $\begin{array}{c}\text { from } \\
\text { Formosa } \\
\text { Coca }\end{array}$ & \\
\hline & & & & \\
1914 & 1,100 & 800 & 14,700 & 0 & 16,600 \\
1915 & 900 & 1,100 & 11,900 & 0 & 13,900 \\
1916 & 600 & 1,300 & 4,400 & 0 & 6,400 \\
1917 & 700 & 1,600 & 3,000 & 0 & 5,300 \\
1918 & 400 & 2,500 & 7,200 & 0 & 10,100 \\
1919 & 900 & 500 & 10,800 & 0 & 12,200 \\
1920 & 1,000 & 1,400 & 18,300 & 0 & 20,700 \\
1921 & 200 & 100 & 12,400 & 0 & 12,700 \\
1922 & 300 & 700 & 13,800 & 0 & 14,800 \\
1923 & 400 & 200 & 9,900 & 0 & 10,500 \\
1924 & 400 & 800 & 12,200 & 0 & 13,400 \\
1925 & 500 & 500 & 10,900 & 0 & 11,900 \\
1926 & 500 & 900 & 11,100 & 400 & 12,800 \\
1927 & 300 & 800 & 7,400 & 500 & 9,000 \\
1928 & 300 & 500 & 4,200 & 900 & 6,000 \\
1929 & 200 & 200 & 6,400 & 1,100 & 7,900 \\
1930 & 400 & 0 & 3,900 & 1,300 & 5,600 \\
& & & & & \\
\hline
\end{tabular}

Source: Table 17.11,

The figures are rounded to the nearest hundred $\mathrm{kg}$ 
Figure 7.1 Graph of Cocaine HCl manufactured worldwide from

Raw Materials exported during the Period 1914-1930

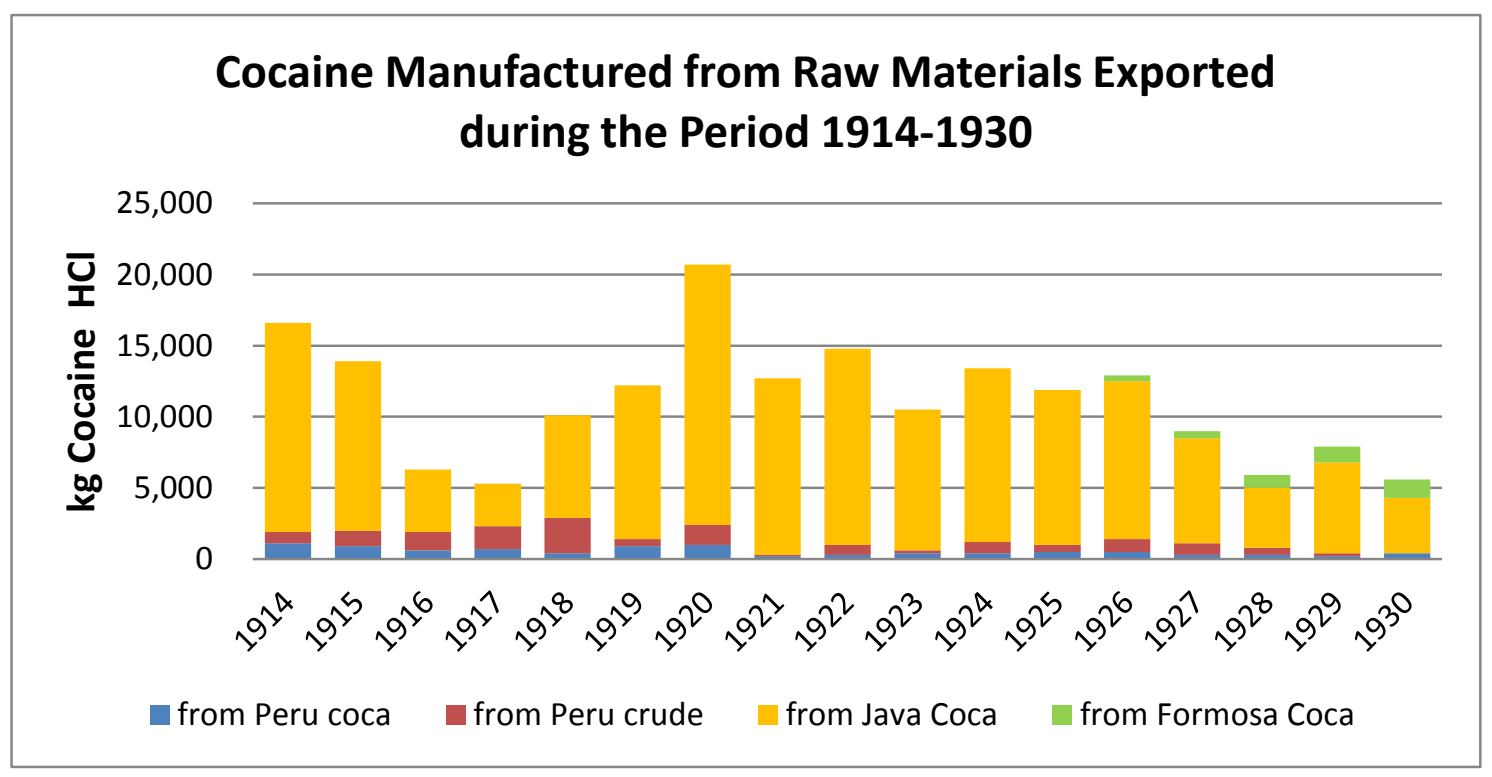

Source: Table 7.1

The graph and table show the serious decline in the exports of raw materials after 1915 that resulted from World War I. From raw materials exported in 1914 an estimated amount of ca. 17 tonnes was produced, equal to the average annual quantity produced during the immediately preceding period 1911-1913. For 1915 the amount is somewhat lower than for 1914 and quantity declined sharply thereafter to reach a level of ca 6 tonnes p.a. for 19161917. From 1918 the situation improved and in 1920 raw materials equivalent to more than 20 tonnes of cocaine hydrochloride were exported worldwide. That large quantity served to bring stock levels back to normal and during 1921-1926 raw material exports stabilized at a level equivalent to ca. 12 tonnes cocaine $\mathrm{HCl}$ p.a. Thereafter we see a further decline to 5.6 tonnes in 1930, a result of the restrictive regulations implemented after the Geneva Convention of 1925. The figures show the almost complete replacement of coca leaf and crude cocaine from Peru by Java coca as the raw material during the 1920s.

The estimated amounts of cocaine produced from raw materials exported (Table 7.1) have been split by sub-period over the manufacturing countries Germany, USA, Other European Countries and the Netherlands (NCF), and are brought together with the figures for 1911-1913 in Table 7.2.

It is important to note that the annual amounts presented in Tables 7.1 and 7.2 represent the quantities of cocaine $\mathrm{HCl}$ manufactured from the raw materials exported during a particular year, and that the actual manufacture of the cocaine from these raw materials took place later, sometimes considerably later, than the shipping of the raw materials. Measured over long periods, the average quantities of cocaine in raw materials exported were virtually equal to the quantities manufactured. During periods with a fairly constant production level, the quantities manufactured will have mimicked the quantities produced from raw materials exported in that year or the year before reasonably accurately. However, under less stable market conditions, in a particular year, the difference between the quantities of cocaine in exported raw materials and the quantities of cocaine actually manufactured could be quite large.

The latter was the case during the periods around World War I and during the 1920s. Building stocks of considerable size occurred under the then prevailing conditions. The result 
was that during these periods the exports represented substantially larger quantities of cocaine than were manufactured during those years, and a reversal of that effect in later years.

Table 7.2 Estimates by Period of Annual averages of Cocaine $\mathrm{HCl}$ manufactured from

Raw Materials exported during the years 1911-1930 split over

Countries and Raw Materials ( $\mathrm{kg}$ Cocaine $\mathrm{HCl}$ per annum)

\begin{tabular}{|c|c|c|c|c|c|c|c|}
\hline Period & $\begin{array}{c}\text { Raw } \\
\text { Material }\end{array}$ & Germany & USA & $\begin{array}{l}\text { Other } \\
\text { Europe }\end{array}$ & NCF & Japan & $\begin{array}{l}\text { Total } \\
\text { World }\end{array}$ \\
\hline \multirow[t]{5}{*}{ 1911-1913 } & Peru Coca & 100 & 1,900 & 100 & 0 & 0 & 2,100 \\
\hline & Peru Crude & 2,900 & 100 & 200 & 0 & 0 & 3,200 \\
\hline & Java Coca & 8,700 & 1,800 & 400 & 500 & 0 & 11,400 \\
\hline & Total & 11,700 & 3,800 & 700 & 500 & 0 & 16,700 \\
\hline & $\%$ & 70 & 23 & 4 & 3 & 0 & 100 \\
\hline \multirow[t]{5}{*}{ 1914-1920 } & Peru Coca & 0 & 1,200 & 0 & 0 & 0 & 1,200 \\
\hline & Peru Crude & 1,100 & 100 & 100 & 0 & 0 & 1,300 \\
\hline & Java Coca & 5,700 & 2,000 & 700 & 700 & 1,000 & 10,100 \\
\hline & Total & 6,800 & 3,300 & 800 & 700 & 1,000 & 12,600 \\
\hline & $\%$ & 54 & 26 & 6 & 6 & 8 & 100 \\
\hline \multirow[t]{5}{*}{$1921-1930$} & Peru Coca & 0 & 200 & 0 & 0 & 0 & 200 \\
\hline & Peru Crude & 400 & 0 & 0 & 0 & 0 & 400 \\
\hline & Java Coca & 4,600 & 300 & 900 & 900 & 2,500 & 9,200 \\
\hline & Total & 5,000 & 500 & 900 & 900 & 2,500 & 9,800 \\
\hline & $\%$ & 51 & 5 & 9 & 9 & 26 & 100 \\
\hline
\end{tabular}

Sources:

The amounts are calculated from the information contained in Tables 16.8 and 17.9.

The split of the periods 1914-1930 into the sub-periods 1914-1920 and 1921-1930 is made for coca leaf USA by using the averages as calculated in Table 7.12. The quantities of Java coca used for the calculations of the quantities exported to the various countries are taken from Table 7.5. The amounts of crude cocaine exported to the USA and Other Europe are those from Table 17.9, the totals are split as per the percentages mentioned there. The amounts exported to Germany represent the difference between the totals and the sum of exports to the other destinations.

Note: The figures are rounded to the nearest hundred kilograms.

The estimates are presented in graphical form in Figure 7.2. 
Figure 7.2 Graph of Annual averages by Period of Cocaine $\mathrm{HCl}$ Manufactured from Raw Materials Exported during the years 1911-1930 Split over Countries of Manufacture Materials ( $\mathrm{kg}$ Cocaine HCl per annum)

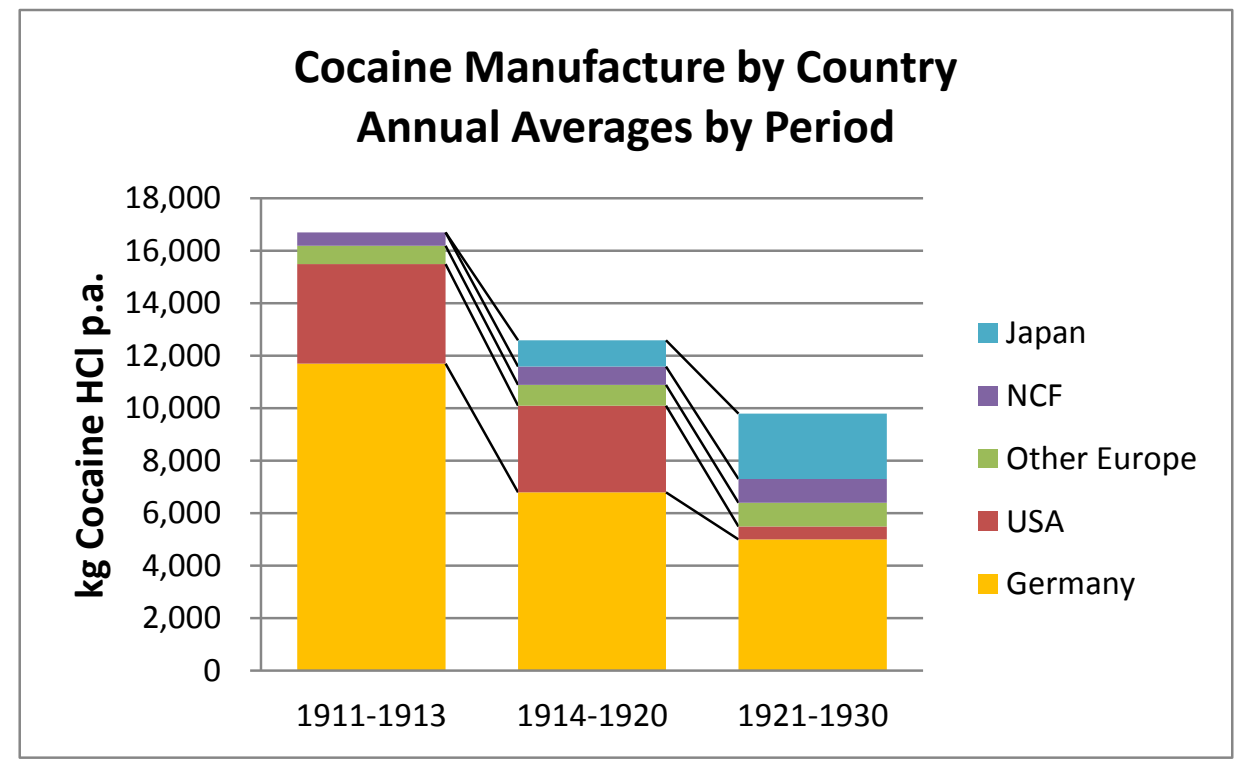

Source: Table 7.2

The strong decline of total production after 1913 has been discussed above. The very steep reduction in output of the USA from the period 1914-1920 to the period 1921-1930 as apparent from the graph is somewhat exaggerated as result of the accumulation of raw material stocks in the USA during the War, as will be argued in Section 7.4. Japan emerged as a major new cocaine producer after 1917. NCF and other smaller European manufacturers managed a modest increase in production while Germany retained its position as the largest manufacturer, though at a seriously reduced level of output.

\section{Manufacturers}

E. Merck, Darmstadt, remained the largest German cocaine producer but its output dropped substantially after 1914 together with that of the other German cocaine manufacturers: Boehringer-Mannheim, Boehringer-Ingelheim, Knoll and Buchler. ${ }^{1}$ In 1914 a new convention (cartel) of European cocaine manufacturers was established in which NCF participated. Its effect was limited because, as a result of the War, the German government issued export permits only very sparingly. ${ }^{2}$ Specific information on the quantities of cocaine produced by any of the German manufacturers is very limited for the period 1914-1930. Little is known with certainty about cocaine producers in European countries other than Germany. NCF was apparently the major one of these; Hoffmann La Roche in Switzerland and Etablissements Roques in France are mentioned as well in various publications. Some Java coca was exported to the UK from 1911 to 1914 but that appears to have been for trading as cocaine was not manufactured in the UK at the time. ${ }^{3}$

In 1924 Merck, Boehringer-Mannheim, Boehringer-Ingelheim, Knoll (Ludwigshafen), Chemische Werke Grenzach (Grenzach), Hoffmann La Roche (Basle), Etablissements Roques (Paris) and the Nederlandsche Cocaine Fabriek established a new

\footnotetext{
${ }^{1}$ Ref. Table 7.2 and Figure 7.2.

${ }^{2}$ Koloniale Bank, Report of Management to the Board, (1914) 6. Nationaal Archief, The Hague, Access No. 2.20.04 Item 58 and Merck,'Conventionen und Vertretungen', 'Bericht über Konventionen in 1915, 7. MerckArchiv F03/6a.

${ }^{3}$ Anonymous, 'De Nederlandsche Cocaine Fabriek NV', Pharmaceutisch Weekblad 76 (1939) 801.
} 
cocaine convention. ${ }^{4}$ The only established European cocaine producer not participating in the Convention was Buchler (Brunswick). In 1928 two new cocaine manufacturers entered the business: May \& Baker (UK) and Sico (Paris); these companies did not become members of the Convention at that time. ${ }^{5}$

US cocaine manufacturers around 1920 were Mallinckrodt, Merck-Rahway and Maywood Chemical (formerly Schaeffer Alkaloid Works), the latter manufacturing cocaine as a byproduct of the de-cocainized coca leaf extract for Coca-Cola. Powers-WeightmanRosengarten produced cocaine hydrochloride from crude cocaine from Peru until 1922, when under the Jones-Miller Act the importation of this raw material was not any longer allowed. ${ }^{6}$ Sankyo. ${ }^{7}$

Japanese companies manufacturing cocaine at the time were Hoshi, Dai Nippon and

\section{Production Processes}

A good description of practical processes for extracting coca leaf, conversion of the secondary alkaloids into cocaine and the purification of the end product as current in 1927, is provided by Julius Schwyzer. ${ }^{8}$ These processes were in essence still the same as those invented by Liebermann, Giesel, Einhorn, Klein and Willstätter around 1890. We can say that in the 1920s each manufacturer would have optimized its processes to reduce cost and will have kept the technical details for themselves as was, and still is, customary in the alkaloid industry. The yields that were obtained by the industry (ref. Chapter 17) were quite high and left little scope for substantial improvement.

\subsection{Raw Materials - The Trade in Java Coca}

Table 7.1 and Figure 7.1 show that the raw materials coca leaf from Peru and crude cocaine from that country were gradually replaced by coca leaf from Java for the simple reason that Java coca was the more economical raw material. During the period 1921-1930 small quantities of coca leaf from Peru were used in the USA primarily for making the extract that flavoured Coca-Cola, and cocaine was obtained as a byproduct. The use of crude cocaine from Peru as a raw material revived in a modest way in the early 1920s after a price increase of Java coca. ${ }^{9}$

\section{Cocaine Raw Materials from Peru}

Exports of Peru coca amounted to an average of ca 350 tonnes p.a. over the period 19141920, of which ca 220 tonnes went to the USA. After 1920 the use of Peru coca as the raw material for cocaine was much reduced because of competition from Java Coca. ${ }^{10}$ Java coca was the more economical raw material yielding about double the quantity of cocaine from an equal amount of raw material in comparison to coca from Peru and Java coca became the raw material of choice for the industrial manufacture of cocaine. Peru coca and crude cocaine could ultimately not compete with Java coca: the varieties of Eryhroxylum taxa grown commercially in Peru had too low an alkaloid content and the cost of cultivation was too high. ${ }^{11}$

\footnotetext{
${ }^{4}$ W. Dethloff, Gründung der Firm und Weiterentwickling der Abteilung Pharmazeutische Chemikalien. (Section on cocaine) Manuscript ca 1957, Ingelheim, Firmen- und Familienarchiv von C.H. Boehringer Sohn.

${ }^{5}$ Letter dated 2 December 1929 from the NCF to Dr. J.B.M. Coebergh, Nationaal Archief, The Hague, Access No. 2.05.21 Item 1596.

${ }^{6}$ Paul Gootenberg, Andean Cocaine, The Making of a Global Drug, (Chapel Hill 2008) 195.

${ }^{7}$ S.B. Karch, A Brief History of Cocaine $2^{\text {nd }}$ Ed (Boca Raton 2006) 151.

${ }^{8}$ Schwyzer, Die Fabrikation de Alkaloide, (Berlin 1927) Section on Cocaine, 82-89.

${ }^{9}$ W. Labohm, 'Uitbreiding Cocacultuur' Mededeelingen van het Nederlandsch-Indisch Landbouw Syndicaat (1922) 26, 91-94.

${ }^{10}$ Table PCL 1 (Part III) and Table 7.1.

${ }^{11}$ Paul Gootenberg, Andean Cocaine, The Making of a Global Drug, (Chapel Hill 2008) 147-156.
} 
Crude cocaine from Peru was exported in quantities of ca 1,800 kg p.a. during World War 1 . That volume shrank to ca $700 \mathrm{~kg}$ p.a. in the period immediately thereafter. Because the price of Java coca was initially set too high by the Coca Producers Association, crude cocaine from Peru became competitive again and the average sales volume increased to ca $900 \mathrm{~kg}$ p.a. during 1924-1927. ${ }^{12}$ In 1927 the price of Java coca was reduced substantially with specific purpose "to compete with the South-American product" and the export of crude cocaine from Peru faded again. ${ }^{13}$

${ }^{12}$ Table PCC 1 (Part III).

${ }^{13}$ Ref. Table 7.7 and Coca Producers Association, Annual Report (1927) 5. 
The Trade in Java Coca

The official statistics of the exports of coca leaf from Java for the period 1908-1930 are compiled in the following table:

Table 7.3 Exports of Coca Leaffrom Java 1908-1930 (tonnes)

\begin{tabular}{|c|c|c|c|c|c|c|c|}
\hline $\begin{array}{c}\text { Year } \\
\text { of } \\
\text { Export }\end{array}$ & $\begin{array}{l}\text { to } \\
\text { the Nether- } \\
\text { lands }\end{array}$ & to the UK & to Germany & to USA & to Japan & $\begin{array}{c}\text { to } \\
\text { Other } \\
\text { Countries }\end{array}$ & $\begin{array}{c}\text { Total } \\
\text { Exports } \\
\text { from Java }\end{array}$ \\
\hline 1908 & 311 & 3 & 102 & & & & 417 \\
\hline 1909 & 353 & 0 & 21 & & & & 373 \\
\hline 1910 & 401 & 15 & 9 & & & 5 & 430 \\
\hline 1911 & 645 & 84 & 12 & & & & 741 \\
\hline 1912 & 1,043 & 26 & 5 & & & & 1,075 \\
\hline 1913 & 1,231 & 92 & 9 & & & & 1,332 \\
\hline 1914 & 1,250 & 103 & & & & & 1,353 \\
\hline 1915 & 909 & 88 & & 80 & 11 & 1 & 1,089 \\
\hline 1916 & 125 & 8 & & 273 & 2 & & 408 \\
\hline 1917 & 17 & 4 & & 235 & 17 & & 273 \\
\hline 1918 & 0 & & & 408 & 254 & & 662 \\
\hline 1919 & 756 & 6 & & 125 & 107 & & 994 \\
\hline 1920 & 1,394 & 3 & & 11 & 269 & & 1,677 \\
\hline 1921 & 677 & & & & 456 & 5 & 1,137 \\
\hline 1922 & 903 & & 1 & & 364 & & 1,269 \\
\hline 1923 & 509 & & 9 & 26 & 364 & & 907 \\
\hline 1924 & 791 & & 21 & & 307 & & 1,118 \\
\hline 1925 & 657 & & 17 & & 323 & & 997 \\
\hline 1926 & 763 & & 19 & & 200 & 38 & 1,020 \\
\hline 1927 & 436 & & 67 & & 175 & & 678 \\
\hline 1928 & 307 & & 34 & 20 & 25 & & 385 \\
\hline 1929 & 396 & 11 & 100 & & 42 & 37 & 585 \\
\hline 1930 & 252 & 30 & 72 & & & & 354 \\
\hline
\end{tabular}

Source: Statistiek van den Handel en de In-en Uitvoerrechten (Statistics Dutch East Indies), Deel IIa (Java en Madoera) [Table JCL 3 (Part IV)].

From 1908 large quantities of Java coca were exported, predominantly to the Netherlands except for a brief period during World War I. The coca was sold at auctions in Amsterdam or directly to the customer. P. Brusse, prominent broker of Java coca and cinchona bark, kept records of stock of Java coca in Amsterdam at year end, in number of bales (colli). ${ }^{14}$ The number of bales has been converted into tonnes of coca by the author and for the period 1912-1930 the resulting amounts are contained in column [2] of Table 7.4 together with the coca imports into the Netherlands and the quantities used by the NCF. ${ }^{15}$ This input is used to calculate the quantities of coca re-exported from the Netherlands which appear in column [4].

\footnotetext{
${ }^{14}$ P. Brusse, Jaarverslag voor Kinabast en Coca (Annual Report on Cinchona bark and Coca), Library Royal Tropical Institute (KIT) Amsterdam.

${ }^{15}$ Ref. Table JCL 6 (Part III).
} 
Table 7.4 Export of Java Coca to the Netherlands, Stock Amsterdam, Usage NCF, Re-export from the Netherlands and Prices 1912-1930

\begin{tabular}{|c|c|c|c|c|c|}
\hline Year & $\begin{array}{c}\text { Export to the } \\
\text { Netherlands } \\
\text { tonnes } \\
\text { [1] }\end{array}$ & $\begin{array}{c}\text { Stock A'dam } \\
\text { at year end } \\
\text { tonnes } \\
\text { [2] }\end{array}$ & $\begin{array}{c}\text { Usage } \\
\text { NCF } \\
\text { tonnes } \\
\text { [3] }\end{array}$ & $\begin{array}{c}\text { Re-export } \\
\text { tonnes } \\
\text { [4] }\end{array}$ & $\begin{array}{c}\text { Average } \\
\text { Price NLcts } \\
\text { per unit } \\
\text { [5] }\end{array}$ \\
\hline 1912 & 1,043 & 133 & 46 & n/a & 22 \\
1913 & 1,231 & 106 & 46 & 1,212 & 19 \\
1914 & 1,250 & 95 & 46 & 1,215 & 15 \\
1915 & 909 & 511 & 65 & 427 & 12 \\
1916 & 125 & 322 & 65 & 249 & 16 \\
1917 & 13 & 23 & 65 & 247 & 20 \\
1918 & 0 & 0 & 65 & -42 & ca 55 \\
1919 & 756 & 201 & 65 & 490 & 67 \\
1920 & 1,394 & 332 & 65 & 1,198 & 30 \\
1921 & 667 & 77 & 96 & 826 & 28 \\
1922 & 903 & 200 & 96 & 684 & 55 \\
1923 & 509 & 227 & 96 & 387 & 62 \\
1924 & 791 & 227 & 96 & 695 & 64 \\
1925 & 657 & 639 & 73 & 172 & 59 \\
1926 & 763 & 1,016 & 73 & 313 & 61 \\
1927 & 436 & 1,221 & 73 & 158 & 30 \\
1928 & 307 & 418 & 73 & 1,037 & 25 \\
1929 & 396 & 520 & 73 & 220 & 25 \\
1930 & 252 & 588 & 73 & 112 & 50 \\
& & & & & \\
\hline
\end{tabular}

Sources and Notes:

[1] Statistiek van Den Handel en de In- en Uitvoerrechten (Statistics Dutch East Indies) Deel IIa (Java en Madoera), Weltevereden, 1874-1923 (Table 7.3)

[2] P.Brusse, Jaarverslag voor Kinabast en Coca (Annual Report on Cinchona bark and Coca), 1905-1930. Amounts in tonnes was calculated from the number of bales and the average weight (HHB)

[3] Table 18.16 (Volume $\mathrm{V}$ divided by the average yield of $10.9 \mathrm{~kg} /$ tonne)

[4] [4] $=[1]+[2]$ previous year $-[2]$ current year $-[3](\mathrm{NCF})$

[5] 1912-1926: Brusse, Annual Reports; 1927-1932: Coca Producenten Vereniging, Annual Reports 
Figure 7.3 Export of Java Coca to the Netherlands and Stock at Year End 1912-1930

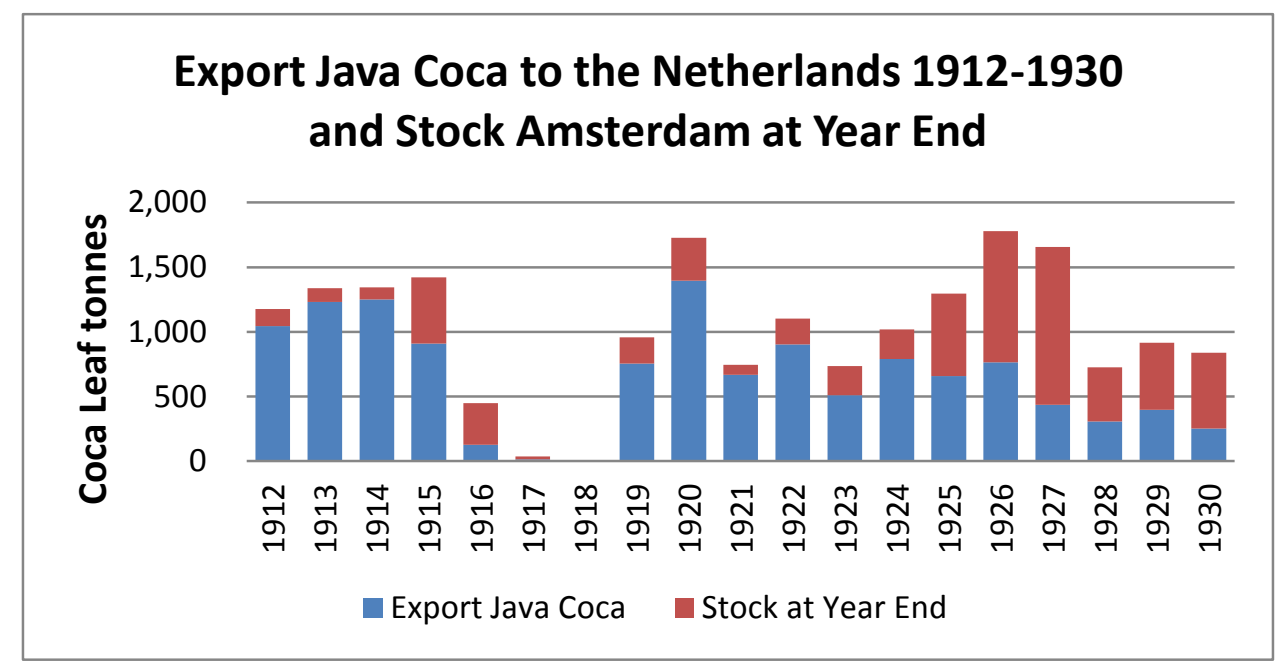

Source: Table 7.4

The graph shows clearly the build-up of large stocks of Java coca in Amsterdam during 19151916 and 1925-1930.

In Table 7.5 (below) data in the imports and exports of Java coca over the period 1892-1930 are compiled with the objective to determine the final destination of the product, i.e. where it was processed and in which quantities. As shown in Table 7.3, from 1908 most of the coca exported from Java went to the Netherlands but some of it went directly to the countries where it was used (mainly USA and Japan). Except for relatively small quantities used by $\mathrm{NCF}$, the bulk of the Java coca imported into the Netherlands was re-exported. About 70 per cent of the Java coca intended for re-export was sold at auctions in Amsterdam while the remainder was in transit in the Netherlands. ${ }^{16}$ Except for the period 1922-1932, for trades reported by the Coca Producers Association, countries of destination of the re-exports are not known.

For the period 1892-1907 Germany was, except for the Netherlands, the only country where Java coca was processed. For that period it is assumed that the quantities of Java coca sold in consignment by the Koloniale Bank all went to Germany and that from 1902 a quantity of $30 \mathrm{t}$ coca leaf p.a. was imported directly by the NCF. For the years 1908-1930 data for the total export of Java coca are available from the official statistics of the Dutch East Indies. Estimates of the total quantities of Java coca exported to the USA have been made in Chapter 16 (Table 16.8) and the amounts of Java coca exported to Japan are known. Deducting these exports plus the estimated usage by NCF from the total exports from Java we arrive at the quantity of Java coca exported to Germany plus Other European Countries (mainly France and Switzerland).

The quantities that were exported to Other European Countries during 1922-1930 are known and estimated for the period 1911-1920. Deducting these from the sum of exports to Germany plus Other European Countries results in the exports to Germany.

\footnotetext{
${ }^{16}$ Average ratio Java coca sold at auction (JCL 6) and exports to the Netherlands (JCL 3) is $68 \%$ for the period $1908-1930$.
} 
Table 7.5 Export Coca Leaf from Java by Country of Final Destination 1892-1930 (tonnes)

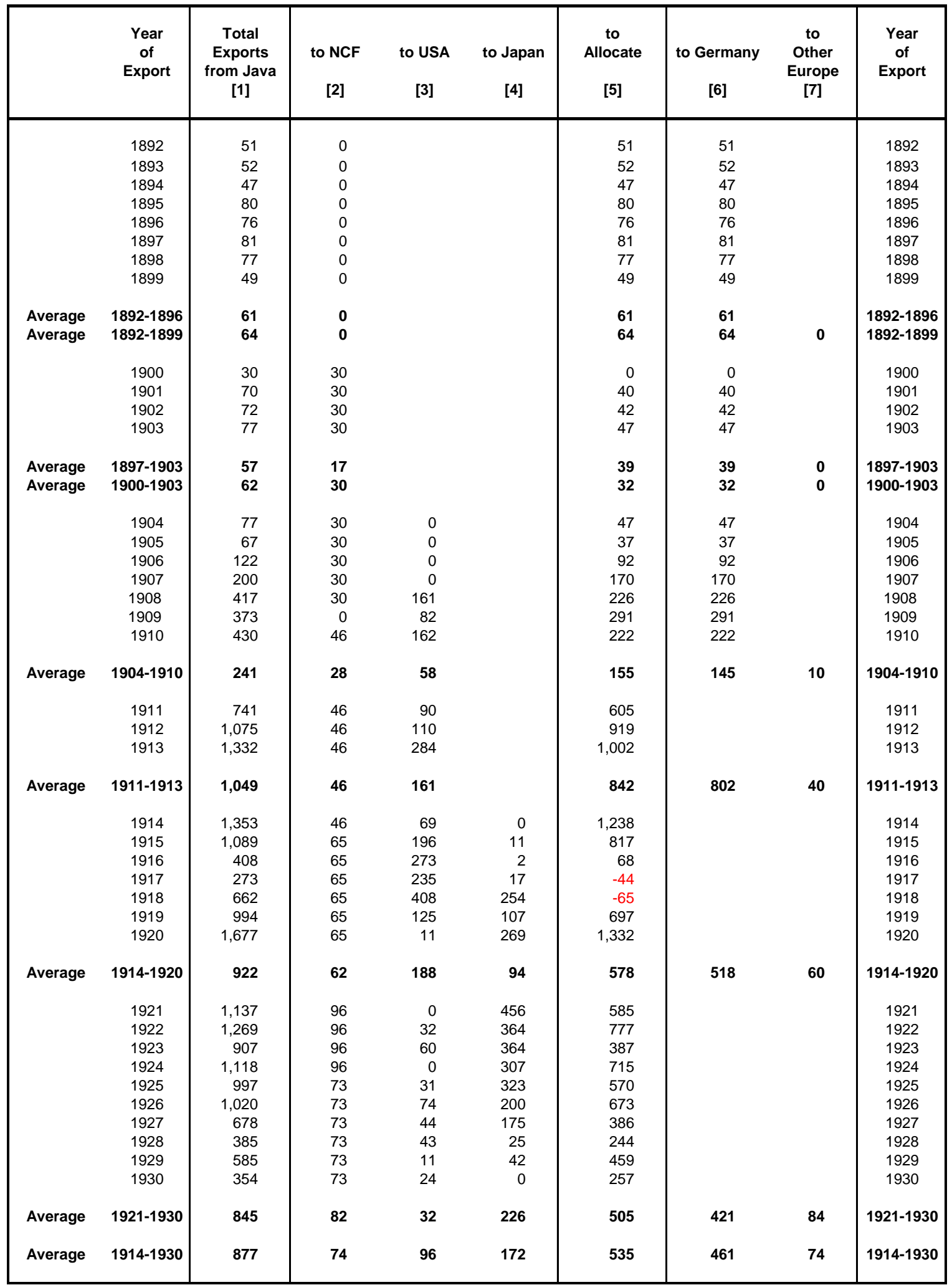

Table 7.5 Sources and Notes:
[1] Table JCL 2 (Part IV)
$[5]=[1]-[2]-[3]-[4]$
[2] Table $18.16(\mathrm{~V} / 10.9)$
$[6]=[5]-[7]$
[3] Table 16.9 column [21]
[7] 1922-1930: Allocated HHB
[4] Table JCL 3 (Part IV) 


\section{Prices Java Coca}

Prices for Java coca remained low in 1916 and 1917, indicating that, despite the reduced exports from Java, the stocks were still sufficient and that there was no strong demand for the product in Europe. Because of the War, shipping of Java coca to the Netherlands was impossible in 1917 and 1918. The price went up in 1918 when the stock had become virtually zero. In 1919 exports from Java resumed and considerable amounts were sold in Amsterdam at good prices. In 1920 an all-time maximum of 1,394 tonnes of Java coca was exported; this saturated the market, and prices came down again. The figures in Table 7.3 show that from 1915 direct exports of Java coca to the USA became important but after the War ended exports to this destination largely disappeared. Direct exports of Java coca to Japan commenced on a small scale in 1915 and reached substantial quantities in 1918; this trade remained important for a period of circa ten years. ${ }^{17}$

\section{Coca Producers Association}

The low prices for Java coca in 1920-1921 led to a cooperative of importers in the Netherlands and producers on Java. ${ }^{18}$ The purpose: joint-marketing and the setting of prices. During 1925 it was decided to convert the arrangement into something more formal and on 7 October 1925 the Coca Producers Association (Coca Producenten Vereniging, CPV) was established. ${ }^{19}$

Forty-three coca producers became members at the foundation of the CPV and by the end of 1925 that number had increased to 59. The CPV, in essence, continued the work of the earlier cooperative. Price limits were established for coca sold in the Netherlands. No price limits existed for direct sales from Java to Japan and the USA. The first major task for the CPV was to negotiate a contract with the buyers / cocaine manufacturers (the European Cocaine Convention). At the year end 1925 the Board of the CPV consisted of ten members: ${ }^{20}$ Management (the "Coca-Bureau") was in the hands of the Koloniale Bank (chair), Mr W.P. Kessler and Mr F.H.M. Koch. Representative in the Dutch East Indies was the Koloniale Bank, Soerabaja. After extensive negotiations agreement was reached with the Cocaine Convention on a supply contract. That contract was approved by the membership on 12 May, $1926 .{ }^{21}$ At the end of 1926 the number of producer-members was 86 , increasing to 89 in 1927 . At the time 37 producers remained outside the Association. ${ }^{22}$

The heart of the contract of 12 May 1926 between the CPV and the European Cocaine Convention was a table that specified the price for the leaf, in NL cents per half $\mathrm{kg}$ at $1 \%$ total alkaloid content (the unit price) in relation to its alkaloid content (a higher unit price applied to a higher content), and the selling price for cocaine $\mathrm{HCl}$ as set by the Convention. The linking of the price paid for the Java coca to the growers and the price for which the cocaine was sold by the cocaine manufacturers was done in such a way that the profit of the cocaine business in total was shared. At the contract date, the cocaine price was set at DEM

\footnotetext{
${ }^{17}$ The price at which the coca was sold to Japan in later years was considerably lower than the European price. Coca Producenten Vereniging, Annual Report (1927) 8.

${ }^{18}$ A.W.K. de Jong, Chapter 'Coca' in: C.J.J. van Hall and C. van de Koppel, editors, De Landbouw in de Indische Archipel Vol II A (The Hague 1948) 874.

${ }^{19}$ Coca-Producenten Vereniging (Coca Producers Association), Report over the Period 7 October - 31

December 1925, Nationaal Archief, The Hague, Access No. 2.20.04 Item 1643.

${ }^{20}$ Nederlandsche Handel-Maatschappij, Nederlandsch-Indische Landbouw Maatschappij, Koloniale Bank, Firma Tiedeman \& van Kerchem, Mr P.W. Janssen, Firma A.van Hoboken \& Co, Internationale Crediet - en Handelsvereeniging "Rotterdam", Mr F.H.M. Koch, Mr W.P. Kessler and Dordtsche Cultuur Maatschappij. Coca-Producenten Vereniging (Coca Producers Association), Report over the Period

7 October - 31 December 1925.

${ }^{21}$ Coca-Producenten Vereniging (Coca Producers Association),

Report over the Period 7 October - 31 December 1925.

${ }^{22}$ Coca-Producenten Vereniging (Coca Producers Association), Annual Report (1927) 1-2.
} 
750/kg (NLG 450/kg) and the corresponding coca price was 64 NL cents per unit at an alkaloid content of $1.50 \% .^{23}$

It turned out that the price was set too high and on 10 December 1926 it was reduced by 15 cents per unit throughout the table. This price reduction was necessary for it to become competitive with crude cocaine from Peru. ${ }^{24}$ The table which was valid from December 1926 is reproduced here as Table 7.6. It covers a wide range of cocaine prices, from as low as DEM 350 (NLG 210) per kg to DEM 750 (NLG 450) and higher.

Table 7.6 Price of Java Coca in Relation to the prevailing Cocaine Price and the Alkaloid Content (valid from December 1926 to December 1931)

\begin{tabular}{|c|c|c|c|c|c|c|c|c|}
\hline & \multicolumn{8}{|c|}{ Cocaine Price in DEM } \\
\hline & $\begin{array}{c}701 \\
\text { and } \\
\text { higher }\end{array}$ & $\begin{array}{c}651 \\
\text { to } \\
700\end{array}$ & $\begin{array}{c}601 \\
\text { to } \\
650\end{array}$ & $\begin{array}{c}551 \\
\text { to } \\
600\end{array}$ & $\begin{array}{c}501 \\
\text { to } \\
550\end{array}$ & $\begin{array}{c}451 \\
\text { to } \\
500\end{array}$ & $\begin{array}{c}401 \\
\text { to } \\
450\end{array}$ & $\begin{array}{c}351 \\
\text { to } \\
400\end{array}$ \\
\hline Alkaloid Content & \multicolumn{8}{|c|}{ Coca Price in NL cents per Unit (half $\mathrm{kg}$ at $1 \%$ alkaloid) } \\
\hline $\begin{array}{c}2.00 \% \text { and higher } \\
1.80-1.99 \%\end{array}$ & $\begin{array}{l}55 \\
53\end{array}$ & $\begin{array}{l}50 \\
48\end{array}$ & $\begin{array}{l}45 \\
43\end{array}$ & $\begin{array}{l}40 \\
38\end{array}$ & $\begin{array}{l}35 \\
33\end{array}$ & $\begin{array}{l}30 \\
28\end{array}$ & $\begin{array}{l}25 \\
23\end{array}$ & $\begin{array}{l}20 \\
18\end{array}$ \\
\hline $1.60-1.79 \%$ & 51 & 46 & 41 & 36 & 31 & 26 & 21 & 16 \\
\hline $1.40-1.59 \%$ & 49 & 44 & 39 & 34 & 29 & 24 & 19 & 14 \\
\hline $1.20-1.39 \%$ & 47 & 42 & 37 & 32 & 27 & 22 & 17 & 12 \\
\hline $1.00-1.19 \%$ & 45 & 40 & 35 & 30 & 25 & 20 & 15 & 10 \\
\hline
\end{tabular}

Source: Coca Producers Association, Annual Report (1927)

The above price table remained valid until the end of 1931 but the price changed when the convention price for cocaine was re-set.

\footnotetext{
${ }^{23}$ Ibidem (1927) 4.

${ }^{24}$ Ibidem.
} 
Table 7.7 Contract Price for Java Coca with an Alkaloid content of $1.50 \%$ As agreed between the CPV and the Convention

\begin{tabular}{|l|c|c|c|}
\hline \multirow{2}{*}{$\begin{array}{c}\text { Contract--/ Reset-- } \\
\text { Date }\end{array}$} & \multicolumn{2}{|c|}{ Cocaine Price } & \multirow{2}{*}{$\begin{array}{c}\text { Unit Price } \\
\text { NL cents }\end{array}$} \\
\cline { 2 - 3 } & DEM/kg & NLG/kg & \\
\hline 14 May 1926 & 750 & 450 & 64 \\
& & & \\
10 December 1926 & 750 & 450 & 49 \\
15 March 1927 & 600 & 360 & 34 \\
1 June 1927 & 500 & 300 & 24 \\
26 February 1930 & 750 & 450 & 49 \\
& & & \\
\hline
\end{tabular}

Source: Coca Producers Association, Annual Reports (1926-1930)

\section{Some Implications of Table 7.6}

The relationship between the alkaloid manufacturer and the supplier of the plant raw material supplier is of utmost importance for both parties. The raw material cost represents often the major part of the total manufacturing cost of the product and the manufacturer needs a reliable source of supply which provides the raw material at relatively low cost. For the cocaine industry the raw material supplier is the grower of the coca plant. He needs customers that buy from him year after year a predictable quantity at a reasonable price. Both buyer and seller need a partner which they can trust in times of shortage, when the price of the product is high and in bad times of overproduction when the price is low. This is the reason that supply arrangements often take the form of long term supply contacts. The terms of the contract should represent the interest of both parties in a fair and balanced way in order to be long lasting.

The contract between manufacturers, the members of the Cocaine Convention and the Coca Producers Association was the result of extensive negotiations and Table 7.6 shows the contract price of Java coca in relation to the prevailing cocaine price and the total alkaloid content of the coca leaf. It was the basis for the relationship between buyer and seller. A detailed analysis of the table will reveal how variations in the cocaine price and the alkaloid content of the coca affect each partner.

To assist in the understanding of the price table, the relationship between the unit price for Java coca (p) and the alkaloid content of the leaf (A) is shown in the graph below for two different cocaine prices $(\mathrm{P})$. The unit price $\mathrm{p}$ is constant when the alkaloid content $\mathrm{A}$ and the cocaine price $\mathrm{P}$ stay within certain ranges. When $\mathrm{A}$ or $\mathrm{P}$ move outside the range, $\mathrm{p}$ changes abruptly. In practice, $\mathrm{P}$ is always set at the highest in the range.

For the underfollowing calculations the stepped line which represents the contract price is replaced by a straight line through the points representing $\mathrm{p}$ at the middle of the range for the alkaloid content. This is a sufficiently correct approximation allowing for a relatively simple mathematical analysis of the figures. 
Figure 7.4 Graphical Representation of the Price of Java Coca in Relation to the prevailing Cocaine Price and the Alkaloid Content

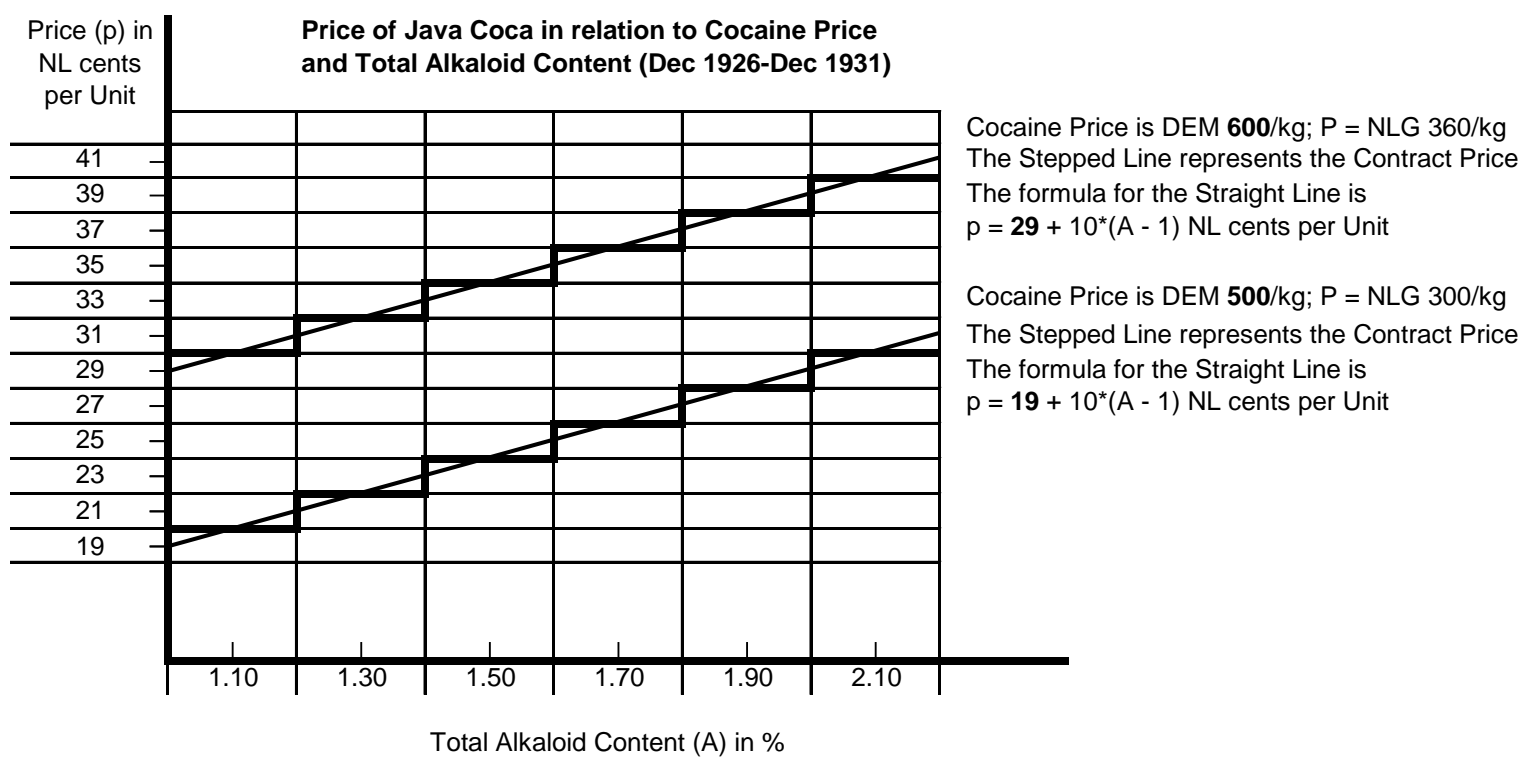

Perusal of the figures in Table 7.6 reveals that the unit prices are based on the price formula $\mathrm{p}=\mathrm{P} / 6-26$ in which $\mathrm{p}$ is the coca unit price in NL cents at $1.50 \%$ (the average) alkaloid content and $\mathrm{P}$ is the price as set by the Convention for cocaine $\mathrm{HCl}$ in $\mathrm{NLG} .{ }^{25}$ From the above formula it follows that if the cocaine price increases by $\Delta \mathrm{P}$ the unit price for coca leaf increases by $\Delta \mathrm{p}=\Delta \mathrm{P} / 6$ and, because the variable production cost of cocaine is $\mathrm{C}=3 \mathrm{p}+\mathrm{q}$, the cocaine cost per $\mathrm{kg}$ goes up by $3 \Delta \mathrm{p}=\Delta \mathrm{P} / 2$. This means that growers and manufacturers shared equally the financial consequences of any variations in the cocaine price set by the convention. $^{26}$

Table 7.6 shows furthermore that an increase of $0.2 \%$ in alkaloid content results in an increase of the price of the leaf by 2 NL cents per unit. Consequently the production cost of the cocaine increases by NLG 6 per $\mathrm{kg}$ which is offset by a reduction in the fixed cost per $\mathrm{kg}$ of cocaine $\mathrm{HCl}$ and additional profit from selling more cocaine if extraction capacity is the limiting factor. ${ }^{27}$

Another implication of the coca price formula is that the total production cost of cocaine $\mathrm{HCl}$ in NLG per $\mathrm{kg}$, which can be calculated from

$$
\mathrm{C}_{\text {total }}=\mathrm{C}+\mathrm{f}=3 \mathrm{p}+\mathrm{q}+\mathrm{f}=\mathrm{P} / 2-78+\mathrm{q}+\mathrm{f}
$$

results in a value for $\mathrm{C}_{\text {total }}$ close to $\mathrm{P} / 2$ if $\mathrm{q}+\mathrm{f}$ is approximately equal to $78 .^{28}$

\footnotetext{
${ }^{25}$ Calculated from the price in DEM at an exchange rate of 1 DEM $=$ NLG 0.60 .

Note: The Convention always set the price at the highest value in the bracket (ref. Table 7.7).

${ }^{26}$ The derivation of the formula $\mathrm{C}=3 \mathrm{p}+\mathrm{q}$ for the variable manufacturing cost of $1 \mathrm{~kg}$ cocaine $\mathrm{HCl}$ is provided in Chapter 18 (Table 18.11).

${ }^{27}$ The reduction in fixed cost (including labour, cf. Section 18.2) per kg cocaine $\mathrm{HCl}$ at an increase of the alkaloid content from 1.5 to $1.7 \%$ amounts to $12 \%$ of the fixed extraction cost, which represent the major part of the total fixed cost. The estimated value for NCF for the fixed cost per kg cocaine $\mathrm{HCl}$ (f) for the period 19211924 is NLG 64. [ref.Table 18.16: $\mathrm{f}=\mathrm{F} / \mathrm{V}=(77,200-10,000) / 1,051=64$ and $\mathrm{q}=19$ ].

Hence, the reduction in fixed cost amounts to $12 \%$ of NLG $64=$ NLG 8 .

${ }^{28} \mathrm{q}$ represents the sum of the cost for chemical solvents and energy and $\mathrm{f}$ is the fixed cost, both expressed in NLG per $\mathrm{kg}$ cocaine $\mathrm{HCl}$, $\mathrm{f}$ is fixed cost in $\mathrm{NLG} / \mathrm{kg}$ and $\mathrm{V}$ is the quantity (kg) of cocaine $\mathrm{HCl}$ produced.
} 
The estimated value of $\mathrm{q}+\mathrm{f}$ for NCF during the period 1921-1924 was NLG83 and hence C total $=\mathrm{P} / 2+5$, corresponding with a profit of $\mathrm{P}-\mathrm{C}_{\text {total }}=\mathrm{P} / 2-5$ per $\mathrm{kg}$ cocaine $\mathrm{HCl}$, which is equivalent to a profit margin of $49 \%$ on sales (at $\mathrm{P}=360$ ).

The above calculations provide a valuable insight into the positions taken by the parties during the negotiations of the supply contract. It is shown that growers and manufacturers shared the financial consequences of any variations in the cocaine price and alkaloid content approximately equally, which is an indication of a good collaboration between the parties, resulting in a fair deal.

\section{The Market for Java Coca from 1927}

From the start the CPV was disappointed with the volume of coca sold. It was, however, considered a success that as a result of the contract with the Convention, outsiders had great difficulties selling their product.

In 1927 the CPV agreed with the Convention that the manufacturers would buy Java coca exclusively and no other raw materials (Peru crude). Despite a further price reduction of the Java coca mid 1927, sales did not increase. ${ }^{29}$ Narcotic controls pursuant to the Geneva Convention of 1925 also affected the growers on Java in a more direct sense. From 1 July 1927 export permits were required for coca from Java and these could only be obtained on the basis of certificates issued by the governments of the importing countries. ${ }^{30}$

Between April and September 1928 an exceptionally large quantity of 1,049 tonnes of Java coca was sold in Amsterdam, 951 tonnes of which was exported, largely (795 tonnes) to Germany. In October the quantity sold fell suddenly back from ca 150 tonnes per month to 11 tonnes. $^{31}$ On 1 October, 1928, the new "Opiumwet" (Opium Act) became law in the Netherlands by which import and exports of cocaine, opiates and their raw materials became more strictly controlled. ${ }^{32}$ It is obvious that the timing and size of the sales was directly related to the export restrictions that came into force on October 1. From 1929 onwards the coca sales in Amsterdam diminished steadily and became unimportant in the 1930s. ${ }^{33}$

\subsection{International Narcotics Control}

As outlined in section 5.6, at the International Opium Convention of The Hague of 19121914 parties agreed to limit the production and trade in opium and to restrict the manufacture of morphine, heroin and cocaine to supply for medical and scientific needs only. The outbreak of World War I resulted in delays in ratification of the treaty and its implementation by most participating countries.

An exception was the USA where the treaty was ratified by the Senate in 1913 and the Harrison Narcotics Tax Act was adopted in $1914 .{ }^{34}$ By the Harrison Act it became unlawful to produce, import and sell opium or coca leaves or any compound or preparation thereof, unless registered with the Government. In the UK, under the Defence of the Realm Act (DORA) in 1916, a regulation was introduced to curb the use of cocaine by soldiers on leave, and other non-medical applications. ${ }^{35}$ This was an ad hoc measure rather than an

\footnotetext{
${ }^{29}$ Coca-Producenten Vereniging (Coca Producers Association), Annual Report (1927) 5.

${ }^{30}$ Ibidem, 8.

${ }^{31}$ P. Brusse, Jaarverslag voor kinabast en Coca (Annual Report for Cinchona bark and Coca) (1928), Library Royal Tropical Institute (KIT) Amsterdam.

32 Anonymous, 'De Nieuwe Opiumwet', Pharmaceutisch Weekblad 65 (1928) 227-233.

${ }^{33}$ See Table JCL 3 (Part III).

${ }^{34}$ W. B. McAllister, Drug Diplomacy in the Twentieth Century (London 2000) 35.

${ }^{35}$ M. Kohn, 'Cocaine girls' Chapter 5 in: P. Gootenberg, editor, Cocaine: Global Histories (London 1999) 105122. The Shipman Inquiry, Chapter 3, A Brief History of the Regulation of Controlled Drugs, Section 3.5 (2004) www. the-shipman-inquiry.org.uk (accessed 29 October 2008).
} 
implementation of the Hague Convention. The same can be said of the regulations in Germany whereby, in 1917, the Pharmacists' Trading Corporation were charged with the control over centralized stocks of drugs including cocaine. Also in Germany one of the reasons for the control was the problem of drug abuse. ${ }^{36}$ Implementation of the Hague convention in a strict sense was affected by the introduction of the Opiumwet ("Opium Act") in the Netherlands in 1919 and the Dangerous Drugs Regulations of 1921 in the UK. ${ }^{37}$ Under these Acts the manufacture, importation, supply and holding of stock was strictly forbidden except for medicinal purposes, and licensed by the authorities. End 1918 the German Demobilisation Office issued an order by which opium and opiates became controlled substances. These regulations were incorporated in an Act of 1920 which included cocaine in the controls, made pharmacists responsible for its distribution for medical purposes and retained the criminal provisions of the order of $1918 .^{38}$

After World War I ended, a large number of countries became party to the Hague Convention through their ratification of the Versailles Treaty, and the supervision of the agreements was entrusted to the newly formed League of Nations. A special "Advisory Committee on Traffic in Opium and Other Dangerous Drugs" (the "Opium Advisory Committee", acronym OAC) was created which laid the ground work for two new conferences on narcotics control to be held in Geneva in 1924-1925. ${ }^{39}$ The first conference was specifically on measures to suppress opium use in the Far East and only parties directly involved were invited. The second had the much broader agenda of implementation of the provisions of the Hague convention and representatives of forty-one governments attended. ${ }^{40}$

The task of the Advisory Committee was a difficult one; the provisions of the Hague Convention were vague, as were the terms of reference of the Committee. ${ }^{41}$ The United States was not a member of the Advisory Committee but participated (forcefully) in the work of the Committee as "consultants". ${ }^{42}$ The basic philosophies on drug control of the various countries involved in the discussions were often diametrically opposed and the American participants led by Congressman Stephen Porter maintained a moralistic dogmatic position on the principles of limitations of use and control on the production of narcotic raw materials. ${ }^{43}$

The deliberations of the delegates at the actual Conference in Geneva were most difficult because of the different views held by the governments and the personalities involved. The American delegation withdrew before the end of the conference. ${ }^{44}$ The remaining delegates managed to agree upon the principles of the Geneva Convention of 1925 which, although lacking in clearly defined procedures, were an important step forward in the direction of a workable system of international narcotics drug control. The main provisions of the Geneva Convention were: creation of the Permanent Central Opium Board (PCOB), a system of import certificates and export authorisations, and restrictions on the trade in coca leaves and controls on processed drugs such as crude cocaine and ecgonine. ${ }^{45}$

In the lead up to the Geneva Conference the Advisory Committee requested quantitative information on the annual production, consumption and stocks of controlled

\footnotetext{
${ }^{36}$ H.R. Friman, 'Germany and the transformations of cocaine, 1860-1920' Chapter 4 in: P. Gootenberg, editor. Cocaine: Global Histories (London 1999) 96-97.

${ }^{37}$ Articles on the "Opiumwet". Pharmaceutisch Weekblad (1919) 1496-1505, 1529-1539. The Shipman Inquiry, Chapter 3, A Brief History of the Regulation of Controlled Drugs, Section 3.5 (2004) www. the-shipmaninquiry.org.uk (accessed 29 October 2008).

${ }^{38}$ H.R. Friman, Chapter 4 in: P. Gootenberg, editor. Cocaine: Global Histories (London 1999) (1999) 96.

${ }^{39}$ K. Bruun, L. Pan and I. Rexed, The Gentlemen's Club - International control of drugs and alcohol (Chicago 1975) 12-13.

${ }^{40}$ McAllister, Drug Diplomacy, 67-69

${ }^{41}$ Brunn c.s. The Gentlemen's Club, 13.

${ }^{42}$ Ibidem.

${ }^{43}$ McAllister, Drug Diplomacy, 65-66.

${ }^{44}$ Ibidem, 76.

${ }^{45}$ Ibidem.
} 
substances and their raw materials from all member countries. Not all governments complied; there was resistance from manufacturing countries to provide the requested information because it was considered to be of a sensitive commercial nature. Reporting of the statistics on controlled substances became more organised under the PCOB and compilations were published annually from the year 1929 onwards. ${ }^{46}$

The Geneva Conference generated publicity which could not be ignored and governments moved, however reluctantly in some cases, to more firm drug control arrangements over the next years. In 1928 members of the Permanent Central Opium Board were nominated and began their task, which was a difficult one because of conflicting interests of governments and the personalities involved. Because of the complexity of the issues, etiological questions such as the impact of social factors on drug use were not discussed. Control of supply by the established producers and manufacturers became the main objective. ${ }^{47}$

To restrict the production of narcotic drugs to medical and scientific purposes strict control measures were required. To obtain agreement of all parties on such measures a further conference was needed. That became the "Conference on the Limitation of the Manufacture of Narcotic Drugs" which was held in Geneva in 1931. There were still considerable differences in opinion between the parties but the consequences of failing to reach an agreement were such that it forced their hands and a compromise solution was found. The main element of the Limitation Conference was a system whereby the signatories would submit annually in advance estimates of the quantities of drugs to be manufactured and to cease production and importing once the estimate was reached. ${ }^{48}$ Viewed from a total world point-of-view the Limitation Treaty turned out to be successful. After implementation of the provisions of the Treaty, drugs manufactured by the legal industry were hardly ever found on the illegal market. ${ }^{49}$ For the Netherlands with a small home market for narcotic drugs, but a sizable export industry, however, the ultimate result was not good. For NCF, the system of import permits issued by governments led ultimately to loss of export markets because several large manufacturing countries, under the pretext of narcotics control, did not issue import permits anymore. In countries having a large home market for cocaine (in Europe e.g. the UK and France), the price was set at a profitable level. That allowed manufacturers in these countries to recover all fixed costs in the home market and to offer additional quantities for export at very low prices. Therefore, in markets that remained open competition became fierce and serious price erosion took place.

An unintended consequence of the new measures was that illegal production facilities were established in countries where the controls were not enforced and thereby a new circuit of illegal trade came into existence. The new measures were effective in controlling the legal production and trade but did not affect the illegal drugs business directly. ${ }^{50}$

\footnotetext{
${ }^{46}$ Permanent Central Opium Board, Annual Report to the Council on the Work of the Board and Statistics for 1929, Document C.629.M.250.1930.XI.

${ }^{47}$ McAllister, Drug Diplomacy, 49-50.

${ }^{48}$ McAllister, Drug Diplomacy, 96.

${ }^{49}$ M. de Kort, 'Doctors, diplomats and businessmen. Conflicting interests in the Netherlands and Dutch East Indies', Chapter 6 in: P. Gootenberg, editor, Cocaine: Global Histories, (London 1999) 74-76.

${ }^{50}$ Nederlandsche Cocaine Fabriek, Letters to Van Wettum, Department of Foreign Affairs (1929) dated

November 6, Nationaal Archief, The Hague, Access No. 2.05.21 Item 1596.
} 


\subsection{The Cocaine Market Worldwide}

\section{Europe 1914-1920}

Just before the outbreak of World War I German manufacturers called a meeting of cocaine manufacturers at Wiesbaden with the objective to re-establish the Cocaine Convention that was abandoned in $1908 .{ }^{51}$ The Convention was established but had little practical effect as shortly after the outbreak of the War an export embargo on essential products came into force in Germany. ${ }^{52}$ As a result, the sales of cocaine by the German manufacturers were strongly reduced because export permits for cocaine were only granted under exceptional circumstances. ${ }^{53}$

How the European cocaine production was affected during the War is best illustrated by the exports of coca leaf from Java because Java coca was the most important raw material by far for the European manufacturers. Until 1914 more than $90 \%$ of all Java coca was exported to the Netherlands where it was sold and re-exported to its final destination, mainly to Germany. Only a small percentage was processed in the Netherlands, by the NCF. Another small fraction went to manufacturers in Switzerland and France.

Figure 7.5 Graph of the Exports of Java Coca to the Final Destinations 1914-1920

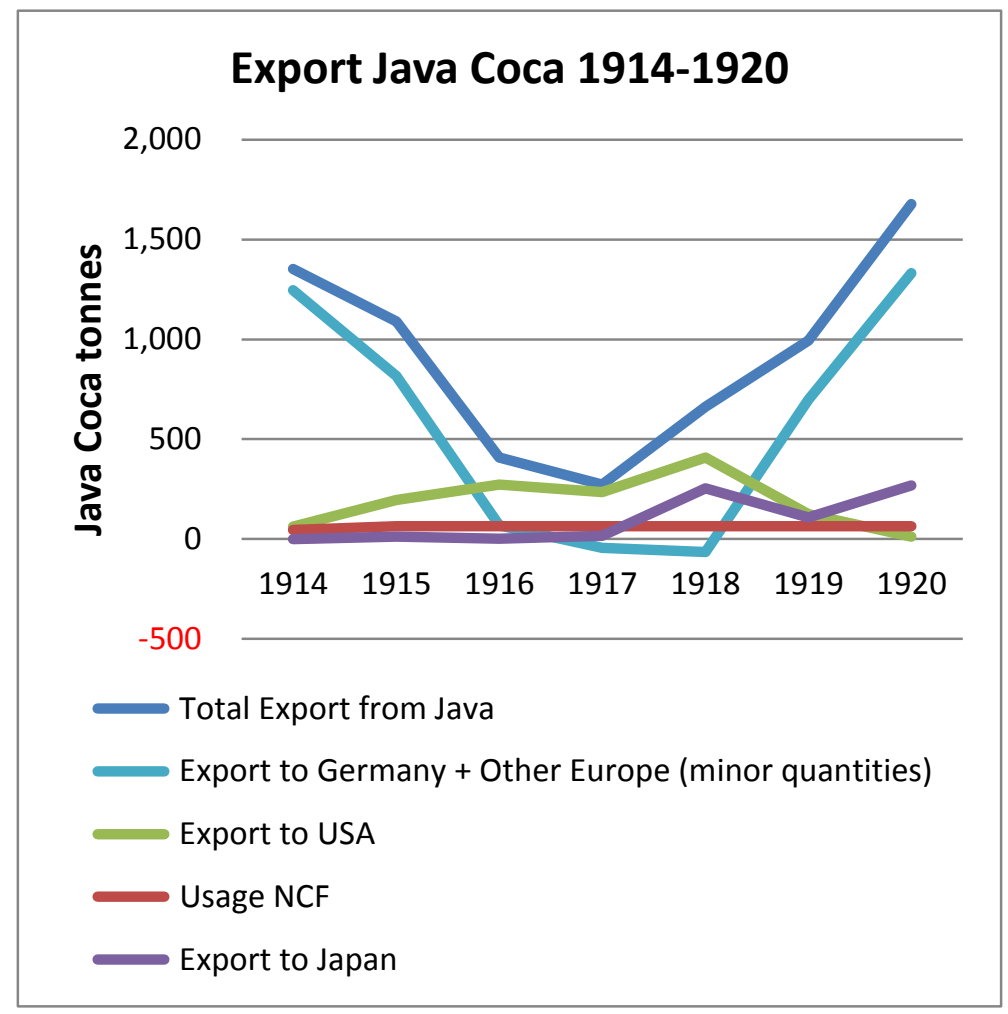

Source: Table $7.5(1914-1920)$

\footnotetext{
${ }^{51}$ Koloniale Bank, Report of Management to the Board, (1914) 6. Nationaal Archief, The Hague, Access No. 2.20.04 Item 58 .

${ }^{52}$ Bernschneider, W.T. Huber, I. Possehl, "Was der Mensch thun kann . . . ." History of the pharmaceutical and chemical company Merck $3^{\text {rd }}$ ed., (Darmstadt 2002), 80.

${ }^{53}$ Merck, Conventionen und Vertretungen, Bericht über das Geschäftsjahr 1915, 8 Merck-Archiv F03/6a.
} 
Table 7.5 and Figure 7.4 show that during 1914 the bulk of the Java coca went to Germany. In 1915 export to the Netherlands were still large but re-export to Germany stalled somewhat and a stock of ca $500 \mathrm{t}$ had accumulated in Amsterdam at year end. The situation changed thereafter because during 1916-1918 shipping from Java to Europe came to a virtual halt. Over the period 1916-1917 European manufacturers covered their raw material requirements from the stocks held in the Netherlands but at the end of 1917 these stocks were exhausted. Manufacture continued in Germany during 1918 including the processing of residues and mother liquors. It is known that Merck manufactured ca 3,000 kg cocaine from such intermediates during 1917-1918. NCF had apparently made arrangements for having sufficient raw material to last until the end of the War.

Direct shipments of coca from Java to the USA commenced during the War and from 1918 substantial quantities went to Japan. Exports via the Netherlands to Germany and the other European countries resumed in 1919 and became large again in 1920.

Reports on actual shortages of cocaine for medical requirements have not been found in the literature. From the figures it appears that during the War sufficient cocaine was available for medical purposes in Europe and also "recreational" use was seemingly not unduly affected.

Also little is known about prices at which cocaine hydrochloride was sold during the War and the period shortly thereafter. Because of the embargo on exports from Germany the Cocaine Convention of 1914 could not increase the price as intended by the members. ${ }^{54}$ The Convention reported that prices remained unchanged during $1915 .{ }^{55}$ However, of the NCF we know that the price for which the cocaine was sold during the latter part of 1914 was very substantially higher than during the earlier part of the year. ${ }^{56}$ Exact prices are not known. In Chapter 18 it is estimated that during the period 1915-1920 the price obtained by NCF was in the order of NLG 360 per kg.

\section{Europe 1921-1924}

In 1920 large quantities of cocaine raw materials, principally Java coca, were shipped from the producer countries allowing for sufficient cocaine production and rebuilding of the War depleted stocks. The price of Java coca that had been high in 1919 came back to a moderate level in 1920, a sure sign that that supply was adequate. Cocaine was manufactured in Germany, Japan, the USA, the Netherlands, France and Switzerland. Incomplete production statistics on cocaine for the years 1920-1923 have been published by the League of Nations. For 1921, in rounded figures, these statistics are ${ }^{57}$

\begin{tabular}{lr} 
Germany & $6,300 \mathrm{~kg}$ \\
Japan & $2,300 \mathrm{~kg}$ \\
USA & $2,300 \mathrm{~kg}$ \\
Switzerland & $700 \mathrm{~kg}$ \\
\hline & $11,600 \mathrm{~kg}$
\end{tabular}

\footnotetext{
${ }^{54}$ Koloniale Bank, Report of Management to the Board (1914) 6. Nationaal Archief, The Hague, Access No. 2.20.04, Item 58 .

${ }^{55}$ Merck, Conventionen und Vertretungen, Bericht űber das Geschäftsjahr (1915) 8 Merck-Archiv F03/6a.

${ }^{56}$ Ibidem.

${ }^{57}$ Ref. Table 7.5.
} 
In 1921 the Netherlands produced ca $1,100 \mathrm{~kg}$ and France probably a few hundred kg. ${ }^{58}$ Hence the total world cocaine production amounted to ca 13 tonnes in that year.

In 1924, manufacturers, members of the newly established Cocaine Convention, agreed that they would not sell cocaine below the agreed minimum price and not knowingly supply cocaine for illegal purposes. They did not restrict the production of the individual members but set up a system by which members would be financially compensated for any differences between quantities actually sold and the allocated quota. ${ }^{59}$

At the establishment of the Convention the NCF received a quota of $20 \%$ and in the period leading up to the establishment NCF produced ca 1,000 kg p.a. This corresponds with a total cocaine production of the members of the convention of $5,000 \mathrm{~kg}$ in $1924 .^{60}$ This figure shows that the market was shrinking rapidly in Europe.

Because manufacturers did not collaborate after the War but strongly competed for volume prices came down considerably. ${ }^{61}$ Specific price information on cocaine is virtually unavailable for the period. In Chapter 18, it is estimated that during 1921-1924 NCF sold cocaine at an average price of approximately NLG 223 per $\mathrm{kg}^{62}$ Because NCF competed mainly on price, this price will have been on the lower end of the range for the period. The price of Java coca increased sharply mid 1922 from 30 cents per unit to an average of 60 cents where it stayed until 1927. For manufacturers the price increase meant that the manufacturing cost of cocaine increased from ca NLG 168 to 258 per kg. ${ }^{63}$ From these figures it follows that profitability of the industry during the years 1921-1924 was low at the beginning and virtually non existent towards the end of the period. As described in Section 7.2 (CPV), the strong price increases of Java coca resulted from an arrangement between growers and importers who had set a minimum price for the product. Initially the coca price was set too high and in 1922 manufacturers resumed buying of crude cocaine from Peru, a raw material that had become competitive again. As a result the growers reduced the coca price somewhat but it remained at a high level until $1927 .{ }^{64}$

\section{Europe 1925-1930}

The quantities of cocaine produced in countries which were signatories to the Geneva Convention of 1925 were reported annually by their governments to the League of Nations. The data were published by the narcotics control body of the League, the Permanent Central Opium Board (PCOB) in 1930. They are summarized in the following table:

\footnotetext{
${ }^{58}$ Rapport du Gouvernement Néerlandais, sur le traffic de l'Opium et autres drogues nuisibles pour les années 1921-1923. Nationaal Archief, The Hague, Access No 2.05.21 Item 1464. Comment on prodution in France: 'In the same order as in the Netherlands", Letter Dr. J.B.M. Coebergh to the "Minister voor Arbeid" dated 10 April 1922. Nationaal Archief, The Hague, Access No 2.05.21 Item 1464.

${ }^{59}$ Letters to Dame Rachel Crowdy (League of Nations) by Van Wettum, Dr Kahler and Dr Carrière, LoN document O.C.1133, dated 16 January 1930, Nationaal Archief, The Hague, Access No 2.05.21 Item 1596.

${ }^{60}$ In 1925 the total sales of the Convention amounted to 4,833 kg cocaine HCl, W. Dethloff, Gründung der Firm und Weiterentwickling der Abteilung Pharmazeutische Chemikalien. (Section on cocaine) Manuscript ca 1957 Ingelheim, Firmen- und Familienarchiv von C.H. Boehringer Sohn.

${ }^{61}$ W. Labohm, 'Uitbreiding Cocacultuur' Mededeelingen van het Nederlandsch-Indisch Landbouw Syndicaat (1922) 26, 91-94.

${ }^{62}$ Chapter 15, Tables 15.16.

${ }^{63}$ The cost formula $\mathrm{C}=3 \mathrm{p}+78$ is used. Ref. Section $7.2(\mathrm{CPV})$.

${ }^{64}$ W. Labohm, 'Uitbreiding Cocacultuur' (1922) XCII.
} 
Table 7.8 League of Nations (PCOB)

Statistics on the Manufacture of Cocaine 1925-1930 ( $\mathrm{kg}$ Cocaine $\mathrm{HCl}$ )

\begin{tabular}{|c|ccccrrr|r|}
\hline Year & Germany & $\begin{array}{c}\text { Nether- } \\
\text { lands }\end{array}$ & France & UK & $\begin{array}{c}\text { Switzer- } \\
\text { land }\end{array}$ & USA & Japan & Total \\
\hline 1925 & 3,300 & 977 & 500 & -- & - & 1,623 & 1,418 & 7,818 \\
1926 & 2,400 & 775 & 500 & -- & 70 & 892 & 1,509 & 6,146 \\
1927 & 2,500 & 692 & 500 & -- & 59 & 1,026 & 1,542 & 6,319 \\
1928 & 2,344 & 668 & 1,100 & 140 & 140 & 818 & 1,420 & 6,630 \\
1929 & 1,826 & 281 & 911 & 238 & 344 & 846 & 1,215 & 5,661 \\
1930 & 1,153 & 135 & 831 & 318 & 328 & 723 & 1,192 & 4,680 \\
\hline
\end{tabular}

Sources: Ref. Table COC 2 (Part III)

The general trend is one of reduction of manufacture, notably in the Netherlands, Germany and the USA. Total world wide production came down from 7,800 kg in 1925 to 4,700 kg in 1930. This was primarily the result of the impact of the control measures agreed upon at the Geneva Conference of 1925: the system of import certificates and export authorisations and newly introduced controls on intermediate products such as crude cocaine and ecgonine. We see, however, an opposite though smaller movement on production in the UK, Switzerland and France. In the UK cocaine manufacture commenced in 1928 and production in Switzerland and France expanded from that year. The explanation of this phenomenon must be that the home markets in these countries became protected resulting in increased sales for the local producers.

To compare the quantities of cocaine produced during 1925-1930 as per the PCOB statistics with the quantities of cocaine manufactured from raw materials as estimated in Chapter 17 it is necessary to adjust the estimates for the stocks of Java coca held in the Netherlands at year end. For the estimates in Chapter 17 it has been assumed that all raw materials, including coca leaf exported from Java, were shipped directly to the countries where they were to be processed. However, Java coca was to a very large extent first shipped to the Netherlands where it was sold and then re-exported to the manufacturing countries. Not all Java coca was re-exported in the same year it arrived in the Netherlands and occasionally quite large stocks of the coca accumulated in the Netherlands at year end. To allow for a good comparison of the estimates with the PCOB figures, the estimates are corrected for the variations in the stocks held at year end. ${ }^{65}$ The results of the calculations appear in the following table and graph:

\footnotetext{
${ }^{65}$ Ref. Table 7.4.
} 
Table 7.9 and Figure 7.6 Cocaine Manufactured Worldwide

Estimates Compared with PCOB Statistics 1925-1930

\begin{tabular}{|c|c|c|c|c|c|}
\hline $\begin{array}{c}\text { Year } \\
\text { of } \\
\text { Manufacture }\end{array}$ & $\begin{array}{c}\text { Estimated } \\
\text { Manufacture } \\
\text { Worldwide } \\
\text { Chapter } 17 \\
\text { kg Cocaine } \mathrm{HCl} \\
\text { [1] }\end{array}$ & $\begin{array}{l}\text { Exported } \\
\text { from Java } \\
\text { to the } \\
\text { Netherlands } \\
\text { t Coca } \\
\text { [2] }\end{array}$ & $\begin{array}{c}\text { Re- } \\
\text { Exported } \\
\text { from the } \\
\text { Netherlands } \\
\text { t Coca } \\
\text { [3] }\end{array}$ & $\begin{array}{c}\text { Estimated } \\
\text { Manufacture } \\
\text { Worldwide } \\
\text { Adjusted } \\
\text { kg Cocaine HCl } \\
\text { [4] }\end{array}$ & $\begin{array}{c}\text { Reported } \\
\text { Manufacture } \\
\text { Worldwide } \\
\text { PCOB } \\
\text { kg Cocaine HCl } \\
\text { [5] }\end{array}$ \\
\hline $\begin{array}{l}1925 \\
1926 \\
1927 \\
1928 \\
1929 \\
1930\end{array}$ & $\begin{array}{r}11,875 \\
12,808 \\
9,020 \\
5,962 \\
7,949 \\
5,556\end{array}$ & $\begin{array}{l}657 \\
763 \\
436 \\
307 \\
396 \\
252\end{array}$ & $\begin{array}{r}172 \\
313 \\
158 \\
1,037 \\
221 \\
111\end{array}$ & $\begin{array}{r}6,589 \\
7,903 \\
5,990 \\
13,919 \\
6,041 \\
4,019\end{array}$ & $\begin{array}{l}7,818 \\
6,146 \\
6,319 \\
6,630 \\
5,661 \\
4,680\end{array}$ \\
\hline & Notes and Sources & $\begin{array}{l}{[2} \\
{[3}\end{array}$ & $\begin{array}{l}\text { Table } 17.11 \\
\text { Table } 7.4 \\
\text { Table } 7.4\end{array}$ & \multicolumn{2}{|c|}{$\begin{array}{l}{[4]=[1]-([2]-[3]) * 10.9} \\
{[5] \text { Table } 7.9}\end{array}$} \\
\hline
\end{tabular}

Figure 7.6

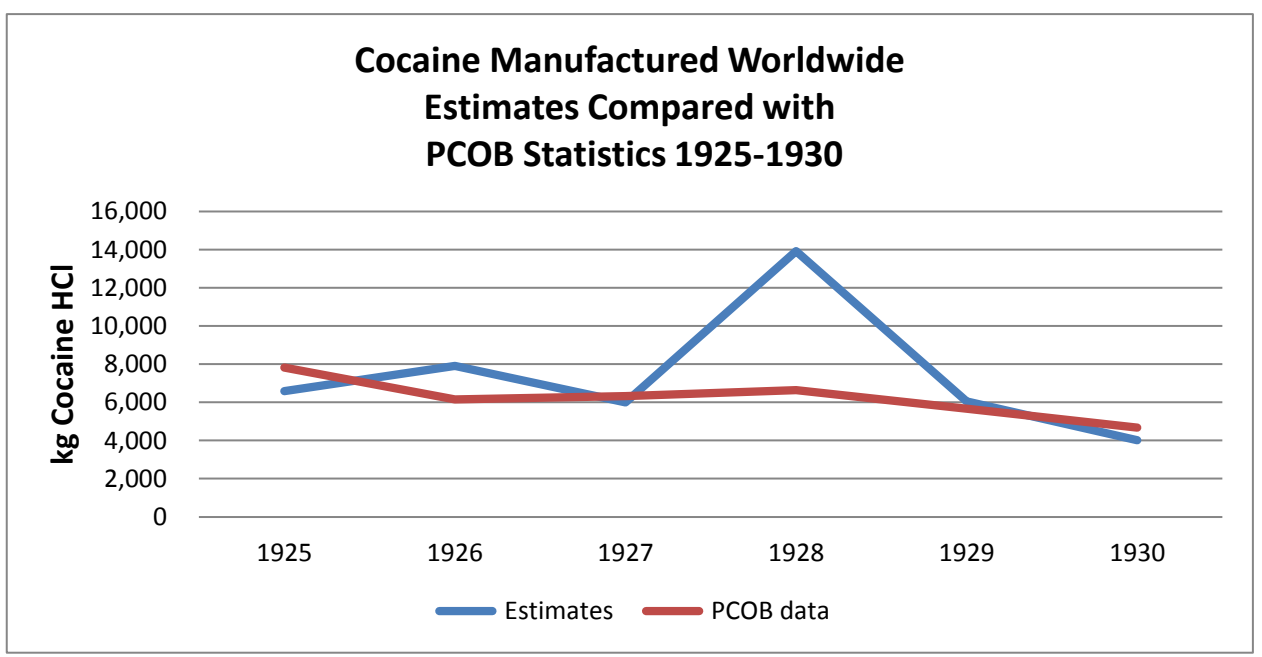

The picture emerging from the graph is that except for the year 1928 the estimates and the PCOB data are in good agreement. This provides evidence that the estimates are realistic.

The peak in the graph for 1928 is the result of the very large amount of ca $800 \mathrm{t}$ of Java coca which was re-exported from the Netherlands to Germany just before the Dutch Opium Act of 1928 came into force. It is quite possible that a major part of the $800 \mathrm{t}$ went into the (semi)illicit trade. ${ }^{66}$

The Cocaine Convention of manufacturers established in 1924 functioned well and from 1925 cocaine prices were set at a profitable level. In 1926 that price was DEM 750 (NLG 450) but was reduced again in 1927: firstly to DEM 600 (NLG 360) and later in the year to DEM 500 (NLG 300) where it stayed until 1930. The price of Java coca followed the cocaine price on the basis of the contractual agreement with the Coca Producers Association (ref. Section 7.2).

\footnotetext{
${ }^{66}$ K. Bruun, L. Pan and I. Rexed, The Gentlemen's Club - International control of drugs and alcohol (Chicago 1975) 14 note in this context: "During this same period [1924-1931] there was much public alarm at overproduction by drug manufacturers and massive diversion from legal supply channels".
} 
From 1926 some Convention members, NCF among them, made a crude cocaine from Java coca. Dr Kramers described this "Java crude" as "artificial" because it was a semi-synthetic product. ${ }^{67}$ The reason for the introduction of Java crude must have been that because the sales of cocaine $\mathrm{HCl}$ by the Convention declined sharply from 1925 (cf. Table 7.10) manufacturers were in need of an alternative outlet for cocaine. They found such outlet by making Java crude which could be sold in competition with Peru crude. Separate quota for crude cocaine were allocated to the Convention members. ${ }^{68}$ The Java crude was mainly sold to the Soviet Union. ${ }^{69}$

Sales of cocaine $\mathrm{HCl}$ and crude cocaine by the members of the Cocaine Convention appear in the following table together with the statistics of cocaine $\mathrm{HCl}$ manufactured in Europe as reported by governments to the PCOB.

Table 7.10 PCOB Statistics Manufactures Cocaine Europe Compared with Sales by the Convention 1925-1930 (kg)

\begin{tabular}{|c|c|c|c|}
\hline \multirow[b]{2}{*}{ Year } & \multirow{2}{*}{$\begin{array}{c}\text { Manufacture } \\
\text { Europe (PCOB) } \\
\text { Cocaine } \mathrm{HCl}\end{array}$} & \multicolumn{2}{|c|}{ Sales by the Convention } \\
\hline & & $\begin{array}{c}\text { Cocaine } \\
\mathrm{HCl}\end{array}$ & $\begin{array}{l}\text { Crude } \\
\text { Cocaine }\end{array}$ \\
\hline 1925 & 4,777 & 4,833 & -- \\
\hline 1926 & 3,745 & 3,659 & -- \\
\hline 1927 & 3,751 & 3,391 & -- \\
\hline 1928 & 4,392 & 3,867 & 730 \\
\hline 1929 & 3,600 & 2,754 & 303 \\
\hline 1930 & 2,765 & 2,516 & 1,005 \\
\hline
\end{tabular}

Sources: PCOB. Ref. Table 7.8, Totals for Europe

Sales Convention: W. Dethloff, Gründung der Firm (Section on cocaine)

The figures are reasonably close for 1925-1926. It appears that a few "outsiders" supplied a minor part of the market from 1927.

\section{The US Market during 1914-1930}

The US market functioned largely independently from Europe except that both markets were heavily affected by narcotic control measures by the local governments and by the newly formed League of Nations. From 1922 onwards importation of cocaine was entirely prohibited by the US government under the Jones-Miller Act. ${ }^{70}$ The developments in US market are best understood by reviewing the imports of Peru coca and Java coca. These imports are summarised in the following table and graph. The data cover the total period 1914-1930 and show the large break that occurred at the end of the first sub-period 19141920.

\footnotetext{
${ }^{67}$ Statement by Dr Kramers during a meeting at the Department of Trade (Departement van Handel).held on 20 October 1930. Nationaal Archief, The Hague, Access No 2.05.21 Item 1596.

${ }^{68}$ W. Dethloff, Gründung der Firm und Weiterentwicklung der Abteilung Pharmazeutische Chemikalien. (Section on cocaine) Manuscript ca 1957 Ingelheim, Firmen- und Familienarchiv von C.H. Boehringer Sohn.

${ }^{69}$ Statement by Dr Kramers during a meeting at the Department of Trade held on 20 October 1930.

${ }^{70}$ See e.g. J.A. Incardie, Handbook on Drug Control in the US (Conneticut, 1990).
} 
Table 7.11 Import Coca Leaf into the USA 1914-1930 (tonnes)

\begin{tabular}{|c|c|c|c|c|c|}
\hline & $\begin{array}{l}\text { Calendar } \\
\text { Year of } \\
\text { Import }\end{array}$ & $\begin{array}{c}\text { Import } \\
\text { USA } \\
\text { Total } \\
\text { Coca } \\
\text { [1] }\end{array}$ & $\begin{array}{l}\text { Import } \\
\text { USA } \\
\text { Java } \\
\text { Coca } \\
\text { [2] }\end{array}$ & $\begin{array}{l}\text { Import } \\
\text { USA } \\
\text { Peru } \\
\text { Coca } \\
\text { [3] }\end{array}$ & $\begin{array}{c}\text { USA } \\
\text { Peru Coca } \\
\text { to Cocaine } \\
{[4]}\end{array}$ \\
\hline & 1914 & 399 & 69 & 330 & 243 \\
\hline & 1915 & 453 & 179 & 274 & 187 \\
\hline & 1916 & 359 & 260 & 99 & 12 \\
\hline & 1917 & 384 & 231 & 153 & 66 \\
\hline & 1918 & 611 & 476 & 135 & 48 \\
\hline & 1919 & 361 & 185 & 176 & 89 \\
\hline & 1920 & 288 & 90 & 198 & 111 \\
\hline & 1921 & 47 & 37 & 10 & -41 \\
\hline & 1922 & 67 & 23 & 44 & -7 \\
\hline & 1923 & 157 & 63 & 94 & 43 \\
\hline & 1924 & 59 & 59 & -0 & -51 \\
\hline & 1925 & 72 & 30 & 42 & -9 \\
\hline & 1926 & 132 & 71 & 61 & 10 \\
\hline & 1927 & 130 & 46 & 84 & 33 \\
\hline & 1928 & 96 & 40 & 56 & 5 \\
\hline & 1929 & 55 & 3 & 52 & 1 \\
\hline & 1930 & 90 & 22 & 68 & 17 \\
\hline Average & 1914-1920 & 408 & 213 & 195 & 108 \\
\hline Average & $1921-1930$ & 91 & 40 & 51 & 0 \\
\hline Average & 1914-1930 & 221 & 111 & 110 & 45 \\
\hline
\end{tabular}

Sources: [1] Table 16.8 Column [9]

[2] Table 16.9 Column [21]

$[3]=[1]-[2]$

[4] 1914-1920 [4] $=[3]-87$ (average to Coca Cola) $1921-1930[4]=[3]-51$ (average to Coca Cola) 
Figure 7.7 Graph of Import Coca Leaf into the USA 1914-1930

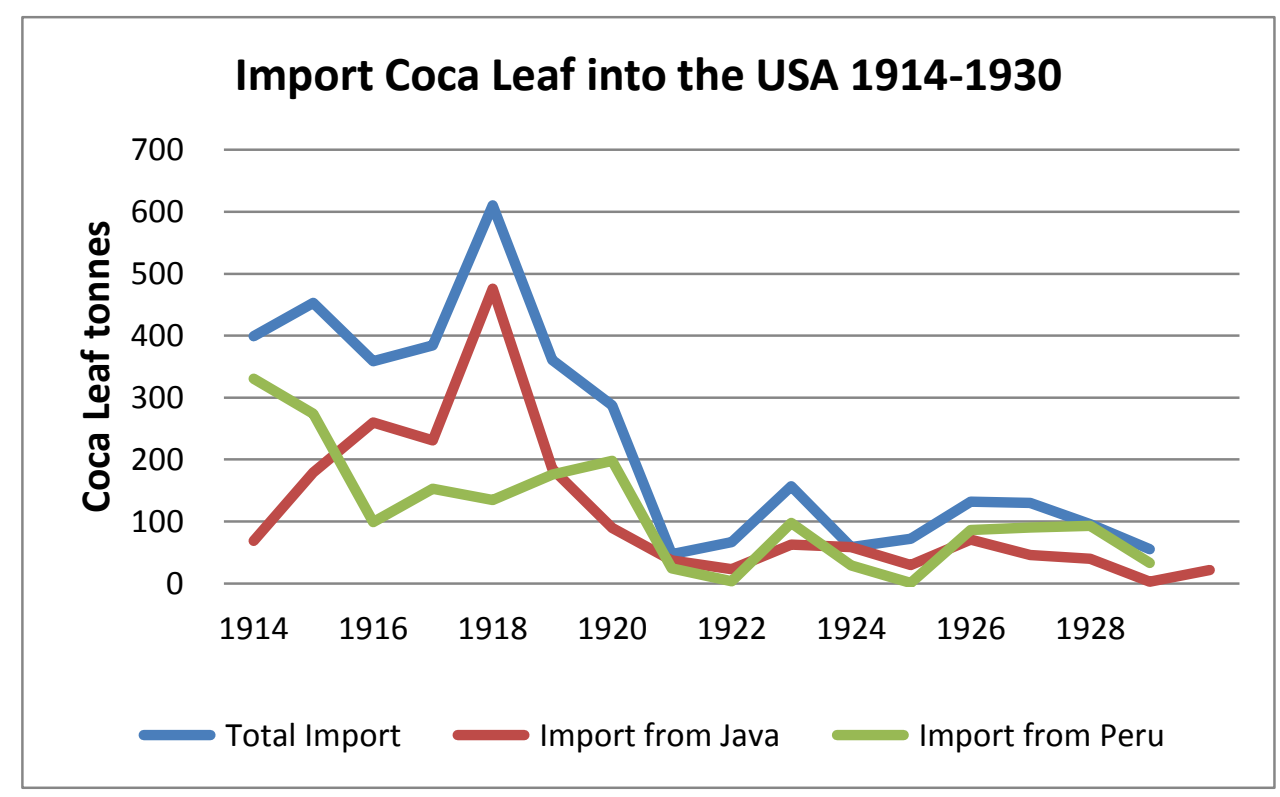

Source Table 7.11

Table 7.11 and Figure 7.7 show that during 1921-1930 the imports were on average only ca $25 \%$ of those during 1914-1920. The two factors which are very likely behind the large difference in import levels are: the surmised building of substantial strategic stocks of coca leaf in the USA during World War I and the coming into force of "The Narcotics Drugs and Export Act of 1922" (the Jones-Miller Act) by which importation of cocaine and its raw materials became illegal in the USA, except for "legitimate medical use". The amounts of cocaine contained in the quantities of Java coca imported into the USA during the period 1915-1918 is so large that it seems improbable that all imported coca leaf was processed into cocaine shortly after importation. It seems more likely that a substantial part of the stock was processed much later, viz. after the end of the War. ${ }^{71}$ As a result, the amounts of cocaine equivalent to the imports as appearing for coca leaf into the USA in Table 7.2 suggest a larger production than actual for the year during the period 1914-1920 and the reverse is the case during the period 1921-1930. The production during the latter period will have been low anyhow as a result of the Jones-Miller Act but not as low as the $500 \mathrm{~kg}$ average calculated in Table 7.2.

Column [3] of Table 7.11 shows that the average quantity of Peru coca imported during 1921-1930 was 51 metric tonnes p.a. That figure is close to the $66 \mathrm{t}$ p.a. estimated in Table 17.8 for the usage of Peru coca for beverages during the total period 1914-1930. ${ }^{72}$ From the figures it is concluded that after 1920 coca leaf from Peru was imported into the USA exclusively for making the flavouring extract for Coca-Cola. ${ }^{73}$ The $66 \mathrm{t} \mathrm{p}$.a. for the period 1914-1930 together with the $51 \mathrm{t}$ p.a. for 1921-1930 equates to a $87 \mathrm{t}$ p.a. average for 1914-1920. Deducting the sub-period averages from the total imports from Peru results in the figures of column [4] showing a $108 \mathrm{t}$ p.a. usage of Peru coca for making cocaine during 1914-1920 and zero thereafter.

\footnotetext{
${ }^{71}$ It is also possible that the coca leaf was extracted shortly after importation (to prevent degradation of the leaf) and that the (stable) alkaloids were stored as an intermediate product until required.

${ }^{72}$ The $66 \mathrm{t}$ p.a. was estimated in an entirely different way from the $59 \mathrm{t}$. That the figures are so close provides support for their correctness.

${ }^{73}$ Preparation of coca leaves which do not contain cocaine were specifically exempted from the provisions of the Harrison Act of 1914.
} 
Using the figures of Table 7.11 the amounts of cocaine manufactured in the USA from the various raw materials imported during 1914-1930 were calculated. These are presented in Table 7.12 together with the statistics collected and published by the League of Nations (OAC and PCOB) on the US cocaine manufacture during 1921-1930. As mentioned above, the figures show that the amounts of cocaine which were manufactured from the raw materials shipped to the USA during the period 1915-1918 are large compared to those of the earlier period. This appears unlikely, the more so as the Harrison Narcotics Tax Act, which intended to reduce cocaine use, and thereby manufacture, came in force at the end of 1914. The large quantities of Java coca imported during the war must have been used to build a strategic stock rather than being processed shortly after arrival.

Table 7.12 and Figure 7.8 Estimates of Cocaine Manufactured

From Cocaine Raw Materials Imported into the USA compared

With League of Nations (OAC/PCOB) Production Data 1914-1930

\begin{tabular}{|c|c|c|c|c|c|c|c|}
\hline & \multirow{2}{*}{$\begin{array}{l}\text { Calendar } \\
\text { Year of } \\
\text { Import }\end{array}$} & \multicolumn{5}{|c|}{ kg Cocaine $\mathrm{HCl}$ Manufactured from } & \multirow{2}{*}{$\begin{array}{c}\text { Production } \\
\text { Calendar } \\
\text { Year } \\
\text { (League) } \\
\text { [6] }\end{array}$} \\
\hline & & $\begin{array}{c}\text { Java } \\
\text { Coca } \\
{[1]}\end{array}$ & $\begin{array}{c}\text { Peru } \\
\text { Coca } \\
{[2]}\end{array}$ & $\begin{array}{c}\text { ex Peru } \\
\text { Coca-Cola } \\
\text { [3] }\end{array}$ & $\begin{array}{c}\text { Crude } \\
\text { Cocaine } \\
{[4]}\end{array}$ & $\begin{array}{c}\text { Total } \\
\text { Imported } \\
{[5]}\end{array}$ & \\
\hline & 1914 & 752 & 1,459 & 348 & 142 & 2,701 & \\
\hline & 1915 & 1,951 & 1,121 & 348 & 142 & 3,562 & \\
\hline & 1916 & 2,834 & 72 & 348 & 142 & 3,396 & \\
\hline & 1917 & 2,518 & 397 & 348 & 142 & 3,405 & \\
\hline & 1918 & 5,188 & 285 & 348 & 142 & 5,964 & \\
\hline & 1919 & 2,017 & 532 & 348 & 142 & 3,038 & \\
\hline & 1920 & 981 & 664 & 348 & 142 & 2,135 & \\
\hline & 1921 & 403 & -245 & 204 & 142 & 505 & 2,311 \\
\hline & 1922 & 251 & -43 & 204 & 142 & 553 & 1,656 \\
\hline & 1923 & 687 & 257 & 204 & 0 & 1,148 & 1,623 \\
\hline & 1924 & 643 & -307 & 204 & 0 & 541 & \\
\hline & 1925 & 327 & -54 & 204 & 0 & 477 & 1,623 \\
\hline & 1926 & 774 & 62 & 204 & 0 & 1,040 & 892 \\
\hline & 1927 & 501 & 199 & 204 & 0 & 904 & 1,026 \\
\hline & 1928 & 436 & 29 & 204 & 0 & 669 & 818 \\
\hline & 1929 & 33 & 9 & 204 & 0 & 245 & 845 \\
\hline & 1930 & 240 & 104 & 204 & 0 & 548 & 723 \\
\hline Average & 1914-1920 & 2,320 & 647 & 348 & 142 & 3,457 & \\
\hline Average & $1921-1930$ & 429 & 1 & 204 & 28 & 663 & 1,280 \\
\hline Average & $1914-1930$ & 1,208 & 267 & 263 & 75 & 1,814 & \\
\hline
\end{tabular}

Sources and Notes:

[1] = Table $7.11[2] * 10.9$

[2] = Table $7.11[4] * 6$

[3] 1914-1920: $87 * 4=348$

1921-1930: $51 * 4=204$

[4] 1914-1922: $168 * 0.845=142$

$[5]=[1]+[2]+[3]+[4]$
[1], [2], [3] and [4] are quantities of raw material multiplied by yield factors (see text)

Table 17.9

[6] Table COC 1 (Part IV) 
Figure 7.8

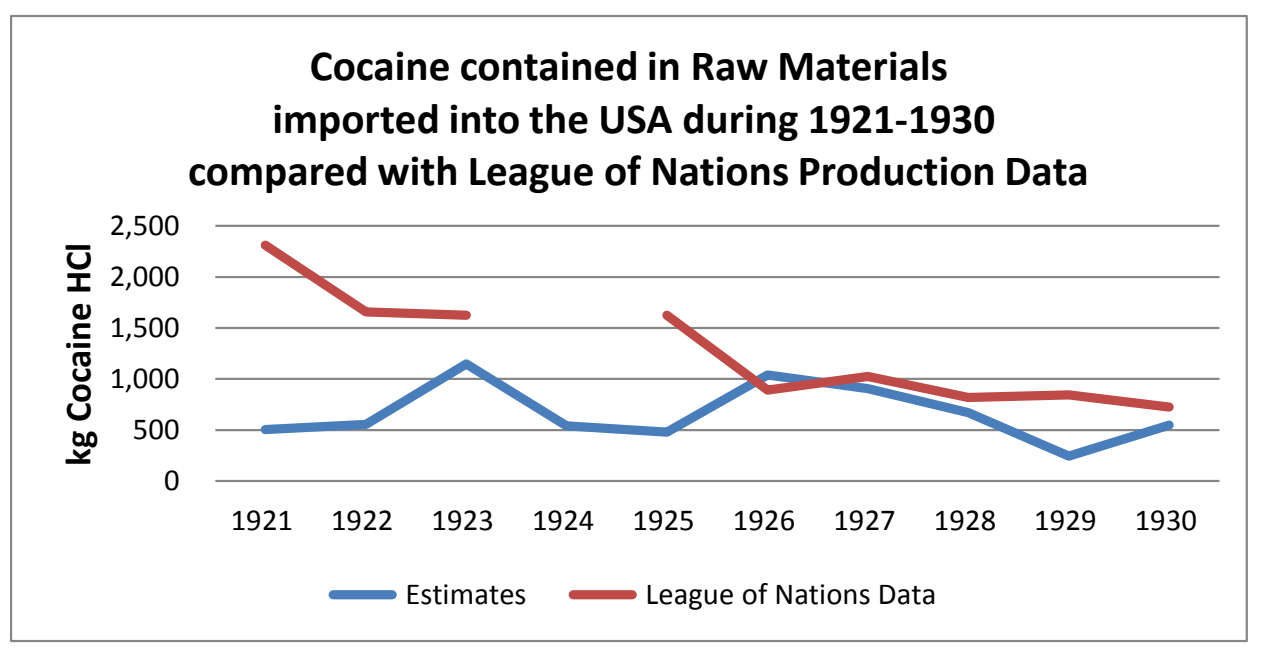

Source: Table 7.12

In the graph we see that the League of Nations statistics are much larger than the estimates for the years before 1926, thereafter they are reasonably close, except for 1929. The likely explanation for the differences, i.e. that the large stocks of coca leaf accumulated during the war years were processed much later, is discussed above. The difference for 1929 remains puzzling, however.

Accepting the above explanation implies that the average production of cocaine in the USA during 1914-1920 was ca 2,300 kg p.a. and during 1921-1930 ca. 1,300 kg p.a. instead of 3,300 and $500 \mathrm{~kg}$ p.a. respectively as calculated in Table 7.2. The first set of figures is more believable as the decline in production is much less abrupt than for the second set. The first set is also more in line with the US average cocaine production of ca $800 \mathrm{~kg}$ during the next period 1931-1935. ${ }^{74}$

\section{Japan 1920-1930}

During World War I the cocaine requirements of Japan were largely supplied by $\mathrm{NCF}^{75}$ However, small quantities of Java coca were imported from 1915 and large quantity $(254 \mathrm{t})$ in 1918 (Table JCL 3). This was sign that Japan had commenced local production of cocaine. ${ }^{76}$ Imports of Java coca became quite large in the mid-1920s but tapered off to almost nil at the end of the decade. League of Nations statistics on the cocaine production in Japan are available from 1920. The data are brought together in the following Table 7.13.

\footnotetext{
${ }^{74}$ PCOB, Report to the Council, C.368.M.242.1936.XI.

75 'De Nederlandsche Cocaine Fabriek NV', Pharmaceutisch Weekblad 76 (1939) 796-802.

${ }^{76}$ S.B. Karch, in chapter 15 'Japan's Adventures in the Cocaine Trade', on pages 147-160 of A Brief History of Cocaine $2^{\text {nd }}$ Ed (Boca Raton 2006) describes in detail how the Japanese cocaine was established and how it continued. Unfortunately he refers in a mostly non-specific way, to not easily accessible US documents. Karch does not refer to any publications by the PCOB or any other League of Nations body involved in international narcotics control.
} 
In the table the yield of cocaine from Java coca is calculated for the years 1920-1927; the average yield is $8.5 \mathrm{~kg} / \mathrm{t}$, an acceptable figure. From 1928 onwards other raw materials must have been used; for the year $1929775 \mathrm{~kg}$ crude cocaine was imported from Formosa. ${ }^{77}$

Table 7.13 Cocaine manufacture Japan 1920-1930

\begin{tabular}{|c|cccc|}
\hline Year & $\begin{array}{c}\text { Cocaine } \\
\text { Manufacture } \\
\text { kg } \\
\text { [1] }\end{array}$ & $\begin{array}{c}\text { Java coca } \\
\text { Import } \\
\text { tonnes } \\
\text { [2] }\end{array}$ & $\begin{array}{c}\text { Yield } \\
\text { from } \\
\text { Java coca } \\
\mathbf{k g / t} \\
\text { [3] }\end{array}$ & $\begin{array}{c}\text { Crude } \\
\text { Cocaine } \\
\text { Import } \\
\mathbf{~ k g} \\
\text { [4] }\end{array}$ \\
\hline & & & & \\
1920 & 4,100 & 269 & 15 & \\
1921 & 2,324 & 456 & 5 & \\
1922 & 3,680 & 364 & 10 & \\
1923 & n/a & 365 & & \\
1924 & 1,479 & 307 & 5 & \\
1925 & 1,418 & 175 & 8 & \\
1926 & 1,509 & 200 & 8 & \\
1927 & 1,542 & 179 & 9 & \\
1928 & 1,420 & 25 & & \\
1929 & 1,215 & 42 & & \\
1930 & 1,192 & -- & & \\
\hline
\end{tabular}

Sources and Notes: [1] Table COC 1

[2] Table JCL 3

[3] $=[1] /[2]$, Average yield 1920-1927: $8.5 \mathrm{~kg} / \mathrm{t}$

[4] $675 \mathrm{~kg}$ export from Formosa. PCOB. Statistics for 1929, C.629.M.250.1930.XI

Japan does not appear to have exported any cocaine; therefore there was no direct interaction with other manufacturers in the world market.

\footnotetext{
${ }^{77}$ Karch 1.c., on p 153-159, discusses statistics of the Japanese cocaine production. His calculations are difficult to follow and can mostly not be checked because of the lack of specific references. His figure on the cocaine $(\mathrm{HCl})$ production in 1929 of $320 \mathrm{~kg}$ (p 158) is at odds with the PCOB figure of 1,215 kg . His "Figure 15.4" (p 159) deals with an undated document, reportedly filed with the League of Nations, dealing with the supply of $750 \mathrm{~kg}$ crude cocaine base by Formosa to Japan during a (unknown) period of 6 months. Karch qualifies Japan's presentations to the League of Nations as "fanciful". Karch does not seem to know that cocaine pure end product $(\mathrm{HCl})$ was reported to the League $(\mathrm{PCOB})$ separately from the raw material 'crude cocaine base'. Karch's calculations on cocaine production 1927 (p 155) provide an, in his opinion "realistic", estimate of 7 tons "purified cocaine" from 684 acres of coca cultivation. A, in the opinion of the author more realistic estimate is 684 acres $\times 0.4=274$ ha, yielding $274 \times 0.7 \mathrm{t}=191$ metric tonnes coca leaf (close to Karch's rejected figure of 205 metric tonnes). $191 \mathrm{t}$ coca leaf of Java quality would yield $191 \times 8.5 \mathrm{~kg} / \mathrm{t}=$ $1,624 \mathrm{~kg}$, say, $1,600-1,700 \mathrm{~kg}$ pure cocaine $\mathrm{HCl}$.

NB: the 4 harvests mentioned by Karch are probably preferential harvests of young leaves (which have a higher alkaloid content), spread over the year. This was also done on Java ("fijnpluk") but reported yield figures mean commonly total annual yields.
} 


\subsection{Summary and Conclusions}

The cocaine industry went through three very different periods viz. firstly World War I, then a period of resumption of competitive business and finally one characterised by the collaboration within the Cocaine Convention and the impact of international narcotic control measures. Worldwide production of cocaine declined from 1914 onwards; until 1919 as a result of the War and increasingly thereafter because of restrictions pursuant to controls initiated by the League of Nations. By 1930 the legal cocaine market had shrunk to ca 30 per cent of its peak in 1913 and had become of limited commercial interest to manufacturers, especially for those located in countries with a small home market. 


\title{
Chapter 8 \\ Culmination of Cocaine Production at the NCF THE PERIOD 1914-1930
}

\subsection{NCF Overview, Organisation and Marketing}

\begin{abstract}
Overview
For NCF the period 1914-1930 was a most eventful and challenging one. While operating in a depressed cocaine market at the beginning of 1914, the outbreak of World War I changed the situation completely by opening markets inaccessible to NCF before. This led to substantially increased sales and to an expansion of the factory that doubled its capacity. After the War competition returned into the market and a few meagre years followed for NCF, but re-establishment of the European Cocaine Convention in 1924 restored profitability. The Geneva Conference of 1925 resulted in a much restricted market for the legal cocaine manufacturers which meant for NCF that after 1930 it had to diversify to remain economically viable.
\end{abstract}

\section{Legal and Organisational}

In 1910, after the nominal share capital was increased to NLG 32,400, the shares were held as follows: J. van Hengst 20, the Koloniale Bank 10, and G. Boldemann and O. Eberhard 3 each. Van Hengst died in 1910 or 1911 and his 20 NCF shares were passed on as part of the estate to his widow Jenny van Hengst née Huygen de Raat. ${ }^{1}$ By 1934 these shares were owned by Miss Laurine Maarschalk, a friend of Jenny van Hengst. ${ }^{2}$ When the transfer of ownership of the shares took place is not known. Mrs J. van Hengst died in 1935. Miss Maarschalk remained the major shareholder of the NCF until her death in 1946.

Already in 1912 Miss Maarschalk had been appointed proxy for Mrs. van Hengst as shareholder and board member of Soekamadjoe. ${ }^{3}$ In the same year Miss Maarschalk became a board member of Soekamadjoe in her own right.

The Koloniale Bank retained its shares and remained the Managing Partner during the period 1914-1930 and beyond. In 1918 NCF Board Members were A. Roelvink, G. Bolderman, C. van Eeghen, Mr P.H. Fromberg and J.H. Zeeman. ${ }^{4}$

The Koloniale Bank had quite an involvement in the coca industry as a whole during the period. The Bank was trading considerable quantities of coca leaf in consignment, was managing partner of the NCF, majority shareholder in Soekamadjoe, and was Chairman of the Executive Committee of the Coca Producers Association. ${ }^{5}$ However, in the minutes of the Board Meetings of the Koloniale Bank the NCF and Soekamadjoe are not often mentioned. The Koloniale Bank apparently used its Board membership of the NCF and administrative

\footnotetext{
${ }^{1}$ In the Minutes of the Board Meeting of the Koloniale Bank of 24 April 1931, Mrs Van Hengst is mentioned as having the right to nominate a NCF Board Member.

${ }^{2}$ Nederlandsche Cocaïne Fabriek Notulenboek, Commissaris vergaderingen (Minutes of Board Meetings (19341950), Meeting of 20 August 1934). Original Manuscript, in the possession of Hans Bosman. Koloniale Bank, Report inzake N.V. Nederlandsche Cocaine Fabriek (1945) November 26, Nationaal Archief, The Hague, Access No. 2.20.04 Item 928. In 1915 Miss Maarschalk and Mrs van Hengst lived at the same address, Prins Mauritslaan 86, The Hague. Naamlijst voor den Telefoondienst, January 1915. http://dewit.net/bronnen/tel1915/index.htm.

${ }^{3}$ Soekamadjoe, Minutes of the Board Meeting of 12 July 1912, Nationaal Archief, Access No. 2.20.04.

${ }^{4}$ Van Nierop \& Baak, Naamloze Vennootschappen, (1918).

${ }^{5}$ Koloniale Bank, Jaarverslagen (Annual Reports) 1889-1935. Nationaal Archief, Access No. 2.20.04, Items 47; Coca-Producenten Vereniging (Coca Producers Association), Annual Report 1925 Nationaal Archief, The Hague, Access No. 2.20.04 Item 1643.
} 
controls to meet its obligations as managing partner. It seems that the Koloniale Bank had a philosophy of decentralised management and that both NCF and Soekamadjoe were quite independent in making the day-to-day decisions for running the business.

Dr Kramers, the Technical Director, who had his office at the factory, was in fact what would be called today the Chief Executive Officer, responsible for all operations, research and sales activities. In 1913 Ir. M.J. Weidema, a young chemist, graduate of the Delft Technical University, was employed as his assistant. At a later stage Ir. Weidema became Chief Chemist of the company, a function that made him head of the laboratory and included responsibility for the chemical production activities, tasks he retained until his retirement in 1960.

\section{Marketing 1914-1920}

The first half of 1914 brought a continuation of the bad market conditions of the year before and cocaine prices were hardly sufficient to cover NCF's production costs. The outbreak of the War changed the situation entirely; prices on the world market increased sharply and the resulting profits allowed NCF to pay a dividend of $20 \%$ over 1914. In June 1914 NCF was invited to discussions with German manufacturers on the resurrection of the Cocaine Convention. ${ }^{6}$ The Convention was established with NCF as one of the participants but because of the outbreak of the War in August not much could be achieved. As in Germany, also in the Netherlands the outbreak of the War gave rise to export restrictions for cocaine but they were waived because of substantial stocks at NCF. ${ }^{7}$ NCF remained in contact with Gehe and Merck, and Dr Kramers travelled to Dresden and Darmstadt for discussions later in 1914. ${ }^{8}$ The NCF had a contract with the Convention whereby NCF supplied the cocaine to Gehe. In 1915, "because of the special circumstances", the Convention allowed the NCF to supply the cocaine directly to Gehe's customers. NCF made a good profit on these transactions, especially in England, but the Convention did not approve NCF supplying more than its quota. ${ }^{9}$ In another document it is stated that at the time no cocaine was manufactured in England and Japan and that NCF supplied virtually the total cocaine requirements of these countries during the War. ${ }^{10}$

In reports to the Board, management of the Koloniale Bank judged the financial results achieved by the NCF for the years 1914-1917 as most satisfactory. ${ }^{11}$

Direct information on the quantities of cocaine hydrochloride produced by NCF during the years 1914-1920 is not available. In Chapter 18 a method for making estimates is developed of the volume of cocaine sold and the price thereof on the basis of the financial results of the company and estimates of the various cost factors. For the period 1915-1920 the method resulted in an estimate for the sales of in the order of $700 \mathrm{~kg}$ cocaine hydrochloride per annum at an average price of ca NLG 360 per $\mathrm{kg}$.

\footnotetext{
${ }^{6}$ Koloniale Bank, Notulen Commissarissen Vergaderingen (Minutes of Board Meetings) Meeting of 18 November 1914, Nationaal Archief, The Hague, Access No. 2.20.04, Item 17.

${ }^{7}$ Letter NCF to the 'Minister van Landbouw, Nijverheid en Handel' dated 25 August 1914 and correspondence between the 'Ministerie van Arbeid' and the 'Ministerie van Oorlog' of 28 August 1914. National Archief - The Hague, Access No. 2.06.01. M. de Kort, Tussen patiënt en delinquent, geschiedenis van het Nederlandse drugsbeleid. (Between patient and delinquent, the history of drug policy in the Netherlands); Dissertation University of Erasmus, Rotterdam (Hilversum 1995) 61, 297.

${ }^{8}$ Koloniale Bank, Notulen Commissarissen Vergaderingen (Minutes of Board Meetings) Meeting of 18 November 1914.

${ }^{9}$ Merck, Conventionen und Vertretungen, Bericht über das Geschäftsjahr (1915) 7 Merck-Archiv F03/6a.

${ }^{10}$ Anonymous, 'De Nederlandsche Cocainefabriek NV', Pharmaceutisch Weekblad 76 (1939) 800-801.

${ }^{11}$ Koloniale Bank, Report of Management to the Board, (1914) 6; (1915) 7; (1916) 12. Nationaal Archief, The Hague, Access No. 2.20.04, Item 58.
} 
Marketing 1921-1924

During the War NCF supplied the Japanese market but lost its position after local manufacture came on stream in that country. To increase its sales volume NCF decided to take an aggressive position in the market. Dr Kramers describes in a memo the sales strategy of NCF during the years before it became a member of the Convention as follows: The NCF competed with large pharmaceutical companies that entertained sales offices in many countries to promote their products. NCF, as a small company, could not afford such expense; it sold through agents abroad and obtained orders by underbidding the competition. 12 That strategy was successful, resulting in a substantial increase in sales and a quite large quota as member of the Cocaine Manufacturers Convention in 1925.

It is estimated in Chapter 18 that $\mathrm{NCF}$ annually sold $1,050 \mathrm{~kg}$ cocaine at an approximate price of $220 \mathrm{NLG} / \mathrm{kg}$ during the period 1921-1924. The profitability was modest but it should be considered as quite a success that the NCF had been able to conquer $20 \%$ of the market. The main reason that NCF could achieve this market penetration was its sales strategy outlined above, which was made possible because of the low cost of the Java coca supplied by Soekamadjoe. In 1923, the Board of the Koloniale Bank, in discussing the results of the NCF, remarked that the company would not have made a profit if it had been required to buy the coca at the open market instead of obtaining it from Soekamadjoe. ${ }^{13}$ The Board concluded that NCF in the future must be profitable in its own right otherwise liquidation of the company would have to be considered. ${ }^{14}$

From submissions by the Dutch government to the League of Nations we know to which countries the NCF exported cocaine during 1921-1923. The most important were: the UK 769 kg, Italy 460 kg, Switzerland 337 kg, France 308 kg, Belgium 227 kg and Japan 215 kg. ${ }^{15}$

\section{Narcotics Control Issues 1921-1924}

From 1921, the League obtained trade and production information from manufacturing countries on the rationale that such information was required for the implementation of the Hague Convention of 1912. In the Netherlands there was strong opposition by NCF and by Chemische Fabriek Naarden (morphine and heroin producer) against submitting detailed information on quantities produced and to which countries the products were sold on the grounds that this was sensitive commercial information which could be used against them by the competition. The industry was supported in its views by the Department of Labour (Ministerie van Arbeid) but Foreign Affairs (Buitenlandse Zaken) was for diplomatic reasons inclined to insist that such information be handed over. ${ }^{16}$ The NCF only agreed to the disclosure of the information after other cocaine producing countries had submitted their production figures. ${ }^{17}$ Strong opposition was also voiced in Switzerland where the Association

\footnotetext{
${ }^{12} \mathrm{NCF}$ "Opmerkingen naar aanleg van het schrijven van de Heer W.G. van Wettum" of 23 September 1929. Nationaal Archief, The Hague, Access No 2.05.21 Item 1596.

${ }^{13}$ Calculation the manufacturing cost at NCF using the open market price for Java coca as input results in NLG 237 per $\mathrm{kg}(3 \mathrm{p}+64+19=3 \times 51.3+83=237)$ versus NLG 158, the manufacturing cost at the Soekamadjoe price for Java coca; ref. Table 18.16 for the period 1921-1924.

${ }^{14}$ Koloniale Bank, Notulen Commissarissen Vergaderingen (Minutes of Board Meetings) Minutes of the Meeting of 17 May 1923 Nationaal Archief, The Hague, Access No. 2.20.04, Items 13-19.

${ }^{15}$ Rapport du Gouvernement Néerlandais sur le traffic de l'Opium et autres drogues nuisibles pour les années 1921-1923.

${ }^{16}$ Letter by Buitenlandse Zaken to the Minister van Arbeid dated 16 October 1922 and Memo from Volkenbondszaken to the Minister van Buitenlandse Zaken. Nationaal Archief, The Hague, Access No 2.05.21 Item 1464.

${ }^{17}$ NCF letter to the Minister van Buitenlandse Zaken, dated 10 April 1924, Nationaal Archief, The Hague, Access No 2.05.21 Item 1466.
} 
of the Swiss pharmaceutical Industry submitted a memorandum to the government rejecting any restrictions in production and opposing reporting on production to the League. ${ }^{18}$

Another result of the activities of the League was that certain countries began to require import permits for cocaine and opiates the issue of which depended on vague rules. This created a lot of paperwork and arbitrariness resulting in NCF's losing the Greek market. ${ }^{19}$ The League in its preparatory work for the Geneva Convention of 1925 caused unease among manufacturers, including NCF, because the proposed systems for restriction of production and control of trade were considered as threatening for the future of the industry. ${ }^{20}$

\section{Ethocaine}

To broaden its product base NCF commenced manufacturing ethocaine (identical to novocaine and procaine) in 1921. It is a local anaesthetic like cocaine and therefore both products were sold to a market in which NCF already operated. It is a totally synthetic product and NCF must have done research to establish and optimize a suitable production process.

Cocaine had been from the start a very successful product. However, already in 1890 medical practitioners began to notice side effects including toxicity and even death. Furthermore, the addictive properties gradually became apparent. These serious side effects resulted in a search for other less toxic, non-addictive compounds with local anaesthetic properties.

Alfred Einhorn at "Farbwerke vormals Meister, Lucius und Brüning" found that derivatives (esters) of $p$-aminobenzoic acid had the desired properties and a patent was obtained on the manufacture of these compounds. ${ }^{21}$ The most successful of these compounds was the hydrochloride of the diethylaminoethyl ester of $p$-aminobenzoic acid.

It was shown by Professor Heinrich Braun that this compound, which he named Novocaine, was a safe, effective local anaesthetic and was non-addictive. Novocaine is not an alkaloid; it is made synthetically from simple carbon compounds supplied by the chemical industry. Marketed as an injectable formulation by Farbwerke (Hoechst), it was well received by the medical and dental profession. Already by 1910 novocaine had replaced cocaine as a local anaesthetic to quite some extent. However, even today solutions of cocaine are still the local anaesthetic of choice for surgery on nose, throat, eyes and larynx. ${ }^{22}$

The substitution of cocaine by novocaine as a local anesthetic was for NCF a reason to take up novocaine (ethocaine) manufacture. NCF could not halt the replacement of cocaine and reasoned that customers who wanted to change over to the new product should be able to buy it from the company. ${ }^{23}$ The Farbwerke patent had expired and the synthesis was straight forward.

Novocaine was also traded under the name Ethocaine. NCF registered the trade name Aethocaine for its product in 1919. Ethocaine was a much less expensive product than cocaine. In the early 1930s NCF was selling approximately $3000 \mathrm{~kg}$ per annum at a price of about NLG 30 per kg. The exact quantities and prices of ethocaine sold by NCF during the 1920s are not known.

\footnotetext{
${ }^{18}$ Switzerland and the Opium Convention, Chemist and Druggist. 1 December 1923, 766.

${ }^{19}$ Letter by Dr. Kramers (NCF) to Mr. W.G. van Wettum, dated 21 October 1924. Nationaal Archief, The

Hague, Access No 2.05.21 Item 1465.

${ }^{20}$ Ibidem.

${ }^{21}$ Farbwerke vormals Meister, Lucius und Brüning, Verfahren zur Darstellung von p-Aminobenzoësäurealkylaminestern, German Patent No. 179,627; 1904 November 27.

${ }^{22}$ P. Parish, Medical Treatments - The Benefits and Risks. London, Penguin Books, 1991.

${ }^{23}$ Anonymous, 'De Nederlandsche Cocaine Fabriek NV', Pharmaceutisch Weekblad 76 (1939) 801-802.
} 
Marketing 1925-1930

As a result of the higher prices set by the Cocaine Convention profit of the NCF increased sharply from 1925 onwards (Section 7.2). Sales volume came gradually down from $977 \mathrm{~kg}$ in 1925 to $668 \mathrm{~kg}$ in 1928 and diminished quickly thereafter to $135 \mathrm{~kg}$ in 1930 . A compensating factor was that from 1926 to 1930 crude cocaine was manufactured and sold at a level of ca $250 \mathrm{~kg}$ p.a. The price at which the crude cocaine was sold is estimated to be at the historical average of $78 \%$ of the price of cocaine $\mathrm{HCl}^{24}$

Table 8.1 NCF Cocaine Price and Production

Cocaine HCl and Crude Cocaine (Java) 1915-1930

\begin{tabular}{|c|c|c|c|c|}
\hline Year & $\begin{array}{c}\text { Price } \\
\text { Cocaine HCl } \\
\text { DEM/kg } \\
{[1]}\end{array}$ & $\begin{array}{c}\text { Price } \\
\text { Cocaine HCl } \\
\text { NLG/kg } \\
\text { [2] }\end{array}$ & $\begin{array}{c}\text { Production } \\
\text { Cocaine HCl } \\
\text { kg } \\
{[3]}\end{array}$ & $\begin{array}{c}\text { Production } \\
\text { Crude Cocaine } \\
\text { kg } \\
{[4]}\end{array}$ \\
\hline 1925 & 600 & 354 & 977 & 0 \\
\hline 1926 & 694 & 409 & 775 & 232 \\
\hline 1927 & 573 & 338 & 692 & 244 \\
\hline 1928 & 500 & 295 & 668 & 141 \\
\hline 1929 & 500 & 295 & 281 & 284 \\
\hline 1930 & 708 & 418 & 135 & 325 \\
\hline $1925-1930$ & \multicolumn{2}{|c|}{$\begin{array}{l}\text { Average Production kg } \\
\text { Average Price NLG/kg }\end{array}$} & $\begin{array}{l}588 \\
350\end{array}$ & 204 \\
\hline
\end{tabular}

Notes to Table 8.1

[1] Prices for cocaine $\mathrm{HCl} 1926-1930$ are calculated as the average By calendar year of the prices as set by the Cocaine Convention The price for 1925 is an estimate.

[2] $=[1]^{*} 0.59$ (the exchange rate).

[3] and [4] 1925-1928 PCOB C.121.M.39.1930.XI, Annual Reports PCOB.

[3] Average price is weighted to production volume cocaine $\mathrm{HCl}$.

[4] Average price is the cocaine $\mathrm{HCl}$ price weighted to production volume crude cocaine multiplied by 0.78 , the historical ratio.

Average production volumes as per the above table were used as input for the estimates of the average cocaine price in chapter 18. That price of NLG 312 is in good agreement with the average of the prices calculated in the above table.

\section{Narcotics Control Issues for NCF 1925-1930}

While the profitability of the NCF was good throughout the period 1925-1930 there was great concern by management over the future of the company. ${ }^{25}$ The actual and proposed international narcotic controls threatened the sheer existence of the NCF. Being located in a

\footnotetext{
${ }^{24}$ The historical ratio of $78 \%$ between the prices of crude cocaine and cocaine $\mathrm{HCl}$ is calculated from the data in Tables PCC 5 and COC 4/5 (Part IV) for the period 1898-1913.

${ }^{25}$ NCF paid a very high dividend over 1928 (Section 7.2); it is not clear why that happened. According to the sales figures as per the table above 1928 was not an outstanding year.
} 
small country and therefore having a small domestic consumption, viability depended on substantial export sales. As a result of the abuse of the system of import certificates and export permits by importing countries as described in the section Narcotics Control Issues 1921-1924, the access to important markets such as England and France became more and more restricted. NCF on its own could not do much more than protest against this (ab)use of the new regulations. It needed the support of the Dutch government to make its voice heard in gatherings of the international forum at Geneva. From 1929 Dr Kramers entered into an extensive correspondence with Mr W.G. van Wettum, the Dutch representative at the OAC in Geneva. Dr Kramers recalled his earlier objections against the abuse of the system of import and export permits, and expressed his deep concern about the recent proposals in Geneva for a compulsory reduction of the cocaine production worldwide. Among his arguments were the following: reduction of production by bona fide manufacturers does not constitute control of the illicit manufacture and trade; legal manufacturers sell for export on the basis of import certificates and locally to authorized wholesalers and pharmacists only, so what will be the result of the restriction? Kramers felt that large countries would obtain large quota and that manufacturers in small counties such as the Netherlands and Switzerland would be prevented from competing, thereby becoming non-viable. Because Java coca, the prime raw material for cocaine, was cultivated within the borders of the Netherlands (including its colony the Dutch East Indies) it was felt as a great injustice if the NCF would be prevented from continuing its legal business of many years, leaving it to manufacturers in other countries to exploit this raw material commercially ${ }^{26}$.

Dr Kramers was of the opinion that, if the Netherlands would prohibit all export of coca leaf from the Netherlands, including from the Dutch East Indies, and the NCF would manufacture all cocaine required for medical purposes in the world, diversion of the cocaine to the illicit market would be virtually impossible. ${ }^{27} \mathrm{NCF}$ presented a plan based on this principle to van Wettum but modified in such a way that it was thought to be more palatable to the rest of the world. The basics of the plan were: 1) prohibition of export of Java coca from the Netherlands (including the Dutch East Indies) 2) a legally binding agreement between NCF and the Cocaine Convention on the manufacture of cocaine 3) a legally binding agreement between NCF and the Coca Producers Association on the supply of coca and 4) a set of agreements between countries on ratification of the plan and operating it under supervision of the League of Nations. ${ }^{28}$ Van Wettum considered the plan seriously, but it was not pursued. It was too complex and too one sided to have a chance in Geneva.

\footnotetext{
${ }^{26} \mathrm{NCF}$ “Opmerkingen naar aanleiding van het schrijven van de heer van Wettum, dated 23 September 1929”.

${ }^{27}$ Ibidem.

${ }^{28}$ Draft Memo by 'Volkenbond Zaken' (van Wettum) dated October 1929, Nationaal Archief, The Hague, Access No 2.05.21 Item 1596.
} 
The Cocaine Manufacturers Convention hoped to play a major role in the allocation of quota under the system of production restrictions as was under consideration at a pre-conference in London of manufacturing countries in preparation of the Limitation Conference of 1931. Manufacturers had agreed to the following quota for cocaine: ${ }^{29}$

$\begin{array}{lc}\text { Germany } & 49.30 \% \\ \text { France } & 20.00 \% \\ \text { UK } & 15.00 \% \\ \text { Netherlands } & 10.28 \% \\ \text { Switzerland } & 5.42 \%\end{array}$

Ultimately, at the actual Limitation Conference of 1931 the quota plan came to naught. The reasons for this are very complex because of the very different interests of the countries and the personalities involved. An excellent review of this subject is provided by William B. McAllister. ${ }^{30}$

\subsection{Coca Supplies to the NCF - Soekamadjoe}

From 1909 Soekamadjoe had been re-establishing its neglected coca plantations and a production level of slightly over 30 tonnes leaf p.a. was reached in 1913-1914. In 1910 an exclusive supply contract between Soekamadjoe and NCF was concluded for a period of 10 years, running from March 1910 to March 1920; the price was NLG 0.40 per $\mathrm{kg}$, c.i.f., irrespective of the alkaloid content. ${ }^{31}$ Under the 1910 supply contract, the agreed target was to set up a total area of 100 bouws ( 70 ha) under cultivation from which ca 50 tonnes coca p.a., equivalent with a production of $500 \mathrm{~kg}$ cocaine $\mathrm{HCl}$, should be expected. ${ }^{32}$ That target was achieved for the years from 1915-1919 but because of the War, shipping of the crop to the Netherlands was not possible during the years 1917-1918. ${ }^{33}$ NCF's coca requirements were in excess of the quantities Soekamadjoe could supply and additional quantities were most likely procured through the services of the Koloniale Bank, which sold coca in consignment, or alternatively at the auctions in Amsterdam.

During the war Soekamadjoe experienced strong increases in production cost and transportation costs and a corresponding reduction in profits. The NCF reimbursed ca NLG 6,000 for increased freight and insurance costs over 1914-1916 but was not willing to increase the price for the leaf despite the much increased cocaine prices. ${ }^{34} \mathrm{NCF}$ argued that the alkaloid content of the 1915 shipments had been considerably lower than that of the 1914 shipments and that a price increase could only be justified if the content would come back to

\footnotetext{
${ }^{29}$ E.D. van Walree, W.G. van Wettum and J.B.M. Coebergh, Report on the International conference on the restriction of manufacture of narcotic drugs, London 27 October 1930 to 11 November 1930. (in Dutch) 9 December 1930, Nationaal Archief, The Hague, Access No. 2.05.21 Item 1468.

${ }^{30}$ W. B. McAllister, Drug Diplomacy in the Twentieth Century (London 2000) 91-102.

${ }^{31}$ Soekamadjoe, Notulen Bestuursvergaderingen (Minutes of Board Meeting) 16 April 1910, National Archief, The Hague, Access No 2.20.04 Item 1481. It was commented at the meeting that, because of the low contract price, which was not dependent on the alkaloid content of the coca supplied, for Soekamadjoe, the quantity supplied was more important the alkaloid content.

${ }^{32}$ Soekamadjoe, Notulen Bestuursvergaderingen (Minutes of Board Meetings) Meeting of 12 January 1912 , National Archief, The Hague, Access No 2.20.04 Item 1481.

${ }^{33} 50$ tonnes of coca produced in 1917 and 25 tonnes produced in 1918 was sold on Java. Soekamadjoe, Jaarverslagen (Annual Reports) 1917-1918, National Archief, The Hague, Access No 2.20.04 Items 1477 and 1478.

${ }^{34}$ Soekamadjoe, Jaarverslagen (Annual Reports) (1916) VII, National Archief, The Hague, Access No 2.20.04 Items 1477 and 1478; Soekamadjoe, (Minutes of Board Meetings) Meeting of 20 April 1916 and 21 November 1916.
} 
the original level. Soekamadjoe considered NCF's position as unjust because the decline in alkaloid content had been the result of factors outside Soekamadjoe's control. ${ }^{35}$ Shipments of coca to NCF resumed in 1919 and to the end of 1920, 138 tonnes was delivered to NCF. NCF and Soekamadjoe negotiated in 1918 a new supply contract for the period 20 March 1920 to 31 December 1922. ${ }^{36}$ The principal conditions were: price NLG 0.20 per unit at the Soekamadjoe estate i.e. all freight costs to be absorbed by NCF, minimum alkaloid content: $1.20 \%$, and all coca supplied to originate from Soekamadjoe plantations. ${ }^{37}$ This contract was much better for Soekamadjoe than the previous one. At $1.50 \%$ alkaloid assay, the price per $\mathrm{kg}$ was $50 \%$ higher and all freight costs would be absorbed by NCF. It provided a financial incentive for Soekamadjoe to supply leaf with high alkaloid content, which was advantageous for NCF. Details of Soekamadjoe shipments of coca to NCF are provided with Table 7.14.

From 1920 the area under cultivation remained at 100 bouws ( 71 ha). The target of shipping a minimum of 40 tonnes p.a. was not achieved from 1922 onwards. Soekamadjoe management blamed the poor condition of the soil and the need for a selective harvest, required for recuperation of the coca plants. ${ }^{38}$ A new supply contract was entered into in March 1923. The unit price was now dependent on the alkaloid content and ranged from 27 to 30 cents per unit. The guaranteed minimum supply quantity was 30 tonnes p.a. ${ }^{39}$ The area under coca cultivation was expanded to 130 bouws but because of a serious drought in 1923 and other unfavourable agricultural conditions in later years, the supply target of 30 tonnes was not achieved. ${ }^{40}$

Over 1924 Soekamadjoe's all-in cost for coca was 40 cents per half $\mathrm{kg}$ and over 1925 42 cents. Return from sales to NCF amounted to 57 and 51 cents per half kg respectively over these years. From these figures we can calculate that the average profit for Soekamadjoe amounted to NLG 260 per tonne or NLG 7,800 per annum for 30 tonnes. That return was distinctly inferior to the profitability of the cultivation of rubber and tea as achieved by Soekamadjoe which was the reason for Soekamadjoe management to decide not to extend the coca supply contract with NCF at its expiry at the end of 1927, to remove the coca, and to replant the area with rubber. ${ }^{41}$

\footnotetext{
${ }^{35}$ Ibidem, Meeting of 21 November 1916. Note: the supply contract did not provide incentive for Soekamadjoe to supply coca with high alkaloid content.

${ }^{36}$ Soekamadjoe, Jaarverslagen (Annual Reports) (1918) 9.

${ }^{37}$ Ibidem (1918) 9.

${ }^{38}$ Ibidem (1922) 4-5, 8.

${ }^{39}$ Ibidem (1923) 11.

${ }^{40}$ Ibidem (1923) 5.

${ }^{41}$ Ibidem (1925) 11.
} 
Table 8.2 Landbouwonderneming "Soekamadjoe" Cultivation of Java Coca Supplies to NCF 1911-1927

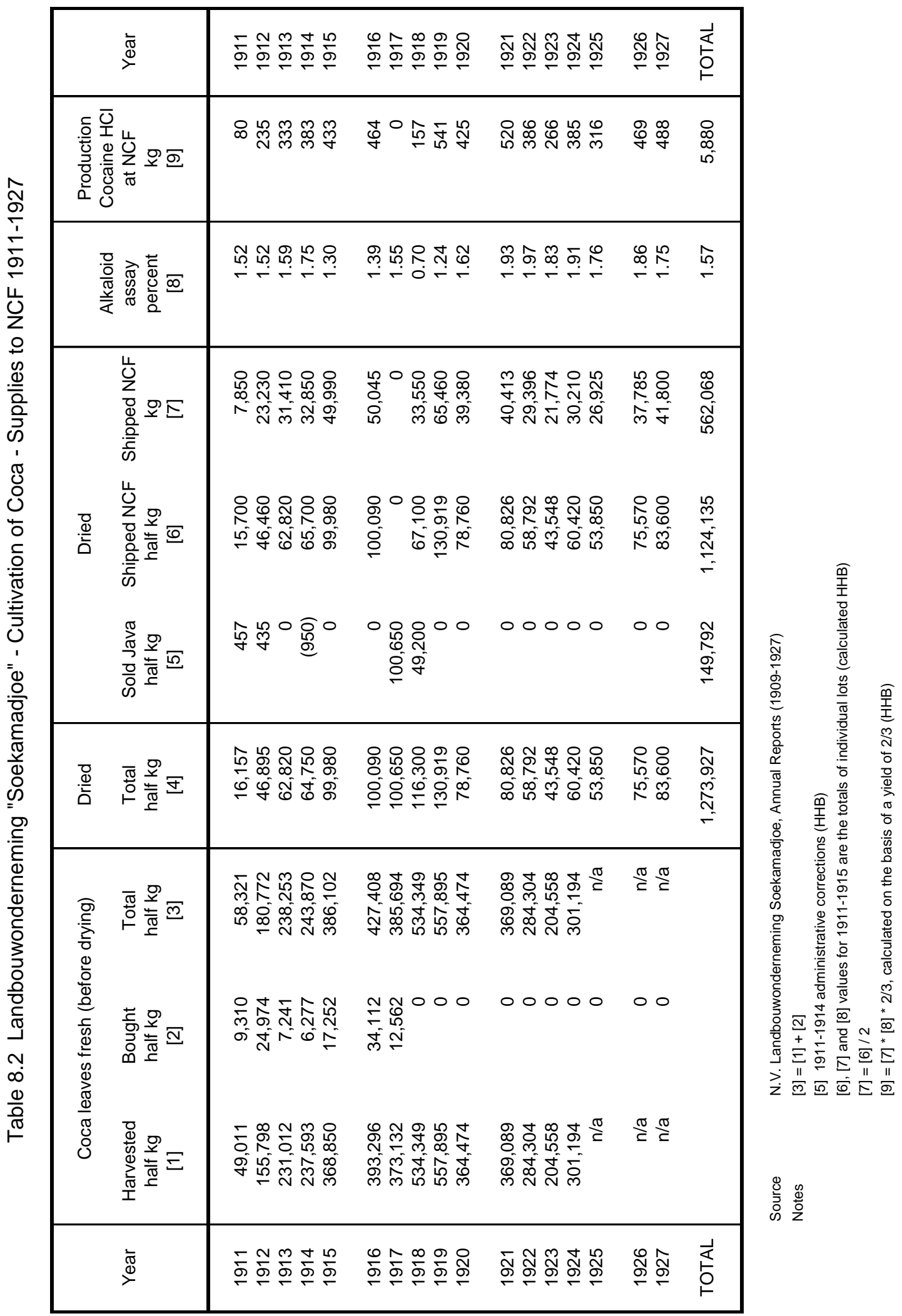




\subsection{Expanding and Operating the NCF Factory.}

All production activities remained at the factory at the Duivendrechtsekade at Ouder Amstel. To cope with the demands for more output resulting from the increased sales opportunities in 1914 plans were drawn up for an expansion of the facilities which were submitted to the municipal authorities in 1915. The master plan envisaged an ultimate doubling of the extraction capacity, to be realised over time in steps, in line with actual increases in sales and income.

The first application (1915/1) dated 11 February 1915 concerned the installation of a distillation unit for the purification of benzoylchloride, an essential chemical used in the synthesis of cocaine from ecgonine. Presumably, until 1915 NCF bought this chemical in Germany but because of the War situation supply of good quality material was interrupted and NCF had to purify a lesser grade product or alternatively make the benzoylchloride in its own factory. In either case a final purification by distillation was required. Because of the rather high boiling point of benzoylchoride $\left(197^{\circ} \mathrm{C}\right)$ steam heating was insufficient and NCF applied for a permit to install a 30 liter steel still to be heated with an open flame kerosene burner. The equipment was to be placed in space B (ref. Figure 7) which would be outfitted with an exhauster. The permit was granted on 27 April 1915 stipulating that the project had to be completed before 27 October of that year. ${ }^{42}$

The second application (1915/2) was one of a much larger scale. It was the realization of the original plan to build a coca leaf extraction facility with twice the capacity of that built in 1908/1910. On 29 May 1915 NCF applied for a permit to build three workspaces of exactly the same size as the existing extraction facilities and to double the size of the engine room (see Figure 7). These three workspaces would comprise two extraction batteries on either side of a space that was to be used for the storage of coca leaf and the milling and the mixing of the leaves with alkali prior to extraction. The ramp used for the transportation of the coca leaf from the drier to the extraction facilities would be moved.

The larger capacity was required to cope with the strongly increased demand for cocaine as a result of the First World War. The application included descriptions of two auxiliary buildings viz. a larger building to accommodate two driers for coca leaf and a building to be used as a canteen, change room and bicycle storage for the factory workers. No objections were received and the permit was granted on 21 July 1915 (completion required by 1 January 1916). ${ }^{43}$

\footnotetext{
${ }^{42}$ All documents related to the application and the approval process are contained in the Files Municipality Ouder-Amstel, Hinderwetvergunningen ('Building Permits and Operating Licenses'), Stadsarchief Amsterdam, Access No.5500, Item 690, file 230 (1915).

${ }^{43}$ Ibidem, file 391 (1915).
} 
Figure 8.1 The Expansions of 1915

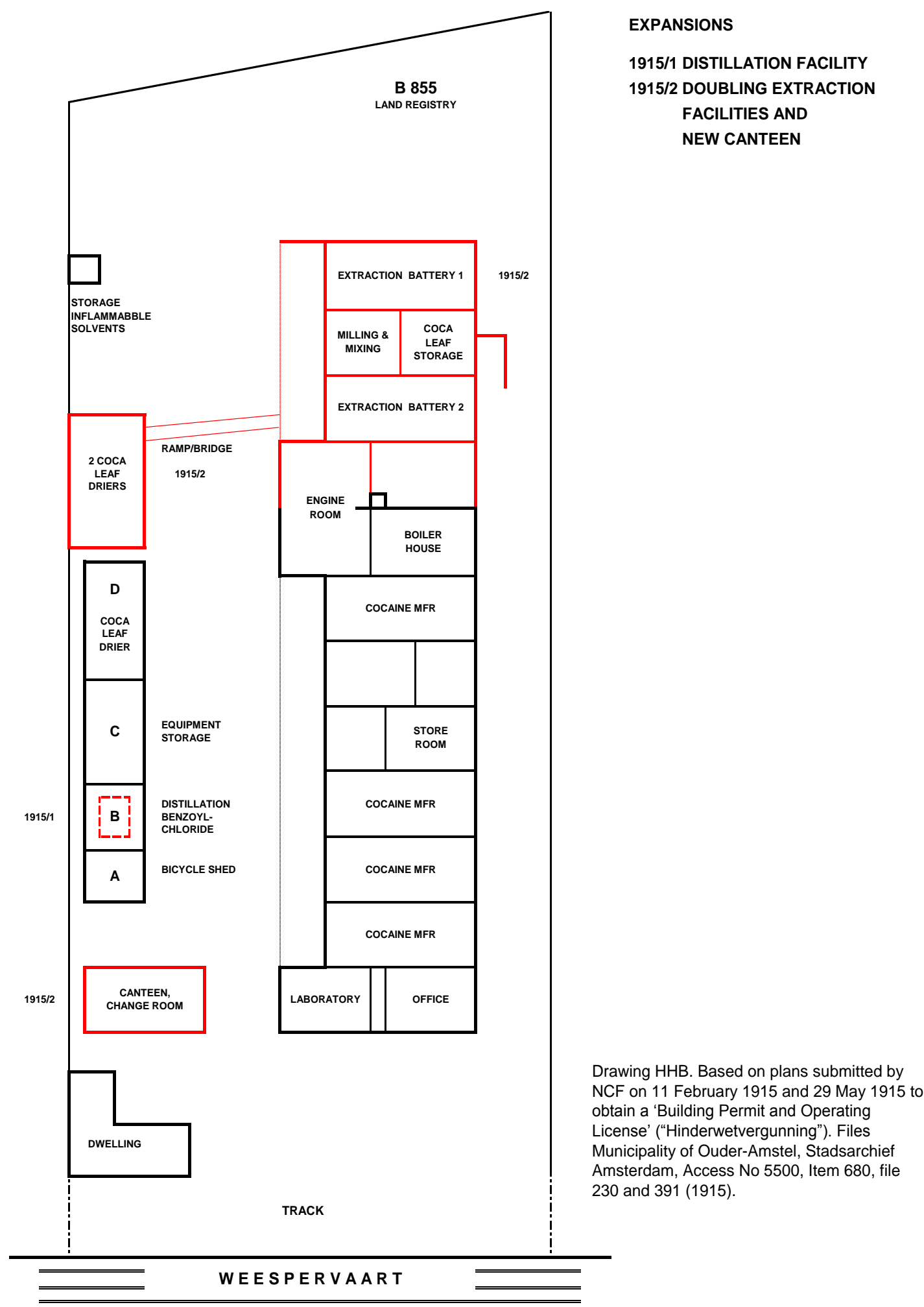

1915/1 DISTILLATION FACILITY FACILITIES AND NEW CANTEEN NCF on 11 February 1915 and 29 May 1915 to

Municipality of Ouder-Amstel, Stadsarchief Amsterdam, Access No 5500, Item 680, file 230 and 391 (1915). 
Figure 8.2 The Expansions of 1916 and 1917

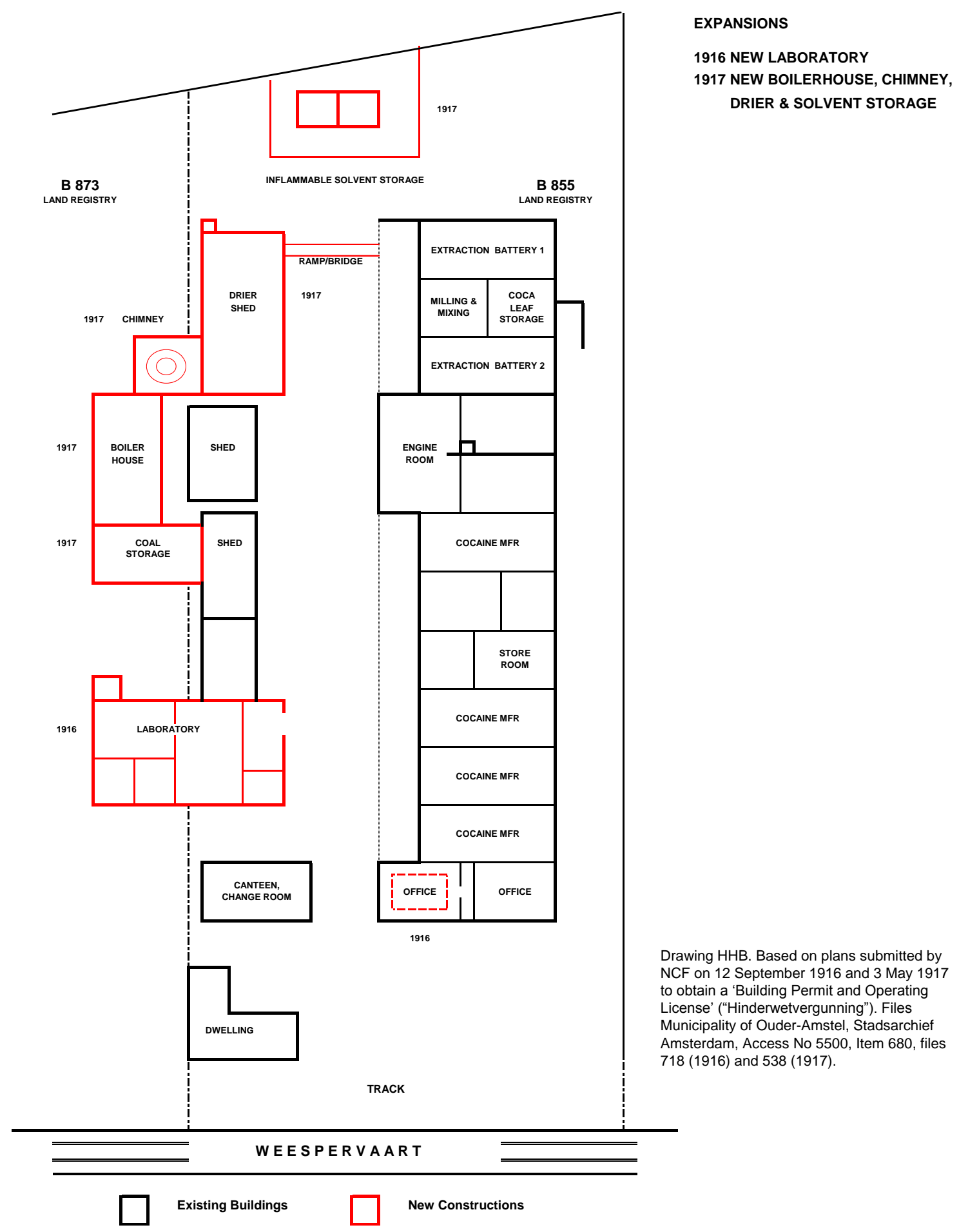


The building of a new laboratory in 1916.

In 1916 and 1917 the NCF constructed a new laboratory intended for quality control of raw materials, intermediates and end products; furthermore for research into processes for the manufacture of existing and new products. On 12 September 1916 an application was submitted for a permit to install a system for heating the air in the laboratory using an evaporator/burner for petrol in a space annexed but not in open connection with the laboratory. Also requested were permits for the placement in the laboratory of a Sterling motor, an electric motor and a converter for $110 \mathrm{~V}$ DC into 6V DC. The Municipality organized a public hearing but no objections were raised and the permit was issued on 11 October 1916 under the condition that NCF should strictly adhere to the "Veiligheidsbesluit" (Safety Act) of 1916. The project had to be completed before 1 May $1917 .{ }^{44}$

A plan of the laboratory building was included in the application but the building as such was not mentioned in the application. ${ }^{45}$ As a result of the building of the new laboratory older buildings A (the bicycle shed) and B (distillation of benzoylchloride) were demolished and the activities transferred to other buildings (see Figures 1 and 2).

\section{The expansion of 1917}

Again, on 3 May 1917 the NCF applied for a permit for further expansions. These expansions were required to allow the extraction facilities to work at full capacity. Apparently, the limiting factor was insufficient capacity for steam generation and for drying the coca leaf. To solve the problem a larger boiler-house had to be built to contain a boiler of $45 \mathrm{~m}^{2}$ heating surface (maximum pressure of $10 \mathrm{~kg} / \mathrm{m}^{2}$ ), with a large new chimney and appropriate coal storage shed. In addition to a new boiler, a large steam engine and driers, the request included specifications for buildings to accommodate the new equipment viz. a boiler house, a chimney, a coal storage space and a building for the new driers. Also applied for were permits/licenses to build two spaces for the storage of solvents, one for the storage of petrol, ether and other highly inflammable solvents, in metal containers to a maximum of 400 litres, and the other for storage of ethanol and methanol, in wooden barrels and demijohns to a maximum of 1,000 litres. These spaces were to be fitted with steel doors and surrounded by a fence of 2 meters height; the space within the fence to be locked at all times except when access would be required for production purposes.

A hearing was organized for June 7 at the Municipal Building to allow objections to be brought forward but nobody appeared and the license was granted on 13 June 1917 with the proviso that the expansion had to be completed by 13 December $1917 .{ }^{46}$

From these dates it follows that the NCF would have been fully operational at the design capacity of ca 1,500 kg cocaine hydrochloride p.a. from the end of 1917 onwards. ${ }^{47}$

\footnotetext{
${ }^{44}$ Ibidem, file 718 (1916).

${ }^{45}$ Possibly there was a separate building permit issued for the laboratory but that was not located in the municipal archives.

${ }^{46}$ Ibidem. File 532 (1917).

${ }^{47}$ Ref. Note [8] Hinderwetaanvraag 1908.
} 
Figure 8.3 Plan for the Expansion of 1917 as submitted to the Municipality of Ouder Amstel on 3 May 1917

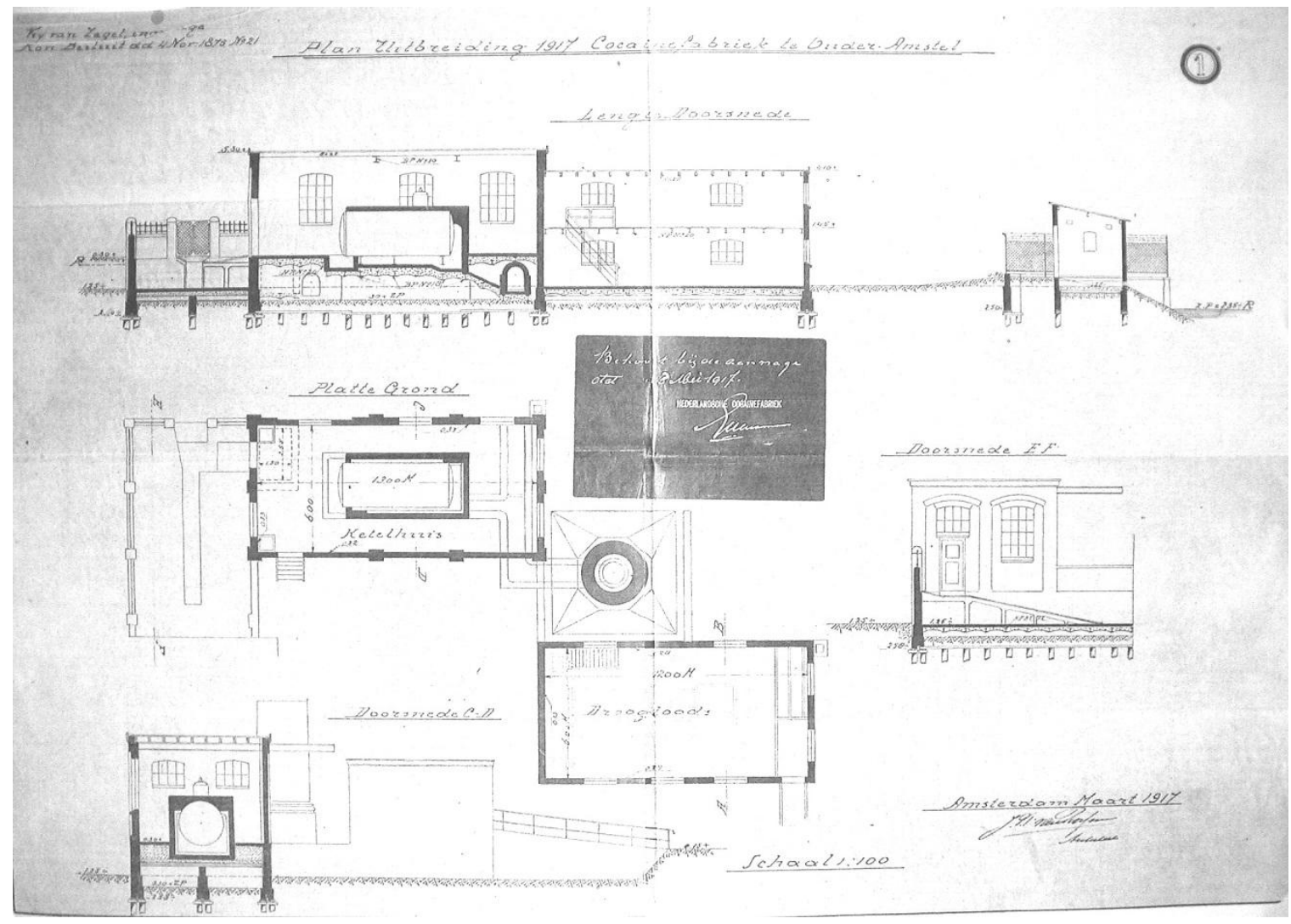


The Expansions of 1921-1927

Ethocaine Manufacture

NCF started the manufacture of Ethocaine in 1921. From the plans submitted to the municipality of Amsterdam to obtain approval for expansion of the facilities required for the manufacture we know the outline of the process that was used. It is a variation of the process invented by Alfred Einhorn and patented by Farbwerke vorm. Meister Lucius \& Brüning (Hoechst) in the USA under No 812,554 of February 13, 1906.

Figure 8.4 Process for the Synthesis of Ethocaine used at NCF

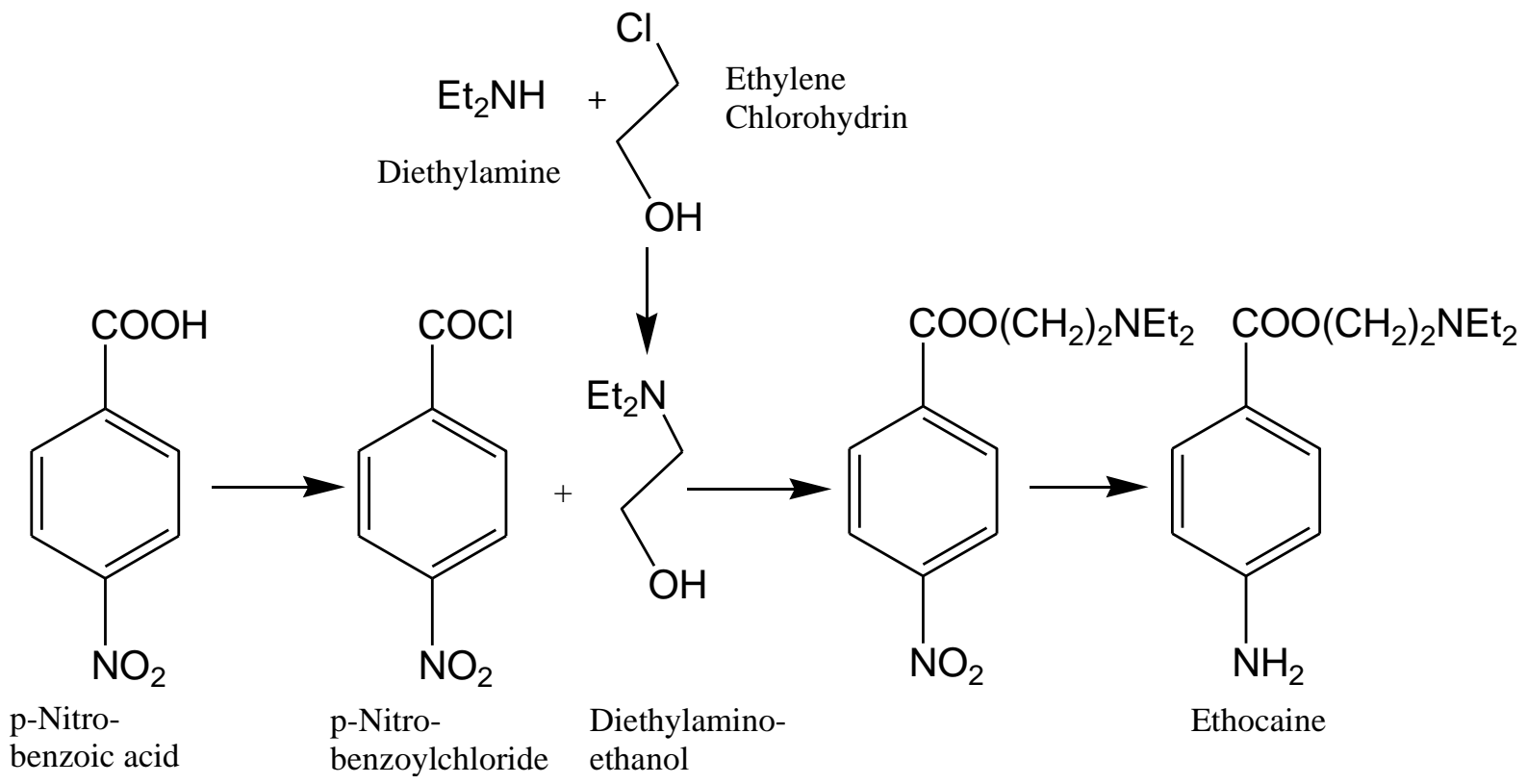

Applications for building and operating permits (Hinderwetvergunningen) were submitted as 870 HW 1921, 394 HW 1924 and 215 HW 1926. The process descriptions contained in application $870 \mathrm{HW} 1921$ are scant and vague. The manufacture of cocaine and related compounds is mentioned without much detail and the conditions of the permits deal almost exclusively with the storage and handling of the inflammable solvents used. Under the permit obtained ethocaine manufacture was apparently started. In a note by a public servant on application 394 HW 1924, nitrobenzoylchloride is mentioned. Permit 215 HW 1926 is more specific: ethocaine, diethylamine and diethylaminoethanol are mentioned. Under the applications requests are made for approval to build new workspaces, to install reactors, distillation equipment, electric motors etc. again without much detail. By comparing various drawings which were part of the submissions the author has constructed Figure 8.5 indicating the most probable places in the factory where the manufacture of ethocaine took place during the 1920s. 
Figure 8.5 Expansions NCF 1921-1927

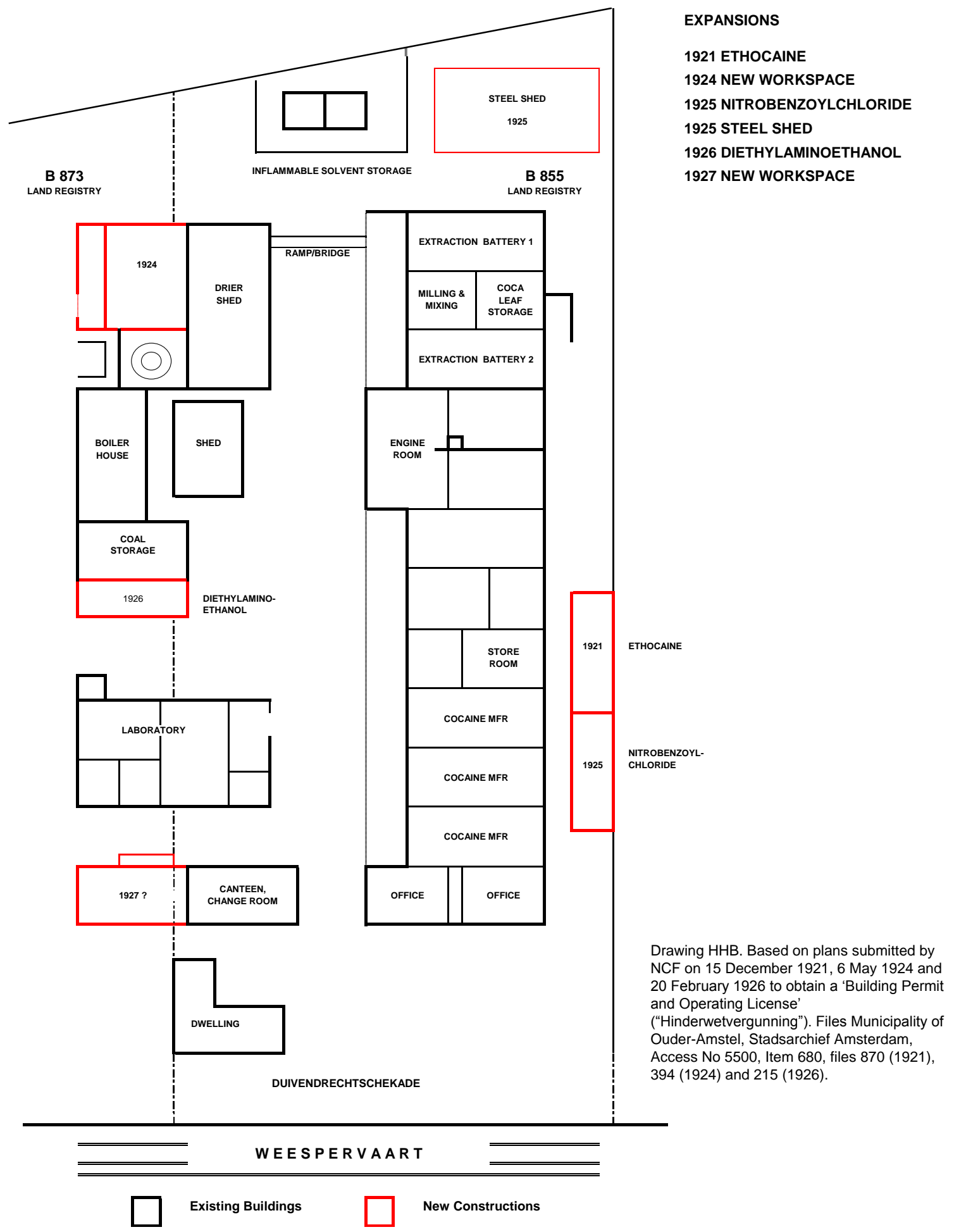




\subsection{NCF - Financial Results}

For the NCF we know the amounts paid as dividend to shareholders for each year over the period 1902-1944. The dividends are presented with the following graph:

Figure 8.6 NCF Dividend 1914-1930

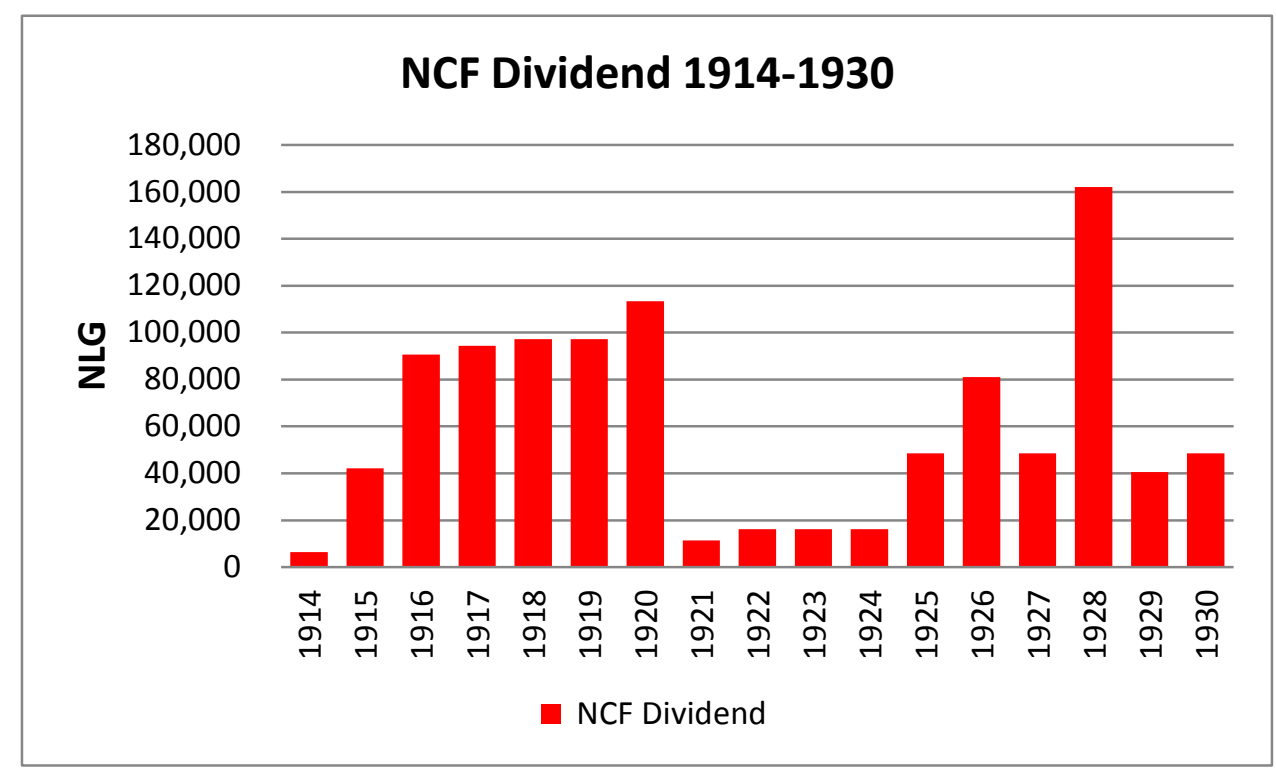

Source: Table FIN 1 (Part III)

For the years 1915-1930 approximate values of average sales volume of cocaine and prices by sub-period are estimated in Chapter 18 by combining available information on the financial performance of the NCF with estimates of the manufacturing costs. These subperiods are:

1914-1920 World War I and its Aftermath

1921-1924 Return of the competition

1925-1930 Impact of the Geneva Convention of 1925

each sub-period representing specific world market conditions resulting in a distinctly different level of profitability for the company as shown in the table below. 
Table 8.6 Summary of Financial Results NCF 1915-1930

\begin{tabular}{|c|cc|crc|}
\hline Period & $\begin{array}{c}\text { Dividend } \\
\text { Actual }\end{array}$ & $\begin{array}{c}\text { Dividend } \\
\text { \% of Capital } \\
\text { Actual }\end{array}$ & $\begin{array}{c}\text { Profit for } \\
\text { Distribution } \\
\text { Estimated }\end{array}$ & $\begin{array}{c}\text { Depreciation } \\
\text { Estimated }\end{array}$ & $\begin{array}{c}\text { Fixed Cost } \\
\text { less Depr. } \\
\text { Estimated }\end{array}$ \\
\hline $1915-1920$ & 89,154 & 275 & 105,286 & 35,662 & 44,316 \\
$1921-1924$ & 14,985 & 46 & 16,434 & 5,994 & 71,214 \\
$1925-1930$ & 71,550 & 221 & 79,284 & 28,620 & 71,064 \\
\hline
\end{tabular}

Source: Table 18.16

Table 8.7 NCF: Average Cocaine Sales and Prices per

Period as Estimated in Chapter 18

\begin{tabular}{|crrl|}
\hline Period & $\begin{array}{c}\text { Volume } \\
\text { kg }\end{array}$ & $\begin{array}{c}\text { Price } \\
\text { NLG/kg }\end{array}$ & Method \\
\hline $1915-1920$ & 712 & 360 & (V,P) pair \\
$1921-1924$ & 1,051 & 223 & P from V \\
$1925-1930$ & 792 & 312 & P from V \\
& & & \\
\hline
\end{tabular}

Source: Table 18.16

Note for the Period 1925-1930:

Volume is the sum of $588 \mathrm{~kg}$ cocaine $\mathrm{HCl}$ and

$204 \mathrm{~kg}$ crude cocaine (Table 7.15). Price is the weighted

average of the prices of these compounds

The estimated values for sales volume and price are approximations but they show clearly that the good profits were directly related to good prices, rather than to sales volume. The large sales volume achieved during 1921-1924 did not compensate for the low price.

Expressed as a percentage of the nominal share capital of NLG 32,400 the dividends paid appear quite high, even over the years 1921-1924. Management of the Koloniale Bank expressed its satisfaction with the financial results of the NCF during the War. ${ }^{48}$ In 1923 the Board of the Koloniale Bank was, however, disappointed about the profit and the deteriorating market situation and the prospects for the future viability of the NCF was considered. $^{49}$

\footnotetext{
${ }^{48}$ Koloniale Bank, Annual Reports of Management to the Board, (1914-1916) Nationaal Archief, The Hague, Access No. 2.20.04 Item 58.

${ }^{49}$ Koloniale Bank, Notulen Commissarissen Vergaderingen (Minutes of Board Meetings) 17 May 1923,

Nationaal Archief, The Hague, Access No. 2.20.04, Items 13-19.
} 


\subsection{Summary and Conclusions}

NCF's profitability was excellent during the first period (1915-1920) and the last (19251930 ), but at the end of the 1920s, because of the very much reduced export market, the outlook for the future was not good. That diversification was required to keep the company viable was understood already much earlier and NCF introduced ethocaine as a new product already in 1921. More was necessary however, and NCF began the manufacture of opiates in the early 1930s. 


\title{
ChaPTER 9 \\ The OPIUM POPPY AND OPIATE MANUFACTURE UNTIL 1930
}

\begin{abstract}
Overview
Already in the late 1920s it became obvious that the cocaine market for NCF would largely disappear, which made finding new products which could be manufactured in the existing facilities essential for the survival of the company. Given its experience with the manufacture of the medicinal alkaloid cocaine it was logical for the NCF to look for new products in the same category as cocaine, and the opium alkaloids morphine and codeine were identified as the most suitable candidates. NCF undertook research to develop processes for the manufacture of these products from crude opium and commenced production on a small scale in 1931.
\end{abstract}

This chapter provides an introduction to the opium alkaloids, outlining their history, uses, manufacture and market until 1930.

\subsection{The Opium Poppy and Opium}

\section{Introduction}

The opium poppy (Papaver somniferum L.) has been cultivated for thousands of years. It is known that around $1000 \mathrm{BC}$ the plant was grown in Mediterranean countries (Egypt, Turkey) for the seed and for the opium, its coagulated latex which contains morphine. The pain killing, sleep inducing and constipating properties of opium were described already in the $5^{\text {th }}$ century BC. ${ }^{1}$

The opium poppy is an annual plant. The plant grows fast, flowers in early summer, and produces a seed capsule thereafter. The seed capsule reaches its maximum size shortly after the fall of the petals. At this stage the capsule is still green, and if it is lanced (incised) by making a shallow cut through its wall while still on the stem, the latex vessels are opened and a white sticky sap (the latex) oozes out.

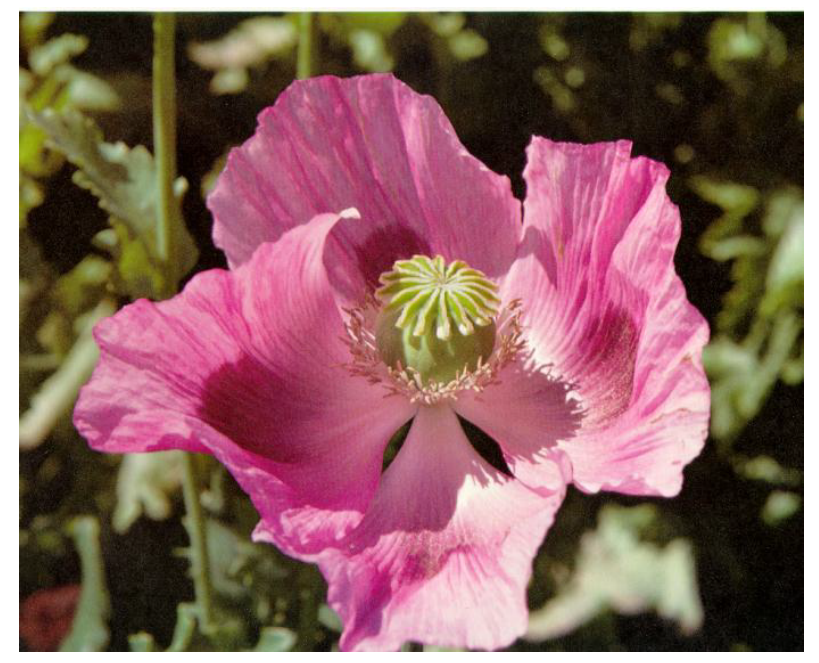

Figure 9.1

Opium Poppy in full bloom

(Photo Rick Rockliff)

\footnotetext{
${ }^{1}$ Matthias Seefelder, Opium, eine Kulturgeschichte 3rd Ed (Hamburg 1996) 9-22.
} 
Figure 9.2

Unripe seed capsule, freshly lanced for opium (Photo Rick Rockliff)

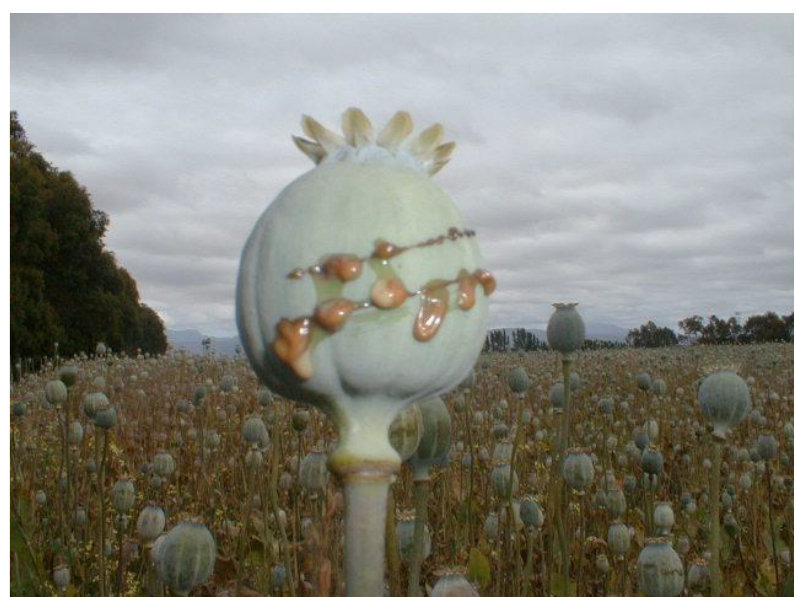

On exposure to air and light the latex changes rapidly, starting to become brown and more viscous in a matter of minutes. This coagulated latex is opium; it sticks to the capsule and is collected a day later by being scraped off. ${ }^{2}$

\section{Early Uses of Opium}

Poppy seeds and poppy capsules dating back from about $3000 \mathrm{BC}$ have been found during excavations of lake-dwellings in Switzerland. A statue found near Heraklion, Crete, thought to be from $1500 \mathrm{BC}$, depicts a goddess wearing a headband adorned with three poppy capsules, very clearly lanced for opium. ${ }^{3}$

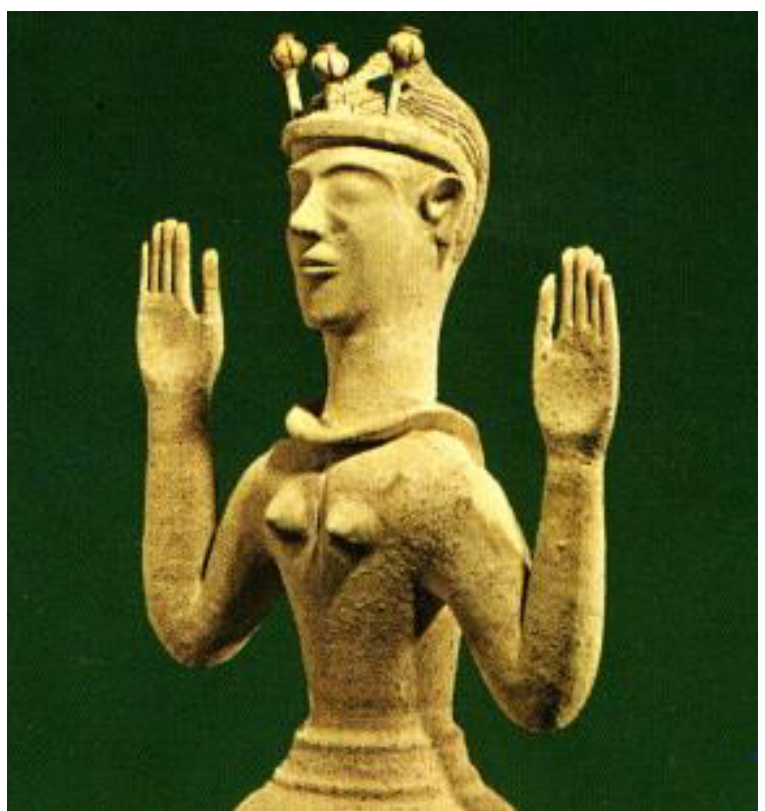

Figure 9.3 Statue of the Poppy Goddess from Minoan Crete (1500 BC)

(Google Images, carriferraro.com)

Laudanum, tincture of opium, and Dover's Powder, a mixture of opium and ipecacuanha, were popular products in the 17th and 18th century. Reportedly, in the 17th century Dr. Sylvius, professor of medicine at Leyden, the Netherlands, stated: "nollem praxium medicam exercere, carerem opio", (I would not practice medicine, if I would be

\footnotetext{
${ }^{2}$ Article on: Opium, Encyclopedia Britannica (Ed.1963) Volume 16, 813-817.

${ }^{3}$ Kritikos P.G. and Papadaki S.P., 'The history of the poppy and of opium and their expansion in antiquity in the eastern Mediterranean area', Bulletin on Narcotics 19[3] (1967) 17-38 and 19[4] (1967) 5-10.
} 
without opium). ${ }^{4}$ In fact, until the 19 th century opium was the only medicine available to mankind to lessen severe pain.

\section{The Use of Opium in China}

During the $17^{\text {th }}$ century mixtures of opium and the then just discovered tobacco were smoked to experience the narcotic effect. Smoking of opium without tobacco became increasingly popular in Asia, especially in China. ${ }^{5}$ Around 1750 the British East India Company took advantage of this development and commenced supplying China and other East Asian countries with opium from India. Sales increased substantially after 1820, creating resistance and leading to an embargo on opium imports by the Chinese government and eventually to the so called Opium Wars of 1839-1842 and 1856-1860 between Great Britain and China. The exact causes leading to the wars and the consequences thereof are very complex and beyond the scope of this dissertation. ${ }^{6}$ We mention here only that as a result of the Opium Wars, which were both lost by China, after 1860 opium could be imported into China and opium cultivation in China was permitted again. ${ }^{7}$

Estimates of quantities of opium exported from India to China are made by Hartwich. ${ }^{8}$ These are the basis for the following Table and graph:

Table 9.1 and Figure 9.4 Export Opium form India and China 1750-1900

\begin{tabular}{|c|c|}
\hline \multicolumn{2}{|c|}{$\begin{array}{l}\text { Export Opium } \\
\text { from India to China } \\
\text { ca } 1750-1900\end{array}$} \\
\hline Year & kg 000 \\
\hline 1767 & 60 \\
\hline 1781 & 169 \\
\hline 1800 & 242 \\
\hline 1805 & 181 \\
\hline 1825 & 730 \\
\hline 1830 & 1,028 \\
\hline 1835 & 1,815 \\
\hline 1850 & 4,235 \\
\hline 1860 & 4,840 \\
\hline 1868 & 4,207 \\
\hline 1880 & 5,859 \\
\hline 1890 & 5,503 \\
\hline
\end{tabular}

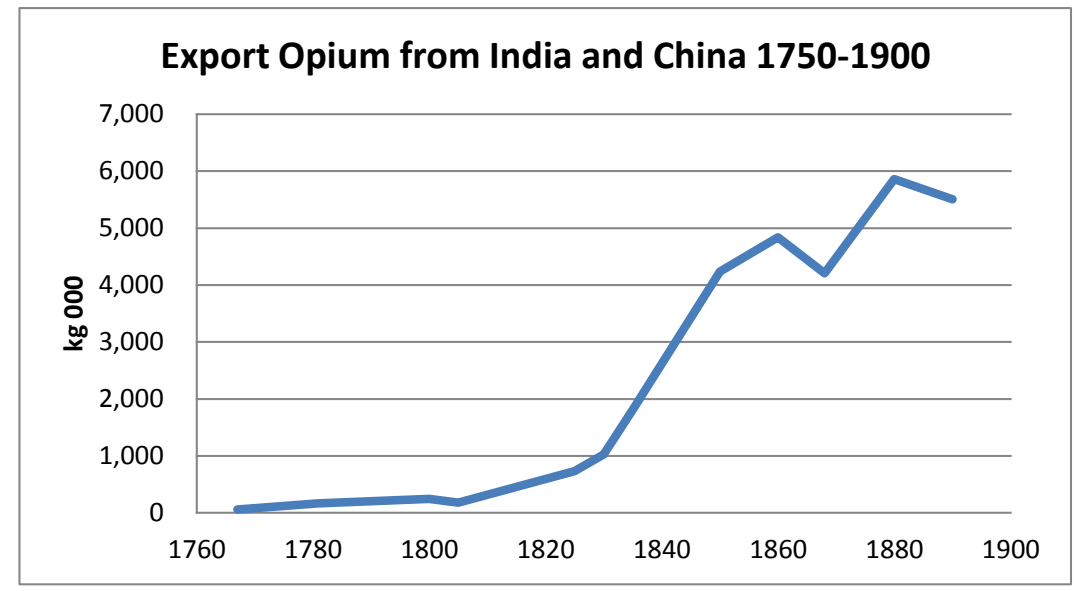

Source: Hartwich I.c (1911) 31-32

\footnotetext{
${ }^{4}$ Seefelder, Opium, 98.

${ }^{5}$ W. B. McAllister, Drug Diplomacy in the Twentieth Century (London 2000) 10-13.

${ }^{6}$ See sections 'Opium in Asia' and 'China in extremis' in McAllister, Drug Diplomacy, 10-13.

${ }^{7}$ McAllister, Drug Diplomacy, 13; J.P. Gavit, Opium (New York 1927) 124.

${ }^{8}$ C. Hartwich, Die menschliche Genuszmittel (Leipzig 1911) 31-34.
} 
Hartwich made also estimates of the total world production of opium in 1890:

Table 9.2 Estimate of Total World Production of Opium in 1890

\begin{tabular}{|l|r|rr|r|}
\hline $\begin{array}{c}\text { Exporting } \\
\text { Country }\end{array}$ & $\begin{array}{c}\text { Opium } \\
\text { Production }\end{array}$ & $\begin{array}{c}\text { Export } \\
\text { to China }\end{array}$ & $\begin{array}{c}\text { Export to } \\
\text { Other } \\
\text { Countries }\end{array}$ & $\begin{array}{c}\text { Production } \\
\%\end{array}$ \\
\hline China & 13,000 & 13,000 & 0 & 66 \\
India & 6,000 & 5,000 & 1,000 & 31 \\
Turkey & 400 & $\mathrm{~T}+\mathrm{I} 300$ & $\mathrm{~T}+\mathrm{I} 300$ & 2 \\
Iran & 200 & & & 1 \\
$\begin{array}{l}\text { Total } \\
\%\end{array}$ & $\mathbf{1 9 , 6 0 0}$ & $\mathbf{1 8 , 3 0 0}$ & $\mathbf{1 , 3 0 0}$ & 100 \\
& 100 & 93 & 7 & \\
\hline
\end{tabular}

Source: Hartwich (1911) 33-34

These are staggering figures. ${ }^{9}$ The utilization of 18,300 metric tonnes p.a. of opium in China represented about 50 grams of opium per inhabitant (children included). Opium use "radically affected all levels of Chinese society" and this phenomenon, together with "prohibition movements directed at tobacco and alcohol" in western countries, resulted in the first attempts at drug control early in the 20th century. ${ }^{10}$ These attempts included the Ten Year Agreement of 1907 between India and China to reduce both Indian opium exports and Chinese domestic production by $10 \%$ annually and the international Shanghai opium conference of 1909. ${ }^{11}$ International narcotics control as it developed thereafter is described in Sections 5.6, 7.4 and 8.1.

\subsection{Opium Alkaloids and Opiates}

Opium as a Raw Material for Alkaloid Manufacture.

As described in chapter 2, in 1806 the German pharmacist Friedrich Sertürner was the first to isolate morphine from opium, and he showed it was the principle responsible for the physiological activity of the poppy. ${ }^{12}$ Sertürner called it the principium somniferum (sleepinducing principle). ${ }^{13}$ It was the first time that a physiologically active principle had been isolated from a plant. After Sertürner's discovery became known, the use of morphine for

\footnotetext{
${ }^{9}$ For later years, even larger figures for the opium production in China are mentioned. Zekert, Opiologia, 131 quotes for 1906 a producton of 35,300 $t$ and W. Dethloff, Gründung der Firm [Boehringer Ingelheim] und Weiterentwickling der Abteilung Pharmazeutische Chemikalien. (Section on opium and opiates) (manuscript, ca 1957) mentions 22,555 t for 1908 and 33,364 t for 1916. Gavit, Opium, 132 reports that the "International Anti-Opium Commission" had found in 1923-24 that the production amounted to 15,000 t p.a.

${ }^{10}$ McAllister, Drug Diplomacy, 13-14.

${ }^{11}$ Ibidem, 24-30.

${ }^{12}$ F.W.A. Sertürner, 'Darstellung der reinen Mohnsäure (Opiumsäure) nebst einer chemischen Untersuchung des Opiums mit vorzüglicher Hinsicht auf einen darin neu entdeckten Stoff und die dahin gehörigen Bemerkungen' Trommsdorff's Journal der Pharmacie 14 (1806) 47-93.

${ }^{13}$ M. Goerig and J. Schulte am Esch, 'Friedrich Wilhelm Adam Sertürner - dem Entdecker des Morphins zum 150. Todestag' Anasthesiol. Intensivmed. Notfallmed. Schmerzther. 26 (1991) 492-498.
} 
pain control instead of opium was taken up by the medical profession because it had the great advantage of making the dose more reliable.

Until 1930 opium was the only raw material used for making opium alkaloids commercially. Opium is a complex substance containing about 20 alkaloids, representing up to $25 \%$ of its weight, and also meconic acid, sugars, resinous and wax-like substances. Morphine, codeine, thebaine, noscapine (narcotine) and papaverine are the principal alkaloids. The alkaloid composition of opium varies with its provenance. This is shown in the table below. Opium from Iran or India was the raw material preferred by some alkaloid manufacturers because of its high content of natural codeine.

Table 9.3 Approximate Alkaloid Content of Opium from India, Turkey and Iran (\%)

\begin{tabular}{|l|rrrr|}
\hline Provenance & Morphine & Codeine & Thebaine & Papaverine \\
\hline & 11.3 & 3.0 & 2.1 & 0.7 \\
India & 12.8 & 1.1 & 1.5 & 1.0 \\
Turkey & 11.1 & 2.9 & 3.7 & 1.4 \\
Persia & & & & \\
\hline
\end{tabular}

Note: The noscapine content of Persian and Indian opium is $>5 \%$ but quite variable. Source: Dethloff, Gründung der Firm, 69

\section{Opium Alkaloids and Opiates - Chemical Structure and Properties}

The five major alkaloids of opium are of two types: morphine, codeine and thebaine, which have a morphinan skeleton, and noscapine and papaverine, which are benzylisoquinoline derivatives. Morphine and some of its derivatives such as heroin are often strong analgesics and are potentially addictive. Codeine is an anti-tussive (cough suppressant) and a mild analgesic. ${ }^{14}$ From around 1920 thebaine has been used as the raw material for synthesizing powerful analgesics with a morphinan structure such as oxycodone. The morphinan alkaloids and their chemical derivatives with analgesic properties and abuse potential are commonly classified as "opiates". 15

Papaverine is an anti-spasmolytic, and noscapine (narcotine) has been used for the relief of cough; they are not analgesics and have no addicting properties. The older name narcotine for noscapine is misleading in this respect. Papaverine and noscapine are opium alkaloids but not opiates. The chemical structure of the alkaloids is shown below:

\footnotetext{
${ }^{14}$ Krueger H., Chapter 38 'Narcotics and Analgesics' in R.H.F. Manske (Editor), The Alkaloids, Chemistry and Physiology. (New York 1955) Volume V, Pharmacology, 1-41.

${ }^{15}$ Note: Opiates are not identical with opioids. The product class "opioids" comprises compounds with morphine like properties; opioids include compounds made by chemical synthesis such as pethidine and methadone.
} 
Figure 9.5 Chemical Structure of the main opium alkaloids<smiles>CN1CC1C[C@]12c3c4ccc(O)c3C(C=C[C@H]1O)N(C)CC2C4</smiles>

Morphine<smiles></smiles>

Codeine<smiles>COC1=CC=C2[C@@H]3Cc4ccc(OC)c5c4[C@@]2(CCN3C)[C@@H]1O5</smiles>

Thebaine<smiles>COc1ccc2c(c1OC)COC2C1c2c(cc3c(c2OC)OCO3)CCN1C</smiles>

Noscapine (Narcotine)<smiles>COc1ccc(Cc2nccc3cc(OC)c(OC)cc23)cc1OC</smiles>

Papaverine

The elucidation of the structure of opium alkaloids, especially of the morphinan alkaloids, is one of the major achievements in organic chemistry. The correct structure of noscapine was suggested by Matthiesen and Foster in 1861 and that of papaverine by Goldschmiedt in 1888. Certain elements of the structure of morphine, such as the phenolic $\mathrm{OH}$-group, the alcoholic $\mathrm{OH}$-group and the tertiary $\mathrm{N}-\mathrm{CH}_{3}$ group, were known around 1880 .

In 1886 Howard and Rosen expressed the relationship between morphine, codeine and thebaine as follows:

$$
\begin{array}{ccc}
\mathrm{C}_{17} \mathrm{H}_{17} \mathrm{NO}(\mathrm{OH})(\mathrm{OH}) & \mathrm{C}_{17} \mathrm{H}_{17} \mathrm{NO}\left(\mathrm{OCH}_{3}\right)(\mathrm{OH}) & \mathrm{C}_{17} \mathrm{H}_{15} \mathrm{NO}\left(\mathrm{OCH}_{3}\right)\left(\mathrm{OCH}_{3}\right) \\
\text { Morphine } & \text { Codeine } & \text { Thebaine }
\end{array}
$$

It took from 1890 to 1907 until a largely correct formula for morphine was derived by Knorr and Hörlein. A great deal of further experimental work by eminent organic chemists was necessary before Gulland and Robinson could come up with the entirely correct structure of morphine in $1925^{16}$

The close relationship between the three morphinan alkaloids makes chemical conversions of one alkaloid into another relatively easy. This applies in particular to the conversion of morphine into its $\mathrm{O}^{3}$-methylether, codeine. This synthetic codeine is in all aspects identical with so-called natural codeine isolated from opium.

\footnotetext{
${ }^{16}$ Lyndon F. Small, Chemistry of the Opium Alkaloids (Washington 1932) 336-356.
} 


\subsection{The Manufacture of Morphine and Codeine until 1930}

\section{Figure 9.6 Flow Chart of Opium Processing into Morphine and Codeine}

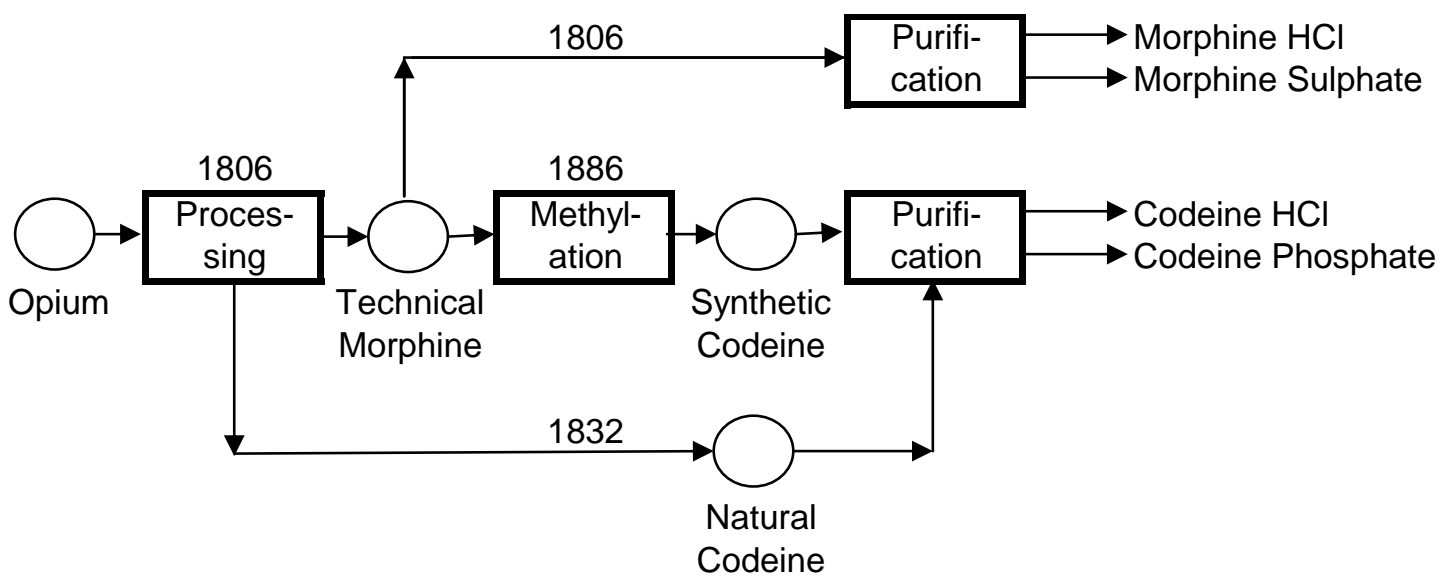

The years indicate the dates of introduction of the processes.

\section{Manufacturers}

The commercial production of opium alkaloids until 1860 is reviewed in section 2.3. It is mentioned there that Thomas Morson of London produced (impure) morphine already in 1821 and that Emanuel Merck was the first to take on the manufacture of morphine on a commercial scale in Germany in $1827 .{ }^{17}$ J.F. Macfarlan commenced commercial morphine production in Scotland in 1834 and Pelletier, in France, added making morphine from opium to its production program around $1835 .{ }^{18}$ Other companies taking up morphine manufacture in the 19th century were T. \& H. Smith (1837, Scotland), the Chimkent Alkaloid Factory (1870s, Russia), Knoll (1886, Germany) and Mallinkrodt (1898, USA). Farbwerke Hoechst (Germany), and Hoffmann La Roche and Sandoz (Switzerland) are mentioned as codeine manufacturers in 1902. ${ }^{19}$ They were followed by C.H. Boehringer Sohn, Ingelheim (Germany) in 1905, and by Merck and Co. Inc, Rahway (USA) at about the same time. ${ }^{20}$

In the 1920s, in the Netherlands two companies embarked on the production of opiates on a very small scale. The companies were the "Nederlandsche Fabriek van Pharmaceutisch-Chemische Producten" at Apeldoorn, trading under the name "Bonnema", and the "Chemische Fabriek Naarden". 21

\section{The Manufacture of Morphine}

The classical processes developed during the 19th century for the isolation of the alkaloids from opium were those of Merck (Germany), Thiboumery-Mohr (France) and Robertson-

\footnotetext{
${ }^{17}$ D. Bolton, 'The Development of Alkaloid Manufacture in Edinburgh 1832-1939' Chemistry and Industry (1976) 702; Bernschneider S., Huber W.T. and Possehl I., "Was der Mensch thun kann . . . " History of the pharmaceutical and chemical company Merck. Darmstadt: Merck KGaA. 3rd edition. (2002) 30.

${ }^{18}$ Barbier, A., The Extraction of Opium Alkaloids, Bulletin on Narcotics (1950) Vol 2[13] 22-29.

${ }^{19}$ Merck, Conventionen und Vertretungen, Jahresbericht über Konventionen 1902. Merck-Archiv F03/6a.

${ }^{20}$ C.H. Boehinger Sohn, 100 Years Boehringer Ingelheim 1885-1985 (1985) 13; Bernschneider, Was der Mensch thun kann, 63.

${ }^{21}$ Bonnema: Department of Foreign Affairs (The Netherlands), Bijeenkomst in verband met de bij den volkenbond zijnde plannen tot beperking van de vervaardiging van verdoovende middelen (1930) October 20, Nationaal Archief, The Hague, Access No. 2.05.21 Item 1596, and Naarden: W.A. van Dorp, De Geschiedenis van de N.V. Chemische Fabriek "Naarden" 1905-1945 (draft document HIG002) (undated) 12.
} 
Gregory (UK). The processes have been critically reviewed by Barbier in $1950 .^{22}$ According to Barbier, the Merck process was not really suitable for use on an industrial scale and the Thiboumery process suffered from a low yield. The Robertson-Gregory process by which the main alkaloids are isolated as a double salt of morphine and codeine hydrochloride (Gregory's Salt) was used from 1834 by the Scottish opiate manufacturers and later also by others. The Robertson-Gregory process was cumbersome but gave reasonably good yields. It is described in detail by Schwyzer. ${ }^{23}$

As a result of the adoption of the superior Gregory process the Scottish manufacturers became the major suppliers of opiates to the world market towards the end of the $19^{\text {th }}$ century. E. Merck's original process had become obsolete and was changed at that time. ${ }^{24}$

Barbier had invented a major improvement of the opium process by purifying the morphine by means of crystallisation of its bitartrate. ${ }^{25}$ His method has been used since by virtually all opium processors.

The salts of morphine most commonly used in pharmaceutical preparations were the hydrochloride and the sulfate. They were supplied complying with the specifications of the various pharmacopoeias. To manufacture these salts, crude morphine from opium was purified extensively via derivatives (e.g. diacetylmorphine) and then converted into the salts. Subsequently the salts were purified further by means of crystallisations. Morphine sulfate and morphine hydrochloride were commonly supplied as crystalline powders. Morphine hydrochloride was also supplied in the form of snow-white cubes (sides10-12 mm).

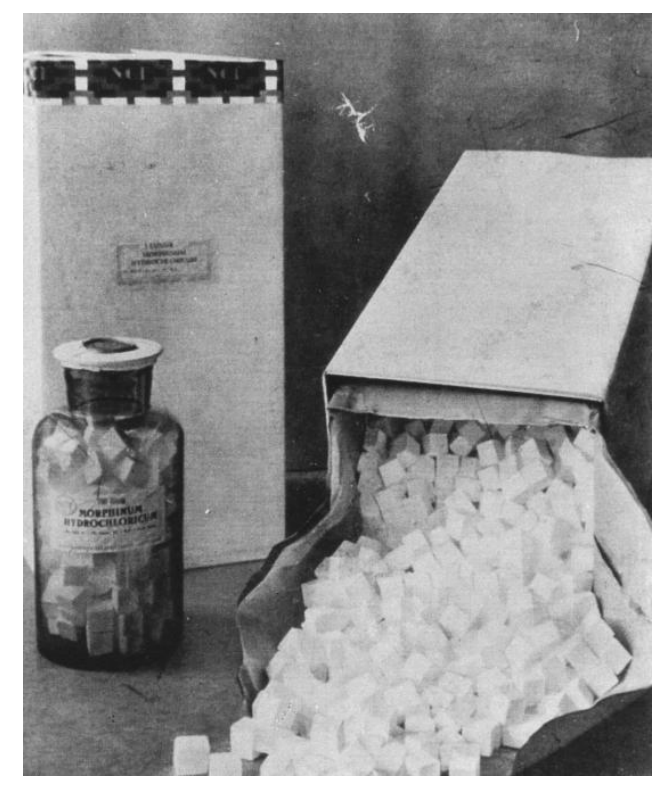

Figure 9.7 Morphine

hydrochloride (NCF)

in cube form.

(Photo archive Akzo Pharma)

Figure 9.8 Equipment for making the cubes. ${ }^{26}$

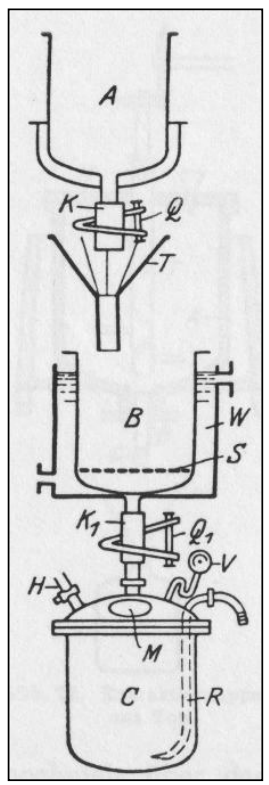

To manufacture morphine hydrochloride in cube form, the first step is to let it crystallise from aqueous solution as a solid cylinder. That cylinder, after removal of mother liquors, is cut into the cubes.

\footnotetext{
${ }^{22}$ Barbier, A., 'The Extraction of Opium Alkaloids', Bulletin on Narcotics (1950) Vol 2[13] 22-29.

${ }^{23}$ Schwyzer J., Die Fabrikation der Alkaloide. (Berlin 1927) 54-68.

${ }^{24}$ H. Dumitriu, Die wissenschaftlische Entwicklung der Alkaloidchemie am Beispiel der Firma Merck in den Jahren 1886-1920, Inaugural Dissertation. (Heidelberg 1993) 29.

${ }^{25}$ A. Barbier, 'The Extraction of Opium Alkaloids' 22-29 and Ann. Pharm. Franc. Vol 5 (1947) 121

${ }^{26}$ Schwyzer J., Die Fabrikation der Alkaloide (1927) 64.
} 


\section{The Manufacture of Codeine}

In 1832 a further alkaloid, codeine, was isolated from opium by Robiquet and became a valuable product, being used for the treatment of moderate pain and in cough preparations. Until the 1880s all codeine manufactured was natural codeine, i.e. codeine isolated from opium. E. Merck was the first to produce codeine in commercial quantities in $1832 .{ }^{27}$ Codeine was valued as an anti-tussive but the availability was limited because the amount of codeine that could be produced from opium was only about $10 \%$ of that of morphine. The price of codeine was about twice that of morphine at that time.

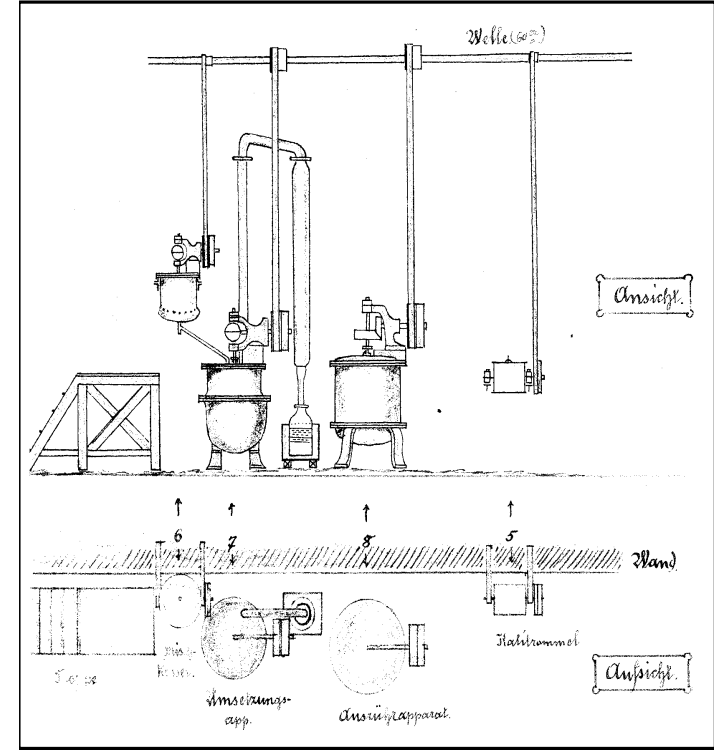

Figure 9.9 Dr. A. Knoll's drawing (1906) of his codeine manufacturing equipment (Drawing: Knoll AG,100 Jahre im Dienst der Gesundheit,1986)

In 1881 it was established by Grimaux that codeine was the $0^{3}$-methyl ether of morphine. That opened up the possibility of making codeine from morphine by chemical synthesis. The first practical method for making semi-synthetic codeine was patented by Albert Knoll in Germany in $1886 .^{28}$

Knoll used monomethyl sulfate as the methylating agent. Made with a yield of $70 \%$ from morphine, synthetic codeine, identical with the natural product, could be manufactured in more of less unlimited quantities and at lower cost than directly from opium. This invention led to the founding of the company "Knoll \& Co", Ludwigshafen am Rhein (Germany). ${ }^{29}$

Merck expanded its codeine production in 1882/83 after Scriba had developed codeine phosphate as an easily soluble compound suitable for oral administration. The company relied initially on the use of Iranian opium as a rich source of natural codeine. Later, because of the patent situation, Merck bought additional quantities of codeine from Knoll. ${ }^{30}$ After the establishment of the "Interessengemeinschaft" between Merck, Boehringer Mannheim and Knoll in 1906, Merck stopped producing codeine entirely, all manufacture of

\footnotetext{
${ }^{27}$ Dumitriu, Die wissenschaftlische Entwicklung, 30.

${ }^{32}$ Knoll, Albert, Verfahren zur Darstellung von Methylmorphin (Codein) und Ethylmorphin. German Patent No. 39,887 (1886) August 7.

${ }^{29}$ Knoll AG 100 Jahre im Dienst der Gesundheit 1886-1986, Ludwigshafen, Knoll Aktiengesellschaft; (1986).

${ }^{30}$ Dumitriu, Die wissenschaftlische Entwicklung, 31.
} 
which was passed on to Knoll. ${ }^{31}$ From 1919/20 onwards Merck produced codeine again in its own facilities in Darmstadt. ${ }^{32}$

From the beginning of the 20th century the demand for codeine has been much larger than that for morphine and most of the morphine produced was not used as such but was converted into codeine. The morphine used as input for the conversion process is a technical morphine, containing about $90 \%$ anhydrous morphine base. The process commonly used for the conversion of morphine into codeine is that patented by C.H. Boehringer Sohn, Ingelheim (Germany) in $1909 .{ }^{33}$ It uses the phenyl- trimethylammonium ion as the methylating agent which is generated from the corresponding chloride that is made by reacting dimethylaniline with methyl chloride.

$\mathrm{PhNMe}_{2}+\mathrm{MeCl} \rightarrow \mathrm{PhN}^{+} \mathrm{Me}_{3} \mathrm{Cl}^{-}$

Figure 9.10 The methylation of morphine

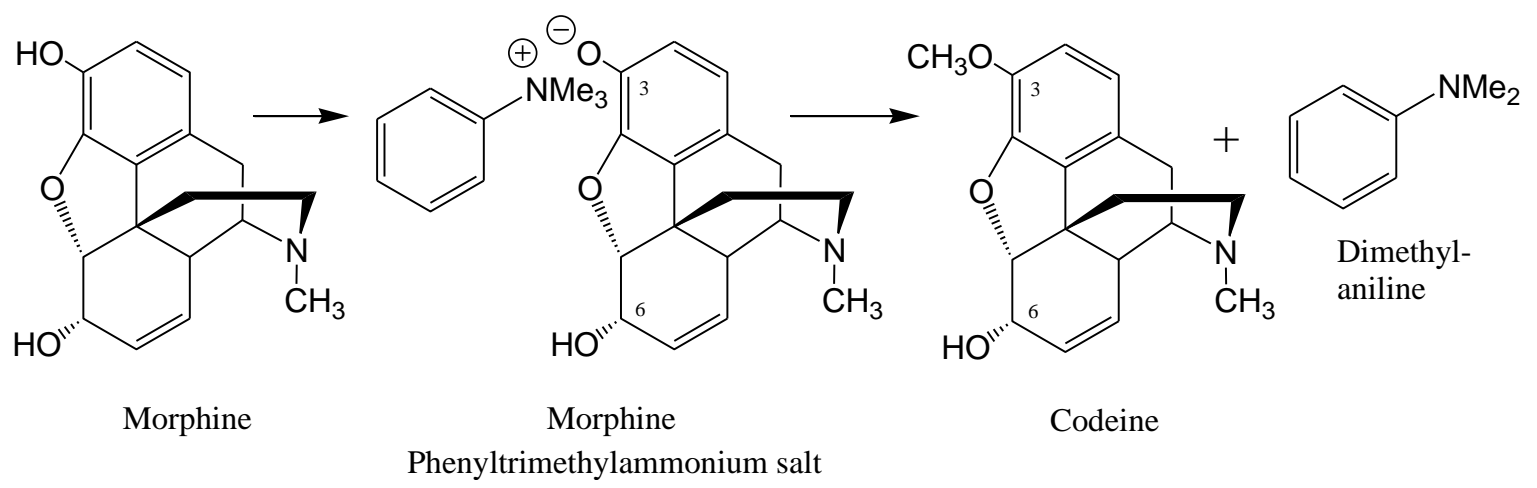

During the methylation reaction one of the methyl groups of the quaternary ammonium salt is transferred to the $0^{3}$ of the morphine molecule under the formation of codeine and dimethylaniline. The dimetylaniline can be isolated from the reaction mixture and is used for making new methylating agent. Overall yield of the process is in the order of $90 \%$. The principal by-product of the reaction is $0^{6}$-methylcodeine (dimethylmorphine). Some morphine remains unconverted and is recovered. After removal of the unconverted morphine the crude codeine is extensively purified and the now pure codeine is converted into its various salts (phosphate, hydrochloride) or base (as the mono-hydrate) complying with pharmacopoeias and customer's specifications.

\footnotetext{
${ }^{31}$ Bernschneider c.s., "Was der Mensch thun kann . . . .", 76.

${ }^{32}$ Dumitriu, Die wissenschaftlische Entwicklung, 31.

${ }^{33}$ C.H. Boehinger Sohn, Patent on the conversion of morphine into codeine using trimethylphenylammonium chloride. German Patent No 247180 (1909).
} 


\subsection{Development of the world market for Morphine and Cocaine.}

\section{Volume and Prices}

Quantitative information on the manufacture of morphine and codeine during the $19^{\text {th }}$ century is scarce. Of Merck's morphine production we know the following data: ${ }^{34}$

Table 9.4 Opium processing by Merck first half $19^{\text {th }}$ Century

\begin{tabular}{|c|c|c|}
\hline Year & $\begin{array}{c}\text { Opium } \\
\text { Processed } \\
\text { kg }\end{array}$ & $\begin{array}{c}\text { Morphine } \\
\text { and Salts } \\
\text { Produced kg }\end{array}$ \\
\hline 1832 & 75 & 7 \\
1840 & 657 & 62 \\
1841 & 682 & 64 \\
1842 & 843 & 79 \\
1847 & 3,041 & 285 \\
\hline
\end{tabular}

Source: G.Huhle-Kreutzer (1989)

Note: The figures in blue are calculated by the author on the basis of the ratio Morphine produced / Opium used for the year 1842

Of the second half of the $19^{\text {th }}$ century no data have been located but it is documented that Merck used $17 \mathrm{t}$ opium as raw material during 1902/03. ${ }^{35}$ We further know that Merck produced $700 \mathrm{~kg}$ codeine in 1904/05 and that it sold $844 \mathrm{~kg}$ and 1,122 $\mathrm{kg}$ codeine in 1908 and 1909 respectively. ${ }^{36}$

In 1902 a codeine convention (cartel) existed in Europe, of which Merck was a member; it is not known who the other members were. Total sales of codeine by the convention amounted to 2,789 and $2.656 \mathrm{~kg}$ for the years 1908 and 1909 respectively. ${ }^{37} \mathrm{~A}$ separate morphine convention, in which also the Scottish manufacturers participated existed at the time but it was dissolved in 1909 (vide infra). ${ }^{38}$ Hoffmann La Roche (Switzerland) and C.F. Boehringer \& Söhne, Mannheim are mentioned as members of a combined codeine and morphine cartel together with E. Merck, Knoll \& Co and Boehringer Ingelheim in $1915 .{ }^{39}$

Some statistics are available for opium processing by Macfarlan and T. \& H. Smith in Edinburgh during the second half of the $19^{\text {th }}$ century. ${ }^{40}$ They are compiled in the following table:

\footnotetext{
${ }^{34}$ Gabriele Huhle-Kreutzer, Die entwicklung arzneilicher Produktionsstätten aus Apothekenlaboratorien (Stuttgart 1989) 135-136.

${ }^{35}$ H. Dumitriu, Die wissenschaftlische Entwicklung, 29.

${ }^{36}$ H. Dumitriu, Die wissenschaftlische Entwicklung, 30; Merck, Conventionen und Vertretungen, Jahresbericht über Konventionen in 1915. Merck-Archiv F03/6a.

${ }^{37}$ Merck, Conventionen und Vertretungen, Jahresbericht 1902 and 1909.

${ }^{38}$ Ibidem, Jahresbericht 1909.

${ }^{39}$ Ibidem, Jahresbericht 1915.

${ }^{40}$ K.C. Reid, The Macfarlan Smith Company. A brief review of its origins. Unpublished manuscript. (1988, modified version 1990) E1-2; D. Bolton, 'Alkaloid Manufacture in Edinburgh', 702-708.
} 
Table 9.5 Opium processing in Scotland during the second half $19^{\text {th }}$ Century

\begin{tabular}{|c|c|c|}
\hline Year & Company & $\begin{array}{c}\text { Opium } \\
\text { Processed } \\
\text { (approx.) kg }\end{array}$ \\
\hline 1858 & T \& H Smith & 500 \\
1870 & T \& H Smith & 5,000 \\
1880 & T \& H Smith & 20,000 \\
1890 s $\left.^{*}\right)$ & Macfarlan & 50,000 \\
\hline
\end{tabular}

*) Annual average of peak years during the 1890s

Sources: K.C. Reid (1990) and D. Bolton (1976)

Bolton writes that during the 1890s: "In a number of years, one firm alone [Macfarlan] sold about $250,000 \mathrm{oz}(7,000 \mathrm{~kg})$ of [morphine] salts. Codeine sold would be much less, about 10 per cent, as all was natural in those days". "From these figures it is concluded that the total production of morphine plus codeine in Scotland in the 1890s was many times larger than the codeine production in continental Europe in the early1900s.

As mentioned above, in the early 1900s a separate morphine convention (cartel) existed of which both German and UK manufacturers were members. That convention was dissolved in 1909 because of strong competition by Boehringer Ingelheim which made that the price target could not be reached, and because the German members sold only ca 2,400 $\mathrm{kg}$, which was half of their quota, resulting in hefty cash payments by the UK members which left them dissatisfied. ${ }^{42}$

Information on selling prices of opiates during the $19^{\text {th }}$ and early $20^{\text {th }}$ century is hardly available. The only price information found came from annual reports by Merck on the codeine convention. ${ }^{43}$ That information is presented with table 9.6

Table 9.6 Prices for Pure Codeine Base Monohydrate 1900-1909

\begin{tabular}{|c|c|}
\hline Year & $\begin{array}{c}\text { Convention Price } \\
\text { Codein Base 1 aq. } \\
\text { DEM per kg }\end{array}$ \\
\hline 1900 & 480 \\
1901 & $420-450$ \\
1902 & $360-420$ \\
1909 & $345-440$ \\
\hline
\end{tabular}

Source: Merck (1909)

\footnotetext{
${ }^{41}$ Bolton, 'Alkaloid Manufacture in Edinburgh', 708. The Knoll patent for making semi-synthetic codeine is from 1886. It is surprising to read that "all codeine [made by Macfarlan?] was "natural" in those days".

${ }^{42}$ Merck, Conventionen und Vertretungen, Jahresbericht 1909, 10.

${ }^{43}$ Ibidem, 1902 and 1909.
} 
Some statistics are available from the League of Nations on the importation of raw opium into the member states for the purpose of manufacturing opiates for the years 1920-1923. These are incomplete but indicate that on average ca $250 \mathrm{t}$ per annum was reported as used for that purpose, with Germany, the USA and the UK as the largest importers of about equal size. ${ }^{44}$ Limited quantitative information on the production of and trade in narcotic drugs during the period 1924-1928 had been obtained by the PCOB (League of Nations) from governments of member countries. This information was compiled by the PCOB and published in $1930 .{ }^{45}$ More complete statistics were published for the years from 1929 onwards. ${ }^{46}$ The quantities reported for morphine produced and converted into non-controlled opiates (codeine) during 1929 and 1930 appear in the following tables: ${ }^{47}$

\section{Table 9.7 Morphine Production \\ Worldwide 1929-1930}

\begin{tabular}{|l|r|r|}
\hline \multirow{2}{*}{$\begin{array}{l}\text { Manufacturing } \\
\text { Countries }\end{array}$} & \multicolumn{2}{|c|}{$\begin{array}{c}\text { Morphine Produced } \\
\text { kg AMA }\end{array}$} \\
\cline { 2 - 3 } & $\mathbf{1 9 2 9}$ & \multicolumn{1}{|c|}{$\mathbf{1 9 3 0}$} \\
\hline & 24,000 & 10,555 \\
Germany & 12,141 & 12,495 \\
France & 8,374 & 5,373 \\
U S A & 4,577 & 1,911 \\
U K & 4,140 & 1,844 \\
Switzerland & 1,989 & 1,904 \\
Japan & 233 & 341 \\
Other Countries & & \\
& $\mathbf{5 5 , 4 5 4}$ & $\mathbf{3 4 , 4 2 3}$ \\
Total & & \\
\hline
\end{tabular}

\section{Table 9.8 Morphine Conversion Worldwide 1929-1930}

\begin{tabular}{|l|r|r|}
\hline \multirow{2}{*}{$\begin{array}{l}\text { Manufacturing } \\
\text { Countries }\end{array}$} & \multicolumn{2}{|c|}{$\begin{array}{c}\text { Morphine Converted } \\
\text { kg AMA }\end{array}$} \\
\cline { 2 - 3 } & \multicolumn{1}{|c|}{$\mathbf{1 9 2 9}$} & \multicolumn{1}{c|}{$\mathbf{1 9 3 0}$} \\
\hline & 18,620 & 9,060 \\
Germany & 6,407 & 6,667 \\
France & 5,769 & 3,461 \\
U S A & 2,848 & 658 \\
U K & 5,475 & 1,874 \\
Switzerland & & \\
Total AMA converted & $\mathbf{3 9 , 1 1 9}$ & $\mathbf{2 1 , 7 2 0}$ \\
Percent of Total & & \\
AMA produced & 71 & 63 \\
\hline
\end{tabular}

Source: PCOB statistics (Synopsis from A.35.1932.XI)

Note: $\quad \mathrm{AMA}=$ Anhydrous Morphine Alkaloid. This is a currently widely used abbreviation for the quantity of Morphine Base $100 \%$ contained in opium, morphine salts, technical morphine etc. Similarly, ACA stands for Anhydrous Cocaine Alkaloid, the quantity of Codeine Base 100\% contained in opium, codeine salts etc.

The total quantity of morphine produced was 55 t AMA for 1929 and 34 t AMA for 1930 (Table 9.7). Of the morphine produced in 1929 ca 39 t AMA was converted, mainly into codeine and to a lesser degree into other opiates such as ethylmorphine. The amount converted was ca $22 \mathrm{t}$ in 1930 (Table 9.8).

As mentioned at the beginning of this Section, during the 1890s the production of morphine in Scotland was much larger than in Germany. In 1929-1930 the situation was reversed and Germany had become the main manufacturer. No information is available on the production in these countries during the more than 30 years between these periods, and the exact reason(s) for the change are not known. The following factor could have played a role: in the 1890s morphine was an uncontrolled substance and it could be sold without any

\footnotetext{
${ }^{44}$ Much larger quantities of opium were imported into East Asian countries during that period. Société des Nations, Deuxième Conférenence de l'Opium, Partie I, Tableaux Statistiques 1920-1923 O.D.C.1. (C.656.M.234.1924.XI) Geneva 1924.

${ }^{45}$ Permanent Central Opium Board, Advisory committee on traffic in opium and other dangerous drugs. Report on the 13th Session, Geneva 1930, Annex 3 Document C.121.M.39.1930.XI (Geneva 1930).

${ }^{46}$ Permanent Central Opium Board, Annual Reports to the Council on the Work of the Board and Statistics for the Year 1929, C.629.M.250.1930.XI and following years (under different document code numbers).

${ }^{47}$ Permanent Central Opium Board, Annual Reports to the Council on the Work of the Board and Statistics. for the Year 1931, A.35.1932.XI (Synopsis).
} 
restrictions while after the Geneva Convention of 1925 the market for the now controlled morphine was different. The growth of the German manufacture was mainly in codeine, still an uncontrolled substance in 1930.

Opiate Manufacture in the Netherlands during the 1920s

As mentioned in section 9.3, in the 1920s two Dutch companies the "Nederlandsche Fabriek van Pharmaceutisch-Chemische Producten" (Bonnema), and the "Chemische Fabriek Naarden" (Naarden) embarked on the production of opiates on a very small scale for which they had obtained licenses required under the Opium Act (Opiumwet) of 1919. Data on production and consumption of morphine and codeine in the Netherlands for the period 19251930 sourced from PCOB publications are presented in the following table:

Table 9.9 Production and Consumption of Morphine and Cocaine in the Netherlands 1925-1930

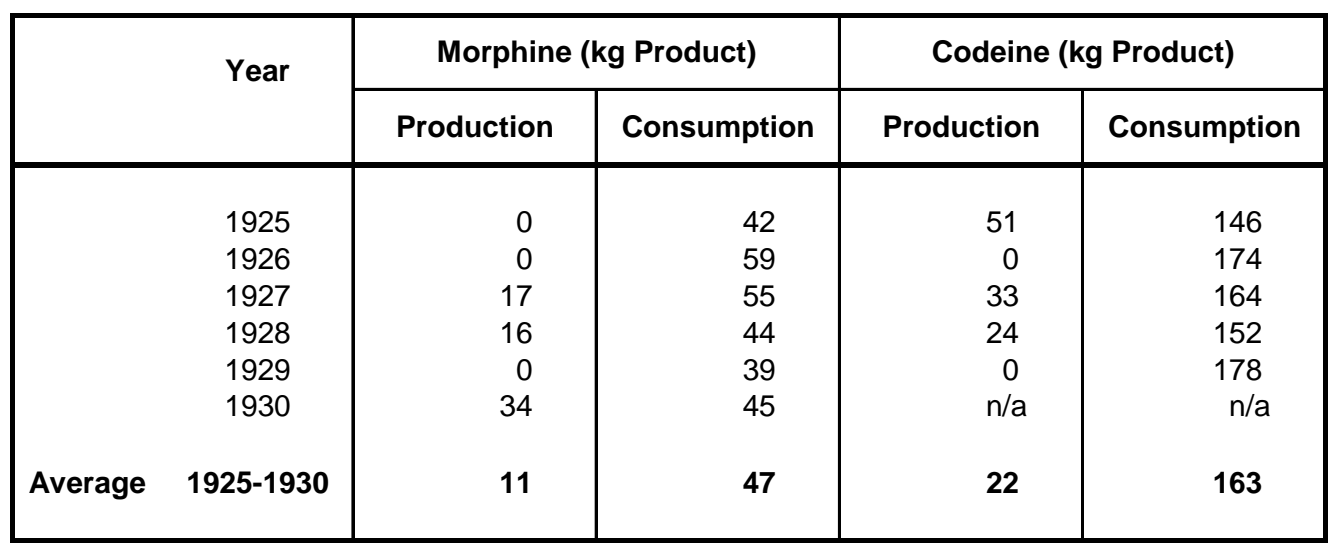

n/a: $\quad$ Not available (Codeine was not an internationally controlled substance until 1934) Source: PCOB publications C.121.M.39.1930.XI and C.518.M.213.1930.XI

The quantities produced were very small and even insufficient for supplying the local requirements. Bonnema manufactured opiates only if the business was rewarding. That was the reason that for 1929 no production was reported. ${ }^{48}$ After World War II Bonnema became a quite large opiate manufacturer and its history is described in detail later in this dissertation.

"Naarden" produced morphine from opium and heroin from [imported] morphine during the period 1922-1928. ${ }^{49}$ During 1927-1928 "Naarden" traded large quantities of morphine, heroin and cocaine that it bought in Germany and Switzerland and shipped in transit (but relabelled) to China. Because of the Geneva Convention of 1925 this was semi-illegal business for which "Naarden" was strongly criticized. ${ }^{50}$.Van Dorp, who wrote "De Geschiedenis van de Chemische Fabriek "Naarden" (The History of the Chemical Factory "Naarden") as a draft after his retirement as Managing Director of the company, mentions that in 1926 traded

\footnotetext{
${ }^{48}$ Mr.C.J. Jansen, manager/owner of Bonnema, stated during a meeting with the Dutch delegates to a meeting in Geneva that only a few kg were produced in 1929. Department of Foreign Affairs (The Netherlands), Bijeenkomst in verband met de bij den volkenbond zijnde plannen tot beperking van de vervaardiging van verdoovende middelen (1930) October 20, Nationaal Archief, The Hague, Access No. 2.05.21 Item 1596.

${ }^{49}$ Van Dorp, 'N.V. Chemische Fabriek "Naarden” ', 12.

${ }^{50}$ M. de Kort, Tussen patiënt en delinquent, geschiedenis van het Nederlandse drugsbeleid (Hilversum 1995) 98-110.
} 
products were often sold under the "Naarden" label while they were purchased from other manufacturers. ${ }^{51}$

The Board of the Koloniale Bank discussed the sales policy of the NCF in relation "Naarden-case" during a board meeting in 1929. Board members expressed their concern that, although NCF was not involved at all in such semi-legal transactions, even totally untrue rumours thereof could discredit the Koloniale Bank, something they wished to prevent at any cost. $^{52}$

De Kort has described and analysed the "Naarden-case" and specifically the involvement of a Mr. Nieuwenhuis in detail in his dissertation. ${ }^{53}$

\subsection{Profitability of the Opiate Business in the 1920s.}

\section{Cost Factors and Factory Management}

Schwyzer provides the following detailed cost calculations for the processing of $100 \mathrm{~kg}$ opium in $1924:^{.54}$

Cost $100 \mathrm{~kg}$ opium (11\% morphine) CHF 5,200

Cost of labour, energy, chemicals and solvents $\quad$ CHF 231

Total Variable Cost

CHF 5,431

Yield $12.8 \mathrm{~kg}$ morphine hydrochloride

$0.5 \mathrm{~kg}$ natural codeine

at $\mathrm{CHF} 550=\mathrm{CHF} 7,040$

$4.0 \mathrm{~kg}$ noscapine (narcotine)

at $\mathrm{CHF} 738=\mathrm{CHF} 369$

at $\mathrm{CHF} 120=\mathrm{CHF} 480$

Total Sales

CHF 7,889

Note In 1924 the value of CHF 1.00 was approximately NLG $0.38=$ USD 0.18

From the Schwyzer's cost figures and general cost considerations the following conclusions can be drawn:

1. The cost of the opium represents more than $95 \%$ of the variable cost and total variable cost represents $5,431 / 7,889=69 \%$ of the sales value of the product and results in a contribution margin of $31 \%$. Schwyzer mentions $18 \%$ of the sales value as a conservative estimate of all other (fixed) cost, implying an estimated net income of $13 \%$ on sales. This is not a very attractive net income for this type of industry. Bolton of Macfarlan comments on the profits of the Scottish opiate manufacturers during the first part of the 20th century that "[The industry gave] a reasonable return on capital invested [...but] certainly, no fantastic fortunes were ever achieved". 55

2. An unfavourable yield variance of, say 3\%, applied to Schwyzer's figures leads to a reduction in contribution margin from 31 to $29 \%$ and a decline in net income as a percentage

\footnotetext{
${ }^{51}$ Van Dorp, 'N.V. Chemische Fabriek "Naarden” ', 14-15.

${ }^{52}$ Koloniale Bank, Notulen Commissarissen Vergaderingen (Minutes of Board Meetings

Meeting of 21 February 1929, Nationaal Archief, The Hague, Access No. 2.20.04, Items 13-19.

${ }^{53}$ De Kort, Tussen patiënt en delinquent, 98-110.

${ }^{54}$ Schwyzer, Die Fabrikation der Alkaloide, 73.

${ }^{55}$ Bolton, 'Alkaloid Manufacture in Edinburgh', 708.
} 
of sales of $2 \%$ (from $13 \%$ to $11 \%$ ), representing a $15 \%$ reduction in net income for the company. This calculation shows that achieving good yields of the end products from the expensive raw material is exceedingly important for the bottom line of an alkaloid business. It puts a heavy responsibility on the shoulders of the factory manager (chief chemist). Schwyzer has interesting things to say about that: in his opinion the factory manager should:

- never forget the 'sensitivity' of the products for chemical and physical influences;

- have complete knowledge of all processes and products;

- have the ability to retain and 'overview' what is going on at any point in time;

- have minimal amount of product in second fractions and mother liquors; they should be worked up with priority;

- make yield calculations as soon as possible to know what is going on in the factory.

The above points were also much stressed at the NCF well into the 1960s. Bolton, in his review of Macfarlan's operations until 1939, mentions the same "meticulous attention to detail, particularly in removing every milligram of alkaloid from liquid or solid residues". 56

3. Historically the opium price has been quite variable. As an example, in the 1930s the price of Turkish opium (at 12\% morphine) imported in Switzerland varied between USD 6 and 12 per kg. ${ }^{57}$ As a result of the price fluctuations opium stocks had to be revalued regularly, which especially in the case of large stocks resulted in considerable purchase price variances which affected net income and made profit forecasting difficult.

The question of the optimal size of the opium stocks to be maintained by the opiate manufacturer was a difficult one to answer anyhow. Considerations that affected the decision of when and how much opium to order were:

- market expectations, both in respect to the opium price and opiate sales;

- the cost of opium, which represented $70 \%$ of sales revenue. The interest burden of carrying, say, one year's stock was considerable;

- the time from ordering the opium to having the finished product made from it in stock, was long. It was in the order of 6-9 months. ${ }^{58}$

Outlook for the NCF as a prospective Opiate Manufacturer in 1930

The profit considerations above together with the figures in tables 9.7 and 9.8 provide a picture of the market that NCF, as a newcomer, had to face in the early 1930s: strong, well established competitors in Europe, a market that was shrinking considerably as a result of the new international controls adopted by the Geneva Conference of 1925, and a small home market in which NCF had already a competitor. In addition to this somewhat scary market outlook NCF will have been well aware of the fact that it still had to gain experience in manufacturing the products, including optimizing the processes.

\footnotetext{
${ }^{56}$ Ibidem.

${ }^{57}$ United Nations. The Movement of Opium Prices during the years 1930-1939 and 1946-1949. Commission on Narcotic Drugs - E/CN.7/AC.4/2/Add.2.Geneva 1950.

${ }^{58}$ Nederlandsche Cocaine Fabriek, Notulenboek Commissarisvergaderingen (Minutes of Board Meetings

23 February 1934 - 15 May 1950). Meeting of 17 September 1946.
} 


\subsection{Summary and Conclusions.}

Opium and preparations thereof were virtually the only medicines available to mankind to lessen severe pain until the $19^{\text {th }}$ century. In 1806, Sertürner was the first to isolate morphine from opium and morphine became the main agent for the control of severe pain thereafter.

The production of morphine on a larger scale was soon taken up by Emanuel Merck and other pharmacists. This development can be seen as the birth of the modern bulk pharmaceutical industry. The isolation of other opium alkaloids such as codeine followed and the manufacture of opium alkaloids became an important industry towards the end of the $19^{\text {th }}$ century, especially in the UK and in Germany. The growth of the opiate market continued in the $20^{\text {th }}$ century, especially for codeine, but became affected by the international narcotics control measures after the Geneva conference of 1925.

Similarly to the cocaine market, the opium alkaloid market was characterized by strong competition and price erosion leading to the formation of cartels (conventions) by manufacturers in an attempt to maintain a reasonable profit. These attempts were not very successful and profits were only moderate throughout the industry.

This was the situation in the opiate market that NCF was facing at its entry into that market in 1931: a for NCF new product range, well established competitors, a shrinking international market, a small home market and small margins on sales. 


\title{
Chapter 10 \\ ENTERING THE OPIATE BUSINESS THE NCF DURING THE 1930S
}

\begin{abstract}
Overview
The main markets in which NCF was operating in the 1930s were the cocaine market and the market for opiates. Both markets were shrinking as a result of the sales limitations pursuant to the Geneva Conventions of 1925 and 1931. It was a challenging situation for NCF, the more so as both opiate manufacture and marketing were new ventures for the company.
\end{abstract}

Bonnema, the other manufacturer of narcotic drugs in the Netherlands, grew in output during the period and supplied about one-third of the home market for opiates.

Statistical information on narcotic drugs, which was published by the League of Nations and later by the United Nations, is extensively used in this dissertation. Knowledge of certain peculiarities of the reporting system is required for good understanding. For this reason the history of the statistics on narcotic drugs and some of its arithmetical peculiarities are set out at the beginning of this chapter.

\subsection{Statistical Information on Narcotic Drugs}

\section{Statistical Publications on Narcotic Drugs by the League of Nations}

In preparation for the 1925 Geneva Opium Conference, the Opium Advisory Commission (OAC) of the League of Nations requested that the governments of participating countries collect statistical information on the production of opium and coca leaves, the manufacture of morphine, heroin and cocaine, and the export and import of these products. ${ }^{1}$ The information was requested for the years 1920-1923.

The information received was processed by the OAC and the results were published as Deuxième Conférence de l'Opium, Partie I, Résumé des Renseignements reçus des Gouvernements. ${ }^{2}$ The data in this publication are quite incomplete in comparison to those appearing in later reports, and the amounts for morphine, heroin and cocaine represent quantities of bases and salts thereof combined, but nevertheless they provide very valuable information. This 1924 publication marks the beginning of data collection for a very large worldwide administrative control system of the production and manufacture of controlled substances, a system which is still in place today. Since 1968 the control system has been governed by the International Narcotics Control Board (INCB) of the United Nations.

In 1930 the newly formed Permanent Central Opium Board (PCOB) requested similar information from the participating countries, this time over the period 1925-1929. The replies from the governments were published as PCOB report Traffic de l'opium et autres drogues nuisibles. Réponses des Gouvernements, addressed to the Secretary General of the League of Nations. ${ }^{3}$ More complete statistics for this period were published as Conference on the Limitations of the Manufacture of Narcotic Drugs. Statistics 1925-1928. ${ }^{4}$ These reports are more complete than the publication from 1924 and are an extensive source of production and

\footnotetext{
${ }^{1}$ William B. McAllister, Drug Diplomacy in the Twentieth Century (London 2000) 47

${ }^{2}$ Document O.D.C.1 (C.656.M.234.1924.XI ) dated 22 July 1924. All PCOB documents published before

World War II mentioned in this chapter were consulted by the author at the LoN Archives and Historical

Collections Section of the United Nations Library Geneva.

${ }^{3}$ PCOB Report C.518.M.213.1930.XI (present at the Nationaal Archief, Den Haag).

${ }^{4}$ PCOB Report C.121.M.39.1930.XI.
} 
trade statistics on opiates and cocaine. However, it is not always clear if the amounts refer to the quantities of bases or salts or mixtures thereof. ${ }^{5}$

\section{"The Statistics"}

From 1929 onwards the Permanent Central Opium Board (PCOB) of the League of Nations collected extensive statistical information on the substances controlled under the Geneva Convention of 1925. That information was supplied to the PCOB by the governments which were signatories to the Convention. The PCOB processed the data and compiled them in a set of tables which were published annually. These publications were issued originally as a part of a "Report to the Council [....] the Statistics for the Year [...]" a title that varied somewhat over the years. They are usually referred to as "The Statistics (on Narcotic Drugs)". The PBOB Statistics provided extensive quantitative information on the manufacture of the controlled substances, their raw materials and intermediates, and their consumption. The statistics also included information on exports and imports.

The PCOB did not check the information obtained from governments for factual correctness; it was however checked for administrative errors and omissions. Additional information was requested if any discrepancies were discovered e.g. when statistics submitted by importing and exporting countries were compared. During the early years the PCOB was, however, not always able to obtain all required information from the governments; especially information from smaller countries was often incomplete. ${ }^{6}$

The "Statistics" became more extensive during the 1930s. The data supposedly refer to quantities of base $100 \%$ contained in the various products but that is not stated explicitly in the Statistics. From 1934 onwards codeine and ethylmorphine (dionine) are included in the statistics. All data reported are by country. Individual manufacturers are not mentioned in the Statistics. In case of more than one manufacturer operating in a country, the governments involved obtained the information from the individual manufacturers and combined the data, which were submitted to the PCOB thereafter.

Today, all quantities of drugs reported in the Statistics are expressed as $\mathrm{kg} 100 \%$ (anhydrous) base contained in the drugs. ${ }^{7}$ This is necessary because the drugs are commonly traded as salts (hydrochlorides, phosphates etc.) of alkaloids or derivatives, and each salt has a different base content. To calculate the total quantity of a drug manufactured over a certain period, the base (alkaloid) content of each salt manufactured is calculated by multiplying the weight of each salt with a conversion factor and the amounts are then added together. ${ }^{8}$ Even the weight of pure pharmaceutical grade bases, e.g. morphine base and codeine base, have to be multiplied by a factor because the pharmaceutical grades contain water of crystallisation. In

\footnotetext{
${ }^{5}$ Document C.518.M.213.1930.XI is a collection of submissions by governments on stocks etc. A few examples of the confusion: Germany reported all quantities as bases ("base de morphine" etc), while the UK reported salts and bases ("sels", "alcaloide") separately. The Netherlands reported morphine and heroin as the totals of salts and bases. Many countries reported just as "morphine" and "cocaine" without any specification.

${ }^{6}$ See e.g. PCOB Report to the Council A.35.1932,XI 3-7.

${ }^{7}$ Remarkably, this fact is still not explicitly stated in the Statistics. However, the Instructions for completion of INCB Form A on Quarterly Statistics (V 02-60737) to be submitted by governments, states that "Figures included in this form should be expressed in terms of the pure anhydrous drug content of the respective quantities of the crude drug, refined drug, base, salt or preparation being accounted for." It is the personal experience of the author, working in the narcotics industry since 1960, that all reporting to the government on controlled substances was always in pure anhydrous drug (= base $100 \%)$ content.

${ }^{8}$ The conversion factors to calculate the weight of the base $100 \%$ from the weights of the salts, are contained in the UN publication Multilingual List of Narcotic Drugs under International Control (New York 1968) and reported as: "\% b.anh." The conversion factors are the ratios of the molecular weights of the base $100 \%$ and the compound.
} 
recent years the acronyms AMA, ACA, and ATA for Anhydrous Morphine Alkaloid, Anhydrous Codeine Alkaloid and Anhydrous Thebaine Alkaloid respectively are used when reporting quantities $100 \%$ base contained in the salts. For example $1 \mathrm{~kg}$ morphine hydrochloride $\left(3 \mathrm{H}_{2} \mathrm{O}\right)$ contains $0.759 \mathrm{~kg}$ AMA and $1 \mathrm{~kg}$ codeine base $\left(1 \mathrm{H}_{2} \mathrm{O}\right)$ contains 0.943 kg ACA.

After World War II the narcotics control function of the League of Nations was transferred to the United Nations. In 1968 the tasks of the PCOB were taken over by the then newly established International Narcotics Control Board (INCB) of the United Nations. The INCB continued issuing the annual statistical information under the name "Statistics on Narcotic Drugs". Current statistics appear as the major section of the INCB annual publication "Narcotic Drugs" of ca 400 pages in total, which is available from the INCB website www.incb.org. The 2011 publication of "Narcotic Drugs" contains the Report of the INCB for 2010 and the Statistics for 2009.

One can conclude that the PCOB/INCB Statistics are invaluable as a source of quantitative information on the history of the opiate and the cocaine industry. They are used extensively in this dissertation. They are a most valuable source of information for those involved in the manufacture and trade of controlled substances. They show the amounts produced and traded by country, which raw materials were used, how large the consumption of the drugs was in each country and to which countries the products were exported. Yields from plant raw materials are included in the statistics and it is even possible to estimate process yields achieved for products made by conversions of morphine from the data provided. These process yields are a measure of the efficiency of the manufacturers and can be used to estimate the cost of the production in individual countries. The estimates can also be used by manufacturers to judge the strength of competitors.

\subsection{The Opiate and Cocaine Business during the 1930s}

\section{The Market for Opiates}

In 1929 an amount of about 55 tonnes of morphine was produced worldwide but from 1930, under the influence of the international controls, production levels came down to about 30 tonnes p.a. in the years thereafter before increasing to ca 40 tonnes p.a. towards the end of the period as is shown in the following table and chart:

Table 10.1 Morphine Manufacture 1929 -1938

by Major and Minor Manufacturing Countries

and Conversion of Morphine into Codeine, Ethylmorphine and Heroin

\begin{tabular}{|c|c|c|c|c|c|c|c|c|c|}
\hline \multirow[b]{2}{*}{ Year } & \multicolumn{6}{|c|}{ Morphine ( kg base $100 \%)$} & \multicolumn{3}{|c|}{ Products ( $k g$ base $100 \%)$} \\
\hline & $\begin{array}{l}\text { Total } \\
\text { Manufac- } \\
\text { tured }\end{array}$ & $\begin{array}{l}\text { by Major } \\
\text { Manufac- } \\
\text { turers }\end{array}$ & $\begin{array}{l}\text { by Minor } \\
\text { Manufac- } \\
\text { turers }\end{array}$ & $\begin{array}{c}\text { Minor as a } \\
\text { Percentage } \\
\text { of Total }\end{array}$ & $\begin{array}{l}\text { used for } \\
\text { Conver- } \\
\text { sions }\end{array}$ & $\begin{array}{c}\text { Un- } \\
\text { converted }\end{array}$ & Codeine & $\begin{array}{c}\text { Ethyl- } \\
\text { morphine }\end{array}$ & Heroin \\
\hline 1929 & 55,453 & 55,221 & 232 & 0 & 41,963 & 13,490 & $\mathrm{~N} / \mathrm{R}$ & $\mathrm{N} / \mathrm{R}$ & 3,621 \\
\hline 1930 & 34,423 & 34,082 & 341 & 1 & 25,150 & 9,273 & $\mathrm{~N} / \mathrm{R}$ & $\mathrm{N} / \mathrm{R}$ & 3,971 \\
\hline 1931 & 30,457 & 29,690 & 767 & 3 & 22,057 & 8,400 & $\mathrm{~N} / \mathrm{R}$ & $\mathrm{N} / \mathrm{R}$ & 1,249 \\
\hline 1932 & 27,580 & 26,010 & 1,570 & 6 & 20,331 & 7,249 & $\mathrm{~N} / \mathrm{R}$ & $\mathrm{N} / \mathrm{R}$ & 1,315 \\
\hline 1933 & 30,466 & 27,441 & 3,025 & 10 & 21,021 & 9,445 & $\mathrm{~N} / \mathrm{R}$ & $\mathrm{N} / \mathrm{R}$ & 1,347 \\
\hline 1934 & 26,761 & 22,716 & 4,045 & 15 & 21,625 & 5,136 & 17,234 & 1,711 & 1,110 \\
\hline 1935 & 30,805 & 26,497 & 4,308 & 14 & 21,807 & 8,998 & 19,893 & 1,850 & 666 \\
\hline 1936 & 36,884 & 31,041 & 5,843 & 16 & 27,708 & 9,176 & 24,222 & 2,598 & 870 \\
\hline 1937 & 41,899 & 35,320 & 6,579 & 16 & 31,572 & 10,327 & 28,345 & 2,704 & 851 \\
\hline 1938 & 39,515 & 35,010 & -- & --- & 29,751 & 9,764 & 24,547 & 2,216 & 611 \\
\hline
\end{tabular}


Source: League of Nations (PCOB) Publications:

1929-1930 A.35 (1932), Statistics for the Year 1931

1931-1933 C.364.M.185 (1935), Report to the Council (Synopsis)

1934-1938 C.261.M.179 (1939), Statistics for the Year 1938

Notes: (1) The PCOB data on the manufacture of morphine for the period 1929-1939 were compiled by country by the author and appear in Table OPI 1 (Part III). This information is virtually complete for most years; for 1938 three countries did not report and for 1939 the figures are very incomplete as a result of the outbreak of World War II.

(2) Codeine and ethylmorphine (dionine) were not controlled substances before 1934 and were consequently not reported (N/R) by the PCOB.

(3) All quantities are expressed as $\mathrm{kg}$ base $100 \%$

The major manufacturing countries were the USA, Germany, the USSR, France, Japan, the UK and Switzerland. The minor manufacturing countries that established a permanent position during the 1930s were Belgium, Czechoslovakia, the Netherlands, Italy, Hungary, Poland and Yugoslavia. The output of the minor manufacturing countries grew steadily over the decade, from $0 \%$ in 1929 to $16 \%$ of the total in 1937.

Figure 10.1 Morphine Manufactured Worldwide 1929-1937 by Major and Minor Manufacturing Countries

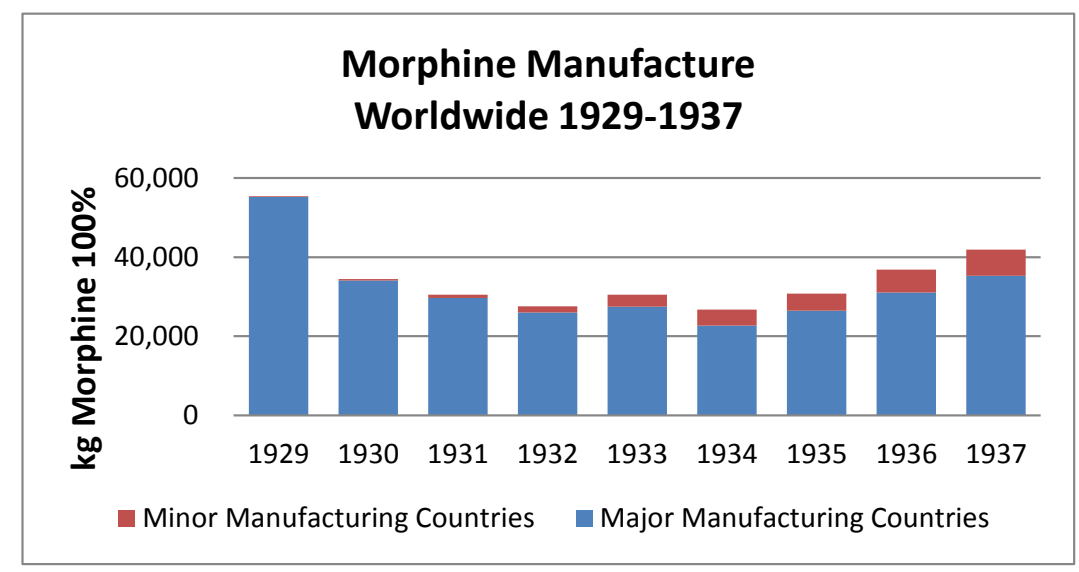

Source: PCOB (Table 10.1)

The data of Table 10.1 pertain to the manufacture of the opiates worldwide. The size of the opiate market accessible for an individual manufacturer was much smaller. All manufacturers had access to their own home markets but as a result of the Geneva Conventions of 1925 and 1931, import permits were required to sell to other countries. These permits were often not issued by governments of countries where opiates and other narcotics were manufactured. As a result, the size of the open world market for narcotics was approximately equal to the consumption in countries with no manufacturing facilities. As in most large countries such facilities existed, the open world market was rather small (see below).

The establishment and growth of new opiate manufacturers in the 1930s were the result of two factors: first, as mentioned above, that under the guise of narcotics control the governments of the countries involved could and often did provide a protected home market by not issuing import permits and second, that morphine could be produced economically from poppy straw as was demonstrated by the pioneering work of János Kabay in Hungary. These issues are discussed in more detail in subsequent sections of this chapter. 
For the period 1934-1937 annual averages of opiate exports were calculated by the author from data contained in a PCOB publication. ${ }^{9}$ These are brought together in the Table 10.2 and show that the total weight of base $100 \%$ exported was ca $6,500 \mathrm{~kg}$ p.a. which represents $19 \%$ of the ca $34,300 \mathrm{~kg}$ opiates (base 100\%) annually produced worldwide. The largest export market was that for codeine, amounting to ca 4,400 kg p.a.

\section{Table 10.2 Annual Average World-wide Manufacture, Consumption and Export of Opiates during the Period 1934-1937 ( $\mathrm{kg}$ base 100\%)}

\begin{tabular}{|l|r|cc|}
\hline \multicolumn{1}{|c|}{ Opiate } & Manufacture & $\begin{array}{c}\text { Consumption in } \\
\text { Manufacturing } \\
\text { Countries }\end{array}$ & $\begin{array}{c}\text { Export = } \\
\text { Consumption in } \\
\text { Other Countries }\end{array}$ \\
\hline Morphine & 8,600 & 7,300 & 1,300 \\
Codeine & 22,600 & 18,200 & 4,400 \\
Ethylmorphine & 2,200 & 1,600 & 600 \\
Heroin & 900 & 700 & 200 \\
Total Opiates & $\mathbf{3 4 , 3 0 0}$ & $\mathbf{2 7 , 8 0 0}$ & $\mathbf{6 , 5 0 0}$ \\
$\quad$ Percent & 100 & 81 & 19 \\
\hline
\end{tabular}

Source: PCOB Publication C.24.M.24 (1944) XI.

A consequence of the closed home markets was that prices for opiates in manufacturing countries were usually higher than on the open world market. As a result manufacturers located in countries with a small number of inhabitants were in a disadvantaged position compared to those located in bigger countries. However, manufacturers in the USA, the USSR and Japan, with large home markets, hardly exported any product. The reason for that is not known. In Table 10.3 we calculate the market share of the three largest exporting countries Germany, Switzerland and the UK. For each product the combined market share of these three countries was 70-75\%. Germany was the major exporter, particularly strong in codeine and ethylmorphine exports, with Switzerland and the UK taking the second and third place.

\footnotetext{
${ }^{9}$ PCOB, Production et distribution des stupéfiants et leurs matières premières avant la guerre. No. C.24.M.24.1944. XI. (Genève, octobre 1944).
} 
Table 10.3 Annual Average Exports of Opiates during the Period 1934(5)-1937 by Exporting Country ( $k g$ base 100\%)

\begin{tabular}{|c|c|c|c|c|c|c|}
\hline Exporting Country & $\begin{array}{c}\text { Morphine } \\
1934-37\end{array}$ & $\begin{array}{l}\text { Codeine } \\
1935-37\end{array}$ & $\begin{array}{c}\text { Ethyl- } \\
\text { Morphine } \\
\text { 1935-37 }\end{array}$ & $\begin{array}{c}\text { Heroin } \\
1934-37\end{array}$ & $\begin{array}{c}\text { Total } \\
\text { Export } \\
1934(5)-37\end{array}$ & $\begin{array}{c}\text { Percent } \\
\text { Total } \\
\text { Export }\end{array}$ \\
\hline Germany & 362 & 1,725 & 366 & 50 & 2,500 & 36 \\
\hline Switzerland & 344 & 894 & 103 & 33 & 1,400 & 20 \\
\hline UK & 322 & 621 & 39 & 63 & 1,000 & 15 \\
\hline Sub-total & 1,027 & 3,239 & 508 & 145 & 4,900 & 71 \\
\hline Other Countries & 319 & 1,476 & 173 & 62 & 2,000 & 29 \\
\hline Total Export & 1,346 & 4,715 & 681 & 207 & 6,900 & 100 \\
\hline $\begin{array}{l}\text { Other Countries } \\
\text { as } \% \text { of Total }\end{array}$ & 24 & 31 & 25 & 30 & 29 & \\
\hline
\end{tabular}

Source: PCOB Publication C.24.M.24.1944.XI.

Note: The average exports for morphine and heroin pertain to 1934-1937, those for codeine and ethylmorphine to 1935-1937. Codeine and Ethylmorphine were not controlled substances in 1934 and data for exports to individual countries for that year are not available. The (rounded) values in the column Total Export 1934(5)-37 are presented to give a broad idea on the values and percentages in the mid-1930s.

In December 1929 a "Convention for Morphine and Codeine" (Opiate Convention) was established by manufacturers from Germany, Switzerland and the UK along the same lines as the existing Cocaine Convention. The company Merck, Darmstadt, took also here a leading role. The object of the convention was defined as the allocation of quota and price fixing. The UK participants were aligned for codeine only. ${ }^{10}$

At the preliminary meeting of parties for the 1931 Geneva Conference, held in London in November 1930 manufacturers proposed the following production quota for morphine: Germany $40 \%$, Switzerland $25 \%$, France $21 \%$ and the UK $14 \% .^{11}$

Information on opiate prices is scarce for the 1930s. For NCF prices in the order of NLG 200 NLG per kg have been mentioned for 1933-1934.

Prices for Turkish, Yugoslav and Iranian opium fluctuated considerably over the period, for Turkish opium (12\% morphine) ranging from USD 3.34 to 7.60 per kg. ${ }^{12}$ The opium price represented in the order of $90 \%$ of the variable cost of opiates and the large price fluctuations made that buying the opium was a major strategic decision for opiate manufacturers. ${ }^{13}$ Because opiate prices fluctuated with the opium price, any mistakes in the

\footnotetext{
${ }^{10}$ Letter by Dr. Kahler, the German representative at the League of Nations for narcotic drugs, to Dame Rachel Crowdy, Chief of Opium Traffic and Social Questions Section of the League of Nations, dated 7 January 1930. Nationaal Archief, The Hague, Access No 2.05.21 Item 1596.

${ }^{11}$ E.D. van Walree, W.G. van Wettum and J.B.M. Coebergh, Report on the International conference on the restriction of manufacture of narcotic drugs, London 27 October 1930 to 11 November 1930 (in Dutch), 9 December 1930, Nationaal Archief, The Hague, Access No. 2.05.21 Item 1468.

${ }^{12}$ UN ECOSOC, The Movement of Opium Prices during the years 1930-1939 and 1946-1949, E/CN.7/AC.4/2/Add.2 of 21 November 1950.

${ }^{13}$ J. Schwyzer, Die Fabrikation de Alkaloide, (Berlin 1927) 73-74.
} 
buying decision could be very costly. Holding of substantial stocks was risky but to a certain extent unavoidable, as customers expected deliveries not too long after placing the order and the time-lag between buying the opium and availability of the finished product made from it was in the order of 6-9 months. ${ }^{14}$

\section{The Market for Cocaine}

The cocaine market during the 1930s shows the same pattern as that for opiates: a gradual reduction of the amounts manufactured, from a high in 1929 to a low in 1934 and a slight recovery thereafter.

Table 10.4 and Figure 10.2 Manufacture of Cocaine World-wide 1929-1937 ( $k g$ cocaine 100\%)

\begin{tabular}{|c|c|}
\hline Year & $\begin{array}{c}\text { Cocaine } \\
\text { Manufac- } \\
\text { tured }\end{array}$ \\
\hline 1929 & 5,699 \\
1930 & 4,718 \\
1931 & 4,612 \\
1932 & 3,988 \\
1933 & 4,010 \\
1934 & 3,472 \\
1935 & 3,889 \\
1936 & 3,983 \\
1937 & 4,142 \\
1938 & --- \\
& \\
\hline
\end{tabular}

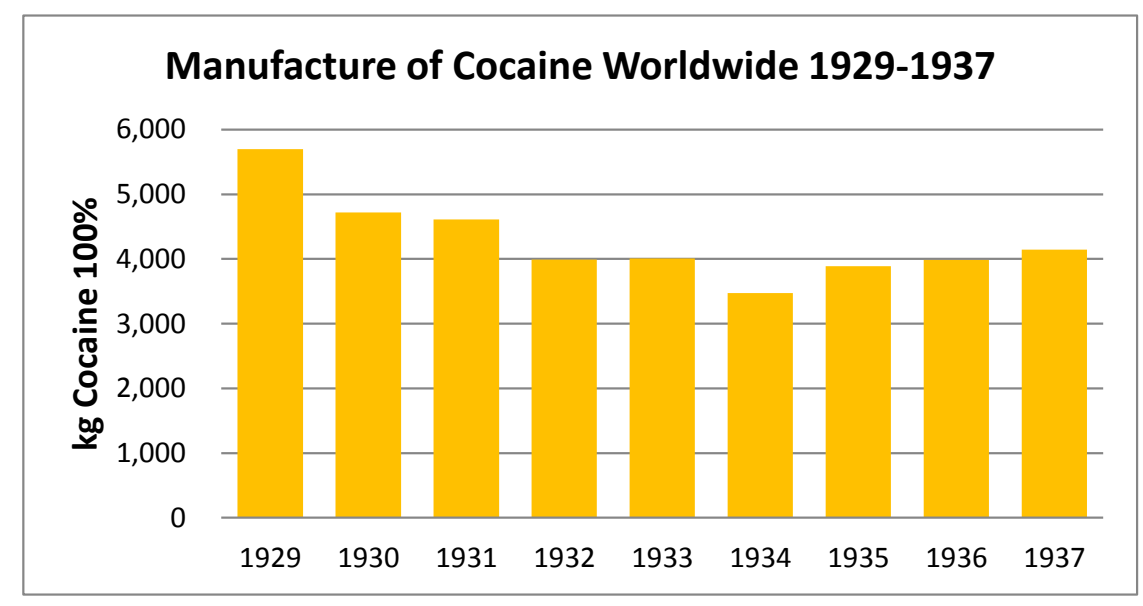

Source: League of Nations (PCOB) Publications

1929-1930 A.35 (1932), Statistics for the Year 1931

1931-1933 C.364.M.185 (1935), Report to the Council (Synopsis)

1934-1938 C.261.M.179 (1939), Statistics for the Year 1938

The comments of the previous section on how international narcotics control affected the opiate industry are also applicable to the cocaine Industry. Also for cocaine, protected home markets developed and the remaining open world market, comprising the countries in which no manufacturing took place, was small and one characterised by low prices.

For the period 1934-1937 for each country annual averages of cocaine manufactured and exported are calculated from data contained in a PCOB publication. ${ }^{15}$ These amounts are shown in Table 10.4. We see that the total quantity of cocaine annually exported was ca $1,000 \mathrm{~kg}$, representing $25 \%$ of the ca $4,000 \mathrm{~kg}$ cocaine annually produced worldwide. Major exporting countries manufactured $1,339 \mathrm{~kg}, 69 \%$ of which was exported, while the major manufacturing countries producing $2,281 \mathrm{~kg}(59 \%$ of the total) exported only $3 \%$.

The conclusion: The total world production of cocaine was reduced to ca one-third of the average production during the years 1900-1926. The export market for cocaine had become insignificant.

\footnotetext{
${ }^{14}$ An extensive discussion on buying opium by NCF is recorded in the Minutes of the NCF Board meeting of 17 September 1946.

${ }^{15}$ PCOB, Production et distribution des stupéfiants (1944).
} 
Table 10.5 Annual Averages of Cocaine Manufactured and Exported

World-wide during the Period 1934-1937

\begin{tabular}{|l|rr|c|}
\hline Country & $\begin{array}{c}\text { Cocaine } \\
\text { Manufactured } \\
{[1]}\end{array}$ & $\begin{array}{c}\text { Cocaine } \\
\text { Exported } \\
{[2]}\end{array}$ & $\begin{array}{c}\text { Percent } \\
\text { Exported } \\
{[1] /[2]}\end{array}$ \\
\hline Germany & 582 & 517 & 89 \\
UK & 385 & 136 & 35 \\
Belgium & 144 & 80 & 56 \\
Netherlands & 87 & 49 & 56 \\
Switzerland & 141 & 138 & 98 \\
Sub-total Major & 1,339 & 919 & 69 \\
Exporting Countries & & & \\
Japan & 902 & 10 & 1 \\
USA & 823 & 17 & 2 \\
France & 321 & 33 & 10 \\
USSR & 235 & 0 & 0 \\
Sub-total Major & 2,281 & 60 & 3 \\
Manufacturing Countries & & & \\
Other Manuf. Countries & 253 & 5 & 2 \\
Total & $\mathbf{3 , 8 7 2}$ & 984 & $\mathbf{2 5}$ \\
\hline
\end{tabular}

Sources for Manufacture: PCOB data compiled in Table COC 2 (Part IV) for Export: PCOB C.24.M.24 (1944) XI

The Cocaine Convention of 1924 remained in force during the 1930s. New members joining the Convention during the period 1930 to 1939 were the German companies Chininfabrik Braunschweig and Riedel - de Haën, the French producers Polonovski \& Nitzberg and Givaudan Lavirotte, and May \& Baker from the UK. ${ }^{16}$ The average annual sales of the Convention during the period 1934-1937 was $1,633 \mathrm{~kg}$ cocaine $\mathrm{HCl}(1,453 \mathrm{~kg}$ cocaine $100 \%) .{ }^{17}$ This figure is in good agreement with the sum of the quantities manufactured in Germany, UK, the Netherlands, Switzerland and France appearing in Table 10.4, above. At the pre-conference in London in 1930 for the 1931 Geneva Limitation Conference manufacturers proposed the following production quota for cocaine: Germany 50\%, France $20 \%$, the UK 15\%, the Netherlands $10 \%$ and Switzerland 5\% and for morphine, Germany $40 \%$, France $21 \%$, the UK $14 \%$ and Switzerland $25 \%$ (rounded figures). ${ }^{18}$

Early in 1930 the Cocaine Convention increased the price for cocaine $\mathrm{HCl}$ from DEM 500 to DEM 750 (NLG 300 to NLG 450). The price remained at that level at least until the end of

\footnotetext{
${ }^{16}$ W. Dethloff, Gründung der Firm und Weiterentwickling der Abteilung Pharmazeutische Chemikalien. (Section on cocaine) Manuscript ca 1957 Ingelheim, Firmen- und Familienarchiv von C.H. Boehringer . ${ }^{17}$ Ibidem.

${ }^{18}$ E.D. van Walree, W.G. van Wettum and J.B.M. Coebergh, Report on the International conference on the restriction of manufacture of narcotic drugs, London 27 October 1930 to 11 November 1930, 8. (in Dutch). Nationaal Archief, The Hague, Access No. 2.05.21 Item 1468.
} 
1934. ${ }^{19}$ Because of competition the convention price could not always be achieved. An example is that NCF sold cocaine hydrochloride for prices around NLG 270 per kg during 1933-1934. ${ }^{20}$ The NCF must have obtained approval from the Convention for selling at such low price because NCF received financial compensation from the Convention throughout the 1930 s. $^{21}$ The reason for the Convention to approve selling below the agreed price was presumably to starve outsiders from sales, an attempt to eliminate them as competitors in the long term.

In closed markets with no competition, cocaine prices were considerably above the convention price. As an example: in 1929, shortly after the UK market had become virtually closed, May \& Baker, the then recently established English producer of cocaine, sold in the UK at a price that was $37 \%$ higher than the price quoted by the NCF, which was the convention price. $^{22}$

The reason for the Convention setting the price at such a high level would have been to take maximum advantage of the entirely inelastic nature of the pharmaceutical cocaine market, the only market open for the licit cocaine manufacturers. For medical purposes cocaine will ultimately be bought at any price. The only market force that could bring the price down was competition by outsiders.

A paradoxical situation developed from 1930 in the market for Java coca. While the cocaine price was set and maintained by the Convention at the high price of NLG $450 / \mathrm{kg}$, the price of Java coca came down substantially, from 49 NLcents per unit (at 1.50\%) in 1930, to 27 NLcents in 1932 and to 18.5 NLcents in $1934 .{ }^{23}$ In reaction on low prices for Peruvian crude cocaine the Coca Producers Association (CPV) established separate price schedules, with lower prices, for Java coca that was to be used for making Java crude. ${ }^{24}$ As a result of the low raw material cost, on the open market outsiders could offer cheap cocaine in competition with Convention members.

Despite the price reduction the export of Java coca from the Netherlands went down from 193 tonnes in 1931 to 107 tonnes in 1932. Already in 1930 the CPV recommended its members reduce or, even better, abandon coca cultivation because management was of the opinion that there was no future for the crop. This recommendation was repeated during subsequent meetings. ${ }^{25}$

During the 1930s Java lost its dominant position of raw material supplier for the manufacture of cocaine. For the period 1934-1937 we know that on average ca 3,900 kg cocaine $100 \%$ was manufactured worldwide. ${ }^{26}$ From raw materials exported during that period we estimate on the basis of data from PCOB documents and other statistics that during 1934-1937 on average approximately $1,100 \mathrm{~kg}$ was annually manufactured from Java coca, $900 \mathrm{~kg}$ from Peru crude, $500 \mathrm{~kg}$ from Peru coca and $700 \mathrm{~kg}$ from coca leaf cultivated on Formosa. ${ }^{27}$ The remaining $700 \mathrm{~kg}$ p.a. was most likely manufactured from the large stocks of

\footnotetext{
${ }^{19}$ Coca-Producenten Vereniging (Coca Producers Association) Annual Reports 1929-1934.

Nationaal Archief, The Hague, Access No. 2.20.04 Item 1643.

${ }^{20}$ Nederlandsche Cocaine Fabriek, Minutes of Board Meetings 23 February 1934 - 15 May 1950. Meeting of 10 December 1934.

${ }^{21}$ NCF, Minutes of Board Meetings of 14 May 1936, 20 April 1939 and 19 September 1949.

${ }^{22}$ Letter by to Mr van Wettum by Dr Kramers dated 23 September 1929, Nationaal Archief The Hague, Access No 2.05.21 Item 1596.

${ }^{23}$ Coca Producers Association, Annual Reports 1930-1934.

${ }^{24}$ Ibidem.

${ }^{25}$ Ibidem.

${ }^{26}$ PCOB, Production et distribution des stupéfiants et leurs matières, C.24.M.24 (1944) XI.

${ }^{27}$ Raw material export: Java Coca: Table JCL 3 (Part III), Peru Coca and Crude: Gootenberg, Andean Cocaine (2008) 158, Formosa Coca: Musto, Drug and Alcohol Dependence (1998) 152.
} 
Java coca accumulated in Germany after the import of almost 800 tonnes (equivalent to ca $7,200 \mathrm{~kg}$ cocaine $100 \%$ ) in $1928 .^{28}$

\section{The Limitation Conference of 1931 and Its Effect on the Market}

The Limitation Convention of 1931 provided the import control system that was necessary to make the measures of the 1925 Geneva Convention fully effective. This has been discussed in detail in Section 7.3 and some of the consequences for the industry are mentioned above.

In summary: the 1931 Convention had a most serious impact on the narcotics industry. It caused the cocaine market to decrease to about one-third of its original size and the morphine production diminished world-wide to ca $60 \%$ of its 1929 level. An unintended effect of the new regulations was the creation of protected home markets for narcotic manufacturers because import permits were in general not easily obtainable if the local industry could supply. This resulted in substantially higher prices at the home markets and a serious distortion of the world market. The shrinking of the open world market was exacerbated by the establishment of new narcotics manufacturers in small countries. Examples of countries where this occurred in the 1930s are Belgium, Czechoslovakia, Hungary, Poland and Yugoslavia. ${ }^{29}$

Consequences were seriously depressed prices in the open world market as a result of some manufacturers, enjoying good prices and sales volume in their protected home markets resulting in the absorption of all fixed costs, quoting export prices that were only marginally over variable cost (dumping). ${ }^{30}$

Codeine and ethylmorphine became controlled substances on 1 January 1934 but were placed in Group II, and were as such subject to less rigorous controls than Group I substances (cocaine, heroin etc.)

\section{Poppy straw as a raw material}

Until about 1930 opium was virtually the only raw material for the production of morphine. That changed in the late 1920s when the Hungarian pharmacist János Kabay succeeded in extracting morphine directly from the whole green poppy plant. The yield was exceedingly low. In 1928, $10 \mathrm{~kg}$ morphine was manufactured from $137 \mathrm{t}$ of plant raw material. ${ }^{31}$ In the early 1930s Kabay changed over to the use of dry poppy straw as the raw material and obtained better results (see table 10.5, below).

Poppy straw was a by-product of the commercial cultivation of Papaver somniferum for seed which was used traditionally as a valued spice on bread and in cakes. The cultivation occurred in Europe, especially in the East, on quite a large scale. The ripe seed capsules were threshed after harvest to collect the seed and the remaining broken capsules were discarded. Therefore the cost of the poppy straw was essentially that of collecting the broken capsules and transporting them to the factory. The morphine content of the European poppy straw was low.

\footnotetext{
${ }^{28}$ Coca Producers Association, Annual Report 1932, 3.

${ }^{29}$ PCOB Document C.24.M.24.1944.XI, p 19.

${ }^{30}$ Note pertaining to a letter by Mr van Wettum to Dr Kramers dated 23 September 1929.Both documents:

Nationaal Archief, The Hague, Access No 2.05.21, Item 1596.

${ }^{31}$ Kabay J.J., János Kabay, The Life of an Inventor (Harbord 1990), 36-37.
} 
For Kabay, to produce morphine from poppy straw in commercial quantities was a formidable task. He only succeeded after an enormous struggle with all scientific, technological, commercial and logistical aspects of the project. ${ }^{32}$ Kabay also initiated commercial poppy straw extraction in Poland. For the period 1934-1937 the following table shows the quantities of poppy straw extracted and the amounts of morphine manufactured.

Table 10.6 Manufacture of Morphine from Poppy Straw 1934-1937

\begin{tabular}{|l|rccc|}
\hline Country & $\begin{array}{c}\text { Poppy } \\
\text { Straw } \\
\text { Utilized } \\
\text { tons }\end{array}$ & $\begin{array}{c}\text { Morphine } \\
\text { Produced } \\
\text { (AMA) } \\
\text { kg }\end{array}$ & Yield & $\begin{array}{c}\text { Fraction } \\
\text { of Total } \\
\text { World Prod. } \\
\%\end{array}$ \\
\hline Hungary & 3,028 & 2,047 & 0.07 & 1.5 \\
Poland & 1,775 & 1,295 & 0.07 & 0.9 \\
Germany & 199 & 561 & 0.28 & 0.4 \\
Switzerland & 4 & 10 & 0.25 & -- \\
Total & 5,006 & $\mathbf{3 , 9 1 3}$ & $\mathbf{0 . 0 8}$ & $\mathbf{2 . 8}$ \\
\hline
\end{tabular}

Source: PCOB publication C.24.M.25 (1944)

Hungary and Poland produced modest quantities of morphine at a low yield, while in Germany a small quantity was produced at a yield that was four times as high. The Swiss production was the result of a laboratory experiment only. The reason for the much larger yield in Germany and Switzerland was the combination of using only the seed capsules which have higher morphine content than the stalks, and application of new extraction processes developed by Hoffmann-La Roche of Basle and independently by Boehringer Ingelheim. ${ }^{33}$ Hoffman-La Roche had an interest in morphine production in Poland but for reasons unknown the commercialisation of the Roche process stalled at the time. ${ }^{34}$

In 1935 the members of the German Opiate Convention were called by Merck to a meeting to discuss the idea of forming a joint venture for the extraction of morphine from local poppy straw with the objective of becoming independent of the import of opium. Hoffmann La Roche had offered a license for its process and to build a factory with a capacity of 1,500-2,000 kg morphine p.a. Boehringer Ingelheim was unpleasantly surprised by the proposal because it had already developed its own process and declined to participate. However, in 1936 members agreed to buy poppy straw jointly in the future. ${ }^{35}$ Apparently the German manufacturers obtained carefully selected poppy capsules through the services of the purchase department of the Merck chemical factory, Darmstadt. The capsules were of German, Austrian, Czechoslovak, Polish and Yugoslav origin and a list of quantities annually purchased during the period 1936-1957 and the morphine content thereof is available. ${ }^{36}$ From that list it is calculated that during the years 1936-1939 a total quantity of $958 \mathrm{t}$ capsules

\footnotetext{
${ }^{32}$ Kabay J.J., János Kabay,

${ }^{33}$ Wuest H.M. and Frey A.J.' Opiate aus Mohnstroh', in Festschrift Emil Christoph Barell,

Hoffmann-LaRoche \& Co. (Basel 1936) 556-570. The process was patented; DRP 637.876, from13 June 1935.

${ }^{34}$ Bensussan I.J., L'Opium. Considérations générales et Études économiques, sociales et législatives (Paris 1946) 75.

${ }^{35}$ Dethloff, W., Rohmaterial zur Herstellung von Morphium, seinen derivaten and Nebenalkaloiden, Manuscript ca 1957, Ingelheim, Firmen- und Familienarchiv von C.H. Boehringer Sohn.

${ }^{36}$ Willi Küssner, 'Poppy straw: a problem of international narcotics control', Bulletin on Narcotics, 1961[2] 1-6.
} 
containing 2,701 kg AMA $(0.28 \%)$ was bought. ${ }^{37}$ These capsules will have been processed subsequently; PCOB Statistics for the period do not report morphine made from poppy straw (capsules) separately. ${ }^{38}$

After the Second World War poppy straw became a more important raw material for the production of opiates and currently ca. $80 \%$ of all opiates are manufactured from alkaloids extracted from poppy straw.

\subsection{Bonnema}

In 1920 a second manufacturer of narcotic drugs was established in the Netherlands trading its products under the name of "Bonnema". Opiate manufacture by Bonnema in the 1920s is discussed in Chapter 9. After the Second World War Bonnema, renamed "Verenigde Pharmaceutische Fabieken" (VPF), became a major producer of opiates from poppy straw. A brief history of Bonnema until 1939 is provided here.

\section{Bonnema and Zwitsal}

The history of the Verenigde Pharmaceutische Fabrieken commenced in 1920 when a Mr C.J. Jansen, then aged 28, returned from a 12 years spell abroad to his native town of Apeldoorn in Netherlands. The major part of his stay abroad had been in Switzerland, where he worked and received training in drugstores and pharmacies. Back in Apeldoorn Jansen decided to start a business himself. He did that by buying a small factory of pharmaceutical products from the widow of pharmacist A.A. Bonnema. He named that enterprise 'Nederlandsche Fabriek van Pharmaceutisch-Chemische Producten' (Netherlands Factory of PharmaceuticalChemical Products). The factory was located at the Floralaan at Apeldoorn and at the beginning its main products were organic silver salts. ${ }^{39}$

During his stay in Switzerland Jansen had acquired knowledge on the production of opiates from opium and already in 1920 he obtained a permit to manufacture these compounds. $^{40}$ He commenced opiate production on a small scale shortly thereafter. The products were sold under the brand name "Bonnema".

In 1924, Jansen added an ointment to the product line that he named 'Zwitserse Balsem' (Swiss Balm), the formula of which he had obtained from pharmacist Dr. A. Thaler in Sankt Gallen (Switzerland) during his stay in that country. ${ }^{41}$ The Swiss Balm was marketed under the brand name "Zwitsal" and promoted as a general protective and healing ointment. The company was successful from the start and in the same year the factory at the Floralaan was expanded. In the same year Jansen founded the 'Centraal Apotheek' (Central Pharmacy) at the Market Square, Apeldoorn, a venture that gave financial stability to his other fledgling enterprises. In 1928 Jansen introduced under the Zwitsal name talcum powder for babies in a special dispenser. This was the beginning of the very successful line of the well-known Zwitsal baby products. We see that Jansen adopted early a strategy of

\footnotetext{
${ }^{37}$ Ref. Part IV, Table OPI 3.

${ }^{38}$ The PCOB Statistics for 1939 and 1940 do not show morphine manufacture in Germany. The German government did not report during the war years (N.R. in the tables).

39 'Van Zwitserse balsem en papaverbollen'. An article published at the occasion of the $40^{\text {th }}$ Anniversary of VPF. Nieuwe Apeldoornse Courant, 9 January 1960. 'Miljoenen Nederlanders groeiden op met Zwitsal', Nieuwe Apeldoornse Courant, 20 July 1974.

${ }^{40}$ Department of Foreign Affairs (The Netherlands), Bijeenkomst in verband met de bij den volkenbond zijnde plannen tot beperking van de vervaardiging van verdoovende middelen. The Hague, Nationaal Archief, File 2.05.21 Item 1596; 20 October 1930.

W.G. Van Wettum, letter to the Minister for Social Affairs (Sociale Zaken) The Hague, National Archief, file 2.05.21, Item 1537; dated 6 February 1935, p 7.

${ }^{41}$ Zwitsal Geschiedenis www.zwitsal.be [2007].
} 
diversification, thereby taking advantage of his Switzerland acquired knowledge and skills, and spreading the risk.

\section{Bonnema as a Manufacturer of Narcotic Drugs}

During the 1920s Bonnema's codeine production was small, on average only ca $25 \mathrm{~kg}$ p.a. Codeine consumption in the Netherlands amounted to ca $160 \mathrm{~kg}$ p.a at the time; Bonnema supplied only a small part of the domestic market, and the rest was imported. It is not known if Bonnema produced pharmaceutical grade morphine hydrochloride.

In preparation for the Geneva Convention of 1931 to limit the manufacture and regulating the distribution of narcotic drugs, Dutch delegates, Dr J.B.M. Coebergh (ChiefInspector of Public Health), Mr W.G. van Wettum (Adviser to the Dutch Government on International Narcotic Affairs) and Mr E.D. van Walree (another Government Delegate), arranged for meetings with Dr Kramers (NCF), Mr Jansen (Bonnema) and Dr de Maar (Brocades) to discuss with these representatives of the industry the possible impact of the proposed regulations on their business. At the meeting, which was held on 20 October, 1930, Mr Jansen stated that in 1929 he had produced only a few $\mathrm{kg}$ of opiates but that currently (1930) he was converting $60 \mathrm{~kg}$ heroin into morphine. He produces only if a profit can be made. $^{42}$

Dr Coebergh stated that he did not expect that the Netherlands would get a substantial export quota for morphine from the Convention but that production of opiates for domestic consumption would most likely be allocated to the local industry provided it could cope with the demand. Mr Jansen replied that he would be pleased to manufacture the requirements of opiates for the Netherlands and its colonies providing that the obtainable profit margin would be sufficient.

Mr Van Wettum mentioned that the domestic requirements of opiates (not including the Dutch East Indies) amounted to ca $240 \mathrm{~kg}$ p.a. and $\mathrm{Mr}$ Van Walree wondered if $\mathrm{Mr}$ Jansen's factory had sufficient capacity [to produce such quantity] and why the profitability had been insufficient in the recent past. Jansen's reply was that it was all a matter of economics, he could produce it [any quantity] if that was worthwhile from a business point of view. He mentioned [competition from] UK opiate-manufacturers which have access to cheap raw material [from India] as the reason for the low opiate prices. When asked, $\mathrm{Mr}$ Jansen confirmed that recently he had become a member of the Morphine Convention and that an annual quota of $100 \mathrm{~kg}$ morphine and $100 \mathrm{~kg}$ of heroin was allocated to him.

After Mr Jansen had left, the delegates discussed the matter further. There was some scepticism about Jansen's ability to guarantee supply of the total domestic demand. Mr van Wettum commented that the NCF already had a permit to manufacture morphine for scientific purposes and that he expected that this company would be in a position to produce sufficient morphine shortly. ${ }^{43}$

\section{Jansen and Nieuwenhuis}

F.M. Nieuwenhuis, chief clerk at the Chemische Fabriek Naarden (CFN), left that company at the end of 1928. Until that time CFN had been involved in shady dealings in narcotic drugs which became impossible after new regulations came into force in the Netherlands.

\footnotetext{
${ }^{42}$ Department of Foreign Affairs (The Netherlands), Bijeenkomst in verband met de bij den Volkenbond aanhangig zijnde plannen tot beperking van de vervaardiging van verdoovende middelen. The Hague, Nationaal Archief, File 2.05.21 Iten 1596; 20 October 1930.

${ }^{43}$ Ibidem.
} 
Nieuwenhuis tried to continue the drug trade on his own account. From 1928 to 1930 he held an official license allowing him to trade but that license was revoked in $1930 .^{44}$

Jansen was known in the trade for his ability to manufacture good quality opiates but did not have connections to sell these products in the export market. ${ }^{45}$ Nieuwenhuis and Jansen complemented each other and they entered a contract whereby Nieuwenhuis would receive $25 \%$ of all profit Jansen would receive if he (Jansen) would become a member of the Morphine Convention. ${ }^{46}$ Nieuwenhuis took care of the marketing for Jansen and started by selling the Bonnema products below the convention price. The result was that Nieuwenhuis upset the Convention but was able to negotiate a deal with that organization whereby, in May 1930, Bonnema became a member. ${ }^{47}$

After becoming a member of the Convention, Jansen received a quota but, for the first few years, he simply did not manufacture opiates at all. The Convention paid him annually NLG 21,000 for abstaining from production. ${ }^{48}$

In the years 1931-1932 Nieuwenhuis acting as the marketing manager of the Nederlandsche Fabriek van Pharmaceutisch-Chemische Production (Bonnema) sold cocaine to Scandinavia, Belgium (Coutelier) and Switzerland at low prices. The result was that Nieuwenhuis was able to negotiate a similar deal with the Cocaine Convention as he had done earlier with the Morphine Convention; Jansen, in return for stopping cocaine production for export, received an amount of NLG 16,000 per annum. ${ }^{49}$

In $1934 \mathrm{Mr}$ L Enthoven, Chief-Commissioner of Police at Rotterdam, wrote a detailed letter to the Minister for Justice on the activities of Nieuwenhuis and Jansen. Enthoven concluded that, because of Nieuwenhuis' poor reputation, the construction whereby Nieuwenhuis represented Bonnema in the trade in narcotic drugs had damaged the international standing of the drug control authorities of the Netherlands. However, Enthoven did not suggest in which way action should be taken to stop Nieuwenhuis' involvement. ${ }^{50}$

Early 1935, Mr van Wettum, Government Adviser on International Narcotic Control, commented on the activities of Nieuwenhuis and Jansen in an extensive letter to the Minister for Social Affairs, who had asked van Wettum's advice on the matter. ${ }^{51}$ The specific question had been if, in Van Wettum's opinion, Jansen's license to manufacture controlled substances should be renewed. Van Wettum, in his reply, reasoned that neither Jansen nor Nieuwenhuis had, strictly speaking, not done anything illegal and that in Van Wettum's experience the standing of the Dutch authorities responsible for narcotics control had not been damaged by the matter. Van Wettum questioned however, if Jansen's narcotic manufacturing license should be renewed because Jansen had used his license mainly to obtain financial rewards by not producing. Van Wettum concluded that because of possible unintended consequences of not renewing the license, such as impact on the NCF, advantages for narcotics manufacturers in other countries and the dependence of the Netherlands on its local industry in the case of a war, it was not recommended to cancel Jansen's license.

\footnotetext{
${ }^{44}$ De Kort, M., Tussen patiënt en delinquent, geschiedenis van het Nederlandse drugsbeleid. (Between patient and delinquent, the history of drug policy in the Netherlands); Dissertation University of Erasmus, Rotterdam (Hilversum 1995). Section 3.3 Case study on CNF and Nieuwenhuis, 98-110.

${ }^{45}$ Enthoven L., Chief-Commissioner of Police at Rotterdam, Letter to the Minister for Justice, dated 25 July 1934. Nationaal Archief, The Hague, Access No 2.05.21 Item 1537.

${ }^{46}$ Draft contract between Jansen en Nieuwenhuis, dated 19 June 1930, appended to the Enthoven letter.

${ }^{47}$ De Kort, Tussen patiënt en delinquent, 110.

${ }^{48}$ Enthoven L., Letter to the Minister for Justice. dated 25 July 1934.

${ }^{49}$ De Kort, Tussen patiënt en delinquent, 110.

${ }^{50}$ Enthoven L., Letter to the Minister for Justice. dated 25 July 1934.

${ }^{51}$ W.G. Van Wettum, letter to the Minister for Social Affairs (Sociale Zaken) The Hague, National Archief, Access No. 2.05.21, Item 1537; dated 6 February 1935, 7.
} 
Bonnema had resumed opiate manufacture on a small scale for the Dutch market around 1934. After the Netherlands borders were closed for imports of controlled substances in 1934, the prices in the home market increased. ${ }^{52}$ In 1936 a deal was entered into between Bonnema and the NCF on quotas for the domestic market. Under that arrangement the agreed market shares were: Opiates, NCF 2/3, Bonnema 1/3; Cocaine, NCF 4/5, Bonnema 1/5. The agreement was approved by the head of the Department of Health. ${ }^{53}$

\subsection{Organization and Marketing.}

\section{Legal and Organizational}

New regulations under the Dutch Corporations Act ("Wet op de Naamlooze Vennootschappen") which came into force on April 1, 1934 required that some changes in the Articles of Association of the company be made. These changes were drafted by a public notary and discussed at a Board meeting of the NCF. The Board members made further changes for inclusion in the draft, including that the name of the company be changed from "N.V. Nederlandsche Cocaine Fabriek" into "N.V. Nederlandsche Cocainefabriek" and that the Directors be explicitly empowered to nominate an operations manager ("bedrijfsleider") with the personal title of Technical Director ("Technisch Directeur"). ${ }^{54}$

An implication of the changes in the Articles of Association was that Directors and Board members ("directeuren en commissarissen") had to be Dutch nationals by birth. This meant that Mr. Boldemann, board member since the inception of the company, would lose his membership automatically. ${ }^{55}$

Miss Laurine Maarschalk had become the major shareholder of the NCF in 1934 or earlier. To the surprise of the Board Miss Maarschalk had serious objections to the drafted changes in the Articles of Association and had her lawyer make a new draft. The nature of the changes desired by Miss Maarschalk is not known. After extensive further discussions between Miss Maarschalk and Board members, an agreement was reached. ${ }^{56}$

During the period 1934-1939 Board members ("Commissarissen") were: W.C. Bonebakker, president, G. Boldemann (until 1939), Prof. Dr. L.P. le Cosquino de Bussy (biologist at the Koloniaal Instituut, Amstredam), J.P. Jager, B.H.A. van Kreel (former director of the Deli railways, Sumatra) and Ch. N.W. Veenstra. The Koloniale Bank as Managing Partner ("de Directie") was represented at Board meetings by one or two of the following directors: J.C.F. Schor, W. Labohm, E.H. van Veen and J.H. Lagers. ${ }^{57}$ Dr G.H. Kramers was the technical director, M.J. Weidema the chief chemist ("Chemiker") and D. Schöyer the correspondence clerk ("correspondent"). ${ }^{58}$

\section{Markets}

NCF operated in three markets during the 1930s: the markets for opiates, cocaine and ethocaine. As previously mentioned the markets for opiates and especially cocaine were difficult because of the reduction in size as a result of international narcotics control. NCF was a newcomer in the market for opiates, it had to establish good customer relations and at

\footnotetext{
${ }^{52}$ Nederlandsche Cocaine Fabriek, Notulenboek, Commissaris vergaderingen 23 Februari 1934 -15 Mei 1950. (Minutes of Board Meetings 23 February 1934 -15 May 1950). Meeting of 23 February 1934.

${ }^{53}$ Ibidem, Meeting of 14 May 1936.

${ }^{54}$ Ibidem, Meeting of 4 May 1934.

${ }_{55}^{55}$ Ibidem, Meeting of 23 February 1934.

${ }^{56}$ Ibidem, Meeting of 20 August1934.

${ }^{57}$ In the minutes of the NCF Board meeting of 20 April 1939 it is mentioned that at the AGM of 11 June 1938

G. Boldemann was not re-elected as a Board member. Why he did not lose this position earlier (possibly on the grounds of not being a Dutch national by birth) is not known.

${ }^{58}$ NCF, Minutes of the Board Meeting of 4 May 1934.
} 
the same time become an efficient low cost producer. This was quite a challenge. Not much is known about the market for bulk ethocaine.

\section{Opiate Market}

Opiate production at NCF commenced on a small scale in 1931 and gradually increased during the 1930s. Of the first eleven months of both 1933 and 1934 we know that a total of $219 \mathrm{~kg}$ and $337 \mathrm{~kg}$ respectively of opiates was sold. For the period 1935-1939 sales figures for each of the major opiate products morphine, codeine and ethylmorphine (dionine) are compiled in the following table and graph.

Table 10.7 NCF Sales of Opiates 1935-1939 ( $\mathrm{kg}$ base 100\%)

\begin{tabular}{|c|cc|c|cc|c|cc|c|}
\hline \multirow{2}{*}{ Year } & \multicolumn{3}{|c|}{ Morphine } & \multicolumn{3}{c|}{ Codeine } & \multicolumn{3}{c|}{ Ethylmorphine } \\
\cline { 2 - 9 } & local & export & total & local export & total & local export & total \\
\hline & & & & & & & & & \\
1935 & 39 & 69 & 108 & 194 & 183 & 377 & 3 & 19 & 22 \\
1936 & 32 & 69 & 101 & 178 & 187 & 365 & 4 & 25 & 29 \\
1937 & 36 & 33 & 69 & 199 & 253 & 452 & 4 & 25 & 29 \\
1938 & 42 & 47 & 89 & 177 & 418 & 595 & 0 & 19 & 19 \\
1939 & 62 & 81 & 143 & 238 & 494 & 732 & 5 & 36 & 41 \\
\hline
\end{tabular}

Source: Minutes NCF Board Meetings 1934-1951, Minutes of the Meeting of 24 July1946.

The above table appears in the minutes of the NCF Board meeting of 24 July 1946 with "kg" as the unit, not "kg 100\%", as indicated in the heading. The reasons for this important change are somewhat complex. Two factors play a role: Firstly, the units "kg morphine" etc. are ambiguous in the context of reporting opiate sales. Morphine, codeine and ethylmorphine were sold as pharmaceutical grade salts, e.g. as the hydrochlorides, and codeine also in the form of its base as the monohydrate. All these products have a specific base content and a different price. As an example: codeine was sold as codeine base $1 \mathrm{H}_{2} \mathrm{O}(94.3 \%$ base $)$, codeine hydrochloride $2 \mathrm{H}_{2} \mathrm{O}\left(80.7 \%\right.$ base) and codeine phosphate $1 \frac{1}{2} \mathrm{H}_{2} \mathrm{O}(70.5 \%$ base $)$ etc. ${ }^{59}$ In general, the manufacturing cost and the selling prices of each product were more or less proportional with the base content. As a measure of how much codeine was sold in total by the company over a year, the sum of the weights of codeine base, hydrochloride and phosphate sold is not as informative as the figure obtained by adding up $\mathrm{kg}$ codeine base $100 \%$ (ACA) contained in each of the products. The latter figure can be used for a more meaningful comparison of the sales with the sales for other years, because the relative amounts of each product sold were not constant from year to year. Secondly, reporting to the government of the amounts of morphine, codeine etc. produced and sold was in base $100 \%$, and therefore the NCF administration will have been geared to provide these figures. Input and output of an alkaloid factory is measured in terms of base $100 \%$ to enable the calculation of process yields in terms of percent of the theoretical amounts.

All the above suggests that the amounts in table 10.7 refer to base $100 \%$ rather than to the total of the weights of the individual products. Strong support of that position was found in the minutes of the NCF board meeting of 1 June 1938 where it is stated that "during the first five months of $1938306 \mathrm{~kg}$ [of opiates] (calculated as base) was supplied versus $557 \mathrm{~kg}$ in 12 months 1937 ". ${ }^{60}$ The total quantity of opiates supplied according to table 10.7 is $550 \mathrm{~kg}$

\footnotetext{
${ }^{59} \mathrm{H}_{2} \mathrm{O}$ indicates water of crystallisation. E.g. codeine hydrochloride $2 \mathrm{H}_{2} \mathrm{O}$ means than the product contains 2 molecules of water for each molecule of codeine $\mathrm{HCl}$.

${ }^{60} \mathrm{NCF}$, Minutes if Board Meeting of 1 June 1938.
} 
and that is sufficiently close to $557 \mathrm{~kg}$ to conclude that the amounts in table 10.7 refer to $\mathrm{kg}$ base $100 \%$.

Figure 10.3 NCF Sales of Opiates 1935-1939 (kg base 100\%)

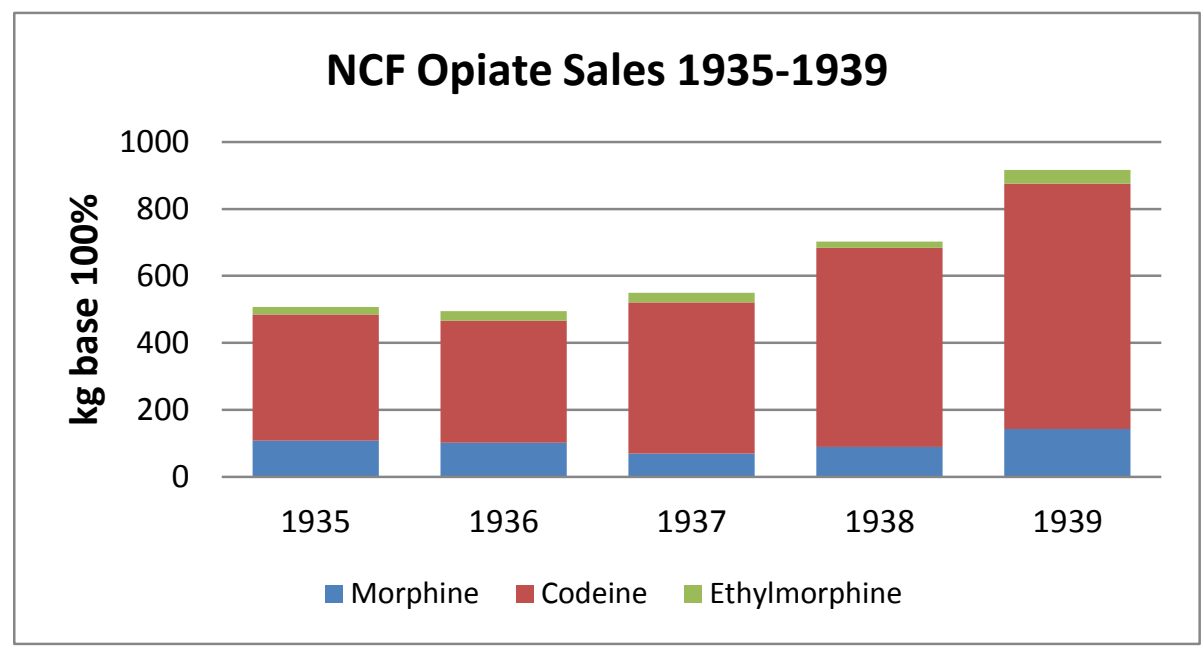

Source: Table 10.7

When comparing the average NCF export sales of codeine of $208 \mathrm{~kg}$ ACA (table 10.7) for the period 1935-1937 with the total export market of 4,715 kg ACA (table 10.3) over the same period we see that NCF had acquired a market share of $4.4 \%$ in 5 years. Export sales for codeine increased considerable in 1938 and 1939, to 418 and $494 \mathrm{~kg}$ ACA respectively, as a result of the threat of war in Europe leading to the building of increased stocks. ${ }^{61}$ Codeine exports for 1938 went largely to Canada. ${ }^{62}$

After the closure of the Netherlands market for imports of narcotic drugs in early 1934 NCF shared the home market with Bonnema. ${ }^{63}$ In Table 10.8 PCOB statistics for morphine and codeine in the Netherlands pertaining to manufacture, export and consumption are combined with the NCF sales figures of these products for the period 1935-1938 and the amounts sold by Bonnema are calculated as the differences between the PCOB figures and those of the NCF. The estimated percentages for NCF's market share are in reasonable agreement with the arrangement between NCF and Bonnema entered into in 1936 whereby NCF would supply two-thirds of the opiate market and Bonnema one-third. ${ }^{64}$ This arrangement was approved by the Dutch Department of Health. ${ }^{65}$

\footnotetext{
${ }^{61}$ Ibidem Meeting of 24 July 1946.

${ }^{62}$ Ibidem, Meeting of 1 June 1938.

${ }^{63}$ Ibidem, Meeting of 23 February 1934.

${ }^{64}$ Ibidem, Meeting of 14 May 1936.

${ }^{65}$ Ibidem.
} 
Table 10.8 and Figures 10.4 and 10.5 Total Sales Morphine and Codeine The Netherlands 1935-1938 ( $\mathrm{kg}$ AMA respectively ACA)
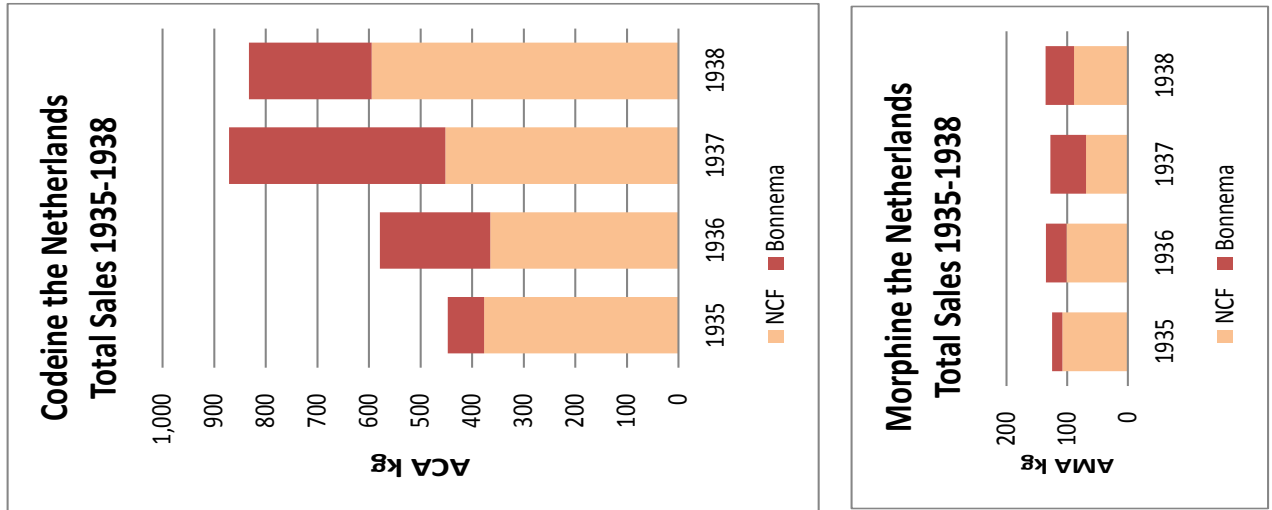

\begin{tabular}{|c|c|c|c|c|c|c|}
\hline \multirow{5}{*}{ 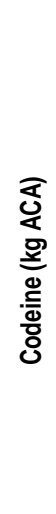 } & 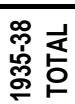 & 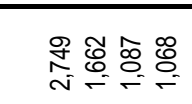 & $\underset{\sigma}{\bar{\sigma}}$ & 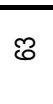 & 赵 ్లి & R \\
\hline & ळ్ & 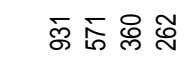 & $\frac{\infty}{y} \underset{7}{\infty}$ & $\Re$ & $\hat{\Sigma} \infty$ & 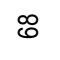 \\
\hline & $\stackrel{\widehat{్}}{\underline{9}}$ & 总贺总令 & 㣽 & $\mathscr{q}$ & $\stackrel{8}{\circ} \stackrel{\infty}{1}$ & $\approx$ \\
\hline & ஜ্g & 吕 㟒 怘志 & $\stackrel{\infty}{\leftarrow} \stackrel{\infty}{=}$ & $\bar{\sigma}$ & $\stackrel{\infty}{\circ} 8$ & 용 \\
\hline & $\stackrel{\mathscr{g}}{\mathscr{\rho}}$ & 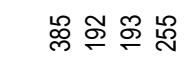 & $\stackrel{\infty}{\infty}^{\infty}$ & \& & Фे & 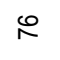 \\
\hline \multirow{7}{*}{ 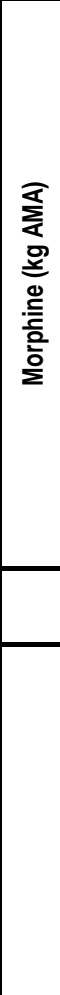 } & 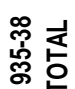 & 心 & $\stackrel{\infty}{\sim}$ & $\hat{\infty}$ & gृ & $\widetilde{\delta}$ \\
\hline & 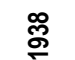 & $\cong \quad \Xi$ & 于 & 묭 & $\approx \approx$ & $\varnothing$ \\
\hline & $\widehat{\hat{g}}$ & 8 : & ల্ল & $\stackrel{\infty}{\sim}$ & $ळ \circledast$ & $\bar{\emptyset}$ \\
\hline & $\mathscr{\mathscr { g }}$ & $\approx \varnothing$ & $8 \%$ & 8 & ๗ & 5 \\
\hline & \multirow[t]{2}{*}{ ळ్ } & ז & $8 \sim$ & $\hat{s}$ & gి & $\approx$ \\
\hline & & $\Xi \approx \Phi \Xi$ & $\underline{\underline{\sigma}} \underline{\sigma}$ & $\Sigma$ & $\Phi$ & 흔 \\
\hline & & 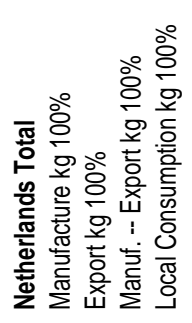 & 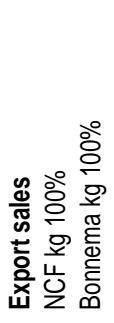 & 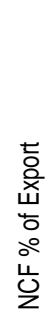 & 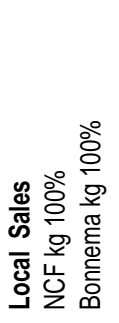 & 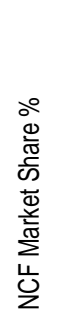 \\
\hline
\end{tabular}

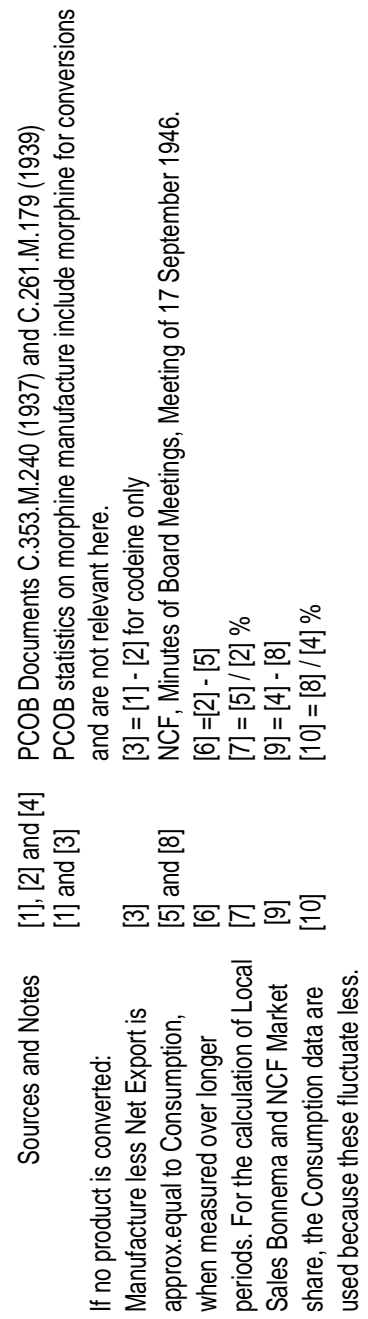


Commercially the 1930s was a difficult period for NCF. The Netherlands home market was small and orders for export could only be obtained at low prices. From 1 January 1934 onwards import restrictions resulting from the coming into force of the 1931 Geneva Convention reduced the size of the export market. NCF entered an agreement with the Opiate Convention by which NCF was allowed to sell $125 \mathrm{~kg}$ per 3 months at a price of $10 \%$ below the convention price. ${ }^{66}$ This arrangement appears to have been insufficient to obtain a sales volume large enough to absorb a major part of NCF's fixed manufacturing cost as NCF exported during the period thereafter at prices below (full) cost. ${ }^{67}$ In 1937 Dr Kramers went to Budapest for a meeting with "outsider" manufacturers to find a solution for the "chaotic situation" and had thereafter discussions with the Convention during which he conveyed the suggestions from the outsiders. An agreement could not be reached, however. ${ }^{68}$ But from mid-1939 onwards the situation changed dramatically as a result of threat of World War II. The traditional major suppliers disappeared and only NCF and some other smaller manufacturers remained, causing orders to flow in at much better prices. ${ }^{69}$

In a publication from 1939 it is stated explicitly that, despite the company name, the NCF had become primarily a manufacturer of opium alkaloids and derivatives. ${ }^{70} \mathrm{NCF}$ continued to bring additional opium products such as ethylmorphine and narcotine to the market.

\section{Cocaine Market}

The manufacture of cocaine in the Netherlands in the 1930s was very much lower than in the 1920s. It fell from an average of ca $720 \mathrm{~kg}$ cocaine $100 \%$ p.a. during $1925-1928$ to ca $120 \mathrm{~kg}$ p.a. during 1931-1934 and ca $70 \mathrm{~kg}$ p.a. during 1935-1938. ${ }^{71}$

Table 10.9 and Figure 10.6 Manufacture of Cocaine in the Netherlands 1931-1938 ( $\mathrm{kg}$ cocaine 100\%)

\begin{tabular}{|c|r|}
\hline Year & $\begin{array}{c}\text { Cocaine } \\
\text { Manufac- } \\
\text { tured }\end{array}$ \\
\hline 1931 & 89 \\
1932 & 189 \\
1933 & 106 \\
1934 & 103 \\
1935 & 58 \\
1936 & 76 \\
1937 & 89 \\
1938 & 60 \\
\hline
\end{tabular}

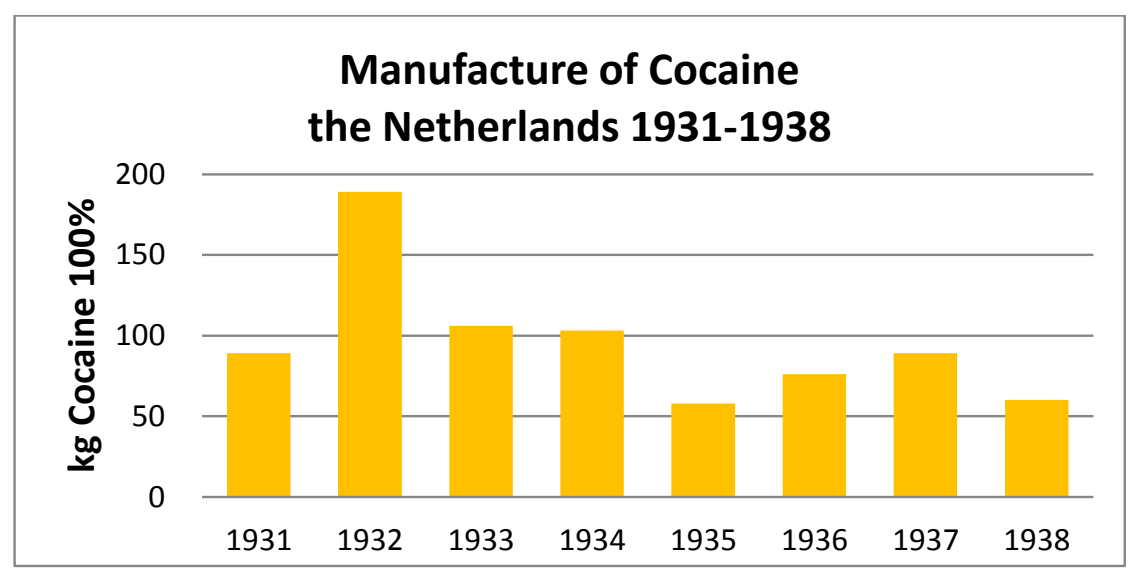

Source: PCOB Documents C.364.M.185.1935.XI and C.261.M.179.1939.XI

\footnotetext{
${ }^{66}$ NCF Minutes of Board meetings, Meeting of 23 February 1934.

${ }^{67}$ Ibidem, Meetings of 1 December 1934, 14 May 1937 and 1 June 1938

${ }^{68}$ Ibidem, Meeting of 14 May 1937.

${ }^{69}$ Ibidem, Meeting of 28 December 1939.

${ }^{70}$ [Anonymous].De Nederlandsche Cocaine Fabriek N.V., Pharmaceutisch Weekblad 76 (1939) 802.

${ }^{71}$ The amount of cocaine manufactured during $1925-1928$ was ca $800 \mathrm{~kg}$ cocaine $\mathrm{HCl}$ equivalent to about $714 \mathrm{~kg}$ cocaine $100 \%$.
} 
The decline in cocaine manufacture in the Netherlands from the 1920s was a consequence of the reduction the total export market for cocaine to ca $1,000 \mathrm{~kg}$ cocaine p.a. (Table 10.5). NCF export and local sales of cocaine are known for 11 months of both 1936 and $1937 .{ }^{72}$ Using these figures the total sales were estimated and the under following table was constructed.

\section{Table 10.10 Export and Local Sales of Cocaine and Crude Cocaine in the Netherlands 1935-1938 ( $\mathrm{kg}$ cocaine 100\%)}

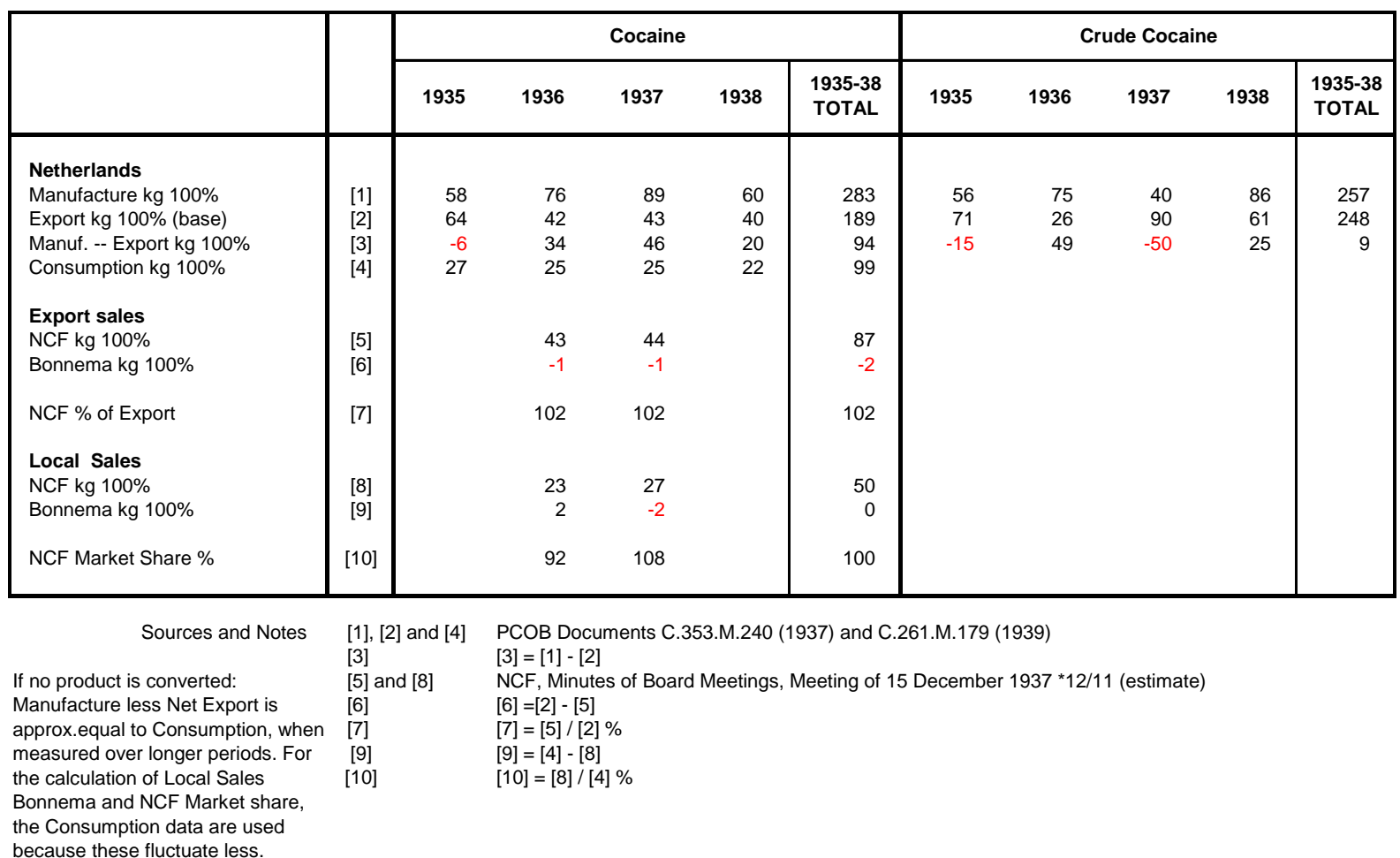

In the table PCOB figures and NCF data are reconciled. It is concluded from the figures in the table that the market share of the NCF for cocaine was $100 \%$ during the years 1936 and 1937. Under the 1936 agreement by which NCF and Bonnema shared the home market, Bonnema was entitled to a quota of $20 \%$ but that was apparently not taken up. ${ }^{73}$ In the early 1930s Bonnema had agreed with the Cocaine Convention not to produce for export in return for an annual payment of NLG $16,000 .^{74}$

The average annual production of crude cocaine in the Netherlands was $61 \mathrm{~kg}$ during 1935-1938. In the Minutes of the NCF Board meetings for 1934-1951 manufacture or sales of crude cocaine are not mentioned at all. It seems unlikely that Bonnema was the manufacturer because the production requires extraction facilities which, as far as we know, Bonnema did not possess at the time.

For the NCF cocaine was still the most important product during the 1930s because of the payments to the NCF by the Cocaine Convention. ${ }^{75}$ In total, the substantial amount of NLG 386,000 was received during the period $1924-1939 .^{76}$

\footnotetext{
${ }^{72}$ NCF Minutes of Board meetings, Meeting of 15 December 1937.

${ }^{73}$ Ibidem, Meeting of 14 May 1936.

${ }^{74}$ De Kort, Tussen patient and delinquent, 110.

${ }^{75}$ NCF Minutes of Board meetings, Meetings of 14 May1936 and 20 April 1939.

${ }^{76}$ Ibidem, statement by Dr Kramers in the meeting of 27 June 1949.
} 


\section{Ethocaine Market}

A complete set of sales and cost figures is not available but NCF was selling around $3,000 \mathrm{~kg}$ ethocaine p.a. until 1934 at a margin over cost of NLG 3-5 per kg which made it a modest contributor to profit and absorption of fixed cost. ${ }^{77}$ The product was sold mainly to Japan. Unfortunately prices continued to come down and, although NCF succeeded in reducing the manufacturing cost by $25 \%$, in 1935 the price fell to below cost while sales volume shrunk to ca $2,000 \mathrm{~kg}$. In 1936 it was decided to stop ethocaine production because of large stocks and limited sales. Three factory workers were made redundant. ${ }^{78}$

\section{Ephedrine}<smiles>CNC(C)C(O)c1ccccc1</smiles>

Figure 10.7 Ephedrine

Another new product for NCF was ( \pm )-ephedrine (racemic), introduced in 1937 when the first few $\mathrm{kg}$ were supplied at a price of ca. NLG 110 per kg. Sales or production figures for NCF ephedrine are not available for the period until 1939.

Ephedrine is a nasal decongestant and used in cough medicine. The product was made synthetically by NCF using propionic acid as the main raw material, following processes described in the chemical literature and optimised for use in the NCF facilities. ${ }^{79}$ $( \pm)$-Ephedrine was sold in competition with the naturally occurring alkaloid (-)-ephedrine which is isolated from plants of the genus Ephedra.

In the minutes of the NCF board meeting of 1 June 1948 appeared a list of new products developed by NCF since 1920. In that list, ephedrine was mentioned as a new NCF product that was introduced in 1940. Kolf and de Kort wrote in a newspaper article of 1989 that the NCF commenced the manufacture of amphetamine in $1941 .^{80}$ Amphetamine is a compound with a chemical structure related to that of ephedrine but with a different physiological action. Amphetamine did not appear in the above mentioned list of new NCF products nor was it referred to at any other place in the minutes of NCF board meetings. It is therefore assumed that the word amphetamine was used by mistake by Kolf and de Kort. ${ }^{81}$

\footnotetext{
${ }^{77}$ Ibidem, Meetings of 23 February 1934 and 10 December 1934.

${ }^{78}$ Ibidem, Meeting of 14 May 1936.

${ }^{79}$ Ibidem, Meeting of 30 June 1947.

${ }^{80}$ Korf, D. and de Kort, M., 'NV De Witte Waan. De geschiedenis van de Nederlandsche Cocaïnefabriek', NRC Handelsblad (Newspaper) (1989) May 13.

${ }^{81}$ Amphetamine is also mentioned as an in 1941 by NCF developed product, in an interview of M. de Kort by Sybilla Claus in Nederland wist de weg met drugs' De Telegraaf (Newspaper) (1994) May 14. Included in the article is the comment that the product was "probably developed for [use by] German soldiers".
} 


\subsection{Manufacturing ${ }^{82}$}

\section{The Processes}

It was a challenge for the NCF to successfully enter the opiate business with respect to both marketing and production. Manufacturing processes for morphine and codeine from opium had to be developed, and equipment had to be designed, constructed and installed. That was a major effort, especially because yields had to be equal to those of its competitors, many of whom were many years in the business. ${ }^{83}$ All other costs had also to be strictly controlled.

Dr. Kramers, Technical Director, and Ir. Weidema, Chief Chemist, did not follow the standard processes known at the time but developed new ones suitable for NCF conditions. Design, construction and installation of equipment was largely done under the supervision of Chief Engineer, H. Brunner. Kramers, Weidema and Brunner were successful: the processes were, with some modifications, used until 1964.

An essential part of NCF's opium process was the addition of sodium benzoate to aqueous extracts of crude opium. The result was that copious volumes of dark brown resins ("tars") were precipitated and that the aqueous phase, containing most of the alkaloids, became much lighter in colour and could be processed with relative ease. For good yields the "tars" had to be subsequently extracted with water at various degrees of acidity $(\mathrm{pH})$ to remove residual alkaloids. Crude morphine was precipitated from the aqueous phase and natural codeine was extracted from the mother liquors.

The crude morphine was purified using standard methods to a grade suitable for conversion into codeine and for manufacturing pure morphine salts, mainly the hydrochloride in cube and powder form.

The process selected for making synthetic codeine was not the standard one for the industry using phenyltrimethylammonium chloride (Boehringer) but one, originally developed and patented by Bayer, using diazomethane. ${ }^{84}$ The yield of the Bayer process was similar to that of Boehringer, about $90-92 \%$ of the theory. As with the Boehringer process, also with the Bayer process $0^{6}$-methylcodeine was the main by-product.

For the NCF the advantage of the diazomethane process was that no high pressure equipment was required, as was for making phenyltrimethylammonium chloride from dimethylaniline and methyl chloride. The disadvantages were that diazomethane is a highly explosive, very toxic gas and that nitrosomethylurea, from which it is generated, is a carcinogenic compound. The problems were solved by using entirely closed equipment in which the diazomethane was generated and, by means of a pure silver tube, led directly into a reactor containing the morphine, in that way keeping the volume of free diazomethane as small as possible at any time. Other metals than silver were known to catalyse explosive decomposition of diazomethane. The building used for the codeine synthesis had one wall, directly behind the reactors, constructed of lightweight sheets. The idea of this was that in case of an explosion that wall would be blown out and that the building would not collapse.

The codeine process was operated by one specialist labourer under immediate supervision of the Chief Chemist (Ir. Weidema). The process was used for a period of 30 years (1933-1964)

\footnotetext{
${ }^{82}$ Sections 10.5 and 10.6 are to a large extent based on the personal experiences of the author and on information obtained during his employment as chief chemist / operations manager at NCF during the period 1960-1964.

${ }^{83}$ The yield of a process is the quantity of end product obtained calculated as a percentage of the theoretical amount obtainable from the quantity of the raw material used. As the cost of opium represented more than $90 \%$ of the production cost of opiates, good yields were essential for making a profit.

${ }^{84}$ Bayer \& Co., A method for manufacturing codeine from morphine,

German Patents No. 92,789 (1897); 95,644 (1897); 96,145 (1898), 189,843 (1907) and 224,388 (1910).
} 
and no process related health problems were reported as occurring during that time, nor did explosions occur. Factory design, process specifications and safety instructions and supervision must have been extremely good.

Codeine was purified mainly by crystallisation of the hydrochloride and then converted into the pure end products: codeine phosphate, codeine hydrochloride and codeine base mono-hydrate.

During the 1930s more processes for making opiates were developed. In 1939 the production programme included next to morphine and codeine and their salts also ethylmorphine, diacetylmorphine, narcotine, thebaine, narceine, cotarnine and various opium preparations such as opium powder, opium extract and opium concentration. ${ }^{85}$

\section{Expansion of the facilities}

To accommodate opiate production NCF expanded its manufacturing facilities at the Duivendrechtsekade, Amsterdam, during the years 1931-1934. Applications for the required building and operating permits (Hinderwetvergunningen) were applied for and obtained. The most important were: 1392 HW 1931, 750 HW 1932 and 672 HW 1934. ${ }^{86}$

\footnotetext{
${ }^{85}$ Anonymous, 'De Nederlandsche Cocaine Fabriek NV', Pharmaceutisch Weekblad 76 (1939) 802.

${ }^{86}$ Stadsarchief Amsterdam, Dienst Milieu en Bouwtoezicht; Hinderwet Dossier 39188 and Brandweer Dossier 29
} 


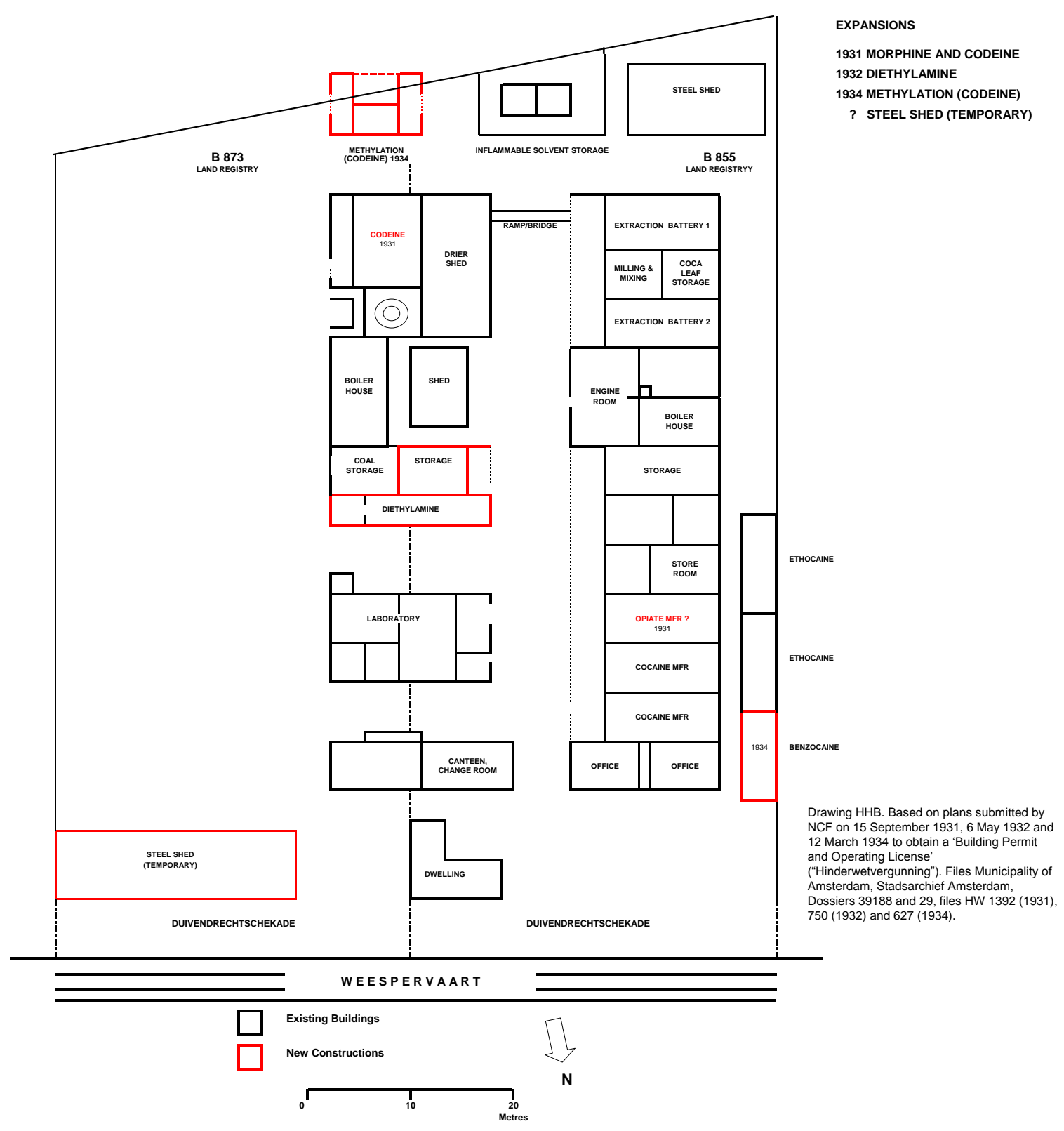

Application 1392 HW 1931 pertained to an expansion of existing spaces to accommodate morphine and codeine manufacture to a maximum of $5 \mathrm{~kg}$ per day. Application $750 \mathrm{HW} 1932$ requested approval to enlarge the manufacturing facilities of diethylamine (an intermediate for making ethocaine) to a maximum of 20 litres per day. By 672 HW 1934 NCF requested approval for building two new working spaces, one for the production of codeine and one for benzocaine (ref. Figure 10.8). The new building for codeine manufacture (methylation) is the one mentioned above with the special safety features. 


\subsection{Opiate Factories and Work Conditions in the 1930s}

Opiate manufacture can be classified as a sector of the fine chemical industry. However, opiate factories in the 1930s did not look like a fine chemicals manufacturing facility as we know them today. The picture below of one of the production spaces at the NCF factory illustrates this point.

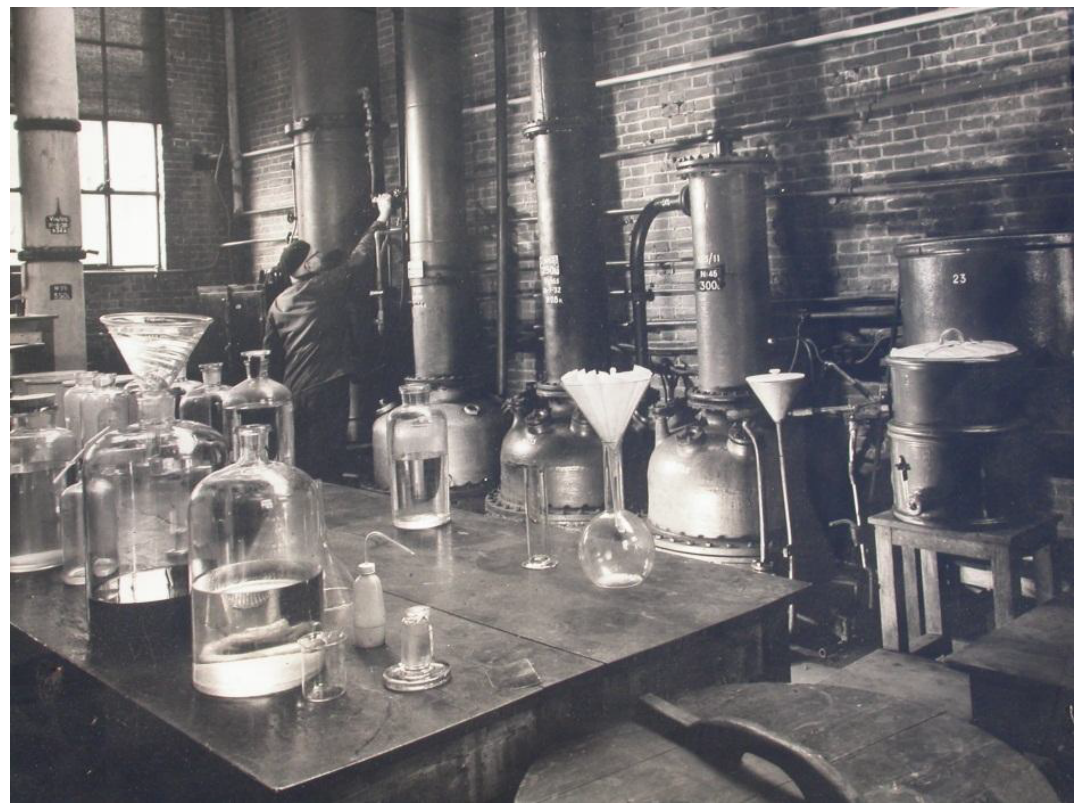

Figure 10.9 Alkaloid manufacture at the NCF in 1950 (Photo collection HHB)

The picture was taken in 1950 but in 1960, when the author joined the company, it looked exactly the same and virtually all of the equipment was from the 1930s and earlier. The factory consisted of a series of sheds, built in 1909, made of un-rendered bricks with concrete floors and daylight entering mainly through large skylights in the saw-tooth roofs (see Figures 6.10 and 10.9). Power for stirrers etc. was delivered by a central driving gear in each shed, and from there, by driving belts, to pulleys connected to the actual equipment. All heating was by steam.

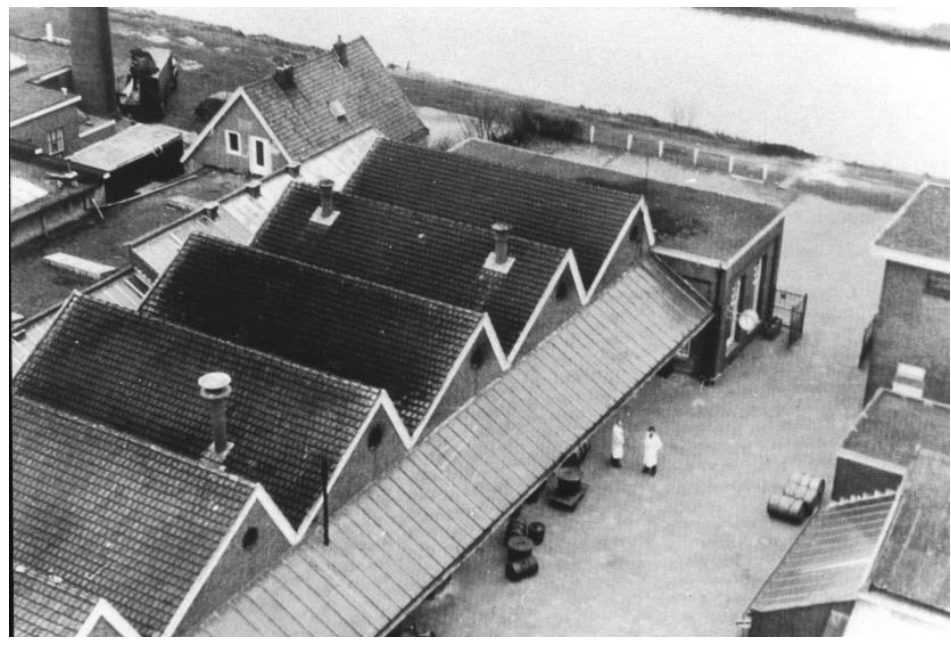

Figure 10.10

Aerial view of the NCF

factory (ca. 1955)

(Archief Akzo Pharna) 
Figure 10.11

Ethocaine manufacture at the NCF in the 1930s

(Archief Akzo Pharma)

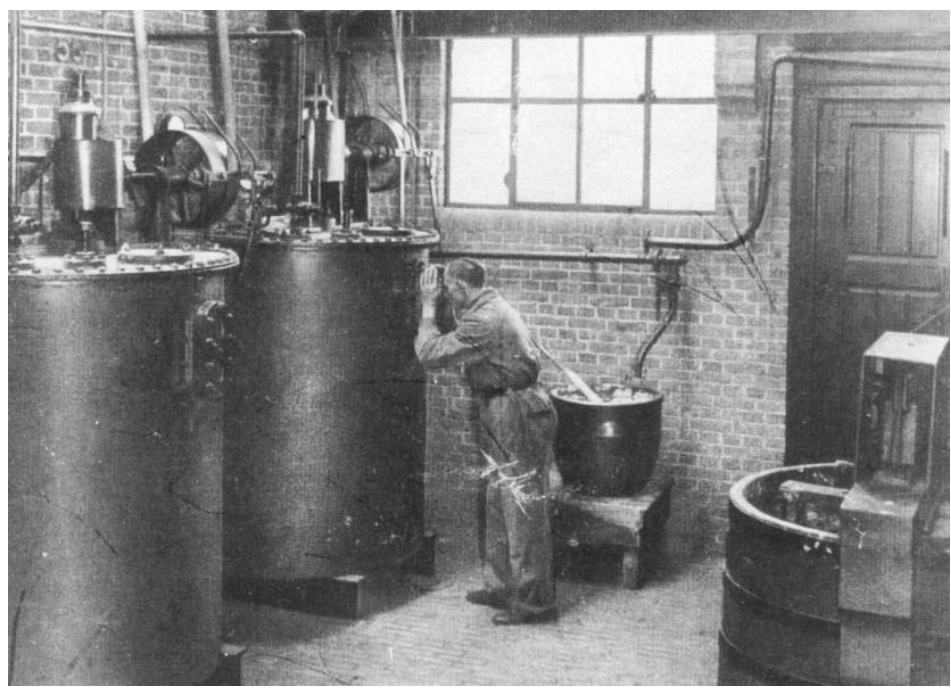

Each shed was equipped for performing special tasks e.g. poppy straw extraction, morphine precipitation, morphine purification, codeine synthesis etc. Inside the sheds there were reactors, distillation units, filters, etc. mainly placed along the walls. Large wooden tables occupied the middle of the space; on the tables smaller auxiliary equipment was placed together with bottles containing solvents and chemicals.

The whole outfit looked quite old fashioned already in 1960; it resembled workplaces from early in the $20^{\text {th }}$ century. All equipment was of a small size, asbestos lagging was everywhere, around the equipment and around the steam pipes. All measuring and weighing of product and chemicals was done by hand, all transportation was manual, by use of trolleys.

Crystallisations took place in enamelled cast iron pots fitted with plywood covers. Isolation of solids was achieved in cloth bags, using manually loaded centrifuges. Smaller quantities were collected on cloth in stoneware filter pots.

Factory workers were unschooled labourers, who got their training on the job. The ones who stayed, and most of them did, acquired over time considerable skills in extracting the plant raw materials and making the pure end products. Ir. Weidema was always present in person when critical chemical reactions were proceeding and certainly during the methylation stage of the codeine process. He would walk around the factory with booklets of red and blue litmus paper, phenolphtaleine paper and congo paper in the pocket of his white laboratory coat, testing the $\mathrm{pH}$ of the various reaction mixtures at the different process stages while teaching the workforce and asking penetrating questions.

An important part of the practical training was instructing the workforce on all safety aspects. Fire hazards, toxicity and corrosive properties of all chemicals and solvents were taught on the spot. Any infringements of safety rules resulted in serious talking to by Ir. Weidema.

There are no reports of any deaths or serious health problems related to the operations at the NCF. One occupational health hazard, which was difficult to overcome, was allergic reactions to some opiates that occasionally developed over time with certain workers. These allergic reactions appeared as skin rashes or respiratory problems. When the problems persisted the worker involved was moved to another department where he would not be exposed to the same product and the allergic reaction would disappear.

Ger Harmsen, in his autobiography Herfsttijloos (1993), delineates his work experiences at the NCF as a young person. He concludes that NCF was an unhealthy place to work, using emotional rather than factual arguments. ${ }^{87}$ His views are opposed in Part III, Appendix 2, 'Some adverse publicity on the NCF'.

${ }^{87}$ Ger Harmsen, Herfsttijloos (Nijmegen 1993). 


\section{Macfarlan}

Deric Bolton, former technical director of J.F. Macfarlan and Co Ltd., describes alkaloid manufacture at Macfarlan and T. \& H. Smith, both at Edinburgh during the period 1832 1939. ${ }^{88}$ Bolton's publication is mentioned here because of his description of the factory and conditions of work in Scotland which were very similar to those at NCF in the 1930s. A few quotes from Bolton's article will illustrate this:

On technology: “... a system relying on a lavish use of manual labour and little on costly equipment. Everything would be moved by hand - in casks, crates, sacks, boxes, carboys and stoneware bottles."

On processes: "... there was considerable measuring of solvents, packing damp alkaloids into filter cloth - 'bundling and squeezing' in presses, drying, sieving and grinding of finished salts in large mortars and weighing into pound bottles."

On workers: "They were hardy, resilient, adaptable, self-reliant, well educated and easily trained up into reliable process workers. They took a great pride in their personal skills, their specialised know-how and 'tricks of the trade', their peculiar and often secret methods of working. The industry owes much to them."

On safety: "Many of the materials they worked with were toxic but poisoning or addiction were practically unknown in the 'folk memory' of the industry. In 46 years in Fine Chemicals, I have not experienced one single case of poisoning in the factory."

\subsection{Financial}

Profitability of the NCF was modest during the period 1931 - 1939. The average dividend amounted to NLG 28,440 p.a.

Table 10.11 and Figure 10.12 Dividend (in NLG) paid to shareholders of the NCF during the period 1931-1939

\begin{tabular}{|c|c|}
\hline Year & NLG \\
\hline 1931 & 30,780 \\
1932 & 17,820 \\
1933 & 27,540 \\
1934 & 25,920 \\
1935 & 24,300 \\
1936 & 27,540 \\
1937 & 29,160 \\
1938 & 24,300 \\
1939 & 48,600 \\
& \\
\hline
\end{tabular}

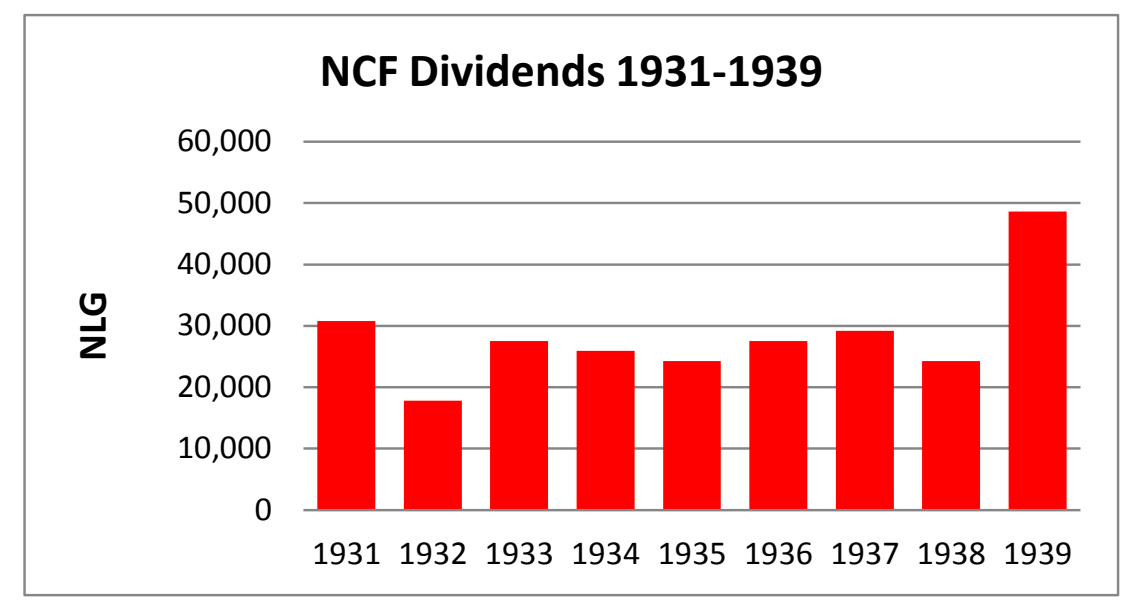

Source: Koloniale Bank, 'Rapport inzake de N.V. Nederlandsche Cocaine Fabriek’ (1945)

\footnotetext{
${ }^{88}$ Bolton, Deric, 'The Development of Alkaloid Manufacture in Edinburgh 1832-1939' Chemistry and Industry (1976) 701-708.
} 
The total dividends of NLG 255,960 paid over 1931-1939 should be seen in the light of the amount of NLG 386,000 received by the NCF from the Cocaine Convention during the period 1924-1939. ${ }^{89}$ If NCF had not received payments from the Convention, profit would have been virtually nil during the 1930s. The words of Dr. Kramers, that income from cocaine during the existence of the Convention (1924-1939) had been essential for the profitability of the company, are certainly true. ${ }^{90}$

The rather flat graph for the dividends over the period shows the combined effect of the various contributing factors to profit. Declining profits from cocaine and ethocaine were compensated by income from the Cocaine Convention and slowly increasing sales of morphine and codeine. During the first three years the opiate operations were not yet profitable, however. In 1939 NCF profit jumped as a consequence of World War II.

Table 10.12 Concise Profit \& Loss Accounts NCF 1933, 1936 and 1939

\begin{tabular}{|c|c|c|c|}
\hline & 1933 & 1936 & 1939 \\
\hline Revenue & 212,034 & 204,298 & 281,032 \\
\hline Operating Expense & 171,727 & 157,236 & 172,572 \\
\hline Operating Income & 40,307 & 47,062 & 108,460 \\
\hline Other Income (Interest) & 5,161 & 3,613 & 2,555 \\
\hline Total Income & 45,468 & 50,675 & 111,015 \\
\hline Actual and Planned Expansions & 5,000 & 6,410 & 13,738 \\
\hline NCF Pension Fund & 1,000 & 1,000 & 5,000 \\
\hline Bonuses Directors and Gratuities & 7,041 & 9,793 & 14,576 \\
\hline Reserve Funds & 0 & 2,271 & 10,953 \\
\hline Taxes & 2,900 & 3,439 & 12,000 \\
\hline Total Other Expense & 15,941 & 22,913 & 56,267 \\
\hline Net Income & 29,527 & 27,762 & 54,748 \\
\hline Dividend Paid & 27,540 & 27,540 & 48,600 \\
\hline
\end{tabular}

Source: Minutes NCF Board Meetings 1934, 1937 and 1940

\section{Table 10.13 Specifications Revenue NCF 1939}

\begin{tabular}{|l|rr|}
\hline Revenue Specification & P \& L & BCI \\
\hline Opium Products & 196,153 & 233,083 \\
Coca Products & 68,437 & 65,096 \\
Synthetic Products & 15,790 & 23,877 \\
Other Products & 652 & 0 \\
\hline Total & 281,032 & 322,056 \\
\hline
\end{tabular}

Note: Synthetic Products comprise ethocaine (mainly) and ephedrine

Sources: Minutes NCF Board Meeting 1940 (P\&L) and a completed $\mathrm{BCl}$ form of 1941 (VNCl Archief)

For the years 1933, 1936 and 1939 concise Profit \& Loss accounts (P\&L accounts) are available from the minutes of NCF board meetings. ${ }^{91}$ The figures are summarised in Table 10.12 above. No specifications are available for "revenue" except for the year 1939. The amounts for revenue must have included the payments by the Cocaine Convention. For 1939 an alternative revenue specification was found in a report submitted by the NCF to the Bedrijfsgroep Chemische Industrie (BCI) in $1941 .{ }^{92}$ The BCI was an administrative body established by the occupying German forces to control the chemical industry. As shown in Table 10.12 above, considerable differences exist between the two specifications. No explanation is available for the differences.

\footnotetext{
${ }^{89}$ NCF Minutes of Board Meetings, Meeting of 27 June 1949.

${ }^{90}$ Ibidem, Meeting of 28 December 1939.

${ }^{91}$ Ibidem. Meetings of 23 February 1934, 14 May 1937 and 12 March 1940.

${ }^{92}$ Bedrijfsgroep Chemische Industrie, ‘Aanmelding tot inschrijving bij de Vakgroep' dated 10 December 1941.

VNCI Archief, Sociaal Historisch Centrum voor Limburg, Maastricht (EAN 1057, Box 27-N12).
} 


\subsection{Summary and Conclusions.}

The 1930s was a period of change for the NCF. As a consequence of the Geneva Conventions of 1925 and 1931 cocaine sales diminished rapidly. Income from the Cocaine Convention was of crucial importance for the company during the period. Ethocaine contributed substantially to income until 1935 but faded thereafter.

NCF developed processes for the manufacture of morphine, codeine and other opiates from crude opium. Manufacturing equipment was installed and opiate production commenced on a small scale in 1931. Production of morphine and codeine and other opiates steadily increased during the 1930s and profit from the new opiate business became worthwhile from 1935. In 1934 the Netherlands became a market closed for imports for narcotic drugs. NCF shared the home market with Bonnema and prices were reasonable. However, because of severe competition prices were depressed in the export market and the NCF had to sell at prices which were below total cost to obtain any orders outside its home market.

The new opiate business was successful from a manufacturing point of view but it took until the outbreak of the Second World War in 1939 before shortages in opiates caused export sales to improve in both volume and price, resulting in good profit. 


\section{CHAPTER 11 \\ THE SECOND WORLD WAR AND REVIVAL NCF AND BONNEMA/VPF FROM 1940 TO THE EARLY 1960S}

\subsection{Overview}

The Second World War led to a lack of raw materials and a slowdown of the business activities of both NCF and Bonnema to a trickle. Some relief came in 1943 when locally grown poppy straw was extracted to yield morphine under a contract with the government. After the war, the companies tried to re-establish their position in the market and made attempts to base opiate production permanently on the extraction of Dutch poppy straw replacing opium, which had become very expensive, as the raw material. However, the Dutch climate proved ultimately to be too wet for the reliable and economical production of high yielding poppy straw and from 1950 both manufacturers changed over to lanced poppy straw imported from Turkey and Yugoslavia.

This was successful and morphine manufacture in the Netherlands increased rapidly, especially at VPF, the company which became the major opiate producer in the Netherlands. ${ }^{1}$ The use of poppy straw as raw material resulted for VPF and NCF in the production of Extractum Papaveris Crudum (EPC), a crude extract of the total alkaloids of the poppy containing about $50 \%$ morphine, a product which could be used as the raw material for codeine production or sold to codeine manufacturers in competition with opium. EPC was not subject to the same import restrictions as codeine because it was not produced in the countries of destination.

The low manufacturing cost of EPC allowed for competition of EPC with opium as a raw material for making opiates. EPC export from the Netherlands became important from 1958; in 1960 the combined morphine output of NCF and VPF was more than ten times as large as the average for 1946-1950.

From 1956 VPF invested heavily in equipment for the extraction of large quantities of poppy straw. NCF also expanded and upgraded its production facilities over the same period but not to the same extent. NCF, requiring further expansion of the factory, but with insufficient means to finance such a move, became part of the multinational KZO which had an interest in acquiring companies with good potential. KZO purchased the NCF shares from Ir. Dénis in 1962.

VPF produced in the early 1960s more morphine than it could sell and accumulated large stocks, while prices declined substantially. The large stocks resulted in pressure by the Dutch government to reduce production, as holding excessive stocks of opiates was discouraged under the Single Convention of 1961. Furthermore, financing the stocks required VPF taking on quite a large debenture loan. Although these impediments were not unsurmountable for the company, when combined with the fact that Mr Jansen, the managing director and major shareholder had reached retirement age, created a situation whereby acquisition of VPF by KZO became a viable option. For KZO it opened up the possibility to merge NCF and VPF by closing NCF's old manufacturing facilities in Amsterdam and to combine marketing efforts at Apeldoorn. KZO also had an interest in acquiring the wellknown Zwitsal baby products line and the pharmaceutical speciality products division of VPF. This was a win-win situation and an agreement was reached on acquisition in 1964.

\footnotetext{
${ }^{1}$ From 1948 Bonnema's opiate operations continued as a division of the Verenigde Pharmaceutische Fabrieken (VPF) at Apeldoorn.
} 


\subsection{Opiate Manufacture during World War II}

The Second World War brought fundamental changes to the narcotics industry. Opium and other raw materials became scarce and prices increased very substantially. International trade in essential drugs came to a virtual halt. Systems of rationing applied within most countries to assure that the limited stocks were optimally distributed.

PCOB Statistics of Narcotics do not exist for the years 1941-1945 and the Statistics for 1940 are incomplete. ${ }^{2}$ PCOB Statistics were published again for the years from 1946 onwards. As a result very little is known on the worldwide manufacture and trade of opiates, cocaine and other narcotic drugs during the war. For the period 1940-1945 this chapter deals mainly with the situation in the Netherlands.

\section{Poppy Straw Extraction in Europe}

Some information is available on the production of morphine from locally grown poppy straw in Europe during the war. In Germany, in 1936, the move to become independent from opium imports started and during the period 1940-1945 7,425 t of poppy capsules containing 20,203 $\operatorname{kg}$ AMA $(0.27 \%)$ were procured by the German manufacturers. ${ }^{3}$ The capsules were probably processed by Boehringer Ingelheim and Merck Darmstadt. ${ }^{4}$

In 1941, in France, the company Francopavot was formed by the three companies which supplied the French market with opiates before the war, to produce alkaloids from locally grown poppies. ${ }^{5}$ From poppy straw harvested in 1941, a quantity of about $400 \mathrm{~kg}$ alkaloids was produced from $200 \mathrm{t}$ of straw. The harvest of 1942 was even larger and in 1943 Francopavot expected that France would be self-sufficient for opiates in $1944 .^{6}$

In the Netherlands the production of morphine from local straw was taken on by both opiate manufacturers, NCF and Bonnema, under a joint-contract with the Dutch government. During 1943-1945 $244 \mathrm{t}$ poppy straw was extracted yielding $480 \mathrm{~kg}$ AMA; details of the processing are discussed later in this chapter.

\section{Opiate Manufacture in the Netherlands}

On May 10, 1940 German troops entered the Netherlands and occupied the country after a brief period of resistance by the Dutch army. Part of the Netherlands, north of the river Rhine, remained occupied until May 1945. Fortunately, neither the NCF factory nor Bonnema's facilities were damaged by military actions, and personnel largely escaped immediate disaster.

After an initial enforced stop NCF was allowed to continue production but supply to wholesalers and pharmacies became regulated and all export was halted. ${ }^{7}$ In August 1940 Professor van der Wielen expressed his concern that supply of opiates could become insufficient. ${ }^{8}$ Both NCF and Bonnema reacted by writing letters to the editor of the Pharmaceutisch Weekblad each stating optimistically that stocks were sufficient to supply the

\footnotetext{
${ }^{2}$ PCOB Publication C.62.M.59.1941.XI.

${ }^{3}$ W. Küssner, 'Poppy straw: a problem of international narcotics control', Bulletin on Narcotics, 1961[2] 1-6.

${ }^{4}$ Dethloff, W., Rohmaterial zur Herstellung von Morphium, seinen derivaten and Nebenalkaloiden,

Manuscript ca 1957, Ingelheim, Firmen- und Familienarchiv von C.H. Boehringer Sohn.

${ }^{5}$ These companies were: la Société pour l'Exportation de Matières Premières Végétales et des Alcaloïdes (S.E.M.P.A), le Comptoir Central (C.C.A) and la Société de Recherches Chimiques et d'Applications industrielles (S.O.R.C.H.A.P.).

${ }^{6}$ Y. Comar, 'Des alcaloides de l'Opium aux alcaloides du Pavot français', Ann. Pharm. Franç. (1943) [2] 89-91.

${ }^{7}$ NCF, Minutes of Board Meetings, Meeting of 8 October 1940.

${ }^{8}$ P. van der Wielen, 'Geneesmiddelen in Oorlogstijd', Pharmaceutisch Weekblad (1940) 921.
} 
local requirements for a number of years. ${ }^{9}$ In May 1940 NCF had placed an order for the purchase of opium in the USSR but this order was cancelled. Dr Kramers stated at the October Board meeting that no government approval could be obtained for buying any opium using foreign currency and that the quantity of opium in stock was sufficient for the continuation of manufacture until February $1941 .{ }^{10}$ In an apparent contradiction, Dr Kramers mentioned at the same meeting that a fear for product shortages was unfounded, because ample stocks were available.

In May 1941 raw material stocks had become low and the factory was gradually running out of work. ${ }^{11}$ Kramers and Weidema had identified earlier discarded process residues containing some alkaloids which could be processed. ${ }^{12}$ This resulted in the isolation of narcotine from opium "tars" which was converted into narceine ethylester, a useful cough suppressant. ${ }^{13}$ The main by-product of the codeine synthesis, dimethylmorphine $\left(\mathrm{O}^{6}\right.$ methylcodeine), was isolated from accumulated process residues and converted in its sulphate. This product was pharmacologically and clinically tested, and proved to be an antitussive of equal potential to codeine. Unfortunately, the quantities which could be produced were only small. ${ }^{14}$

Quantities of the various products sold by NCF and prices thereof are not known for the war period. In general, prices were controlled by the government and for all price increases approval had to be obtained. Total NCF sales are known for certain years. They were: NLG 327,000 for 1940, NLG 188,000 for 1942 and NLG 162,000 for $1943 .{ }^{15}$

\section{Morphine Production from Poppy Straw (NCF and Bonnema)}

Some relief of the raw material situation occurred during 1943/45 when $340 \mathrm{~kg}$ morphine (AMA) was produced by the NCF by the extraction of $165 \mathrm{t}$ locally grown poppy straw under a contractual arrangement with the Government. ${ }^{16}$ Bonnema also produced morphine under the same contract. Bonnema began processing in 1944 and produced $140 \mathrm{~kg}$ AMA from $79 \mathrm{t}$ of poppy straw. ${ }^{17}$ The government supplied the poppy straw at no cost and reimbursed all cost to the companies. The morphine produced was later transferred in ownership to the companies at a price which was to be determined on the basis of cost calculations by the Government at a later date. ${ }^{18}$ This price was established on 29 March 1946 at NLG 715.74 per kg AMA. This price was not acceptable to the processing companies as they had converted the morphine into codeine which had been sold at government controlled prices which were based on a cost of NLG 130 per kg AMA in crude morphine used as the raw material. ${ }^{19}$ How this problem was ultimately solved is not exactly known.

The cost of NLG 130 per kg AMA represented approximately the cost of crude morphine produced from opium at the pre-war price of NLG 12.50 (USD 5) per kg at $12 \%$ AMA. The price was also considerably higher than the cost of NLG 576 calculated in the 1947 government audit report of the project. $^{20}$ The latter figure should be considered as

\footnotetext{
${ }^{9}$ G.H. Kramers, Pharmaceutisch Weekblad, (1940) 804; C.J. Jansen, Pharmaceutisch Weekblad, (1940), 945.

${ }^{10} \mathrm{NCF}$, Minutes of Board Meetings, Meeting of 8 October 1940.

${ }^{11}$ Ibidem, Meeting of 15 May 1941.

12 Ibidem.

${ }^{13}$ Ibidem, Meeting of 12 May 1944.

${ }^{14}$ Ibidem and Mededeling van het Rijks-Instutuut voor pharmaco-therapeutisch onderzoek, Nederlands Tijdschrift voor Geneeskunde (1943) 1611.

${ }^{15}$ NCF, Minutes of Board Meetings, Meeting of 21 December 1943.

${ }^{16}$ Ibidem, Meeting of 21 December 1943 and File: Project Bolkafverwerking voor de Nederlandsche Overheid gedurende 1943-1945, Nationaal Archief, The Hague, Access No 2.06.076.07 Item 389.

${ }^{17}$ File: Project Bolkafverwerking voor de Nederlandsche Overheid gedurende 1943-1945.

${ }^{18}$ Ibidem.

${ }^{19}$ Ibidem, Audit Report dated 21 November 1947," IV Prijsvaststelling" p3.

${ }^{20} \mathrm{Cf}$. The calculations in Table 11.1.
} 
correct. After the War opium prices had increased very much, to USD 21 (NLG 75) per kg at $12 \%$ AMA, corresponding with a cost of approx. NLG 650 per kg AMA in crude morphine. ${ }^{21}$ Compared with this figure, the cost of AMA from Dutch poppy straw of NLG 576 was competitive. It was the reason that, after the War, both NCF and Bonnema attempted to make morphine production from poppy straw economically viable.

Quantities of straw processed and morphine produced under the contract and costs incurred are known from specifications submitted to the government by NCF and Bonnema, and from an audit report by the Department of Economic Affairs. ${ }^{22}$ Key figures from these documents are summarised in the following table together with some basic parameters calculated by the author (in blue).

Table 11.1 Extraction of Poppy Straw by NCF and Bonnema 1944-1945

Under Contract with the Government

\begin{tabular}{|c|c|c|c|c|}
\hline & & \multicolumn{2}{|c|}{ Split NCF } & \multirow{2}{*}{ Total } \\
\hline & & 1944 & 1945 & \\
\hline $\begin{array}{l}\text { Poppy straw } \\
\text { Usage } \\
\text { tonnes }\end{array}$ & $\begin{array}{l}\text { Total } \\
\text { Refuse } \\
\text { Net }\end{array}$ & & & $\begin{array}{r}255.45 \\
11.53 \\
243.92\end{array}$ \\
\hline $\begin{array}{l}\text { Straw processed } \\
\text { tonnes }\end{array}$ & $\begin{array}{l}\text { NCF } \\
\text { Bonnema } \\
\text { Total }\end{array}$ & $\begin{array}{c}116.70 \\
\mathrm{n} / \mathrm{a}\end{array}$ & $\begin{array}{l}48.12 \\
\mathrm{n} / \mathrm{a}\end{array}$ & $\begin{array}{r}164.82 \\
79.10 \\
243.92\end{array}$ \\
\hline Yield kg AMA & $\begin{array}{l}\text { NCF } \\
\text { Bonnema } \\
\text { Total }\end{array}$ & $\begin{array}{c}242.33 \\
\mathrm{n} / \mathrm{a}\end{array}$ & $\begin{array}{l}97.78 \\
\mathrm{n} / \mathrm{a}\end{array}$ & $\begin{array}{l}340.11 \\
140.00 \\
480.11\end{array}$ \\
\hline Yield kg AMA / $t$ & $\begin{array}{l}\text { NCF } \\
\text { Bonnema } \\
\text { Average }\end{array}$ & $\begin{array}{r}2.08 \\
\mathrm{n} / \mathrm{a}\end{array}$ & $\begin{array}{r}2.03 \\
\mathrm{n} / \mathrm{a}\end{array}$ & $\begin{array}{l}2.06 \\
1.77 \\
1.97\end{array}$ \\
\hline $\begin{array}{l}\text { Processing cost } \\
\text { NLG }\end{array}$ & $\begin{array}{l}\text { NCF } \\
\text { Bonnema } \\
\text { Total }\end{array}$ & $\begin{array}{c}45,785 \\
n / a\end{array}$ & $\begin{array}{c}17,295 \\
n / a\end{array}$ & $\begin{array}{r}63,080 \\
39,340 \\
102,420\end{array}$ \\
\hline $\begin{array}{l}\text { Processing cost } \\
\text { NLG / t }\end{array}$ & $\begin{array}{l}\text { NCF } \\
\text { Bonnema } \\
\text { Average }\end{array}$ & $\begin{array}{r}392 \\
\mathrm{n} / \mathrm{a}\end{array}$ & $\begin{array}{r}359 \\
\mathrm{n} / \mathrm{a}\end{array}$ & $\begin{array}{l}383 \\
497 \\
420\end{array}$ \\
\hline $\begin{array}{l}\text { Processing cost } \\
\text { NLG / kg AMA }\end{array}$ & $\begin{array}{l}\text { NCF } \\
\text { Bonnema } \\
\text { Average }\end{array}$ & $\begin{array}{r}189 \\
\mathrm{n} / \mathrm{a}\end{array}$ & $\begin{array}{r}177 \\
\mathrm{n} / \mathrm{a}\end{array}$ & $\begin{array}{l}185 \\
281 \\
213\end{array}$ \\
\hline $\begin{array}{l}\text { Cost of Popppy Straw } \\
\text { NLG }\end{array}$ & $\begin{array}{l}\text { Total } \\
\text { per tonne } \\
\text { per kg AMA }\end{array}$ & & & $\begin{array}{r}174,028 \\
713 \\
362\end{array}$ \\
\hline $\begin{array}{l}\text { Cost per kg AMA } \\
\text { in Crude Morphine } \\
\text { NLG }\end{array}$ & $\begin{array}{l}\text { NCF } \\
\text { Bonnema } \\
\text { Average }\end{array}$ & & & $\begin{array}{l}548 \\
643 \\
576\end{array}$ \\
\hline
\end{tabular}

Source: File "Project Bolkafverwerking 1943-1945"

Note: The figures in blue are calculated by the author

\footnotetext{
${ }^{21}$ United Nations, The Movement of Opium Prices during the years 1930-1939 and 1946-1949, Commission on Narcotic Drugs - E/CN.7/AC.4/2/Add.2 (Geneva 1950).

${ }^{22}$ File: Project Bolkafverwerking voor de Nederlandsche Overheid 1943-1945.
} 
The average cost per kg AMA in crude morphine of NLG 576 appearing in the table above corresponds with the amounts calculated in the audit report by the government. ${ }^{23} \mathrm{NCF}$ processed the major part of its straw allocation from December 1943 until September 1944. Because stocks of solvents, chemicals and coal were depleted, the NCF factory was closed from September 1944 until September 1945 and the remainder of the straw was processed late 1945. In November 194414 factory workers were put on unemployment pay at $80 \%$ of their normal salary. ${ }^{24}$

Bonnema had first to install equipment for the extraction and did not commence processing before August 1944. For NCF the key figures are available for the two separate periods; Bonnema processed all straw in one single run. The figures show that the extraction yield was higher at NCF and that the processing cost was lower. This was no doubt the consequence of NCF's having extraction facilities in place and extensive experience with coca leaf extraction, while Bonnema had to improvise by putting equipment together during the war-year 1944 and to develop a process at the same time.

The figures in Table 11.1 are of particular interest because both NCF and Bonnema endeavoured in the years after the war to base their opiate production on the use of poppy straw as the raw material rather than opium because of the enormous price increase of opium. The cost and yields the companies experienced with the extraction of straw during 1944-45 allowed them to evaluate the economic feasibility of using poppy straw as the primary raw material.

\section{NCF Organization}

In 1940 J.P. Jager resigned as a Board member and B.C. Slotemaker was nominated to fill the vacancy. Sitting Board member B.H.A. van Kreel took over Jager's position as proxy for Miss Maarschalk. ${ }^{25}$ Professor L.P. le Cosquino de Bussy died in 1943; he was replaced by C.J. van der Weijden. ${ }^{26}$

W.C. Bonebakker was re-elected as chairman of the Board in 1943. Mr Bonebakker stated at the occasion that he, having reached the age of 77 , was of the opinion that a younger person should have taken over his position but that in view of the special circumstances [the War] he was willing to accept the nomination with the proviso that he would relinquish the position as soon as the circumstances would change. ${ }^{27}$

Also in 1943, Dr Kramers reached the age of 65 and although he was ready to retire he realised that his doing so would be most inconvenient for the company because a suitable successor was not available. The earlier tentative plan that in an emergency situation he would be succeeded by two people viz. Ir Weidema for scientific and technical matters and Mr Schöyer for commercial affairs, was no longer possible because Mr Schöyer had left the company. Dr Kramers agreed to stay on until such time that a successor could be found. The Board expressed the opinion that succession by a single person with the right talents was the preferred option. $^{28}$

\footnotetext{
${ }^{23}$ Ibidem, Audit Report dated 21 November 1947," V. Taxatie van het verlies" p4.

${ }^{24}$ NCF, Minutes of Board Meetings, Meeting of 20 December 1945.

${ }^{25}$ Ibidem, Meeting of 8 October 1940.

${ }^{26}$ Ibidem, Meetings of 12 December 1943 and 20 December 1945.

${ }^{27}$ Ibidem, Meeting of 2 April 1943.

${ }^{28}$ Ibidem.
} 


\section{NCF Financial Results}

Profits decreased gradually during the war years; no dividend was paid in 1945. In fact, 1945 was a loss making year; NLG 46,120 was transferred from a Special Provisions Reserve on the balance sheet to the Profit and Loss account, resulting in zero profit (Table 11.2). ${ }^{29}$

Table 11.2 and Figure 11.1 NCF Dividend 1940-1950

\begin{tabular}{|c|r|}
\hline Year & \multicolumn{1}{|c|}{ NLG } \\
\hline & \\
\hline 1940 & 45,360 \\
1941 & 32,400 \\
1942 & 9,720 \\
1943 & 17,496 \\
1944 & 9,720 \\
1945 & 0 \\
1946 & 11,664 \\
1947 & 34,020 \\
1948 & $\mathrm{~N} / \mathrm{A}$ \\
1949 & 19,440 \\
1950 & 29,160 \\
& \\
\hline
\end{tabular}

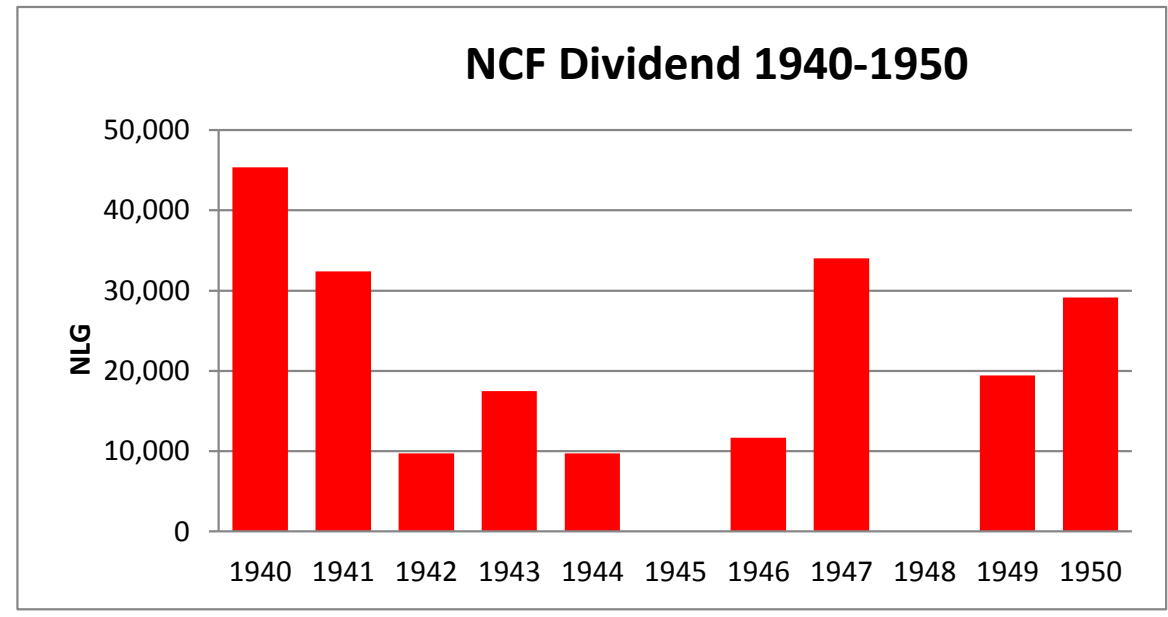

Source: Table FIN 1 (Part III)

Laws were introduced in the Netherlands in 1941 resulting in a substantial increase of the tax on dividends. The tax was progressive in the sense that dividends representing a larger percentage of the statutory capital were subject to a higher tax rate. For the NCF with its small capital of NLG 32,400, dividends as a percentage of that capital were large and consequently the tax would be high. ${ }^{30}$ Recapitalization of the company was discussed by the Board as a means of minimise the impact of the tax. Expert advice was obtained and it was decided with respect to the 1940 dividend, which amounted to $140 \%$ of the share capital, to issue and hand over one new share for each share held (nominal value NLG 900) and to pay the remaining $40 \%$ in cash. ${ }^{31}$

\section{The Bonnema Organisation}

Bonnema expanded its production facilities and moved into new premises at the Deventerstraat, Apeldoorn, in 1941. ${ }^{32}$ In 1943 the name of the company was changed to "N.V. Nederlandsche Fabriek van Pharmaceutisch-Chemische Producten v.h. A.A. Bonnema" and G.Th. Wilmink was nominated as director. The existing alkaloid business was continued by that company. The other business activities of Mr Jansen were brought together in the "Zwitsal Fabrieken", a partnership of C.J. Jansen and G.Th. Wilmink. ${ }^{33}$

Except for the extraction of poppy straw under the government contract during 19441945, no details are known on Bonnema's alkaloid operations during the War. It took Bonnema from the end of 1943 when the contract was signed until August 1944 to work out a process and to install the equipment for the poppy straw extraction. The cost of the equipment required for the operations was NLG $41,000{ }^{3}$

\footnotetext{
${ }^{29}$ Ibidem, Meeting of 24 July 1946.

${ }^{30}$ Ibidem, Meeting of 15 May 1941.

${ }^{31}$ Ibidem, Meeting of 3 June 1941.

32 'Van Zwitsal en Diosynth', SAM-Kroniek 47 (2007) 7.

${ }^{33}$ Pharmaceutisch Weekblad 1943, pp. 363 and 844.

${ }^{34}$ File: Project Bolkafverwerking voor de Nederlandsche Overheid gedurende 1943-1945.
} 


\subsection{The World Market for Opiates 1946-1960}

\section{International Narcotics Control.}

The Geneva Conventions of 1925 and 1931 remained in force after the end of World War II. The narcotics control functions of the League of Nations were transferred to the newly established United Nations (UN) in 1946. The Commission of Narcotic Drugs (CND), members of which were countries, signatories to the earlier Conventions, was created as an independent control apparatus. ${ }^{35}$ The CND reported directly to the Economic and Social Council (ECOSOC) of the UN and took over the tasks of the former Opium Advisory Commission (OAC) and the Division of Narcotic Drugs (DND) of the UN was formed as the equivalent of the old Opium Section. ${ }^{36}$

The practicalities of the pre-war control system remained largely unchanged. International trade in the controlled substances required import and export permits and import permits were difficult, if not impossible, to obtain for exports to manufacturing countries.

The UN Opium Conference of 1953 adopted a Protocol for limiting the cultivation of the poppy plant which included provisions for compulsory reporting of imports and exports of poppy straw. The protocol was however not ratified before 1963 and had little impact on the opiate industry. The provisions on reporting poppy straw international trade were included in the Single Convention of 1961 (see chapter 12).

\section{Developments in the World Market for Opiates}

Detailed information on the manufacture, consumption and trade in narcotics drugs is available from the PCOB Statistics, the publication of which was resumed in 1946. Specific information on individual manufacturers and opiate prices are scarce for the period. The world market for opiates is described here mainly on the basis of the PCOB figures. ${ }^{37}$

The key statistic for the description is the quantities of morphine manufactured in the producing countries because that figure is a direct measure of the size of the opiate industry in these countries. Except for relatively small quantities of natural codeine isolated directly from opium and poppy straw, the opiates used in medicinal products were either morphine itself or were made from morphine or thebaine by chemical synthesis. Of all morphine manufactured, $80-85 \%$ was converted into codeine. Thebaine was not used as such in medicine but it was used as a raw material for synthesizing strong analgesics with a morphinan structure.

Table 11.3 shows the quantities of morphine manufactured during the period 19461960 as the total and for the six most important manufacturing countries. Statistics for the Netherlands are included for the sake of comparison.

In the years 1937-1939 the total world production of morphine was ca $40 \mathrm{t}$ p.a. and in 1960120 t. This represents a growth of ca $10 \%$ per annum. Measured in kg AMA produced, the USA remained the largest producer of opiates but did not expand over the period 19461960. The output of all other producers increased considerably over the same period.

\footnotetext{
${ }^{35}$ William B. McAllister, Drug Diplomacy in the Twentieth Century (London 2000), 154.

${ }^{36}$ Ibidem.

${ }^{37}$ The PCOB Statistics were published as addenda to annual Reports to the Economic and Social Council. The statistics for a particular year appeared commonly in the Report dated one year later.
} 
Table 11.3 Manufacture of Morphine Worldwide during 1946-1960 (kg AMA)

\begin{tabular}{|c|c|c|c|c|c|c|c|c|c|c|}
\hline & Year & USA & UK & USSR & $\begin{array}{l}\text { Fed. Rep. } \\
\text { Germany }\end{array}$ & France & Hungary & Netherlands & $\begin{array}{c}\text { Other } \\
\text { Manuf. } \\
\text { Countries }\end{array}$ & $\begin{array}{l}\text { World } \\
\text { Total }\end{array}$ \\
\hline & 1946 & 19,848 & 8,493 & 3,224 & 2,644 & 3,598 & 312 & 555 & 5,125 & 43,799 \\
\hline & 1947 & 18,907 & 11,019 & 5,915 & 1,673 & 5,816 & 783 & 633 & 8,651 & 53,397 \\
\hline & 1948 & 17,326 & 7,286 & 6,794 & 4,274 & 7,375 & 2,076 & 834 & 10,283 & 56,248 \\
\hline & 1949 & 15,181 & 10,591 & 6,980 & 3,615 & 6,372 & 4,836 & 501 & 8,528 & 56,604 \\
\hline & 1950 & 19,797 & 11,054 & 10,006 & 6,375 & 5,883 & 4,522 & 470 & 7,642 & 65,749 \\
\hline \multirow[t]{7}{*}{$1946-1950$} & average & 18,212 & 9,689 & 6,584 & 3,716 & 5,809 & 2,506 & 599 & 8,046 & 55,159 \\
\hline & percent & 33 & 18 & 12 & 7 & 11 & 5 & 1 & 15 & 100 \\
\hline & 1951 & 15,963 & 14,052 & 11,206 & 5,650 & 7,849 & 6,594 & 1,040 & 10,212 & 72,566 \\
\hline & 1952 & 16,446 & 11,754 & 10,577 & 6,903 & 5,944 & 8,685 & 1,451 & 16,351 & 78,111 \\
\hline & 1953 & 18,855 & 9,913 & 9,466 & 5,635 & 6,031 & 6,289 & 2,705 & 14,923 & 73,817 \\
\hline & 1954 & 17,013 & 15,303 & 13,588 & 8,169 & 6,249 & 5,240 & 2,842 & 15,097 & 83,501 \\
\hline & 1955 & 16,858 & 16,593 & 12,671 & 9,196 & 7,032 & 6,801 & 2,557 & 17,288 & 88,996 \\
\hline \multirow[t]{7}{*}{ 1951-1955 } & average & 17,027 & 13,523 & 11,386 & 7,111 & 6,621 & 6,722 & 2,119 & 14,774 & 79,398 \\
\hline & percent & 21 & 17 & 15 & 9 & 8 & 8 & 3 & 19 & 100 \\
\hline & 1956 & 16,650 & 15,273 & 10,809 & 8,719 & 8,907 & 3,977 & 2,530 & 20,545 & 87,410 \\
\hline & 1957 & 19,232 & 18,295 & 13,229 & 11,551 & 10,004 & 8,578 & 3,778 & 24,288 & 108,955 \\
\hline & 1958 & 17,477 & 17,361 & 14,810 & 13,271 & 9,300 & 7,479 & 5,590 & 26,566 & 111,854 \\
\hline & 1959 & 16,673 & 17,057 & 17,683 & 13,248 & 8,287 & 5,436 & 5,818 & 23,798 & 108,000 \\
\hline & 1960 & 17,118 & 17,884 & 17,607 & 12,744 & 9,078 & 8,292 & 8,266 & 29,011 & 120,000 \\
\hline \multirow[t]{2}{*}{$1956-1960$} & average & 17,430 & 17,174 & 15,832 & 11,907 & 9,115 & 6,752 & 5,196 & 23,837 & 107,244 \\
\hline & percent & 16 & 16 & 15 & 11 & 8 & 6 & 5 & 22 & 100 \\
\hline
\end{tabular}

Source: PCOB Statistics on Narcotic Drugs 1946-1960, Tables III.

Note: "Other Manufacturing Countries" by period were calculated by the author as the differences between the World Totals and the sum of the quantities mentioned in the first 7 columns.

Figure 11.2 Morphine Manufacture by Country 1964-1960

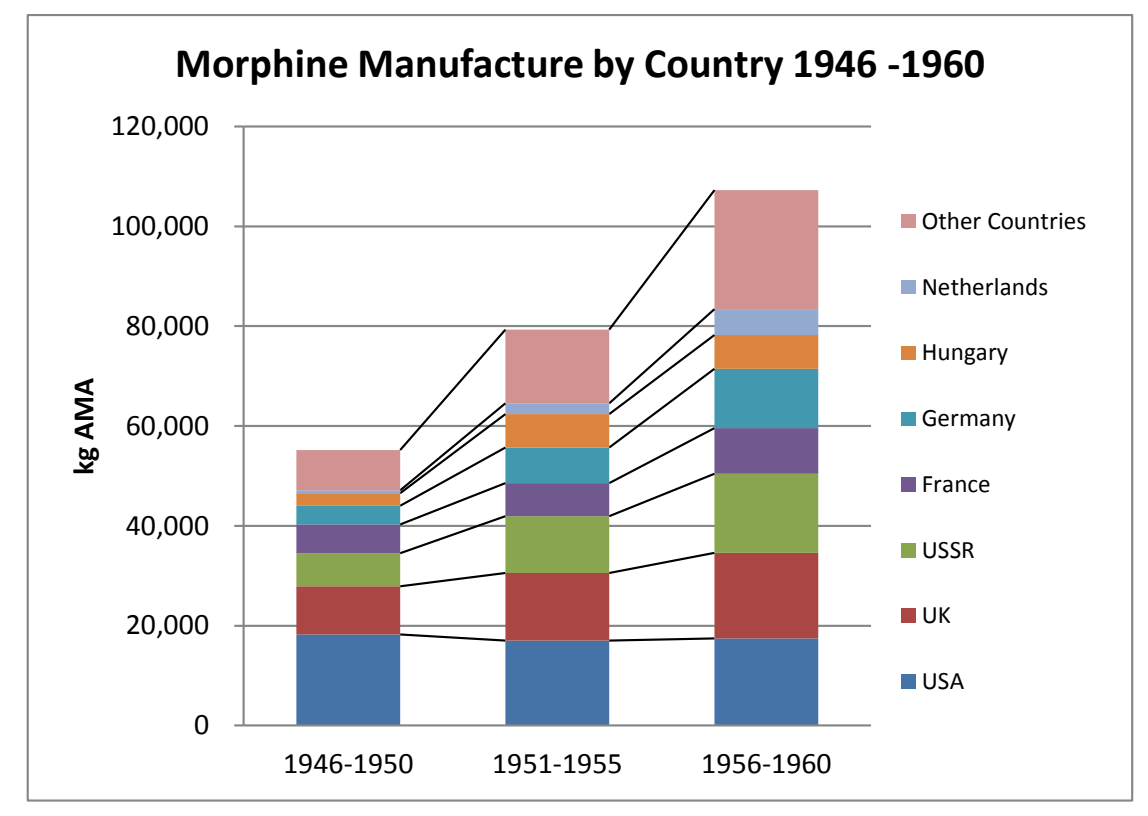

Source: Table 11.3 
The Manufacture of Morphine from Poppy Straw

Until 1930 morphine was manufactured almost exclusively from opium. That changed in the 1930s when first Hungary and later Poland and Germany began to produce morphine from poppy straw. During the years 1934-1937 3,900 kg AMA was manufactured from poppy straw representing $3 \%$ of the total of $136,000 \mathrm{~kg}$ produced. ${ }^{38}$ Statistics for the years $1939-$ 1945 are incomplete but we know that during that time quite large quantities of good quality poppy straw were processed in Germany and smaller quantities in France and in the Netherlands. ${ }^{39}$

After the end of World War II the production of morphine from poppy straw was continued or taken up in several countries spurred on by the strong price increase of opium from ca USD 5 per $\mathrm{kg}$ in the 1930s to over USD 20 per $\mathrm{kg}$ during the period 1946-1949. ${ }^{40}$ The quantities of morphine produced from opium and from poppy straw during 1946-1964 are compiled in Table 11.6.

Table 11.4 and Figure 11.3 Manufacture of Morphine Worldwide from Opium and Poppy Straw 1946-1960

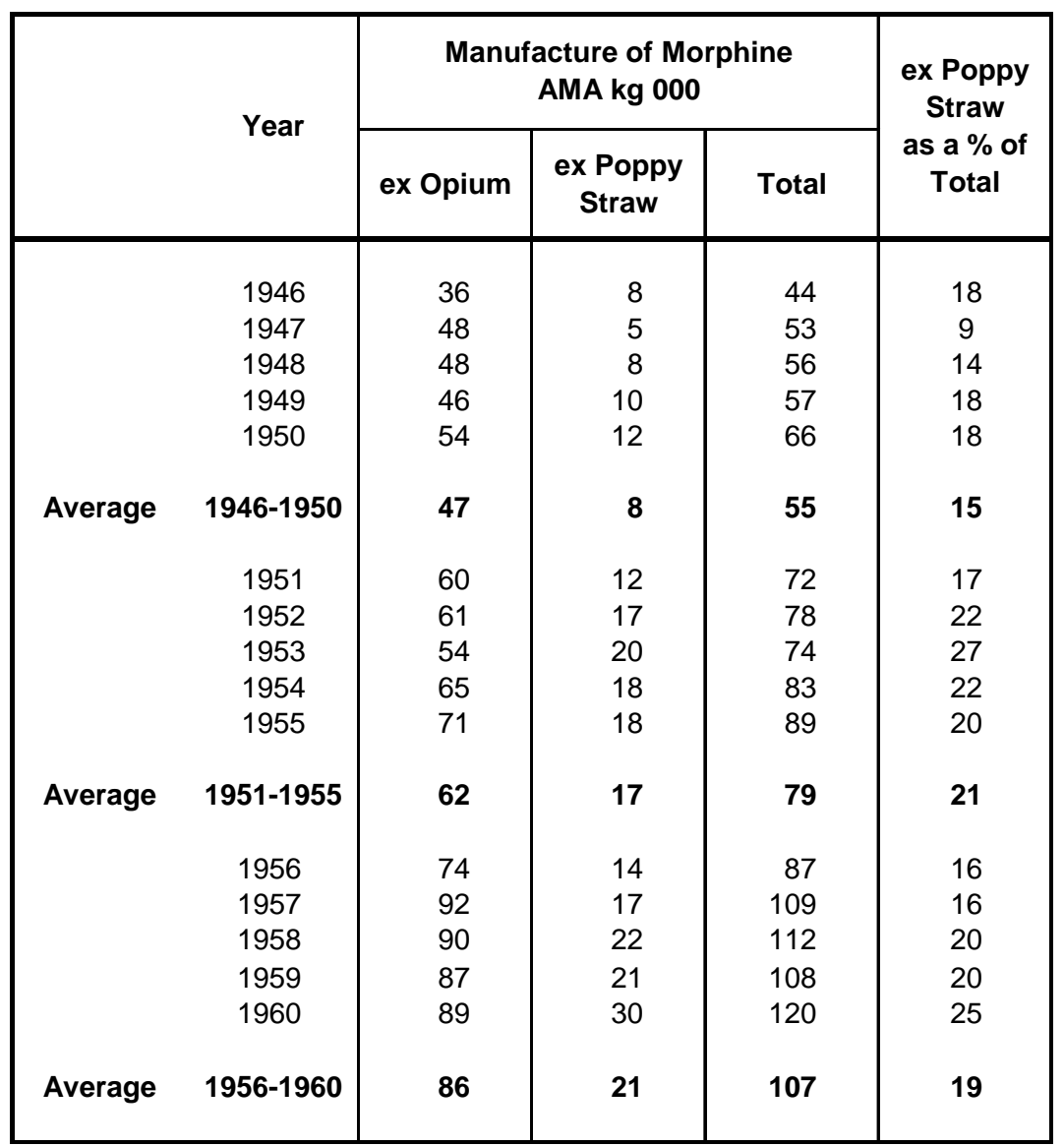

Source: PCOB Statistics 1964-1960.

The figures are rounded to the nearest $\mathrm{kg} 000$

Non-rounded totals appear in Table 11.3

\footnotetext{
${ }^{38}$ Ref. Tables 10.1 and 10.6.

${ }^{39}$ Ref. Sections 10.2 and 11.1.

${ }^{40}$ United Nations, The Movement of Opium Prices during the years 1930-1939 and 1946-1949, Commission on Narcotic Drugs - E/CN.7/AC.4/2/Add.2 (Geneva 1950).
} 
Figure 11.3

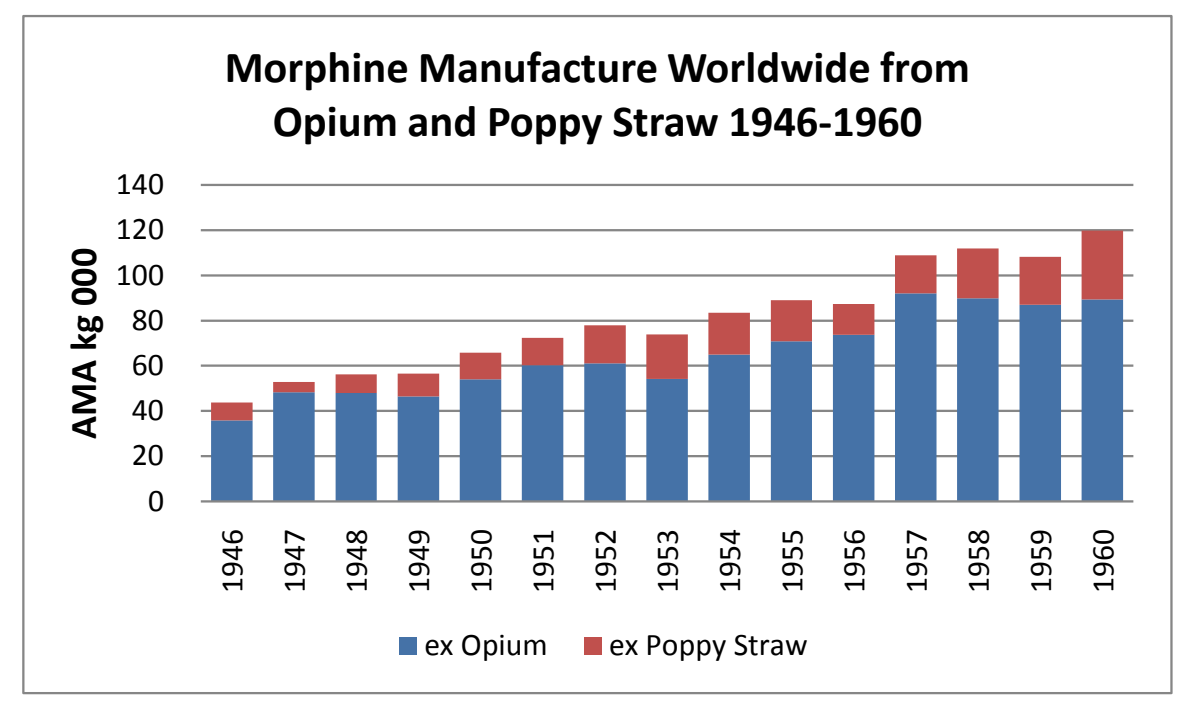

During the period 1946-1950 ca 15\% of all morphine was manufactured from poppy straw, a percentage that increased to an average ca $20 \%$ for the years 1951-1960. Producers of morphine from poppy straw during 1946-1950 were located in Germany, Hungary, France Argentina and Poland. Alkaloida in Hungary continued the operations which commenced around 1930. In Germany, Boehringer Ingelheim and Merck had been involved in the use of locally grown poppy straw for morphine already before the war and presumably these companies were also the straw processors after the war. ${ }^{41}$

From 1951 onwards more, mainly Eastern European, countries embarked on the production of morphine from poppy straw. The situation in the years 1950, 1955 and 1960 is summarised in the following table showing the quantities of morphine manufactured from poppy straw in the major producing countries and the yields achieved.

Table 11.5 Manufacture of Morphine from Poppy Straw in the major Producing Countries and Yields achieved in the Years 1950, 1955 and 1960.

\begin{tabular}{|c|c|c|c|c|c|c|c|c|c|c|c|c|}
\hline & & Germany & Hungary & France & Argentina & Poland & $\begin{array}{l}\text { Nether- } \\
\text { lands }\end{array}$ & $\begin{array}{l}\text { Czecho- } \\
\text { slovakia }\end{array}$ & DDR & Romania & USSR & Total \\
\hline 1950 & $\begin{array}{l}\text { AMA kg } \\
\text { Yield \% }\end{array}$ & $\begin{array}{r}4,619 \\
0.34\end{array}$ & $\begin{array}{r}4,522 \\
0.21\end{array}$ & $\begin{array}{r}769 \\
0.33\end{array}$ & $\begin{array}{r}500 \\
0.25\end{array}$ & $\begin{array}{l}441 \\
0.06\end{array}$ & 0 & $?$ & 0 & 0 & 0 & 10,851 \\
\hline 1955 & $\begin{array}{l}\text { AMA kg } \\
\text { Yield \% }\end{array}$ & $\begin{array}{r}3,354 \\
0.24\end{array}$ & $\begin{array}{r}4,525 \\
0.13\end{array}$ & $\begin{array}{r}1,212 \\
0.26\end{array}$ & $\begin{array}{r}1,008 \\
0.23\end{array}$ & $\begin{array}{r}2,600 \\
0.12\end{array}$ & $\begin{array}{r}2,570 \\
0.24\end{array}$ & $\begin{array}{r}1,892 \\
0.12\end{array}$ & $\begin{array}{l}994 \\
?\end{array}$ & 0 & 0 & 18,155 \\
\hline 1960 & $\begin{array}{l}\text { AMA kg } \\
\text { Yield \% }\end{array}$ & $\begin{array}{c}0 \\
\mathrm{n} / \mathrm{a}\end{array}$ & $\begin{array}{r}8,792 \\
0.15\end{array}$ & $\begin{array}{r}653 \\
0.22\end{array}$ & $\begin{array}{r}199 \\
0.16\end{array}$ & $\begin{array}{r}4,939 \\
0.14\end{array}$ & $\begin{array}{r}8,266 \\
0.23\end{array}$ & $\begin{array}{r}3,112 \\
0.10\end{array}$ & $\begin{array}{r}2,220 \\
0.13\end{array}$ & $\begin{array}{r}1,180 \\
0.21\end{array}$ & $\begin{array}{r}1,189 \\
0.15\end{array}$ & 30,550 \\
\hline
\end{tabular}

Source: PCOB Statistics for the years 1950, 1955 and 1960

Around 1955 most of the morphine produced from poppy straw was used by the manufacturers as raw material for their own codeine production. Germany changed back to opium as the raw material for economic reasons. European poppy straw was a by-product of the cultivation of the poppy plant for seed and the morphine content of the capsules was low

\footnotetext{
${ }^{41}$ Dethloff, W., Rohmaterial zur Herstellung von Morphium, seinen derivaten and Nebenalkaloiden, Manuscript ca 1957, Ingelheim, Firmen- und Familienarchiv von C.H. Boehringer Sohn. Willi Küssner, 'Poppy straw: a problem of international narcotics control', Bulletin on Narcotics, 1961[2] 1-6.
} 
and dependent on the weather during the period just before harvest. The French opiate manufacturer tried to reduce the impact of the weather on the morphine content by harvesting the capules in the unripe stage (pavot vert) but this was not a commercial success and opium remained the main raw material.

From 1957 onwards crude morphine (EPC) extracted from straw was sold to codeine manufacturers as an alternative raw material to opium. Until 1960 the forerunners of this new marketing approach were Hungary and the Netherlands. Compared to selling codeine in a very much restricted market, selling EPC had the advantage that import permits were readily available because EPC competed with opium and not with locally produced codeine. This opened up a large market for the producers provided the manufacturing cost of the EPC was low. That was the case in the Netherlands where low cost imported poppy straw was used. It was the basis for the expansion of the extraction facilities at both VPF and NCF, and the commercial successes during the years thereafter.

The manufacturing cost of the morphine depends not only on the purchase price of the poppy straw but also strongly on the alkaloid content thereof. In table 11.5 above yield figures are included. The yields in Western European countries were substantially higher than those in Eastern European countries. This was mainly the result of the morphine content of the poppy straw used as the raw material. In Eastern Europe the raw material was poppy straw that was left as a waste after the poppy crop was harvested for the seed. The poppy varieties cultivated were the ones that gave a high yield of seed of a good culinary quality and not varieties selected for high morphine content. The morphine yields in Eastern Europe were in the range of 0.10-0.20\%, while in Western European countries the yields were in the range of $0.20-0.30 \%$ as a result of more selective buying of the poppy straw i.e. mainly capsules rather than stalks, and from countries with a warmer, drier climate e.g. Yugoslavia and Turkey.

The Eastern European morphine producers were all state owned and were dependent for the poppy straw supply on the agricultural departments that were in charge of poppy seed production. ${ }^{42}$ The morphine producer and the agricultural department had usually different objectives and coordination was not easy to achieve. This resulted in erratic marketing of opiates from Eastern Europe. Longer term they were not reliable suppliers. They were spot lot sellers, who towards the end of a planning period sold the products at virtually any price. In doing so they drove the prices in the market down considerably. Profitability of the business played not really a role. What counted primarily for the morphine manufacturer was that the quantity specified in the plan was sold on time. The real economic profitability was difficult to establish anyhow because the sales were in US dollars and the costs were in local currency, the exchange rate of which was set arbitrarily by the government. ${ }^{43}$

\section{The Conversion of Morphine}

Table 11.4 shows for the period 1946-1960 the quantities of morphine which were converted into codeine, ethylmorphine and other opiates, and the quantity which remained unconverted. Until 1955 'Other opiates' represented mainly heroin, but included from 1956 onwards increasing quantities of pholcodine, the $\mathrm{O}^{3}$-morpholinoethyl ether of morphine, a potent cough depressant. ${ }^{44}$ Until 1957 almost all (synthetic) codeine was made from morphine that was isolated from opium or poppy straw by the codeine manufacturer. It was a vertically

\footnotetext{
${ }^{42}$ Poppy seed is called in Dutch "maanzaad", in German "Mohnsamen", in French "graines de l'oeillette" or "graines de pavot". An old English name is "maw seed".

${ }^{43}$ This paragraph is largely based on factual knowledge of the opiate trade acquired by the author during his employment as manager of NCF and VPF (1960-1977).

${ }^{44}$ Pholocodine was discovered by 'Les Laboratoires Dausse' and was patented in 1952. Merck Index, 11 th Ed. (1989) \#7303
} 
integrated business; there was virtually no trade in crude morphine. ${ }^{45}$ That changed. From 1957 the Statistics included quite large quantities of morphine made by extraction of poppy straw as "unconverted morphine", which were exported, mainly from Hungary and the Netherlands, to new or existing smaller codeine manufacturers who used it as the raw material for codeine.

The supply of morphine to the other opiate manufacturers was either in the form of a crude solid extract, containing 50-60\% AMA, called "Extractum Papaveris Crudum" (EPC), or in the form of Technical Morphine (TM), containing 85-90\% AMA suitable for direct conversion into codeine. ${ }^{46}$

Table 11.6 Conversion of Morphine and Manufacture of Codeine Worlwide1946-1960 (kg AMA except for the last column)

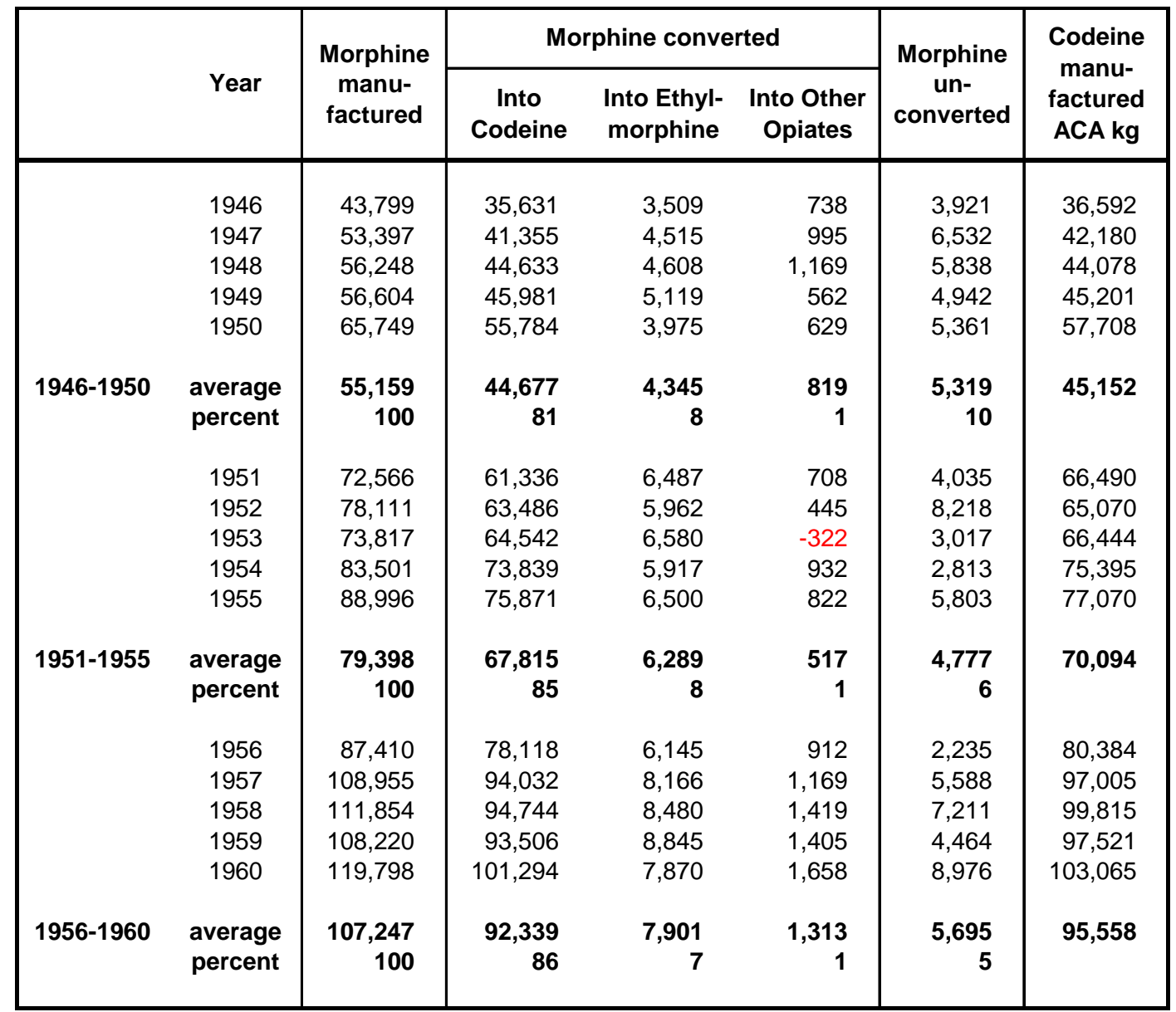

Source: PCOB Statistics on Narcotic Drugs 1946-1960.

Note: the values for "Morphine converted into Other Opiates" and the averages by period were calculated by the author.

Statistics of codeine produced by the major manufacturing countries and in the Netherlands during the years 1946-1960 are compiled from the PCOB statistics and appear in Table OPI 6

\footnotetext{
${ }^{45}$ In table 11.4, the column "morphine unconverted" represents until 1957 mainly the amount morphine used for the manufacture of pure morphine and salts for medicinal use.

${ }^{46}$ EPC was under the name of "Concentrate of Poppy Straw" (CPS) included as a controlled substance in Schedule 1 of the 1961 Single Convention of Narcotic Drugs.
} 
(Part IV). The six largest codeine manufacturing countries are the same as the six largest morphine manufacturing countries. The world totals are included in Table 11.6, above.

\section{Export of Codeine}

In the following Table 11.7 the differences between codeine manufactures and codeine consumed are calculated for the six major manufacturing countries and for the Netherlands, for the years 1950, 1955 and 1960. These differences are ballpark estimates of the quantities exported from these countries. ${ }^{47}$

Table 11.7 Manufacture and Consumption of Codeine in the major Manufacturing Countries and in the Netherlands for the years 1950, 1955 and 1960 (ACA kg 000)

\begin{tabular}{|c|c|c|c|c|c|c|c|c|}
\hline Year & & USA & UK & USSR & France & $\begin{array}{l}\text { Fed. Rep. } \\
\text { Germany }\end{array}$ & Hungary & Netherlands \\
\hline \multirow{3}{*}{1950} & Manufacture & 17.9 & 11.3 & 8.1 & 5.5 & 4.6 & 4.1 & 0.5 \\
\hline & Consumption & 16.6 & 5.8 & 7.9 & 4.3 & 2.2 & 1.1 & 0.4 \\
\hline & Manuf. - Cons. & 1.3 & 5.5 & 0.2 & 1.2 & 2.4 & 3.0 & 0.1 \\
\hline \multirow[t]{3}{*}{1955} & Manufacture & 15.8 & 17.6 & 10.0 & 5.8 & 8.1 & 4.2 & 1.6 \\
\hline & Consumption & 16.7 & 10.7 & 12.0 & 5.4 & 4.2 & 1.4 & 1.0 \\
\hline & Manuf. - Cons. & -0.9 & 6.9 & -2.0 & 0.4 & 3.9 & 2.8 & 0.6 \\
\hline \multirow[t]{3}{*}{1960} & Manufacture & 17.0 & 19.9 & 14.2 & 7.7 & 10.8 & 6.3 & 3.8 \\
\hline & Consumption & 19.1 & 9.9 & 17.3 & 6.6 & 5.3 & 1.4 & 1.4 \\
\hline & Manuf. - Cons. & -2.1 & 10.0 & -3.1 & 1.1 & 5.5 & 4.9 & 2.4 \\
\hline
\end{tabular}

Source: PCOB Statistics for manufacture and the 1980 INCB Report for consumption. ${ }^{48}$

The differences show that the USA and the USSR were not active on the export market and that the UK was the major codeine exporting country for all three years. Germany and Hungary were about equal in size as codeine exporters, France exported modest quantities and the Netherlands came up strongly in 1960.

The export market for codeine had some unusual characteristics which still prevail today. Opiates are internationally controlled substances and as a result the trade in opiates is subject to restrictions and that has a profound effect on the structure of the market. Codeine is commercially the most important opiate. Worldwide, the demand for codeine is determined by the requirements for medical purposes. There is, however, not a single world market for codeine encompassing all countries. As outlined in Chapter 10, in countries where an opiate manufacturer is located, import permits are commonly not issued and the market is thereby closed for competition from manufacturers residing in other countries. In most countries with a large demand one or more manufacturers operate. In smaller countries local manufacturers may or may not be present. Countries without local manufacture satisfy their demand by importation. The total requirements of these countries without local manufacture constitute

\footnotetext{
${ }^{47}$ The differences include quantities of dihydrocodeine made from codeine and as a result exports of codeine are biased. The actual exports are somewhat lower than suggested.

${ }^{48}$ INCB, Demand and Supply of Opiates for Medical and Scientific Needs, United Nations, New York (1981) E/INCB/52/Supp.
} 
the open world market. Prices in the closed markets are usually higher than in the open world market.

For any manufacturer the accessible market consists of its home market plus the open world market. Manufacturers based in large countries are in a better position to compete in the open market than those located in smaller countries. Because of their large home market they have, even without export sales, a lower cost compared to manufacturers operating from a smaller home base. Together with the high home market price, the large production volume enables them to absorb all fixed costs on the home market sales and to offer additional quantities in the open market at low prices whenever it suits them. Manufacturers from smaller countries have less room to manoeuvre, their home market is usually too small to absorb all fixed cost on local sales, and they have to sell a minimum quantity in the open market at a reasonable price to remain viable.

\subsection{Opiate Manufacture in the Netherlands and Trade 1946-1965}

\section{Morphine and Codeine Manufactured, Converted, Consumed and Exported}

Exact quantitative information on production and sales of opiates by NCF and Bonnema/VPF individually is hardly available for the period 1946-1964. What is available, however, are the very detailed PCOB Statistics on the total manufacture opiates in the Netherlands i.e. the sum of the manufacture by NCF and Bonnema/VPF. The PCOB Statistics are used in conjunction with other information to describe the opiate industry in the Netherlands and, to the extent possible, the individual companies involved. From 1965 onwards the PCOB/INCB data represent VPF, the then only manufacturer of opiates in the Netherlands.

For morphine and codeine information on manufacture, conversions, consumption and export is compiled for the years 1946-1965 in Table 11.8; 5 year averages are calculated. 
Table 11.8 Morphine and Codeine

Manufacture, Conversion, Consumption and Export - the Netherlands 1946-1965

\begin{tabular}{|c|c|c|c|c|c|c|c|c|c|}
\hline 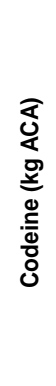 & 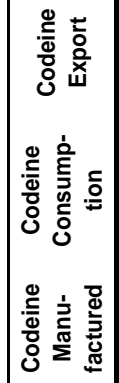 & 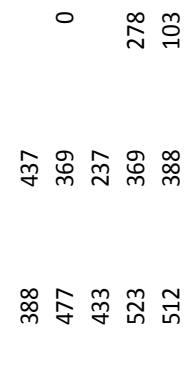 & $\hat{q}$ & 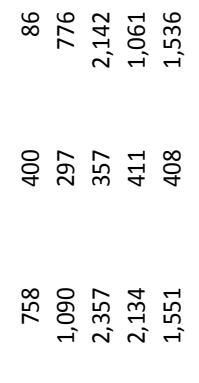 & $\stackrel{7}{\pi}$ & 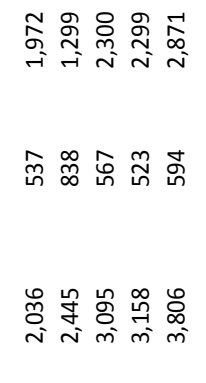 & $\frac{q}{i}$ & 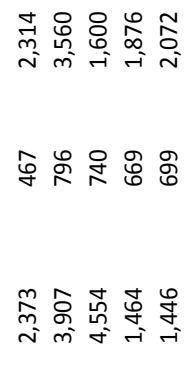 & 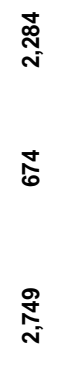 \\
\hline \multirow{5}{*}{ 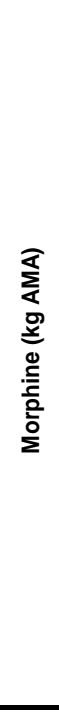 } & 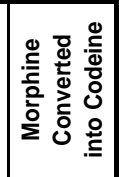 & 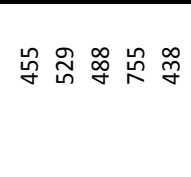 & 氾 & 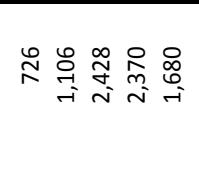 & $\stackrel{\Xi}{:}$ & 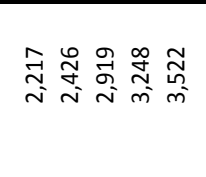 & 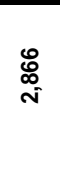 & 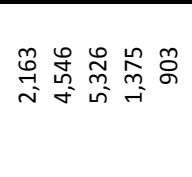 & 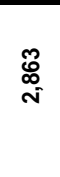 \\
\hline & 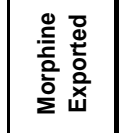 & $+\quad \overbrace{}^{\infty}$ & 우 & $ナ \stackrel{\sim}{\sim} \underset{\sim}{\stackrel{D}{\infty}}$ & $\stackrel{\Phi}{\stackrel{\infty}{ }}$ & 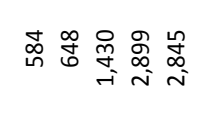 & $\stackrel{\Phi}{\stackrel{\circ}{\circ}}$ & 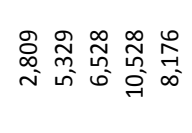 & $\underset{0}{\mathbb{T}}$ \\
\hline & 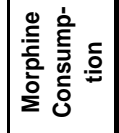 & 吕 & $\stackrel{\circ}{\sim}$ & $\ddot{0} \infty$ & ஜ & $\vec{b}$ 出闹 $\vec{F}$ 出 & in & $\stackrel{d}{\sim} \vec{m} \hat{m} \stackrel{n}{n}$ & $\bar{m}$ \\
\hline & 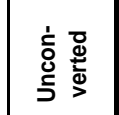 & $\infty \infty \infty_{\infty}^{\infty} \circ 0$ & 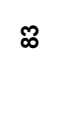 & 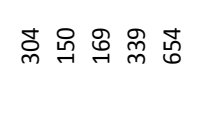 & ల్ల & 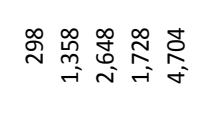 & $\frac{\mathfrak{v}}{i}$ & 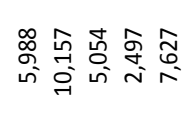 & 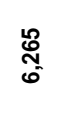 \\
\hline & 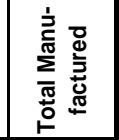 & 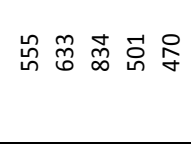 & 思 & 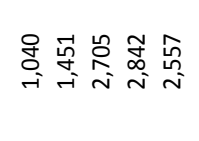 & $\stackrel{0}{i}$ & 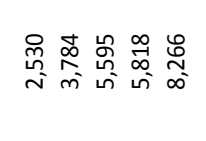 & $\frac{8}{i 5}$ & 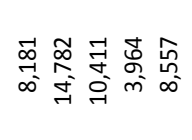 & $\frac{8}{5}$ \\
\hline \multirow{3}{*}{$\begin{array}{l}3 \\
\frac{3}{50} \\
\text { के } \\
\text { o. } \\
0 \\
0\end{array}$} & 迨 & 궁 $\stackrel{9}{9} \stackrel{0}{0} \stackrel{0}{0}$ & $\frac{9}{0}$ & 承苾 & స్త & 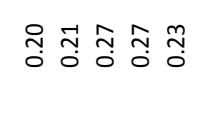 & Ĩ্ & 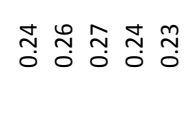 & $\stackrel{\text { ม્ఝ }}{0}$ \\
\hline & 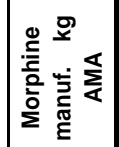 & $\underset{\gamma}{m} \stackrel{\sim}{\sim} \vec{\sim}$ & in & 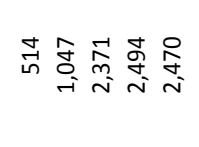 & $\stackrel{R}{F}$ & 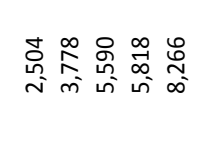 & $\frac{5}{i s}$ & 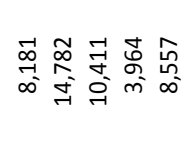 & $\frac{8}{0}$ \\
\hline & 疋 & $\stackrel{\sim}{\sim} \circ \stackrel{\infty}{0} \underset{\sim}{m} 0$ & ล & 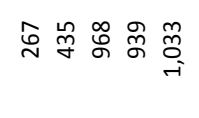 & $\stackrel{\infty}{\sim}$ & 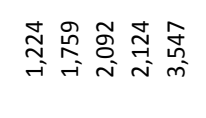 & $\frac{g}{i}$ & 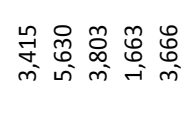 & $\underset{\substack{0 \\
\infty}}{\mathscr{N}}$ \\
\hline \multirow[t]{2}{*}{$\Xi$} & 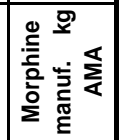 & 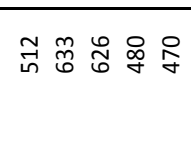 & 胥 & 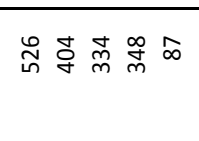 & 足 & $\stackrel{N}{\infty} 0$ in 0 & $r$ & 00000 & 0 \\
\hline & 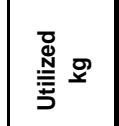 & 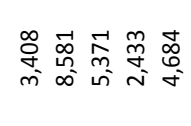 & 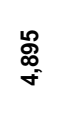 & 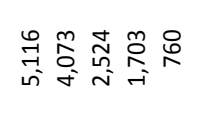 & 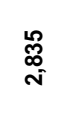 & $\underset{d}{d} \circ \infty$ & $\Xi$ & 00000 & o \\
\hline & $\stackrel{\text { ॠ }}{\succ}$ & 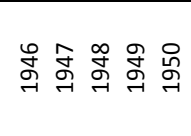 & 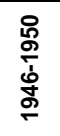 & 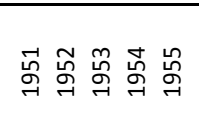 & 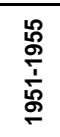 & 员恕骂品品 & $\begin{array}{l}\stackrel{\circ}{\circ} \\
\stackrel{\circ}{0} \\
\stackrel{0}{\circ}\end{array}$ & 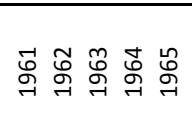 & 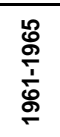 \\
\hline & & & 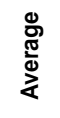 & & 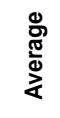 & & 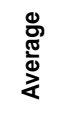 & & 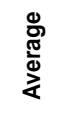 \\
\hline
\end{tabular}

Source: PCOB Statistics 1946-1960 
Figure 11.4-11.6 Charts of Morphine and Codeine Manufacture, Conversion, Export and Consumption - The Netherlands 1946-1965

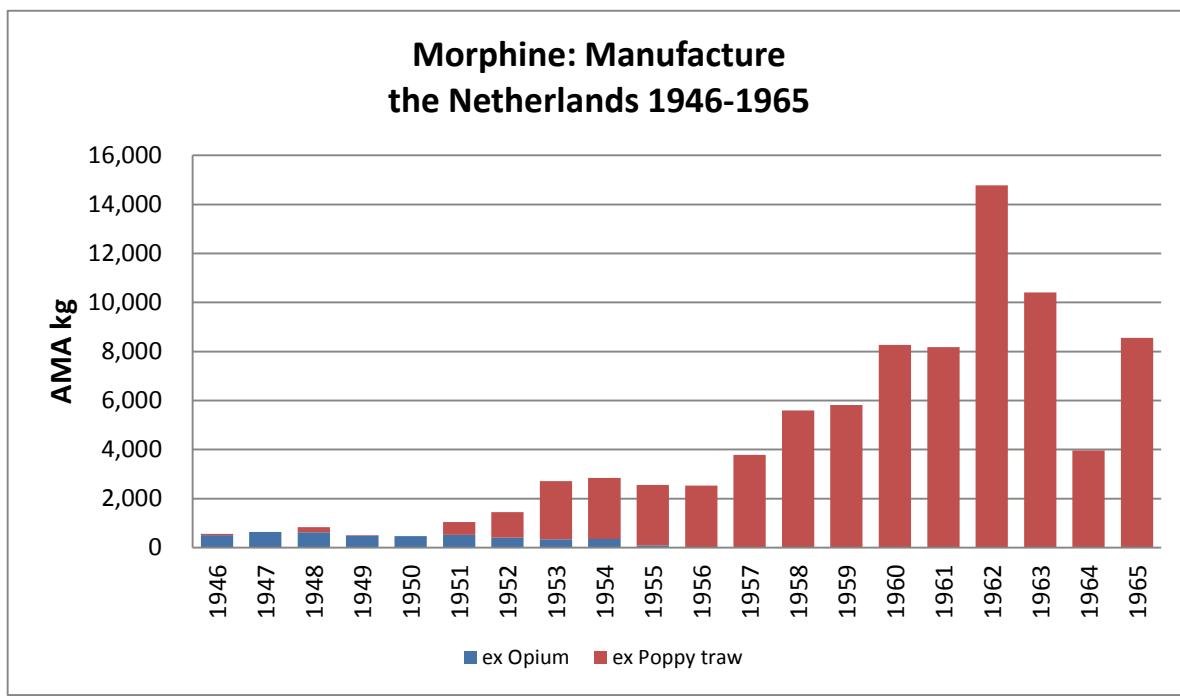

Figure 11.4

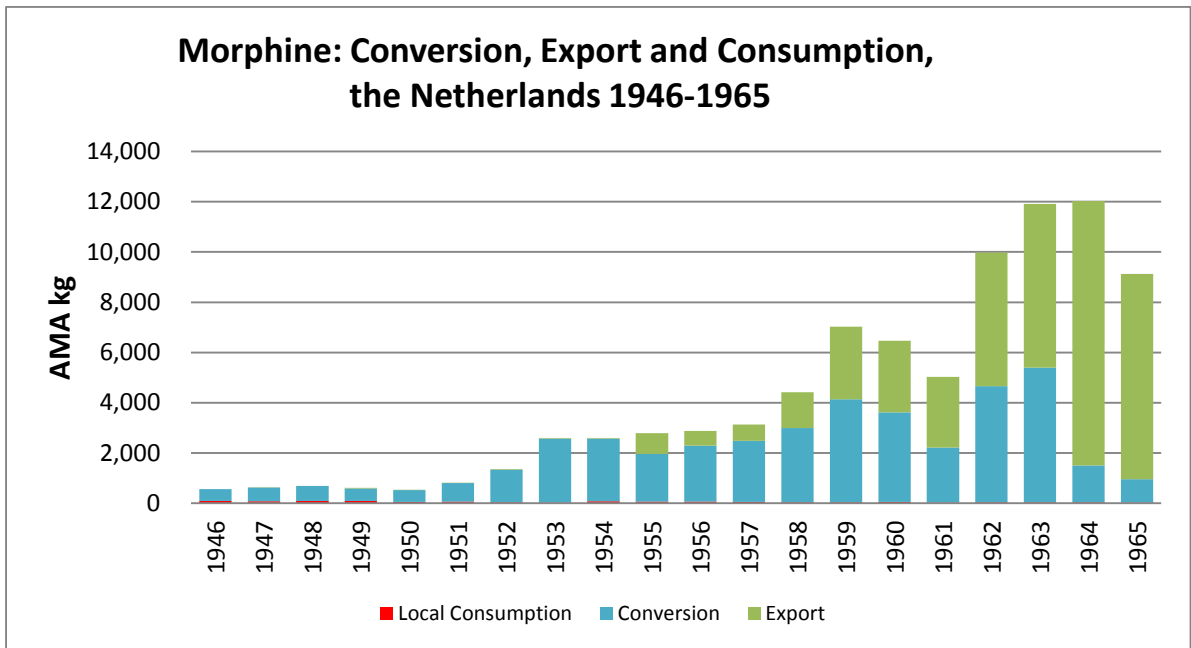

Figure 11.5

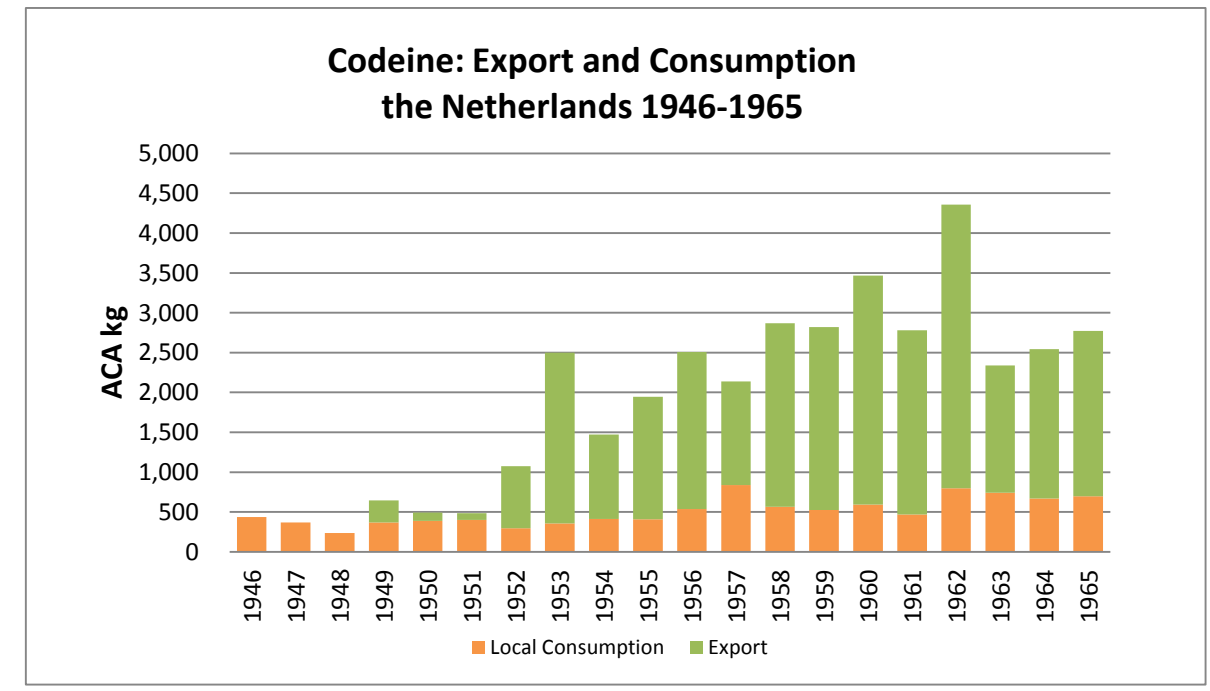

Figure 11.6

Source: Table 11.8 
Table 11.8 and graphs 11.4-11.6 show that the opiate industry in the Netherlands had a slow start after the War, reaching the 1937-1938 level of morphine output not before 1951. During 1946-1950 90\% of the morphine was made from opium and sales of codeine and morphine were mainly domestic.

That changed rapidly over the next period; from 1951 to 1955 morphine production increased by a factor five, and in 1955 only 3\% was made from opium. About $80 \%$ of the morphine produced was converted into codeine which was from 1953 largely sold in the export market.

The market in which NCF and Bonnema /VPF initially operated was the market for pure opiates, principally codeine. From the mid-1950s onwards, after the companies began to produce morphine from poppy straw, that morphine was not only used as the raw material for the pure opiates manufactured, but was also sold to other opiate manufacturers as an alternative to opium as a raw material.

During 1959-1965 all morphine was made from poppy straw at an average production level of $8.6 \mathrm{t}$ AMA p.a., more than twice the level of the five years earlier period; $5.6 \mathrm{t}$ of the 8.6 t AMA was exported as EPC/TM. The quantity of morphine converted into codeine also increased greatly compared to the previous period. Not all morphine produced was sold, however, and stocks of EPC were substantial at the end of 1960.

For the sub-period 1946-1950, when opium was the main raw material, it is known for 1947 that NCF sold opiates equivalent to $352 \mathrm{~kg}$ AMA which is $55 \%$ of the total quantity of $633 \mathrm{~kg}$ AMA produced during the year. These figures suggest that NCF and VPF produced about equal quantities of morphine during the period.

For later sub-periods the capacity of the extractors is used as the yardstick for estimating morphine production. In 1953, VPF's capacity for extraction of poppy straw was reported to be 1,000 t p.a. and NCF's capacity is estimated by the author to be in the order of 480 t p.a. at that time. ${ }^{49}$ In 1957 VPF had two Desmet extractors operational, with a capacity 1,000 t p.a. each and NCF had just expanded its extraction facilities presumably thereby increasing the capacity to ca 1,000 t p.a. ${ }^{50}$ In 1960 VPF installed a large Lurgi extractor with a capacity in the order of 5,000 t p.a. ${ }^{51}$ On this basis it is estimated that from 1950 to 1959 VPF produced on the order of two-thirds, and from 1960 onwards about $80 \%$ of the total quantity of morphine manufactured in the Netherlands.

\section{Morphine Production from Poppy Straw (NCF and Bonnema)}

After the War the opium price remained high and both NCF and Bonnema were interested to explore the commercial viability of using locally produced poppy straw as the raw material for the manufacture of morphine. Both companies had gained experience in extracting morphine from this raw material collected by a government department and supplied to them during the period 1943-1945. That experience had been favourable, yields in the order of $0.2 \%$ had been achieved and cost calculations had shown that the crude morphine produced was competitive with opium at the then current price. Uncertainties affecting the future viability of using locally produced poppy capsules as raw material were: the morphine content as a function of the weather during the growing season, the cost of collecting sufficient quantities of poppy capsules, and the future opium price.

\footnotetext{
${ }^{49}$ VPF: Letter Dr Roozendaal to the Minister for Health dated 11 February 1953, National Archief. The Hague, Access No 2.15.39 Item 72. NCF: Double capacity of 1946, Minutes Board Meeting of 24 July 1946.

${ }^{50}$ Extractors A and B are mentioned in the article 'Bolkaf-extractie definitief historie', Akzo News, February 1992. Further information is recollections by the author.

${ }^{51}$ The large Lurgi extractor is extractor $\mathrm{C}$ mentioned in the previous reference.
} 
Poppy capsules were a discarded by-product of cultivating the opium poppy (Papaver somniferum) for the purpose of the seed. It was a matter of sufficient financial remuneration to make collecting the capsules attractive for the farmer. The farmer had to modify the harvesting and threshing operations in such a way that the capsules were largely free of stems and leaves and that the product was kept as dry as possible to limit invasion by moulds. In 1947 Bonnema made arrangements with contractors in the provinces of Zeeland and Groningen to act on Bonnema's behalf by distributing the bags in which the product had to be stored to the farmers, and collecting the bags from the farm after the harvest. Bonnema distributed pamphlets among farmers with detailed instructions on how to optimize the threshing operation and offered a price of NLG 12.00 per $100 \mathrm{~kg}$ capsules, collected. ${ }^{52}$ The total cost for the government department to obtain the capsules in 1943-1944 and to supply them to the processors had been NLG 71.46 per $100 \mathrm{~kg}$ capsules. ${ }^{53}$

As a result of unfavourable weather conditions, experiences at NCF with collecting poppy straw were not good in 1946 and $1947 ; 1946$ was qualified as too wet and 1947 as too dry. ${ }^{54}$ How much straw was collected in 1947 is not known, but no straw was extracted in the Netherlands in that year. In 1948 there was apparently strong competition between NCF and VPF for buying the straw. VPF's buying tactics were qualified by NCF as "inelegant, to say the least". ${ }^{55}$ In 1948108 t of poppy straw was extracted in the Netherlands, in 1949 and 1950 hardly any.

Specialised harvesters were required to achieve an adequate separation of the capsules from the stems. NCF attempted to develop such equipment in collaboration with a consultant. ${ }^{56}$ No immediate success was forthcoming but NCF persisted with the approach, ordered a prototype harvester in 1950 and committed NLG 5,000 in 1951 for evaluation. No information is available on practical experiences with the harvester but two patents were granted to NCF on the separation of seed capsules and stems of Papaveraceae (inventor Hans Brunner, chief engineer at NCF). ${ }^{57}$

The question of the alkaloid content of ripe seed capsules of $P$. somniferum varieties cultivated in the Netherlands was jointly studied by Reith and Indemans (University of Utrecht) and Becker (Agricultural Research Institute, Wageningen) during the years 1946, 1947 and 1948. These studies were supported financially by the national research institute TNO, and by NCF and Bonnema. The results were published one year later. ${ }^{58}$

Assays of capsules arising from seed of different provenance showed that the morphine content of the varieties developed in the Netherlands was on average about the same as that of the varieties originating from other countries, and that the Dutch variety "Noordster" gave the best results.

In a separate trial the morphine content of individual capsules of promising varieties harvested in 1946 was determined; there was a great variation in the morphine content and the seed of capsules with high morphine content was sown in 1947. The resulting capsules were analysed and the average morphine content was high; it did not fall back to the 1946

\footnotetext{
52 Pamphlets: "Verzamelt het Bolkaf van Blauwmaanzaad, Het Heeft Waarde", and "[Aanwijzingen voor] de Dorsmachinist", Bonnema, MK 7-8/'47, 5493 and 5541.

${ }^{53}$ Ref. Table 11.1: NLG 174,028/243.92 = 713.46 NLG/t.

${ }^{54} \mathrm{NCF}$, Minutes of Board Meetings, Meeting of 22 December 1947.

${ }^{55}$ Ibidem, Meeting of 21 June 1948.

${ }^{56}$ Ibidem. Meeting of 21 May 1951.

${ }^{57}$ German Patent 931,862 dated 18 .08.1955 (priority from 12.07.1952 -the Netherlands) and French Patent 1,091,702 dated 14.04.1944 (priority from 26.07.1952- the Netherlands).

58 J.F. Reith, A.W.M. Indemans and W.R. Becker, Pharmaceutisch Weekblad 82 (1947) 581-591, 83 (1948) 449-459 and 84 (1949) 669-675.
} 
average. In other words morphine content was heritable. The researchers concluded that the results indicated a good potential for breeding of poppy varieties with high morphine content.

The morphine content of the capsules harvested in 1948 was, however, much lower than of those harvested in 1947. The authors attributed that to the unfavourable weather in the Netherlands in 1948 resulting in leaching of the morphine out of the capsules by rain, an effect especially pronounced for varieties with high morphine content. The morphine content of the selection from the variety Noordster, although still higher than that of 1946, was in 1948 lower than in 1947.

As a part of the research, poppy seed from crossbred varieties was tested for taste, flavour and colour by of a panel of reputable poppy seed exporters. The conclusion was that the quality of the seed was inferior to typical Dutch poppy seed valued by the customers.

The overall 1949 conclusion of Reith c.s. was that the opiate manufacturers would have to be satisfied with the existing local poppy varieties because cross breeding with other varieties was unlikely to result in a new variety with both high morphine content and poppy seed of a quality acceptable to the customers.

Because of unfavourable experiences with the collection of poppy straw during 19461950, the difficulties with the development of harvesters and the limited potential for breeding poppy varieties with high morphine content NCF and VPF did not succeed in basing the morphine production on the use of locally produced poppy straw..

In the early 1950s VPF began to import lanced poppy capsules from Turkey where it established a company, "Unipharm", for buying the capsules and shipping them to the Netherlands. ${ }^{59}$ Traditionally, poppies cultivated in Turkey were lanced (incised) for the production of opium when unripe and harvested for seed when mature. After the harvest the broken lanced capsules remained on the fields and were burned. The morphine content of this waste material was still considerable and as a result of the high opium price the lanced capsules obtained commercial value after World War II because extracting morphine from them had become economical. VPF was one of the first to recognise this.

$\mathrm{NCF}$ acted in a similar way to VPF and commenced importing lanced poppy capsules from Yugoslavia which were transported by rail to Amsterdam. ${ }^{60}$ The PCOB statistics show that from 1955 onwards, in the Netherlands virtually all morphine was manufactured from poppy straw, achieving an average yield of $0.24 \%$ (Table 11.8) which proved that the strategy of using imported poppy straw as the raw material had been the right one.

\section{Other opiates}

Morphine and codeine were the most important opiates manufactured by NCF and VPF, with ethylmorphine at an average production of $110 \mathrm{~kg}$ p.a. during 1946-1960 occupying the third place. A few semi-synthetic derivatives with a morphinan-structure with a smaller sales volume were also of interest because of the relatively high price. These products were mainly derivatives of thebaine, developed in Germany between 1917 and 1923, and having the following chemical structures:

\footnotetext{
${ }^{59}$ Oral history as told to the author in 1960.

${ }^{60}$ Ibidem.
} 
Figure 11.7 Some Pharmaceutically Important Semi-synthetic Morphinans<smiles></smiles>

Dihydrocodeinone Mannich (1920) Dicodid (Knoll 1923) Hydrocodone<smiles>CN1CC[C@]23c4c(ccc(O)c4C2CCC(=O)O)CC3CN1C</smiles>

Dihydromorphinone Dilaudid (Knoll 1926) Hydromorphone

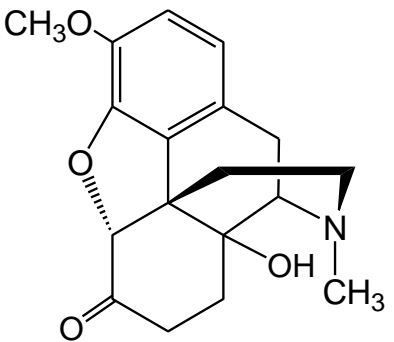

14-Hydroxydihydrocodeinone Freund and Speyer (1916) Eukodal (Merck 1917) Oxycodone

PCOB statistics for these compounds show an average annual production in the Netherlands of $40 \mathrm{~kg}$ hydrocodone, $4 \mathrm{~kg}$ of hydromorphone and $3 \mathrm{~kg}$ oxycodone over the period 19461960. Bonnema and NCF agreed on a 2:1 split of the local market for these products, an indication that Bonnema had taken the lead. NCF sold them as "branded" products under names of cofacodone, cofacodid and cofacodal respectively. ${ }^{61}$

\subsection{The NCF during the Period 1946-1962}

The Organisation until 1960

The period from 1946 to 1950 was characterised by a slow rebuilding of the business. Major organisational changes for the NCF included the retirement of the Technical Director Dr. G.H. Kramers in 1946. The Board found a successor in Ir. J.P.H. Nieukerke, a manager at the Amsterdamsche Chinine Fabriek (Amsterdam Quinine Factory). Nieukerke attended an NCF board meeting for the first time on 24 July $1946 .{ }^{62}$ Kramers continued his involvement in the company as a consultant. ${ }^{63}$

\footnotetext{
${ }^{61} \mathrm{NCF}$, Minutes of Board Meetings, Meeting of 30 June 1947. NCF also used the names Cophedrine (for ephedrine) and Cofapon (for Opium concentratum = Pantopon) .

${ }^{62} \mathrm{NCF}$, Minutes of Board Meetings, Meeting of 24 July 1946.

${ }^{63}$ Ibidem.
} 


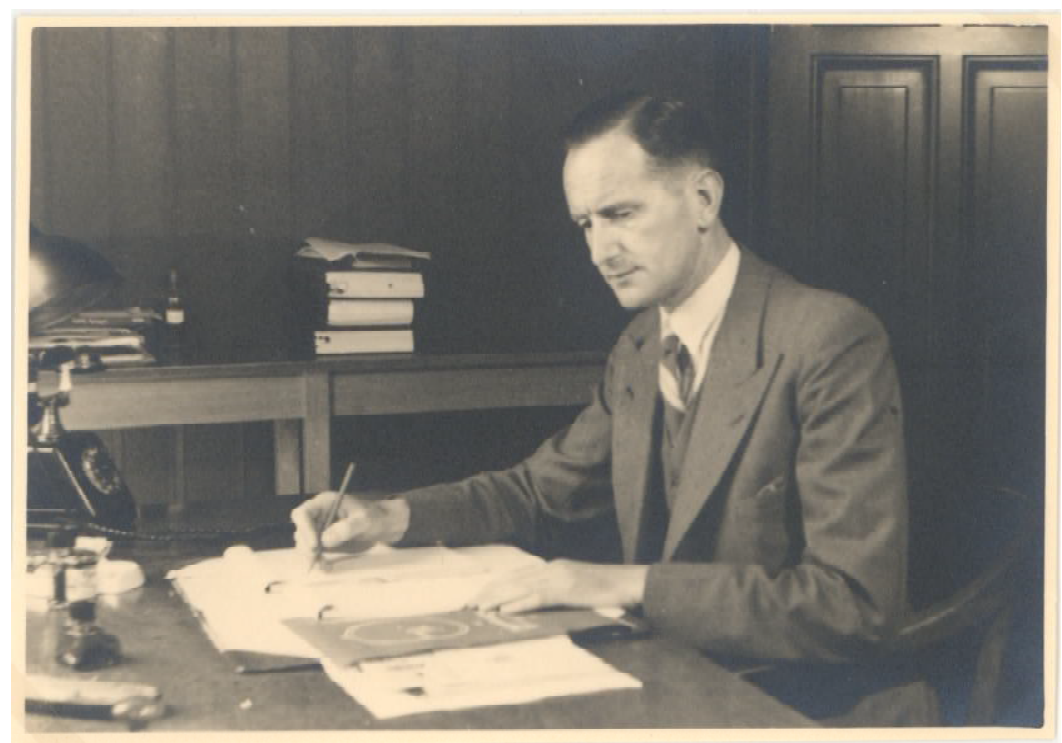

Figure 11.8 Ir. J.P.H. Nieukerke, Technical Director NCF 1946-1964 Managing Director VPF 1964-1975 (Photo: 'NCF 1900-1950', IISH Amsterdam)

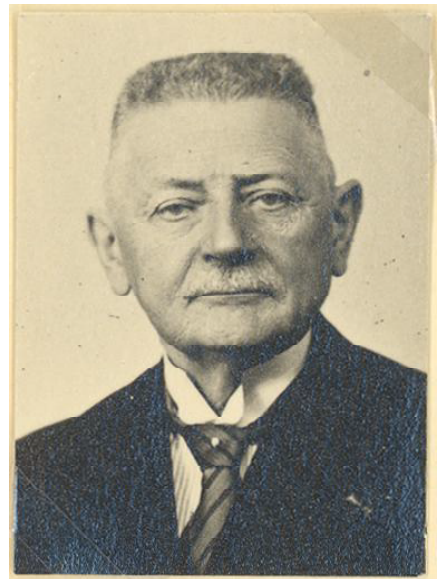

Figure 11.9 Mr W.C. Bonebakker, Chairman of the NCF Board 1931-1946 (Photo: 'NCF 1900-1950', IISH Amsterdam)

As well in 1946 W.C. Bonebakker, chairman of the NCF Board, reached the age of 80 and decided to retire after many years of service both with the Koloniale Bank and the NCF. He was succeeded as Chairman of the Board by P. Leendertz, also from the Koloniale Bank. ${ }^{64}$ Mr Leendertz stayed on the Board for only one year; he was succeeded as president by Ch. N.W. Veenstra and as board member by G.Warning. ${ }^{65}$

Nineteen forty six also saw the sudden passing of Miss L. Maarschalk, NCF's majority shareholder. She bequeathed her NCF shares to Ir. H.L.B. (Harry) Dénis, who took a seat on the Board of Directors. ${ }^{66}$ Dénis took a much more active personal interest in the operation of the company than had Miss Maarschalk. He requested in writing that an auditor, to be nominated by him, draw up a report on the annual accounts of 1946 and of the functioning of

\footnotetext{
${ }^{64} \mathrm{NCF}$, Minutes of Board Meetings, Meeting of 24 July 1946

${ }^{65}$ Ibidem, Meetings of 30 June and 22 December1947.

${ }^{66}$ Henri Léonard Barthélémi (Harry) Dénis (1896-1971) was a civil engineer (TH Delft) and a famous Dutch soccer player who, during the period 1919-1930 played in the national team, most of the time as its captain. Huygens Instituut voor Nederlandsche Geschiedenis, www.inghist.nl.
} 
the company in general. The other Board members, led by the representatives of the Koloniale Bank, the managing partner of the NCF, did not agree to the request in its original form; but a report on the 1946 accounts only, by an auditor to be nominated by the Board, was acceptable. ${ }^{67}$ Dénis' attitude resulted in considerable tensions between him and other Board members. In subsequent Board meetings he coined ideas to reduce costs and stocks and proposed the buying of opium in small lots to reduce price risk and interest burden. Nieukerke and Kramers opposed this view because of the long lead times from buying the opium to having the finished products available for the customer. Many sales opportunities would be lost, in their opinion. During later Board meetings Dénis came back to his subject of a broad audit by an outside financial advisor to identify cost savings and to recommend other changes where appropriate. ${ }^{68}$ This was also not immediately accepted by the other Board members. Much time was spent during many Board meetings in 1947-1950 on the subject. Ultimately there was agreement on a watered down version of the audit; the actual audit was, however, leading to further conflicts within the Board. ${ }^{69}$

The available Minutes of the Board Meetings of the NCF do not go further than the 1951 meetings but how the relationship between Dénis and the other Board members developed thereafter is known from Minutes of the Board Meetings of the Cultuurbank (formerly the Koloniale Bank). ${ }^{70}$ In 1954 Dénis became dissatisfied with organisational structure of the NCF, specifically with the Cultuurbank as a Board member. Dénis proposed a recapitalisation of the NCF to suit his position as a tax payer. ${ }^{71}$

Meanwhile, in 1954 the NCF acquired all the shares of N.V. Folia, a company involved in the extraction and distillation of oils from seeds, such as caraway seed, with a factory at Oostermeer. Ir. Nieukerke was appointed as managing director, the Cultuurbank, Ir. Dénis and Mr. Lagerhorst became Board members. ${ }^{72}$

Early in 1956 management of the NCF presented a plan for doubling the capacity of the poppy straw extraction facility to the Board. It was intended that the additional production would be sold entirely in the export market. The projected standard cost of the morphine was sufficiently low to make this a realistic proposition. The capital requirements were estimated at NLG 400,000, of which NLG 136,000 for investments in the factory and NLG 364,000 for working capital. The Cultuurbank discussed the project with Dénis, who was in favour. Dénis intended to finance the project by means of a loan. The Cultuurbank was in agreement provided that its position as managing partner was guaranteed during the time the loan was outstanding. ${ }^{73}$

Obtaining a loan to finance the project turned out to be not a simple matter. Dénis had discussions with the Nationale Levensverzekerings Bank but without immediate success. Dénis would have liked to reduce the amount of the loan by forgoing the dividend over 1955 .

\footnotetext{
${ }^{67}$ NCF, Minutes of Board Meetings, Meeting of 30 June 1947.

${ }^{68}$ Ibidem, Meeting of 1 June 1948.

${ }^{69}$ Ibidem, Meeting of 27 June 1949.

${ }^{70}$ In 1949 the name of the Koloniale Bank N.V. was changed into Cultuur- Handel- en Industrie-Bank (Cultuurbank) N.V. This name change appears to have been a formality only. Remarkably, in a review of the history of the Cultuurbank written at the occasion of its 75 year jubilee in 1956, the name of the Koloniale Bank is not mentioned at all.( Cultuurbank N.V. 'Kort Historisch Overzicht' dated 22 March 1956. Nationaal Archief, The Hague, Accesss No 2.20.05 Item 108).

${ }^{71}$ Minutes of Board Meetings of the Cultuurbank. Meetings of 19 February 1954 and 20 April 1954. Nationaal Archief, The Hague, Access No 2.20.04 Item 27.

${ }^{72}$ Ibidem, Item 28, Meetings of 28 January and 25 February 1955.

${ }^{73}$ Ibidem, Item 28, Meeting of 24 February 1956.
} 
However, the Cultuurbank could not agree; there were other shareholders than Dénis they argued. The Cultuurbank proposed a dividend of 20 percent, which would reduce the amount required for the loan by NLG 50,000. A building permit for a storage shed for poppy straw had been already obtained and the Board had authorised the technical director to commence the works (amount involved NLG 80,000). ${ }^{74}$

The Nationale Levensverzekerings Bank commissioned a report on the NCF and it seemed that they were willing to provide the loan as a mortgage on the factory. The Cultuurbank disagreed as it had substantial outstanding loans with the NCF without any security. The relationship between Dénis and the Cultuurbank began to deteriorate. Dénis accepted most reluctantly the proposal of the Cultuurbank to set the dividend at 10 percent over 1955; he had proposed nil. Subsequently Dénis took steps to cut back on bonuses. This was qualified by the Cultuurbank as mean and "a smallness which they did not appreciate." The Cultuurbank was furthermore dissatisfied with the remuneration it received for managing the NCF and decided to bring that point up for discussion the following year. ${ }^{75}$

A few months later the Cultuurbank received a letter from Dénis by which the Bank was advised that his attempts to obtain a loan had been unsuccessful. In the letter Dénis laid the blame for the failure on the Cultuurbank referring to insufficient reserves being set aside in the past, disagreements with financial accountants and "management by a bank". The Cultuurbank specified during the subsequent Board meeting that laying the blame on them was not appropriate as NLG 175,000 of the reserves were used for the acquisition of N.V. Folia, that the disagreements with the accountants were the result of attempted interference by the accountants with management of the company and that the Cultuurbank was not a "bank" in the ordinary sense of the word. ${ }^{76}$ It is clear that Dénis' actions were inspired by his wish to terminate the involvement of the Cultuurbank in the Cocainefabriek.

Further discussions between the Cultuurbank and Dénis did not solve outstanding issues and the credit provided by the Cultuurbank to the NCF increased to NLG 300,000 at an interest rate of 5 per cent. Dénis persisted in his attempts to obtain a loan elsewhere and was ultimately successful with the Nationale Handelsbank for a loan of NLG 400,000, a mortgage with all real estate of NCF as security. A further condition was that all banking of NCF would be conducted via the Nationale Handelsbank. Dénis insisted that all financial administration be transferred from the offices of the Cultuurbank to the NCF factory, including Mr. G.J. Kloet, already specifically employed for NCF/Folia by the Cultuurbank. It was also noted by Board member Veenstra that it appeared that Nieukerke was manoeuvring for an independent position. $^{77}$

On 1 November 1956 the financial administration was transferred to the NCF and in early December the loans of the Cultuurbank were repaid. ${ }^{78}$ Mid 1957 there was a new (unspecified) conflict between the Cultuurbank and Dénis and the Cultuurbank concluded that the relationship had deteriorated to such an extent that the basis for the collaboration had disappeared. $^{79}$

The Cultuurbank resigned as Director of the NCF and communicated its decision by letter to Dénis with a copy to the NCF Board, who discussed it at its meeting of 12 July 1957. The Cultuurbank offered its holding of NCF shares with a nominal value of NLG 46,500 to Dénis, who acquired them at a price of 295 per cent (ex-dividend). Dénis also acquired NCF shares,

\footnotetext{
${ }^{74}$ Ibidem, Meeting of 27April 1956.

${ }^{75}$ Ibidem, Meeting of 18 May 1956

${ }^{76}$ Ibidem, Meeting of 21 August 1956

${ }^{77}$ Ibidem, Meetings of 28September 1956 and 2 November 1956.

${ }^{78}$ Ibidem, Meeting of 5 December 1956.

${ }^{79}$ Ibidem, Meeting of 28 June 1957.
} 
probably previously owned by Jewish shareholders, at the same unit price from "Rechtsherstel" (Fund for Legal Restitution), for an amount of NLG 18,750. ${ }^{80}$

The annual statutory accounts for 1956 were not signed but were submitted by the 'acting directors' ("De Waarnemend Directie"). The 1956 accounts were drawn up in a slightly different format from earlier accounts and the 1955 accounts were re-issued in the new format with some changes. The statutory accounts for 1957-1960 were signed by J.P.H. Nieukerke as director ("De Directeur"), and new Board members were: J.B.M. Langerhorst, from 1953, and H.W.van Hardeveld, from $1958 .^{81}$.

\section{Market and Sales}

Incomplete sales figures NCF for the period 1946-1950, in Dutch Guilders, are found in the Minutes of the Board meetings. They are shown in Table 11.9, below. Sales statistics NCF in weight are only available for 1947 and for 10 months in 1948.

Table 11.9 Incomplete Sales Records NCF 1946-1950 (NLG 000)

\begin{tabular}{|c|c|c|c|c|c|c|}
\hline $\begin{array}{c}\text { Year } \\
\text { Pumber }\end{array}$ & 1946 & 1947 & 1948 & 1949 & $\begin{array}{c}1950 \\
4\end{array}$ & $\begin{array}{c}1951 \\
4\end{array}$ \\
\hline Opiates & 356 & 310 & 89 & 83 & 130 & 319 \\
\hline Ephedrine & & & 70 & 26 & 3 & 20 \\
\hline Ethocaine & & & 25 & 26 & 23 & 11 \\
\hline Cocaine & & & 13 & 6 & 23 & 19 \\
\hline Tubocurarine & & & & & 14 & 14 \\
\hline Other Products & 75 & 94 & & & 5 & 7 \\
\hline Total & 431 & 404 & 197 & 141 & 198 & 390 \\
\hline
\end{tabular}

\begin{tabular}{|l|rrrrrr|}
\hline \multicolumn{1}{|c|}{ Year } & 1946 & 1947 & 1948 & 1949 & 1950 & 1951 \\
Number of Months & & 12 & 10 & 4 & 4 \\
\hline Export & & 385 & 244 & 55 & 26 \\
Local & 67 & 164 & 143 & 364 \\
Total & 452 & 408 & 198 & 390 \\
\hline
\end{tabular}

Source: Minutes of NCF Board Meetings 1946-1951

The figures show that opiates was NCF's largest product group and that cocaine had become an unimportant product. In the minutes of a 1946 board meeting it was noted that the price of opium had increased to USD 19 (NLG 68) / $\mathrm{kg}$ which implied that the codeine

\footnotetext{
${ }^{80}$ Ibidem, Meeting of 9 August1957. Also Mr. Jansen (VPF) had made a (higher) bid on the shares in care of "Rechtsherstel" bod his bid had not been accepted as a result of a negative advise by the Department of Health. ${ }^{81}$ N.V. Nederlandsche Cocainefabriek, Balansen en Winst-en Verlies-rekeningen (Balance sheets and Profit and Loss accounts) 1950-1960. Library of the International Institute for Social History, Amsterdam.
} 
selling price had to be about NLG 800/kg. ${ }^{82}$ In 1947 NCF bought 4,000 kg opium for NLG 242,000 , representing a price of NLG 60 per $\mathrm{kg}$ which was ca $10 \%$ lower than the 1946 price.

Because of the large amounts of money involved and the risk attached, opium purchases were discussed at length at the board meetings. The dilemma was that buying too much opium created the risk of losses if the opium price would drop, and that not buying enough opium, resulting in low stocks, would imply that no advantage could be taken of suddenly arising sales opportunities. It was emphasized by Mr Schor of the Koloniale Bank that the quantities purchased had to be based on expected codeine sales in the home market, where the price was more stable than in the open world market. ${ }^{83}$

The quantity of $4,000 \mathrm{~kg}$ opium bought in 1947 was sufficient to produce ca $400 \mathrm{~kg}$ opiates as anhydrous bases. NCF opiate sales 1947 amounted to $290 \mathrm{~kg}$ codeine, $44 \mathrm{~kg}$ morphine and $18 \mathrm{~kg}$ other opiates, in total $352 \mathrm{~kg}$

In section 11.3, it is reasoned that the ratio of the quantities of AMA produced from poppy straw during the period 1951-1959 at NCF and VPF respectively was in the order of 1:2. On that basis, it is estimated for the periods 1951-1955 and 1956-1959 that morphine was produced at NCF and VPF in average annual quantities approximately equal to those appearing in the following table:

Table 11.10 Ballpark Estimate of Average Morphine Production NCF and VPF 1951-1959 (kg AMA p.a.)

\begin{tabular}{|c|rc|}
\hline Period & NCF & VPF \\
\hline $1951-1955$ & 700 & 1,400 \\
$1956-1959$ & 1,500 & 3,000 \\
\hline
\end{tabular}

Source: Based on Table 11.8

The split of the home market between NCF and Bonnema, which was established for opiates at the ratio 2:1 before the war, was suspended in 1944 because of supply problems. ${ }^{84}$ It is unclear what the situation was immediately after the war, but in 1947 NCF agreed with Bonnema on a 1:2 split for thebaine derivatives such as oxycodone and hydrocodone. ${ }^{85}$ In 1951 NCF had discussions with the Department of Health on the subject if the ratio for codeine should be $60: 40$ or $50: 50 .{ }^{86}$ The outcome of the discussions is not known but assuming that the ratio was 50:50 each company's share of the codeine and morphine home market is estimated at about 250 and $25 \mathrm{~kg}$ p.a. respectively for the period 1951-1960 (Table 11.8)

In summary, it is clear that codeine and morphine were commercially the most important products for NCF and growing substantially over the period. Table 11.8 and Figure 11.5 show for the Netherlands that export of morphine in the form of EPC from 1955 onwards had become considerable.

\footnotetext{
${ }^{82}$ NCF Minutes of Board Meetings, Meeting of 30 June 1947.

${ }^{83}$ Ibidem, Meeting of 17 September 1946.

${ }^{84}$ Ibidem, Meeting of 25 May 1951.

${ }^{85}$ Ibidem, Meeting of 30 June 1947.

${ }^{86}$ Ibidem, Meeting of 25 May 1951.
} 
Specific price information for opiates is not available for the 1950s but the codeine phosphate price was at or below $100 \mathrm{USD} / \mathrm{kg}$ in 1960. NCF employees realised at the time that although some profit was made the business was not flourishing. ${ }^{87}$

Other opiates of some interest were ethylmorphine and hydrocodone. Average cocaine manufacture was $90 \mathrm{~kg}$ p.a. and it is likely that virtually all was produced by NCF. Pethidine was produced in average quantities of over $300 \mathrm{~kg}$ p.a. under a toll manufacturing agreement for Nourypharma. Further specific quantitative information on NCF sales is hardly available. Other products contributing to profit but to an unknown extent were: ethocaine, ephedrine, lidocaine and tubocurarine.

Little is known on how NCF managed its export activities until 1960. Presumably they had agents in the more important markets and a correspondence clerk to maintain the contacts. In the early 1960s, H. Soetens was the sales manager and director Nieukerke kept personally in touch with major customers who bought EPC on annual contracts, for example Coutelier Frères, Brussels, and Sandoz, Basle. ${ }^{88}$ Technical morphine was sold mainly to Gödecke (Germany). Governments of numerous countries issued tenders for the annual requirements of essential bulk pharmaceuticals including codeine and other opiates. For NCF winning a tender contract for a large quantity of codeine was essential for having a profitable year. ${ }^{89}$

As opiates were commodities, most of the sales were made on price only. At equal price the company with the best record of quality compliance and service would obtain the order. From 1952 increased sales opportunities for codeine arose because the low manufacturing cost from poppy straw enabled quoting at low prices.

EPC (a crude poppy extract containing ca 50\% morphine) was an exception because the content of secondary alkaloids (codeine and thebaine) and the presence or absence of impurities that could interfere with the processing made that customers could distinguish between the qualities of EPC from different suppliers. EPC of good quality would justify a higher price. As EPC was commonly sold in large quantities on the basis of longer term contracts the (personal) relationship with the customer was most important. EPC was for the customer an essential raw material for its codeine business and guarantee of supply even beyond the term of the supply contract was paramount. For the EPC manufacturer the long term relationship with the customer was of equal importance. The EPC manufacturer needed at the time of contracting for the poppy crop that there would be customers for the product more than a year later. These conditions and considerations made that for EPC the buyerseller relationship became in practice often an informal long term partnership based on mutual trust and understanding. Management of the highest level of both buyer and seller were commonly involved in maintaining the relationship.

\footnotetext{
${ }^{87}$ Recollection of the author.

${ }^{88}$ Personal experiences by the author.

${ }^{89}$ Recollections of the author.
} 


\section{Manufacture}

Until 1957 manufacture of opiates and other products mainly took place in the facilities as they existed in 1939 with rearrangements and additions as required. ${ }^{90}$ In 1956 approval was sought and obtained from the municipal authorities for the building of the large shed for poppy straw storage including a milling and mixing section (ref. Figure 11.11). ${ }^{91}$ The cost of the building was estimated at NLG 70,000. During the period 1957-1960 a total amount of NLG 410,000 was invested, an enormous difference compared to the total of NLG 23,000 invested during the previous six years. ${ }^{92}$

\footnotetext{
${ }^{90}$ In 1940 an existing space was demolished and rebuild as storage room with cellar, which in a later stage was used for the manufacture of EPC and technical morphine Application 754 BT 1940 dated 5 March 1940.

91 Application 981 BT 1956 dated 13 March 1956.

${ }^{92}$ Ref. Section 11.6 Finance.
} 
Figure 11.10 The Expansions of 1940 and 1956

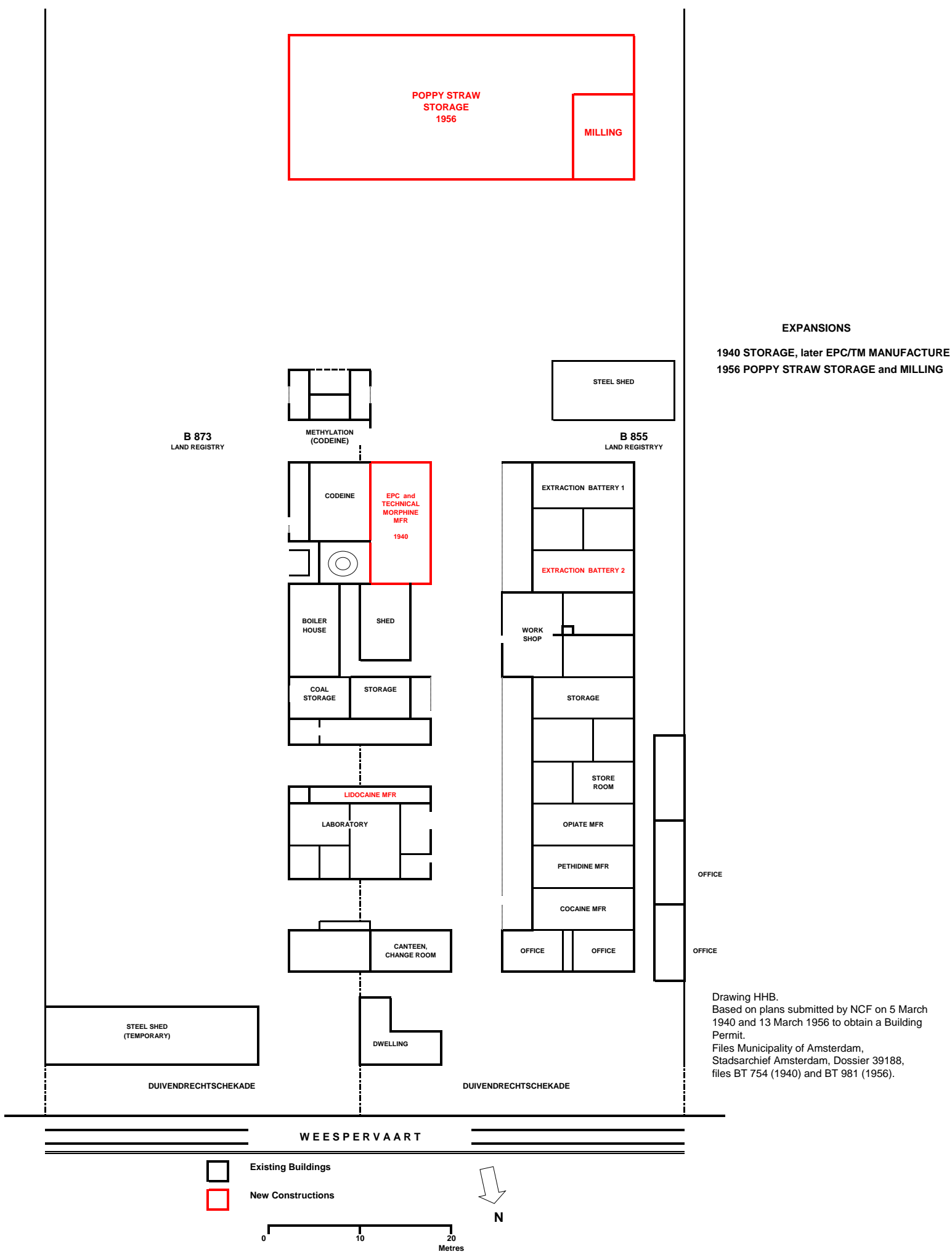


No documental evidence was found, but the investments will have been predominantly in equipment for the manufacture of morphine from poppy straw. In 1960 two batteries were operational, one quite new the other the original coca extractor from $1917 .{ }^{93}$ Installing the new extractor must have been part of the 1957 overhaul of the facilities. In 1947 NCF's capacity for extracting poppy straw was estimated at $240 \mathrm{t}$ p.a. when working two shifts. ${ }^{94}$ This must have been for one extraction battery. The capacity in 1960 was in the order of $1,000 \mathrm{t}$ p.a. This was the result of the new second battery and halving the cycle-time. ${ }^{95}$ It ties in with the ca $800 \mathrm{t}$ more poppy straw extracted in the Netherlands in 1958 compared to $1956 .^{96}$

In 1960-61 the situation at NCF with respect to manufacturing was about the same as in the late 1950s. The main products were codeine and morphine and the extraction capacity, although increased in 1957 to ca 1,000 t poppy straw p.a., was too small to bring manufacturing cost down sufficiently to compete effectively in the open market with the Eastern European manufacturers and with VPF. NCF's main raw material was lanced poppy capsules imported from Yugoslavia. Opiate production at NCF is estimated by the author to be in the order of 2,000-2,500 kg AMA/ACA p.a. for the early $1960 \mathrm{~s}$.

Other products manufactured during the period were the existing products: cocaine, ethocaine, ephedrine and the new products: pethidine, lidocaine and tubocurarine. In the following section some process details of new products are discussed.

\section{New products}

Tubocurarine chloride

Curare is the collective name of extracts from certain South American plants that are used by natives as arrow poisons. When the curare enters the bloodstream of the victim, death follows by paralysis of the motor nerves. A specific curare is tube-curare, named after its traditional container which is a bamboo tube. It is an extract of the Peruvian liana Chondodendron tomentosum.

Figure 11.11 (+)-Tubocurarine chloride<smiles></smiles>

\footnotetext{
${ }^{93}$ Personal experiences by the author.

${ }^{94} \mathrm{NCF}$, Minutes of Board Meetings, Meeting of 30 June 1947.

${ }^{95}$ Equilibrium between the phases is reached quickly in poppy straw extraction (HHB from NCF experience).

${ }^{96}$ Ref. Table 11.8.
} 
In 1935 Harold King isolated an alkaloid from tube-curare that he named tubocurarine chloride. ${ }^{97}$ It was shown that (+)-tubocurarine chloride is the active compound that causes the paralysis. Tubocurarine chloride is used as a muscle relaxant during certain surgical procedures. ${ }^{98}$.

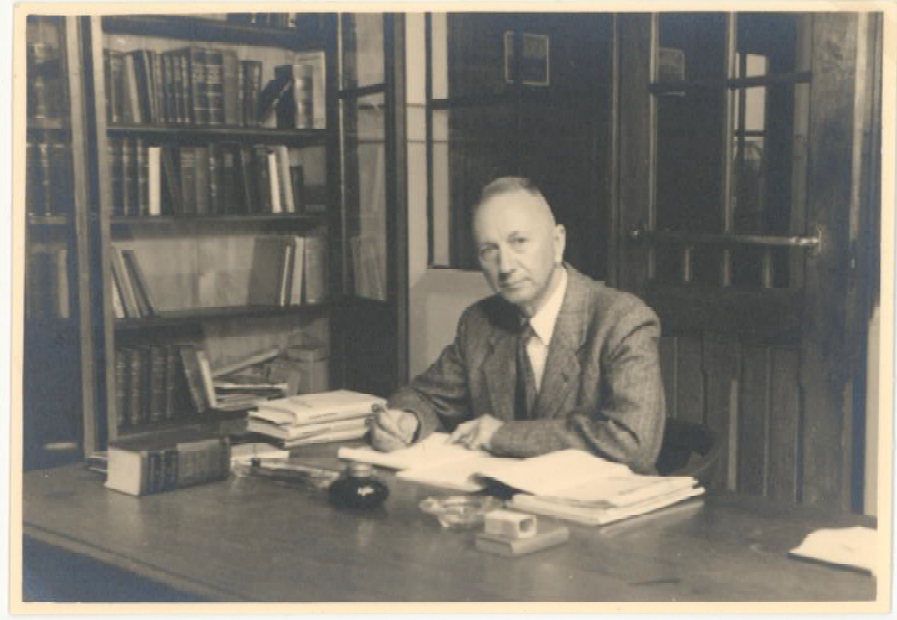

Figure 11.12

Ir. M.J. Weidema

Chief Chemist NCF (1913-1960)

(Photo: 'NCF 1900-1950', IISH

Amsterdam)

As a high priced, difficult to isolate alkaloid, tubocurarine chloride fitted well in NCF's product range and in 1949 Weidema had developed an efficient method for isolating it from the curare. In essence, he modified the benzoate method used for opium alkaloids to isolate the tubocurarine chloride.

The product was marketed in ampules as a specialty product. In 1948 future sales were forecast at 50-60 grams alkaloid p.a. and actual sales amounted to NLG 14,000 during the first four months of both 1950 and $1951 .^{99}$

\section{Lidocaine (Xylocaine)}

Lidocaine was developed as a local anaesthetic by Astra, a pharmaceutical company from Sweden. Astra had obtained a patent on a method for its chemical manufacture. As a local anaesthetic it was used in competition with ethocaine and fitted NCF's product programme. Weidema found a way around Astra's patent by making the key intermediate $N$-chloroacetyl2.6-xylidine by heating $N$-acetyl-2.6-xylidine with monochloro-acetic acid.

\footnotetext{
${ }^{97}$ King H. 'Curare Alkaloids - Part 1: Tubocurarine', Journal of the Chemical Society (1935) 1381-1389.

${ }^{98}$ Lee M.R. 'Curare: the South American arrow poison'

Journal of the Royal College of Physicians: Edinburgh 35 (2005) 83-92.

${ }^{99}$ NCF Minutes of Board Meetings, Meetings of 3 November 1948 and 25 May 1951.

Total sales for the years 1950 and 1951 are not known.
} 
Figure 11.13 NCF synthesis of Lidocaine<smiles></smiles>

This reaction of monochloroacetic acid and the xylidine is an equilibrium and proceeds because the acetic acid is distilled off continuously. The resulting $N$-chloroacetyl-2.6xylidine reacts with diethylamine to yield the desired lidocaine.

NCF applied for an independent patent but the application was opposed by Astra and ultimately, in 1956, NCF was granted a dependent patent only. ${ }^{100} \mathrm{NCF}$ manufactured lidocaine for a number of years but because of the patent restrictions it was not a great commercial success.

\section{Pethidine}

Pethidine is a totally synthetic analgesic, developed in Germany by Eisleb under the name "Dolantin" (Farbwerke Hoechst) in 1939. Pethidine was manufactured by NCF from an intermediate product, pethidine nitrile, manufactured and supplied by Nourypharma (Deventer, the Netherlands). The finished product is pethidine hydrochloride. It is a substance controlled under the Single Convention of Narcotic Drugs.

Pethidine was made from the nitrile using to the process below, developed by Farbwerke Hoechst and described in a BIOS report. ${ }^{101}$

Figure 11.14 The last Step of the Pethidine Synthesis

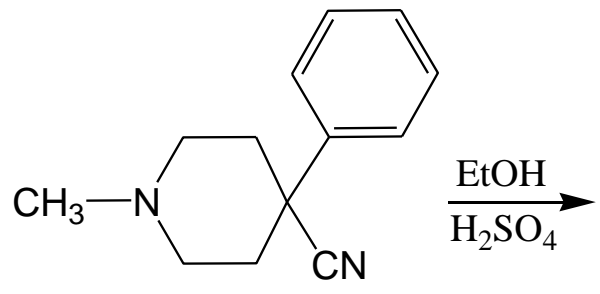

Pethidine nitrile

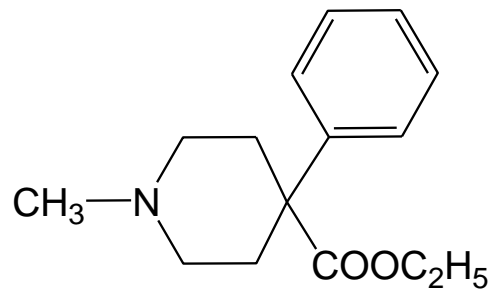

Pethidine

\footnotetext{
${ }^{100}$ Nederlandsche Cocaine Fabriek, A Process of Preparing Substituted Amides and Intermediates therefor. Inventor: Weidema M.J. Great Britain Patent 792,791, 1958 July 16.

${ }^{101}$ British Intelligence Objectives Sub-Committee (BIOS), Trip 1155, Report No. 766, 'Dolantin, I.G.

Farbenindustrie - Hoechst' (1947) 60-66.
} 
Nourypharma was not allowed to perform the last process step because it did not have a narcotics manufacturing license. It was therefor produced by NCF under a toll-manufacturing arrangement; all pethidine end product was marketed by Nourypharma. ${ }^{102}$

NCF manufacture of pethidine commenced in 1949, and the average production for the period 1952 to 1960 was $318 \mathrm{~kg}$ per annum.

\section{NCF Financial Results}

Annual financial account statements for NCF are available for the Period 1950-1960. ${ }^{103}$ They consist of balance sheets and profit and loss accounts (income statements) without written reports. NCF did not report sales figures. The Profit and Loss Accounts 1950-1960 are summarised (re-arranged) in Table FIN NCF 4 (Part III).

Key figures of the P\&L accounts: Total Revenue, Operating income and Net Income are presented in Table 11.11 and Figure 11.15 below.

Table 11.11 and Figure 11.15 Key Figures from Profit \& Loss Account

NCF 1950-1960 (NLG 000)

\begin{tabular}{|c|ccc|}
\hline & $\begin{array}{c}\text { Margin on } \\
\text { Operations }\end{array}$ & $\begin{array}{c}\text { Operating } \\
\text { Income }\end{array}$ & $\begin{array}{c}\text { Net } \\
\text { Income }\end{array}$ \\
\hline & & & \\
1950 & 56 & 55 & 34 \\
1951 & 135 & 135 & 72 \\
1952 & 42 & 39 & 20 \\
1953 & 99 & 95 & 56 \\
1954 & 140 & 136 & 78 \\
1955 & 137 & 134 & 89 \\
1956 & 106 & 101 & 50 \\
1957 & 120 & 106 & 73 \\
1958 & 278 & 257 & 127 \\
1959 & 272 & 241 & 144 \\
1960 & 111 & 70 & 76 \\
& & & \\
\hline
\end{tabular}

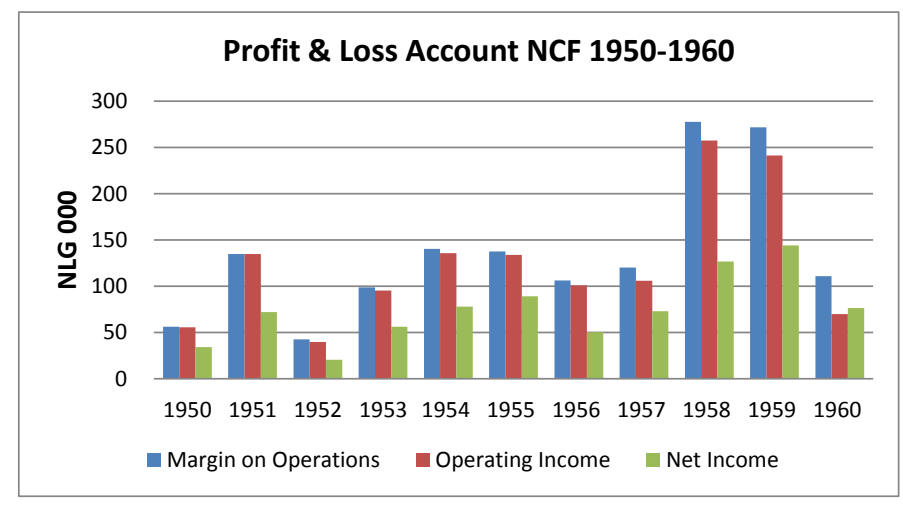

Source: Annual Accounts NCF 1950-1960 - Table FIN NCF 4 (Part III)

The effect on income of the larger morphine production after the expansions of 1957 shows clearly in table and graph. The strong drop in the margin on operations in 1960 is probably related to increased competition from VPF and East European poppy straw processors.

The Balance Sheets 1950-1960 are summarised (re-arranged) in Table FIN NCF 3 (Part III). Key figures appear in Table 11.12 below:

\footnotetext{
${ }^{102}$ NCF, Minutes of Board Meetings, Meeting of 27 June 1949.

103 N.V. Nederlandsche Cocainefabriek, Balansen en winst-en verlies-rekeningen (Balance sheets and profit and loss accounts) 1950-1960. Library of the International Institute for Social History, Amsterdam.
} 
Table 11.12 and Figures 11.16 and 11.17

Key Figures from Balance Sheets NCF 1950-1960 (NLG 000)

\begin{tabular}{|c|c|c|c|c|c|c|c|c|}
\hline & $\begin{array}{l}\text { P,P \& E } \\
\text { Assets }\end{array}$ & $\begin{array}{c}\text { Total } \\
\text { Inventory }\end{array}$ & $\begin{array}{l}\text { Share } \\
\text { Capital }\end{array}$ & $\begin{array}{l}\text { Retained } \\
\text { Earnings }\end{array}$ & $\begin{array}{c}\text { (Shareholder) } \\
\text { Loans }\end{array}$ & $\begin{array}{l}\text { Bank } \\
\text { Credit }\end{array}$ & $\begin{array}{l}\text { Depre- } \\
\text { ciation }\end{array}$ & $\begin{array}{l}\text { Invest- } \\
\text { ments }\end{array}$ \\
\hline 1950 & 25 & 443 & 97 & 185 & 0 & 138 & 1 & \\
\hline 1951 & 25 & 474 & 97 & 183 & 29 & 158 & 0 & 0 \\
\hline 1952 & 31 & 474 & 97 & 183 & 29 & 169 & 3 & 9 \\
\hline 1953 & 28 & 311 & 97 & 182 & 0 & 0 & 4 & 1 \\
\hline 1954 & 25 & 303 & 162 & 182 & 0 & 64 & 5 & 2 \\
\hline 1955 & 31 & 361 & 162 & 177 & 25 & 110 & 4 & 10 \\
\hline 1956 & 102 & 371 & 162 & 177 & 90 & 239 & 5 & 76 \\
\hline 1957 & 205 & 624 & 162 & 182 & 125 & 387 & 15 & 118 \\
\hline 1958 & 245 & 679 & 162 & 182 & 160 & 254 & 20 & 59 \\
\hline 1959 & 285 & 693 & 162 & 182 & 235 & 258 & 31 & 72 \\
\hline 1960 & 332 & 826 & 162 & 182 & 260 & 560 & 41 & 88 \\
\hline
\end{tabular}

$\mathrm{P}, \mathrm{P} \& \mathrm{E}=$ Property, Plant and Equipment

Source: Tables FIN NCF 3-5 (Part III) ${ }^{104}$

Figure 11.16

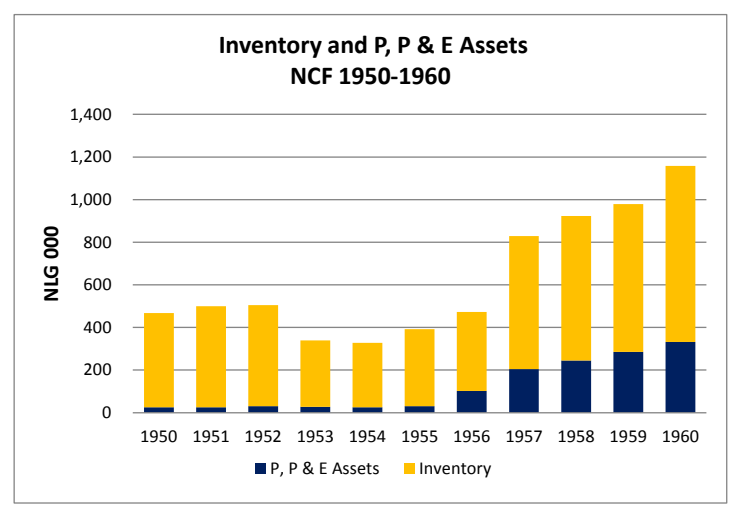

Figure 11.17

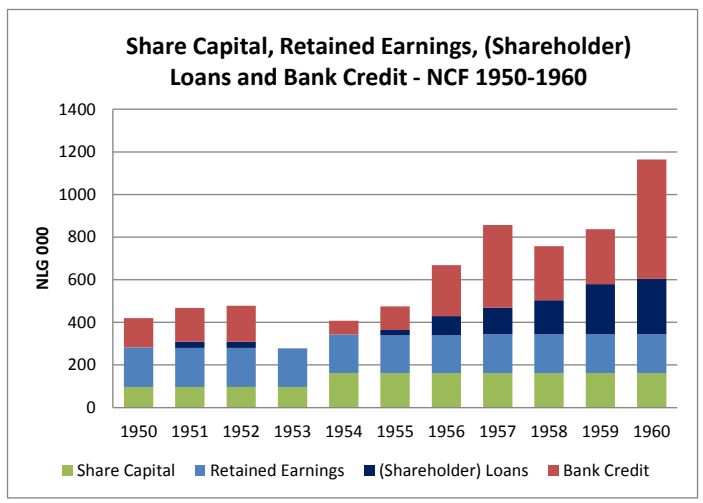

The table and charts show that during the period 1950-1955 hardly any investments were made but that investments in factory assets took place from 1956 to 1960. The investments during the latter period were mainly made to increase the capacity for poppy straw processing. Inventories of finished product and raw materials increased correspondingly. The expansions were financed by increases in shareholder loans and bank credit. ${ }^{105}$

\section{In Search of a New Owner}

In 1960 the organisation at NCF was led by Ir. Jan Nieukerke, managing director; Gerard Kloet was his deputy and the finance manager, Henk Soetens was the sales manager, and Hans Bosman, the author, employed from 1 April 1960 as chief chemist, succeeding Ir. Weidema, who retired after 47 years of service. As chief chemist he was responsible for

\footnotetext{
${ }^{104}$ Inventory 1952 excluding third party inventory.

105 The balance sheet item "Renewal Fund" is not clearly defined in the accounts. The amounts do not occur in the P\&L account and are there for not retained earnings but loans, almost certainly from shareholders, as is the "Dividend Reserve". For the year 1960 the fund includes a NLG 65,000 re-allocation from the balance sheet item "Retained Earnings". Which arrangements were made with shareholders regarding the loans is not known.
} 
quality control production, supervision and research, assuming one year later additional responsibilities as operations manager. ${ }^{106}$

Nieukerke believed in the future of the NCF provided that sufficient investments were made to enlarge the capacity for opiate production to such extent that the unit production cost would come down sufficiently allowing for quoting competitively. It appears that Harry Dénis, after the quite large investments of the late 1950s, was not willing or able to commit more money for additional investments. This was the reason for Nieukerke's active search, with the consent of Dénis, for a large pharmaceutical company that would be interested to acquire NCF.

Around 1960 Nieukerke had become President of "Nepropharm", the Association of Producers of Pharmaceutical Products in the Netherlands. This gave him the opportunity to get to know top managers of the Dutch pharmaceutical industry quite well. One of these was Jhr. G. Kraijenhoff, then recently appointed as member of the Board of KZO (Koninklijke Zwanenberg Organon). ${ }^{107}$ Organon was originally a subsidiary of Zwanenberg, a large meat packing industry and slaughter house located at Oss, in the Southern part of the Netherlands.

In 1923 Organon was founded as the company to produce pharmaceutical products from offal from Zwanenberg's slaughter-house. Its first product was insulin isolated from pork and beef pancreas. Later Organon also produced steroid hormones and corticosteroids. Kraijenhoff's nomination resulted in Organon becoming a more market oriented company. That new attitude led to an open eye for possibilities of acquiring other companies, and for mergers. Nieukerke drew Kraijenhoff's attention to the NCF and its potential for growth as an alkaloid manufacturer. Kraijenhoff's reaction was positive and the result was that, KZO (Koninklijke Zwanenberg Organon), the parent company of Organon, made a bid for NCF. Possibly influenced by the decline in profit in 1960 (Table 11.11) that bid was accepted by Dénis and NCF became part of KZO in 1962. Management of NCF remained unchanged with Nieukerke as managing director. The acquisition was paid for by transfer of KZO shares with the nominal value of NLG $250,000 .^{108}$

The acquistion of NCF was one of the first by KZO. It was made before Kraijenhoff became President of KZO on 1 January 1963. Shortly after his nomination Kraijenhoff engaged management consultants McKinsey \& Company to critically review the structure of Zwanenberg-Organon and to formulate recommendations for a reorganisation, leading to internationalization and full commercialization of the knowledge base of KZO. ${ }^{109}$

\subsection{Bonnema/VPF during 1946-1964}

\section{Organization}

In 1947 Jansen brought all his business activities together in the Verenigde Pharmaceutische fabrieken N.V. (VPF). These activities comprised the opiate business of Bonnema, the Zwitsal baby product line, the manufacture and trade in some popular pharmaceutical products, and a pharmacy. Inducement to the formation of VPF was the wish to expand the capacity for opiate manufacture from poppy straw for which larger facilities were required. A new factory was to be built at the Vlijtseweg, Apeldoorn.

\footnotetext{
${ }^{106}$ Reporting to the author were: Production Manager Ton Kramer, Chief Engineer Jansen and Laboratory Staff members: André Lipplaa and Versteeg.

${ }^{107}$ The date of appointment of Kraijenhoff as KZO Board member was 15 October 1959. Marius Tausk, Organon. De geschiedenis van een bijzondere Nederlandse onderneming (Nijmegen 1978) 307.

${ }^{108}$ VNCI publication No 24 of 18 December 1962. The acquisition was retrospective from 1 January 1962.

109 Tausk, Organon, 308.
} 
Figure 11.18 Verenigde Pharmaceutische Fabrieken, Apeldoorn

Factory and Offices (Photo: VPF, Annual Report 1956)

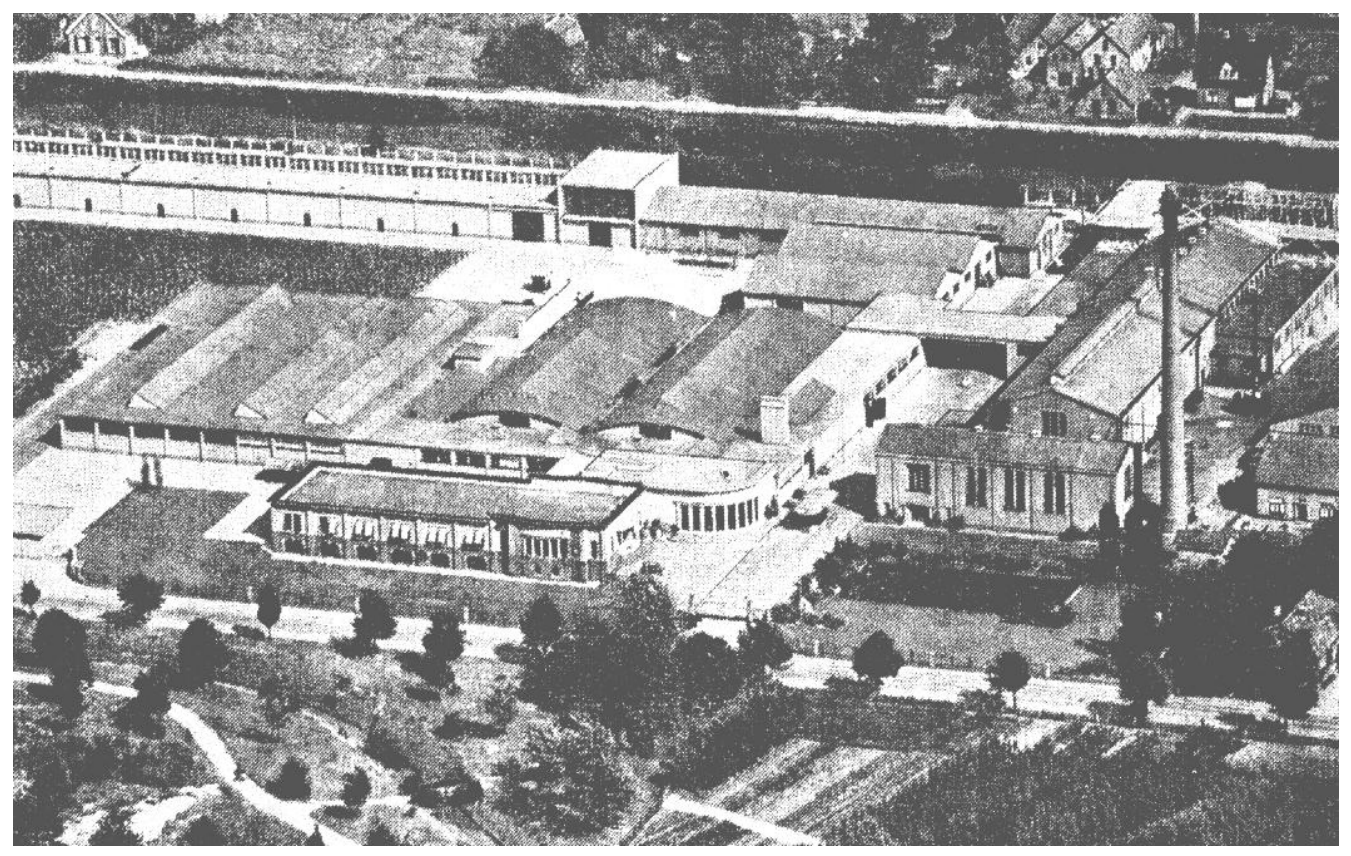

The memorandum of association of the VPF mentions a statutory capital of three million guilders divided over 10 priority shares and 2,990 ordinary shares of NLG 1,000 each; it was registered at Apeldoorn on 10 December 1947. ${ }^{110}$ At the end of 1948 2,000 shares were placed. ${ }^{111}$ The first members of the board of directors were Dr W.H. Bloemendal and Mr L.W. Wildervanck. Jansen was the managing director and major shareholder. The shares were traded at the Amsterdam stock exchange. ${ }^{112}$

During 1949 differences in opinion arose between Jansen and the board members. ${ }^{113}$ The result was that at the end of that year the board consisted of Messrs C.J. Jansen, Chr. ten Tuynte and T. Vroom. Jansen continued to conduct the business under the title acting managing director ("waarnemende directie"). The composition of the board did not change until 1956 when Mrs A.M. Prins-Jansen, daughter of Jansen, became the fourth board member and in 1958 when Mr G.J. Prevoo became the fifth. In 1960 Jansen left the board but remained in charge of the operations under the title of [President of the] Executive Board ("Raad van Bestuur"). ${ }^{114}$

Jansen was a charismatic and autocratic leader. There was never any doubt about who was in charge of the VPF, the "Zwitsal" as is was known locally. It was his vision and pushing power that was behind the creation and successes of the enterprises incorporated in the VPF. ${ }^{115}$ His belief in the ultimate commercial success of the use of poppy straw as the raw material for opiates made that he persevered with investing considerable amounts in the manufacturing facilities at a time when the prospects for the supply of sufficient quantities of poppy straw were dim. This issue was at the root of the above mentioned differences in opinion with the board in 1949, resulting in the departure of the board members.

\footnotetext{
${ }^{110}$ Nederlandsche Staatscourant of 30 November 1948, No 232 - No 1458.

${ }^{111}$ Annual Report VPF 1948, Balance Sheet.

${ }^{112}$ Nederlandsche Middenstandsbank, Aandelencommentaar No 458 on VPF dated 19 November 1960.

113 Article in "Trouw" of 10 December 1949.

${ }^{114}$ VPF Annual Reports 1948-1963.

115 "Van Zwitserse balsem en papaverbollen", article in the Nieuwe Apeldoornse Courant of

9 January 1960, written at the occasion of the 40 year jubilee of Jansen's businesses in Apeldoorn.
} 
Jansen employed a group of competent people as managers of the various activities in which the company was involved but the ultimate decisions were taken by him. In the 1950s and 60s among those managers were Dr F. Steenmeier, pharmacist, in charge of pharmaceutical manufacture and quality control, J. Wijnberg, extraction specialist, C. H. Moorhoff, chemist and opiate specialist, and B. Docter, chief engineer. Chr. ten Tuynte was the architect who designed the factories at the Deventerstraat (1941) and at the Vlijtseweg (from 1947). Ten Tuynte became board member of the VPF in 1949.

\section{Marketing and Sales}

No sales statistics on opiates appear to be available for VPF. In section 11.6 (table 11.10) it is estimated that during 1951-1955 VPF produced and sold in the order of 1,500 kg opiates and during 1956-1959 3,000 kg. Arrangements existed under which the home market for codeine and morphine was split between VPF and NCF in an approximately 1:1 ratio.

Mr D. Kerkmeer was reportedly in charge of export sales and the procurement of poppy straw. ${ }^{116}$ For EPC, VPF's main customer was Fine Chemicals Corporation Pty Ltd of Cape Town, South Africa, a subsidiary of South African Druggists Ltd, which company remained a large client well into the 1980s. ${ }^{117}$ No specifics are known about VPF's sales organisation for opiates but the market was the same as for NCF and the selling methods through pharmaceutical wholesalers, agents in important countries and bidding on tenders will have been very similar. The statistics show that VPF was most successful in its sales activities, from 1953 onwards with codeine, and from 1955 onwards also with morphine, especially in the years 1959 and 1960 when large quantities were sold as EPC. These successes go back ultimately to the vision of Jansen who saw already in 1947 that low cost morphine produced from poppy straw would be the key to market penetration.

\section{Opiate Manufacture}

Initially opiate manufacture took place at the premises at the Deventerstraat. In preparation for the establishment of the VPF a five hectare block of land between the Vlijtseweg and the Apeldoorns kanaal (canal) was acquired where the new factory was to be built. By mid-1949 some of the buildings were completed and the production of popular speciality pharmaceuticals was moved to the new facilities. Towards the end of 1950 the opiate production was moved, followed in 1951 by the Zwitsal plant. ${ }^{118}$

The actual manufacture of morphine from poppy straw depended on the availability of poppy straw from the poppy cultivation for seed in the Netherlands. VPF stated in its annual report for 1948 that the lack of interest by farmers had resulted in insufficient availability and that VPF would do something about that. For 1949 VPF reported that the situation had improved considerably but in 1950 some problems still existed. In 1951 the extraction equipment at the Vlijtseweg was commissioned and functioned well and sufficient raw material was available. The uncertainty of raw material supply due to harvest results was mentioned again in the annual report for 1953. However, in the years thereafter raw material problems do not get a mention because by then VPF had turned to Turkey for the supply of poppy straw. Table 11.8 shows that in 1952 almost double the quantity of poppy straw was extracted in the Netherlands compared to the year before and that the yield had jumped from 0.17 to $0.24 \%$, a sure sign that the change from Dutch to Turkish poppy straw (respectively to Yugoslavian poppy straw for NCF) had taken place.

In 1955-1956 the extraction facilities were upgraded and expanded by the installation of two extractors with a total capacity estimated at 2,000 t of poppy straw p.a., and in 1960 a

\footnotetext{
${ }^{116}$ Common knowledge in the industry in the early 1960 s.

${ }^{117}$ Recollection of the author.

${ }^{118}$ VPF Annual Reports 1948-1951.
} 
further expansion of the capacity, to ca 6,000 t p.a., was achieved by the replacement of the two smaller extractors by a new large Lurgi extractor. ${ }^{119}$ The new facility around extractor $\mathrm{C}$ was well designed by Mr Wijnberg. A mixture of toluene and butanol was used as the primary extraction solvent and the factory operated without problems and with good yields until 1983. The codeine production facilities were also substantially enlarged to accommodate the increased production from 1953.

\section{VPF Financial Results}

VPF's shares were traded on the stock market and the company published from 1948 to 1963 annually a report to shareholders including a set of financial statements. The balance sheets and profit $\&$ loss accounts (income statements) are re-arranged and summarised in tables FIN VPF 1-3 (Part III). The figures pertain to the total business i.e. opiates consolidated with the "Zwitsal" baby products and other activities.

Key figures from the P\&L accounts 1948-1963 are presented in the table and chart below:

Table 11.13 and Figure 11.19 Profit and Loss Account VPF 1948-1963 (NLG 000)

\begin{tabular}{|r|rrr|}
\hline & $\begin{array}{r}\text { Margin on } \\
\text { Operations }\end{array}$ & $\begin{array}{c}\text { Operating } \\
\text { Income }\end{array}$ & $\begin{array}{c}\text { Net } \\
\text { Income }\end{array}$ \\
\hline 1948 & 181 & 147 & 99 \\
1949 & 222 & 127 & 90 \\
1950 & 383 & 193 & 100 \\
1951 & 446 & 53 & 192 \\
1952 & 650 & 317 & 196 \\
1953 & 719 & 347 & 200 \\
1954 & 834 & 446 & 201 \\
1955 & 1,072 & 518 & 225 \\
1956 & 879 & 514 & 231 \\
1957 & 798 & 435 & 377 \\
1958 & 1,507 & 1,057 & 494 \\
1959 & 1,615 & 1,067 & 490 \\
1960 & 2,239 & 1,273 & 422 \\
1961 & 1,884 & 1,124 & 464 \\
1962 & 1,405 & 646 & 321 \\
1963 & 1,878 & 1,090 & 370 \\
& & & \\
\hline
\end{tabular}

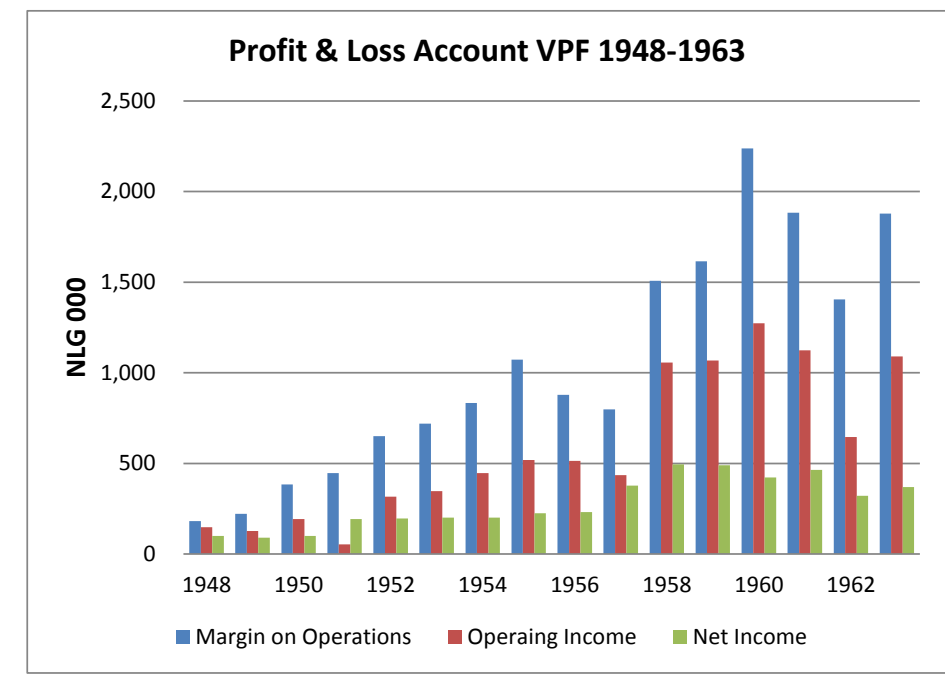

Source: VPF Annual Reports 1948-1963 - Table VPF FIN 1 (Part III)

Table and chart show how successful VPF was. Compounded increases over the period 19481963 amounted for Margin on Operations 17\%, for Operating Income 14\% and for Net Income 9\%. The difference between Margin on Operations and Operating Income represents largely depreciation and the difference between Operating Income and Net Income largely taxes.

The figures for the years 1948-1950 refer largely to the non-opiate business of VPF. Opiate production increased rapidly from 1951 and became the major contributor to operating income from 1957.

119 "Extractor C is gesloopt", Akzo News, February 1992, 3. 
Table 11.14 and Figures 11.20 and 11.21

Key Figures from Balance Sheets VPF 1950-1963 (NLG 000)

\begin{tabular}{|c|c|c|c|c|c|c|c|}
\hline & $\begin{array}{l}\text { P,P \& E } \\
\text { Assets }\end{array}$ & $\begin{array}{c}\text { Total } \\
\text { Inventory }\end{array}$ & $\begin{array}{l}\text { Share } \\
\text { Capital }\end{array}$ & $\begin{array}{l}\text { Retained } \\
\text { Earnings }\end{array}$ & $\begin{array}{l}\text { Loans \& Bank } \\
\text { Credit }\end{array}$ & $\begin{array}{l}\text { Depre- } \\
\text { ciation }\end{array}$ & $\begin{array}{l}\text { Invest- } \\
\text { ments }\end{array}$ \\
\hline 1948 & 840 & 1,250 & 2,000 & 250 & 0 & 34 & \\
\hline 1949 & 874 & 781 & 2,000 & 250 & 0 & 95 & 129 \\
\hline 1950 & 758 & 741 & 2,000 & 250 & 0 & 190 & 73 \\
\hline 1951 & 989 & 1,437 & 2,000 & 300 & 0 & 393 & 624 \\
\hline 1952 & 1,073 & 1,412 & 2,000 & 354 & 0 & 333 & 418 \\
\hline 1953 & 1,125 & 1,006 & 2,000 & 409 & 0 & 372 & 424 \\
\hline 1954 & 1,155 & 1,113 & 2,000 & 464 & 0 & 388 & 418 \\
\hline 1955 & 1,248 & 1,019 & 2,000 & 519 & 0 & 554 & 647 \\
\hline 1956 & 1,551 & 1,579 & 2,000 & 576 & 0 & 365 & 668 \\
\hline 1957 & 1,496 & 1,958 & 2,000 & 734 & 220 & 364 & 309 \\
\hline 1958 & 1,394 & 1,481 & 2,000 & 1,000 & 0 & 450 & 348 \\
\hline 1959 & 3,159 & 4,656 & 2,000 & 2,255 & 1,484 & 548 & 1,308 \\
\hline 1960 & 3,301 & 5,138 & 2,000 & 2,455 & 2,696 & 966 & 1,108 \\
\hline 1961 & 2,910 & 5,417 & 2,100 & 2,705 & 2,620 & 760 & 369 \\
\hline 1962 & 2,272 & 3,256 & 2,100 & 2,805 & 2,500 & 759 & 121 \\
\hline 1963 & 1,555 & 2,474 & 2,100 & 2,955 & 2,500 & 788 & 71 \\
\hline
\end{tabular}

$\mathrm{P}, \mathrm{P} \& \mathrm{E}=$ Property, Plant and Equipment

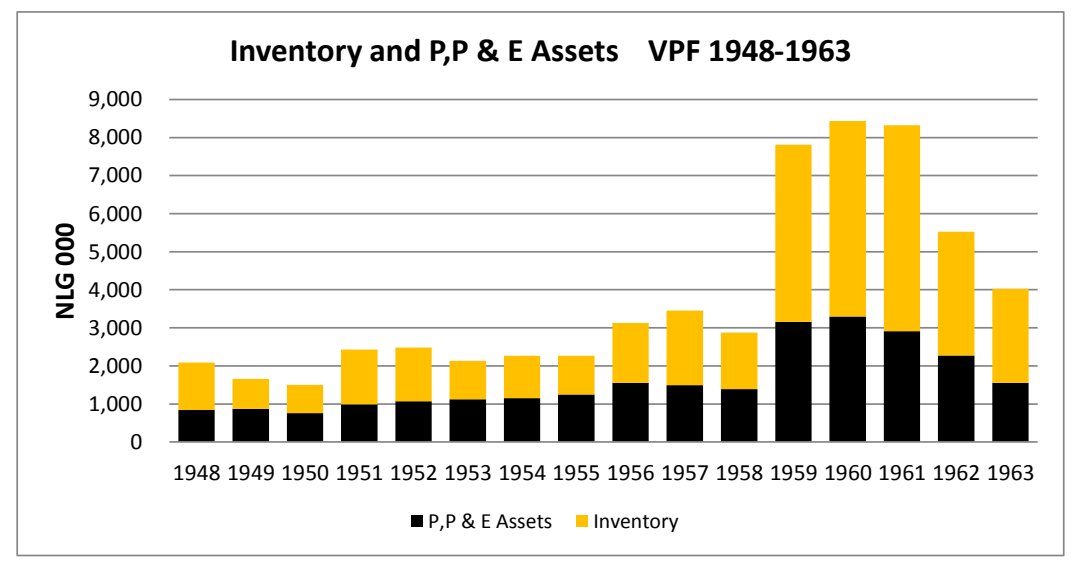

Figure 11.20

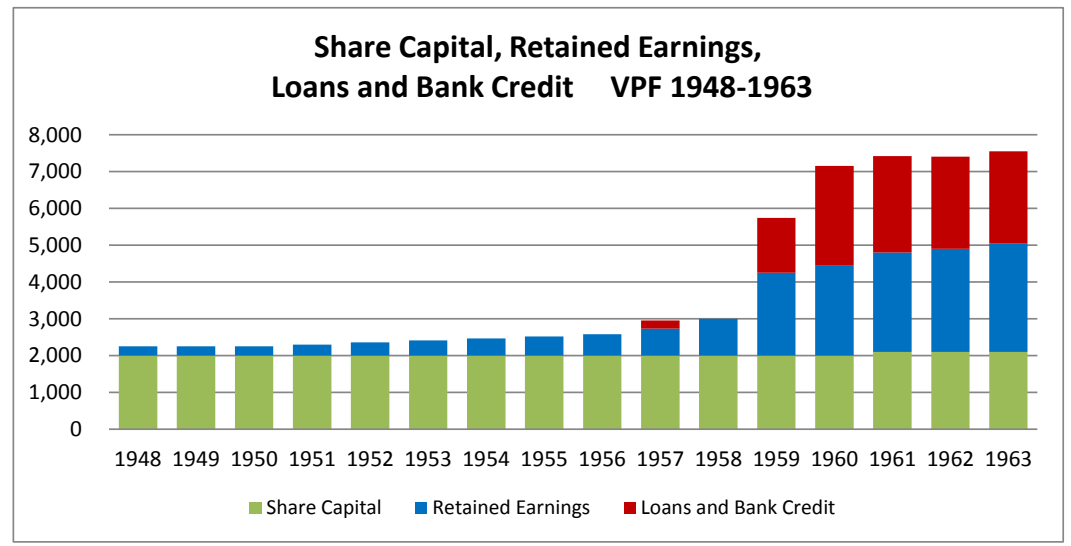

Sources: VPF Annual Reports 1948-1963 - Tables FIN VPF 1-3 (Part III) 
The table and charts show increased investment activity during the period 1955-1956 and large investments in 1959 and 1960. These investments were mainly in new continuous extractors and auxiliary equipment to increase the capacity for poppy straw processing. Inventories of finished product and raw materials increased correspondingly. The expansions were financed by increased loans and bank credit in 1959 and by a NLG 2.5 million 5\% debenture bond in 1960 .

The figures in Tables 11.13 and 11.14, and the accompanying charts pertain to the $\mathrm{VPF}$ as a whole, including the Zwitsal activities, but large movements in Margin from Operations, Inventory and Investments are clearly related to the opiate business. The reasons for the reduction in margin are provided with the comments in the annual reports (below) and the increase in inventory value reflects the accumulation of stocks shown in Table 12.9. In the annual report for 1962 it is mentioned that the valuation of inventory [at year end] reflected current market conditions. In other words the inventory value would have been (much) larger if the valuation had been made using the unit cost of a year earlier. Investments dwindled after the large expenditure on equipment of 1960 but it was possible to keep Net Income more or less constant.

\section{Opiate Production at VPF during the early 1960s}

Morphine manufacture in the Netherlands amounted to almost 15 tonnes AMA in 1962, about 12.5 tonnes of which was produced by VPF, the remaining 2.0-2.5 tonnes by NCF. The figures show that NCF was a minor producer at the time whereas VPF was one of the larger poppy straw processors in the world, together with "Alkaloida" in Hungary and to a lesser degree "Ciech-Polfa" in Poland.

VPF with its large modern extractor and low cost poppy straw from Turkey was able to produce morphine, and hence also codeine, at low cost. However, the producers from Eastern European countries were prepared to sell at any price and that created a problem for VPF. As mentioned earlier VPF had increased its morphine output very substantially since 1958 but had not been able to sell all material produced and this had resulted in large stocks. The overproduction at VPF of morphine and codeine during the early 1960s is demonstrated clearly in the following table and chart.

Table 11.15 and Figure 11.22 Morphine and Codeine Stocks in the Netherlands 1957-1965

\begin{tabular}{|c|rr|}
\hline Year & $\begin{array}{c}\text { Morphine } \\
\text { Stock at } \\
\text { Year End } \\
\text { AMA kg }\end{array}$ & $\begin{array}{r}\text { Codeine } \\
\text { Stock at } \\
\text { Year End } \\
\text { ACA kg }\end{array}$ \\
\hline 1957 & 999 & 800 \\
1958 & 2,187 & 1,093 \\
1959 & 980 & 1,429 \\
1960 & 2,789 & 1,773 \\
1961 & 5,989 & 1,365 \\
1962 & 10,790 & 948 \\
1963 & 9,283 & 3,119 \\
1964 & 1,217 & 2,067 \\
1965 & 1,107 & 1,017 \\
& & \\
\hline
\end{tabular}

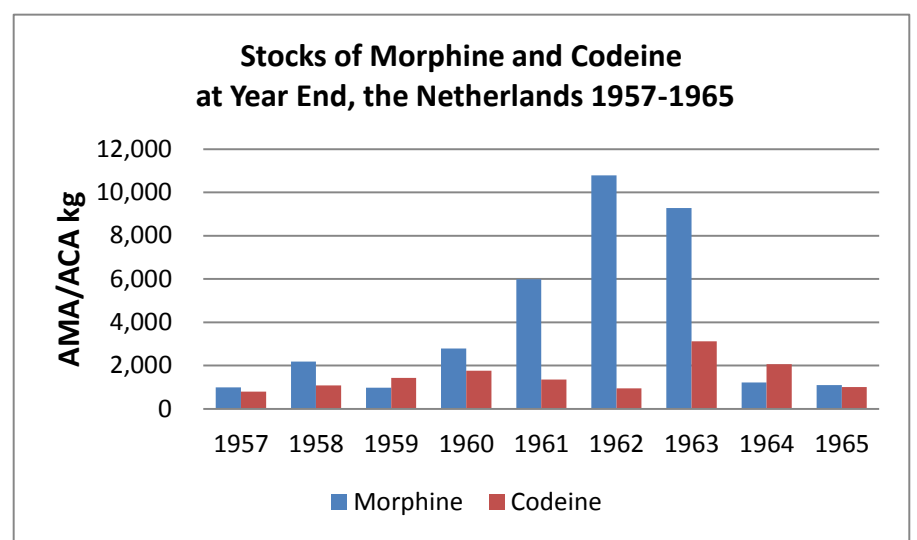

Source: PCOB Statistics

The figures apply to the total inventory in the Netherlands but the large stocks were mainly the result of overproduction at VPF. The Netherlands Government had to object to excessive stocks which were not allowed to accumulate under the rules of the Single Convention. This placed VPF in a difficult position. 
In VPF's annual reports 1961-1963, the situation of its alkaloid operations was commented on as follows:

1961: "Turnover of the alkaloid-sector was considerably below that of 1960 as a result of decreasing prices in the export market [in USD] and revaluation [of the NLG versus the USD, of about 5\%]."

1962: "For the alkaloid-sector it had not been an easy year. An increase in sales in NLG of $19 \%$ was achieved by selling $40 \%$ more in weight. Competition from Eastern European countries had become considerably fiercer. The trading by government agencies of these countries had caused severe price erosion. In the opinion of the VPF Board it was indicated that manufacturers in the opiate industry would attempt to collaborate internationally."

1963: "The situation in the international opiate market continued to cause anxiety".

\section{The Acquisition of VPF by KZO}

It was obvious for insiders that a merger of VPF and NCF would be an interesting proposition. NCF had good sales opportunities for opiates and had a limited production capacity, whereas VPF had large modern production facilities. At the VPF the owner/managing director Jansen had reached retirement age. VPF was not only a world-class opiate producer but also manufactured and marketed a range of other interesting products. ${ }^{120}$ KZO had bought NCF recently and continued its expansion by the acquisition of smaller companies, and VPF appeared to be a good new candidate. On the initiative of Nieukerke negotiations were started and on 24 June 1964 it was announced that KZO was acquiring all VPF shares on the basis of a swap of all 10,000 VPF shares for KZO shares in the ratio of 9:4. ${ }^{121}$ The NCF factory at Amsterdam was closed and existing management of NCF became the new management of VPF in its totality, with Nieukerke as the managing director.

\subsection{Summary and Conclusions}

During the period 1940-1960 the combined opiate manufacture of the Netherlands narcotic manufacturers grew from a production of about 1,000 kg AMA in 1939 to exceeding 10,000 kg AMA in the early 1960s, representing 2.5 and $8 \%$ of the total world production respectively. In fact, that growth started only in 1951 because the war was a period of deterioration and the first five years thereafter one of slowly rebuilding of the economy.

During the war both Bonnema/VPF and NCF used small quantities of locally grown poppy straw as the raw material and continued to do so after the war in an attempt to replace opium, which had become very expensive. Production from Dutch poppy straw was not a success because of the low and variable morphine content. Both companies switched over to the use of poppy straw lanced for opium, mainly from Turkey and Yugoslavia, and the use of this raw material resulted in the production of low cost crude morphine (EPC) and codeine. Both VPF and NCF were successful in developing a market for EPC, a product supplied to (smaller) opiate manufacturers as an alternative raw material for opium. This new market was much less restricted than that for codeine and allowed for growth of the companies. VPF managed the largest expansion of the two companies, investing courageously in modern extractors, while NCF used mainly existing equipment until 1956 and upgraded the facilities thereafter.

\footnotetext{
${ }^{120}$ Fusie van Organon en de Verenigde Pharmaceutische Fabrieken, NRC. (Newspaper) 30 July 1964.

${ }^{121} \mathrm{KZO} / \mathrm{VPF}$, Bericht inzake de fusie tussen de vennootschappen. (Announcement of the merger of the companies). Oss/Apeldoorn; 1964 July 30.
} 
In 1962 NCF was taken over Koninklijke Zwanenberg-Organon (KZO) on the basis of its potential for growth and it became obvious that merging NCF and VPF would be an economical proposition. That happened in 1964 when KZO also acquired VPF. The opiate production was moved to the VPF facilities at Apeldoorn and the NCF factory was closed. 


\section{CHAPTER 12 \\ NCF AND VPF UNDER KZO DURING THE 1960S}

\subsection{Introduction and Overview}

The 1960s was a period of major organisational restructure for both NCF and VPF. The shares of NCF were acquired by Koninklijke Zwanenberg Organon (KZO) in 1962, and in a subsequent move KZO obtained control over VPF by an exchange of shares in 1964. For both $\mathrm{NCF}$ and VPF this meant the end of an independent existence. However, the prospect for the future of the combined alkaloid operations under KZO was much better than for the two individual companies to be in competition with each other. Production facilities were merged at the VPF site and the integrated alkaloid marketing activities continued under the VPF name. NCF management was put in charge of the total VPF operations, including the Zwitsal and Pharmaceutical divisions.

As opiate stocks were high at VPF at the time of the acquisition, production was very substantially reduced and sales efforts were increased, leading to the desired correction. From 1965 morphine production was resumed at a modest level and expanded from 1967 onwards to meet increased demand, mainly for codeine. The main reason for the increased demand for codeine was probably that the Single Convention in Narcotics Drugs which came into force end 1964 had placed codeine in Schedule II, requiring less stringent controls for the drug. Opiate prices in the early 1960s were very low but improved gradually towards the end of the decade. Financial results of NCF and VPF were not published by KZO but the reported large sales volume of both morphine and codeine are an indication that, despite strong competition, the alkaloid business was performing well financially during the second half of the 1960s.

Extensive quantitative information on the manufacture of and the trade in opiates by country and worldwide is available from the 'Statistics on Narcotic Drugs'. ${ }^{1}$ These data are used widely in this chapter to describe the developments in the opiate industry world-wide and in the Netherlands, the more so as other published information is scarce for the period.

\subsection{The World Market for Opiates 1961-1970}

\section{International Narcotics Control}

In 1948 the ECOSOC of the United Nations had initiated consolidation of the 1925 and 1931 Geneva Conventions, and the Commission on Narcotic Drugs (CND) worked during the 1950s on the draft. At a conference held in New York in 1961 the draft was discussed by the signatories to the existing conventions and the aim of some parties to protect their local narcotics industry led to severe opposition to particular provisions of the draft. The negotiations resulted in a treaty, the Single Convention on Narcotic Drugs 1961, that did not go much further than consolidation of the existing Geneva Conventions. It achieved, however, a significant simplification of the control regime, while the principles of the previous treaties were upheld. The PCOB and the Drugs Supervisory Body were merged into a new body, the International Narcotics Control Board (INCB). ${ }^{2}$ For manufacturers of morphine from poppy straw, among them NCF and VPF, the most important change was that the trade in poppy straw became controlled in the sense that import certificates and export

\footnotetext{
${ }^{1}$ Statistics on Narcotic Drugs were published annually by the Permanent Central Opium Board (1946-1966) and from 1967 by the International Narcotics Control Board.

${ }^{2}$ William B. McAllister, Drug Diplomacy in the Twentieth Century (London 2000), 204-208.
} 
authorizations were required. ${ }^{3}$ It is reported that during the negotiations on the treaty: "Opium producers garnered enough support to insert language calling for controls over poppy straw, thereby placing one of their competitors under some limitations". 4

Another change in the regulations was that codeine, together with some minor opiates, was placed in Schedule II, thereby requiring somewhat less controls than substances such as heroin, morphine and concentrate of poppy straw (CPS), which were placed in Schedule I. An important consequence was that a medical prescription was not any longer required for the supply of codeine to individuals. Ratification of the Single Convention took some time, and the treaty came into force in December $1964 .^{5}$

\section{Developments in the World Market for Opiates Morphine}

Table 12.1 and chart shows that the average total world morphine production over the period 1961-1970 amounted to140 t p.a., a 50\% increase over the average production of $94 \mathrm{t}$ p.a. for the period 1951-1960.

Table 12.1 Morphine Manufacture by Country 1961-1970 (AMA kg)

\begin{tabular}{|c|c|c|c|c|c|c|c|c|c|c|c|}
\hline & Year & USSR & UK & USA & Hungary & Netherlands & France & Poland & $\begin{array}{l}\text { Czecho- } \\
\text { slovakia }\end{array}$ & $\begin{array}{c}\text { Other } \\
\text { Manuf. } \\
\text { Countries }\end{array}$ & $\begin{array}{l}\text { World } \\
\text { Total }\end{array}$ \\
\hline \multirow{11}{*}{$1961-1965$} & 1961 & 17,406 & 17,875 & 16,416 & 10,050 & 8,181 & 9,116 & 4,321 & 4,566 & 27,699 & 115,630 \\
\hline & 1962 & 18,614 & 15,625 & 19,024 & 12,064 & 14,782 & 7,009 & 5,099 & 4,777 & 24,054 & 121,048 \\
\hline & 1963 & 21,391 & 19,625 & 18,753 & 13,058 & 10,411 & 9,556 & 6,610 & 6,064 & 22,206 & 127,674 \\
\hline & 1964 & 23,392 & 16,819 & 17,850 & 13,007 & 3,964 & 10,484 & 6,230 & 7,146 & 20,108 & 119,000 \\
\hline & 1965 & 24,465 & 18,121 & 20,989 & 9,407 & 8,557 & 8,710 & 5,050 & 7,238 & 20,671 & 123,208 \\
\hline & $\begin{array}{l}\text { Average } \\
\text { Percent }\end{array}$ & 21,054 & 17,613 & 18,606 & 11,517 & 9,179 & 8,975 & 5,462 & 5,958 & 22,948 & 121,312 \\
\hline & 1966 & 33,917 & 25,163 & 23,261 & 9,634 & 7,718 & 11,513 & 6,458 & 4,505 & 26,689 & 148,858 \\
\hline & 1967 & 31,543 & 23,150 & 17,888 & 10,247 & 13,699 & 11,307 & 7,558 & 6,105 & 25,391 & 146,888 \\
\hline & 1968 & 32,606 & 24,018 & 20,512 & 14,561 & 13,140 & 11,081 & 7,495 & 7,384 & 25,455 & 156,252 \\
\hline & 1969 & 34,443 & 26,052 & 23,084 & 11,485 & 13,256 & 13,181 & 6,975 & 7,460 & 27,060 & 162,996 \\
\hline & 1970 & 37,031 & 26,896 & 22,349 & 8,645 & 17,172 & 14,650 & 8,661 & 6,253 & 34,752 & 176,409 \\
\hline \multirow[t]{2}{*}{$1966-1970$} & Average & 33,908 & 25,056 & 21,419 & 10,914 & 12,997 & 12,346 & 7,429 & 6,341 & 27,869 & 158,281 \\
\hline & Percent & 21 & 16 & 14 & 7 & 8 & 8 & 5 & 4 & 18 & 100 \\
\hline
\end{tabular}

Source: PCOB/INCB Statistics on Narcotic Drugs 1961-1970.

Note: the values for "Other Manufacturing Countries" by period were calculated by the author as the differences between the World Totals and the sum of the quantities mentioned in the first 8 columns.

\footnotetext{
${ }^{3}$ United Nations (ECOSOC), Single Convention on Narcotic Drugs 1961, Article 25.

${ }^{4}$ McAllister, Drug Diplomacy, 208.

${ }^{5}$ K. Bruun, L. Pan and I. Rexed, The Gentlemen's Club - International control of drugs and alcohol (Chicago 1975), 21.
} 
Figure 12.1 Morphine Manufacture by Country 1961-1970

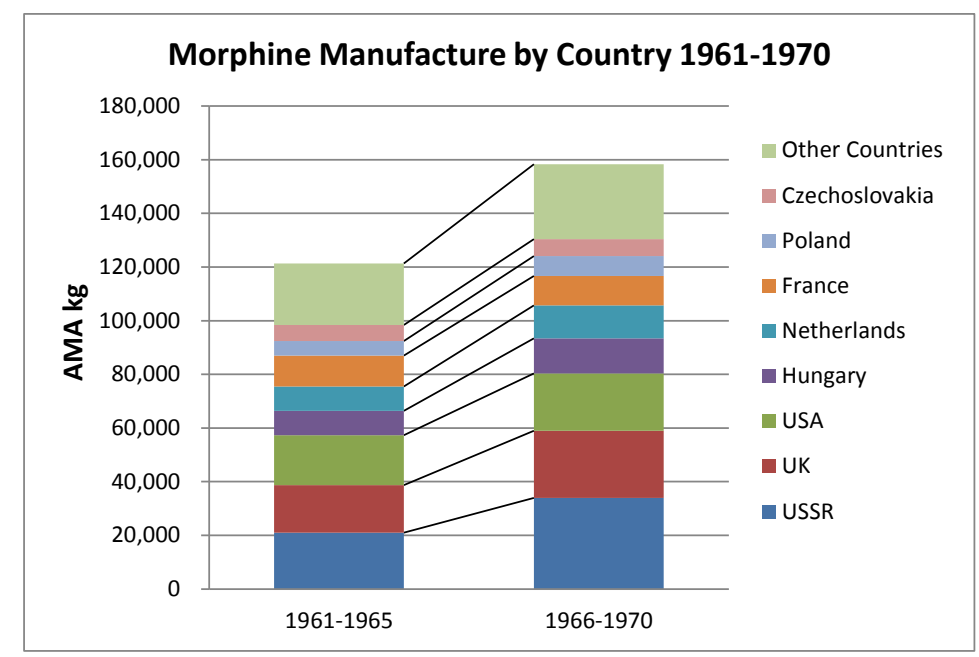

Source: Table 12.1

From 1963 the USSR became the largest producer of morphine, followed by the USA and the UK, which were number 1 and 2 during the 1950s. In the mid-1960s, in the USSR the quality of the poppy straw used as the raw material had improved substantially by the cultivating of a high yielding variety and harvesting the capsules more selectively. ${ }^{6}$ This must have been the reason for the increased morphine production in the Soviet Union. The UK, the Netherlands and France expanded morphine manufacture considerably compared to the 1950s to meet the demand for export of opiates. The strong reduction in production in the Netherlands in 1964 was a correction following the too large production in previous years. ${ }^{7}$ The production of morphine in the Federal Republic of Germany became insignificant. Germany had changed over to the use of imported technical morphine as the raw material for its codeine production

The manufacture of morphine from poppy straw had become much more important over the decade, not only in volume, which increased from $32 \mathrm{t}$ in 1961 to $59 \mathrm{t}$ in 1970, but also as a percentage of the total morphine production, which increased from $20 \%$ during the 1950 s to $32 \%$ during the period 1961-1970 (Table 12.2 and chart, below). In the 1960s the manufacture from poppy straw was largely confined to the Netherlands and Eastern European countries (table 12.3 below).

\footnotetext{
${ }^{6}$ G.Shuljgin,' Cultivating the opium poppy and the oil poppy in the Soviet Union', Bulletin on Narcotics, 1969[4]. 1-8.

${ }^{7}$ This correction is discussed in detail later in this chapter.
} 
Table 12.2 and Figure 12.2 Manufacture of Morphine Worldwide from Opium and Poppy Straw 1961-1970

\begin{tabular}{|c|c|c|c|c|}
\hline \multirow{2}{*}{ Year } & \multicolumn{3}{|c|}{$\begin{array}{c}\text { Manufacture of Morphine } \\
\text { AMA kg 000 }\end{array}$} & $\begin{array}{c}\text { ex Poppy } \\
\text { Straw } \\
\text { as a \% of } \\
\text { Total }\end{array}$ \\
\cline { 2 - 4 } & ex Opium & $\begin{array}{c}\text { ex Poppy } \\
\text { Straw }\end{array}$ & Total & \\
\hline 1961 & 83 & 32 & 116 & 28 \\
1962 & 77 & 44 & 121 & 37 \\
1963 & 84 & 33 & 117 & 28 \\
1964 & 81 & 38 & 119 & 32 \\
1965 & 88 & 35 & 123 & 28 \\
1966 & 114 & 35 & 149 & 23 \\
1967 & 97 & 50 & 147 & 34 \\
1968 & 94 & 63 & 156 & 40 \\
1969 & 105 & 58 & 163 & 36 \\
1970 & 118 & 59 & 176 & 33 \\
& & & & \\
Average & $\mathbf{9 4}$ & $\mathbf{4 5}$ & $\mathbf{1 3 9}$ & $\mathbf{3 2}$ \\
Percent & $\mathbf{6 8}$ & $\mathbf{3 2}$ & $\mathbf{1 0 0}$ & \\
\hline
\end{tabular}

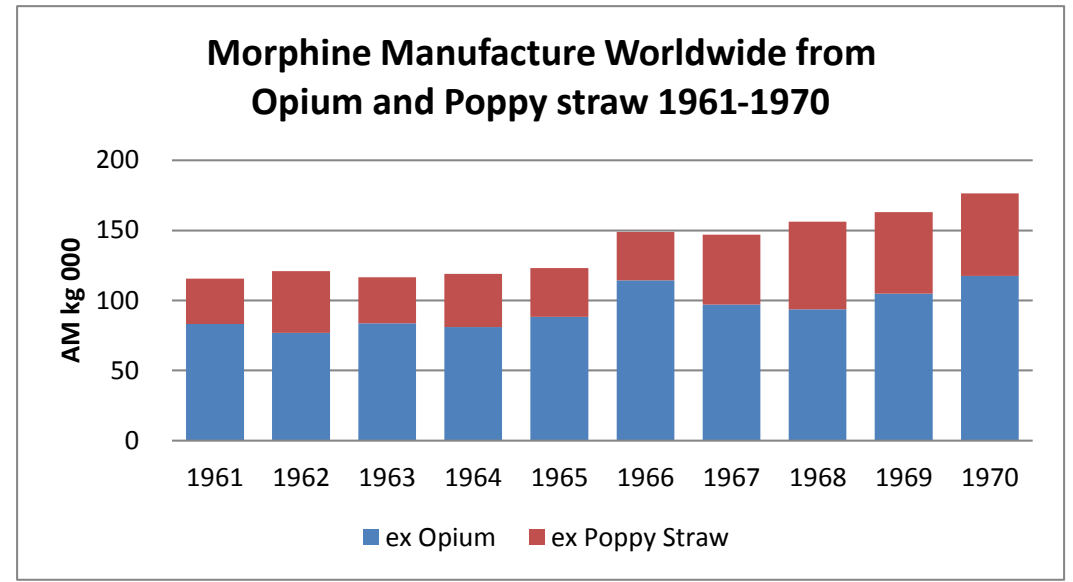

Source: PCOB Statistics 1961-1970

Table 12.3 Manufacture of Morphine from Poppy Straw in the major producing Countries in the Years 1960, 1965 and 1970

\begin{tabular}{|r|rrrrr|r|r|}
\hline Year & $\begin{array}{c}\text { Nether- } \\
\text { lands }\end{array}$ & USSR & Hungary & Poland & $\begin{array}{c}\text { Czecho- } \\
\text { slovakia }\end{array}$ & $\begin{array}{c}\text { Other } \\
\text { Countries }\end{array}$ & $\begin{array}{c}\text { World } \\
\text { Total }\end{array}$ \\
\hline 1960 & 8,266 & 1,189 & 8,292 & 4,939 & 3,112 & 4,619 & 30,417 \\
1965 & 8,557 & 905 & 6,766 & 5,050 & 7,238 & 6,337 & 34,853 \\
1970 & 15,894 & 11,820 & 11,038 & 8,661 & 6,253 & 5,202 & 58,868 \\
\hline
\end{tabular}


Except for the USSR, the other major manufacturers of morphine from poppy straw exported the product mostly as a raw material for the manufacture of codeine. The morphine was offered in various grades of purity, depending on the process used by the manufacturer and by the demands of the customer. The names of the various grades require some clarification as from 1966 the PCOB reported in Table III (Manufacture of Morphine) of the Statistics: "Concentrate of Poppy Straw (CPS) manufactured", "Morphine manufactured from poppy straw" and "Morphine manufactured from CPS" as separate items. The amount of CPS was reported as the (calculated) weight of a hypothetical product containing 50.00\% AMA.

The appearance of CPS in the Statistics followed from the inclusion of "Concentrate of Poppy Straw", defined as "The material arising when poppy straw has entered into a process for the concentration of its alkaloids, when such material is made available in trade", in Schedule 1 of the Single Convention on Narcotic Drugs $1961 .^{8}$ The sub-division of morphine produced from poppy straw in three different product categories, as done by the PCOB, is confusing and unnecessary from a technical point of view: it was the consequence of the politically motivated inclusion of poppy straw in the list of controlled substances of the Single Convention. ${ }^{9}$

The various grades of morphine require some technical explanation. When poppy straw is extracted for its alkaloids, the properties of the first solid product arising depend entirely on the quality of the poppy straw used as input and the extraction process applied. The Hungarian Kabay process used water as the primary solvent and the first solid product was a mixture of the alkaloids and a range of impurities, containing in the order of 50\% of AMA. In the Netherlands the extraction was performed with organic solvents and the first solid product was a crude morphine containing some secondary alkaloids, with an AMA content in the range of $60-70 \%$. The Hoffmann La Roche process used water as the primary solvent followed by an extraction of the aqueous phase with organic solvents and the first solid product had an AMA content of 80-85\%. Formally, all three first solid products arose from poppy straw and are therefore all "CPS" according to the definition of the Single Convention. However, technically and commercially they are quite different products. They all can be considered as a crude form of morphine and as such a potential raw material for making codeine but the amount of purification required before entering the codeine synthesis is very different and thereby the price of the "CPS" per kg AMA varies considerably with the morphine content. In the trade only the crude morphine containing ca 50\% AMA was considered to be a "true" Concentrate of Poppy Straw (formerly called EPC, Extractum Papaveris Crudum); crude morphine containing over $80 \%$ AMA was called "Technical Morphine". The crude morphine produced in the Netherlands was often diluted with inert substances to bring the AMA content down to ca 50\% allowing the product to be sold as CPS, carrying a lower duty than technical morphine. Technical morphine appears in the PCOB Statistics as "morphine manufactured from opium" or "morphine manufactured from poppy straw" depending on the raw material. These categories include relatively small quantities of pure morphine of pharmaceutical grade.

\footnotetext{
${ }^{8}$ United Nations, Multilingual List of Narcotic Drugs under International Control, E/CN.7/513 (New York 1968).

${ }^{9}$ Is discussed in Section 12.1 International Narcotics Control (McAllister).
} 
To show how much morphine was exported for use as raw material for the manufacture of codeine (including minor quantities for some other products), the total of the PCOB/INCB Statistics for exports of CPS and for Morphine combined are presented with the following table. Also shown are the major importing countries and the provenance of the goods.

Table 12.4 Total of Exports of CPS and Morphine Worldwide 1964-1970 (AMA kg)

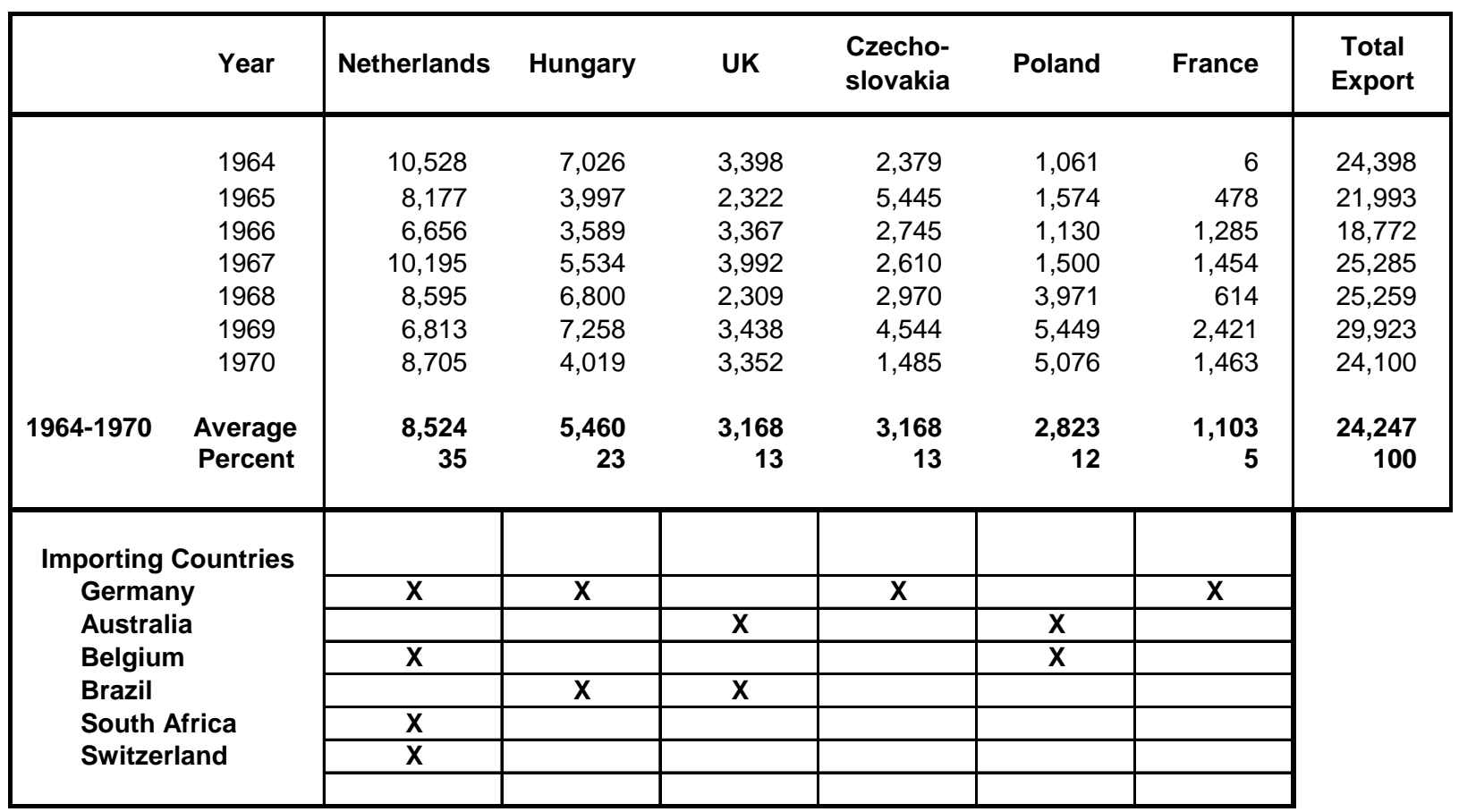

Source: PCOB Statistics 1964-1970.

Exports from the Netherlands and Poland were mainly in the form of CPS, exports from Hungary, Czechoslovakia were largely as technical morphine. ${ }^{10}$ For all these countries the principal raw material was poppy straw. The exports from the UK and France pertain almost totally to technical morphine made from opium.

Prices for CPS and technical morphine are not known for the period; the average opium price for the years 1962-1970 was USD 13.10 per kg. ${ }^{11}$ The maximum CPS price will have been equivalent to the opium price and is estimated at USD 132 per kg AMA. ${ }^{12}$ Prices for technical morphine will have been higher but, because of the high opium price, it must have been difficult for the companies in the UK and France to compete with the poppy straw processors in the open world market.

The UK manufacturer (Macfarlan Smith Ltd) exported technical morphine principally to Glaxo Australia, an affiliated company within the Glaxo Group. Ciech-Polfa from Poland supplied the other Australian codeine manufacturer, Abbott Australasia. VPF was the long

\footnotetext{
${ }^{10} \mathrm{EPC}$ from East European manufacturers was made using water as the primary solvent and contained difficult to remove impurities. The customers therefore preferred to buy technical morphine.

${ }^{11}$ Table OPI 9 (Part IV).

${ }^{12} 10 \mathrm{~kg}$ Indian opium at $10 \%$ AMA yields on average about $1.40 \mathrm{~kg}$ codeine phosphate, $1 \mathrm{~kg}$ AMA in CPS yields about $1.16 \mathrm{~kg}$ codeine phosphate (industry rules-of-thumb). Manufacturing cost codeine phosphate from CPS is USD 20 per kg less. USD $131 * 1.16 / 1.40+20 * 1.16=$ USD 132.
} 
term supplier of Bios-Coutelier (Belgium), Fine Chemical Corporation (South Africa) and Sandoz (Switzerland).

\section{Codeine}

The other important market for NCF/VPF was the codeine export market. The total codeine market grew by ca 50\% from the 1950s. This growth largely took place from 1965 and is probably mainly a result of the Single Convention on Narcotic Drugs coming into force end 1964. The new Convention placed certain substances, including codeine, in Schedule II which meant that no medical prescription was required for the supply of codeine containing preparations to individuals. ${ }^{13}$ An overview of the codeine export market compared to the total world consumption of codeine is provided with the following table:

Table 12.5 and Figure 12.3 Codeine Net Exports by Country 1964-1970 (ACA kg)

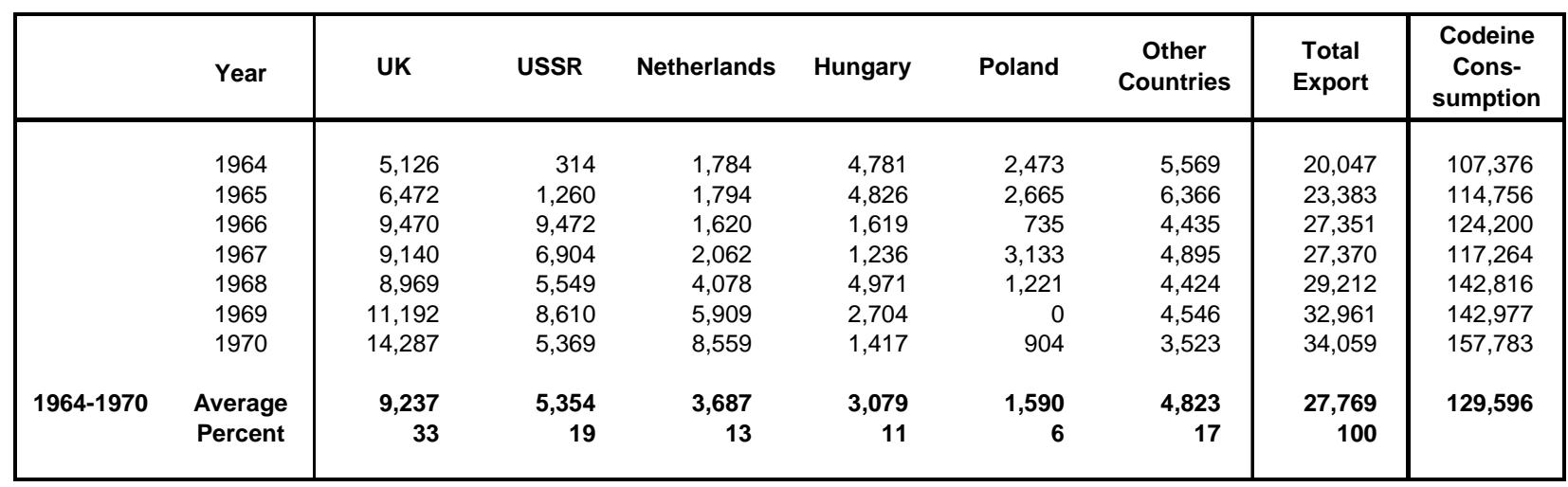

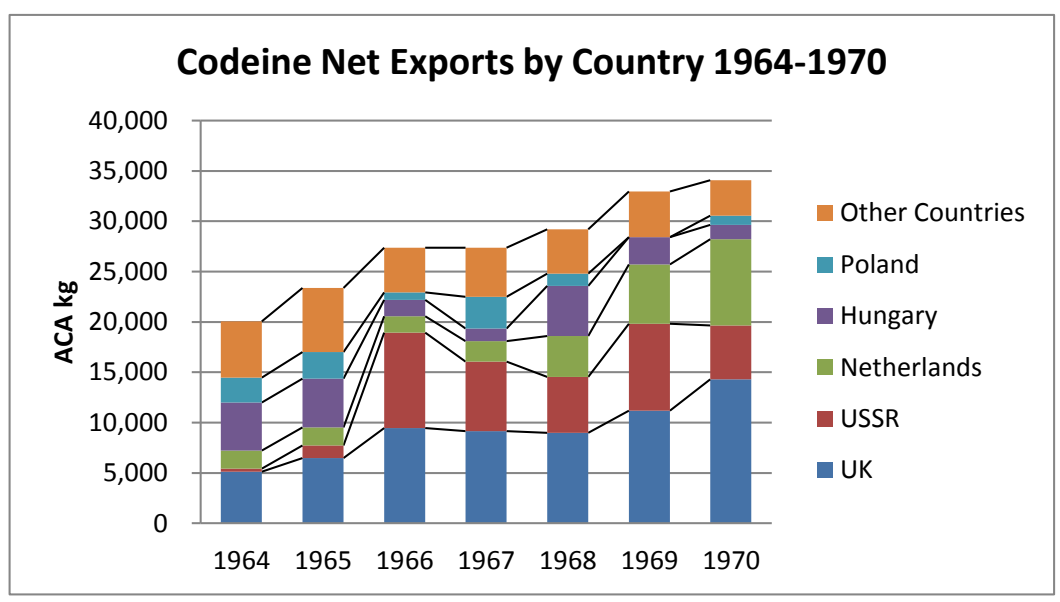

Source: PCOB Statistics 1964-1970. ${ }^{14}$

The UK remained the largest codeine exporter during the 1960s. The USSR exported from 1966 considerable quantities, almost exclusively to communist countries. The expansion of codeine export from the USSR can be attributed to the increased morphine production following improvements in the methods for poppy cultivation (Section 12.2). Codeine export from the Netherlands grew very substantially by penetration into new markets e.g. Turkey, Denmark and Mexico. Hungary stayed on average about the same. During the period 19641970 the codeine export market represented $21 \%$ of the total codeine consumption. All

\footnotetext{
${ }^{13}$ Population growth and better medical insurance coverage have been mentioned as main contributors to the increase of codeine use in the USA. INCB Report for 1980, p10. $\$ 30$.

${ }^{14}$ Figures largely taken from a compilation of PCOB data appearing in the Report of the INCB for 1980, Demand and Supply of Opiates for Medical and Scientific Needs E/INCB/52/Supp, UN, New York 1981.
} 
exporters supplied codeine to customers in many countries, of which Canada was the largest in terms of consumption. Patterns of who supplied who shifted with time and cannot easily be identified.

Codeine was a genuine commodity product; there was ample supply during the 1960s; the product had to comply with pharmacopoeia specifications but for the rest, selling was a matter of price only. As was the case in the 1950s, the Eastern European manufacturers quoted to sell. As a result codeine prices on the export market were low to very low during the period. The author remembers very clearly the horror at NCF when it became known, around 1962, that Slovakopharma, the Czechoslovakian opiate manufacturer, had offered codeine phosphate for USD 67 per $\mathrm{kg}$. This was an extreme case but the codeine phosphate price remained below USD 100 until the late 1960s. When the first order for codeine phosphate at a price above USD 100 was booked at VPF, the sales department shouted a round of coffee and cakes for all at the alkaloid department.

\section{Competitors - Macfarlan Smith Ltd.}

The main competitors of VPF/NCF in both the market for CPS/technical morphine were the state owned companies Alkaloida from Hungary, Ciech-Polfa from Poland and Slovakopharma from Czechslovakia. The UK company Macfarlan Smith was VPF's main competitor for codeine. The USSR supplied codeine largely to Bulgaria, the DDR, Czechoslovakia, Cuba and Vietnam which were for VPF not accessible markets. ${ }^{15}$

Macfarlan Smith Ltd was formed in 1960 by a merger of the Edinburgh based companies J F Macfarlan and T\&H Smith, both enterprises having their roots in eponymous pharmacies which commenced morphine manufacture already in the 1830s and continued to do so. Macfarlan and T \& H Smith were important opiate producers throughout the $19^{\text {th }}$ and the first half of the $20^{\text {th }}$ century. ${ }^{16}$ The timing of the 1960 merger is possibly related to increased competition from Eastern Europe and the corresponding decline of opiate prices.

Both companies pursued their manufacturing operations in a scientific way. In 1956 Dr E.L. Grew, deputy head of the Opiates Department at Macfarlan developed an improved process for the isolation of morphine from opium with yields that exceeded the official (Herd $\&$ Mundy) assay of the opium by 3 to 4 per cent. This was a major economic advantage and a new opium extraction facility using the new process was built in 1958. It was the basis for Macfarlan Smith's low manufacturing cost and thererby its strong position in the codeine export market during the 1960s.

Macfarlan and T \& H Smith collaborated closely already in 1951 when they jointly employed Mr Stephen M. King to investigate the possibility of developing new varieties of the opium poppy with a high morphine content that could be grown in the UK. This research was undertaken with the ultimate objective to produce low cost morphine in the UK, independent from opium imports. ${ }^{17}$ Mr King was successful and developed in a few years plants, the capsules of which contained close to 1 per cent morphine. Unfortunately, the weather in the UK was such that a large part the morphine was leached out of the capsules by rain before they could be harvested and it was decided to find a region more suitable than the UK to grow the poppies. The region identified as such was Tasmania, Australia, where trials started in 1964. New strains suitable for the Tasmanian conditions were developed and within a few years poppy capsules with a morphine content approaching $1 \%$ were produced on a

\footnotetext{
${ }^{15}$ Report of the INCB for 1980, E/INCB/52/Supp. UN, New York 1981.

${ }^{16}$ Information for this section was largely sourced from: K.C. Reid, 'The Macfarlan Smith Company. A brief review of its origins'. Unpublished manuscript. (1988, modified version 1990).

${ }^{17}$ King has reviewed his work in 'A brief history of poppy growing in Britain and Australia', Glaxo Australia Report (1980), quoted by K.C. Reid in 'The Macfarlan Smith Company', ref. [22].
} 
small scale. ${ }^{18}$ This was a major breakthrough as a morphine content of $0.4 \%$ in capsules was considered high at the time. Growing such high yielding poppies on a commercial scale should result in the manufacture of low cost morphine which was a challenge and steps were taken to achieve that objective as soon as possible in Tasmania. The plant breeding efforts were time consuming but eventually successful, and from 1972 onwards morphine was produced by Glaxo Australia in commercial quantities from locally grown poppies with yields of about $0.5 \% .{ }^{19}$ That yield would improve further in later years to exceed $1.0 \%$ for the first time in $1981 .^{20}$

\subsection{Opiate Manufacture in the Netherlands and Trade 1961-1970}

In this section data taken from the PCOB/INCB Statistics are used to describe the developments at NCF and VPF in terms of quantities manufactured and traded. For the years 1960-1964 the PCOB/INCB figures represent the sum of quantities manufactured and traded by these companies. During this period the capacity of NCF's manufacturing facilities was small in comparison to that of VPF, which had recently installed a large extractor. Hence, the INCB Statistics represent mainly VPF's output. ${ }^{21}$

Mid 1964 the NCF and VPF operations were merged and the manufacturing facilities of NCF were dismantled. From 1965 onwards the PCOB/INCB data for the Netherlands refer to the amounts produced at the VPF-site at Apeldoorn only.

\footnotetext{
18 'The Macfarlan Smith Company', page E2.

${ }^{19}$ K.C. Reid in 'The Macfarlan Smith Company', states on page E2 that "within a few years [from1964] full scale crops yielding one percent of morphine were being produced [in Tasmania].” However, the INCB Statistics for the years from 1972 show for Australia yields of morphine manufactured from commercial crops of around $0.5 \%$ until 1977, thereafter increasing to ca $1.0 \%$ in $1981 .$.

${ }^{20}$ Ibidem. INCB Statistics for 1981.

${ }^{21}$ Cf. Table 11.10 .
} 


\section{Morphine}

The data for morphine are compiled in Tables 12.6 and 12.7, and graphically represented in Figures $12.4-12.6$

Tables 12.6 and 12.7 Morphine Manufacture, Trade, Utilisation and Stocks the Netherlands 1961-1970

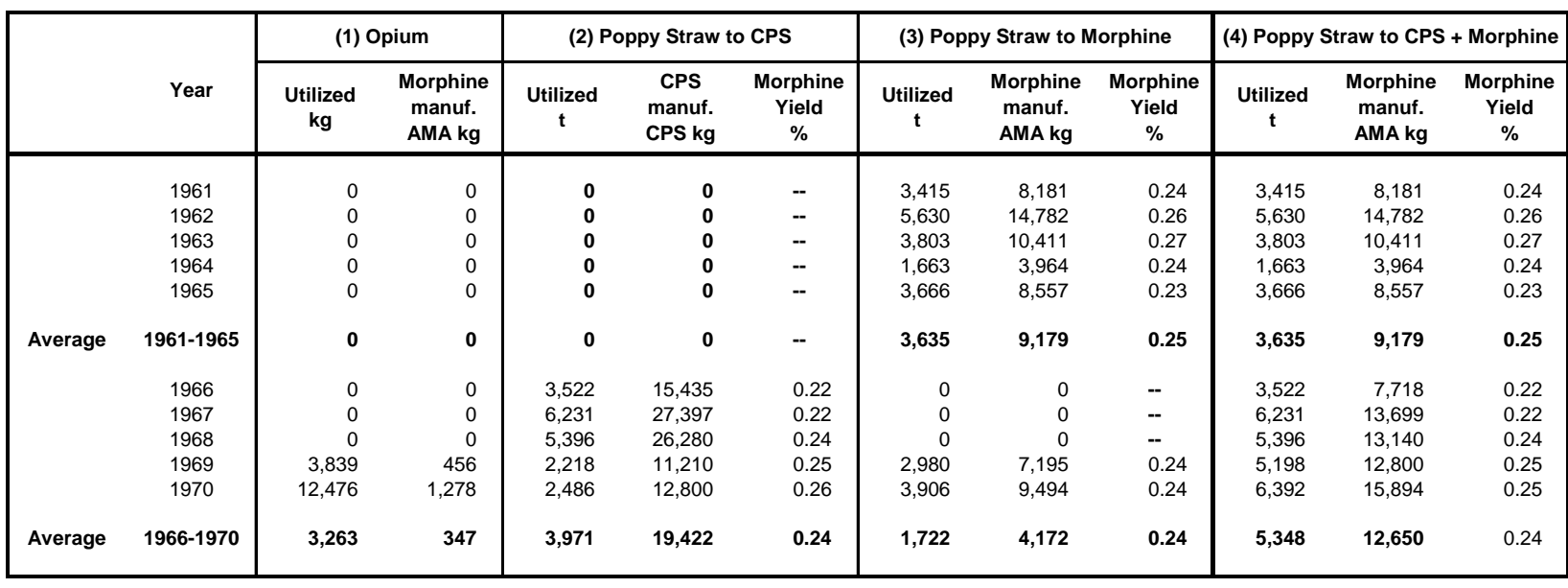

\begin{tabular}{|c|c|c|c|c|c|c|c|c|c|c|c|}
\hline & \multirow[b]{2}{*}{ Year } & \multicolumn{10}{|c|}{ Morphine (AMA kg) } \\
\hline & & $\begin{array}{c}\text { Total } \\
\text { Manu- } \\
\text { facture }\end{array}$ & Export & Import & $\begin{array}{l}\text { Converted } \\
\text { into } \\
\text { Codeine }\end{array}$ & $\begin{array}{c}\text { Converted } \\
\text { into Other } \\
\text { Opiates }\end{array}$ & \begin{tabular}{|} 
Local \\
Consump- \\
tion
\end{tabular} & $\begin{array}{l}\text { Total Net } \\
\text { Trade and } \\
\text { Converted }\end{array}$ & $\begin{array}{c}\text { Stock } \\
\text { Increase }\end{array}$ & $\begin{array}{c}\text { Stock } \\
\text { Calculated }\end{array}$ & $\begin{array}{l}\text { Stock } \\
\text { PCOB }\end{array}$ \\
\hline \multirow{12}{*}{ Average } & 1960 & & & & & & & & 0 & 2,789 & 2,789 \\
\hline & 1961 & 8,181 & 2,809 & 45 & 2,163 & 30 & 24 & 4,981 & 3,200 & 5,989 & 5,989 \\
\hline & 1962 & 14,782 & 5,329 & 7 & 4,546 & 72 & 31 & 9,971 & 4,811 & 10,800 & 10,790 \\
\hline & 1963 & 10,411 & 6,528 & 4 & 5,326 & 23 & 37 & 11,910 & $-1,499$ & 9,301 & 9,283 \\
\hline & 1964 & 3,964 & 10,528 & 2 & 1,375 & 90 & 37 & 12,028 & $-8,064$ & 1,237 & 1,217 \\
\hline & 1965 & 8,557 & 8,177 & 468 & 903 & 22 & 25 & 8,659 & -102 & 1,135 & 1,107 \\
\hline & $1961-1965$ & 9,179 & 6,674 & 105 & 2,863 & 47 & 31 & 9,510 & & & \\
\hline & 1966 & 7,718 & 6,656 & 928 & 2,201 & 101 & 16 & 8,046 & -329 & 807 & \\
\hline & 1967 & 13,699 & 10,195 & 0 & 2,297 & 54 & 29 & 12,575 & 1,124 & 1,930 & \\
\hline & 1968 & 13,140 & 8,595 & 492 & 3,995 & 145 & 23 & 12,266 & 874 & 2,804 & \\
\hline & 1969 & 13,256 & 6,813 & 99 & 6,709 & 47 & 32 & 13,502 & -246 & 2,558 & \\
\hline & 1970 & 17,172 & 8,705 & 0 & 8,243 & 0 & 22 & 16,970 & 202 & 2,760 & \\
\hline Average & $1966-1970$ & 12,997 & 8,193 & 304 & 4,689 & 69 & 24 & 12,672 & & & \\
\hline
\end{tabular}

Source: PCOB/INCB Statistics (INCB from 1967)

Notes: Stock is inventory at year end. The reason for the small differences between the calculated amounts of morphine in stock and the PCOB statistics is not known. For the years from 1966 no PCOB/INCB statistics on stocks were found.

The column "Total Manufacture" of Table 12.7 is the sum of the quantities of morphine manufactured appearing in sections (1) and (4) of Table 12.6. 
Note to Tables 12.6 and 12.7: In accordance with the Single Convention of 1961, from 1966 exports of concentrate of poppy straw (CPS) were reported as such by the INCB; formerly they were declared as morphine of unspecified quality, the quantity expressed in kg AMA. ${ }^{22}$ It was for formal reasons that the name changed from morphine into CPS when it "was made available in trade". ${ }^{23}$ Even the INCB got confused and from 1966 to 1968 all morphine produced from poppy straw (sold or not) was included in the Statistics as CPS but from 1969 onwards morphine produced from poppy straw was split in CPS and "morphine" (See table 12.6). Apparently from 1969 CPS was a crude morphine of ca 50\% AMA and "morphine" included technical morphine (TM) containing over 80\% AMA, suitable for conversion into codeine. Sections 2 and 3 of Table 12.6 contain the INCB figures, the amounts of CPS are reported (recalculated) as containing 50\% AMA. The figures in section 4 of Table 12.6 are the sum of the corresponding figures in sections 2 and 3, the amounts of CPS being counted as 50\%. All amounts are expressed in kg AMA. The figures in section 4 provide allow for comparison of the manufacture of morphine from poppy straw of all years during the period.

Table12.6 and Figure 12.4 show that in the Netherlands virtually all morphine was produced from poppy straw, but during 1969 and 1970 small amounts were made from opium. There was a steep increase in production in the Netherlands during 1961-62 to almost 15,000 kg AMA in 1962, followed by a steep fall to 4,000 kg AMA in 1964. Figure 12.6 shows that the morphine production during 1961-62 was substantially larger than the total requirements for export and conversions. In other words there was over-production (at VPF) and stocks increased to reach high levels at the end of 1962 and 1963 (Table 12.7). ${ }^{24}$ That situation was remedied by the sharp reduction in production and large sales in the export market in 1964 (Figures 12.5 and 12.6). Morphine export receded somewhat in 1965-66 but recovered thereafter, and the amounts converted into codeine increased (Figure 12.5). Morphine manufacture amounted to over $17,000 \mathrm{~kg}$ in 1970 . Increased competition for Turkish poppy straw by Eastern European processors during 1969-1970 and an expanding codeine market resulted in a minor raw material shortfall for VPF which was solved by buying Indian opium which was processed by co-extracting it with Turkish poppy straw.

\footnotetext{
${ }^{22}$ INCB Report for 1980 (E/INCB/52/Supp) Paragraph 181.

${ }^{23}$ United Nations, Multilingual List of Narcotic Drugs under International Control, E/CN.7/513 (New York 1968).

${ }^{24}$ Presumably, large quantities of poppy straw were bought during 1959-1960 on the basis of (in hindsight) an optimistic sales forecast. Extraction capacity was available and, probably, processing the poppy straw without delay was the most economical option.
} 
Figures 12.4 - 12.6 Charts of Morphine Manufacture,

Conversions and Net Export, the Netherlands 1961-1970

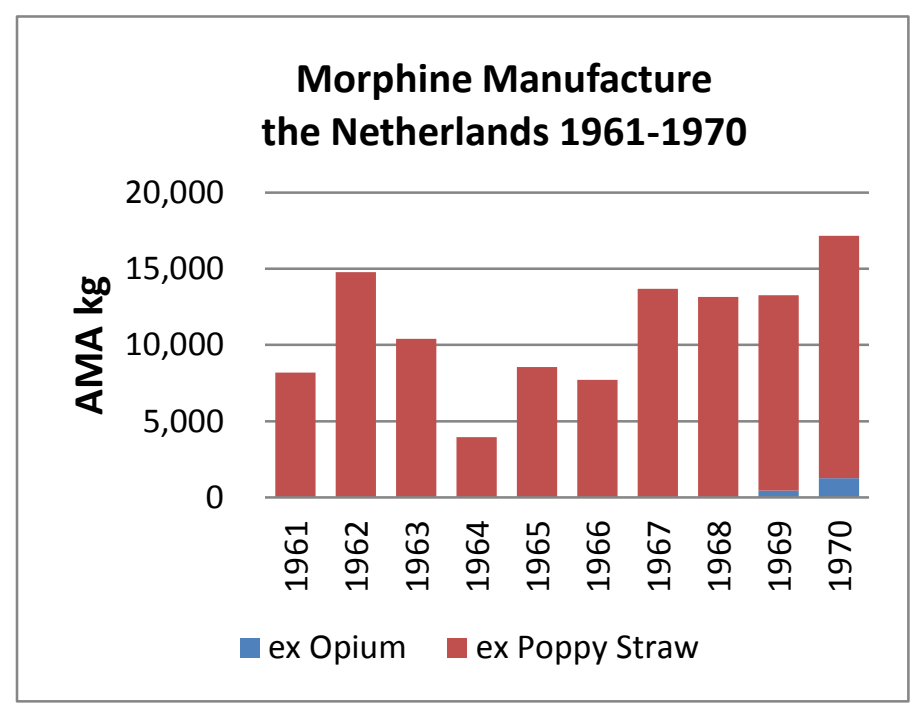

Figure 12.4

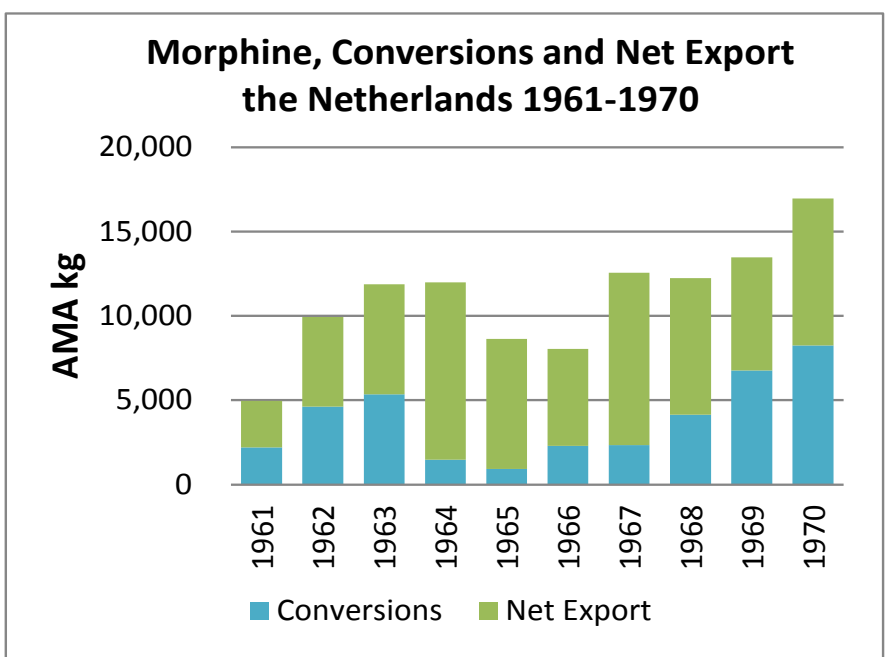

Figure 12.5

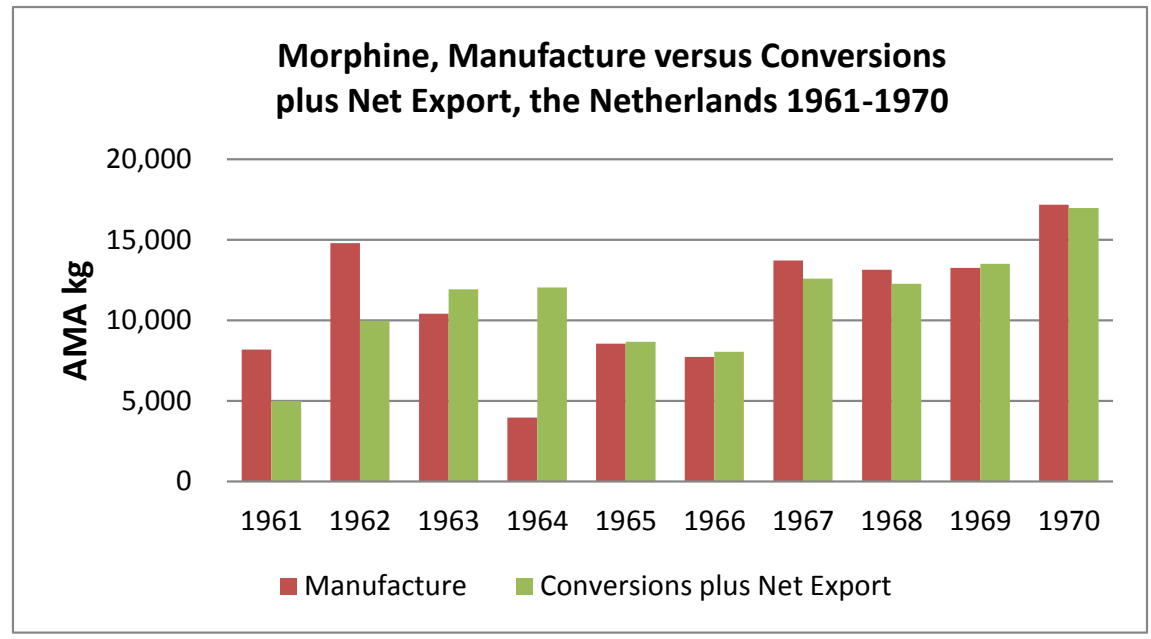

Figure 12.6 


\section{Codeine}

The data for codeine are compiled in Table 12.8 and are graphically represented in Figure 12.7

Table 12.8 and Figure 12.7 Codeine Manufacture, Net Export and Local Consumption, the Netherlands 1961-1970

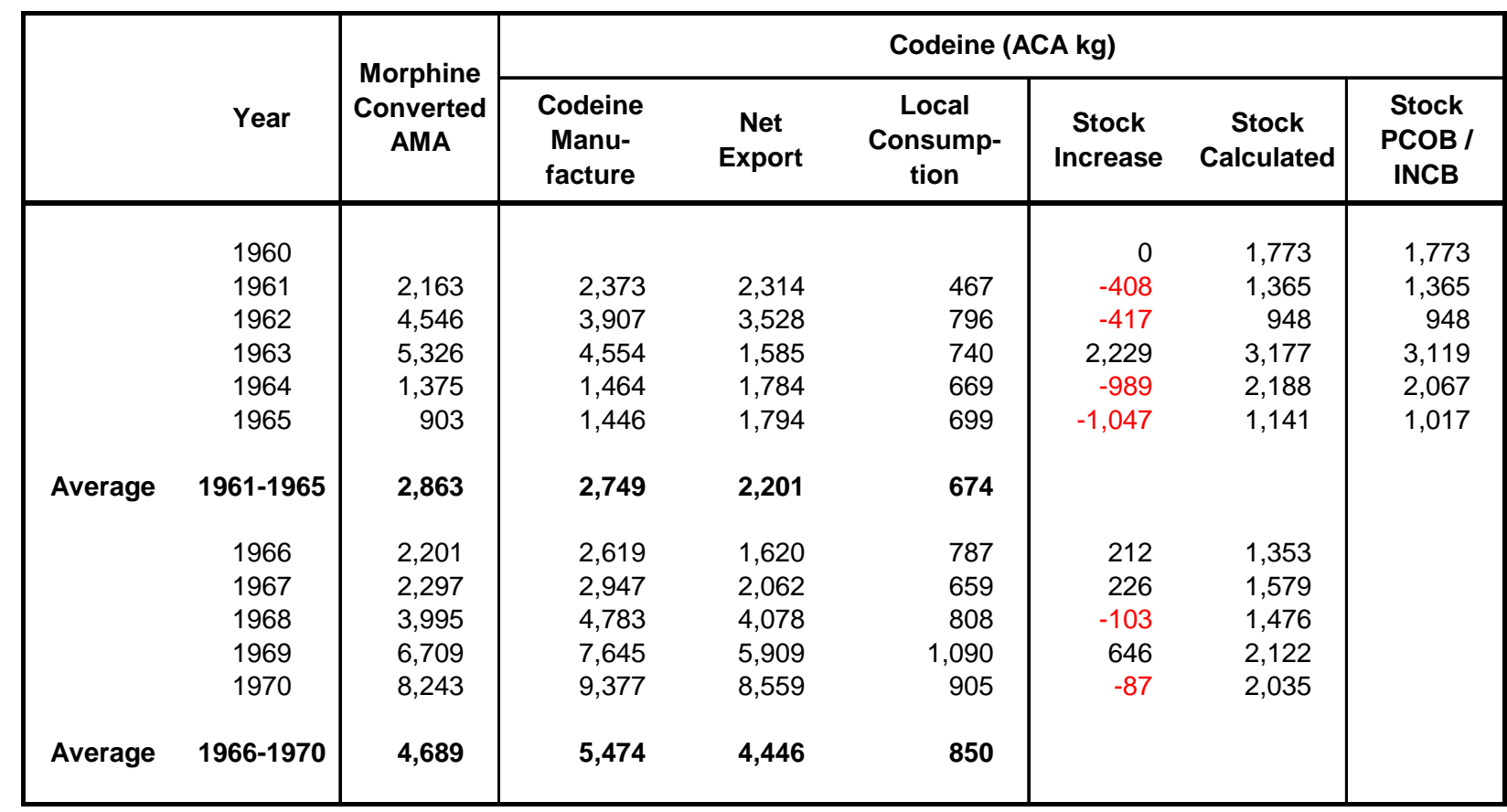

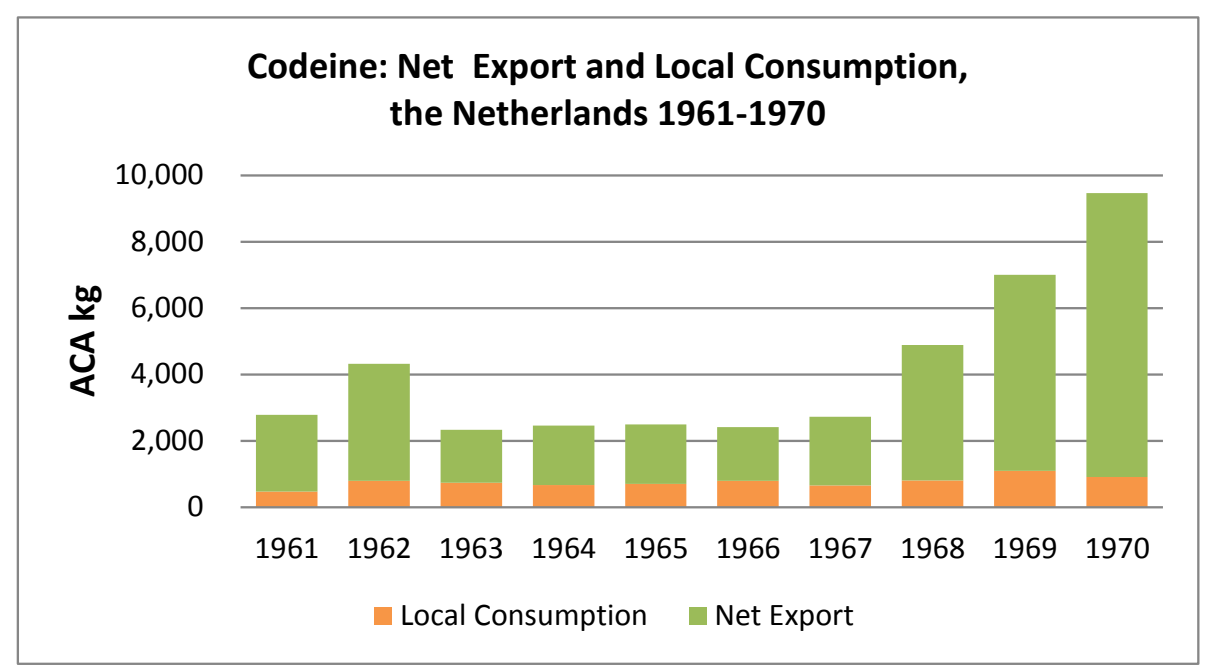

Source: PCOB/INCB Statistics (for net export from 1964: INCB Report for 1980, E/INCB/52/Supp).

Note: Net export means total exports less (minor quantities of) imports.

Table 12.8 and Graph 12.7 show a similar picture for codeine as appearing for morphine i.e. overproduction during 1963, a correction during 1964-65 and a considerable increase in output and export during 1968-70 in an expanding market. 


\subsection{NCF under KZO}

Despite the acquisition by KZO NCF continued to operate quite independently. Except for the financial reporting and approvals required for investments, no direct influences of the KZO organisation on running the business were noticeable. With respect to the NCF organisation, Nieukerke remained managing director, Gerard Kloet his deputy and the author's function stayed the same.

For NCF the acquisition by KZO meant that money became available for upgrading and expansion of the production facilities and the laboratory. This caused a general feeling of the company starting a new life and the wish by management and employees to make that happen. The projects that were undertaken in 1962-1963 were: ${ }^{25}$

- An expansion of the poppy straw extraction facilities by replacing the oldest extraction battery (from 1917) with a new and larger one, in doing so increasing the extraction capacity by about $50 \%$;

- Mechanisation of the milling and mixing operations for poppy straw and installation of moving belts for the transportation of the pre-treated straw to the extractors;

- Installation of a 50-litre QVF glass reactor in a newly tiled room for making thebaine derivatives such as hydrocodone and oxycodone;

- Building a production facility for tubocurarine chloride;

- Substantial upgrading of the laboratory for both quality control and research.

For the purpose of improved process control the laboratory developed and implemented a fast colorimetric assay of morphine in poppy straw and process liquors. Research on new and improved processes for making codeine, dihydrocodeine, tubocurarine chloride and cocaine and other tropa alkaloids was undertaken. ${ }^{26}$

$\mathrm{NCF}$ also became involved in research work for Organon in the framework of evaluating alternative raw materials. Organon had an interest in funtumine, an alkaloid with a steroid skeleton occurring in the leaves of the African tree Funtumia latifolia. ${ }^{27}$ At NCF a process for the extraction of funtumine from the leaves was developed successfully.

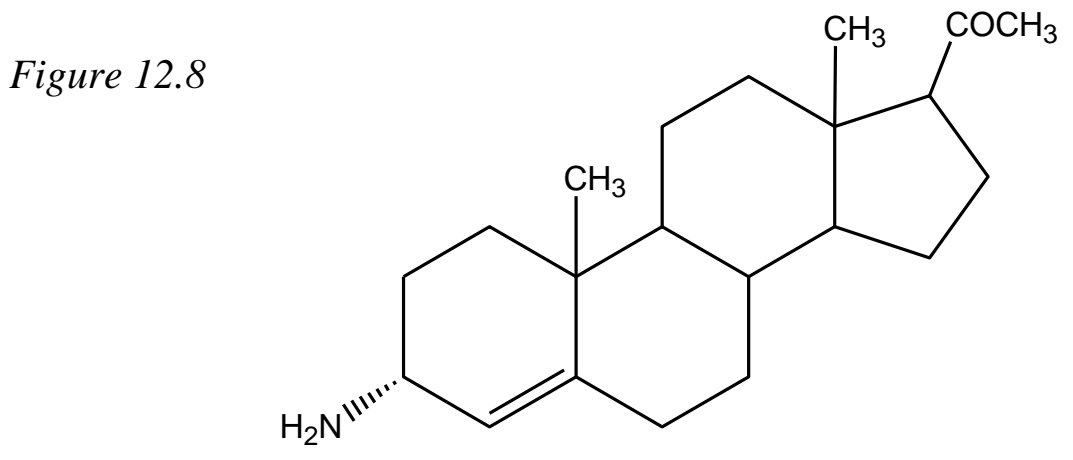

Funtumine

\footnotetext{
${ }^{25}$ Projects undertaken by the author.

${ }^{26}$ It was mentioned in the KZO Annual Report for 1963 that NCF intended to produce alkaloids other than opiates in 1964. VNCI publication No 10 of 10 May 1964.

${ }^{27}$ M.-M. Janot et al., 'Alkaloids from Funtumia latifolia', Comptes rendus, 246 (1958) 3076.
} 


\subsection{Impact of the Acquisition on VPF}

\section{Organisational}

After the acquisition VPF became part of the pharmaceutical division of KZO. It was clear from the start that a major implication of the acquisition was that the NCF manufacturing facilities in Amsterdam would close down and that the alkaloid operations of both companies would merge and all production facilities would be located at the VPF site at Apeldoorn. $\mathrm{Mr}$ Jansen retired and NCF management became the new management of VPF. Nieukerke was appointed as managing director, Kloet as finance director and the author became operation manager of the total VPF factory and chief chemist. Under the new organisation, existing VPF management viz.: Dr F. Steenmeijer, pharmacist; J. Wijnberg, manager technical services; Gratama, manager alkaloid production and Hans Prins, manager pharmaceutal/cosmetical production, retained their functions, reporting to former $\mathrm{NCF}$ management. Piet van den Biggelaar joined the team as marketing manager.

\section{Morphine and Codeine production \\ Processes and Equipment}

The NCF factory was dismantled and some valuable equipment (e.g. the new tubocurarine production unit) was transferred to Apeldoorn. Most of the manufacturing equipment, however, was considered too old and was disposed of. A few years later all factory buildings at Duivendrecht were demolished and the land was sold.

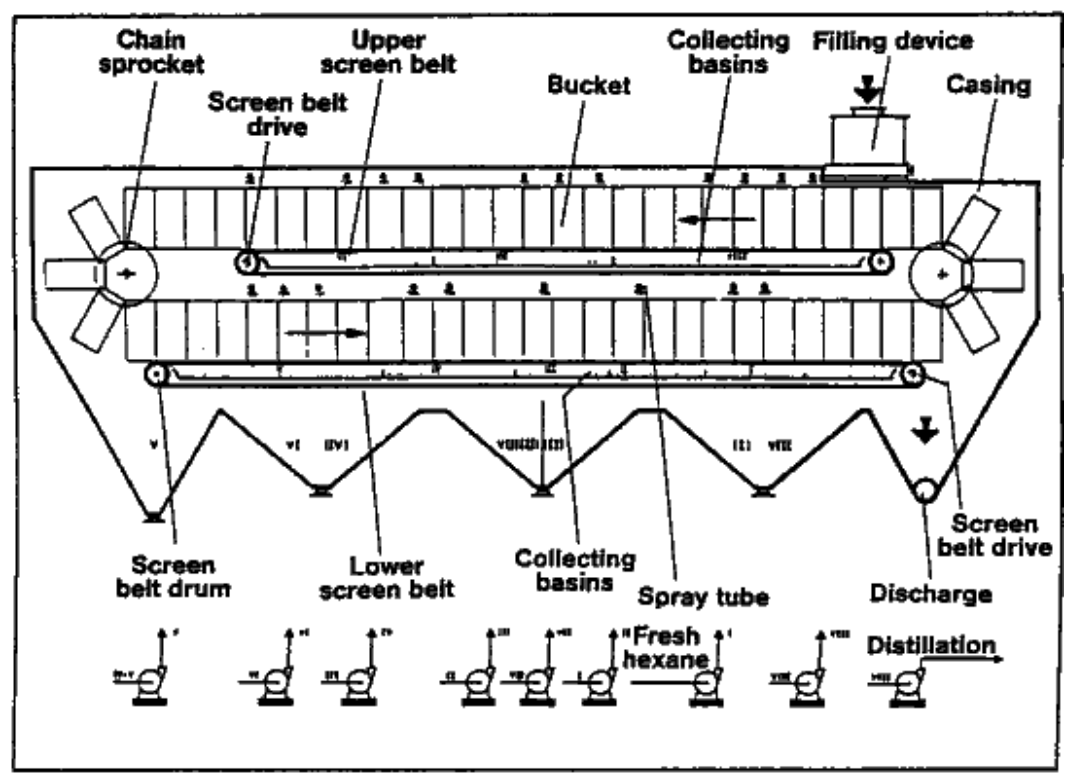

Figure 12.9

Diagram of the Lurgi Belt Extractor

The large Lurgi extractor commissioned by VPF in 1960 (Figure 12.9) had a capacity for processing 5,000-6,500 tonnes poppy straw p.a. yielding 12,500-16,000 kg morphine (AMA), sufficient to cope with the sales forecast for morphine and codeine of VPF and NCF combined. Process and equipment performed very well, and the morphine extraction yield was about $95 \%$ of the input in poppy straw. 
The primary extraction solvent was a toluene/butanol mixture. ${ }^{28}$ The alkaloids were re-extracted with acid to an aqueous phase and CPS (crude morphine) was precipitated there from by adjusting the $\mathrm{pH}$ to 9 (Figure 12.10 and 12.11). After subsequent extraction of the natural codeine and thebaine the mother liquors were recycled by adding them to fresh poppy straw before it entered the extractor.

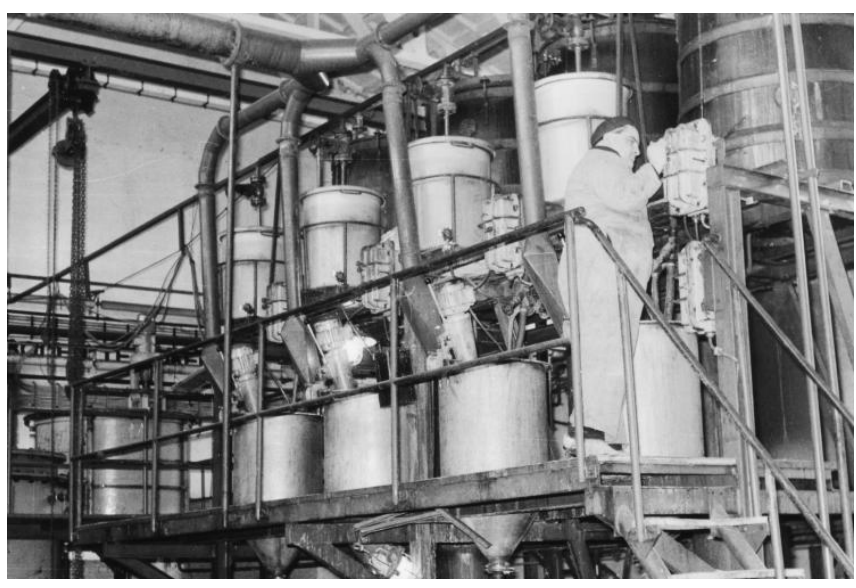

Figure 12.10

Morphine (CPS) precipitation unit at $V P F$ (Photo Collection HHB)

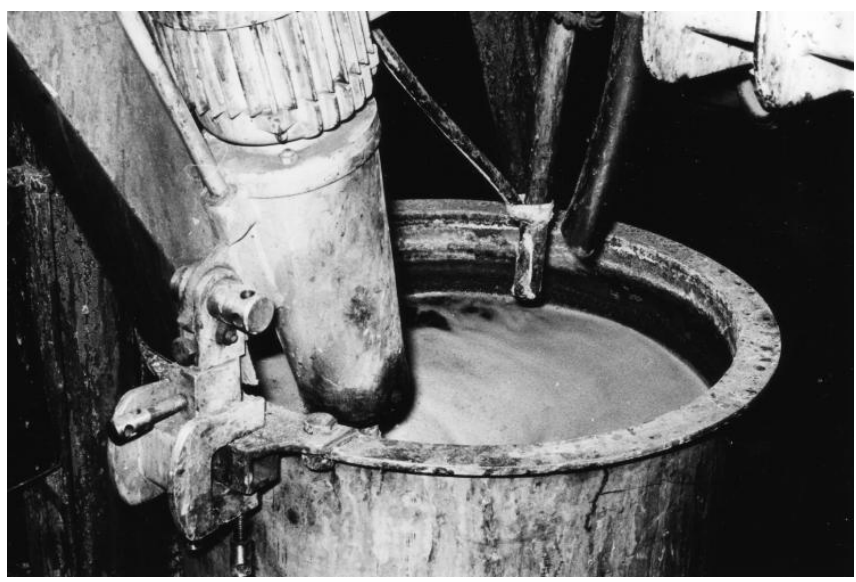

Figure 12.11

Close-up of the morphine precipitation (Photo Collection HHB)

The VPF codeine process was the traditional one using phenyltrimethylammonium chloride. $^{29}$ There was sufficient capacity for making codeine to satisfy the sales opportunities for the foreseeable future. The alkaloid processes developed at the VPF by chemists Gratama and Moorhoff worked well and with good yields. From 1964 NCF process know-how was compared with that of VPF and improvements to the VPF processes were implemented wherever feasible.

Mid 1964 stocks of morphine and codeine at VPF were high in comparison with immediate sales prospects. This was the reason that production at NCF was halted completely as soon as agreement was reached on the acquisition of VPF by KZO. Morphine production at VPF was substantially reduced and inventory of morphine came down to an

\footnotetext{
${ }^{28}$ The primary extraction solvent that was used at NCF was a mixture of benzene and butanol. Although this was the better solvent from a process point of view, the use of toluene instead of benzene was indicated on the basis of health and safety considerations.

${ }^{29}$ The NCF process using diazomethane as the methylating agent was abandoned.
} 
acceptable level already at the end of 1964 (Table 12.7) and for codeine that was the case at the end of 1965 (Table 12.8).

\subsection{VPF under KZO - The Years 1964-1970}

\section{Opiate Marketing and Prices}

The combined customer base of NCF and VPF was supplied from Apeldoorn. CPS exports were to South Africa (Fine Chemicals Corporation), Belgium (Coutelier) and Switzerland (Sandoz), and Technical Morphine (TM) was exported mainly to Germany (Gödecke), all on the basis of long-term contracts. Codeine exports went to a multitude of countries, the largest of which were Mexico, Denmark and other Scandinavian countries; details are available from the INCB statistics. Larger codeine export sales contracts could be obtained by quoting low for international tenders. Direct sales to international customers were mostly on the basis of regular visits by the marketing manager and local representatives, and quoting by phone/telex. Alternatively, codeine for export was sold via large traders in fine chemicals such as Helm (Hamburg) and Marsing (Copenhagen).

Towards the end of the decade VPF and the government owned organisations in the USSR and in Hungary had together become the largest producers of morphine from poppy straw.

Competition in the export markets remained fierce. Prices improved somewhat towards the end of the decade but the price for codeine phosphate in the open world market still did not exceed USD 100 per kg until the late 1960s..

Total sales volume of morphine and codeine VPF 1965-1970 are summarised in the table and chart below. Total sales volume (export plus local sales) increased considerably during the period, largely the result of increased codeine sales.

Table 12.9 and Figure 12.12 Total Sales Volume

Morphine and Codeine at VPF 1965-1970 (kg AMA/ACA)

\begin{tabular}{|r|rr|r|}
\hline Year & Morphine & Codeine & \multicolumn{1}{|c|}{ Total } \\
\hline 1965 & 7,734 & 2,493 & 10,227 \\
1966 & 5,744 & 2,407 & 8,151 \\
1967 & 10,224 & 2,721 & 12,945 \\
1968 & 8,126 & 4,886 & 13,012 \\
1969 & 6,746 & 6,999 & 13,745 \\
1970 & 8,727 & 9,464 & 18,191 \\
\hline
\end{tabular}

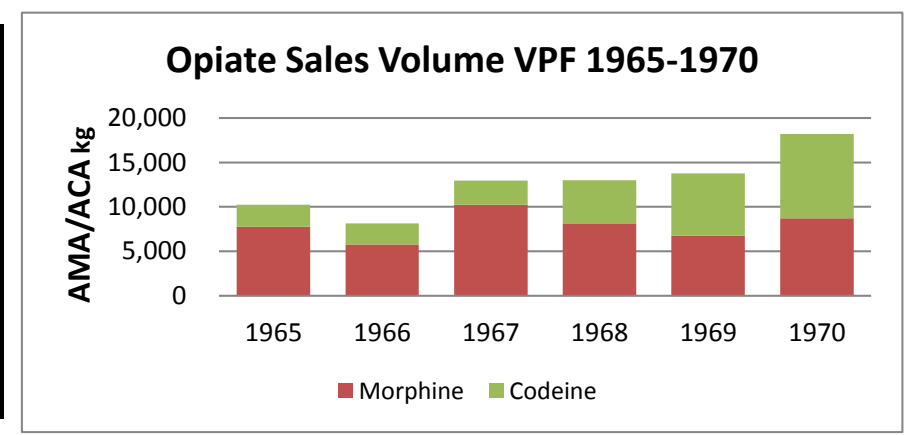

Source: INCB Reports 1965-1970 (Tables 12.7 and 12.8).

Using the volume of morphine and codeine sales of Table 12.12 together with an estimated morphine price of USD 127 per kg AMA (price equivalent to the average Indian opium price of USD 12.50) and an estimated codeine (ACA) price of USD 147 per $\mathrm{kg}$ (an average codeine phosphate price USD 109 per $\mathrm{kg}$ ), a ballpark estimate of average total sales revenue has been made, resulting in an amount of NLG 6 million p.a. 


\section{Raw Materials}

VPF imported the poppy straw to a very large extent from Turkey where it had set up an affiliate "Unipharma", director Mr Nedim Zaim, to organise the buying and the shipping to the Netherlands. Some poppy straw was imported from Yugoslavia and in 1969-70 also from the USSR. VPF was the largest buyer of poppy straw from Turkey during the 1960s.

Table 12.10 and Figure 12.13 Import of Poppy Straw into the Netherlands 1964-1970

\begin{tabular}{|c|c|c|c|c|c|c|c|c|c|}
\hline & \multicolumn{3}{|c|}{ Turkey } & \multicolumn{3}{|c|}{ Yugoslavia } & \multicolumn{3}{|c|}{ USSR } \\
\hline & Total & $\begin{array}{l}\text { Nether- } \\
\text { lands }\end{array}$ & Neth. \% & Total & $\begin{array}{l}\text { Nether- } \\
\text { lands }\end{array}$ & Neth. \% & Total & $\begin{array}{l}\text { Nether- } \\
\text { lands }\end{array}$ & Neth. \% \\
\hline 1964 & 2,431 & 1,964 & 81 & 1,060 & 670 & 63 & -- & -- & -- \\
\hline 1965 & 4,091 & 2,798 & 68 & 1,478 & 485 & 33 & -- & -- & -- \\
\hline 1966 & 9,283 & 7,155 & 77 & 356 & 51 & 14 & -- & -- & -- \\
\hline 1967 & 5,717 & 3,952 & 69 & 316 & 286 & 91 & -- & -- & -- \\
\hline 1968 & 6,518 & 4,416 & 68 & 35 & 35 & 100 & -- & -- & -- \\
\hline 1969 & 12,628 & 6,364 & 50 & 611 & 603 & 99 & 205 & 205 & 100 \\
\hline 1970 & 10,832 & 5,450 & 50 & 611 & 611 & 100 & 2,181 & 1,666 & 76 \\
\hline
\end{tabular}

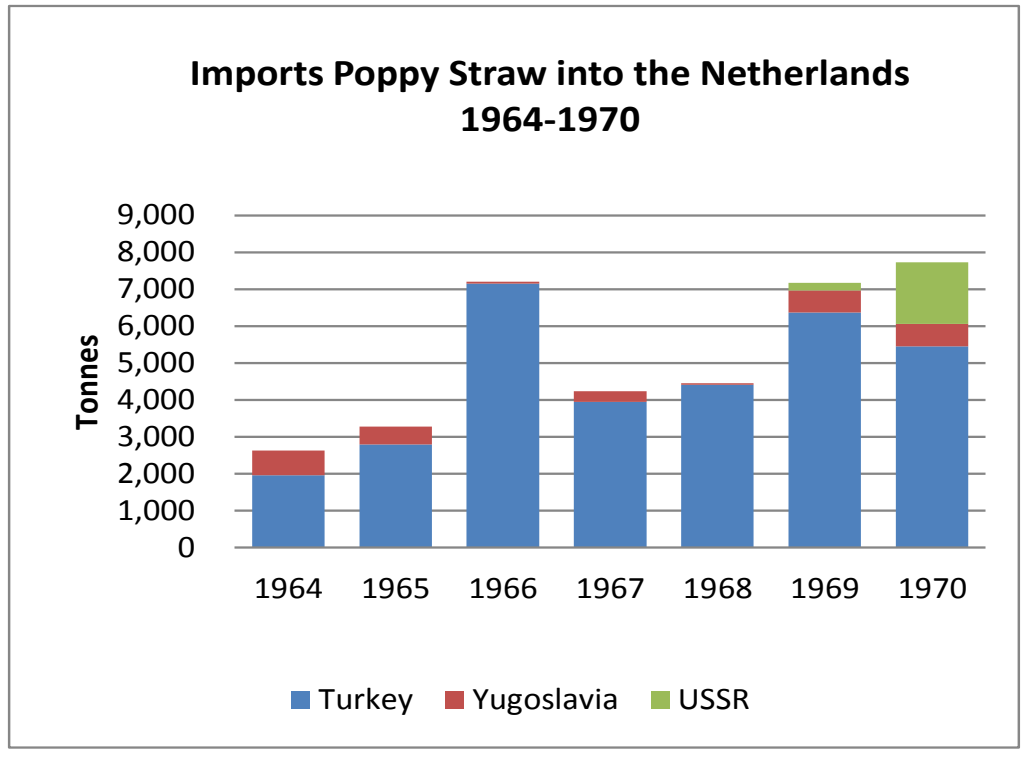

Source: INCB Report for 1980, E/INCB/52/Supp

From 1962, Turkey progressively reduced the number of provinces where opium cultivation was authorised and the opium production fell to about half the quantity produced during the previous decade. ${ }^{30}$ Remarkably, despite the reduction in opium production, the volume of poppy straw exported from Turkey increased strongly during the 1960s (Table 12.10). That VPF imported additional quantities of poppy straw during 1969-70 from the USSR and Yugoslavia and the processing of small quantities of opium at VPF at the time is an indication that quantities available for export from Turkey were not entirely sufficient. The reason for the shortfall was increased demand for the Turkish poppy straw by Eastern European countries. ${ }^{31}$

\footnotetext{
${ }^{30}$ INCB Report for 1980 E/INCB/52/Supp $§ \S 83-84$.

${ }^{31}$ Ibidem Table 23.
} 
Worldwide morphine production from poppy straw increased strongly. In 1968 morphine extracted from poppy straw represented a record of 40 per cent of the total quantity of morphine manufactured during that year (Table 12.2).

From 1964-1968 opium production in India was low resulting in a decline of opium stocks but supply was not unduly affected. ${ }^{32}$

\section{Alkaloid Research at VPF}

After the merger with NCF the chemical laboratory at the VPF was reorganised. Newly appointed head of the laboratory was Cees Agasi. One of the first subjects of research was an improved method for the assay of morphine in poppy straw, CPS and process liquors. The various gravimetric and colorimetric methods in use were not satisfactory. A new method was developed on the basis of quantitative thin layer chromatography which was in use at VPF until the advent of HPLC methods.

In 1964, at NCF, collaboration was established with the group led by Professor H.C. Beyerman and Dr. L. Maat of the Delft University of Technology. The group had been working on piperidine alkaloids, tropa-alkaloids and pelletierine, and had an interest in research relating to cocaine. The collaboration included regular meetings of the scientists at which $\mathrm{NCF}$, and later VPF, were informed on developments in alkaloid chemistry e.g. new analytical methods (NMR, HPLC) and received suggestions on process improvements. The Delft group, in return, heard about interesting alkaloid problems that had arisen in the factory or laboratory at NCF, and later at VPF, which could be suitable subjects for research at Delft. Over time, that research resulted in publications on the "Configuration and confirmation of all four cocaines from NMR Spectra", on "The Structure of Willstätters Compound" and on "Analysis of Cocaine, Pseudococaine, Allococaine, and Allopseudococaine by Ion-Pair Reverse-Phase HPLC". 33

Research at VPF included experimental work on the extraction of the alkaloid pilocarpine from Pilocarpus microphyllus (jaborandi) leaves. This interest in pilocarpine led to exploration of new methods for the total synthesis of alkaloids at Delft, resulting in a thesis by A. Noordam titled "Stereoselective Synthesis of $(+)$ - Pilocarpine. ${ }^{34}$

In the 1970s the collaboration with the Delft University of Technology continued with a joint project on the total synthesis of codeine. That project is discussed in detail in Chapter 13.

Within the KZO group there was an interest by Dr William Buckett of Organon Scotland in certain oxycodone derivatives. That resulted in a joint project of making a series of 14acyloxydihydromorphinone derivatives at VPF which were tested for analgesic activity in Scotland. A patent was obtained in $1974 .^{35}$

\footnotetext{
${ }^{32}$ Ibidem $\S 80$ and Table 19.

${ }^{33}$ A. Sinnema, L. Maat, A.J. van der Gugten and H.C. Beyerman, 'Configuration and confirmation of all four cocaines from NMR-spectra', Receuil des Travaux Chimiques des Pays-Bas 87 (1968) 1027-1041. H.C. Beyerman, L. Maat, A. Sinnema, 'The structure of Willstätter's compound: 3-Benzoyloxy-2methoxycarbonyl-2-tropene', Receuil des Travaux Chimiques des Pays-Bas 89 (1970) 257-260.

C. Olieman, L. Maat and H.C. Beyeman 'Analysis of cocaine, pseudococaine, allocaine and allopseudococaine by ion-pair reverse phase high-performance liquid chromotography', Recueil des Travaux Chimiques des PaysBas 108 (1979) 501-502.

${ }^{34}$ A. Noordam, Stereoselective Synthesis of (+)-Pilocarpine, Dissertation, Technische Hogeschool Delft (1979).

${ }^{35}$ Akzona, '3-Alkoxy-14-acyloxydihydromorphinone Derivatives', Inventors: Buckett, W.R. and Bosman, H.H., US Patent 3,828,050; (1974) Aug 6.
} 


\subsection{Summary and Outlook for the Next Period}

The acquisition of NCF and VPF by KZO and the integration of these companies at Apeldoorn proceeded smoothly and the combined alkaloid operations made further inroads into the opiate market. The strength of the company resulted from the excellent extraction and processing technology and equipment, its position as the largest buyer of Turkish poppy straw and good customer relations. In 1970 VPF had become the fourth largest morphine manufacturer after the USSR, the UK and the USA, and the largest morphine producer from poppy straw.

\section{A major Development that would determine the Course of Events of the 1970s. ${ }^{36}$}

In the late 1960s there was an upsurge of drug use worldwide which governments and international agencies attempted to control. ${ }^{37}$ The US Ad Hoc Committee on Narcotics concentrated on the so called "French connection" in its efforts to fight drug abuse in the USA. The theory behind this move was that Turkish opium was assumed to be the major source of morphine from which heroin was manufactured in French clandestine laboratories and found its way to the USA. The CIA had established that Turkey was not the major source of the morphine for the heroin entering the USA but Turkey was expected to give in to American pressure. In the opinion of a member of the US Committee: "Turkey was the only country where we could expect dramatic results, and that was what the president [Nixon] wanted". William Handley, the US ambassador to Turkey warned about the difficulties to persuade the Turkish government that opium should be banned in Turkey while India and other countries expanded their production. However, in early 1970 the US Ad Hoc Committee on Narcotics, incited by Nixon, decided to make an all-out effort to stop the production of opium in Turkey. The ultimate result was that in 1971 the new Turkish military government agreed to discontinue poppy cultivation in Turkey if the US would agree to compensate the farmers for lost income. As a consequence a serious raw material shortage for opiates developed which determined to a large extent the course of events with respect to the demand and supply situation for opiates during the 1970s. The impact on VPF and the opiate industry as a whole is the main subject of the next chapter.

\footnotetext{
36 'Agency of Fear' by Edward J. Epstein, Part III: The Nixon Crusades, Chapter 8, “The War on Poppies" (www.edwardjayepstein.com).

${ }^{37}$ McAllister, Drug Diplomacy, 225.
} 


\section{Chapter 13 \\ A MARKET IN TURMOIL AND REORGANIZATIONS: VPF AND DIOSYNTH DURING THE 1970S}

\subsection{Overview}

During the 1970s the opiate industry was in a state of flux worldwide as a result of a 1971 agreement between the United States' and the Turkish governments, to the effect that Turkey stopped poppy cultivation completely. Within a few years this caused a serious raw material shortage for the opiate industry, leading to much higher prices and a search for alternative raw materials. VPF was particularly affected because of its reliance on Turkish poppy straw as the source of morphine. VPF was, however, able to organize importation of (lanced) poppy straw from India as a temporary solution.

In 1975 Turkey resumed poppy cultivation but refrained from lancing for opium. At the same time, the Turkish government announced plans to build a poppy extraction facility in Turkey. Until such time that the new opiate production facility would be operational, the Turkish government sold the unlanced poppy straw by tender. From 1976 large quantities of Turkish poppy straw were bought and extracted by VPF. VPF entered into long term agreements with US opiate manufacturers for the supply of substantial amounts of Concentrate of Poppy Straw (CPS) to the USA. As a result, VPF's output of CPS and codeine was larger than ever before. This situation continued until the early 1980s when the Turkish factory became operational and Turkish poppy straw was no longer available for export.

In 1973, as a result of a reorganisation, the alkaloid business of VPF became a product group of Diosynth, the newly formed bulk- pharmaceutical business unit of Akzo Pharma, the pharmaceutical division of Akzo. Sales or profit figures were not published for the alkaloid product group nor for any of the other product groups of Diosynth but from the INCB production and trade statistics and world market prices prevailing at the time it can be concluded that the second half of the 1970s was a very profitable period for Diosynth's Alkaloid Group.

During the early 1970s among alternative solutions that were attempted by VPF/Diosynth to find a long term solution for the raw material problem were the cultivation of Papaver bracteatum and the total synthesis of morphine and codeine. Although a promising new morphine synthesis was developed neither of the alternatives was a commercially viable substitute for the extraction of poppy straw.

In reaction to the raw material shortage, India expanded its opium production from 1975 and poppy cultivation for straw increased, especially in Australia and France. The combined effect of these expansions plus Turkey's resuming poppy cultivation resulted in a serious overproduction of opiate raw materials from 1978 onwards. This caused concerns for the International Narcotics Control Board (INCB) and the Commission on Narcotic Drugs, and led in 1979 and subsequent years to the adoption of resolutions aiming at reducing excessive stocks by giving "traditional supply countries" (India and Turkey) a preferred position as suppliers. The ramifications of the resolutions affected the industry seriously in the 1980s. 


\subsection{Turkey Abandoning Poppy Cultivation and its Consequences}

Towards the end of the 1960s the upsurge in illicit drug use caused governments and international agencies to decide on how to deal with the problem. 'Many western states blamed their domestic difficulties on inadequate control abroad'. In 1970 the US Government led by President Nixon decided to attack the heroin addiction problem in the USA from the supply side. It was assumed that most of the heroin came ultimately from Turkish opium, illegally produced and transported to Marseilles where it was converted into heroin and subsequently forwarded via other illegal channels to the USA. ${ }^{2}$ This was the so called "French Connection".

The reasoning of the US Government was that if it could convince the Turkish Government to forbid poppy cultivation, there would be no Turkish opium produced and thereby no heroin would be manufactured for supply to the USA. That was a very naive reasoning. It appears that the moral loftiness of the goal, fighting heroin addiction, interfered with realistic critical thinking or, more likely, it was one of political expediency because, as a member of the US Ad Hoc Committee reportedly said: 'Turkey was the only country where we could expect dramatic results, and that was what the president [Nixon] wanted'. ${ }^{3}$ The ultimate result was that in 1971 the new Turkish military government agreed to discontinue poppy cultivation in Turkey if the US would agree to compensate the farmers for lost income.

The agreement between the US and Turkish governments on the cessation of poppy cultivation in Turkey should be seen as the result of an initiative by the USA to achieve international narcotics control without the direct involvement of the UN Commission on Narcotic Drugs. It was an example of US attempts to take a leading role in international drug control by politically motivated unilateral actions. The prohibition of opium poppy cultivation was qualified later, in a statement by the Turkish government to the INCB of 1980, as resulting from 'exaggerated reports on the diversion of opium from legal cultivation to the illicit market'. ${ }^{4}$

Alfred W. McCoy, Professor of History at the University of Wisconsin-Madison, wrote: 'The Nixon drug war rested on the premise that Turkey was an isolated opium producer that could be eliminated through a strong enforcement effort.'

'Any reduction of production in a single sector, such as Turkey, soon became a strong market stimulus for increased production elsewhere along the opium zone. $^{5}$

A major fallacy of the Nixon solution was the assumption that eliminating Turkish opium would result in no heroin going to the USA. In reality, heroin affects the addicts so strongly that addicts are willing to pay any price for the product. Consequently heroin will come to the USA from somewhere in the world no matter what.

\footnotetext{
${ }^{1}$ William B. McAllister, Drug Diplomacy in the Twentieth Century (London 2000), 225-226.

${ }^{2}$ This assumption is a doubtful one. Cf. Edward J. Epstein , 'Agency of Fear', Part III: The Nixon Crusades, Chapter 8, The War on Poppies (www.edwardjayepstein.com). From experience, it is the opinion of the author this chapter describes the international narcotics control situation of the time in a realistic, sceptical way, mirroring the opinions of managers of international narcotic manufacturing companies at the time.

${ }^{3}$ Ibidem.

${ }^{4}$ Emphasis added. United Nations, Demand and Supply of Opiates for Medical and Scientific Needs, Report of the INCB for 1980 (New York 1981) E/INCB/52/Supp. Annex C, Country Statements, Turkey, p 199, §2.

5 Alfred W. McCoy, 'Opium History 1940 to 1979 ' (www.alb2c3.com/drugs/opi 011.htm).
} 
Since the 19th century Turkey had been a major exporter of opium as a raw material for the production of opium alkaloids. Before World War II, Turkey exported an average of about 275 tonnes annually for that purpose. ${ }^{6}$ During the period 1964-1970 Turkey exported an annual average of 172 tonnes of opium and 5,150 tonnes of (lanced) poppy straw, in total containing approximately 33 tonnes of morphine. ${ }^{7}$ This amount represented about $20 \%$ of the total world requirements of opiate raw materials for the period.

A consequence of stopping Turkish poppy cultivation was that within a few years it would lead to a severe shortage of opiate raw material for the licit production of opiates for medicinal purposes. The INCB, in its report to the Board for 1971, assumed optimistically that supplies from other regions would fill the vacuum that would be created when Turkey stopped production. The UN Division of Narcotic Drugs recognised, however, that a shortfall could occur and organised during the period 1972-1975 a series of meetings on "Scientific Research on Papaver bracteatum". The objective of the project was to evaluate if the cultivation of $P$. bracteatum, a thebaine containing poppy species, could assist in restoring the balance of supply and demand for opiate raw materials.

For various reasons the cultivation of $P$. bracteatum did not succeed, among them a USA rulemaking of 1977 to the effect that, despite its being extremely unlikely that drugs of abuse can be produced in that way, cultivation in the USA was not allowed. ${ }^{8}$ It is a further example of the USA taking a unilateral step in narcotic control matters. Some details of the US rulemaking are included in the section on VPF participating in the P. bracteatum project later in this chapter.

The agreement between the US and the Turkish Government specified that from the 1972 harvest onwards the cultivation of the opium poppy in Turkey be abandoned. The price for the deal paid by the USA was USD 35 million, USD 15 million to compensate Turkey for losses in foreign exchange and USD 20 million for crop substitution. ${ }^{9}$

Some major consequences of the USA - Turkey deal were:

- a rapidly developing shortage of opiate raw materials which resulted in shortages of opiates and sharply increasing prices from 1971 onwards;

- for VPF, Turkish poppy straw, the basic raw material for its opiate production, no longer available. This was a serious threat to the business. The only short term solution that appeared feasible was importation of lanced poppy straw from India;

- for the US opiate manufacturers Mallinckrodt, Penick and Merck it meant insufficient availability and sharply increasing prices of Indian opium;

- for the Turkish poppy growers it meant loss of income from a good cash crop. Furthermore, poppy seed would no longer be available in Turkey. The main use of poppy seed was the production of poppy seed oil, a very much valued product used for cooking purposes. This resulted in quite strong political pressure by the rural community on the Turkish Government to revoke the deal with the USA. ${ }^{10}$

\footnotetext{
${ }^{6}$ Bensussan I.J., L'Opium. Considérations générales et Études économiques, sociales et législatives (Paris1946).

${ }^{7}$ International Narcotics Control Board Statistics on Narcotic Drugs New York: United Nations; annual publication.

${ }^{8}$ United States Department of Justice, DEA (Drug Enforcement Administration), In the matter of Papaver bracteatum, Report, Synopsis of Testimony, and recommendations of Administrative Law Judge, Docket No. 76-46 (1977) April 11.

${ }^{9}$ Bruun K., Pan L. and Rexed I, The Gentlemen's Club - International control of drugs and alcohol. Chicago: The University of Chicago Press (1975) 213-215.

${ }^{10}$ UN, Demand and Supply of Opiates, Report of the INCB for 1980, C. Country Statements, Turkey, p $199, \S 3$.
} 
By 1974 the US medical profession became most concerned because of the shortage of codeine that had developed. ${ }^{11}$ Dr Joseph Cochin wrote:

'The Turkish opium ban as put into effect by our government, the resulting shortages of indispensable drugs, and the adverse effects on the practice of medicine are all results of the application of simplistic solutions to extremely complex problems,'

'The Turkish opium ban merely resulted in the replacement of Turkish heroin with Mexican heroin within a matter of several months.' 12

In 1974, as a result of the shortage of opiates and protests in Turkey on the lack of poppy seed oil for cooking purposes it became clear that the Turkish government could not sustain the ban on cultivation. With support of the US government poppy cultivation was resumed but lancing for opium was not allowed. ${ }^{13}$ To re-establish the position of Turkey as a major raw material supplier the government announced plans to build a local poppy extraction facility. ${ }^{14}$ Until such time that a new facility would be operational, the unlanced poppy straw produced was sold to existing processors such as VPF. As a result the average morphine production at VPF increased to 22 t AMA p.a. during the period 1976-1980 (Table 13.1).

A major effect of the shortage was that opiate prices skyrocketed; the price of codeine phosphate increased from USD125 per kg in 1970 to USD400 in 1974, and to over USD800 in 1977 (Table13.3). As a consequence, during the period 1976-1980, poppy cultivation in France, Australia and Hungary expanded substantially resulting in a morphine production of 25, 23 and 12 t AMA p.a. respectively in these countries (Table 13.1). ${ }^{15}$ This led, in turn, to a shortage turning into excess production and consequently to a decrease of the codeine phosphate price to USD400 in 1980.

\subsection{International Narcotics Control}

International narcotics control through the UN organisations CND and INCB faced, as a result of Turkey abandoning poppy cultivation, in the early 1970s for the first time a potential shortfall in the supply of opiates for medicinal needs. Initially the INCB was of the opinion that other producing countries would fill the gap but the UN Division on Narcotic Drugs recognised the problem and organised from 1972 to 1975 a series of meetings on scientific research on Papaver bracteatum to explore its potential as an alternative raw material for codeine. ${ }^{16}$ With Turkey reversing its position in 1975 this route was not any longer actively supported by the UN bodies and $P$. bracteatum cultivation was even prohibited in the USA from 1977 onwards. ${ }^{17}$ The latter move foreshadowed the strong support by the USA in later

\footnotetext{
${ }^{11}$ Greentree L.B, 'No Opium for Pain - A Threatening Medical Crisis', New England Journal of Medicine 291 (1974) 1411-1412.

${ }^{12}$ J. Cochin, 'The Opium Shortage: Politics and Health',

New England Journal of Medicine (1975) 990-991.

${ }^{13}$ US Department of State and Department of Justice (DEA), Report to Congress: Licit Opium Review (1989) 18.

${ }^{14}$ UN, Demand and Supply of Opiates, INCB Report for 1980, C. Country Reports, Turkey, p 203, §21.

${ }^{15}$ These movements are discussed in detail in Section 13.4.

${ }^{16}$ UN Division of Narcotic Drugs, Scientific Research on Papaver bracteatum, ST/SOA/SER.J/1-28 (1973-1977).

${ }^{17}$ US Department of State and Department of Justice (DEA),

Report to Congress: Licit Opium Review (1989) 17.
} 
CND meetings for measures to "ensure that production in the 'traditional producer' countries, i.e. Turkey and India, went to satisfy the legitimate market and not the illicit market". ${ }^{18}$

The over-production of opiate raw materials in the late 1970s became, from 1979, a major issue in the discussions on demand and supply in the annual meetings of the Commission on Narcotic Drugs (CND). In 1979 the CND and the UN Economic and Social Council adopted Resolution 471 titled "Maintenance of a world-wide balance between the supply of narcotic drugs and the legitimate demand for those drugs for medical and scientific purposes". For the opiate industry the most important paragraphs of Resolution 471 were:

'Noting with serious concern the Board's assessment that, unless there is a large and unforeseen increase in demand between 1978 and 1982, morphine manufacturing capacity will be, on average, 50 per cent greater than requirements.'

'Taking note of the continued reliance placed by the world community on countries constituting the traditional sources of supply for its medical needs of opiate raw materials and the positive response of those countries in meeting the world requirements and their contribution to the maintenance of effective control systems.'

'1. Calls upon importing countries, in so far as their constitutions and legal authority permit, to support the traditional supply countries and give all possible practical assistance in preventing the proliferation of producing and manufacturing sources for export.'

'2. Urges the Governments of major producing countries which have set up additional capacities in recent years to take effective measures to restrict their production programmes so as to restore a lasting balance between supply and demand and to prevent drug diversion to illicit channels. ${ }^{19}$

To observers from the industry it was clear from the beginning that Resolution 471 would have far reaching implications. A major consequence was the United States rulemaking "Limitations on Imports of Narcotic Raw Materials" (NRM) of 1981 by which it was determined that the traditional suppliers, India and Turkey, must be the source of at least $80 \%$ of the US requirements for NRMs. Five other countries France, Poland, Hungary, Australia and Yugoslavia were to be the source of not more than $20 \% .^{20}$

This quota system would become known as the "80/20 Rule". The major impact of the 80/20 Rule was on Australia, but also the Netherlands was affected in the sense that CPS produced from poppy straw from origins other than Turkey or India would be excluded from competing for $80 \%$ of the very important US market.

The UN Resolution of 1979 and subsequent US rulemaking were based on a concept which was not part of the Single Convention on Narcotic Drugs of $1961 .^{21}$ This new concept was that of "moral obligations". It was mentioned by the representative of the US State Department in 1977 at the Drug Enforcement Administration (DEA) hearing on Papaver

\footnotetext{
${ }^{18}$ Ibidem.

${ }^{19}$ The complete text of the resolution is included in: Demand and Supply of Opiates, INCB Report for 1980 Annex B, Resolution [471] 1979/8 on page 144.

${ }^{20}$ Definition as appearing in: United States Department of Justice (Drug Enforcement Administration). 21 CFR

Part 1312, Document: Authorized Sources of Narcotic Raw Materials, dated October 4, 2006

${ }^{21}$ United Nations. Single Convention on Narcotic Drugs (1961).
} 
bracteatum that at recent INCB and CND meetings "A number of governments had expressed the view that developed countries have an overriding moral obligation to refrain from initiating commercial Papaver bracteatum cultivation" because of serious adverse economic and social impact on poorer traditional supply countries. ${ }^{22}$

In the opinion of the author, introduction of the concept of 'moral obligations' to narcotics control is largely politically motivated. It is exceedingly vague, it diverts the attention from real narcotics control and has an aura of superiority, implying that it would be "immoral" to oppose any conclusion drawn from it.

The UN Resolution of 1979 had diverted attention from the real cause of the large stocks of opiate raw materials at the time, which was over-production by India and Turkey. Accumulation of excessive stocks by manufacturers was not allowed under Article 29.3 of Single Convention on Narcotic Drugs. Instead of enforcing the provisions of the Single Convention, the CND and INCB, led by the USA, gave India and Turkey a preferential position in the market, to the detriment of other opiate raw material producers that had adhered to the rules.

The excessive stocks were largely the result of over-production by India and Turkey, as shown clearly with the graphs 13.1 and 13.2. The graphs are based on data compiled in the INCB Special Report for 1980, which are summarized in Table OPI 10 (Part IV). ${ }^{23}$ The concept is that opiate raw materials (opium and poppy straw) are produced in a few countries which, firstly, satisfy their own needs for opiates. These needs, "Consumption met by Domestic Production", are shown in column (2) of table OPI 10. The producing countries try to export the remainder of their production, "Production available for Export", column (4), to the rest of the world i.e. to non-raw material producing countries. The latter countries will long term in total buy not more than their requirements for consumption, "Consumption met by Import", column (3), and the difference between columns (4) and (3) represents "Excess/Shortfall Production", column (5). The cumulative totals of column (5) appear in column (6); they represent the difference of total stocks of raw materials worldwide plus opiates at year end in comparison to the amount in stock at year end 1963.

The values of the data in columns (3), (4) and (5) of Table OPI 10 are plotted in Figure 13.1; those in columns (4), (8) and (9) in Figure 13.2. The latter represent "Production available for Export" Total, India and India plus Turkey respectively.

\footnotetext{
${ }^{22}$ Emphasis added. Statement by Mathea Falco, Senior Advisor to the Secretary of State. Hearing conducted by Francis L. Young, Administrative Law Judge of the DEA, On the Matter of Papaver bracteatum, Docket No. 76-46, Dated April 11, 1977.

${ }^{23}$ Demand and Supply of Opiates, INCB Report for 1980 E/INCB/52/Supp, Tables 17-18, p 108-109.
} 
Figures 13.1 and 13.2 Opiate Consumption met by Imports and Production available for Export.1964-1980
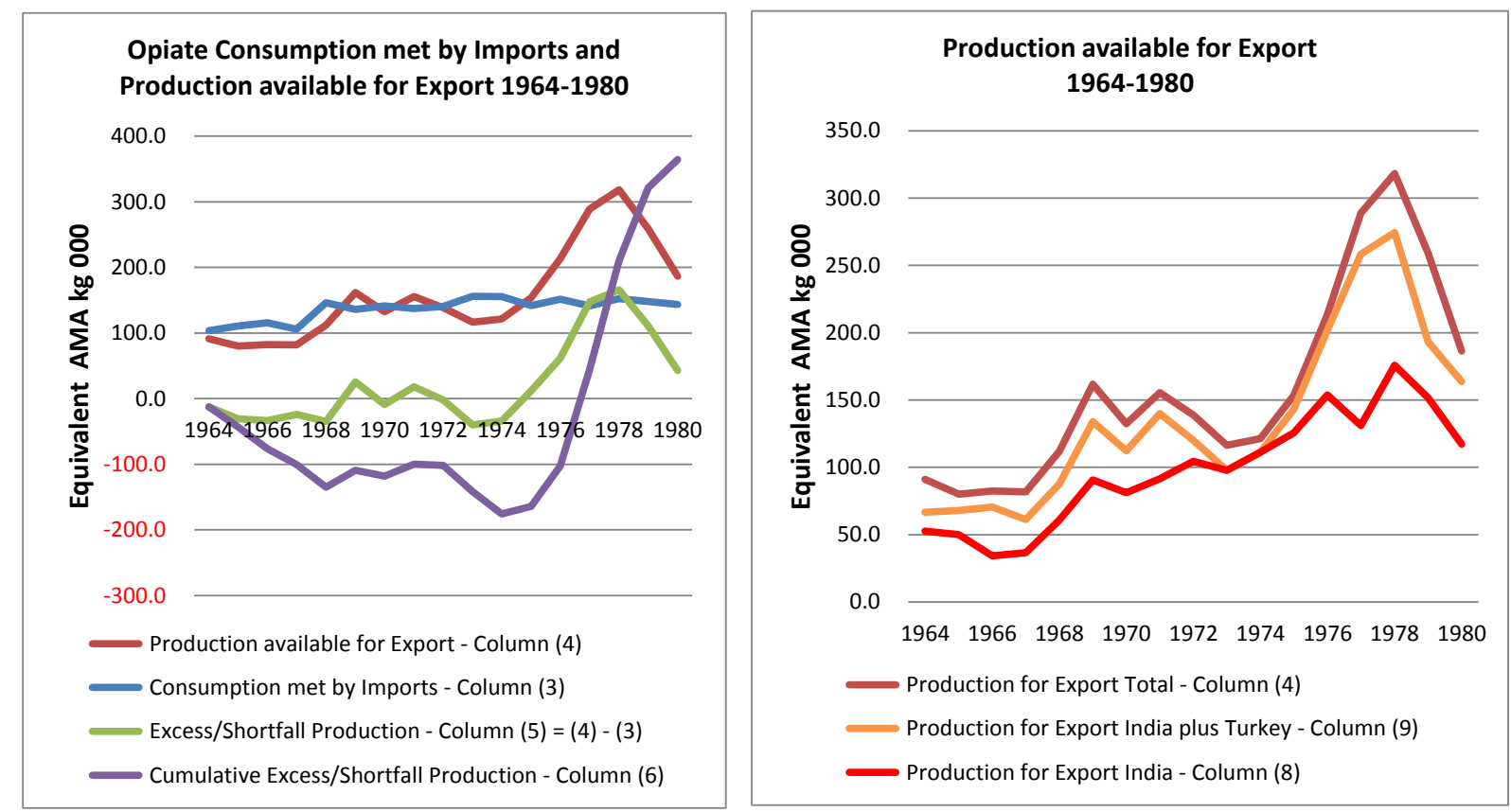

Source: Demand and Supply of Opiates, INCB Report for 1980 E/INCB/52/Supp, Tables 17-18. The data are summarised in Table OPI 10 (Part IV) and plotted in above graphs.

The column numbers refer to Table OPI 10.

Figure 13.1 shows that stocks of opiates plus raw materials worldwide at year end decreased from 1963 to reach a minimum in 1974. Thereafter stock levels increased, were about at the same level of 1963 in 1977, and shot up thereafter. The excess ended up as stock in the supply countries, mainly India. Figure 13.2 shows that "Production available for export" was largely from India and Turkey also after 1974. If there had been no production at all in countries other than India and Turkey the surplus production (the orange line) would have been almost as large as the actual total (the brown line).

\subsection{The World Market for Opiates 1971-1980}

\section{Morphine}

Table 13.1 and chart show that the average total world morphine production over the period 1971-1980 amounted to $176 \mathrm{t}$ p.a., a $24 \%$ increase over the average production of $140 \mathrm{t}$ p.a. for the period 1961-1970. 
Table 13.1 Morphine Manufacture by Country 1971-1980 (AMA kg)

\begin{tabular}{|c|c|c|c|c|c|c|c|c|c|c|c|}
\hline & Year & USA & USSR & France & UK & Netherlands & Australia & Hungary & Poland & $\begin{array}{c}\text { Other } \\
\text { Manuf. } \\
\text { Countries }\end{array}$ & $\begin{array}{l}\text { World } \\
\text { Total }\end{array}$ \\
\hline & 1971 & 20,519 & 35,763 & 14,350 & 24,106 & 20,086 & 398 & 8,238 & 7,781 & 43,441 & 174,682 \\
\hline & 1972 & 24,207 & 29,000 & 13,800 & 24,755 & 18,422 & 2,933 & 11,105 & 9,129 & 38,418 & 171,769 \\
\hline & 1973 & 26,036 & 25,129 & 12,322 & 23,412 & 12,872 & 4,237 & 11,352 & 8,963 & 37,676 & 161,999 \\
\hline & 1974 & 36,485 & 17,406 & 14,531 & 22,267 & 8,920 & 2,998 & 6,046 & 6,632 & 38,958 & 154,243 \\
\hline & 1975 & 34,674 & 17,238 & 17,234 & 15,255 & 13,224 & 3,993 & 6,848 & 6,467 & 41,134 & 156,066 \\
\hline & 1976 & 31,484 & 15,468 & 21,758 & 27,281 & 15,948 & 8,001 & 10,007 & 6,664 & 40,805 & 177,415 \\
\hline & 1977 & 20,298 & 17,011 & 28,924 & 18,847 & 19,692 & 16,679 & 12,119 & 7,565 & 48,300 & 189,434 \\
\hline & 1978 & 26,803 & 16,992 & 24,311 & 17,783 & 31,206 & 31,526 & 14,810 & 4,911 & 44,301 & 212,643 \\
\hline & 1979 & 28,006 & 19,188 & 24,849 & 9,193 & 22,188 & 33,083 & 12,411 & 4,760 & 37,668 & 191,345 \\
\hline & 1980 & 31,434 & 15,324 & 26,887 & 3,406 & 21,818 & 27,497 & 11,038 & 7,269 & 27,229 & 171,902 \\
\hline \multirow[t]{2}{*}{$1971-1980$} & Average & 27,995 & 20,852 & 19,897 & 18,631 & 18,437 & 13,135 & 10,397 & 7,014 & 39,793 & 176,150 \\
\hline & Percent & 16 & 12 & 11 & 11 & 10 & 7 & 6 & 4 & 23 & 100 \\
\hline \multirow[t]{2}{*}{$1971-1975$} & Average & 28,384 & 22,193 & 14,447 & 21,959 & 14,705 & 2,912 & 8,718 & 7,794 & 42,639 & 163,752 \\
\hline & Percent & 17 & 14 & 9 & 13 & 9 & 2 & 5 & 5 & 26 & 100 \\
\hline \multirow[t]{2}{*}{$1976-1980$} & Average & 27,605 & 17,129 & 25,346 & 15,302 & 22,170 & 23,357 & 12,077 & 6,234 & 39,328 & 188,548 \\
\hline & Percent & 15 & 9 & 13 & 8 & 12 & 12 & 6 & 3 & 21 & 100 \\
\hline
\end{tabular}

Source: Demand and Supply of Opiates, INCB Report for 1980 E/INCB/52/Supp, Table 15.

Each figure is the sum of the amounts of AMA manufactured from opium (line 1) and from poppy straw (line 2).

Note 1: The data appearing for morphine production in the INCB Statistics for the years 1971-1980 differ from the ones in the table above as CPS produced is not recognised as morphine produced in the Statistics before it is purified into Technical Morphine.

Note 2: the values for "Other Manufacturing Countries" by period were calculated by the author as the differences between the World Totals and the sum of the quantities mentioned in the first 8 columns.

Figure 13.3 Morphine Manufacture by Country 1971-1980

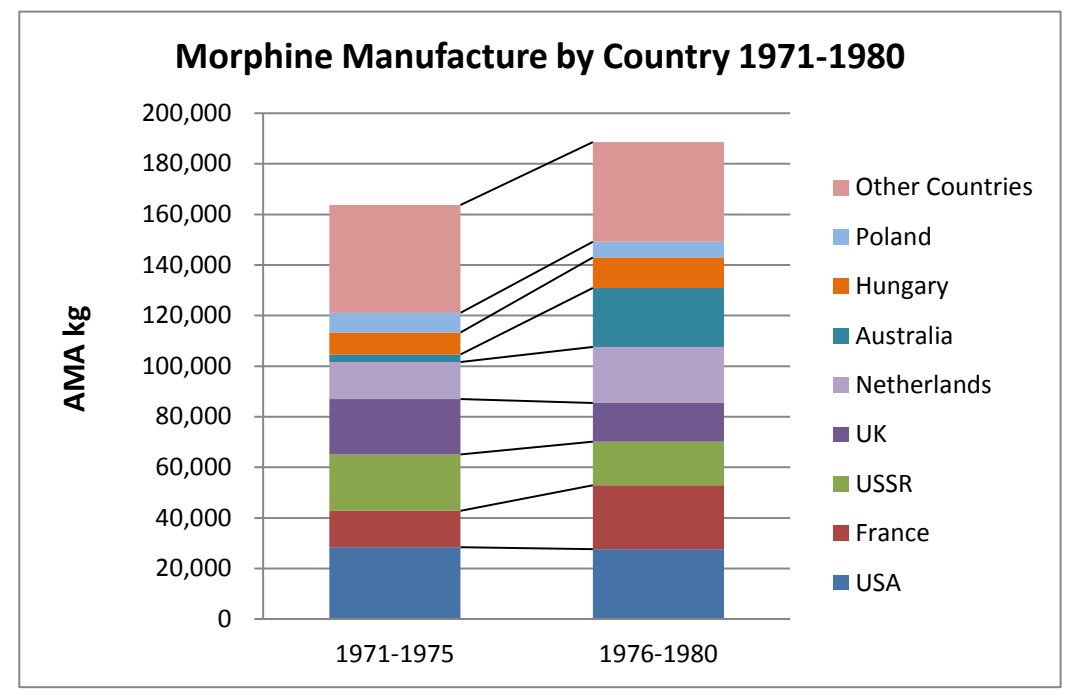

Source Table 13.1 
During the second half of the 1970s in comparison to the first half the production in the USA stayed at about the same level, while the production in Australia, France and the Netherlands increased sharply, and the production in the UK and the USSR decreased. The very noticeable increase in Australia was the result the emergence of a poppy industry in Tasmania based on the cultivation of high yielding P. somniferum strains. Glaxo Australia exported a large part of the CPS produced to the affiliated company Macfarlan Smith in the UK, where it was used as the raw material for the manufacture opiates instead of opium. This is the reason for the sharp decline of the morphine production in the UK as appearing in Table 13.1 above.

In 1975 another company, Tasmanian Alkaloids, was established in Australia with the objective of producing CPS from locally grown poppies. It was a 50/50 joint venture of Abbott Laboratories from Chicago and Ciech-Polfa from Poland. ${ }^{24}$ Tasmanian Alkaloids became operational in 1977 and supplied CPS to the partners as the raw material for their codeine manufacture. The partnership ended in 1979, Abbott Laboratories becoming the sole owner of Tasmanian Alkaloids.

During the second half of the 1970s Francopia in France expanded local poppy cultivation at the expense of the use of opium as the raw material for the manufacture of codeine and other opiates.

The effect of the disruption in the supply of poppy straw from Turkey during 1973-1975 is clearly visible in the chart below: morphine production from poppy straw declined markedly from 1971 to 1975 and expanded again from 1976. Morphine manufacture from opium diminished considerably from 1976 to 1980.

Table 13.2 and Figure 13.4 Morphine Manufacture Worldwide from Opium and Poppy Straw 1971-1980

\begin{tabular}{|c|c|c|c|c|c|}
\hline & \multirow{2}{*}{ Year } & \multicolumn{3}{|c|}{$\begin{array}{l}\text { Manufacture of Morphine } \\
\text { AMA kg } 000\end{array}$} & \multirow{2}{*}{$\begin{array}{c}\text { ex Poppy } \\
\text { Straw } \\
\text { as a \% of } \\
\text { Total }\end{array}$} \\
\hline & & ex Opium & $\begin{array}{l}\text { ex Poppy } \\
\text { Straw }\end{array}$ & Total & \\
\hline $1971-1980$ & $\begin{array}{c}1971 \\
1972 \\
1973 \\
1974 \\
1975 \\
1976 \\
1977 \\
1978 \\
1979 \\
1980 \\
\\
\text { Average } \\
\text { Percent }\end{array}$ & $\begin{array}{r}110 \\
109 \\
106 \\
108 \\
101 \\
109 \\
88 \\
94 \\
80 \\
64 \\
\\
\\
97 \\
55\end{array}$ & $\begin{array}{r}64 \\
63 \\
56 \\
46 \\
55 \\
69 \\
102 \\
118 \\
111 \\
108 \\
\\
\\
79 \\
45\end{array}$ & $\begin{array}{l}175 \\
172 \\
162 \\
154 \\
156 \\
177 \\
189 \\
213 \\
191 \\
172 \\
\\
\\
\mathbf{1 7 6} \\
\mathbf{1 0 0}\end{array}$ & $\begin{array}{l}37 \\
36 \\
35 \\
30 \\
35 \\
39 \\
54 \\
56 \\
58 \\
63 \\
\end{array}$ \\
\hline
\end{tabular}

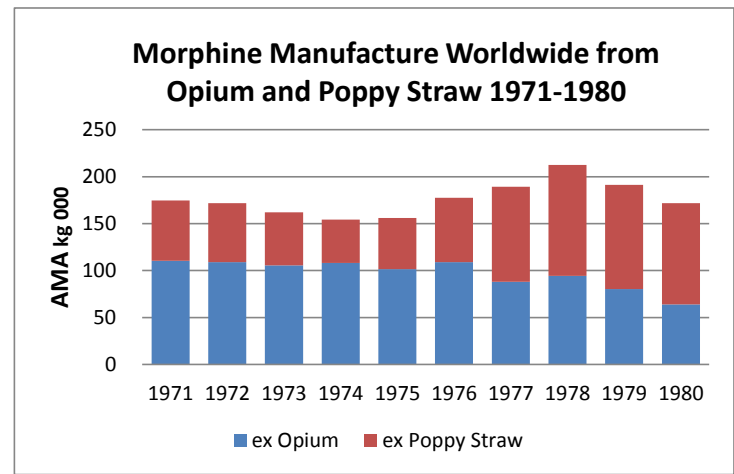

Source: Demand and Supply of Opiates, INCB Report for 1980 E/INCB/52/Supp, Table 15

The total of the INCB Statistics for exports of CPS and Morphine combined are presented in the following table. Also shown are the major importing countries and the provenance of the goods.

\footnotetext{
${ }^{24}$ In 1934 the company "Motor-Alkaloida" was established by Kabay as the Polish affiliate of his Hungarian poppy extraction enterprise. The factory was located at Kutno and was in 1967 known as Kutno Pharmaceutical Works "Polfa". At an unknown date Polfa became "Ciech-Polfa", as part of "Ciech", a Polish government organisation for the import and export of chemicals. UNODC, Bulletin on Narcotics (1967) [3], 1-6.
} 
Table 13.3 Total of Exports of CPS and Morphine Worldwide 1964-1970 (AMA kg)

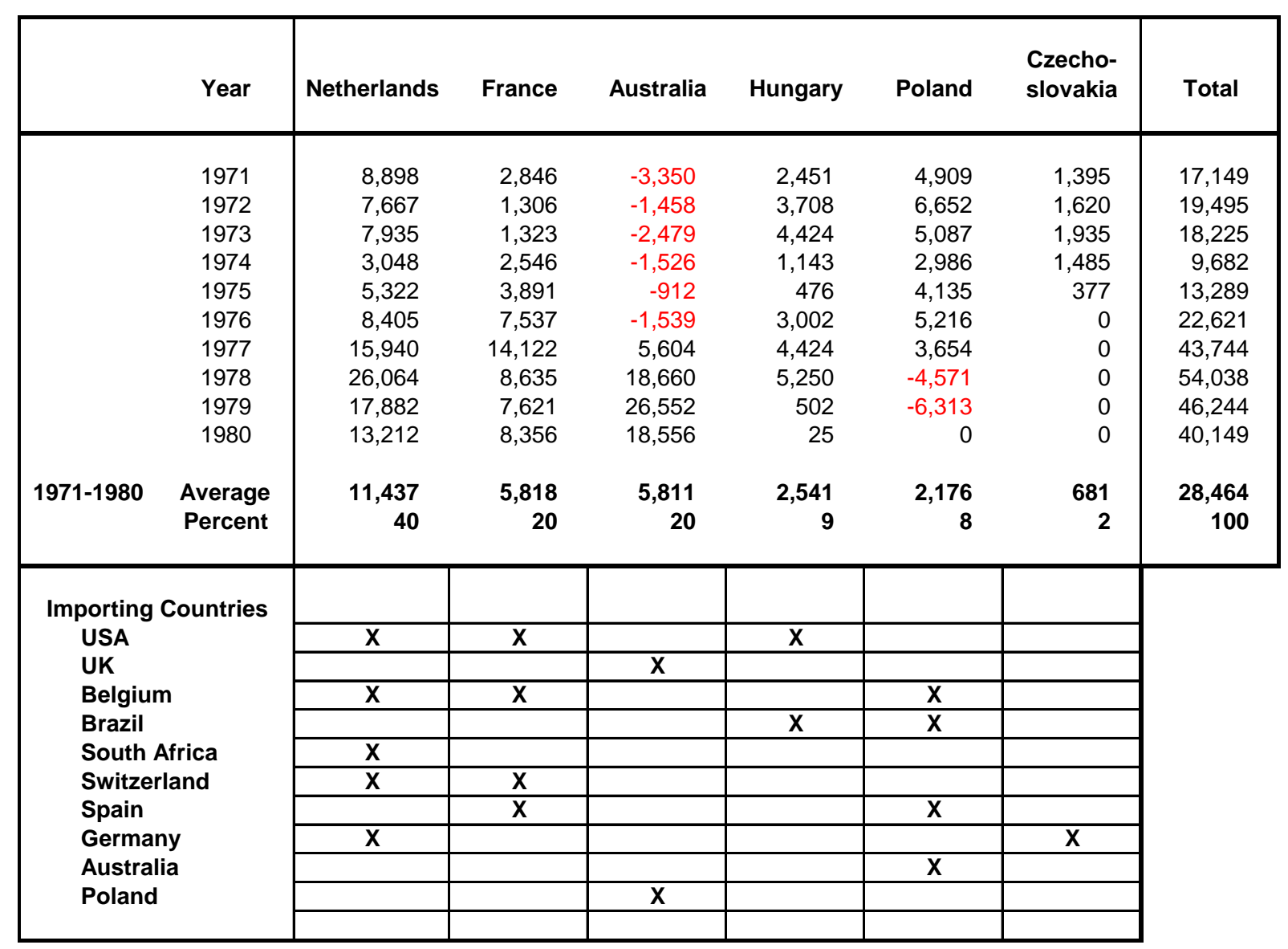

Source: INCB Statistics 1971-1980

The large exports from the Netherlands during 1977-1980 represent mainly those to the USA, on the basis of toll manufacturing arrangements between VPF(Diosynth) and the large US codeine manufacturers Mallinckrodt, Penick and Merck. The negative export figures for Australia over 1971-1976 indicate morphine imports by Abbott Australasia from Ciech-Polfa, Poland; the negative export figures for Poland 1978-1979 represent imports from Australia. The exports from Australia from 1977 were mainly those by Glaxo to Macfarlan and from Abbott (Tasmanian Alkaloids) to Ciech. 


\section{Codeine}

The UK and the Netherlands were the most important codeine exporters during the period. Australia became an important codeine exporter from 1977 onwards. Details are shown in the table and chart below.

Table 13.4 and Figure 13.5 Codeine: Net Export by Country 1971-1980

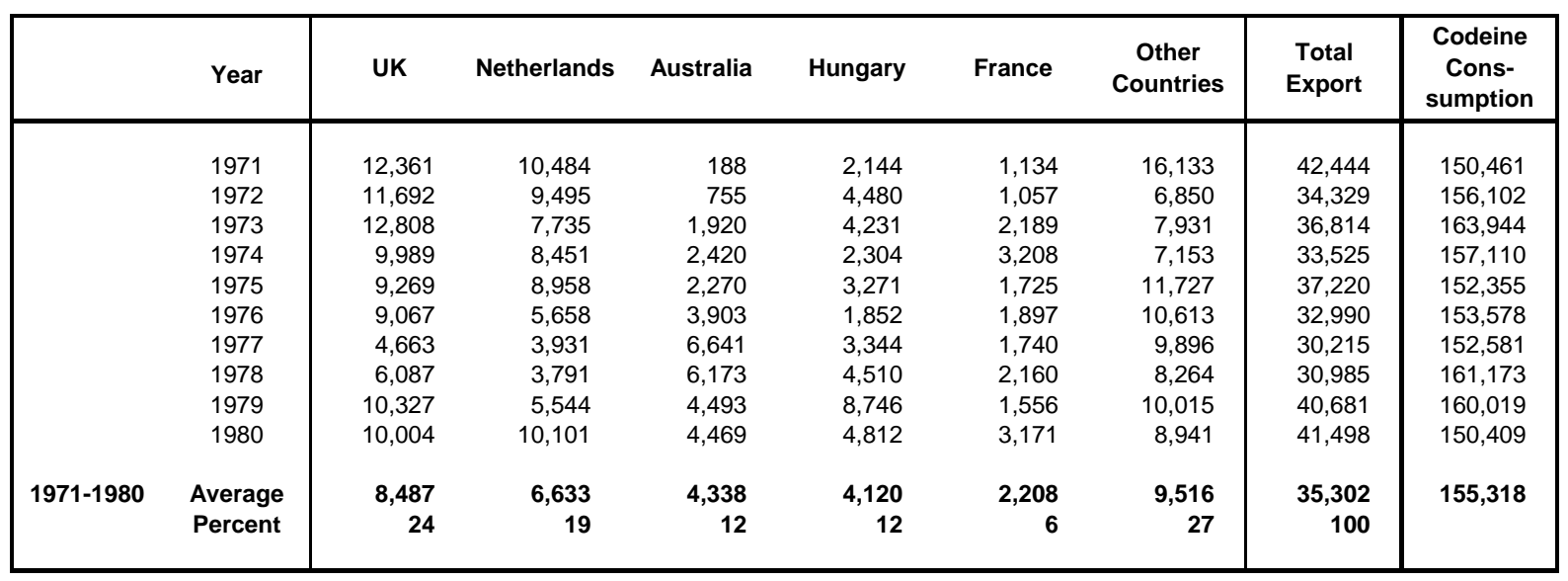

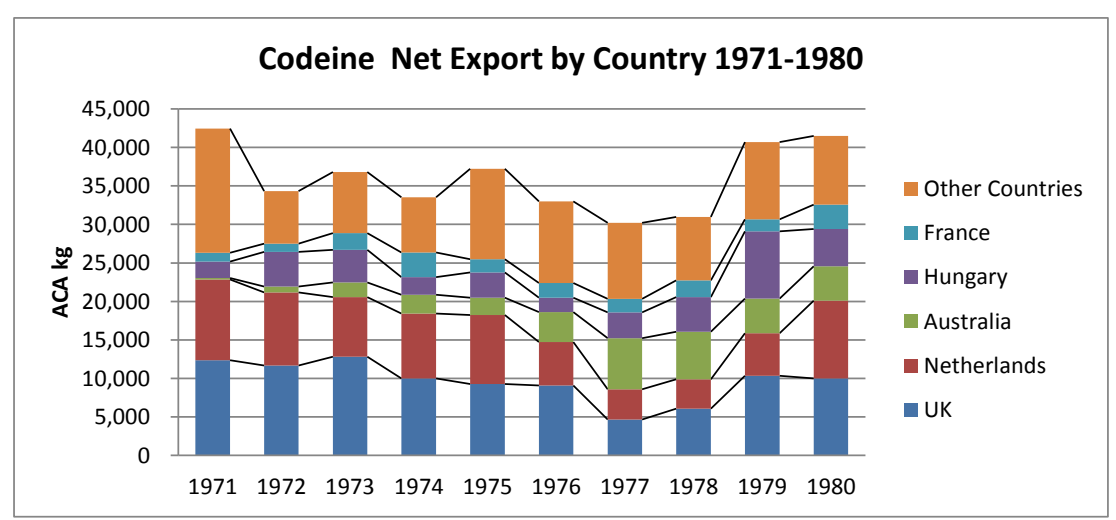

Source: INCB Statistics 1971-1980

Total codeine average consumption of codeine over the decade was 155 tonnes ACA p.a., 20\% higher than during the previous period of ten years. The UK and the Netherlands were the largest exporters, followed by newcomer Australia and by Hungary. The lower codeine exports from the Netherlands during the years 1976-1979 are the result of using the existing extraction capacity at VPF primarily for making CPS for supply to US customers. This was for Diosynth/VPF the most profitable option, as is discussed in more detail in section 13.8.

\section{Prices, Costs and Profit}

The effect of the raw material shortage during the first part of the 1970s on opiate prices was very large. The demand for opiates is virtually $100 \%$ inelastic and the price increased by a factor 8 over eight years (1969-1977). This is depicted in the table and graph below for codeine phosphate, the principal opiate, in comparison with the raw material cost assuming that the codeine phosphate were made from Indian opium. 
Table 13.5 and Figure 13.6 Codeine Phosphate Price and

Raw Material (Opium) Cost 1969-1980

\begin{tabular}{|c|ccc|}
\hline Year & $\begin{array}{c}\text { Indian } \\
\text { Opium } \\
\text { Price }\end{array}$ & $\begin{array}{c}\text { Raw } \\
\text { Material } \\
\text { Cost }\end{array}$ & $\begin{array}{c}\text { Codeine } \\
\text { Phosphate } \\
\text { Price }\end{array}$ \\
& $\begin{array}{c}\text { per kg at } \\
10 \% \text { AMA }\end{array}$ & $\begin{array}{c}\text { per kg } \\
\text { Codphos }\end{array}$ & per kg \\
& & & \\
\hline & & & \\
1969 & 12.0 & 86 & 100 \\
1970 & 15.0 & 107 & 125 \\
1971 & 18.0 & 129 & \\
1972 & 18.0 & 129 & 325 \\
1973 & 24.0 & 171 & 330 \\
1974 & 26.7 & 191 & 405 \\
1975 & 32.0 & 229 & 650 \\
1976 & 49.0 & 350 & 825 \\
1977 & 60.0 & 429 & 780 \\
1978 & 60.0 & 429 & 650 \\
1979 & 50.0 & 357 & 495 \\
1980 & 45.0 & 321 & 400 \\
& & & \\
\hline
\end{tabular}

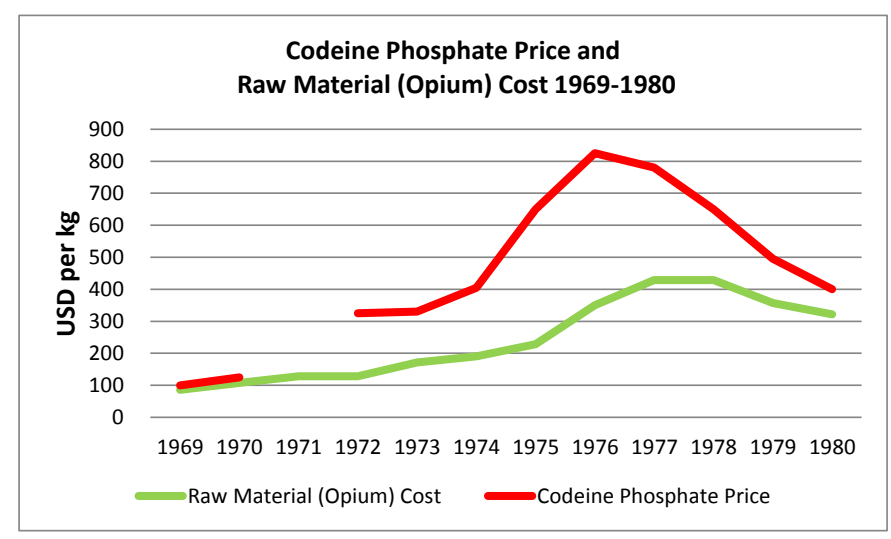

Sources and Notes: The Indian opium price is the price as established by the government of India (Files Tasmanian Alkaloids). The codeine phosphate prices from 1972-1980 are open market annual averages for commercial quantities (Files Tasmanian Alkaloids), those for 1969-1970 are estimates by the author. The raw material (opium) cost per $\mathrm{kg}$ codeine phosphate is estimated by multiplying the Indian opium price at $10 \%$ AMA with the factor 10/1.40, in which 1.40 represents the yield (rule of thumb of the industry: $10 \mathrm{~kg}$ Indian opium yields $1.40 \mathrm{~kg}$ codeine phosphate).

From the table and graph the following conclusions can be drawn: As the production cost of codeine phosphate from Indian opium was raw material cost plus in the order of USD 50 per kg manufacturing cost, codeine phosphate made from opium could not compete in the open market with codeine phosphate made from poppy straw during 1969-1970. From 1972 to 1978 there was a healthy profit for the codeine manufacturer; the problem was, however, that Indian opium and other raw materials were in short supply. During 1979-1980 profit margins fell back to a normal level.

Profits for the codeine manufacturers using poppy straw or CPS as the raw material cannot be estimated in a simple way as many cost factors were involved and these differed considerably between manufacturers. However, in general, profits achieved by manufacturers with access to sufficient raw material would have been excellent during the second half of the 1970s.

\subsection{Organisational Changes at Akzo}

During the 1960s, Koninklijke Zwanenberg Organon, the parent company of VPF, had grown considerably as the result of a series of mergers. In 1967 Koninklijke Zwanenberg Organon combined with Koninklijke Zout Ketjen to form Koninklijke Zout Organon and in 1969 that company merged with AKU/Enka- Glanzstoff resulting in a large conglomerate thereafter 
named Akzo. ${ }^{25}$ In 1970 Organon, VPF, Nourypharma and a few other companies comprised the pharmaceutical division Akzo Pharma. ${ }^{26}$

In the early 1970s Organon operated as two quite separate branches: one was involved in the development and marketing of ethical pharmaceutical products and the other in the making and selling of active pharmaceutical ingredients (APIs) in bulk. Many of the APIs were made specifically for Organon's pharmaceutical products but some were also sold to pharmaceutical companies outside Akzo. This selling of APIs to other companies, which were sometimes competing with Organon's pharmaceutical products, resulted in tension within the Organon organisation. ${ }^{27}$

In 1973 it was decided to split Organon into two separate business units: the pharmaceutical specialty business to continue under the name of Organon, and the API branch became a separate unit, Diosynth. Both business units would operate under the umbrella of Akzo Pharma. Appointed as joint Managing Directors of Diosynth were F. Vekemans (commercial management) and W. Smit (technical management). ${ }^{28}$

This reorganisation had implications for VPF. VPF was a diversified company including the product groups: alkaloids, pharmaceutical products, baby-care products and aerosols. Given the structure of Akzo it was considered advantageous to split VPF into three parts. The product group Alkaloids was to become the new product group A of Diosynth, next to Diosynth's existing production groups B: Biochemicals and C: Chemicals (steroids). ${ }^{29}$ The baby-care products (Zwitsal) and aerosols were moved to the Consumer Product Division of Akzo and the pharmaceutical products to Nourypharma. All manufacturing operations were to remain however at the VPF facilities in Apeldoorn.

VPF's Managing Director Nieukerke retired in 1975. Kloet left the company and the author and Van den Biggelaar moved to Diosynth at Oss assuming the functions of Manager Business Development and Regional Sales Manager respectively. In 1977 Management of Product Group A, Alkaloids, consisted of Hans Vermeer, marketing manager, Fred Vis, factory manager (Apeldoorn) and Edward Buurman manager research and development. ${ }^{30}$

In September 1977 the author left Diosynth to become General Manager Chemical Operations of Abbott Australasia and of Tasmanian Alkaloids, a joint venture of Abbott Laboratories (USA) and Ciech-Polfa (Poland). Tasmanian Alkaloids was established in 1975 to produce morphine from locally grown $P$. somniferum. Codeine manufacture was located at Abbott Australasia, Sydney, at the time.

\subsection{Alternatives for Turkish Poppy Straw at VPF}

\section{Indian Poppy Straw}

When it became known at VPF that Turkey would cease poppy cultivation from 1972 the question arose: which alternative raw material could replace Turkish poppy straw as the source of morphine? There was not much choice and short term poppy straw from India seemed to be the only viable option. Disadvantages of this option were the low morphine

\footnotetext{
${ }^{25}$ Akzo Nobel N.V., ‘ Tomorrow’s Answers Today, De geschiedenis van AkzoNobel’ (2008);

L.S. Wolpert, Management van organisatievernieuwing, Dissertation University of Groningen (2002) 58.

${ }^{26}$ M. Tausk, Organon De geschiedenis van een bijzondere Nederlandse onderneming (Nijmegen 1978), Section 95: 'Akzo Pharma als een geheel', 486-496.

${ }^{27}$ Ibidem. Section 84: 'Twee in één', 421-424.

${ }^{28}$ Ibidem. Section 85: 'Eén in tweeën', 424-428.

${ }^{29}$ Diosynth, Personel Department, Organisation Chart 5.0, Diosynth Group, January 1977

${ }^{30}$ Ibidem.
} 
content $(0.16-0.20 \%)$ of the heavily lanced Indian poppy straw, and the fact that the Indian straw had never been traded. At the time it was a waste product and the buying and collection of the straw in India and the transportation to the Netherlands had to be organised from scratch. This became a major responsibility of the author.

The buying and transportation problems were tackled and solved with the assistance of VPF's sister company Organon India. ${ }^{31}$ A first obstacle was the status of Indian poppy straw in terms of narcotic control. Discussion with public servants in Delhi on the subject did not proceed smoothly in the beginning. Indian officials required that the same restrictions would apply to poppy straw as to opium. That would have killed the project because of the paperwork and controls involved. Eventually, with the help of the Netherlands ambassador in New Delhi, the problem was solved: only an export permit would be required, and no special permits for the local trade. ${ }^{32}$ Samples of poppy straw were obtained from various regions and a network of "middlemen" for buying from the farmers and transportation to the Indian rail system was established. Exports of the Indian poppy straw were from major ports such as Bombay and Calcutta. Imports of Indian poppy straw into the Netherlands next to imports from Turkey and the USSR during the 1970s are presented in the following table:

\section{Table 13.6 and Figure 13.7 Imports of Poppy Straw into the Netherlands 1971-1980 (tonnes)}

\begin{tabular}{|c|c|c|c|c|c|c|c|c|c|c|}
\hline \multirow{2}{*}{ Year } & \multicolumn{3}{|c|}{ Turkey } & \multicolumn{3}{|c|}{ India } & \multicolumn{3}{|c|}{ USSR } & \multirow{2}{*}{$\begin{array}{c}\text { Total } \\
\text { Nether- } \\
\text { lands }\end{array}$} \\
\hline & Total & $\begin{array}{c}\begin{array}{l}\text { Nether- } \\
\text { lands }\end{array} \\
\end{array}$ & Neth. \% & Total & $\begin{array}{l}\text { Nether- } \\
\text { lands }\end{array}$ & Neth. \% & Total & $\begin{array}{l}\begin{array}{l}\text { Nether- } \\
\text { lands }\end{array} \\
\end{array}$ & Neth. \% & \\
\hline 1971 & 14,507 & 8,000 & 55 & 0 & 0 & -- & 1,274 & 1,077 & 85 & 9,077 \\
\hline 1972 & 4,146 & 3,505 & 85 & 692 & 11 & 2 & 0 & 0 & -- & 3,516 \\
\hline 1973 & 65 & 0 & 0 & 3,392 & 2,229 & 66 & 0 & 0 & -- & 2,229 \\
\hline 1974 & 0 & 0 & -- & 7,925 & 6,535 & 82 & 0 & 0 & -- & 6,535 \\
\hline 1975 & 50 & 0 & 0 & 8,324 & 6,434 & 77 & 320 & 320 & 100 & 6,754 \\
\hline 1976 & 6,406 & 4,085 & 64 & 13,114 & 10,262 & 78 & 0 & 0 & -- & 14,347 \\
\hline 1977 & 7,794 & 1,500 & 19 & 3,748 & 1,022 & 27 & 0 & 0 & -- & 2,522 \\
\hline 1978 & 11,691 & 7,991 & 68 & 799 & 9 & 1 & 0 & 0 & -- & 8,000 \\
\hline 1979 & 4,797 & 4,797 & 100 & 1,952 & 1,952 & 100 & 0 & 0 & -- & 6,749 \\
\hline 1980 & 13,331 & 13,331 & 100 & 28 & 2 & 7 & 0 & 0 & -- & 13,333 \\
\hline Total & & & & & & & & & & \\
\hline $1971-1980$ & 62,787 & 43,209 & 69 & 39,974 & 28,456 & 71 & 1,594 & 1,397 & 88 & 73,062 \\
\hline
\end{tabular}

\footnotetext{
${ }^{31}$ Organon India, managing director Mr Gupta, Direct assistance was provided by: Dr S.L. Mukherjee, Mr V. Iyengar and Mr P.N. Sharma (Diary notes HHB).

${ }^{32}$ Meeting of Mr Jasjit Singh, Revenue Commissioner [for Opium] of India, with Dr Tj. A. Meurs, Ambassador of the Netherlands to India, and the author at North Block, New Delhi, on 29 November 1973. At that occasion also the VPF proposal to construct a poppy extraction plant in India was discussed (Diary notes HHB). The proposal from the Netherlands to construct a poppy extraction plant in India is mentioned in a cable from the US Embassy in New Delhi to the Secretary of State, Washington, dated December 1973. Declassified document 14803 (aad.archives.gov/aad) 30 June 2005.
} 
Figure 13.7

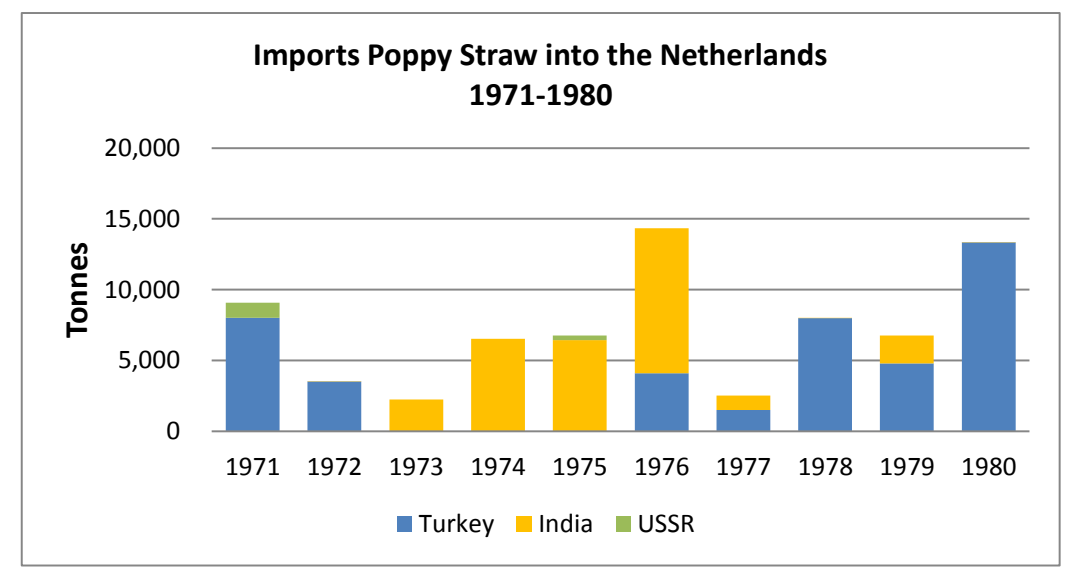

Sources: INCB Statistics 1971-1980 and INCB Report for 1980 E/INCB/52/Supp.

Papaver bracteatum Lindl.

The raw material shortage pursuant to Turkey ceasing poppy cultivation resulted in renewed interested in other papaver species as potential sources of morphinan alkaloids. Among those, Papaver bracteatum Lindl, a species found in Northern Iran, stood out because it contains thebaine as the dominant alkaloid in high concentrations. As thebaine can be converted chemically into codeine in a two-step synthesis, Papaver bracteatum was identified as the subject for further study by a working group of experts, a project which was initiated by the United Nations Division of Narcotic Drugs. The first meeting of the working group was held in Geneva in 1972 followed by meetings in Teheran (1973), in Beltsville (USA, 1974) and Rennes (France, 1975). Participants were specialists from universities and government organisations from all over the world and representatives from major opiate manufacturers. The author participated as representative of the VPF in the meetings in 1973, 1974 and 1975. The project was called "Scientific Research on Papaver bracteatum" and the results of the coordinated research were published in a series of papers by the UN Division of Narcotic Drugs. ${ }^{33}$ Number 16 in the series was a contribution by the VPF laboratory on the determination of thebaine in Papaver bracteatum. ${ }^{34}$

\footnotetext{
${ }^{33}$ UN Division of Narcotic Drugs, 'Scientific Research on Papaver bracteatum', ST/SOA/SER.J/1-28 (1973-1977).

${ }^{34}$ C.J. Agasi and H.H. Bosman, 'Determination of Thebaine in Papaver bracteatum', ST/SOA/SER.J/16 (1974) Nov 27.
} 
The conversion of thebaine into codeine had been elaborated notably by scientists at the laboratories of Sempa Chimie (France) ${ }^{35}$ and at Macfarlan Smith (Scotland) ${ }^{36}$ The Sempa method that gave an overall yield of $70 \%$ from thebaine to codeine was the following:

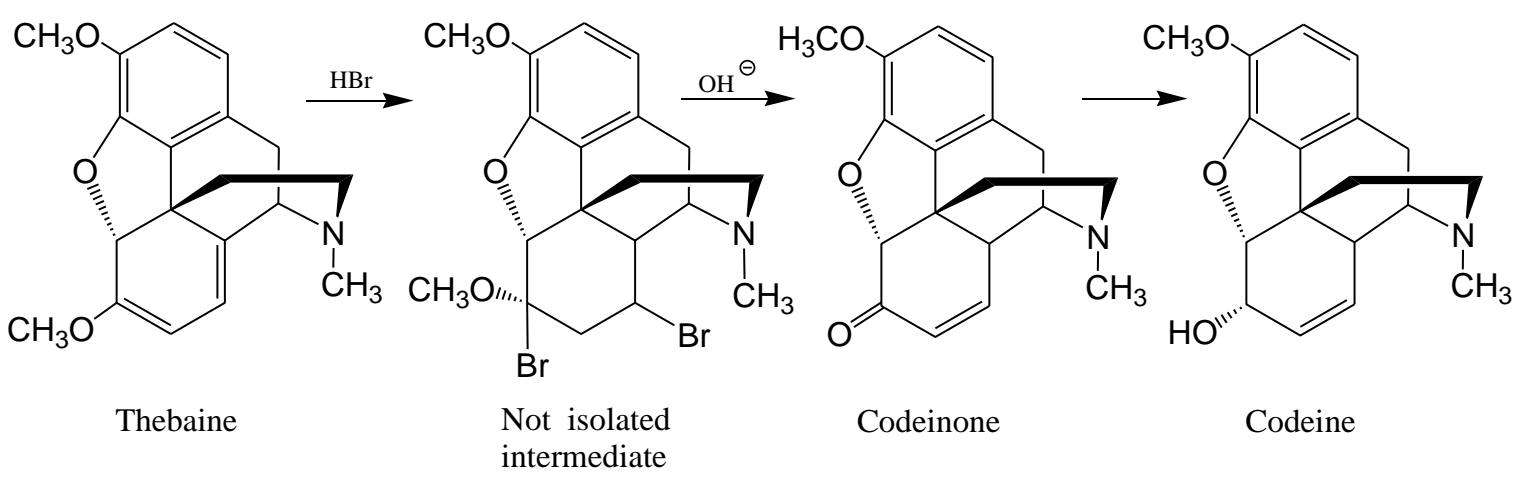

Figure 13.8 The conversion of thebaine into codeine

In 1974 experimental cultivation of Papaver bracteatum in the Netherlands was taken up by VPF using the services of Mommersteeg, a commercial plant breeding company. The project was not successful, however. Despite the availability of good quality seed from Iran, the seedlings became a collection of very irregular mature plants, with a disappointing thebaine content of the capsules. VPF had been more optimistic, but it can be seen as a confirmation of the statement by Professor Teteny (Hungary) during one of the Papaver bracteatum conferences that it takes at least ten years of selection and study to transform a wild plant into one suitable for commercial cultivation.

The VPF project was later abandoned and although the cultivation was more successful in other countries $P$. bracteatum did not become a crop from which thebaine was produced commercially on a large scale as a raw material for codeine. The reasons for this included the specific problems with $P$. bracteatum cultivation and also the knowledge that $P$. somniferum plants with high morphine content were now being cultivated in Australia, highlighting the potential of the traditional opium poppy to remain the most economical raw material for opiate production.

The United Nations appeared to have lost interest in the project after the 1976 meeting of the Working Group. By then the notion that P. bracteatum cultivation could replace poppy growing in India and Turkey as a source of raw materials had reached the UN. That was considered politically unpalatable, hence the reaction. ${ }^{37}$ Early in 1977, at a hearing of the US Drug Enforcement Administration (DEA) "In the matter of P. bracteatum" 38 all US opiate manufacturers stated to be in favour of the cultivation of P. bracteatum in the USA, whereas the US State Department (represented by Mathea Falco, senior advisor to the Secretary of State) declared to be against it.

Among the arguments used by the US State Department were:

\footnotetext{
${ }^{35}$ Sempa Chimie, Inventor: François Krausz, 'Method for the preparation of Codeinone from Thebaine', US Patent 3,112,323 (1963) Nov 26.

${ }^{36}$ Macfarlan Smith Ltd,'Process for the production of 8-halodihydrocodeinone hydrohalides', Inventors:

E.L Grew. and H.A.S. Payne, US Patent 4,140,687 (1979) Feb 20.

${ }^{37}$ Smith D.M., 'Problem Areas in the International Control of Narcotic Drugs', Interdepartmental Committee on International Narcotics Matters (Canada) (1980).

${ }^{38}$ United States Department of Justice (DEA) In the matter of Papaver bracteatum, Report, Synopsis of Testimony, and recommendations of Administrative Law Judge, Docket No. 76-46 (1977) April 11.
} 
[it would result in] 'increased availability of narcotic raw materials for illicit purposes.'

[because of] 'serious adverse economic and social impact [it would have] on poorer countries which have been the traditional legal narcotic raw material producers for export'.

[hence] 'developed countries have an overriding moral obligation to refrain from initiating commercial P. bracteatum cultivation.'

Apparently the US State Department took the view that if India and Turkey would sell less than planned quantities of narcotic raw materials to licensed buyers, the unsold product would be offered to illicit users. However, if that would not happen, then these 'poor countries' would suffer economically, something that could be prevented by refraining from $P$. bracteatum cultivation, and this was therefor an 'overriding moral obligation'. The objections by the US opiate manufacturers based on the shortage of thebaine from opium as the exclusive raw material for oxycodone and nal-compounds were considered less important, and the cultivation was not allowed by the DEA on the grounds that it would have been contrary to US international control policy. ${ }^{39}$

This kind of reasoning was eagerly taken up by the Commission on Narcotic Drugs and is at the base of later UN resolutions to support traditional supplier countries.

\section{Total Synthesis of Codeine}

A totally different alternative to producing opiates from the poppy plant was total synthesis from simple chemicals. The first total synthesis of morphine was achieved by Gates and Tschudi in 1952. ${ }^{40}$ The number of steps involved was great and the yield was low. Over the next twenty years several other synthesis of the morphinan skeleton were published, none of them resulting in a commercially viable route to codeine.

The sharply increasing prices for morphine and derivatives in the early 1970 s caused VPF to have another look at total synthesis. This was also spurred by a publication of G.C. Morrison c.s. on the acid-catalysed ring closure of certain benzylisoquinolines leading to the morphinan ring system. ${ }^{41}$ This route was further explored by the group of Professor H.C. Beyerman and Dr. Leen Maat at Delft University of Technology in collaboration with the VPF laboratory led by the author. The original Morrison synthesis yielded only $3 \%$ of the desired intermediate product and $37 \%$ of an unwanted isomer. A breakthrough, based on an idea generated during a discussion between the author and Maat, was achieved by using a symmetrically substituted benzylisoquinoline that after ring closure could yield only one intermediate product which was subsequently converted into dihydrothebainone. The transformation of the latter compound into codeine and morphine had been achieved by others earlier.

\footnotetext{
${ }^{39}$ Jane Lang, Esq., Spenger \& Lang, Attorneys at Law, Washington D.C., 'United States Narcotic Raw Materials Import Policy, A memorandum prepared for Mallinckrodt, Inc. (August 1989), Page 17.

Submitted by Mallinckrodt as part of 'Testimony on the licit importation of opiate raw materials into the US', dated February 27, 1990, to the Subcommittee on Crime of the House Committee on the Judiciary.

${ }^{40}$ M. Gates and G. Tschudi, Journal of the American Chemical Society 74 (1952) 1109.

${ }^{41}$ Morrison G.C., Waite R.O. and Shavel J., Tetrahedron Letters (1967) 4055
} 
The Delft/VPF codeine synthesis was published in $1976 / 1978 .{ }^{42,43}$ It has been qualified as one of the best [practical] syntheses of morphine [codeine]. ${ }^{44}$<smiles>COC1=CCC2=C(CCN(C)C2Cc2cc(O)c(OC)c(O)c2)C1</smiles>

Key Intermediate

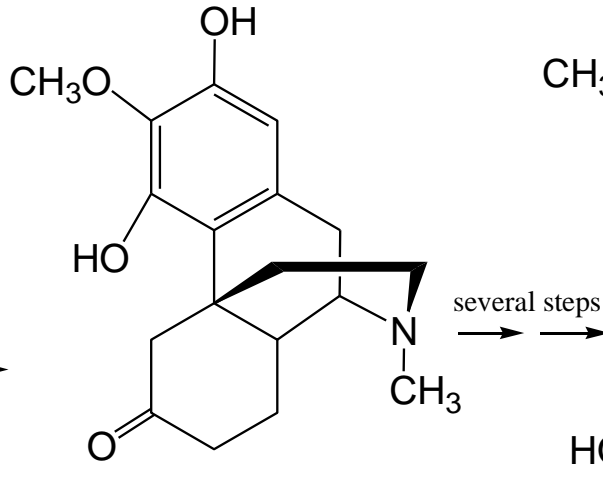

After ring closure<smiles>COc1ccc2c3c1O[C@@H]1C[C@@]34CN(C)[C@@H](C2)C4C=C[C@H]1O</smiles>

Codeine

Figure 13.9 The Delft/VPF codeine synthesis

At the time the research work was completed the prices of codeine had come down substantially, making the synthesis not commercially viable.

\subsection{Construction of the Opiate Manufacturing Facility at Bolvadin (Turkey) Involvement of Akzo}

In 1974 the Turkish Government announced that the poppy extraction plant and codeine manufacturing facilities would be built at Bolvadin, near Afyon, and put out a tender for its construction. A few companies, amongst them VPF and Knoll (Germany) made a bid. VPF decided to participate in the hope that if it were to win the tender there would be a possibility to make a deal with the Turkish government that would include an option for supplying Turkish poppy straw to VPF after the completion of the new factory.

VPF's bid was based on the technology used in the Apeldoorn facilities and was prepared by Akzo Engineering (Ir. Jacobs). In 1975, a Turkish delegation visited the VPF to inspect the opiate manufacturing facilities as the first round of the tender process.

\footnotetext{
${ }^{42}$ H.C. Beyerman, T.S. Lie, L. and Maat (TH Delft) and

H.H. Bosman, E. Buurman, E.J.M. Bijsterveld and H.J.M. Sinnige (VPF),

'A convenient Synthesis of Codeine and Morphine',

Receuil des Travaux Chimiques des Pays-Bas 95 (1976) 24-25.

${ }^{43}$ H.C. Beyerman, T.S. Lie, L. Maat, and J.C.M. Wessels (TH Delft) and

H.H. Bosman, E. Buurman, E.J.M. Bijsterveld and H.J.M. Sinnige (VPF),

'Synthesis of racemic and potically active codeine and morphine via N-formyl-nordihydrothebainones', Receuil des Travaux Chimiques des Pays-Bas 97 (1978) 127-130.

${ }^{44}$ E. Homburg and L. Palm (Editors), Geschiedenis van de scheikunde in Nederland 3, Delft (2004), 261.
} 
Figure 13.10

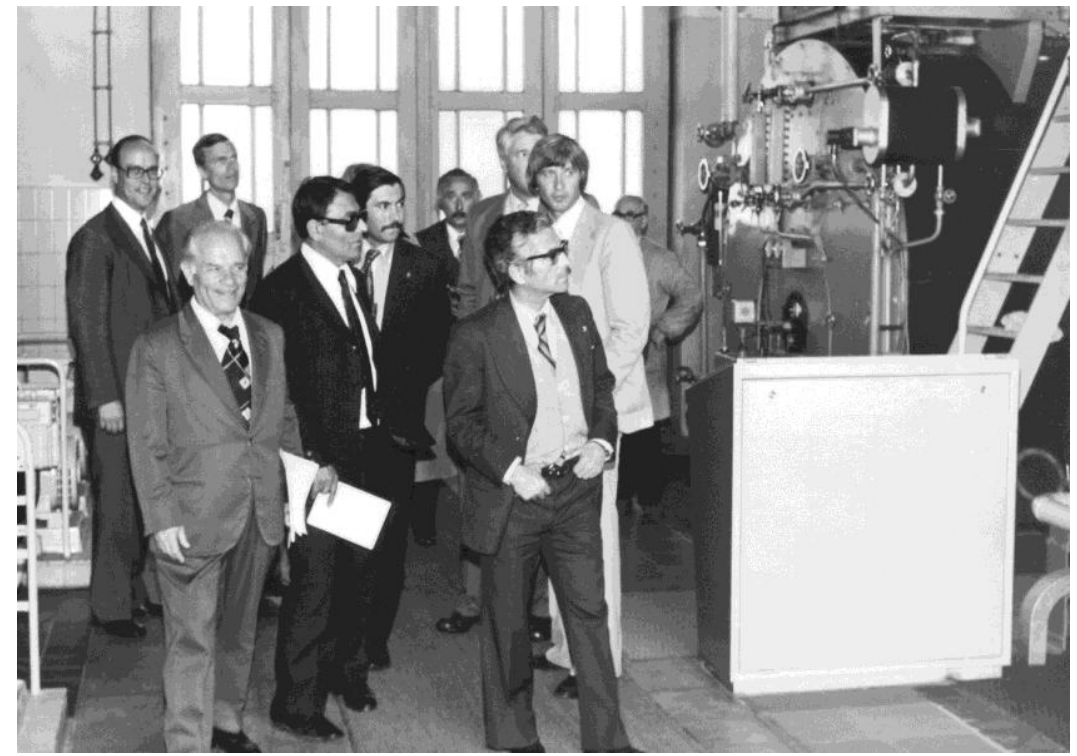

A Turkish delegation visiting the VPF in 1975 (Photo Collection HHB)

Ultimately the tender was won by Knoll which together with the Deutsche Bank offered to finance the project. Akzo was not willing to match the financing arrangements offered by Knoll and consequently the tender was lost.

Construction of the Turkish plant took much longer than originally anticipated but the plant was inaugurated in August 1980. As a result, 1980 was the last year the VPF (Diosynth) received poppy straw from Turkey.

The Turkish factory had a design capacity of 20,000 tonnes poppy straw p.a. input and an output of $60,000 \mathrm{~kg}$ morphine (AMA). It would employ 300 people and in the order of 150,000 farmers would be involved in growing the crop. The price paid to farmers for the poppy straw was USD 1,200-1,400 per tonne in 1975/76. Cost of the factory was originally estimated at USD 40 million but is likely to have been around USD 60 million. ${ }^{45}$ On the basis of the above cost data it is easy to see that the cost of morphine and codeine produced in the Turkish factory would be very high in comparison with its competitors in other countries.

\subsection{Morphine and Codeine Manufacture at VPF/Diosynth}

The resumption of poppy cultivation in Turkey in 1975 meant that from 1976 Turkish poppy straw became available again for export which opened up very favourable business opportunities for Diosynth. The shortage of Indian opium had led to a reduced production of codeine in the USA. The price of codeine phosphate had gone up greatly and US opiate manufacturers were desperate to obtain raw materials. Until the 1970s opium was the sole raw material lawfully imported into the US but that changed when, in 1975, the DEA authorized the importation of CPS to meet medicinal needs. ${ }^{46}$ VPF had experience in

\footnotetext{
${ }^{45}$ D. Shirreff, 'Opium poppy growing thrives but marketing proves difficult', Middle East Economic Digest (1977) September 23, 7.

${ }^{46}$ Lang, 'Testimony on the licit importation of opiate raw materials into the US', dated February 27, 1990, to the Subcommittee on Crime of the House Committee on the Judiciary).
} 
extraction of Turkish poppy straw and had considerable capacity for the processing. Already during 1974 discussions started between Diosynth and Mallinckrodt, St. Louis, on VPF entering an agreement to extract Turkish straw for supply of CPS to Mallinckrodt. ${ }^{47}$ Poppy straw was purchased in Turkey and CPS supplies to the USA commenced in 1976. Supply agreements for CPS with the other US narcotic manufacturers, Merck Inc. and Penick, were concluded shortly thereafter.

The terms of the contracts with the US manufacturers were favourable for VPF/Diosynth because of the raw material shortage, the unique position of VPF as experienced processor of Turkish poppy straw and the high prices in the closed US codeine market. The US demand for CPS was so large that in 1977 extraction capacity was doubled to $10,000 \mathrm{t}$ poppy straw p.a. by VPF installing a second extractor. ${ }^{48}$ Supplying CPS to the USA was for VPF more profitable than converting the CPS into codeine and selling the codeine in the open world market. Figures 13.12 and 13.13 (below) show clearly that during the period 1977-1979, and very pronounced during 1977-1978, VPF/Diosynth exported preferentially CPS rather than codeine.

Production figures for VPF/Diosynth during the 1970s have been extracted from the INCB statistics and are presented in the following tables and graphs.

Table 13.7 Morphine Manufacture from Opium and Poppy Straw The Netherlands 1971-1980

\begin{tabular}{|c|c|c|c|c|c|c|c|c|c|c|c|c|}
\hline & \multirow[b]{2}{*}{ Year } & \multicolumn{2}{|c|}{ (1) Opium } & \multicolumn{3}{|c|}{ (2) Poppy Straw to CPS } & \multicolumn{3}{|c|}{ (3) Poppy Straw to Morphine } & \multicolumn{3}{|c|}{ (4) Poppy Straw to CPS + Morphine } \\
\hline & & $\begin{array}{l}\text { Utilized } \\
\mathbf{k g}\end{array}$ & $\begin{array}{c}\text { Morphine } \\
\text { manuf. } \\
\text { AMA kg }\end{array}$ & $\begin{array}{c}\text { Utilized } \\
t\end{array}$ & $\begin{array}{c}\text { CPS } \\
\text { manuf. } \\
\text { CPS kg }\end{array}$ & $\begin{array}{c}\text { Morphine } \\
\text { Yield } \\
\%\end{array}$ & $\begin{array}{c}\text { Utilized } \\
t\end{array}$ & $\begin{array}{c}\text { Morphine } \\
\text { manuf. } \\
\text { AMA kg }\end{array}$ & $\begin{array}{c}\text { Morphine } \\
\text { Yield } \\
\%\end{array}$ & $\begin{array}{c}\text { Utilized } \\
t\end{array}$ & $\begin{array}{c}\text { Morphine } \\
\text { manuf. } \\
\text { AMA kg }\end{array}$ & $\begin{array}{c}\text { Morphine } \\
\text { Yield } \\
\%\end{array}$ \\
\hline \multirow{11}{*}{ Average } & 1971 & 13,364 & 1,326 & 2,246 & 13,500 & 0.30 & 4,727 & 12,010 & 0.25 & 6,973 & 18,760 & 0.27 \\
\hline & 1972 & 14,520 & 1,249 & 2,007 & 11,700 & 0.29 & 4,808 & 11,323 & 0.24 & 6,815 & 17,173 & 0.25 \\
\hline & 1973 & 11,974 & 1,197 & 3,684 & 14,000 & 0.19 & 2,486 & 4,675 & 0.19 & 6,170 & 11,675 & 0.19 \\
\hline & 1974 & 17,034 & 1,703 & 2,121 & 6,002 & 0.14 & 2,500 & 4,216 & 0.17 & 4,621 & 7,217 & 0.16 \\
\hline & 1975 & 21,232 & 1,974 & 2,892 & 10,441 & 0.18 & 3,339 & 6,029 & 0.18 & 6,231 & 11,250 & 0.18 \\
\hline & 1971-1975 & 15,625 & 1,490 & 2,590 & 11,129 & 0.21 & 3,572 & 7,651 & 0.21 & 6,162 & 13,215 & 0.21 \\
\hline & 1976 & 9,748 & 880 & 4,903 & 21,327 & 0.22 & 2,024 & 4,404 & 0.22 & 6,927 & 15,068 & 0.22 \\
\hline & 1977 & 15,080 & 1,363 & 7,077 & 33,885 & 0.24 & 579 & 1,386 & 0.24 & 7,656 & 18,329 & 0.24 \\
\hline & 1978 & 7,397 & 702 & 8,601 & 53,884 & 0.31 & 1,138 & 3,562 & 0.31 & 9,739 & 30,504 & 0.31 \\
\hline & 1979 & 0 & 0 & 7,766 & 34,613 & 0.22 & 2,191 & 4,881 & 0.22 & 9,957 & 22,188 & 0.22 \\
\hline & 1980 & 0 & 0 & 5,026 & 27,376 & 0.27 & 2,986 & 8,130 & 0.27 & 8,012 & 21,818 & 0.27 \\
\hline Average & 1976-1980 & 6,445 & 589 & 6,675 & 34,217 & 0.26 & 1,784 & 4,473 & 0.25 & 8,458 & 21,581 & 0.26 \\
\hline
\end{tabular}

\footnotetext{
${ }^{47}$ Diary notes by the author (1974).

48 'Bolkaf-extractie definitief historie. Extractor C is gesloopt.', Akzo Publication, February( 1992).
} 
Table 13.8 Morphine Total Manufacture, Export, Import and Conversions Codeine Manufacture, Yield, Net Export and Consumption The Netherlands 1971-1980

\begin{tabular}{|c|c|c|c|c|c|c|c|c|c|c|}
\hline & \multirow[b]{2}{*}{ Year } & \multicolumn{5}{|c|}{ Morphine (AMA kg) } & \multicolumn{4}{|c|}{ Codeine (ACA kg) } \\
\hline & & $\begin{array}{c}\text { Total } \\
\text { Manu- } \\
\text { facture }\end{array}$ & Export & Import & $\begin{array}{c}\text { Converted } \\
\text { into Codeine }\end{array}$ & $\begin{array}{c}\text { Converted } \\
\text { into Other } \\
\text { Opiates }\end{array}$ & $\begin{array}{l}\text { Codeine } \\
\text { Manu- } \\
\text { factured }\end{array}$ & $\begin{array}{c}\text { Codeine } \\
\text { Yield } \\
\text { w/w \% }\end{array}$ & $\begin{array}{c}\text { Net } \\
\text { Export }\end{array}$ & $\begin{array}{l}\text { Local } \\
\text { Consump- } \\
\text { tion }\end{array}$ \\
\hline \multirow{11}{*}{ Average } & 1971 & 20,086 & 8,898 & 288 & 10,985 & 93 & 11,751 & 107 & 10,494 & 987 \\
\hline & 1972 & 18,422 & 7,667 & 1,285 & 10,725 & 244 & 11,559 & 108 & 9,495 & 670 \\
\hline & 1973 & 12,872 & 7,935 & 1,508 & 5,422 & 171 & 7,331 & 135 & 7,735 & 864 \\
\hline & 1974 & 8,920 & 3,048 & 855 & 8,364 & 24 & 10,482 & 125 & 8,451 & 1,453 \\
\hline & 1975 & 13,224 & 5,322 & 0 & 6,765 & 258 & 10,424 & 154 & 8,958 & 807 \\
\hline & 1971-1975 & 14,705 & 6,574 & 787 & 8,452 & 158 & 10,309 & 122 & 9,027 & 956 \\
\hline & 1976 & 15,948 & 8,405 & 0 & 5,239 & 0 & 7,614 & 145 & 5,658 & 1,114 \\
\hline & 1977 & 19,692 & 15,940 & 1,051 & 1,913 & 264 & 4,683 & 245 & 3,931 & 870 \\
\hline & 1978 & 31,206 & 26,064 & 0 & 1,872 & 0 & 4,342 & 232 & 3,792 & 790 \\
\hline & 1979 & 22,188 & 17,882 & 0 & 6,221 & 225 & 9,943 & 160 & 5,544 & 1,200 \\
\hline & 1980 & 21,818 & 13,212 & 0 & 7,733 & 0 & 9,433 & 122 & 10,101 & 698 \\
\hline Average & 1976-1980 & 22,170 & 16,301 & 210 & 4,596 & 98 & 7,203 & 157 & 5,805 & 934 \\
\hline
\end{tabular}

Source: INCB Statistics 1971-1980 and Demand and Supply of Opiates, INCB Report for 1980

Note: the Codeine Yield includes natural codeine (It is not a measure for the synthetic codeine yield)

Figure 13.11 illustrates the raw material shortage of 1974, the resumption of supplies of Turkish poppy straw from 1976 and the installation, in 1977, of the second large extractor. The largest morphine production ever at VPF was 31,206 kg AMA in 1978. Figures 13.12 and 13.13 depict for 1976-1979 the above mentioned VPF/Diosynth strategy of selling the maximum quantity of CPS to the USA at the expense of codeine sales.

During the years 1970-1978 considerable quantities of Indian opium were coextracted with the poppy straw to augment the alkaloid output. The low morphine yield from poppy straw during 1973-1975 (Table 13.7) reflected the use of heavily lanced Indian straw as the main raw material. From 1976 onwards Turkish poppy straw, now unlanced and with a morphine content of approximately $0.30 \%$, became available and the imports from India were reduced.

The content of natural codeine and thebaine in lanced Indian poppy straw was surprisingly high. The natural codeine content was occasionally as high as $50 \%$ of the morphine content. As the cost of the Indian poppy straw did not depended on its alkaloid content and the natural codeine and the thebaine were isolated from the process liquors at low cost, this was a windfall. It made processing of Indian poppy straw more economical than anticipated. At VPF a large liquid / liquid extractor was commissioned to isolate the considerable quantities of secondary alkaloids originating from the Indian poppy straw. In view of the high value of the products this was a worthwhile investment. On the basis of the amounts of codeine produced and morphine converted into codeine appearing in tables 10.2 and 10.3 it was calculated that an annual average of about $2,500 \mathrm{~kg}$ natural codeine was produced from poppy straw and opium over the period 1971-1980. That quantity is equal to $14 \%$ of the amount of morphine produced over the same period. 
Figure 13.11 Morphine Manufacture

Figure 13.12 Morphine Conversions and Net Export

Figure 13.13 Codeine Net Export and Local Consumption

The Netherlands 1971-1980

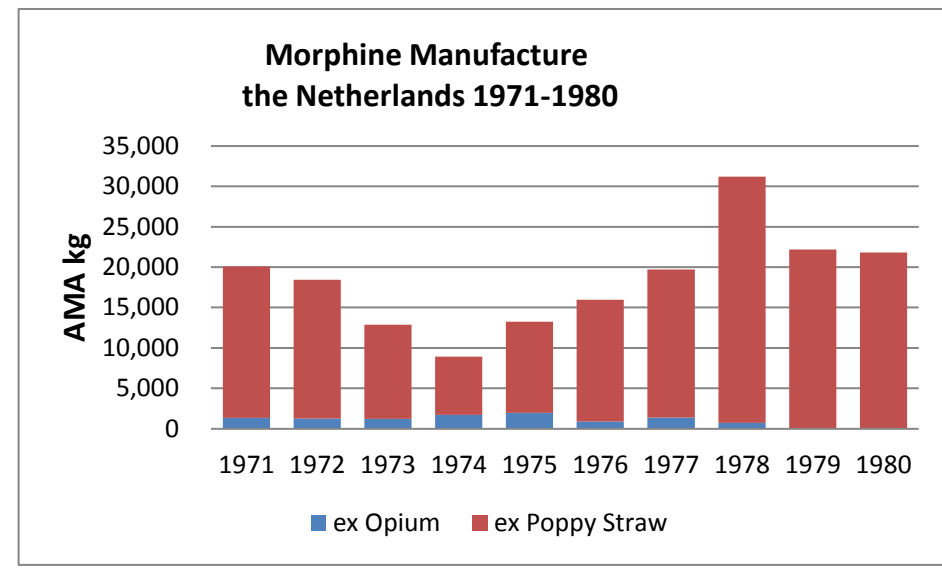

Figure 13.11

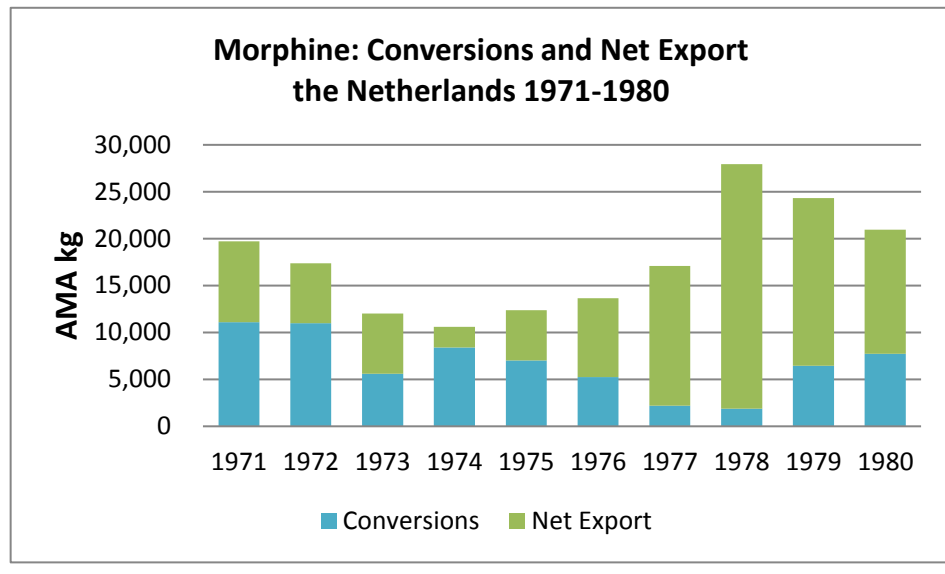

Figure 13.12

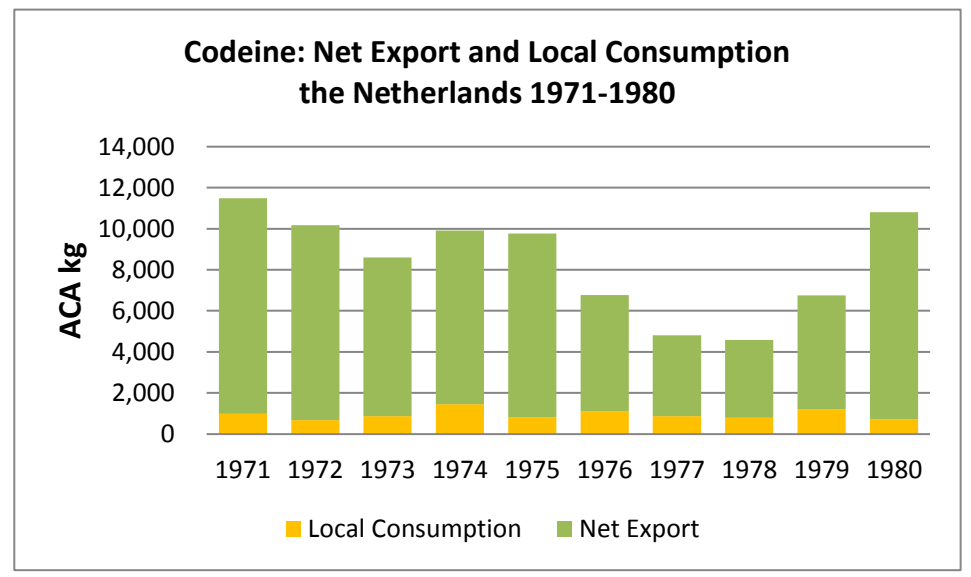

Figure 13.13

Source: Tables 13.7 and 13.8 


\subsection{Opiate Marketing and Prices 1971-1980}

All marketing of opiates during the 1970s was dominated by the consequences of Turkey abandoning poppy cultivation in 1972 and resuming it in 1975. Prices for opium, CPS and codeine in the world market rose sharply from 1970, reaching maximum values during 19761977. In the USA, where codeine imports were (and are) not allowed, the price for codeine phosphate exceeded USD 1,000 per kg for a brief period.

As discussed in previous sections, VPF solved its raw material problem in the early 1970s by importing poppy straw from India. During the second half of the decade large quantities of unlanced Turkish poppy straw were imported. The general shortage of opiates allowed VPF to achieve, compared to the 1960s, very substantially increased codeine sales at much better prices during the years 1970-1975. When the poppy straw from Turkey became available again, production of morphine as CPS for the US market became the most profitable way of utilising VPF's extraction capacity and as a result codeine sales declined.

The following table shows for VPF/Diosynth quantities of morphine exported as CPS and of codeine produced together with Indian opium prices (as set by the Government of India) and open world market prices for codeine phosphate. Assuming conservatively that $\mathrm{VPF} /$ Diosynth sold all morphine in CPS at a price equivalent to the Indian opium price and all codeine at the prevailing codeine phosphate price, a ballpark estimate of total sales revenue from morphine plus codeine has been made:

Table 13.9 and Figures 13.14 -13.15 Estimates of Sales VPF/Diosynth 1972-1980

\begin{tabular}{|c|rc|rc|c|c|}
\hline Year & $\begin{array}{c}\text { Morphine } \\
\text { Sold } \\
\text { AMA kg }\end{array}$ & $\begin{array}{c}\text { Opium } \\
\text { Price } \\
\text { USD/kg }\end{array}$ & $\begin{array}{c}\text { Codeine } \\
\text { Sold } \\
\text { ACA kg }\end{array}$ & $\begin{array}{c}\text { Price } \\
\text { codphos } \\
\text { USD/kg }\end{array}$ & $\begin{array}{c}\text { Exchange } \\
\text { Rate } \\
\text { NLG/USD }\end{array}$ & $\begin{array}{c}\text { Total } \\
\text { Value } \\
\text { NLG milj. }\end{array}$ \\
\hline 1972 & 6,382 & 18.0 & 10,165 & 325 & 3.21 & 18 \\
1973 & 6,427 & 24.0 & 8,599 & 330 & 2.78 & 15 \\
1974 & 2,193 & 26.7 & 9,904 & 405 & 2.68 & 17 \\
1975 & 5,322 & 32.0 & 9,765 & 650 & 2.52 & 26 \\
1976 & 8,405 & 49.0 & 6,772 & 825 & 2.64 & 30 \\
1977 & 14,889 & 60.0 & 4,801 & 780 & 2.45 & 32 \\
1978 & 26,064 & 60.0 & 4,582 & 650 & 2.16 & 38 \\
1979 & 17,882 & 50.0 & 6,744 & 495 & 2.01 & 25 \\
1980 & 13,212 & 45.0 & 10,799 & 400 & 1.99 & 23 \\
& & & & & & \\
\hline
\end{tabular}
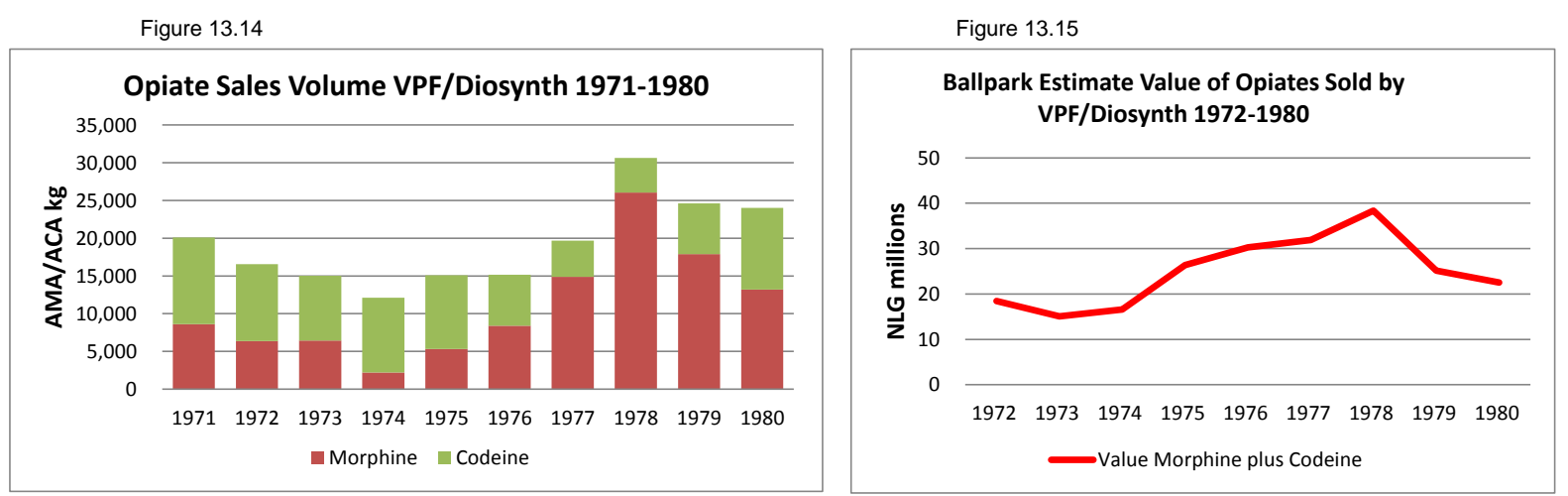

Source: Morphine Sold = Export-Import, and Codeine Sold = Net Export + Local Consumption (Table 13.8); Indian opium price and codeine phosphate price (Table 13.5); AMA price $=$ Opium price $* 116 / 14+23($ Chapter 12 , footnote 12), ACA price $=$ codeine phosphate price $/ 0.74$ (base content). 
From the estimated sales values of opiates in the table and graph it can be seen how well the opiate business developed for VPF/Diosynth during the 1970s. Annual sales rose from about NLG 17 million during 1972-1974 to a maximum in the order of 38 million in 1978, to decline somewhat thereafter.

\subsection{Summary and Outlook for the next Period}

The period 1971-1980 was successful for VPF/Diosynth. Because of the large capacity for the extraction of poppy straw the company could take full advantage of the high opiate prices resulting from the raw material shortage once Turkish poppy straw was obtainable again.

However, signs of a much less prosperous future for Diosynth were already obvious from 1975. Turkey had made arrangements for the construction of a large opiate production facility. India substantially expanded opium production and export. Glaxo Australia commenced commercial cultivation of high yielding strains of Papaver somniferum in 1970, followed in 1975 by Tasmanian Alkaloids; poppy cultivation also expanded in France.

It was clear that these expansions of production of opiate raw materials would fill the "gap" created by Turkey abandoning poppy cultivation in 1971, many times over resulting in a severe over-production, and consequently a price collapse. The decline of the world market price for codeine from 1977 was a first indication of worse things to come. For Diosynth, to maintain its profitable position in the opiate market the challenge became how to find a reliable and cheap source of poppy straw with reasonably high morphine content for the years after 1980 when the Turkish factory would come on stream and Turkish poppy straw would not any longer be available. This was a difficult problem for which, as we will see in Chapter 14 , no adequate solution was found. 


\section{ChaPTER 14 \\ THE END OF AN ERA \\ DECLINE OF DIOSYNTH'S OPIATE BUSINESS 1981-2005}

\subsection{Overview}

Two events that marked the beginning of major developments in the opiate raw materials business worldwide in the 1980s were the start-up of the poppy extraction facility in Turkey and the publication of the rule of the DEA (Drug Enforcement Administration) on the importation of opiate raw materials into the USA in 1981. The DEA-rule specified that India and Turkey must be the source of at least 80 per cent of the United States requirements for 'narcotic raw materials' (NRMs). ${ }^{1}$ The result was limited access of other manufacturers to the large US market and increased competition in all markets, leading to severe price erosion for NRMs and codeine, especially after 1984.

Diosynth's opiate business deteriorated during the 1980s. Turkish poppy straw was no longer available after 1980; poppy straw from other sources was used for a few years thereafter but for a number of economic and political reasons this was not successful. 1988 was the last year that poppy straw was extracted in Diosynth's factory. Codeine manufacture continued on the basis of purchased CPS but longer term this also proved to be not economically feasible and codeine production ceased in 1993. It was the end of an era of almost 70 years of codeine manufacture in the Netherlands.

From 1993 to 2005 Diosynth continued importation of CPS for the purposes of trading and manufacturing non-controlled substances such as naloxone and naltrexone, using its own patented process. The product group 'Alkaloids' of Diosynth ceased to exist as a separate unit. Diosynth, in its totality, was absorbed again into the Organon organisation in $2005 .^{2}$

\subsection{International Narcotics Control}

As described in section 13.2, over the years 1977-1980 India had maintained its opium production at a high level and Turkey cultivated poppies on a large scale, both far in excess of demand. The result was the build-up of large stocks of opium in India and poppy straw in Turkey, which led in 1979 to adoption of Resolution 471 by the UN Commission on Narcotic Drugs calling upon importing countries to support the traditional supply countries. ${ }^{3}$

In the USA, Resolution 471 gave rise to an advanced notice of a rulemaking by the DEA on "Proposed Limitations on Imports of Narcotic Raw Materials" on which public comments were requested, and in September 1980 a hearing on the matter was conducted by the administrative law judge. ${ }^{4}$ Affected parties from Australia, France and Hungary opposed the proposed rulemaking, but to no avail. The ultimate result was that in August 1981 the DEA

\footnotetext{
${ }^{1}$ Definition as appearing in the US DEA publication 21 CFR Part 1312, 'Authorized Sources of Narcotic Raw Materials', dated October 4, 2006.

${ }^{2}$ Akzo-Nobel.' Announcement of the integration of Organon and Diosynth' (2005)

www2.akzonobel.nl/nl/pharma/index.asp [2005].

${ }^{3}$ Stocks of opium in India and poppy straw in Turkey at year end 1980 amounted to an equivalent of about 180 and 220 tonnes AMA respectively. (Opium stock ref. Diagram 5, INCB Statistics for 1990; Poppy Straw stocks calculated by the author from Tables 18 and 23 in INCB Report for 1980.

${ }^{4}$ United States Department of Justice (Drug Enforcement Administration) In the matter of Proposed Limitations on imports of Narcotic Raw Materials Report to the Administrator, Docket No. 80-18 (1981) January 16.
} 
published the final rule (21 CFR 1312.13) specifying that "traditional suppliers India and Turkey must be the source of at least 80 per cent of the US requirement for narcotic [opiate] raw materials. Five countries - France, Poland, Hungary, Australia and Yugoslavia - may be the source of not more than 20 per cent." 5

The above '80/20 Rule' provided Turkey with exclusive access of CPS manufactured in its in 1981 completed poppy extraction facility to 80 per cent of the large US opiate raw materials market in competition only with opium from India. However, CPS from Turkey and Indian opium were not fully equivalent raw materials. CPS from Turkey contained next to morphine only some natural codeine while Indian opium contained the full range of alkaloids, including thebaine, an important raw material for the manufacture of oxycodone, naloxone and naltrexone. ${ }^{6}$ While price was an important factor for the decision of US opiate manufacturers on which raw material to buy, the need for thebaine resulted in the buying of considerable quantities of Indian opium, and, when necessary, at a higher morphine price than the CPS price.

From 1983 Turkey produced considerable quantities of CPS (table 14.1) but exports stayed low until 1987 (table 14.3), reportedly as a result of a quality control problem. ${ }^{7}$ It was not before 1987 that export of Turkish CPS to the USA became substantial. During the years 1987-1988, 42 per cent of the AMA in raw materials imported into the USA was supplied by Turkey, 38 per cent by India, 15 per cent by Australia and 5 per cent by France. ${ }^{8}$

The quantities of Indian opium and Turkish CPS produced remained large in comparison to the demand and resulted in large stocks in the producing countries during most of the 1980s. The amounts of stocks held at year end in the countries of origin are depicted in the following graphs:

Figures 14.1 and 14.2 Opiate Raw Material Stocks in India and Turkey 1971-1990
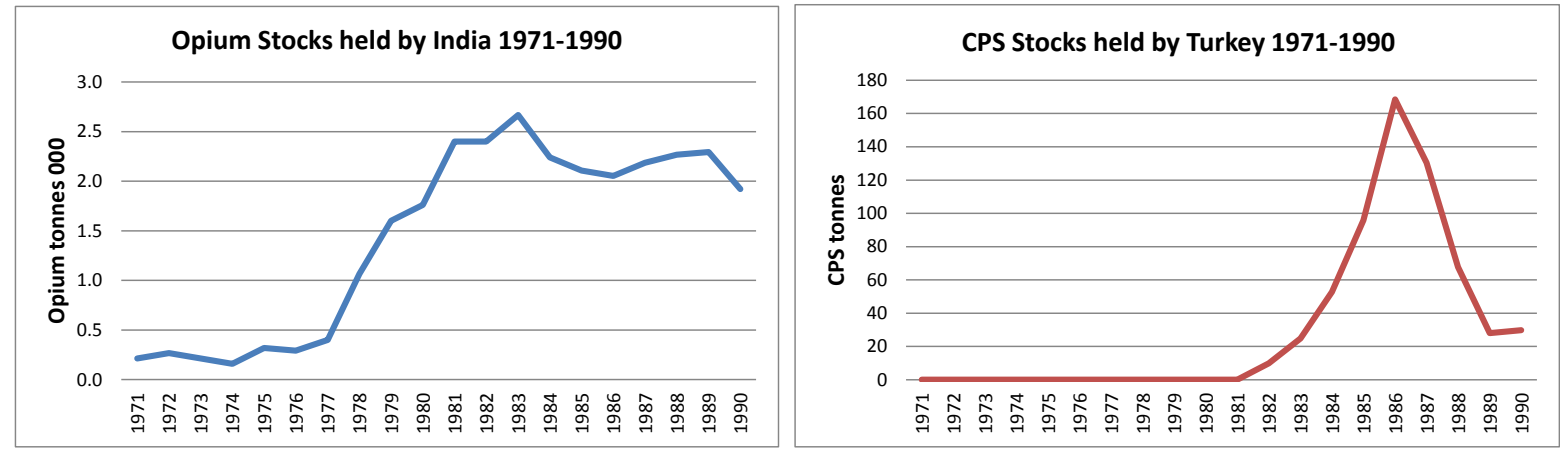

Source: INCB Statistics for 1990, Diagram 5 on p 42 and diagram 10 on p 44.

The average stock level of both Indian opium and Turkish CPS was equivalent to about three years sales during the latter part of the 1980s. The UN Commission on Narcotic Drugs continued to see as the remedy for the excessive stocks: "restriction of opiate raw

\footnotetext{
${ }^{5}$ DEA, 'Authorized Sources of Narcotic Raw Materials' (2006).

${ }^{6}$ Mallinckrodt, Inc., Testimony on the licit importation of opiate raw materials into the United States, Submission to the Subcommittee on Crime of the House committee on the Judiciary ( 1990) February 27, 6-8. Oxycodone was an important analgesic for mild to moderate pain, and Naloxone and Naltrexone were considered to be "irreplaceable opiod antagonists".

${ }^{7}$ US Licit Opium Imports: Foreign Policy Issues, F. Marian Chambers, 'Report of a Staff Study Mission to Turkey, India and Australia', (1989) 6.

${ }^{8}$ US Department of State (Bureau of International Narcotics Matters) and Department of Justice (DEA), 'Report to Congress: Licit Opium Review' (1989), 42.
} 
material production in "countries which have set up additional capacities in recent years" and urged Governments of importing countries to support the traditional supply countries (India and Turkey)'. To that end, virtually each year during the 1980s, resolutions were proposed and adopted in the CND meeting with wording very similar to that of Resolution 471 of 1979 (see Section 13.2). However, not many countries followed the example of the USA of putting strict import restrictions into place, and opium stocks in India remained high until the early 1990s. ${ }^{9}$ Another narcotics control issue played in Europe. As mentioned in previous chapters, from the 1930s governments of manufacturing countries such as the UK, France, and the Netherlands were of the opinion that narcotics control required that no imports of final products would be allowed and, consequently, if the local industry could supply, then import permits for codeine were not issued. In the late 1960s the German government took a different position. The German authorities considered the principle of free movements of goods within the European Economic Community as more important than the risk that allowing imports of narcotics would result in diversion, and issued import permits. The result was that Germany became the largest importer of codeine from 1970 onwards. ${ }^{10}$ Codeine manufacture continued on a small scale in Germany but ceased entirely in 1986 when prices reduced sharply in the open market. ${ }^{11}$

In the early 1980s the authorities in the UK, France, the Netherlands and some other EEC countries held on to the original position that narcotics control required that imports should be restricted, and kept the borders largely closed. Diosynth lobbied that the European Common Market as a whole become a closed market for narcotics from outside the EEC, but with free movement of goods within the market. ${ }^{12}$ That would have given Diosynth access to large markets for codeine (France, UK, Spain, Italy), at the time closed for imports from the Netherlands because of local codeine (opiate) manufacture in these countries. ${ }^{13}$ Diosynth's attempts were unsuccessful, however.

To make matters worse for Diosynth, in the mid-1980s the Dutch position on imports was successfully challenged by importers on the basis that the principle of free movement of goods should prevail over the small possibility that imports of codeine would be diverted, and the result was that from 1987 onwards codeine imports into the Netherlands eventuated. ${ }^{14}$ For Diosynth, the opening up of the Netherland's codeine market amounted to a further weakening of its position as an opiate producer.

\footnotetext{
${ }^{9}$ INCB Statistics for 1994, Figure 5, p78.

${ }^{10}$ INCB Statistics for 1967-1975.

${ }^{11}$ INCB Statistics for 1981-1990.

${ }^{12}$.A discussion paper on free trade opiates in the EEC was circulated in the UK in Sep 1984.

Note by the author on discussions with the UK opiate manufacturer May \&Baker.

${ }^{13}$ Interview of Jack Nijssen, Marketing manager product group C, Diosynth, Oss, 27 August 2002.

${ }^{14}$ INCB Statistics for 1985-1990.
} 


\subsection{The Opiate Market Worldwide during the 1980s}

\section{Morphine Manufacture}

The average total world production of morphine for the 1980s amounted to 198 tonnes AMA p.a., an $11 \%$ increase over the $176 \mathrm{t}$ AMA p.a. produced during the 1970s. The largest increases in production volume were achieved by Australia and Turkey, followed by France.

Table 14.1 Morphine Manufacture by Country 1980-1990 (kg AMA)

\begin{tabular}{|c|c|c|c|c|c|c|c|c|c|c|c|}
\hline & Year & Australia & USA & France & Turkey & USSR & Netherlands & Hungary & UK & $\begin{array}{c}\text { Other } \\
\text { Manuf. } \\
\text { Countries }\end{array}$ & $\begin{array}{c}\text { World } \\
\text { Total }\end{array}$ \\
\hline & 1981 & 29,518 & 20,948 & 26,023 & 0 & 17,396 & 19,064 & 7,099 & 5,506 & 27,920 & 153,473 \\
\hline & 1982 & 28,340 & 31,218 & 25,297 & 9,633 & 18,017 & 13,410 & 6,111 & 5,922 & 27,796 & 165,743 \\
\hline & 1983 & 43,767 & 28,730 & 21,766 & 28,207 & 20,038 & 13,832 & 6,701 & 8,408 & 32,407 & 203,855 \\
\hline & 1984 & 42,657 & 35,867 & 24,556 & 25,031 & 19,142 & 15,557 & 7,306 & 6,499 & 29,533 & 206,148 \\
\hline & 1985 & 47,114 & 43,243 & 30,337 & 30,013 & 13,342 & 24,251 & 10,308 & 12,720 & 33,744 & 245,070 \\
\hline 1981-1985 & Average & 38,279 & 32,001 & 25,596 & 18,577 & 17,587 & 17,223 & 7,505 & 7,811 & 30,280 & 194,858 \\
\hline \multirow[t]{6}{*}{$1986-1990$} & Percent & 21 & 16 & 13 & 10 & 9 & 9 & 4 & 4 & 35 & 100 \\
\hline & 1986 & 46,340 & 40,097 & 25,924 & 46,125 & 21,036 & 14,398 & 8,523 & 8,577 & 25,692 & 236,712 \\
\hline & 1987 & 41,506 & 24,428 & 27,868 & 28,522 & 20,697 & 9,931 & 9,250 & 7,444 & 24,179 & 193,824 \\
\hline & 1988 & 39,196 & 22,622 & 27,845 & 33,008 & 16,862 & 7,508 & 13,142 & 5,001 & 29,760 & 194,944 \\
\hline & 1989 & 46,710 & 23,314 & 31,626 & 18,779 & 723 & 0 & 19,779 & 891 & 30,257 & 172,078 \\
\hline & 1990 & 47,953 & 41,010 & 29,515 & 13,300 & 15,025 & 0 & 21,105 & 8,117 & 34,438 & 210,462 \\
\hline \multirow[t]{2}{*}{ 1986-1990 } & Average & 44,341 & 30,294 & 28,556 & 27,946 & 14,869 & 6,367 & 14,360 & 6,006 & 28,865 & 201,604 \\
\hline & Percent & 22 & 15 & 14 & 14 & 7 & 3 & 7 & 3 & 14 & 100 \\
\hline
\end{tabular}

Source: INCB Statistics on Narcotic Drugs.

Note: In the above table the amounts of morphine manufactured are calculated as the sum of morphine manufactured from opium, morphine manufactured from poppy straw and morphine contained in CPS manufactured.

\section{Figure 14.3 Morphine Manufacture by Country 1980-1990 (kg AMA)}

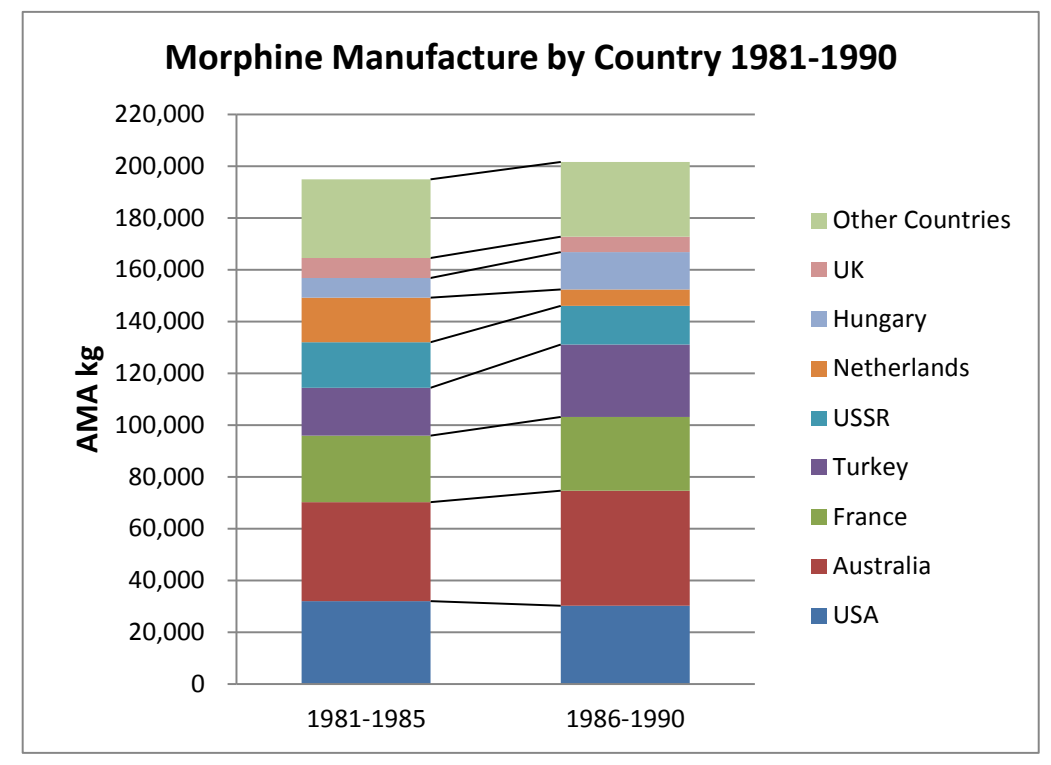

Source: Table 14.1 
In stark contrast, in the Netherlands poppy extraction was abandoned in 1988 primarily as a result of Diosynth's not being successful in finding an adequate substitute for Turkish poppy straw as the raw material.

Until 1986 Turkey produced CPS in quantities far above the demand for its product resulting in very large stocks in 1984-1988 despite the destruction of 17,700 tonnes of poppy straw in 1985. ${ }^{15}$ Turkey attempted to increase its market share by offering CPS at ever lower prices. That attempt had some success but the ensuing severe competition resulted in very low prices for CPS and codeine during the second half of the 1980s and severe price erosion for all opiates and opiate raw materials worldwide, making CPS manufacture a loss making activity for all involved.

During the 1980s opium production in India gradually declined but stocks remained at a high level. CPS, being less expensive, became more and more the raw material of choice for codeine manufacturers at the expense of opium. This is illustrated in the following table and chart.

Table 14.2 and Figure 14.4 Morphine Manufactured Worldwide from Opium and Poppy Straw 1981-1990 (AMA kg 000)

\begin{tabular}{|c|c|c|c|c|c|}
\hline & \multirow{2}{*}{ Year } & \multicolumn{3}{|c|}{$\begin{array}{l}\text { Manufacture of Morphine } \\
\text { AMA kg } 000\end{array}$} & \multirow{2}{*}{$\begin{array}{c}\text { ex Poppy } \\
\text { Straw } \\
\text { as a \% of } \\
\text { Total }\end{array}$} \\
\hline & & ex Opium & $\begin{array}{l}\text { ex Poppy } \\
\text { Straw }\end{array}$ & Total & \\
\hline & 1981 & 59 & 94 & 153 & 61 \\
\hline & 1982 & 82 & 84 & 166 & 51 \\
\hline & 1983 & 80 & 124 & 204 & 61 \\
\hline & 1984 & 77 & 129 & 206 & 63 \\
\hline & 1985 & 87 & 158 & 245 & 64 \\
\hline & 1986 & 75 & 162 & 237 & 68 \\
\hline & 1987 & 63 & 131 & 194 & 68 \\
\hline & 1988 & 59 & 136 & 195 & 70 \\
\hline & 1989 & 42 & 130 & 172 & 76 \\
\hline & 1990 & 81 & 129 & 210 & 61 \\
\hline \multirow[t]{2}{*}{$1981-1990$} & Average & 71 & 128 & 198 & 64 \\
\hline & Percent & 36 & 64 & 100 & \\
\hline
\end{tabular}

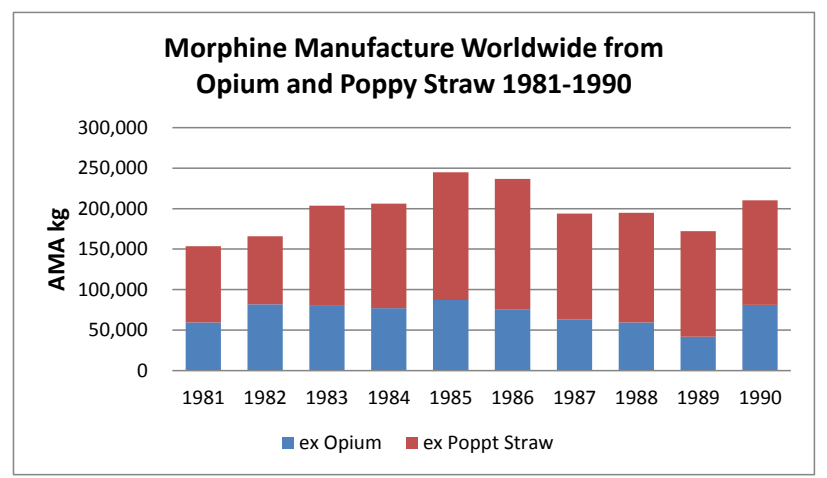

Source: INCB Statistics 1981-1990

\section{Trade in CPS and Morphine}

Statistics of the sum of exports of AMA in CPS and morphine are compiled in the table below. These totals are presented as a measure of the total quantities of AMA traded as opiate raw materials. ${ }^{16}$ The table shows the dominant position of Australia with an almost $50 \%$ share of the market, followed by Turkey with large sales during the years 1987-1989. The Netherlands faded away as a morphine manufacturer towards the end of the 1980s but continued to manufacture codeine from imported CPS after 1988. Hungary returned after a period of virtual absence to the opiate raw material market in 1989. CPS from Spain was supplied to France in modest quantities as part of a collaboration between Alcaliber and Francopia.

\footnotetext{
${ }^{15}$ INCB Statistics for $1986, \S 8$, page $x$.

16 The data for morphine exported as reported by the INCB represent mainly technical morphine used as a raw material for codeine but include minor quantities of pure morphine used as such in pharmaceutical preparations and the effect of the inclusion thereof in the total is only small.
} 
Certain patterns in the trade of CPS became discernable during the late 1980s. Glaxo Australia supplied mainly Macfarlan Smith in the UK, and Tasmanian Alkaloids supplied First State Chemical (USA) and Weiders (Norway). Alcaliber (Spain) supplied Francopia while TMO (Turkey) sold most of its CPS to the US companies Mallinckrodt, First State Chemical and Penick. ${ }^{17}$

Table 14.3 Total of Exports of CPS and Morphine Worldwide 1981-1990 (AMA kg)

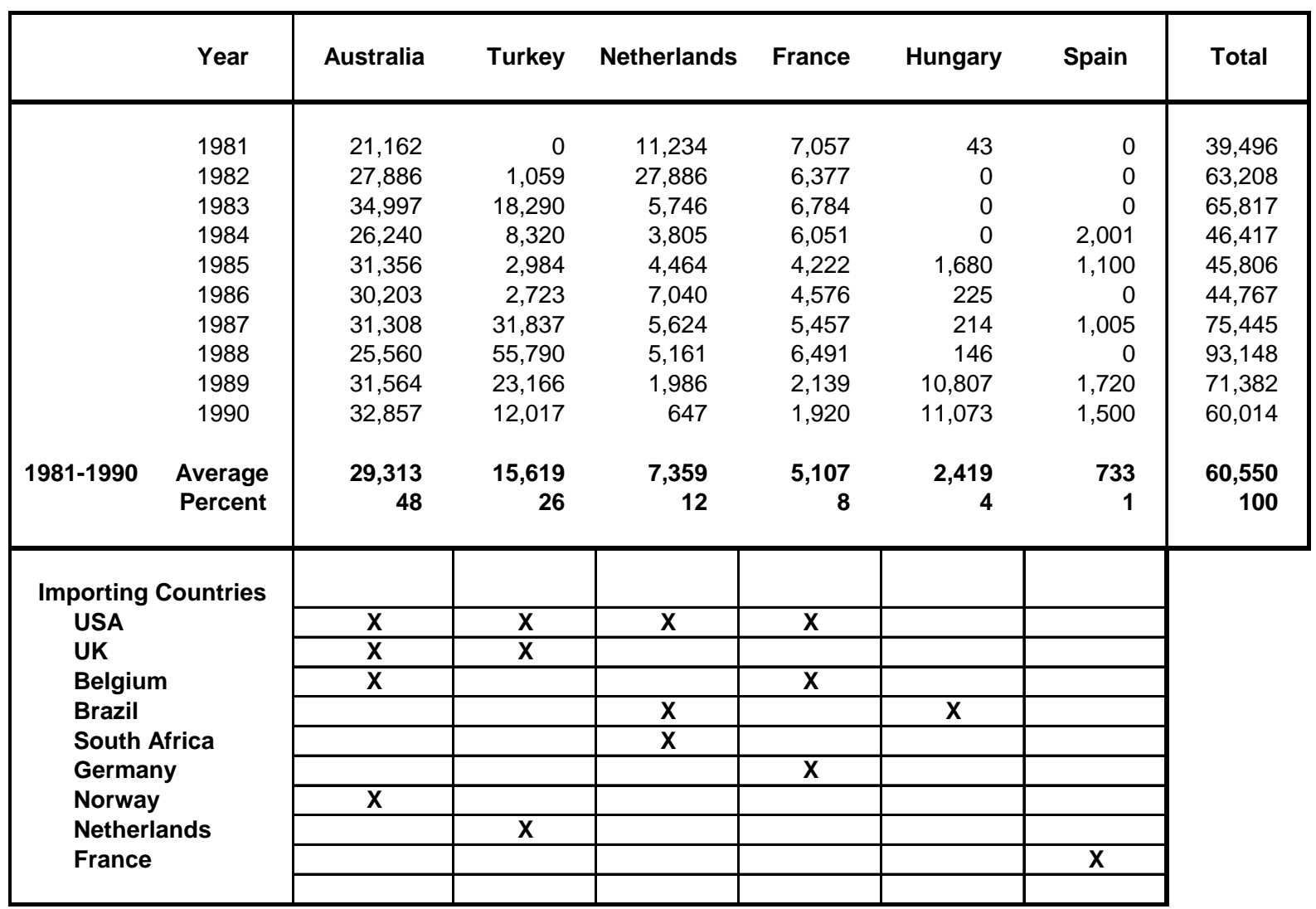

Source: INCB Statistics 1981-1990.

First State Chemical (later renamed Noramco) was the US company acquired by Johnson \& Johnson in 1981 to locate new facilities for the manufacture of very large quantities of codeine phosphate for its affiliate McNeil Pharmaceutical which used this opiate in one of its speciality products. ${ }^{18}$ To secure a guaranteed supply of opiate raw material, Johnson \& Johnson acquired Tasmanian Alkaloids together with Abbott Australasia's codeine manufacturing equipment from Abbott Laboratories in 1982.

\footnotetext{
${ }^{17}$ This information was general knowledge in the industry at the time. Merck Inc. (USA) had ceased codeine manufacture in the early 1980s. NRM Supplies to the US manufacturers during 1988-1989 are specified in Report to Congress: Licit Opium Review (1989), 41-42.

18 'Opiates' Shifting Scene' Chemical Business, (1983) February 7.
} 


\section{Codeine}

Table 14.4 and Figure 14.5 Codeine Net Export by Country 1981-1994 (ACA kg)

\begin{tabular}{|c|c|c|c|c|c|c|c|c|c|c|}
\hline & Year & UK & Australia & USA & France & Hungary & Netherlands & $\begin{array}{c}\text { Other } \\
\text { Countries }\end{array}$ & $\begin{array}{l}\text { Total } \\
\text { Export }\end{array}$ & $\begin{array}{l}\text { Codeine } \\
\text { Cons- } \\
\text { sumption }\end{array}$ \\
\hline & 1981 & 10,234 & 4,269 & 0 & 3,699 & 6,184 & 9,220 & 15,982 & 49,588 & 142,047 \\
\hline & 1982 & 8,306 & 4,756 & 0 & 4,952 & 3,666 & 7,531 & 15,124 & 44,335 & 130,760 \\
\hline & 1983 & 6,723 & 6,509 & 0 & 4,791 & 2,326 & 9,279 & 14,042 & 43,670 & 139,721 \\
\hline & 1984 & 11,234 & 7,755 & 2,297 & 7,170 & 7,042 & 9,235 & 12,465 & 57,198 & 139,238 \\
\hline & 1985 & 11,824 & 6,865 & 4,704 & 6,345 & 3,780 & 11,366 & 9,312 & 54,196 & 144,560 \\
\hline & 1986 & 12,235 & 9,931 & 1,074 & 6,711 & 5,253 & 6,955 & 18,017 & 60,176 & 161,077 \\
\hline & 1987 & 11,193 & 9,617 & 2,479 & 3,792 & 6,308 & 5,112 & 19,190 & 57,691 & 164,794 \\
\hline & 1988 & 13,557 & 9,173 & 85 & 7,063 & 9,505 & 6,764 & 12,927 & 59,074 & 160,450 \\
\hline & 1989 & 13,349 & 8,189 & 5,166 & 3,583 & 5,036 & 8,318 & 13,139 & 56,780 & 161,207 \\
\hline & 1990 & 12,681 & 10,431 & 8,860 & 5,526 & 6,624 & 4,647 & 28,000 & 76,769 & 150,631 \\
\hline & 1991 & 9,584 & 11,227 & 5,178 & 5,902 & 2,916 & 4,179 & 21,558 & 60,544 & 171,099 \\
\hline & 1992 & 13,915 & 12,482 & 7,509 & 5,856 & 2,623 & 6,898 & 12,553 & 61,836 & 159,427 \\
\hline & 1993 & 12,822 & 15,795 & 11,780 & 7,532 & 6,002 & 2,521 & 12,021 & 68,473 & 175,226 \\
\hline & 1994 & 16,539 & 13,271 & 10,678 & 8,425 & 3,382 & 0 & 21,157 & 73,452 & 161,192 \\
\hline \multirow[t]{2}{*}{ 1981-1994 } & Average & 13,207 & 11,510 & 7,037 & 6,270 & 5,155 & 4,761 & 17,336 & 65,275 & 162,747 \\
\hline & Percent & 20 & 18 & 11 & 10 & 8 & 7 & 27 & 100 & \\
\hline
\end{tabular}

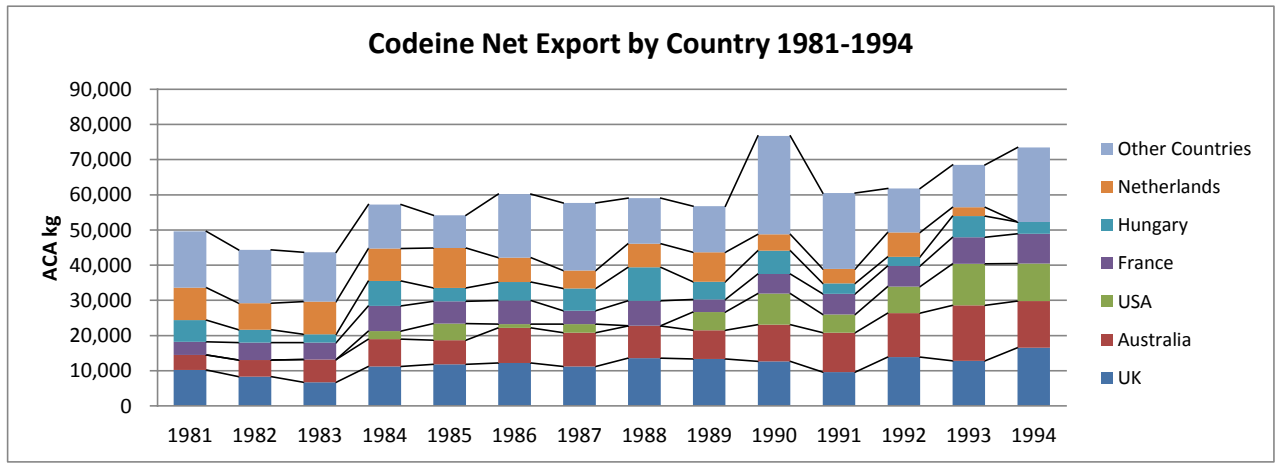

Source INCB Statistics 1981-1994.

Average codeine consumption worldwide hardly increased from 155 tonnes p.a. during 1971-1980 to 163 tonnes p.a. during 1981-1994, while the total export market increased from an average of 35 tonnes p.a. to 65 tonnes p.a. over these periods.

The USA appeared as a codeine exporter for the first time in 1984 with supplies mainly to India and Canada. The UK, Australia and France increased their market share while codeine manufacture in the Netherlands ceased in 1993 as making codeine from CPS bought from its competitors was not any longer a viable option for Diosynth.

The increased codeine exports were not only made by USA and traditional codeine exporting countries but also by emerging codeine producing countries such as Turkey, Norway and Czechoslovakia who gained market share at the expense of smaller local manufacturers.

\section{Prices, Costs and Profit}

The open world market price for codeine phosphate began to deteriorate sharply from 1984 as a result of Turkey offering CPS at very low prices to codeine producers. The situation worsened with time and during the years 1986-1989 codeine phosphate prices were in the order of USD 210 per kg, which was below raw material cost when made from opium. This is shown in the table and graph below: 
Table 14.5 and Figure 14.6 Codeine Phosphate and Indian Opium Prices and Raw Material Cost in Codeine Phosphate made from Opium (1981-1994)

\begin{tabular}{|c|ccc|}
\hline Year & $\begin{array}{c}\text { Indian } \\
\text { Opium } \\
\text { Price }\end{array}$ & $\begin{array}{c}\text { Raw } \\
\text { Material } \\
\text { Cost }\end{array}$ & $\begin{array}{c}\text { Codeine } \\
\text { Phosphate } \\
\text { Price }\end{array}$ \\
& $\begin{array}{c}\text { per kg at } \\
10 \% \text { AMA }\end{array}$ & $\begin{array}{c}\text { per kg } \\
\text { Codphos }\end{array}$ & per kg \\
\hline & & & \\
1981 & 42.4 & 303 & 350 \\
1982 & 35.0 & 250 & 345 \\
1983 & 35.0 & 250 & 340 \\
1984 & & & 330 \\
1985 & & & 280 \\
1986 & 30.0 & 214 & 230 \\
1987 & 31.5 & 225 & 200 \\
1988 & 31.5 & 225 & 205 \\
1989 & 31.5 & 225 & 210 \\
1990 & 31.5 & 225 & 380 \\
1991 & 35.0 & 250 & 485 \\
1992 & 36.5 & 261 & 442 \\
1993 & 38.0 & 271 & 385 \\
1994 & 42.0 & 300 & 400 \\
& & & \\
\hline
\end{tabular}

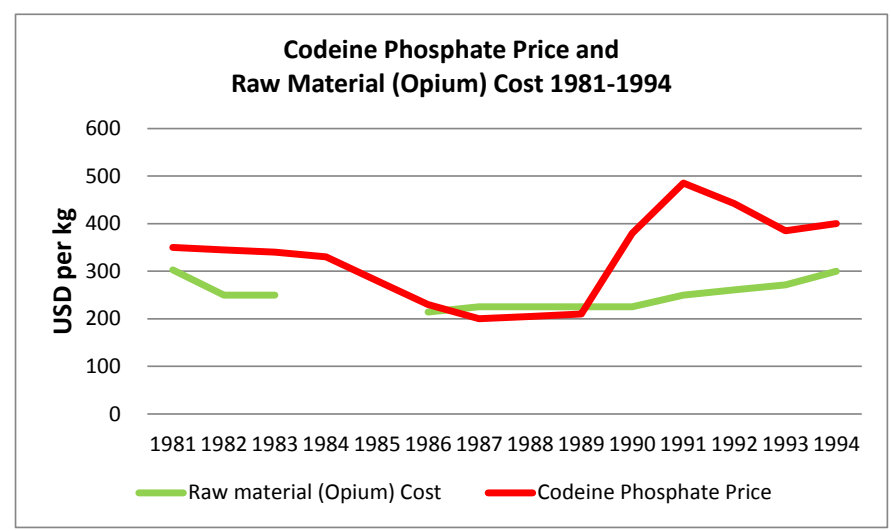

Sources and Notes: Ref. Table 13.5 of Chapter 13.

The price at which TMO (Toprak Mahsulleri Ofisi), the Turkish Grain Board, the government organisation in charge of all opiate operations in Turkey, was selling CPS in 1988 was USD 175 per kg AMA. ${ }^{19}$ A ballpark estimate of the production cost of Turkish CPS is in the order of USD 350 per $\mathrm{kg}$ AMA. ${ }^{20}$ The TMO pricing must be considered as dumping, selling far below cost in an attempt to eliminate the large CPS stocks (figure 14.1) and to destroy competitors, with the hope to become profitable once the competitors were gone. The strategy was successful to the extent that the large stocks of CPS accumulated in Turkey until 1986 were sold in two years, as can be seen in figure 14.2 and table 14.3.

All CPS producers operating in the open world market had to follow the low prices set by TMO during the years 1986-1989 and, although production costs in Australia and France were certainly much lower than in Turkey, these manufacturers must have sold CPS below full cost and had to depend on long term supply contracts and the protected home market for codeine to remain profitable. Codeine manufacturers using Turkish CPS as the raw material should have been able to make a small profit.

Fortunately, once the Turkish large stocks had gone (figure 14.1) some sense came back in the market and from 1990 onwards codeine prices recovered (figure 14.5).

\footnotetext{
19 'Report to Congress: 'Licit Opium Review' (1989) 44.

${ }^{20}$ Estimated cost in USD per kg AMA in CPS: Raw material (poppy straw) cost 120, variable production cost 136, fixed cost (depreciation) 100, Total 356.
} 


\subsection{Raw material supplies and Morphine Manufacture at Diosynth during the 1980s}

\section{Importation of Poppy Straw}

In 1980 Diosynth imported a large quantity of Turkish poppy straw (figure 14.7), providing sufficient raw material for the next two years. The Turkish opiate manufacturing facilities came on stream in 1981 and an unfavourable consequence for Diosynth was that the Turkish Government placed an embargo on the export of poppy straw. In the first instance Diosynth turned to India for the supply of poppy straw and opium as the raw material for its opiate manufacture. The low morphine content of Indian poppy straw made this raw material an unattractive option and from 1982 onwards Diosynth imported poppy straw also from Poland, Spain and Australia. In 1986 and 1987 the Company even managed to buy some poppy straw from Turkey but buying the principal raw material from its competitors was long term not an economic option, and 1988 was the last year of the import of commercial quantities of poppy straw into the Netherlands.

The quantities of poppy straw which were imported during the 1980s are shown in the table and chart below.

Table 14.6 and Figure 14.7 Imports of Poppy Straw into the Netherlands 1981-1990 (tonnes)

\begin{tabular}{|r|rrrrrr|r|}
\hline Year & Turkey & India & Poland & Spain & Australia & Other & Total \\
\hline 1981 & 0 & 3 & 0 & 0 & 0 & 10 & 13 \\
1982 & 0 & 1,800 & 0 & 50 & 0 & 0 & 1,850 \\
1983 & 0 & 2,743 & 0 & 197 & 0 & 1 & 2,941 \\
1984 & 0 & 1,085 & 2,810 & 401 & 250 & 0 & 4,546 \\
1985 & 0 & 604 & 5,019 & 198 & 0 & 0 & 5,821 \\
1986 & 1,530 & 0 & 2,655 & 0 & 0 & 0 & 4,185 \\
1987 & 2,000 & 0 & 0 & 0 & 0 & 189 & 2,189 \\
1988 & 0 & 0 & 0 & 0 & 251 & 0 & 251 \\
1989 & 0 & 0 & 0 & 0 & 0 & 2 & 2 \\
1990 & 0 & 0 & 0 & 0 & 0 & 2 & 2 \\
& & & 0 & & & & \\
\hline
\end{tabular}

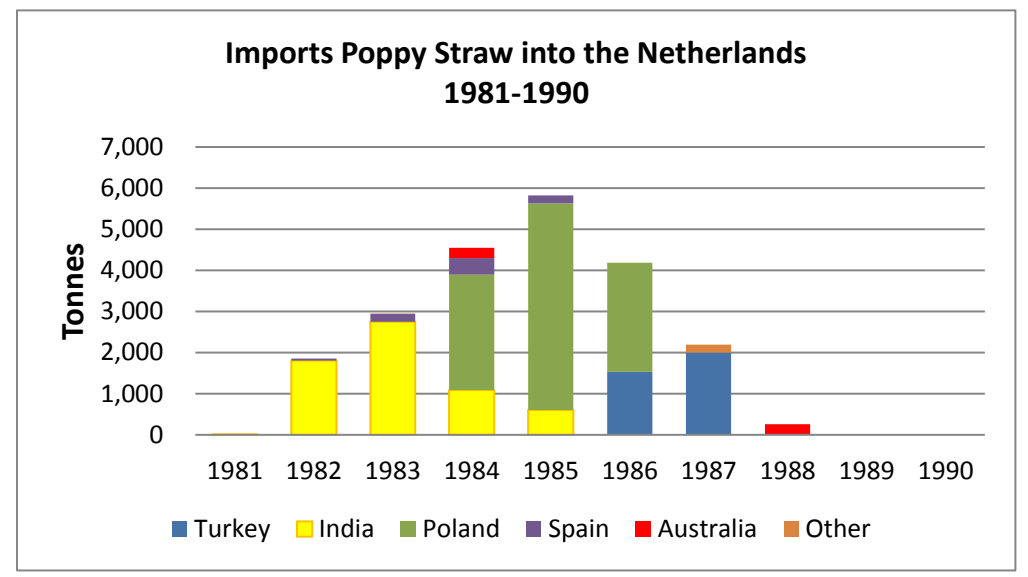

Source: INCB Statistics 1981-1990 


\section{Poppy Cultivation in the Netherlands}

Diosynth sought to solve the opiate raw material problem longer term by growing a relatively high yielding strain of the opium poppy in the Netherlands. This strain was developed in collaboration with Zelder, a commercial plant breeding organisation, located at Ittersum. The breeding programme commenced in 1981 and in 1984 an area of about 800 ha was sown and harvested with assistance of the firm Cebeco, an agricultural contractor. ${ }^{21}$ Two more production years followed.

However, Diosynth ran into problems with the project. ${ }^{22}$ The first problem was the weather in the Netherlands, which is often wet during August and September when the poppies ripen in the field. The result was leaching out of the alkaloids from the capsules by rain and the low morphine content of the harvested poppy straw made it an expensive raw material. This problem could have been anticipated as the phenomenon of the leaching had been already described by Reith c.s. in a series of publications on their experimental work on poppy growing in the Netherlands during the years 1946-1948 and experienced by both NCF and VPF when processing Dutch poppy straw during these years. ${ }^{23}$ Also, the quality of the seed produced with the Diosynth poppy variety was of inferior quality compared to the common Marianne poppy strain, which was widely cultivated in the Netherlands for its excellent culinary grade of poppy seed.

The second problem was the opposition by the INCB to poppy cultivation for opiate production in the Netherlands which led to questions in the Dutch parliament. ${ }^{24}$ Akzo Pharma had stated earlier in a Dutch newspaper that no opium would be produced in the Netherlands but only poppy straw, the raw material for making pure pharmaceutical products of which codeine was the most important. ${ }^{25}$

Overall, the venture was uneconomical and did not provide the long term solution of Diosynth's raw material problems and 1986 was the last year of poppy cultivation by the company.

\section{Discussions with Tasmanian Alkaloids}

In 1984 Diosynth initiated discussions with Tasmanian Alkaloids on the supply of poppy straw and/or CPS to Diosynth. Diosynth expressed a preference for a full partnership whereby Diosynth would be the marketing arm and codeine producer for Europe and Tasmanian Alkaloids would provide the basic raw material (CPS). The proposed arrangement was not attractive for Tasmanian Alkaloids and the discussions stalled. ${ }^{26}$

\footnotetext{
${ }^{21}$ Akzo Pharma, Geen illegale opium van eigen velden, article in NRC/Handelsblad (Newspaper) of 11October 1984.

${ }^{22}$ Interview of Jack Nijssen, Marketing manager product group C, Diosynth , Oss, 27 August 2002.

${ }^{23}$ See Section 11.5 and J.F. Reith, A.W.M. Indemans and W.R. Becker, Pharmaceutisch Weekblad 82 (1947) 581-591, 83 (1948) 449-459 and 84 (1949) 669-675.

${ }^{24}$ [Anonymous]. VN gekant tegen papaverteelt in Flevopolder. de Volkskrant (Newspaper) (1985) January 25.

${ }^{25}$ Akzo Pharma Geen illegale opium van eigen velden. NRC Handelsblad (Newspaper) (1984) October 11.

${ }^{26}$ Reports on discussions of the author as managing director of Tasmanian Alkaloids with Diosynth management during the period October 1984 to February 1985.
} 
Quantities of Morphine manufactured from opium and poppy straw at Diosynth Annual statistics of morphine manufactured in the Netherlands from opium and poppy straw are compiled in Table 14.7, below. The data show that 1988 was the last year of poppy extraction in the Netherlands. Diosynth did however continue to manufacture codeine after 1988, but using imported CPS as the raw material. The imported CPS was upgraded (purified) to technical morphine prior to the conversion into codeine. Technical morphine made from imported CPS is not included in the table below but appears in Table 14.9.

Table 14.7. Morphine Manufacture from Opium and Poppy Straw the Netherlands 1981-1990

\begin{tabular}{|c|c|c|c|c|c|c|c|c|c|c|c|c|c|}
\hline & \multirow[b]{2}{*}{ Year } & \multicolumn{2}{|c|}{ (1) Opium } & \multicolumn{3}{|c|}{ (2) Poppy Straw to CPS } & \multicolumn{3}{|c|}{ (3) Poppy Straw to Morphine } & \multicolumn{3}{|c|}{ (4) Poppy Straw to CPS + Morphine } & \multirow{2}{*}{$\begin{array}{c}\text { (5) Total } \\
\text { Morphine } \\
\text { manuf. } \\
\text { AMA kg }\end{array}$} \\
\hline & & $\begin{array}{l}\text { Utilized } \\
\text { kg }\end{array}$ & $\begin{array}{c}\text { Morphine } \\
\text { manuf. } \\
\text { AMA kg }\end{array}$ & $\begin{array}{c}\text { Utilized } \\
t\end{array}$ & $\begin{array}{l}\text { CPS manuf. } \\
\text { CPS kg }\end{array}$ & $\begin{array}{c}\text { Morphine } \\
\text { Yield } \\
\%\end{array}$ & $\begin{array}{c}\text { Utilized } \\
t\end{array}$ & $\begin{array}{l}\text { Morphine } \\
\text { manuf. } \\
\text { AMA kg }\end{array}$ & $\begin{array}{c}\text { Morphine } \\
\text { Yield } \\
\%\end{array}$ & $\begin{array}{l}\text { Utilized } \\
t\end{array}$ & $\begin{array}{c}\text { Morphine } \\
\text { manuf. } \\
\text { AMA kg }\end{array}$ & $\begin{array}{c}\text { Morphine } \\
\text { Yield } \\
\%\end{array}$ & \\
\hline & 1981 & 19 & 1 & 4,823 & 26,177 & 0.27 & 2,202 & 5,974 & 0.27 & 7,025 & 19,063 & 0.27 & 19,064 \\
\hline & 1982 & 22,707 & 2,457 & 1,549 & 7,900 & 0.26 & 2,753 & 7,003 & 0.25 & 4,302 & 10,953 & 0.25 & 13,410 \\
\hline & 1983 & 72,425 & 7,016 & 1,948 & 7,490 & 0.19 & 1,603 & 3,071 & 0.19 & 3,551 & 6,816 & 0.19 & 13,832 \\
\hline & 1984 & 24,660 & 2,461 & 1,621 & 8,808 & 0.27 & 3,198 & 8,692 & 0.27 & 4,819 & 13,096 & 0.27 & 15,557 \\
\hline & 1985 & 0 & 0 & 507 & 4,255 & 0.42 & 5,289 & 22,123 & 0.42 & 5,796 & 24,251 & 0.42 & 24,251 \\
\hline \multirow[t]{6}{*}{ Average } & 1981-1985 & 23,962 & 2,387 & 2,090 & 10,926 & 0.26 & 3,009 & 9,373 & 0.31 & 5,099 & 14,836 & 0.29 & 17,223 \\
\hline & 1986 & 0 & 0 & 0 & 0 & n/a & 4,314 & 14,398 & 0.33 & 4,314 & 14,398 & 0.33 & 14,398 \\
\hline & 1987 & 0 & 0 & 0 & 0 & $n / a$ & 2,935 & 9,931 & 0.34 & 2,935 & 9,931 & 0.34 & 9,931 \\
\hline & 1988 & 0 & 0 & 0 & 0 & $\mathrm{n} / \mathrm{a}$ & 1,692 & 7,508 & 0.44 & 1,692 & 7,508 & 0.44 & 7,508 \\
\hline & 1989 & 0 & 0 & 0 & 0 & $n / a$ & 0 & 0 & $\mathrm{n} / \mathrm{a}$ & 0 & 0 & $\mathrm{n} / \mathrm{a}$ & 0 \\
\hline & 1990 & 0 & 0 & 0 & 0 & $n / a$ & 0 & 0 & $n / a$ & 0 & 0 & $\mathrm{n} / \mathrm{a}$ & 0 \\
\hline Average & 1986-1990 & 0 & 0 & 0 & 0 & $n / a$ & 1,788 & 6,367 & 0.36 & 1,788 & 6,367 & 0.36 & 6,367 \\
\hline
\end{tabular}

Source: INCB Statistics 1981-1990. ${ }^{27}$ That all morphine produced from 1986 onwards is reported as morphine rather than as CPS and morphine is purely an administrative matter. It was reported by the Netherlands authorities to the INCB in that way. ${ }^{28}$

The reasons for the decline and ultimate cessation of morphine production at Diosynth viz. the inability to secure a cheap and reliable source of poppy straw after the Turkish factory began production in 1981 and the disappearance of the USA as a market for CPS originating from the Netherlands are already discussed in previous sections.

Of the two large Lurgi extractors installed in the factory at Apeldoorn, the oldest one (extractor C) was decommissioned in1982-1983 and the second (extractor D) followed in $1988 .^{29}$ It was the end of an era: 1988 was the last year of poppy straw extraction in the Netherlands.

\subsection{Codeine Manufacture at Diosynth during the period 1981-1994}

Despite Diosynth's problems with securing supplies of poppy straw codeine production and exports remained at a high level during the 1980s. Germany was the main export market; Denmark and Eastern European countries, such as the DDR and Bulgaria, were also important outlets. Diosynth bought the raw material, CPS, in 1987 and 1988 from Turkey and in later years mainly from Australia (Glaxo) and Hungary.

\footnotetext{
${ }^{27}$ The total of morphine manufactured (column 5) is calculated as the sum of morphine manufactured from opium, morphine manufactured from poppy straw and morphine contained in CPS manufactured. Morphine produced from imported CPS is not included.

${ }^{28}$ INCB Statistics for 1986, page xi.

${ }^{29}$ Akzo, 'Bolkaf-extractie definitief historie. Extractor C is gesloopt', Akzo Publication (1992), February.
} 
Table 14.8 shows for the Netherlands: data of total quantities of morphine manufactured, including from imported CPS, exports and imports of CPS plus TM, conversions of morphine, codeine manufactured, exported and locally consumed for the period 1981-1994. Despite an improvement of the codeine price in the early 1990s Diosynth terminated the production of codeine $1993 .^{30}$

Table 14.8 Morphine Manufacture, Trade and Conversions and

Codeine Manufacture Trade and Consumption, the Netherlands 1981-1994

\begin{tabular}{|c|c|c|c|c|c|c|c|c|c|c|c|c|}
\hline & \multirow[b]{2}{*}{ Year } & \multicolumn{5}{|c|}{ Morphine (AMA kg) } & \multirow[b]{2}{*}{$\begin{array}{l}\text { Converted } \\
\text { into Nal- } \\
\text { compounds }\end{array}$} & \multirow[b]{2}{*}{$\begin{array}{c}\text { Converted } \\
\text { Total }\end{array}$} & \multicolumn{4}{|c|}{ Codeine (ACA kg) } \\
\hline & & $\begin{array}{c}\text { Total } \\
\text { Manu- } \\
\text { facture }\end{array}$ & $\begin{array}{l}\text { Export } \\
\text { CPS+TM }\end{array}$ & $\begin{array}{l}\text { Import } \\
\text { CPS+TM }\end{array}$ & $\begin{array}{l}\text { Converted } \\
\text { into } \\
\text { Codeine }\end{array}$ & $\begin{array}{c}\text { Converted } \\
\text { into Other } \\
\text { Opiates }\end{array}$ & & & $\begin{array}{l}\text { Codeine } \\
\text { Manu- } \\
\text { factured }\end{array}$ & $\begin{array}{c}\text { Codeine } \\
\text { Yield } \\
\text { w/w \% }\end{array}$ & $\begin{array}{c}\text { Net } \\
\text { Export }\end{array}$ & $\begin{array}{l}\text { Local } \\
\text { Consump- } \\
\text { tion }\end{array}$ \\
\hline & 1981 & 19,064 & 11,223 & 0 & 8,220 & 108 & 0 & 8,328 & 10,038 & 122 & 9,220 & 395 \\
\hline & 1982 & 13,410 & 8,755 & 0 & 6,721 & 84 & 0 & 6,805 & 8,567 & 127 & 7,531 & 371 \\
\hline & 1983 & 13,832 & 5,746 & 0 & 7,843 & 331 & 0 & 8,174 & 9,774 & 125 & 9,524 & 214 \\
\hline & 1984 & 15,557 & 4,306 & 501 & 10,970 & 326 & 20 & 11,316 & 12,169 & 111 & 10,315 & 441 \\
\hline & 1985 & 24,695 & 8,907 & 0 & 12,664 & 374 & 0 & 13,038 & 11,980 & 95 & 11,366 & 529 \\
\hline \multirow[t]{6}{*}{ Average } & 1981-1985 & 17,311 & 7,787 & 100 & 9,284 & 245 & 4 & 9,532 & 10,506 & 113 & 9,591 & 390 \\
\hline & 1986 & 14,398 & 7,053 & 13 & 6,844 & 53 & 62 & 6,959 & 6,377 & 93 & 6,955 & 451 \\
\hline & 1987 & 12,571 & 5,670 & 3,345 & 8,807 & 369 & 10 & 9,186 & 7,736 & 88 & 5,112 & 620 \\
\hline & 1988 & 8,219 & 5,229 & 18,068 & 3,524 & 416 & 67 & 4,007 & 7,689 & 218 & 6,754 & 842 \\
\hline & 1989 & 13,836 & 4,699 & 4,024 & 11,615 & 1,160 & 450 & 13,225 & 10,174 & 88 & 8,318 & 465 \\
\hline & 1990 & 8,406 & 5,494 & 15,135 & 7,439 & 578 & 1,801 & 9,818 & 5,892 & 79 & 4,647 & 721 \\
\hline \multirow[t]{5}{*}{ Average } & $1986-1990$ & 11,486 & 5,629 & 8,117 & 7,646 & 515 & 478 & 8,639 & 7,574 & 99 & 6,357 & 620 \\
\hline & 1991 & 14,961 & 5,146 & 15,259 & 11,551 & 124 & 1,195 & 12,870 & 9,855 & 85 & 4,179 & 960 \\
\hline & 1992 & 9,701 & 3,933 & 12,373 & 7,467 & 573 & 1,105 & 9,145 & 6,339 & 85 & 6,898 & 913 \\
\hline & 1993 & 2,976 & 6,511 & 7,899 & 446 & 0 & 909 & 1,355 & 300 & 67 & 2,521 & 1,054 \\
\hline & 1994 & 2,882 & 5,721 & 6,683 & 0 & 0 & 1,596 & 1,596 & 0 & $\mathrm{n} / \mathrm{a}$ & $-1,343$ & 1,017 \\
\hline Average & 1991-1994 & 7,630 & 5,328 & 10,553 & 4,866 & 174 & 1,201 & 6,242 & 4,124 & 79 & 3,064 & 986 \\
\hline
\end{tabular}

Source: INCB Statistics 1981-1994. Ref Tables OPI

When Diosynth ceased manufacture of codeine and other opiates it entered an arrangement with Macfarlan Smith, the major manufacturer of codeine located in the UK and a former Glaxo affiliate, under which Diosynth would transfer its opiate business to Macfarlan. ${ }^{31}$ It was the end of almost 70 years of codeine manufacture in the Netherlands.

\subsection{Nal-compounds}

After Diosynth ceased codeine production in 1993 it continued to manufacture so called nalcompounds such as naloxone and naltrexone. These compounds have a morphinan skeleton and are commonly produced from thebaine as the starting material. Nal-compounds are opioid antagonists which block the effects of morphine in humans and are therefore administered in cases of people suffering from the effects of an overdose of morphine or other opiates. Because they are opioid antagonists, nal-compounds are not controlled substances under the Single Convention.

\footnotetext{
${ }^{30}$ Akzo Pharma (Diosynth), 'Announcement of termination of the production of certain opiates', Company Publication (1993) March 9.

${ }^{31}$ Ibidem.
} 


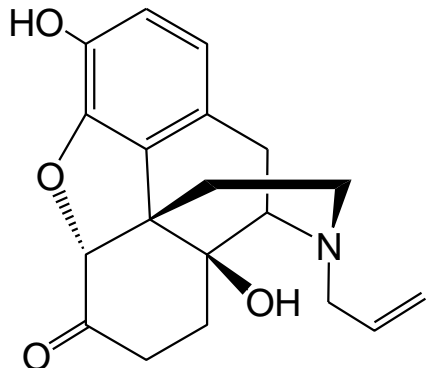

Naloxone<smiles>O=C1CC[C@@]2(O)[C@H]3Cc4ccc(O)c5c4[C@@]2(CCN3CC2CC2)[C@H]1O5</smiles>

Naltrexone

Figure 14.8 Nal-compounds

In Diosynth's research laboratory a method was developed for making nal-compounds from morphine as a starting material, rather than from thebaine. Diosynth continued to import CPS for this purpose after 1993. In 2003, a presumably improved process for making the nalcompounds from morphine was published as an International Patent Application. ${ }^{32}$ Jan Linders, a former student of Dr. Maat, and Pieter Vrijhof are mentioned as the inventors. The essential step of the process is the formation of 14-hydroxymophinones in a good yield using a cobalt (II) salt as the oxidant and air or oxygen as the co-oxidant.

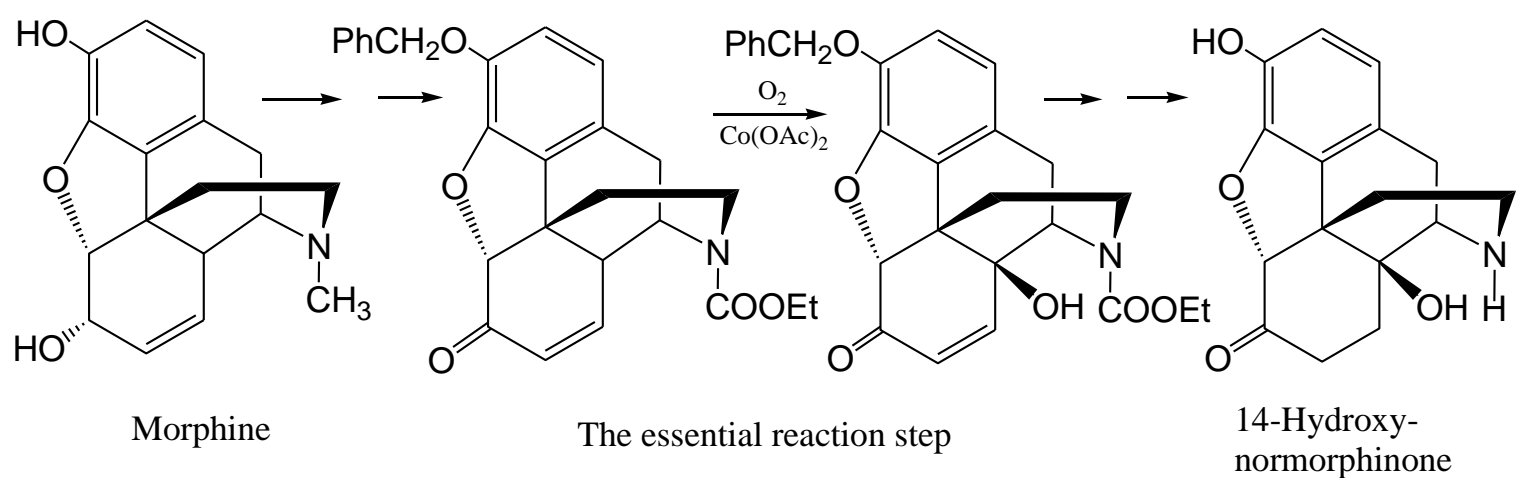

Figure 14.9 The Diosynth process for making 14-hydroxymorphinone

From 1994 to 2005 an average quantity of ca 3,670 kg AMA p.a. was converted into nalcompounds (Table 14.8). Assuming a 50\% overall yield from morphine to naloxone/naltrexone, Diosynth's average production of nal-compounds is estimated to be in the order of $1,800 \mathrm{~kg}$ per annum over the period. ${ }^{33} 2005$ was the last year for which transformation of morphine into non-controlled substances in the Netherlands was mentioned in the INCB Statistics. ${ }^{34}$ The reason for the manufacture coming to an end is not known but could well be related to competition with naloxone and naltrexone made from thebaine which had become available at lower cost from Australia.

\footnotetext{
${ }^{32}$ Akzo-Nobel, C-14 Oxidation of morphine derivatives, Inventors: Linders J.T.M. and Vrijhof P. (Diosynth), International Patent Application WO 03/018588 A2 (2003).

${ }^{33}$ In the patent application improbable high yields (average $95 \%$ per step) are mentioned for the process when tested on laboratory scale. A more realistic yield of 50\% overall yield for the 6 steps synthesis from morphine, requires the achievement an average yield of $89 \%$ per step (opinion of the author).

${ }^{34}$ INCB Statistics for 2009.
} 
For the years 2005 to 2007 the conversion of small quantities of thebaine into noncontrolled substances in the Netherlands was reported by the INCB but such conversions did not take place in 2008 and 2009. ${ }^{35}$ Thebaine is an alternative raw material for the making of nal-compounds and it is quite possible that Diosynth ran tests to evaluate the commercial feasibility of using thebaine during 2005-2007 but did not continue this path.

\subsection{Survey of the Production of Opiates at Diosynth 1981-2005}

To put the total period 1981-2007 in perspective, the data on morphine manufacture, conversions and exports are summarised in the following table:

Table 14.9 Morphine Manufacture, Conversions and Net Exports CPS and TM the Netherlands 1981-2007

\begin{tabular}{|c|c|c|c|c|c|c|c|c|c|c|c|}
\hline \multirow{2}{*}{ Year } & \multicolumn{4}{|c|}{ Morphine Manufacture } & \multicolumn{4}{|c|}{ Morphine Conversions } & \multicolumn{3}{|c|}{ Morphine Net Export } \\
\hline & $\begin{array}{c}\text { ex Poppy } \\
\text { Straw }\end{array}$ & ex Opium & $\begin{array}{c}\text { ex Imported } \\
\text { CPS }\end{array}$ & Total & $\begin{array}{c}\text { into } \\
\text { Codeine }\end{array}$ & $\begin{array}{c}\text { into Other } \\
\text { Opiates }\end{array}$ & $\begin{array}{l}\text { into Nal- } \\
\text { compounds }\end{array}$ & Total & as CPS & as $\mathrm{TM}$ & Total \\
\hline 1981 & 19,063 & 1 & 0 & 19,064 & 8,220 & 108 & 0 & 8,328 & 11,189 & 34 & 11,223 \\
\hline 1982 & 10,953 & 2,457 & 0 & 13,410 & 6,721 & 84 & 0 & 6,805 & 7,800 & 955 & 8,755 \\
\hline 1983 & 6,816 & 7,016 & 0 & 13,832 & 7,843 & 331 & 0 & 8,174 & 3,882 & 1,864 & 5,746 \\
\hline 1984 & 13,096 & 2,461 & 0 & 15,557 & 10,970 & 326 & 20 & 11,316 & 3,714 & 91 & 3,805 \\
\hline 1985 & 24,251 & 0 & 444 & 24,695 & 12,664 & 374 & 0 & 13,038 & 8,872 & 35 & 8,907 \\
\hline 1986 & 14,398 & 0 & 0 & 14,398 & 6,844 & 53 & 62 & 6,959 & 0 & 7,040 & 7,040 \\
\hline 1987 & 9,931 & 0 & 2,640 & 12,571 & 8,807 & 369 & 10 & 9,186 & $-3,299$ & 5,624 & 2,325 \\
\hline 1988 & 7,508 & 0 & 711 & 8,219 & 3,524 & 416 & 67 & 4,007 & $-18,000$ & 5,161 & $-12,839$ \\
\hline 1989 & 0 & 0 & 13,836 & 13,836 & 11,615 & 1,160 & 450 & 13,225 & $-1,312$ & 1,986 & 675 \\
\hline 1990 & 0 & 0 & 8,406 & 8,406 & 7,439 & 578 & 1,801 & 9,818 & $-10,289$ & 647 & $-9,642$ \\
\hline 1991 & 0 & 0 & 14,961 & 14,961 & 11,551 & 124 & 1,195 & 12,870 & $-10,911$ & 797 & $-10,114$ \\
\hline 1992 & 0 & 0 & 9,701 & 9,701 & 7,467 & 573 & 1,105 & 9,145 & $-9,062$ & 622 & $-8,440$ \\
\hline 1993 & 0 & 0 & 2,976 & 2,976 & 446 & 0 & 909 & 1,355 & $-3,509$ & 2,121 & $-1,388$ \\
\hline 1994 & 0 & 0 & 2,882 & 2,882 & 0 & 0 & 1,596 & 1,596 & $-2,240$ & 1,278 & -962 \\
\hline 1995 & 0 & 0 & 3,290 & 3,290 & 0 & 0 & 2,034 & 2,034 & $-4,007$ & 114 & $-3,893$ \\
\hline 1996 & 0 & 0 & 4,702 & 4,702 & 0 & 0 & 3,324 & 3,324 & $-4,531$ & 287 & $-4,244$ \\
\hline 1997 & 0 & 0 & 3,303 & 3,303 & 0 & 0 & 2,052 & 2,052 & $-2,500$ & 838 & $-1,662$ \\
\hline 1998 & 0 & 0 & 3,658 & 3,658 & 0 & 0 & 2,649 & 2,649 & 0 & $-3,465$ & $-3,465$ \\
\hline 1999 & 0 & 0 & 0 & 0 & 0 & 0 & 2,642 & 2,642 & 0 & $-1,753$ & $-1,753$ \\
\hline 2000 & 0 & 0 & 788 & 788 & 0 & 0 & 4,358 & 4,358 & $-5,639$ & 493 & $-5,146$ \\
\hline 2001 & 0 & 0 & 4,222 & 4,222 & 0 & 0 & 2,707 & 2,707 & $-2,859$ & 656 & $-2,203$ \\
\hline 2002 & 0 & 0 & 7,391 & 7,391 & 0 & 0 & 6,207 & 6,207 & $-5,997$ & 1,772 & $-4,225$ \\
\hline 2003 & 0 & 0 & 12,063 & 12,063 & 0 & 0 & 11,794 & 11,794 & $-12,597$ & 2 & $-12,595$ \\
\hline 2004 & 0 & 0 & 3,215 & 3,215 & 0 & 0 & 2,695 & 2,695 & 0 & 317 & 317 \\
\hline 2005 & 0 & 0 & 1,998 & 1,998 & 0 & 0 & 1,998 & 1,998 & $-1,998$ & 260 & $-1,738$ \\
\hline 2006 & 0 & 0 & 0 & 0 & 0 & 0 & 0 & 0 & 0 & -205 & -205 \\
\hline 2007 & 0 & 0 & 0 & 0 & 0 & 0 & 0 & 0 & 0 & -522 & -522 \\
\hline
\end{tabular}

Source: INCB Statistics 1981-2007, the net export amounts for CPS and Technical Morphine (TM) are calculated from the INCB data (ref. Table OPI 8).

Note: The year 2005 was the last year of opiate manufacture at Diosynth. Some trading in CPS and TM and importation of pure morphine salts for pharmaceutical use continued after 2005.

The data contained in Table 14.7 are depicted in three charts, Figures 14.10-14.12, each showing clearly the three sub-periods characterizing Diosynth's opiates business:

The period 1981-1988: morphine production mainly from poppy straw, coming to an end, some export of CPS and TM, and codeine manufacture at a level comparable to that of the previous period;

The period 1989-1993: Morphine production from imported CPS, some export of technical morphine, cessation of codeine production the beginning of the manufacture of nalcompounds at a commercial level;

\footnotetext{
${ }^{35}$ Ibidem. The quantities of thebaine converted in the years 2005-2007 amounted to 207, 93 and $186 \mathrm{~kg}$ respectively.
} 
The period 1994-2005: No morphine and codeine manufacture, nal-compounds business expanding until 2003, and coming to an end thereafter.

Figures 14.10 Morphine Manufacture

Figure 14.11 Morphine Conversions

Figure 14.12 CPS and Morphine Net Export

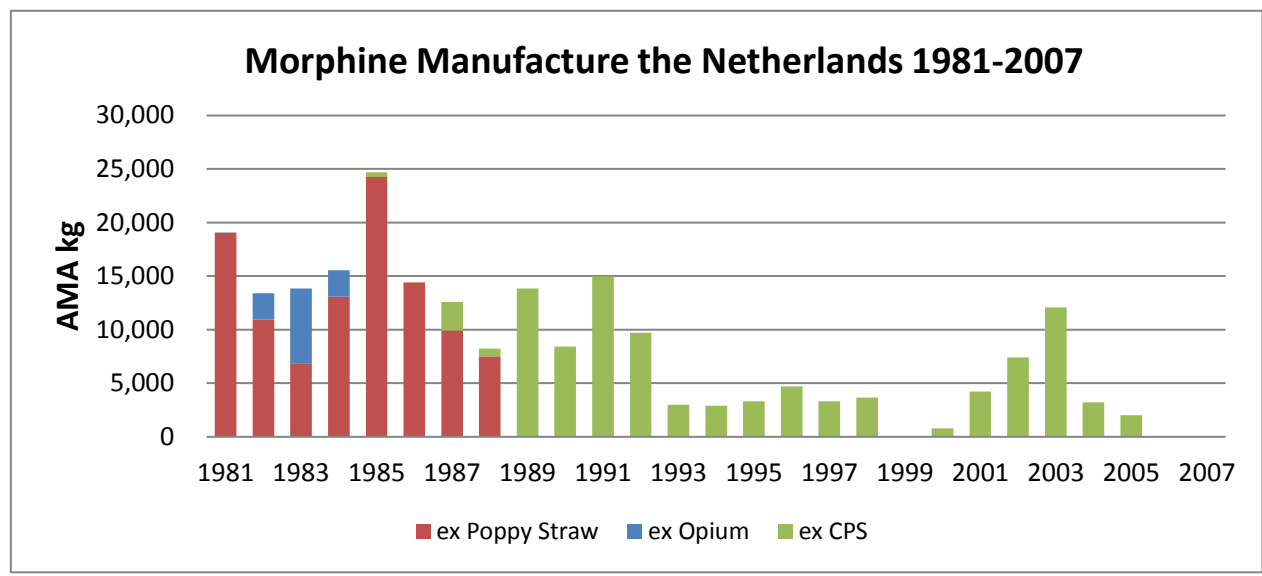

Figure 14.10

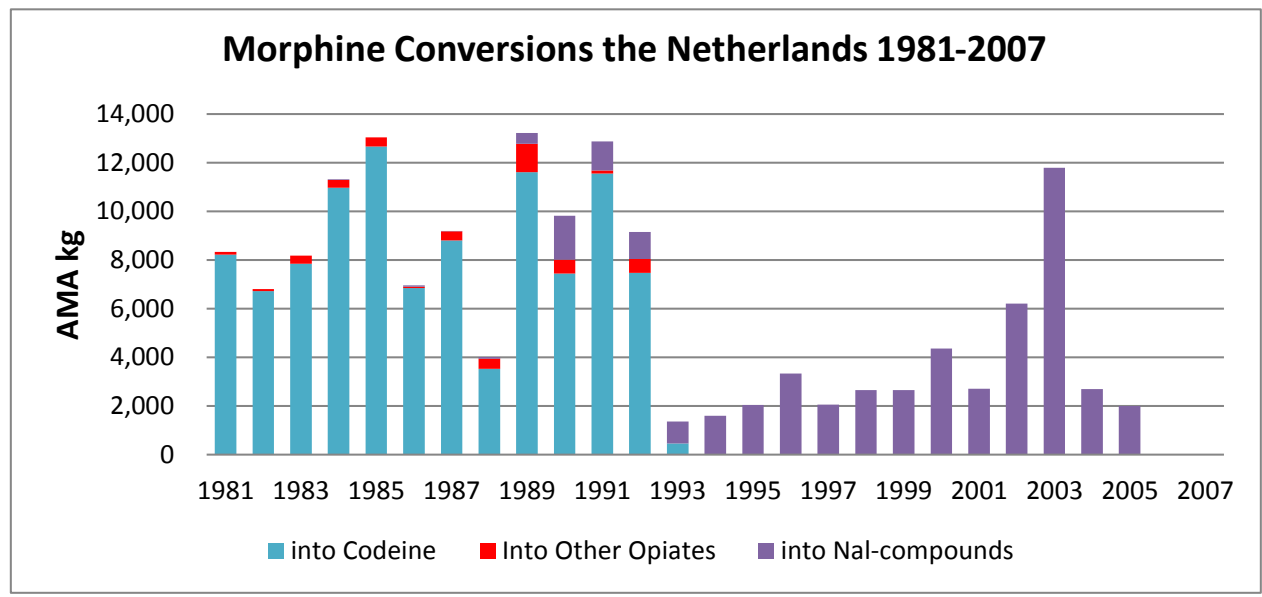

Figure 14.11

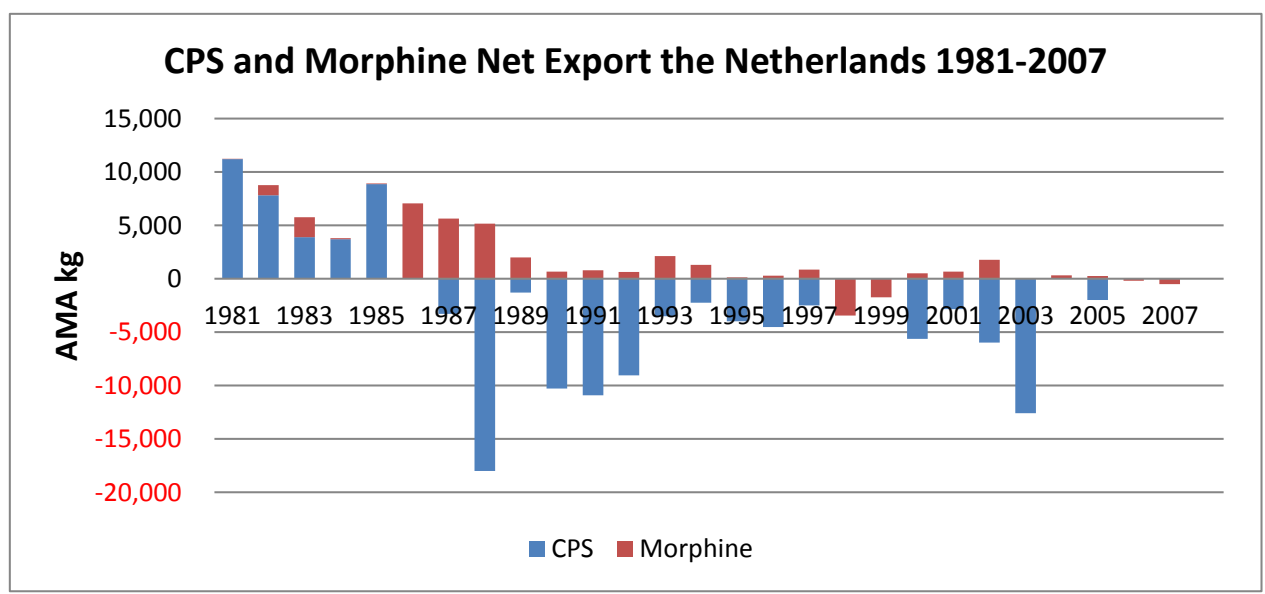

Figure 14.12 
In the following table ballpark estimates of sales revenue of Diosynth's opiate business are presented. The quantities are estimated on the basis of INCB statistics, the prices are based on limited market information and the total sales revenues as calculated are to be considered as broad approximations.

Table 14.10 Ballpark Estimate of Sales Revenue Opiates Diosynth 1981-2005 (Averages by sub-period)

\begin{tabular}{|c|cc|rr|rr|rrr|}
\hline \multirow{2}{*}{ Period } & \multicolumn{2}{|c|}{ Morphine } & \multicolumn{2}{c|}{ Codeine } & \multicolumn{2}{c|}{ Nal-Compounds } & \multicolumn{3}{c|}{ Total Revenue } \\
\cline { 2 - 9 } & AMA kg & USD/kg & ACA kg & $\begin{array}{c}\text { Codphos } \\
\text { USD/kg }\end{array}$ & kg & USD/kg & USD 000 & $\begin{array}{c}\text { Exch. Rate } \\
\text { USD/NLG }\end{array}$ & $\begin{array}{c}\text { NLG } \\
\text { million }\end{array}$ \\
\hline $1981-1988$ & 4,400 & 250 & 8,500 & 300 & 0 & $n / a$ & 5 & 2.6 & 12 \\
$1989-1993$ & 1,200 & 300 & 8,200 & 400 & 500 & 4,000 & 7 & 1.9 & 13 \\
$1994-2005$ & 0 & $n / a$ & 0 & $n / a$ & 1,800 & 4,000 & 7 & 2.2 & 16 \\
\hline
\end{tabular}

Sources: Table 14.9, codeine open world market prices from Tasmanian Alkaloids, and estimates by the author.

The figures in the above table indicate that Diosynth's opiate average sales revenue during 1981-2005 were in the order of 50\% of that achieved over the years 1975-1980 (ref. table 13.9 and figure 13.10). The profit margin on sales over 1981-1988 must have been low and somewhat better over the next sub-period. The margin as a percentage of sales during 1994-2005 will have been substantially larger than for the previous sub-periods as the nalcompounds have a much higher added value over raw material cost.

The average opiate sales revenue 1981-2005 amounted to about USD 6 million, approximately $1 \%$ of Diosynth's total sales of USD 500 million in $2002 .{ }^{36}$

\subsection{Summary and Conclusions}

The Netherland's opiate industry that had commenced in the 1920s with the manufacture on a very small scale of codeine in Jansen's "Bonnema" facilities at Apeldoorn came to an end in 2005 when Diosynth ceased to convert substantial quantities of morphine into nalcompounds.

The main reason for terminating the poppy extraction in 1988 was the inability to find an alternative source for the raw material once the Turkish factory had commenced production and poppy straw from that country was not any longer available. Diosynth continued codeine manufacture from imported CPS but this came to an end in 1993 when it became clear that the profit margin on a product made from a raw material which had to be bought from its competitors was insufficient. After 1993 opiate manufacture at Diosynth continued on the basis of making nal-compounds from morphine using its own patented process. The quantities converted were quite substantial and the profit margins must have been good but the last year of morphine conversion was 2005. It seems likely that competition with nal-

\footnotetext{
${ }^{36}$ The total sales figure of USD 500 million for 2002 was mentioned by Jack Nijssen, Marketing manager product group C, Diosynth, Oss, during an interview on 27 August 2002.
} 
compounds made from thebaine, now available at lower cost from high yielding thebaine poppies cultivated in Australia, was the reason for the cessation.

The opiate business had become unattractive for Diosynth. The Netherlands was not the right place to base a large scale opiate manufacturer. The wet Dutch climate was not suitable for the local cultivation of high yielding $P$. somniferum strains and the domestic codeine market was small and at the end not any longer protected from competition. The important US market was closed for opiate raw materials produced in the Netherlands and within the Akzo Pharma (Organon) organisation no large captive use of opiates existed. The merger of Organon, including Diosynth, with Schering-Plough in 2007 may also have been a factor.

The Summary and Conclusions of Part I (chapter 1 to 14) and Part II (chapters 15 to 18) appear in chapter 19. 
